\title{
Transnational networks and the common market : business views on European integration, 1950-1980
}

Citation for published version (APA):

Geven, R. (2014). Transnational networks and the common market : business views on European integration, 1950-1980. [Doctoral Thesis, Maastricht University]. Universitaire Pers Maastricht. https://doi.org/10.26481/dis.20140417rg

Document status and date:

Published: 01/01/2014

DOI:

10.26481/dis.20140417rg

Document Version:

Publisher's PDF, also known as Version of record

\section{Please check the document version of this publication:}

- A submitted manuscript is the version of the article upon submission and before peer-review. There can be important differences between the submitted version and the official published version of record.

People interested in the research are advised to contact the author for the final version of the publication, or visit the DOI to the publisher's website.

- The final author version and the galley proof are versions of the publication after peer review.

- The final published version features the final layout of the paper including the volume, issue and page numbers.

Link to publication

\footnotetext{
General rights rights.

- You may freely distribute the URL identifying the publication in the public portal. please follow below link for the End User Agreement:

www.umlib.nl/taverne-license

Take down policy

If you believe that this document breaches copyright please contact us at:

repository@maastrichtuniversity.nl

providing details and we will investigate your claim.
}

Copyright and moral rights for the publications made accessible in the public portal are retained by the authors and/or other copyright owners and it is a condition of accessing publications that users recognise and abide by the legal requirements associated with these

- Users may download and print one copy of any publication from the public portal for the purpose of private study or research.

- You may not further distribute the material or use it for any profit-making activity or commercial gain

If the publication is distributed under the terms of Article $25 \mathrm{fa}$ of the Dutch Copyright Act, indicated by the "Taverne" license above, 


\section{TRANSNATIONAL NETWORKS AND THE COMMON MARKET: BUSINESS VIEWS ON EUROPEAN INTEGRATION, 1950-1980}


Solvay S.A.'s financial support for the purpose of printing this thesis is gratefully acknowledged.

(C) Ruud Geven, Maastricht 2014

ISBN 9789461593238

Production: Datawyse | Universitaire Pers Maastricht

Coverpictures:

Front cover and back cover, middle: First Bilderberg Conference at the Bilderberg Hotel, Oosterbeek, May 1954, photograph, (C) Courtesy of Bilderberg meetings.

Back cover, top: First Trilateral Commission Executive Committee Meeting, Tokyo, October 1973, photograph, Trilateral Commission, (C) Courtesy of Rockefeller Archive Center.

Back cover, down: ELEC Conference on a Community energy policy, October 1980, photograph of printed image in: LECE (1980). Pour une politique communautaire de l'énergie. Colloque du 10 octobre 1980, Paris, salle Médici du Sénat. Paris: LECE, p. 44, (C) Courtesy of the European League for Economic Cooperation. 


\title{
TRANSNATIONAL NETWORKS AND THE COMMON MARKET: BUSINESS VIEWS ON EUROPEAN INTEGRATION, 1950-1980
}

\author{
DISSERTATION \\ to obtain the degree of Doctor at Maastricht University, \\ on the authority of the Rector Magnificus, Prof. dr. L. L. G. Soete \\ in accordance with the decision of the Board of Deans, \\ to be defended in public \\ on Thursday the $17^{\text {th }}$ of April 2014, at 14.00 hours,
}

by

Ruud Geven

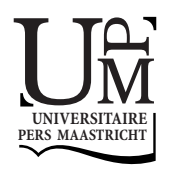




\section{Supervisors}

Prof. dr. E. Homburg

Prof. dr. S. Vanhoonacker

\section{Assessment Committee}

Prof. dr. K. K. Patel (chairman)

Dr. G. Geuens (University of Liège)

Prof. dr. A. Knotter

Prof. dr. K. E. Sluyterman (Utrecht University) 


\section{Table of contents}

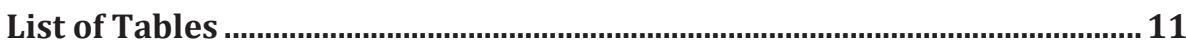

List of figures........................................................................................ 13

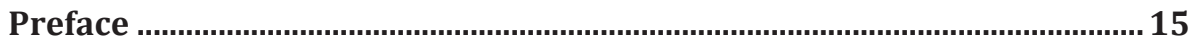

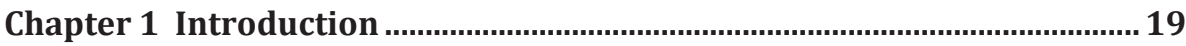

Methodology .............................................................................................. 24

Selection and comparison of networks .............................................................. 24

Chronological subdivision and thematic choices: cases ...................................... 25

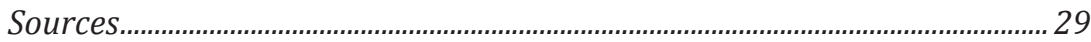

Historiography: a terrain at a crossroads of disciplines ............................ 30

Role of business in European integration theory .................................................30

Role of business in European integration history .............................................. 35

Business history and European integration.......................................................... 40

Transnational networks: historiography........................................................... 44

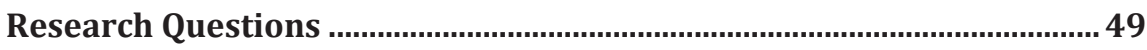

Chapter 2 Transnational networks: the participation of businessmen .... 51

Introduction ...................................................................................51

European League for Economic Cooperation, 1946-1980........................ 52

Founding ELEC, 1946-1949............................................................................ 53

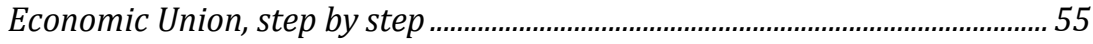

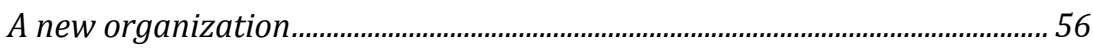

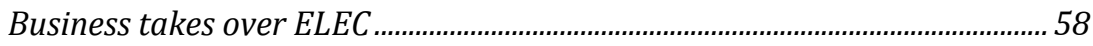

Central Council composition, 1950-1980................................................................ 63

Themes discussed, 1950-1980............................................................................... 64

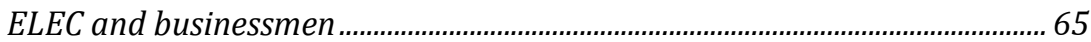

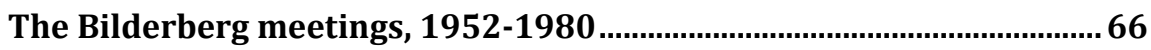

Founding the Bilderberg meetings, 1952-1954 ............................................67

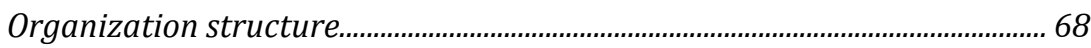

Participants and Steering Committee composition, 1954-1980..................... 70

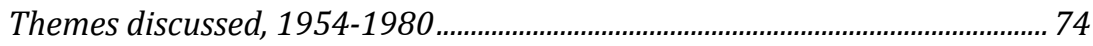

Bilderberg meetings and businessmen................................................................... 76

Trilateral Commission, 1972-1980 ……...................................................

Founding the Trilateral Commission, 1972-1973 ................................................ 80

Differing assessments of trilateralism ................................................................... 81

Organization structure ............................................................................................ 83

Executive Committee composition, 1973-1980 ……………………………….... 85

Thematic development, 1973-1980.................................................................... 86 
The Trilateral Commission and businessmen .................................................. 87

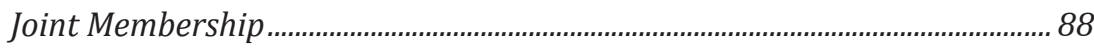

Discussion ............................................................................................................... 89

Chapter 3 European multinationals in national and sectoral contexts ... 91

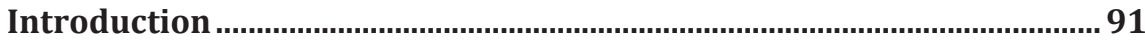

Interpreting multinationals in national contexts ................................... 92

Federal Republic of Germany ............................................................................... 92

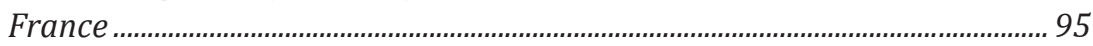

The Netherlands …........................................................................................ 98

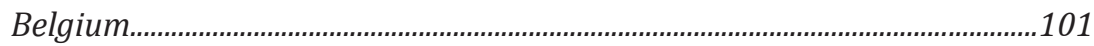

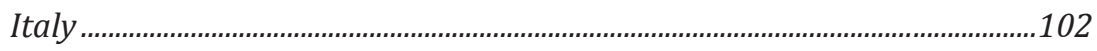

The United Kingdom ...................................................................................104

Interpreting multinationals in sectoral contexts...................................105

Banking industry........................................................................................114

Chemical industry ...........................................................................................115

Steel industry ...............................................................................................116

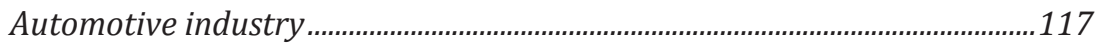

Conclusion .............................................................................................118

Chapter 4 Business leaders and the integration of European markets, 1950-

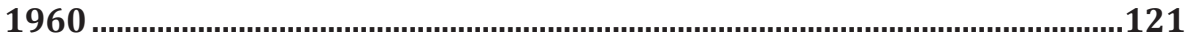

Introduction ..........................................................................................................121

International context, 1945-1960.......................................................122

American plans for European trade structures, 1945-1950 .........................122

The settlement of WWII, 1945-1950 .................................................................125

The liberalization of the Western European market, 1950-1960................127

European League for Economic Cooperation ..........................................131

The Schuman Plan ................................................................................................131

The many roads to trade liberalization...........................................................137

The Beyen plan .....................................................................................................141

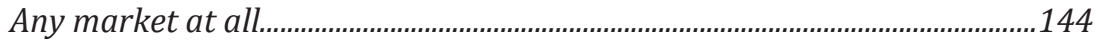

Disappointment and recalibration ................................................................148

The Bilderberg meetings .........................................................................151

European integration: "...dictated by the circumstances of our times..."...152

A web of high authorities ..................................................................................154

Mending the Schism ..........................................................................................158

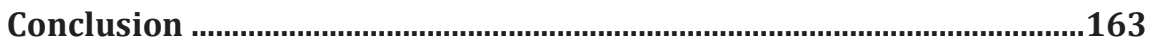

Chapter 5 Facing challenges from the West and the East, 1960-1970....169

Introduction ............................................................................................169

European and transatlantic tensions....................................................170

Emerging challenges for business in European markets .......................172 
Complexities in East-bloc trade .......................................................................172

American investments in Western Europe .......................................................174

Changing circumstances, new priorities..................................................176

Eastern European markets and the Bilderberg meetings ......................177

Eastern European markets and the ELEC ................................................182

The Western European chemical industry and Eastern Europe...................182

Overcoming narrow bilateralism .......................................................................184

Organizing international markets ...................................................................186

American investments in Europe and the ELEC......................................189

European industrial concentration ...............................................................190

Financial protectionism .................................................................................193

American Investments in Europe and the Bilderberg meetings ...........197

Capital markets .............................................................................................198

Strength through unity......................................................................................199

A code for multinationals.....................................................................................201

Conclusion ..........................................................................................204

Chapter 6 European multinationals during the oil crises, 1970-1980...209

Introduction .............................................................................................209

Economic circumstances during the early 1970s ...............................210

The monetary crisis.............................................................................................210

The oil crises of the 1970 s ...............................................................................210

Economic crisis and protectionism .................................................................212

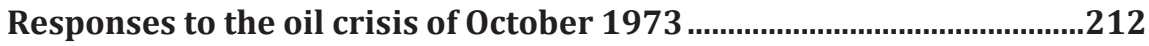

Western European energy policy response .......................................................214

The United States energy policy response........................................................215

Japanese energy policy response.........................................................................216

Energy security and the European League for Economic Co-operation216

European energy policy, 1972-1974 ….......................................................217

Economic crisis..............................................................................................222

European energy policy, 1978-1981 …...........................................................225

Bilderberg meetings ......................................................................................231

To block or absorb the Arabs?...........................................................................233

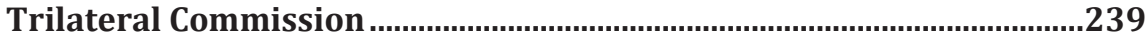

Trilateral Commission's energy actors ............................................................240

The energy debates .............................................................................................24

Economic cooperation with OPEC, 1974 .....................................................247

Criticizing American energy policy...................................................................251

Conclusion ..............................................................................................................254

Chapter 7 Changing views on a changing European market.....................259

Changing circumstances................................................................................260

Adaptation problems...........................................................................................262 
Explaining diverging views: national and sectoral contexts ..................264

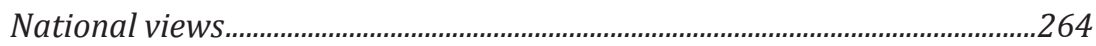

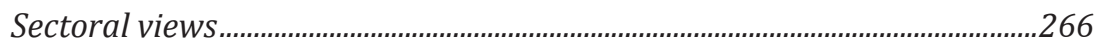

Transnational networks.............................................................................267

European League for Economic Co-operation....................................................268

Bilderberg meetings ..........................................................................................268

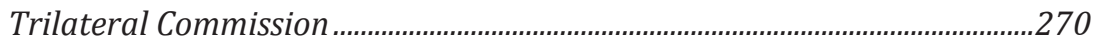

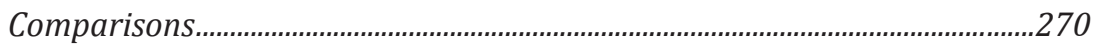

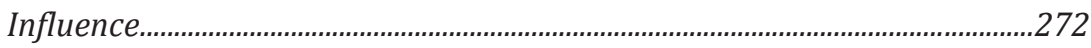

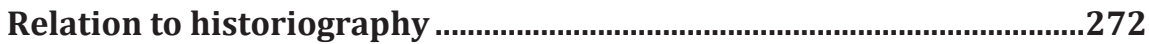

Business and European integration theory.....................................................273

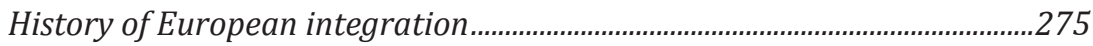

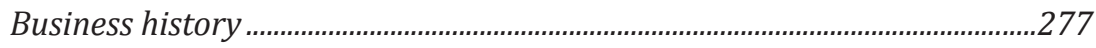

Geo-political insights...............................................................................................28

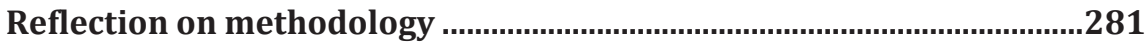

Opportunities for further research .......................................................282

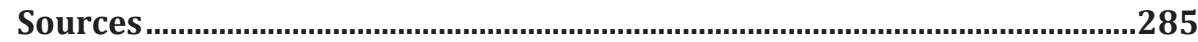

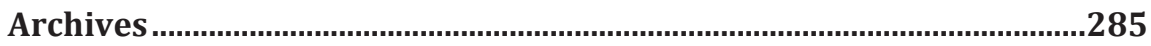

European League for Economic Cooperation ………......................................285

Bilderberg meetings ..........................................................................................286

Trilateral Commission ……………………………………..........................................287

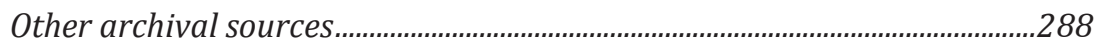

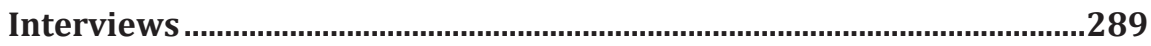

Publications of networks ......................................................................289

European League for Economic Cooperation (1949-1980) ...........................289

Bilderberg meetings (1954-1980).....................................................................292

Trilateral Commission (1973-1980) .....................................................................293

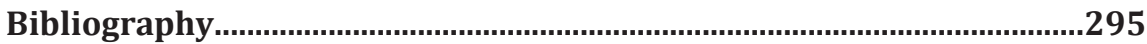

Appendix - The leadership of the ELEC, Bilderberg meetings and the Trilateral Commission, 1950-1980: a database ............................................303

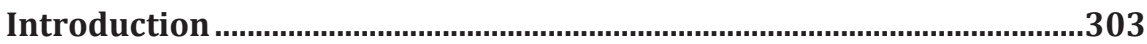

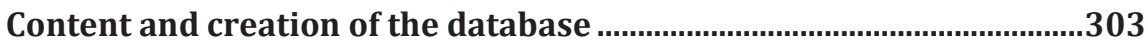

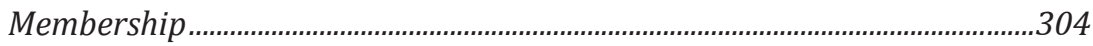

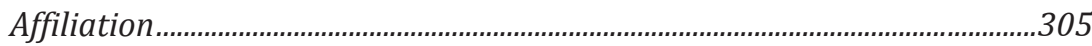

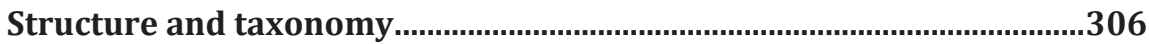

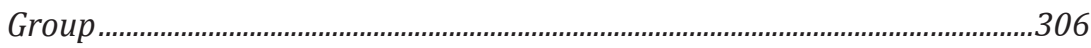

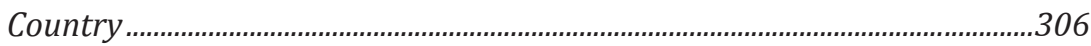

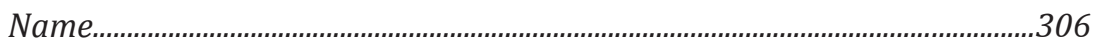

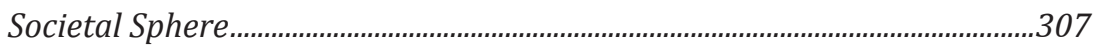

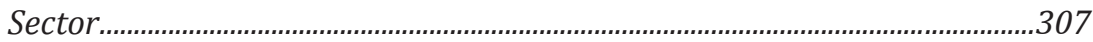

Company/Institution ..............................................................................................309 


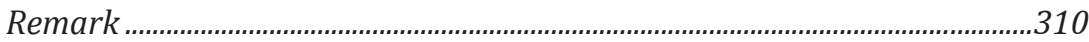

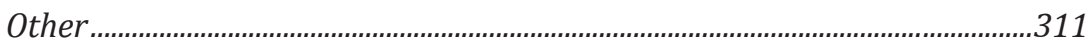

Tables and figures .................................................................................311

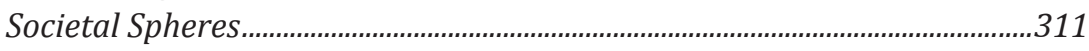

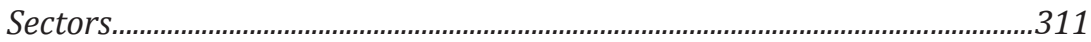

Results......................................................................................................312

Country database table .....................................................................................312

Database tables sorted by group ............................................................313

Database tables sorted per country ........................................................336

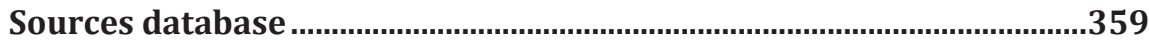

Membership-sources per group ..................................................................359

"Professional affiliations" sources per group ..................................................359

"Professional affiliations" sources per country...............................................360

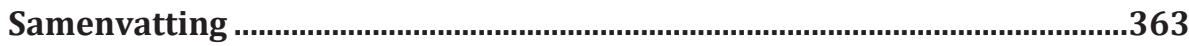

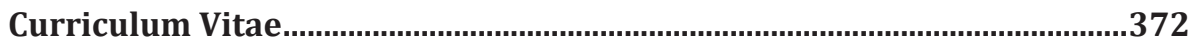





\section{List of Tables}

Table 1.1: Themes investigated within the transnational networks. 28

Table 2.1: Founding years of ELEC's national sections. 57

Table 2.2: Composition of ELEC's Central Council membership in societal spheres, 1950-1980 (absolute figures).

Table 2.3: Start participation of members of Bilderberg meetings, per country, and start Steering Committee membership, 19541980.

Table 2.4: All individuals with 11 to 28 visits to Bilderberg conferences, 1954-1980.

Table 2.5: Number of visitors in relation to the number of conferences visited.

Table 2.6: Composition of the Bilderberg meetings' Steering Committee membership in societal spheres, 1955-1980 (absolute figures).

Table 2.7: Composition of the Trilateral Commission's Executive Committee membership in societal spheres, 1975-1980 (absolute figures).

Table 2.8: Overlaps between the ELEC, Bilderberg meetings and Trilateral Commission's leading bodies in the years 1950, 1955, 1960, 1965, 1970, 1975 and 1980.

Table 3.1: Composition of the combined leadership of ELEC, Bilderberg meetings and Trilateral Commission in societal spheres, 19501980 (absolute figures).

Table 3.2: The representation of different industries in the combined business societal sphere of the ELEC, Bilderberg and Trilateral leadership, 1950-1980 (absolute figures).

Table 3.3: The representation of different industries in the business societal sphere of the ELEC Central Council, 1950-1980 (absolute figures).

Table 3.4: The representation of different industries in the business societal sphere of the Bilderberg meetings' Steering Committee, 1955-1980 (absolute figures).

Table 3.5: The representation of different industries in the business societal sphere of the Trilateral Commission's Executive Committee, 1975-1980 (absolute figures).

Table 6.1: $\quad$ Participants in the small ad-hoc ELEC Energy Committee (November 1979) and the permanent ELEC Energy Committee thereafter (April 1980, December 1980, April 1981). 
Table 6.2: $\quad$ Overview European participants from business, Bilderberg Saltsjöbaden Conference, May 1973.

Table 6.3: Overview of the members of the Trilateral Commission Executive Committee in 1975.

Table 6.4: Overview of Energy/Oil Related Members of the Trilateral Commission 1973-1980.

Table 7.1: Schematic overview of changes in views on the European market among European multinationals.

Table A.1: Percentage of uncategorized members in database in relation total member in database.

Table A.2: Professional affiliations of leadership ELEC 1950, sorted by group.

Table A.3: Professional affiliations of leadership ELEC and Bilderberg meetings 1955, sorted by group.

Table A.4: Professional affiliations of leadership ELEC and Bilderberg meetings 1960, sorted by group.

Table A.5: Professional affiliations of leadership ELEC and Bilderberg meetings 1965, sorted by group.

Table A.6: Professional affiliations of leadership ELEC and Bilderberg meetings 1970, sorted by group.

Table A.7: $\quad$ Professional affiliations of leadership ELEC, Bilderberg meetings and Trilateral Commission 1975, sorted by group.

Table A.8: Professional affiliations of leadership ELEC, Bilderberg meetings and Trilateral Commission 1980, sorted by group.

Table A.9: Professional affiliations of leadership ELEC 1950, sorted by country.

Table A.10: Professional affiliations of leadership ELEC and Bilderberg meetings 1955, sorted by country.

Table A.11: Professional affiliations of leadership ELEC and Bilderberg meetings 1960 , sorted by country.

Table A.12: Professional affiliations of leadership ELEC and Bilderberg meetings 1965 , sorted by country.

Table A.13: Professional affiliations of leadership ELEC and Bilderberg meetings 1970, sorted by country.

Table A.14: Professional affiliations of leadership ELEC, Bilderberg meetings and Trilateral Commission 1975, sorted by country. 348

Table A.15: Professional affiliations of leadership ELEC, Bilderberg meetings and Trilateral Commission 1980, sorted by country. 


\section{List of figures}

Figure 2.1: Relative composition of ELEC's Central Council membership in societal spheres, 1950-1980.

Figure 2.2: Relative composition of the Bilderberg meetings' Steering Committee membership, divided according to societal spheres, 1955-1980.

Figure 2.3: Relative composition of the Trilateral Commission's Executive Committee membership in societal spheres, 1975-1980.

Figure 3.1: Relative composition of combined leadership ELEC, Bilderberg meetings and Trilateral Commission in societal spheres, 19501980.

Figure 3.2: Relative representation of different industries in the combined business societal sphere of the ELEC, Bilderberg and Trilateral leadership, 1950-1980.

Figure 3.3: Relative representation of different industries in the business societal sphere of the ELEC Central Council, 1950-1980.

Figure 3.4: Relative representation of different industries in the business societal sphere of the Bilderberg meetings' Steering Committee, 1955-1980.

Figure 3.5: Relative composition in sectors of the combined business components of the Trilateral Commission's Executive Committee, 1975-1980. 



\section{Preface}

In the late 1940s, many new ideas about the integration of Europe were introduced. One of these ideas proved to be particularly successful: it suggested a reorganization of the West-European national markets into one larger, liberalized market. That idea gradually materialized during political negotiations and was laid down in treaties during the 1950s. The result was the European Economic Community (EEC), or, the Common Market, which was realized step by step from 1959 onwards. This book is about how European large multinationals and internationally oriented corporations came to view several major developments in and around this trade bloc, from the early 1950s onwards until the late 1970s. The project was a spin-off of an investigation on the history of the Solvay company, which resulted in the book Solvay: History of a Multinational Family Firm (2013). Leaders of the company were co-founders of the European League for Economic Cooperation (ELEC) and played prominent roles in other transnational networks.

By investigating several important debates in three transnational networks, the ELEC, the Bilderberg meetings and the Trilateral Commission, this dissertation reconstructs how the views of European corporations on this Common Market developed. In doing so, this investigation moreover provides a basis for a transnational history of European corporations in a context of European integration. Additionally, the book offers new insights in the workings of the transnational networks mentioned and on exchange of ideas on changing circumstances in European, Transatlantic and global markets.

When I was invited to investigate this wide-ranging topic I awaited my first day of research with eager anticipation. The topic was fascinating and the prospect of delving into the archives of several obscure-regarded organizations appealed to me. I fostered great expectations about what I would encounter. However, as one becomes trained in the practice of historical research, one learns that archival sources are not as accessible as one hopes and that they are seldom as transparent about the subject under investigation as one imagines.

Whether I would acquire access to the archives of the Bilderberg meetings and the Trilateral Commission was a nearly permanent worry during most of the first three years. Only after more than two years into the project the required sources on the Bilderberg meetings for the 1960s and 1970s could be located and only after more than three years I accidentally learned about the only since mid-2011 available institutional archive of the Trilateral Commission. Nonetheless, persistence and patience paid off. This is the first time that these sources have been used for a better understanding of these organizations, and it has resulted in new insights into their work that are introduced throughout the book. 
Much more daunting than the task of acquiring access to archives however was the sheer labour that was involved in singling out the actors and determining their backgrounds and positions in the selected debates. Additionally it was necessary to create an elaborate database on the networks' main members to understand their dominant social make-up. As a result, the practice of investigating this subject quickly became a sobering, even humbling experience. Transnational research on business debates about European integration poses several challenges due to the range of individual, industrial, national, institutional, European and global contexts involved. Any naiveté that I fostered about the required effort and knowledge for the interpretation of a single European-level debate was soon dispelled.

Nonetheless, the investigation of business perspectives on European integration in an international context has deepened my fascination for the slow germination of an actual European market, which was only truly realized thirty-five years after the decision to establish it. Throughout this process, European corporations were very active and well-informed actors in debates regarding the further development of the European market. It was particularly interesting to learn how well positioned they were to assess the global context of the European market and the European Community at large. For this reason I believe that not only this book but also the continued investigation of the European business experience will contribute to new perspectives on the global forces and narratives that have co-shaped the present European Union.

Many have been involved in my academic education and more specifically the materialization of this dissertation. I feel privileged to be able to express my gratitude here to those that aided me and added joy to the experience.

Firstly, I wish to thank the Faculty of Arts and Social Sciences of Maastricht University for enabling me to write this book. I would like to thank the Maastricht University Library team, which kindly helped me out of a fix at numerous occasions. My appreciation is also directed at the members of the N. W. Posthumus Institute and the 2010 cohort of PhD candidates. In particular I wish to thank Joep, Marten and Simone whose company truly turned the conferences in Brussels, Amsterdam, Vienna and Antwerp into great experiences!

Often I preferred libraries and archives to my desk. Despite my absence, my office fellows Christoph, Natasja and Rik made me feel at home and anchored me in the Faculty. The banter, discussions and the white-board that kept track of the successful office-door-swings-at-students will always remain a warm memory.

My friends in Eindhoven, 's-Hertogenbosch and Utrecht are the most precious group of people I know. Their understanding for the reasons of my continuous absence has been limitless, for which I am very grateful. As a true master of Excel, Marcel deserves credit for helping me in exacting structure and meaning from my biographical data. 
During the most crucial phase of writing, my parents in law and Mark and Miriam kindly took it on themselves to entertain our young boy at several occasions while I was fine-tuning this manuscript. Thanks to them I was able to maintain the necessary flow for tying everything together. They are true lifesavers!

I am also thankful for the several engaging conversations with my BasicTraining-Qualification coach Manuel Stoffers, who helped me to explicate my views on academic teaching.

At several crucial supervisory meetings my second supervisor Sophie Vanhoonacker taught me to take rigorous decisions about the structure and scope of the book. These lessons included the crucial subject on whether we were overreaching with a fourth empirical chapter or not. I deeply appreciate the role that she played in these decisions and the general bird's eye view that she kept on the process.

During the past eight years, my supervisor Ernst Homburg was repeatedly involved in my academic education. In the years preceding this project he introduced me to the ins and outs of archival research. My first experiences with a biographical database as presented in this book resulted from contributions to his collaborative project with Johann Peter Murmann on the social networks of chemists. By suggesting to me to undertake the present investigation Ernst did not just offer me a major opportunity but also his engaged and generous supervision. His ability to identify my intellectual doubts based on mere drafts never ceased to amaze me. More importantly his confidence in the value of my work was crucial for maintaining my determination to finish this book. I feel privileged to have been his student and he has become more than a mentor to me.

My parents have been a permanent source of encouragement in my initial and more recent studies. At the occasion of unpleasant setbacks, they have aided me in several ways, thereby allowing me to remain focussed on the book. I hope one day to do the same for our children, with a similar understanding for their predicament as my parents had for mine.

Jennie, my gratitude to you is unending and I love you for supporting me so wholeheartedly. You forgave me my forgetfulness and absent-mindedness that typically emerged around periods of intense writing. For some reason you ignored my truly disturbing working habits such as my repeated attempts at finishing a section until well into the early hours. I cannot imagine what would have happened without your loving care for our young family. Now it is your turn to depend on me. And it is time to enjoy life áfter the dissertation, together. Finally, our young boy: Son. Your obvious lack of intention to help me write this book was more important than any aid I received. Being there for you has been the most rewarding experience of all. 



\section{Chapter 1}

\section{Introduction}

This chapter first introduces the reasons for investigating the views of large European businesses and multinationals on the European market. Subsequently the methodology of this investigation will be explained. The main part of the chapter discusses the historiography on the role of business in three areas of research: European integration theory, history of European integration and business history in relation to European integration. Additionally the historiography on the three investigated networks will be discussed and related to insights on business associations. The chapter concludes with a recapitulation of the main themes and questions that will be investigated in this book.

Between WWI and WWII the European market turned from a relatively liberal trade area into a patchwork of carefully protected national markets. Nation states erected tariff walls and consciously set out to build powerful, national industries. Protectionism became the norm. ${ }^{1}$

After WWII, impressed by the economic growth of the world's largest market, the USA, Western European governments gradually accepted the need for liberalization. They engaged in the integration of markets, the creation of trade blocs and the founding of supranational institutions to supervise the process of market enlargement. Multinationals and companies with activities across Europe saw the organization of markets change before their eyes. Yet we know little about businesses' views on the matter. This book is about the developing business-views on the changing organization of the European market. ${ }^{2}$

Different countries chose different means and routes for the liberalization of markets, which resulted in an uncertain situation in Europe. The governments of the Benelux, France, the Federal Republic of Germany and Italy committed themselves to economic integration. In 1952 they founded the European Coal and Steel Community (ECSC), involving the establishment of a customs union for the coal and steel industries. Moreover the High Authority was founded, a supranational institution which was responsible for commercial and industrial policy for all coal and steel companies with activities in those six countries. Moreover in 1957 these

\footnotetext{
${ }^{1}$ Berend, I. T. (2006). An economic history of twentieth-century Europe. Cambridge: Cambridge University Press, pp. 61-73.

2 Ibidem.
} 
countries also signed the Rome Treaties in which they agreed to gradually implement a Common Market for industrial goods, the European Economic Community (EEC). Import tariffs were diminished step by step and a common external tariff wall was established. A trade bloc was the result. Moreover, another supranational institution was founded, the European Commission, that would oversee the implementation of a Community competition policy, an agricultural policy, a transport policy and several others. The principal aim of these moves was to fuse their markets into one. ${ }^{3}$

Other Western European governments rejected such a supranational organization of markets. The government of the United Kingdom declined invitations to join the negotiations on the ECSC and the EEC because British trade was mainly geared to the Commonwealth. Moreover the British government was not prepared to delegate parts of its sovereignty to supranational institutions. Instead the government of the United Kingdom decided to establish a trade bloc itself based on its own preferences. In response to the creation of the EEC, in 1960 the United Kingdom founded the European Free Trade Area (EFTA), together with Austria, Denmark, Norway, Switzerland and Sweden. This organization of economic integration was of a different nature than the Common Market. The free trade area only eliminated internal tariffs between the participating countries. No common external tariff was introduced nor was there any supranational institution founded to supervise the developments in the area. Still, Western Europe was now in practice divided into two trade blocs. Each bloc liberalized trade within its own area and discouraged trade between the blocs, resulting in trade creation and trade diversion effects. Proposals to mitigate these effects by eliminating the tariffs between the blocs, ultimately failed after intense discussions. ${ }^{4}$

In the following year the British government reconsidered its position on devolving sovereignty to supranational institutions. Moreover, it became aware of the declining importance of British trade with the Commonwealth. In 1961 the government requested to join the European Economic Community. In 1963 however the application was denied by the French President de Gaulle. Eventually the United Kingdom would join the EEC nonetheless in 1973, together with Ireland and Denmark. ${ }^{5}$

Particularly the period from 1950 until 1963 was ridden with uncertainty about how the organization of European markets would turn out. According to economic integration theory European multinationals and other large corporations in the EEC were affected by this uncertainty. Economic theory suggests that corporations that gain access to larger markets are in a position to realize economies of

\footnotetext{
3 Dinan, D. (2004). Europe recast: a history of European Union. Basingstoke: Palgrave Macmillan, pp. 4579.

${ }^{4}$ Dinan, D. (2004). Europe recast, pp. 89-94. Balassa, B. (1969[1962]). The theory of economic integration. London: George Allen \& Unwin Ltd., p. 25.

${ }^{5}$ Dinan, D. (2004). Europe recast, pp. 89-94.
} 
scale. The emerging division of Western Europe in two trade blocs however limited the prospect of a truly sizeable market. In addition, conditions, rules and institutional settings changed considerably. Little is known about what European business at large thought about these developments. ${ }^{6}$

Some business historians did investigate the EEC context of a small group of large multinationals that had realized their industrial networks across European national borders before 1950. They were some of the most widely distributed companies in the world, such as for example Unilever and Philips. Scholars demonstrated that the firms saw great opportunities for scale advantages and indeed set out to restructure their organizations accordingly. However, because local management resisted change and governments refused relocation of production the adaptation to the large market was difficult and painful. The question therefore arises how the established multinational corporations viewed the role of the European Community in these matters? This will be one of our leading questions. ${ }^{7}$

Many other companies, for example the aluminium producer Pechiney, steel producer Hoogovens or car-builder Fiat developed into multinationals after the 1950s, during the period in which the European market was gradually integrated. These companies expanded within Europe and beyond and merged with other European firms. Which direction for European integration did they prefer, what shaped their ideas and to what extent did their ideas change as they were confronted with an enlarging market?

The question on the views of European multinationals and large businesses on the European market becomes all the more pressing after considering the few available accounts about the views of business on the European market, namely those by Sandholtz \& Zysman, Maria Green Cowles and Bastiaan van Apeldoorn. They do not investigate the crucial 1950s or the 1960s but focus on the early 1980s and the early 1990s. From 1983 onwards the European Round Table of Industry, a group of presidents from European industrial corporations demanded the completion of the Common Market as was agreed in the Treaties of Rome. According to them the decisions of 1957 had not been realized. Extensive differences between the national markets and national policies had remained and had turned into de-facto non-tariff protectionism. Whether or not due to ERTI's lobbying, the requests were ultimately met in the Single European Act of 1986. Yet, no account exists on how European companies with a multinational outlook came to such a view after the broad move towards liberalization during the 1950s (as we will show in Chapter 4). One wonders therefore how the views of European multinationals changed with regard to the developments in the organization of the Euro-

\footnotetext{
6 Balassa (1969[1962]). The theory, pp. 131-137.

7 Blanken, I. (2002). Een Industriële Wereldfederatie. Zaltbommel: Europese Bibliotheek; Jones, G. G., \& Miskell, P. (2005). European integration and corporate restructuring: the strategy of Unilever, c. 1957-c. 1990. Economic History Review, 28, 113-139

${ }^{8}$ Jones, G. \& Schröter, H. G. (Eds.) (1993). The rise of multinationals in continental Europe. Aldershot: Edward Elgar.
} 
pean market between 1950-1980? This will be a second leading question of this book. $^{9}$

Asking this question however does not necessarily imply that all companies held identical views. Business historians and sociologists of business associations have demonstrated that often businessmen lack a common perspective. It is unlikely that businesses were able to find an uncontested consensus on such an encompassing and multifaceted theme as the organization of the Western European market. We therefore will also investigate which different views were held and how such differences can be explained ${ }^{10}$

Two possible determinants of company preferences may explain such differences in perception and position. The first is the national origin of a corporation. Business historians have identified the significance of national business systems as a basis for explaining structures and strategies of firms. The origin of firms from different national institutional contexts and markets co-determine the ease with which a firm from one country can transfer its activities to other countries. National origin thus also matters to our understanding of multinationals. Moreover, since the question that is central to this investigation is related to aspects of European integration, it is important to acknowledge that the nation state has been interpreted as the decisive actor in this process. In his influential European rescue of the nation state Alan Milward shows how the national contexts of the economy and concerns about the future prosperity of dominant national industries can explain governmental positions in the European integration process during the 1950s. The formation of the European Coal and Steel Community and the European Economic Community and their associated policies can be seen as confrontations between national contexts, economic path dependencies and preferences. Therefore it is interesting to find out to what extent even the views of multinationals were determined by their national origin. ${ }^{11}$

The second plausible determinant of company preferences is the industry in which a company operates. According to H.W. de Jong companies shape their future by competing with other firms, through cooperation with other firms or by controlling other firms within their industries. Industrial contexts of companies vary strongly. De Jong has explained how structural differences between industries result in different priorities. Consider for example the research and development

\footnotetext{
9 See on the ideas of the European Round Table of Industrialists: Sandholtz, W. \& Zysman, J. (1989). Recasting the European bargain. World Politics, 42, 95-128; Green Cowles, M. (1995). Setting the agenda for a new Europe: the ERT and EC 1992. Journal of Common Market Studies, 33, 501-526; Apeldoorn, B. van (2002). Transnational capitalism and the struggle over European integration. London: Routledge. ${ }^{10}$ See for example: Waarden, F. van (1995). Employers and employers' associations. In J. Ruysseveldt, R. Huiskamp \& J. van Hoof (Eds.), Comparative industrial and employment relations (pp. 68-108). London: Sage, p. 70 .

${ }_{11}$ Milward, A. S. (1992). The European rescue of the nation-state. London: Routledge; Whitley, R. (1992). The comparative study of business systems in Europe: issues and choices. In R. Whitley (Ed.), European business systems. Firms and markets in their national contexts (pp. 267-284). London: Sage, pp. 267-272, 276-279.
} 
costs for the pharmaceutical industry for which product innovation stands at the core of its ability to compete, versus that of the steel producers whose competitiveness was long determined by process innovations. Different priorities among industries may explain differing views on the organization of the European market. Such views include stances on European Community policies but also on how the Community shaped relations between the European market and external markets. $^{12}$

This book is thus not merely concerned with the changes in multinationals' views on the European market, but also with the question how possible differences in views between them can be understood? Can any patterns be identified as a result of zooming in on the national origin or industrial characteristics of companies? Or do other factors possibly explain a divergence in views?

Asking these questions enables us to explore a long-term development of views of European business about the organization of the European market and to be able to describe how and perhaps why these views changed.

Before turning to how these questions are investigated it is important to explain the use of two central terms throughout the book. The first term is multinational. The multinational firm is generally defined as a company that either engages in portfolio investment in a second country, which refers to owning shares in foreign companies without management control, or a company that engages in foreign direct investments in a second country which does involve management control. The companies studied in this book mostly fall into the second category. ${ }^{13}$

Not all companies that receive attention however fall within this definition. In practice this book zooms in on three transnational networks in which leaders of a variety of firms played important roles: the European League for Economic Cooperation, the Bilderberg meetings and the Trilateral Commission. These networks included companies that were already widely distributed multinationals before 1950 . They also included large European companies that were not multinationals during the 1950s, which however turned into multinationals during the 1960s and 1970s. The ELEC also included some non-multinational export oriented companies. Nonetheless, industries with a strong focus on international exports or an involvement in international financial developments had a multinational outlook whether or not they invested outside their home-market. Employing the organizational definition of multinationals above too strictly would exclude the views of internationally oriented companies that were similarly affected by the changing conditions on the European market. Considering this aspect, the term multinationals is generally used throughout this book. When necessary however, a concrete distinction will be

\footnotetext{
${ }^{12}$ See for this industry-based perception of the market and the dynamics of the market through firms' industrial coordination strategies: Jong, H. W. de (1996). Dynamische markttheorie. $4^{\text {th }}$ edition, Weteringbrug: Eddusa, pp. 3-20. But also see: Jong, H.W. de (Ed.) (1981). The structure of European industry. The Hague: Nijhoff. Also see Chapter 3.

${ }^{13}$ Jones, G. G. (2005). Multinationals and global capitalism: from the nineteenth to the twenty-first century. Oxford: Oxford University Press, p. 5.
} 
made between companies that were already widely distributed before WWII and companies that were not.

The second term that requires explanation is "European market". When reference is made to "views on the European market", this refers mostly to views on the organization of the European markets. Because the investigation zooms in on three networks that mainly involve companies originating from the EEC, the term generally refers to the area covered by the Benelux, France, Germany and Italy, also in the 1950s.

\section{Methodology}

As mentioned, the views of European multinationals will be investigated via a comparative perspective on three transnational networks. These are the European League for Economic Cooperation (since 1947), the Bilderberg meetings (since 1954) and the Trilateral Commission (since 1973).

\section{Selection and comparison of networks}

The selection of the above-mentioned networks was motivated by the following criteria. Firstly, they all include representatives from European business of which a striking share were, or later became multinationals. However, members were not exclusively active in business. Economists, politicians, public administrators and businessmen interacted in debates about the European, Western and global political-economic developments.

Secondly the networks are transnational in the sense that its members interacted across national boundaries with international goals in mind. This element of selection is crucial because it enables our investigation to go beyond mere national viewpoints on the European market and to remain open to transnational viewpoints and international conceptions of the European market that multinational businesses might have fostered.

Thirdly the value of choosing these three networks lies in their varying positions in relation to the European market in the world economy: the European League for Economic Cooperation (ELEC) focussed on the place of Western European companies in the European market, the Bilderberg Meetings approached the European market in the context of Transatlantic relations and the Trilateral Commission discussed the European market within European, American and Japanese economic relations. The wide international angle of these networks offers a perspective on the interaction between Western Europe and the external economic environment where large multinationals also operated.

At the same time these differences between the networks may have had consequences for how businessmen formulated their views on the European market. 
In order to understand how the networks' different aims and membership (European, Transatlantic, Europe-US-Japan) affected the discussions on the European market, the network debates are placed in a comparative perspective. Each empirical chapter (4, 5 and 6) will thus juxtapose the views expressed in the networks under discussion to find out whether relevant differences existed and to determine how these differences can be explained.

A comparative approach requires a significant amount of additional context, on two levels. At a more general level the interpretation of activities, views and perceptions of European business within the three networks firstly requires a comparative awareness of their histories, organizational structure, goals and thematic preoccupations. Especially an awareness of the differences between the networks is of importance. Where possible this book draws on previous research about the networks. As will become clear the consultation of new archival sources on the networks has also generated new insights on the histories and achievements of these networks.

Moreover, in order to gain an overview of the importance of businessmen in the work of the networks, a database mapping the composition of their leadership was created. The database includes information on membership and on biographical details. It identifies the characteristics of actors regarding nationality, professional affiliation, industrial typology and their position in a selection of societal spheres. ${ }^{14}$

The views of European business are investigated through an analysis of the debates that were held within the networks' meetings. Information on such meetings is available via minutes, correspondence, publications and policy papers that reflect the networks' main activities. An interpretative framework is employed that on the one hand considers national and on the other hand sectoral contexts for explaining views. In support of this interpretive goal, chapter three will give background information on companies that played a major role in the three networks.

\section{Chronological subdivision and thematic choices: cases}

This investigation covers the period going from 1950 until 1980. The beginning of this period marks the birth of concrete proposals for the integration of European markets, starting with the Schuman Plan. The end of the period is based on the foundation of the European Round Table of Industrialists (ERTI) in 1983. Investigations on the ERTI have already resulted in extensive knowledge on the views of European business on the European market for the 1980s. According to several scholars the ERTI marked a discontinuity of how European multinationals shaped their relations with the European Community. Our investigation from 1950 until

\footnotetext{
${ }_{14}$ See chapter 2 for a discussion of some results of this database, and the Appendix for a complete introduction into its structure and sources.
} 
1980 provides a rich background for discussing whether this indeed was the case. $^{15}$

As this book covers a long period and involves a comparative perspective on three organizations, some reduction of complexity is required. The mere quantity of available material and subjects prevents one from investigating all possible angles within the scope of a PhD thesis. It was therefore decided to divide the period from 1950 to 1980 into three sub-periods of one decade each, and to select one major theme per decade that played a role in all networks during the same period. These three cases should reflect typical topics that preoccupied business at that time, in particular concerning the European market. The cases should therefore also be broad enough to affect or encompass most industrial sectors. It has to be stressed that the goal of comparing the debates of the networks requires a selection of cases that were more or less simultaneously under discussion in both or all three networks. ${ }^{16}$

The population of cases to choose from was large. From 1950 to 1980, the ELEC published approximately 60 reports. The Bilderberg meetings discussed about five subjects at each of the 28 meetings between 1954 and 1980 . However, half of the agenda items on the Bilderberg meetings were considered less relevant for our purpose, due to their strong focus on international security. The other, relevant share focussed largely on international economic affairs. The Trilateral Commission published 19 reports from 1972 until 1980 with a large variety of subjects. ${ }^{17}$

Instead of choosing small cases of one publication or agenda item, the choice was made to select themes that encompassed several publications and agenda items per decade. This way a reasonable representation of the priorities of the organizations could be assured. Given the mentioned constraint due to comparability across the networks, what options were available and what factors determined the final selection?

\footnotetext{
${ }^{15}$ See for an illustration of the commonality of seeing the ERT as a break with the past for multinational lobbies: Green Cowles, M. G. (1996). Business means Europe. Who built the market? In M. Bond, J. Smith \& W. Wallace (Eds.), Eminent Europeans: personalities who shaped contemporary Europe (pp. 192-213). London: The Greycoat Press, p. 193. Coen, D. (1997). The evolution of the large firm as a political actor in the European Union. Journal of Public Policy, 4, 91-108, pp. 92-93; Gehler, M., Kaiser, W. \& Leucht, B. (2009). Networks in informal European governance. Diachronic perspectives on the European Union as a multi-level polity. In M. Gehler, W. Kaiser, \& B. Leucht (Eds.), Netzwerke im europäischen Mehrebenensystem. Von 1945 bis zur Gegenwart = Networks in European multi-level governance. From 1945 to the present. (pp. 9-26). Wien: Böhlau, p. 23.

${ }^{16}$ Gerring, J. (2007). Case study research: principles and practices. Cambridge: Cambridge University Press, pp. 91-92, 164.

${ }_{17}$ See Sources for complete lists of publications of the European League for Economic Cooperation and the Trilateral Commission. An overview of the agenda items of the Bilderberg meetings from 1954 until 1985 can be located at: Nationaal Archief (1988). Inventaris van het archief van de Bilderberg Conferenties: Secretariaat, 1952-2004. Den Haag: Nationaal Archief. Retrieved August 20, 2013, from http://gahetna.nl/collectie/archief/pdf/NL-HaNA_2.19.045.ead.pdf, pp. 7-14.
} 
For the period of the 1950s the following options were available. Recurrent themes in the Bilderberg meetings were European economic integration, the position of developing countries in the international economy and a less recurrent theme of energy (nuclear energy, the Middle East). Energy and the relations with developing countries were only incidental subjects for the ELEC and were treated as peripheral to the subject of the Common Market, whereas European economic integration clearly was a dominant theme in most ELEC publications. European market integration thus became the obvious choice due to its sufficient broadness, and opportunities for comparison. Moreover a clear relevance for European corporations existed, based on the earlier mentioned restructuring plans that multinationals developed around proposals for economic integration. ${ }^{18}$

During the 1960s the ELEC focussed on several subjects. In terms of publications the subject of East-West trade stood out as a major theme. Additionally a publication was dedicated to transport policy and two to monetary integration. However, a reconnaissance of ELEC's archives made clear that another topic had dominated its proceedings without resulting publications: the European response to American investments. Moreover, as will be argued in chapter 5, the themes of East-West trade and American investments emerged on ELEC's agenda as the result of an explicit consultation process among business leaders. During the same period the Bilderberg meetings combined four different economic subjects: economic relations with the Communist countries, trade relations with the developing countries, international monetary cooperation, and the tensions that resulted from American investments in Europe. East-West trade, monetary integration and American investments offered opportunities for comparison. At the same time each single subject seemed rather limited as a broader theme. Because the subjects on East-West trade and American investments had so clearly emerged from a consultation among European business leaders as urgent issues, both these subjects were selected. The subject of monetary integration was thus not selected because corporations deemed it less salient to their experiences of the Common Market. As will be seen in chapter 5 however, the theme of American investments in Europe was tied to French frustrations on the US government's behaviour within the Bretton Woods system. Clearly, themes were connected to each other in a variety of ways, but choices had to be made to remain within the scope of a dissertation. ${ }^{19}$

For the 1970s the selected theme required comparison across three networks simultaneously. The 1950s and 1960s offered plenty thematic overlap between the organizations but this was not the case for the 1970s. Unlike the Bilderberg meetings and the Trilateral Commission, the ELEC did not publish on monetary affairs. ELEC's interest in European institutional subjects were ignored by the other organizations. The Trilateral Commission discussed several major economic subjects of global relevance such as tensions in global trade or regulations on oceans that

\footnotetext{
18 Ibidem.

${ }^{19}$ Ibidem.
} 
were not discussed in the other networks. Another interesting aspect is that during the 1970s according to scholars such as Sandholtz \& Zysman the priority for European corporations was Japanese competition in sophisticated technologies. Surprisingly the theme did not come up in the three networks. The only major theme that was explicitly and repeatedly discussed in all networks was energy security. The topic of energy security was moreover sufficiently representative of major developments in the 1970s. Moreover, the subject was likely to have affected a range of European multinationals. ${ }^{20}$

Surprisingly, subjects with regard to the European labour market were barely discussed in the three networks and never simultaneously. In 1951 the ELEC did discuss the mobility of labour in the context of the European Coal and Steel Community. Moreover, in 1957 the subject of social security in relation to the founding of the Common Market was discussed. The Bilderberg meetings never paid attention to these subjects. In 1979, the Trilateral Commission paid attention to the subject of collective bargaining and employee participation. But none of these examples offered an opportunity for comparison with the other networks. ${ }^{21}$

These considerations result in the following selection:

Table 1.1: Themes investigated within the transnational networks.

\begin{tabular}{lll}
\hline Period & Subject & Networks \\
\hline $1950-1960$ & European market integration & ELEC \& Bilderberg meetings \\
$1960-1970$ & US investments; East-West trade & ELEC \& Bilderberg meetings \\
$1970-1980$ & Energy security & ELEC, Bilderberg meetings \& Trilateral Commission \\
\hline
\end{tabular}

1950-1960 European market integration: the theme is ideal for understanding business views on the European market. During the 1950s the governments of the Benelux, France, Italy and Germany made great strides towards Western European economic integration. Several models of approaching economic integration in Europe were subject to extensive review. Moreover the question of which role supranational institutions should play in the organization of markets was discussed. In addition the size of the European market was a recurrent issue. Moreover, these issues were informed by broad debates on liberalization and the question on the degree of freedom of entrepreneurship that should be allowed in the European market.

\footnotetext{
${ }^{20}$ Ibidem. Sandholtz \& Zysman (1989). Recasting the European Bargain.

${ }^{21}$ LECE (1951). La mobilité des travailleurs en Europe occidentale (Vol. 8). Bruxelles: LECE. ELEC (1957). European integration and social security (Vol. 23). Brussels: ELEC. Roberts, B. C., Okamoto, H., \& Lodge, G. C. (1979). Collective bargaining and employee participation in western Europe, North America and Japan: report of the trilateral task force on industrial relations to the Trilateral Commission (Vol. 18). New York: The Trilateral Commission.
} 
1960-1970 US investments / East-West Trade: together these subjects represent a theme of external competition for the industries already present in the EEC. The founding of the European Common market in 1958 had triggered increasing investments from multinationals from the United States. Due to their size they had a competitive edge over the markedly less sizeable multinationals in Europe. European companies feared to become marginalized by American competition in their home markets. On the opposite flank of the Common Market the relaxation of economic relations with the East-bloc was causing problems. Western European governments increasingly extended export loan guarantees to European banks in order to finance capital goods exports to Eastern Europe. Companies that exported capital goods profited from this state of affairs. Others however were facing fierce competition. An external trade policy for the EEC however did not exist.

1970-1980 Energy security: the oil crisis of 1973-1974 turned international oil trade relations into an important aspect of international politics. Industry in Europe, Japan and the United States now had to cope with energy shortages and unprecedented price hikes. The European Community lacked a common energy policy and had almost no control over the supply of feedstocks. As will become clear, in order to improve their positions in the global marketplace Western European industries tried to push the topic on the European and international policy agenda.

It is important to stress that it is not the goal of this investigation to study these themes exhaustively. Instead, the goal is to explore the above-mentioned themes to gain a better understanding of views of multinationals on the European market.

\section{Sources $^{22}$}

This project is partly based on the institutional papers of the ELEC, the Bilderberg meetings and the Trilateral Commission. The selected archives typically include minutes of meetings, correspondence and publications.

The European League for Economic Cooperation: the institutional archive of ELEC covers the period from 1946 to 1985 and is located at the University of Louvain-la-Neuve, Belgium. From 1950 onwards it contains a complete collection of minutes of ELEC's international governing body, the Central Council. Additionally it includes preparatory documents for meetings, minutes of the meetings of ELEC's several committees and correspondence of the secretary-general on behalf of ELEC's president. All the documents of the archive are accessible. ELEC's publications can be acquired via several European libraries.

The Bilderberg meetings: the institutional archive is located at the National Archive in The Hague, The Netherlands. However, only documents older than fifty years can be accessed. The archive therefore could only provide the documents for

${ }^{22}$ For an inventory of archival sources and published sources, see the section Sources, following Chapter 7. 
the period from 1952 until 1962. It contains correspondence, Steering Committee minutes and incidentally verbatim reports of conferences. Fortunately, the documents could be supplemented with material from a similarly endowed archive of Otto Wolff von Amerongen, a German steel products trader. The archive is located at the Rheinisch Westfälisches Wirtschaftsarchiv in Cologne, Germany. The basic material for investigation are the Bilderberg conference reports which contain elaborate summaries of the debates that were held during the meetings. These however do not contain contributions of specific individuals. A substantial share of the reports is available through libraries across Europe and the United States.

The Trilateral Commission: the institutional archive of the Trilateral Commission's North American section is located at the Rockefeller Archive Center in Sleepy Hollow, New York, the United States. The archive includes minutes of Executive Committee meetings, Chairmen meetings, reports of plenary meetings and correspondence on the entire drafting processes of the Trilateral Commission's policy studies. Due to "preservation concerns" however, restrictions were imposed on documents of some key individuals such as Zbigniew Brzezinsky, Gerard C. Smith and early Trilateral Commission correspondence. The Trilateral Commission's policy papers, the Triangle papers, and its US-based periodical on Trilateral affairs, Trialogue are available through libraries.

Additionally, a small amount of interviews was conducted. They were especially valuable in yielding insights about the involvement of businessmen in the selected networks.

\section{Historiography: a terrain at a crossroads of disciplines}

The views of business with regard to European integration as a research theme is related to several sub-disciplines. Roughly three major areas can be identified: political science with a focus on European integration, the history of European integration, and business history. The following sections review the literature about business-views on the European market within and between these subdisciplines. The main motives and direction for this dissertation are highlighted in the process. Additionally, the historiography of the three transnational networks will be discussed. Finally an assessment is made whether these networks can be compared to typical business associations and other forms of post-war transnational organization of business.

\section{Role of business in European integration theory}

Integration theorists have forwarded several interpretations of the role of business in European integration. These insights are important as they help in identifying 
implicit theoretical angles in historical analyses. Moreover, they offer anchors for reflection on empirical findings, particularly in our concluding chapter 7.

Since the 1950s, theorists of regional integration have tried to explain and predict the processes that were unfolding in Europe. Originally the domain of integration studies was the area of theorists of international relations working from the perspective of functionalism. The key representative of these ideas was David Mitrany who worked on the question of how lasting international institutions should be realized in order to create an enduring peace. ${ }^{23}$

The founding of the European Coal and Steel Community in 1952, kick-started a specific branch of integration theory in which Europe became the dominant case. In 1958 the first comprehensive theory of regional European integration was presented by Ernst B. Haas. He argued that the creation of a supranational institution such as the ECSC's High Authority could start a process in which actors that were normally involved in decision-making within the member states would "shift their loyalties, expectations and political activities toward a new centre." These decision-makers, or elites as Haas called them, typically included members of public administration, politics, organized labour and, central to the concern of this book, organized business. ${ }^{24}$

Haas also introduced the concept of spill-over. It refers to a continuous process that begins after an institution executes its initial task. According to the concept, this first act inherently results in a situation that requires a solution in the form of imposing extra tasks on the institution. The spill-over concept was thought of as a continuous force that would create a cascade of shifting loyalties of elites and the representation of interests away from the nation state, towards supranational institutions. ${ }^{25}$

In this way neo-functionalist theory attributed an influential role to societal interests in general, including business interests. However, the early integration theorists were not interested in the perception, motives and strategies of business as such. Their investigations into the role of business in this process mainly focussed on the institutional orientation of organized business in relation to the changes of the European political-economic system. They were looking for evidence whether organized business actually directed their activities, loyalties and expectations to supranational institutions. This reduction of organized business to its structure, form and function is not uncommon for political scientists that nowa-

\footnotetext{
23 Rosamond, B. (2000). Theories of European integration. Basingstoke: Macmillan Press, pp. 31-36.

${ }^{24}$ Haas, E. B. ([1958]1968). The uniting of Europe: political, social and economical forces, $1950-' 57$. London: Stevens, pp. 9-10, 16-17.

${ }^{25}$ Lindberg, L. N. (1963). The political dynamics of European economic integration. Stanford: Stanford University Press, pp. 10-11.
} 
days investigate practices of interest representation in the European Union. An interest in the actual business-perspective is largely absent. ${ }^{26}$

An alternative explanation of European integration was offered by Stanley Hoffmann in 1964 and more comprehensively in 1966. He conceptualized European integration from a realist perspective, which also originated from international relations theory. This became known as intergovernmentalist integration theory: Hoffmann explained that any progress in European integration was entirely determined by and under control of state actors who firmly guarded the calculated interests of the nation state. Business interests or any other non-state interests played no direct role in this theory because the state was seen as the mediator of all interests. Intergovernmentalist theory gained much recognition, especially due to its contribution to explaining the anti-supranationalist motives of the French President de Gaulle during the 1960s. ${ }^{27}$

In the face of intergovernmentalist intellectual criticism, neo-functionalist theory was not abandoned but adapted and business was given a different role in it. In the 1970s, Werner Feld emphasized the function that European multinationals could perform in the integration of the largely separate national economies. By means of transnational collaboration and international mergers they contributed to economic integration of the European market. At the same time he concluded that transnational collaboration between European multinationals was being blocked by Community Member States in order to protect their national economies. According to neo-functionalist theory, transnational behaviour by European firms could lead to spill-over pressures which prompted Feld to claim that the member states were interfering with tendencies towards European integration. By contrast, in 1975 Erwin Häckel concluded that European multinationals had little reason to merge with firms from other countries within the European market. According to him, the export of goods had become so attractive within Europe that instead of forming pan-European collaborations, they opted for expanding their production facilities in their home-markets and exporting the surplus that the home-market would not absorb. Additionally, they focussed their investments outside the EEC, according to Häckel. More important than the outcome of these studies was how its respective authors implicitly viewed the function of business in the integration process: business was still seen as a potentially integrative force, but now due to

\footnotetext{
${ }^{26}$ Examples are Greenwood, J., \& Aspinwall, M. (Eds.) (1998). Collective action in the European Union: interests and the new politics of associability. London: Routledge; Greenwood, J. (2007). Interest representation in the European Union. Basingstoke: Palgrave.

${ }^{27}$ Hoffmann, S. (1964). De Gaulle, Europe, and the Atlantic alliance. International Organization, 18, 1-28; Hoffmann, S. (1964). The European process at Atlantic crosspurposes. Journal of Common Market Studies, 3, 86-101; Hoffmann, S. (1966). Obstinate or Obsolete? The Fate of the Nation State and the Case of Western Europe. Daedalus, 95, 862-915.
} 
its competitive and international behaviour instead of its institutional orientation. ${ }^{28}$

During the 1970s neo-Marxist integration theorists developed similar ideas about the relation between multinationals and European integration. In terms of neo-Marxist theory, European integration is an effect of, or a response to the internationalization of economic activity and an increasing development of production forces. In 1978 Axt argued that EEC member states were forcing national capital into productive applications within the state. However, to allow integration to take place they should let businesses seek added-value for their capital outside the state instead. By channelling capital towards national investments, economic relations within the EEC remained politicised. So also in neo-Marxist theory business was seen as a potential force of economic integration. ${ }^{29}$

Summing up, until the late 1980s integration theorists presented the relation between European business and European integration in rather abstract terms. Neo-functionalist theorists stressed the functional reorientation of organized business towards supranational institutions on the one hand, and the efforts of business to realize economic integration by means of collaboration or foreign direct investments on the other hand. Ideas about what European integration meant to individual firms were limited to theoretic considerations of how the firm in general acts in processes of international economic integration.

It was not until 1989 that the first more empirically informed investigation of business-preferences and political behaviour in European integration surfaced. Sandholtz \& Zysman rekindled the integration theory debate between neofunctionalists and intergovernmentalists by investigating the strategic lobby of European business leaders in favour of the European Single Act, a treaty between Community member states signed in 1986. Sandholtz \& Zysman explain how leaders of Europe's largest industrial companies were mobilized by the European Commission in order to co-initiate, co-define and forward the goal of a single market. As a result the companies became organized as the European Round Table of Industrialists (ERTI) and joined the European Commission in its effort to persuade the member states. According to the authors the industrialists had no choice: competition from Japanese firms forced them to realize lower production costs by concentrating production. However, the concentration of European industry was hindered by intra-Community protectionism. The completion of the single market was expected to solve this problem. By acknowledging an important role for the ERTI in bringing about the treaty, Sandholtz \& Zysman reintroduced the force of elites and argued that a new concept of "elite bargains" could significantly improve

\footnotetext{
${ }_{28}$ Feld, W. J. (1970). Transnational business collaboration among common market countries. Its implication for political integration. New York: Praeger; Häckel, E. (1975). Multinationale Konzerne und Europäische Integration. Bonn: Europa-Union Verlag.

${ }^{29}$ Axt, H.-J. (1978). Staat, multinationale Konzerne und politische Union in Westeuropa: ein Beitrag zur Staatstheorie und Analyse regionaler Integration. Köln: Pahl-Rugenstein.
} 
our understanding of the European integration process. Business-motives now entered the debate. ${ }^{30}$

Their renewed focus on the role of elites sparked a fierce academic debate. In 1991 to intergovernmentalist theorist Andrew Moravcsik argued that the ERTI business leaders had entered the process of consensus formation among member states too late to affect it. Instead he argued how converging state interests had resulted in the treaty. In later years, Moravcsik did incorporate the role of business interests in the process of preference formation, but he only acknowledged a contribution of business on the domestic level of states. In doing so Moravcsik designed an initial version of a liberal intergovernmentalist theory. Now business was thus also understood as affecting European integration from an intergovernmentalist viewpoint, but only through mediation of the member states. ${ }^{31}$

Maria Green Cowles investigated the ERTI more closely and observed that industrialists had shaped positions on the national and supranational level simultaneously. Green Cowles argued that neither intergovernmentalist nor neofunctionalist integration theory could properly explain the political role that business leaders had performed. As the earliest theorists of neo-functionalism had explained, it was anticipated that organized business would shift its lobbies to supranational institutions. But according to Green Cowles they had gone beyond traditional styles of interest representation. By building consensus between governments and supranational institutions, while influencing public opinion through the media, they had turned into political actors in their own right. ${ }^{32}$

Sandholtz \& Zysman and Green Cowles have expanded the role of business in European integration theory: these authors no longer perceived the role of business as limited to the form and function of their organization, or to a role assigned to them based on pluralist political theory and neo-functionalist integration theory. In these more recent accounts, motives and views of business matter. The most important innovation that these authors added to the debate was the new perception of business as political actors in their own right. This enables a different approach to studying business, also for the period that preceded the founding of the European Round Table of Industrialists. As any other societal entity European business developed its own ideas about European integration and contributed to the development of ideas in the broader political landscape.

\footnotetext{
${ }^{30}$ Sandholtz \& Zysman (1989). Recasting the European Bargain.

${ }_{31}$ Moravcsik, A. (1991). Negotiating the Single European Act: National interests and conventional statecraft in the European Community. International Organization, 45, 19-56; Moravcsik, A. (1993). Preferences and power in the European Community: a liberal intergovernmentalist approach. Journal of Common Market Studies, 41, 473-524.

${ }^{32}$ Green Cowles (1995). Setting the agenda.
} 
Until recently, historians of European integration paid little attention to business ideas on European integration. Until well into the 1990s the dominant historiography on European integration was focussed on national diplomatic histories. The perspectives of the nation states dominated such approaches. During the 1990s a differently informed approach of investigating Europe emerged from an increasing interest in cultural history. In 1995 the interdisciplinary sociologist Gerard Delanty introduced an awareness of the role of ideas and identity in the historiography of Europe with his Inventing Europe. Idea, identity, reality. In 1998 Peter Rietbergen presented a cultural history of Europe and in 2002 several scholars in Anthony Pagden's edited volume The idea of Europe. From antiquity to the European Union investigated changing conceptions of Europe in multiple periods and contexts. Instead of tracing the political origins of European integration these authors tried to explain how broad cultural notions of Europe had changed in the past. ${ }^{33}$

Only as part of a broader interest in the economic dimension of European integration did an interest in the positions of business emerge, albeit gradually. Economic history first began to play a serious role in explaining European integration through the work of Alan S. Milward. In 1984 he presented an economically informed account of the immediate post-war years, in which he argued how the Schuman Plan had become an economic peace settlement for Western Europe. Additionally, in 1992 his influential The European rescue of the nation-state argued that European nation states had chosen to integrate their economies during the 1950 s in order to defend their key industrial bases. Milward demonstrates how the governments based their decisions on developments in the most important national industries. But in Milward's accounts only states were presented as mediators of such interests. Economic actors such as businessmen merely fulfilled a passive role in these state decisions. Milward's presentation thus includes important characteristics of intergovernmentalist theory. ${ }^{34}$

Also during the 1980s, other historians such as Werner Bührer, Ruggero Ranieri and Philippe Mioche started to approach the economic aspects of European integration from a perspective of business interests. Investigations were undertaken on how the steel industries of especially France and Germany had dealt with the coal and steel focussed Schuman Plan. The Schuman Plan and the coal and steel sector-based competences of the High Authority resulted in a clear focus on those industries. This did not mean that these authors were working from a transnational industrial perspective however. The perspective of the nation state was still dom-

\footnotetext{
33 Delanty, G. (1995). Inventing Europe. Idea, identity, reality. Basingstoke: Macmillan; Rietbergen, P. (1998). Europe. A cultural history. London: Routledge; Pagden, A. (Ed.). (2002) The idea of Europe. From antiquity to the European Union. Cambridge University Press.

34 Milward, A. S. (1984). The reconstruction of western Europe, 1945-1951. Berkeley: University of California Press; Milward (1992). The European rescue.
} 
inant in these accounts. Coal and steel were of such a strategic importance to any country that the interests of national industries and the interests of the nation state appeared to be similar, hybrid even. ${ }^{35}$

This national perspective in the investigation of business in relation to European integration remained dominant until the late 2000s. It is important to note however that a change in scholarly interest occurred. The focus of investigations shifted from the Schuman Plan to the Rome Treaties and the subsequent founding of the European Economic Community. In an attempt at singling out the business interests that were involved in the run-up to the founding of the EEC, historians directed their attention to national umbrella business associations. These organizations represented a multitude of industries, each fostering expectations about how the future market organization might affect them. Authors such as Werner Bührer, Marine Toursel, and Neil Rollings demonstrated the close relations between national business interests and national governments. By focussing on national umbrella associations of industry, the analysis of European business inevitably resulted in a focus on national preference formation processes regarding the future of national economies. In these preference formation processes the state was the key aggregator of interests. The scholars confirmed the perspective of the nation state as central actor in European integration by choosing national centres of preference formation for an investigation on the role of business in European integration. ${ }^{36}$

A first sign of an alternative approach in the investigation of European business was introduced in the early 1990s by Eric Bussière and Michel Dumoulin. They aimed at identifying European economic elites such as economists or businessmen, their views, identities and transnational activities regarding European

\footnotetext{
${ }^{35}$ See for an alternative perspective: Berger, F. (2011). Premières approches historiques sur l'intégration économique européenne: une réflexion sectorielle. In Badel, L. \& Michel, H. (Eds.), Patronats et intégration européenne: pour un dialogue disciplinaire raisonée (pp. 17-40). Paris: Harmattan. On the coal and steel industries: Bührer, W. (1986). Ruhrstahl und Europa. Die Wirtschaftsvereinigung Eisenund Stahlindustrie und die Anfänge der europäische Integration (1945-1952). Munich: Oldenburg; Mioche, P. (1988). Le patronat de la Sidérurgie francaise et le Plan Schuman en 1950-1952: les apparences d'un combat et la réalité d'une mutation. In K. Schwabe (Ed.), Die Anfänge des Schuman-Plans. 1950/51 (pp. 305-318). Baden-Baden: Nomos; Ranieri, R. (1988). The Italian Steel Industry and the Schuman Plan negotiations. In K. Schwabe (Ed.) (1988). Die Anfänge des Schuman-Plans. 1950/51 (pp. 345-356). Baden-Baden: Nomos. Gillingham (1991). Coal, steel.

${ }^{36}$ Key examples are: Bührer, W. (1992). Der Bundesverband der Deutschen Industrie und die Aussenpolitik der Bundesrepublik in den fünfziger Jahren. In Viertelsjahrshefte für Zeitgeschichte, 40, 241-261. Bührer, W. (1995). German Industry and European Integration in the 1950's. In C. A. Wurm (Ed.), Western Europe and Germany: the beginnings of European integration, 1945-1960. Oxford: Berg Publishers. Leitolf, J. (1996). Wirtschaft, Verbände, Integration: britische Industrie und westeuropäische Integration von 1945 bis 1975. Bochum: Brockmeyer. Rhenisch, T. (1999). Europäische Integration und Industrielles Interesse. Die Deutsche Industrie und die Gründung der Europäische Wirtschaftsgemeinschaft. Stuttgart: Franz Steiner; Moguen-Toursel, M. (2002). L'ouverture des frontières européennes dans les années 50: fruit d'un concertation avec les industriels? Bruxelles: P.I.E. Lang; Rollings, N. (2007). British business in the formative years of European integration, 1945-1973. Cambridge: Cambridge University Press.
} 
integration. Michel Dumoulin and Anne-Myriam Dutrieue's work on the European League for Economic Cooperation (ELEC) and the Comité européen pour le progrès économique et social (CEPES) which focussed on the ideas of businessmen, economists and public administrators, was particularly significant for the subject of this dissertation. However, as a result of their focus on individuals, both accounts remained detached from business practices and from the experiences and preferences of corporations and multinationals. Instead, ELEC and CEPES were presented as expressions of a liberal ethos that fostered ideas on rejecting a European institutional order with interventionist powers. ${ }^{37}$

The results of Bussière's and Dumoulin's research are difficult to summarize. Rasmussen concludes that the project appeared to have no outcome. It resulted in a diversity of empiric observations that were difficult to turn into a narrative. According to Rasmussen the lack of an underlying concept or theory about the place of individual ideas, identity and ideology in the process of European integration made this rather impossible. Nevertheless the project was an interesting attempt at going beyond the national and state-central approaches to the history of European integration, particularly with regard to European business. ${ }^{38}$

Since the mid-2000s, a new and broad research agenda has gained shape around a conception of European history that moves beyond the nation state that has significantly influenced the investigation of European business narratives of European integration. This broad agenda was energized by three different, yet related approaches. A first step in this direction was formulated in 2006 by two historians of technology: Thom Misa and Johan Schot. They proposed to investigate the integration of Europe through the lens of technology in order to write a "history of the technological shaping of Europe." They suggested to investigate instances of "linking" of technological or infrastructural networks throughout Europe and beyond, to follow the "circulation" of people, ideas, objects, companies, and the "appropriation" of their meanings in different contexts as they circulate. Such an approach could identify the shaping of new identities within and throughout Europe. Their intention was to start from the question of how technology shaped

${ }_{37}$ Dumoulin, M., \& Dutrieue, A.-M. (1993). La Ligue Européenne de Cooperation Économique (19461981): un groupe d'étude et de pression dans la construction européenne. Berne: Lang. Dutrieue, A.-M. (1993). Le CEPES, un mouvement patronal européen? (1952-1967). In M. Dumoulin \& R. Girault (Eds.), L'Europe du patronat: de la guerre froide aux années soixante: actes du colloque de Louvain-la-Neuve des 10 et 11 mai 1990 (pp. 213-230). Berne: Lang.

${ }^{38}$ For a discussion of this approach see: Rasmussen, M. (2010). European rescue of the nation-state? Tracing the role of economics and business. In W. Kaiser \& A. Varsori (Eds.), European Union history: themes and debates (pp. 128-149). Basingstoke: Palgrave Macmillan. See for examples of this approach: Bussière, E., \& Dumoulin, M. (Eds.)(1998). Milieux économiques et intégration européenne en Europe occidentale au XXe siècle. Arras: Artois presses université; Bussière, E., Dumoulin, M., \& Schirmann, S. (Eds.) (2006). Milieux économiques et intégration européenne au XXe siècle: la crise des années 1970. Bruxelles: P.I.E. Peter Lang; Bussière, E., Dumoulin, M., \& Schirmann, S. (2009). The development of economic integration. In Wilfried Loth (Ed.), Experiencing Europe. 50 years of European construction, 1957-2007 (pp. 45-101). Baden-Baden: Nomos. 
Europe and write a transnational history in which the nation-state becomes a subordinate factor. Due to their Europe-wide activities in introducing technologies business corporations in particular play an interesting role in these investigations. This initiative by Schot and Misa has led to a very productive Europe-wide research collaboration, first under the flag of "Tension of Europe", later followed by the programmes "Inventing Europe" and "Making Europe." Several book-length studies are just being published, or will appear soon. ${ }^{39}$

The second example of a research agenda for a transnational history of European integration stays closer to the political history of the European Union. In 2009 Wolfram Kaiser, Brigitte Leucht, Michael Gehler and Morten Rasmussen introduced the notion of "political networks." In differentiating that concept from network-concepts originating from political science, such as "policy networks," they argue that political networks denote a broader, more general and at the same time more informal "set of actors engaged in communication and cooperation which is geared towards shaping the political organization of social life." In choosing this definition they advocate a reliance on contextualized narrative instead of depending on narrowly defined ideal types as is often done in network approaches in political science. An example of such a transnational political network is the post-war transnational party organization of European Christian democrats, investigated by Kaiser. He argued that between 1947 and 1955, European Christian democrats had not only cemented transnational political relations, but were also able to mobilize these relations for collective interpretation and the formation of preferences regarding European integration. The networks were also used to build transnational and strategic alliances with other political forces and public administrators of the negotiating European governments, thereby influencing the direction of European treaties. ${ }^{40}$

Kaiser and his co-authors study political networks as an aspect of the European Union or its earlier forms. They see these networks as immersed in an emerging "supranational polity" or "a supranational political space." With those concepts they refer to exchanges between networks of a multitude of actors who are involved in "advancing their ideas and material interests, influencing European policy-making or transferring institutional rules and practices between memberstates." These exchanges include the activities of the actors from European institu-

\footnotetext{
${ }^{39}$ Misa, T. J. \& Schot, J. (2006). Inventing Europe: technology and the hidden integration of Europe. History and Technology, 21, 1-19, pp. 9-10. http://www.tensionsofeurope.eu/; http://www .inventingeurope.eu/; http://europeinterrupted.eu/invent/; http://www.makingeurope.eu/.

${ }^{40}$ Kaiser, W. (2007). Christian democracy and the origins of the European Union. Cambridge: Cambridge University Press. Kaiser, W. \& Leucht, B. (2008). Informal politics of integration: Christian Democratic and Transatlantic networks in the creation of ECSC core Europe. Journal of European integration history, 14, 35-50, pp. 46-49; Kaiser, W., Leucht, B \& Rasmussen, M. (2009). Origins of a European polity. In W. Kaiser, B. Leucht \& M. Rasmussen (Eds.), The history of the European Union: origins of a trans- and supranational polity 1950-1972 (pp. 1-11). New York: Routledge, pp. 6-7. Gehler, Kaiser \& Leucht (2009). Networks in informal European governance, pp. 4, 17.
} 
tions and member states. This "space" in which ideas and ideology on the European Community were exchanged, tested and negotiated, offers an alternative to the established approach of investigating the policies of supposedly coherent states, investigations on national preference formation processes and intergovernmental negotiations. ${ }^{41}$

Examples of this approach include highly diverse networks. Political party networks, but also social networks that were concerned with the formation of the EU agricultural policy or monetary policy have been investigated. Additionally, results that were already published before the seminal studies by Kaiser and his co-authors are now seen as belonging to that approach. Examples include work by Valérie Aubourg on the Bilderberg meetings, which also plays a significant role in this book, and the work of Maria Green Cowles on the European Round Table of Industrialists. Another example is Sigfrido M. Ramírez Pérez' work on a transnational network of the European automotive industry. During the 1970s that network attempted to persuade the European Community to adopt collective European technical safety standards. Whereas this contribution would hitherto have been more at home in an edited volume on business history, it now found a place in a volume on the transnational history of the European Union. ${ }^{42}$

A third and final research agenda for shaping a transnational history of Europe was suggested by Ulrike von Hirschhausen and Kiran K. Patel in 2010. They redefined the concept of Europeanization, originally coined by social and political scientists to indicate transformations in Europe that were the result of the European integration process. From the perspective of historical research they propose to investigate "to what extent the history of Europe can be conceptualized in terms of processes of Europeanization", or in other words, how Europe was "imagined" in cultural expressions, "constructed" through the formation of infrastructure or spaces through social practices, or at those instances when practices or events unintentionally became European without immediately receiving that label. This

\footnotetext{
${ }^{41}$ Kaiser, Leucht \& Rasmussen (2009). Origins of a European polity, pp. 6-7; Gehler, Kaiser \& Leucht (2009). Networks in informal European governance, pp. 4, 17.

${ }^{42}$ Aubourg, V. (2009). Transatlantische Geschäftsbeziehungen. Die Bilderberg-Gruppe. In M. Gehler, W. Kaiser, \& B. Leucht (Eds.), Netzwerke im europäischen Mehrebenensystem. Von 1945 bis zur Gegenwart = Networks in European multi-level governance. From 1945 to the present. (pp. 69-86). Wien: Böhlau; Green Cowles, M. (2009). The European Round Table of industrialists and the single market programme. From political to policy network. In M. Gehler, W. Kaiser, \& B. Leucht (Eds.), Netzwerke im europäischen Mehrebenensystem. Von 1945 bis zur Gegenwart = Networks in European multi-level governance. From 1945 to the present. (pp. 139-150). Wien: Böhlau; Ramírez Pérez, Sigfrido M. (2009). Transnational business networks propagating EC industrial policy: The role of the Committee of Common Market Automobile Constructors. In W. Kaiser, B. Leucht \& M. Rasmussen (Eds.), The history of the European Union: origins of a trans- and supranational polity 1950-1972 (pp. 74-92). New York: Routledge.
} 
approach practically subsumes the aforementioned approaches into one, covering "the plurality of forms of Europeanization." 43

In these three complementary approaches and conceptualizations of European history, transnational actors, ideas and meanings that go beyond the nation state or national borders become the central focus of research. In such a perception of European history, global influences may link up with European or national identities and fuse into more hybrid entities. Kiran K. Patel and Johan Schot have successfully shown how such transnational ideas and meanings of particularly transnational actors played a role in decision-making outcomes regarding the agricultural and transport policies of the European Union. Their work indicates that the historical investigation of the views of business actors on the European market can contribute to a better understanding of how such ideas have played a role in decision-making processes on European integration. ${ }^{44}$

Over the years the investigation of business as part of European integration history has developed significantly. Since the 1990s business was interpreted as a factor in explaining national motives with regard to European integration. Later the investigation of European businessmen was undertaken in order to identify liberal ideas about the organization of the European Union. The interpretation of these ideas however remained detached from the actual experiences of European businesses. Since the mid-2000s the research agenda on the history of Europe has changed though. The focus on the formation of ideas, meanings and the activities of transnational actors give the nation state a secondary role within the field of European integration history. Moreover, these approaches have introduced the conceptual flexibility that is necessary for linking European and international influences. The investigation of the ideas of businessmen on the emerging European market is ideally suited to contribute to the transnational history and to a better insight into the Europeanization of Europe.

\section{Business history and European integration}

A third important discipline for this historiographical overview is that of business history. Business historians can contribute significantly to a better understanding of the formation of business views on the European market. Until now only a few business historians have shown an interest in the relation between European integration and business though. Moreover, results remained largely isolated from the abovementioned debates on the history of European integration. Some investiga-

\footnotetext{
${ }^{43}$ Hirschhausen, U. von \& Patel, K. K. (2010). Europeanization in history: an introduction. In M. Conway \& K. K. Patel (Eds.), Europeanization in the twentieth century. Historical approaches (pp. 1-18). Basingstoke: Palgrave Macmillan, pp. 1, 7-12.

${ }_{44}$ Patel, K. K. \& Schot, J. (2011). Twisted paths to European integration: comparing agriculture and transport policies in a transnational perspective. Contemporary European History, 20, 383-403.
} 
tions, however, have yielded original and important insights on strategies of specific companies in relation to European integration.

Since the late 1970s, business historians have mainly focussed on aspects of the Chandlerian research agenda. Alfred D. Chandler Jr. practically laid the foundation of modern business history with his book The visible hand. The managerial revolution in American business. Chandler argued that American multinational business took a lead over European business in the early twentieth century by investing in three crucial aspects of the firm: manufacturing, marketing and management. This enabled them to make use of what Chandler called the economies of scale and scope in international markets. ${ }^{45}$

His influential presentation of business dynamics resulted in a historical discipline with a focus on company practices of internal management in relation to an awareness of competitive advantages. Matters of strategy regarding the external environment, such as the question on how phenomena of international economic integration affected firm-level decision-making or competitive advantage received little attention until very recently. 46

Traditionally, economic historians and business historians have used economic theories in their investigation of European integration. The "theory of the firm," for instance, was employed to predict the response of business to economic integration. The outcomes are largely in line with what can be expected to occur according to the theory of international economic integration. The fact that a reduction of import tariffs as occurred in the EEC has caused an immediate increase in trade, is a case in point. The changed tariff order also led to a diversion of trade as a result of changing cost structures. Moreover, if new regulatory frameworks accompany a reduction of tariffs, cost structures are affected again, and the competitive positions of multinationals are affected even more. In other words: a level playing field changes the balance of competitive advantage for each firm. The theory predicts that companies have to attain a new optimal form of organization which is aimed at realizing economies of scale. Under such circumstances they are likely to invest in relocation and centralization of production. ${ }^{47}$

Recent empiric investigations of interaction between multinationals and international economic integration demonstrate though that achieving a new optimal structure and strategy was a difficult challenge. The response to European

\footnotetext{
${ }^{45}$ Chandler, A. D. (1977). The Visible Hand. The managerial revolution in American business. Cambridge: Harvard University Press.

46 E.g. Murmann, J. P. (2003). Knowledge and competitive advantage: The coevolution of firms, technology, and national institutions. Cambridge: Cambridge University Press; Cantwell, J., Dunning, J. H. \& Lundan, S. M. (2010). An evolutionary approach to understanding international business activity: The coevolution of MNEs and the institutional environment. Journal of International Business Studies, 41, 567586.

47 Dunning, J. H. \& Lundan, S. M. (2008). Multinational enterprises and the elobal economy. Cheltenham: Edgar Elder, pp. 717-718. United Nations (1993). From the common market to EC 92: regional economic integration in the European Community and transnational corporations. New York: United Nations.
} 
economic integration included several aspects: path dependencies of company structures, national contexts and the mostly unpredictable political developments among nation states and the European supranational institutions complicated matters severely. The investigation by Geoffrey Jones of British-Dutch detergents and foods multinational Unilever illustrates this nicely. During the Interbellum Unilever's structure became well adapted to the nationally fragmented and protectionist market structure of Europe. Its many smaller national businesses across Europe operated almost completely autonomously in marketing, research and development and production. Jones shows that the establishment of the Common Market triggered plans with Unilever's management for a centralization of production to achieve economies of scale. However, when in the early 1970s Unilever began the restructuring of the company the idea met with resistance from local management. They were convinced that products could only be marketed on a national scale and denounced the plans for marketing on a European scale. Moreover the relocation and centralization of production became politicized due to the inflexibility of European labour markets in crisis-ridden Western Europe. At the same time Unilever's American competitor in detergents, Procter \& Gamble could make a fresh start in Europe. As a result, Procter \& Gamble did much better in reaping the scale-related fruits of the larger market. Ivo Blanken described similar restructuring experiences of electronics firm Philips. Moreover, in the case of the European experiences of car builder Ford, Steven Tolliday shows how uncertainty about European integration formed another problem for the reorganization of existing production-structures. From the signing of the Rome Treaties in 1957 onwards, the American multinational had to postpone plans for the integration of its several European car production processes until the late 1960s due to uncertainty about EFTA-EEC relations. ${ }^{48}$

Some themes emerge: firstly, early multinationals with a structure distributed across several countries potentially had something to gain from the creation of a European Common Market. As tariffs were gradually abandoned, the decentralized organizations that they built to adapt to nationalist circumstances became increasingly inefficient compared to more centrally organized competitors. In contrast with Unilever and Philips however, which were (partly) rooted in the Netherlands which small market forced them to expand abroad, other European companies with large home markets had been able to expand their operations nationally during the 1920s and 1930s. After import tariffs were gradually removed during the 1960s they could likely benefit more from an increased flow of exports. ${ }^{49}$

\footnotetext{
${ }^{48}$ Jones, G. G., \& Miskell, P. (2005). European integration; Blanken (2002). Een Industriële Wereldfederatie, pp. 262-280; Tolliday, S. (2003). The origins of Ford of Europe: from multidomestic to transnational corporation. In H. Bonin \& Y. Lung (Eds.), Ford, 1903-2003: the European history (pp. 153-242). Paris: P.L.A.G.E.

${ }^{49}$ Gales, B. P. A. \& Sluyterman, K. E. (1993). Outward bound. The rise of Dutch multinationals. In G. Jones \& H. G. Schröter (Eds.), The rise of multinationals in continental Europe (pp. 65-98). Aldershot: Edward Elgar, p. 91.
} 
Secondly, the creation of the EEC destabilized the competitive positions of several European multinationals. American companies could introduce more efficient and centrally managed foreign subsidiaries. They competed with European companies that had company structures that were not well adapted to the emerging scale of the European market.

Thirdly, the uncertainties that were caused by the existence of two different trade blocs within Western Europe were delaying initiatives towards the centralization of company structures.

These insights lead to new questions. As the European market changed, preferences and views of businessmen most likely changed along with it. It is interesting to see whether the dynamic that was introduced by the creation of the Common Market affected the ideas of European multinationals with regard to investments from outside the EEC.

Business historians have also investigated the theme of business in relation to European integration through transnational business networks, while employing a focus on business interest associations. ${ }^{50}$ Neil Rollings' and Matthias Kipping's work on the Council of European Industrial Federations (CEIF) is a key example of such a study. CEIF was a federation of national trade-associations of organized business, founded in 1949. The authors show how CEIF on the one hand functioned as an instrument to forward the goals of national associations on a European level. On the other hand they found that forging transnational contacts was "a crucial benefit in the uncertain world of post-war Europe" of the 1950s. According to them the continuous political debate about the organization of the European market, such as the creation of supranational institutions and a Common Market was an important reason for the formation of business networks. According to them these were founded with the goal to reduce uncertainty. The work of Ramírez Pérez which was mentioned earlier in the section on European integration history also falls in this research category. ${ }^{51}$

A final development in the investigation of business in European integration merely confirms the earlier identified move from an abstract interpretation of business in European integration to a business-centred investigation: the book Stratégie d'entreprise et action publique dans l'Europe intégrée, edited by Marine Moguen-Toursel, actually moves from the investigation of the formation of ideas within business networks to the investigation of causal effects in policy making. ${ }^{52}$

\footnotetext{
50 Lanzalaco, L. (2008). Business interest associations. In G. G. Jones \& Zeitlin, J. (Eds.), The Oxford handbook of business history (pp. 293-315). Oxford: Oxford University Press.

${ }^{51}$ Rollings, N. \& Kipping, M. (2008). Private transnational governance in the heyday of the nation-state: the Council of European Industrial Federations (CEIF). Economic History Review, 61, 409-431; Pérez (2009). Transnational business networks.

52 Kaiser, W. (2009). Bringing people and Ideas back in: Historical research on the European Union. In D. Phinnemore \& A. Warleigh-Lack (Eds.), Reflections on European Integration: 50 Years of the Treaty of Rome (pp. 22-39). Basingstoke: Palgrave Macmillan, pp. 28-31; Moguen-Toursel, M. (Ed.) (2007). Stra-
} 
Summing up how the study of integration theory, European integration history, and business history have developed in relation to the role played by business actors, one can conclude that a major shift in perspective has occurred. Originally, in accounts inspired by the dynamic of spill-over or in state-centric accounts about European integration, business was merely studied as a function of integration or as a function of the state's role in integration. Only more recently Jones, Rollings, Kipping and Ramírez Pérez have shown a perspective which started from the preoccupations from business itself. They zoomed in on the business experience of the changing European markets, the introduction of new institutional layers and the adaptation of companies to emerging challenges.

This changed perspective leads to new questions. Rollings wonders whether European businesses indeed sat idly by when new institutions designed to oversee them were created. Did they perhaps interfere with the process of institution formation and did they try to shape the competencies and properties of the High Authority and the European Commission? Rollings also suggests to consider the effects of a new world of international cooperation that undermined the existing mechanisms for organizing international markets by business itself. The proliferation of new institutions overseeing and governing their activities created a sense of uncertainty. Rollings and Moguen-Toursel have suggested to start explaining the activities of organized business as expressions of such uncertainty, instead of merely sticking to the dominant discourse of policy-making influence. In addition the response of European business views to American investments and Japanese competition should be considered. Also it is important to pay attention to the question of how these problems became Europeanized, using the concept of Hirschhausen and Patel. By zooming in on the changing views of European multinationals and businesses on the European market one comes closer to answering such questions. ${ }^{53}$

\section{Transnational networks: historiography}

The final part of this introductory chapter will give a historiographical overview of the three transnational networks through which the views of European business will be investigated. The study of the role of businessmen in activities of the European League for Economic Cooperation, the Bilderberg meetings and the Trilateral Commission form the empirical basis of this book. Thus far they have been characterized as transnational networks. As was hinted at earlier, this terminology is based on the concepts of Wolfram Kaiser and his co-authors, who investigate polit-

tégie d'entreprise et action publique dans l'Europe intégrée (1950-1980). Affrontement et apprentissage des acteurs (pp. 47-86). Bruxelles: PIE-Peter Lang.

53 Rollings, N. (2007). British business in the formative years of European integration, 1945-1973. Cambridge: Cambridge University Press, pp. 266; Rollings \& Moguen-Toursel (2012). European organised business, pp. 117-118; Hirschhausen \& Patel (2010). Europeanization in history. 
ical networks that are geared to the exchange of ideas, interests or ideology across states. ${ }^{54}$

Given the high involvement of businessmen in their ranks, how should we characterize these networks in relation to business associations and other types of interest groups? To answer these questions, this section firstly presents the main historical studies on these networks. Additionally, the networks' features will be discussed in relation to general characteristics of business associations and some other transnational business associations that particularly operated in a European context. 55

The oldest transnational network investigated in this study is ELEC. This is a European lobbying organization with a clear focus on promoting European economic unification. Michel Dumoulin and Anne-Myriam Dutrieue, who investigated ELEC's history over the period 1946-1981, concluded that it was a "movement of employers" and a "study and action movement in European matters." The organization was based on the dominant membership of industry and finance, assisted by a smaller group of economists and politicians. However Dumoulin and Dutrieue did not investigate the ELEC as an expression of European industry and finance. Instead of focussing on the competing interests of these individuals they pointed out the liberal characteristics of ELEC's activities. ${ }^{56}$

Dumoulin and Dutrieue's dual characterization of ELEC as a study ánd pressure movement was based on the combination of the several functions it performed for its members. ELEC was in the first place involved in lobbying activities. Its national sections conveyed ELEC's preferences to national governments and European institutions. In order to fulfil this function effectively, the ELEC also studied European debates and proposals for integration. A permanent secretariat monitored and informed the members on the stream of plans in the context of European economic relations, cooperation and integration. Central Council meetings were partly devoted to the gauging of likely outcomes. Moreover, the Central Council initialized studies on specific treaties, policies, and institutional developments which were published as position papers. They were presented as neutral studies, best described as preferences in the disguise of technical narratives. ${ }^{57}$

\footnotetext{
${ }^{54}$ Kaiser, Leucht \& Rasmussen (2009). Origins of a European polity, pp. 6-7; Gehler, Kaiser \& Leucht (2009). Networks in informal European governance, pp. 4, 17.

55 See Chapter 2 for a detailed discussion of the networks' goals, structure, membership, etc.

56 Translations by the author of: "un mouvement d'étude et d'action en matières européennes", "mouvement d'inspiration libérale", "Mouvement de patrons" \& "mouvement des patrons". Dumoulin \& Dutrieue (1993). La Ligue, p. 257. It is important to point out that from 1947 until late 1949, ELEC was led by personalities from politics and public administration instead of business. See Chapter 2 for an elaborate consideration of this earlier founding period of the ELEC. Gisch, H. (1991). The European League for Economic Co-operation (ELEC). In Lipgens, W. \& Loth, W. (Eds.), Transnational organizations of political parties and pressure groups in the struggle for European union, 1945-1950 (pp. 186-276). New York: Walter de Gruyter, pp. 189-193.

${ }^{57}$ Dumoulin \& Dutrieue (1993). La Ligue. Also, see Chapter 2.
} 
The Bilderberg group was not directly involved in lobbying. Instead it mainly organized the exchange of views. Annual Bilderberg meetings were organized since 1954 and gathered European and American decision-makers and advisors from business, public administration, politics and academia around topics of strategic importance to the West. The discussions mostly focussed on Transatlantic security and Transatlantic economic relations. Bilderberg's most important difference with the ELEC was its Transatlantic structure. Valérie Aubourg explains that the original purpose of the Bilderberg meetings was to establish a "common understanding" between Western Europe and the United States. Its founding members felt that the meetings could contribute to repairing the deterioration of Transatlantic relations in the early 1950s. Thomas Gijswijt concludes that due to the Bilderberg meetings' contribution to a sense of unity, cooperation and unofficial consultation it developed into an informal supplement to the NAT0.58

Both Gijswijt and Aubourg saw the Bilderberg meetings as opportunities for participants to learn about the differing views on international security and the international economy, but also opportunities to influence each other regarding current international affairs. Both authors moreover agreed that the meetings were not aimed at the formation of a consensus. ${ }^{59}$

The Trilateral Commission is a group of private individuals from the United States, Western Europe and Japan. Since it was founded in 1973 its membership grew to about 250 representatives, mainly stemming from industrial and financial multinationals. The membership also included politicians, public administrators and people from academia who were involved in policy making. They discussed the tensions between the three main industrialized regions in the world. Themes such as the global monetary system, financial relations, energy security, nuclear proliferation and north-south relations dominated the Trilateral Commission's work in the 1970s. Meetings revolved around discussions on current affairs in international economic relations. Moreover, the Trilateral Commission published reports that instructed the three regions to cooperate on a range of matters in which the differing interests of the United States, Western Europe and Japan were causing friction.

Scholars have regarded the dominance of multinationals in the Trilateral Commission with suspicion. Stephen Gill interpreted the Trilateral Commission along the lines of a Marxist class struggle on an international level. According to him, the organization served the purpose of shaping the identity of a transnational, capitalist ruling class. He sees the Trilateral Commission as a conscious, collective and collusive attempt of multinational corporations at reshaping the world in their

\footnotetext{
${ }^{58}$ Aubourg, V. (2003). Organizing Atlanticism: The Bilderberg Group and the Atlantic Institute, 19521963. Intelligence and National Security, 18, 92-105, p. 103. Gijswijt (2007). Uniting the West, pp. 294298.

${ }^{9}$ Aubourg (2009). Transatlantische Geschäftsbeziehungen. pp. 83-84. Gijswijt (2007). Uniting the West, p. 293.
} 
image, by lobbying in the service of their collective private needs. Other scholars have coined the term of an elite planning organization. The also stress the lobbycharacter of the Trilateral Commission but also identify the Commission as a means to study international developments. Holly Sklar characterizes the Trilateral Commission and its corporate members as "seeking to strengthen and rationalize the world economy in their interests." A similar assessment is made by Johannes Beverungen. According to him the Trilateral Commission's focus on global economic and political themes offers the private participants an edge in the field of information, enabling them to plan better in a globalized world. ${ }^{60}$

Notwithstanding the obviously different political arena's in which the organizations operated, they also shared several characteristics: an important or even dominant role of multinational business, a membership from different spheres of society, and a requirement for expertise and up to date information to determine their positions. They also shared the characteristic of subtle lobby practices, either external, as the ELEC and the Trilateral Commission, or in the case of the Bilderberg meetings, internal, by confronting Europeans and Americans with each other, or by confronting several spheres of society with the outlook of international business. Furthermore, they undertook study and lobby activities in response to a changing international system.

As business played such a large role in their work, these networks come close to the category of business interest associations. But in order to make the comparison, it is important to distinguish between two main forms that business associations take: employers' associations and trade associations. Through employers' associations business approaches unions and industrial relations issues. Trade associations, by contrast, fulfil the role of study groups, interest representation and lobbying. As far as the ELEC, the Bilderberg meetings and the Trilateral Commission are similar to business interest associations, they come closer to the category of the trade association. Still, the differences cannot be overlooked.61

In this perspective, it is useful to be aware of how the organizational structure of business associations has developed in the past. Until WWII the highest degree of organization of business was that of national organizations. But the post-war history has seen the transnationalization of business interest associations. Associations such as the Council of European Industrial Federations (CEIF), the Union des Industries de la Communauté Européenne (UNICE) and the European Round Table of Industrialists (ERTI) developed and were particularly geared to the emerging European Union. It is useful to shortly compare these organizations to the ELEC, the

${ }^{60}$ Gill, S. (1991). American hegemony and the Trilateral Commission. Cambridge: Cambridge University Press, pp. 90-93 and 96-98. Sklar, H. (1980). Trilateralism: Managing Dependence and Democracy. In H. Sklar (Ed.), Trilateralism: the Trilateral Commission and elite planning for world management. (pp. 1-57). Montréal: Black Rose Books, pp. 4, 8, 21. Beverungen, J. ([2003] 2005). Elite Planning Organizations: Traditionen, Charakteristika, Implikationen der Trilateral Commission. University Dissertation Freiburg im Breisgau, 2003. Baden-Baden: Nomos., pp. 156, 160.

${ }^{61}$ Lanzalaco (2008). Business interest associations, pp. 293-295, 308-309. 
Bilderberg meetings and the Trilateral Commission. The CEIF and UNICE were both European federations of national umbrella trade associations of business. CEIF included members from Western Europe, UNICE was limited to the membercountries of the European Community. Until the late 1970s these organizations were particularly active in the collection of information. Furthermore they mainly pursued the goals of their national counterparts on a European level. Business was only indirectly represented: CEIF and UNICE aggregated highly diverse interests from a multitude of sectors and several countries. The ERTI was quite different in this regard. Its cross-sectoral membership was based on the direct representation of leaders of large European industrial companies. As a result the ERTI was a much more focussed and decisive organization. It concentrated on a limited number of strategic issues such as the future of the European market, whereas UNICE for example became an all-round contact on European Community policy debates. The ELEC, and the Trilateral Commission with their partly direct representation and resolutions on strategic subjects were much more similar to the ERTI than to CEIF and UNICE. The Bilderberg meetings however is difficult to place in any of the categories. ${ }^{62}$

Lastly, it is useful to briefly consider the underlying logic of business associations. According to Frans van Waarden, cooperation between different firms is based on the desire to achieve a collective good. This good can take several forms: a defence against, or lobby in favour of certain policies or regulations in a range of areas. Van Waarden stresses that cooperation between firms is hardly evident. He notes a "heterogeneity" of interests among firms, that are based on differing activities, sectoral specificities and several aspects of company organization. At the same time, Van Waarden explains that in order to reach their goals, business associations have to maximize their representativeness to remain viable interlocutors for governments, regulatory institutions and other organizations. However, it is important to realize that business associations are not just engaged in a struggle with politicians and public administrators; they indirectly also cater to the needs of governments and institutions. Justin Greenwood indicates that due to a lack of resources, institutions such as the European Commission require the expertise of firms that actually engage with the problem that the Commission wishes to solve or the behaviour that it wants to regulate. Expertise, study and lobbying thus can be seen as expressions of the same activity. ${ }^{63}$

It is clear from the above that the ELEC, the Bilderberg meetings and the Trilateral Commission are not typical business associations. Their membership is not sufficiently homogeneous to be categorized as business associations. However,

62 Lanzalaco (2008). Business interest associations, pp. 293-295, 308-309; Rollings \& Kipping (2008). Private transnational governance; Green Cowles (1996). Business means Europe; Brodkey, R. M. (1964). U.N.I.C.E. in European integration. Princeton: Woodrow Wilson School of public and international affairs, Princeton University; Matvia, M. (1999). Der Einfluss der Vereinigung der Industrie- und Arbeitgeberverbände Europas (UNICE) auf den Entscheidungsprozess der Europäischen Union. Bern: Lang. ${ }^{63}$ Waarden (1995). Employers, pp. 70-72, 74; Greenwood (2007). Interest representation, pp. 70-71. 
with the exception of the Bilderberg meetings they very much acted along the lines of how business associations behave, and were particularly similar to the European Round Table of Industrialists. They gathered information about the developing international economic system, they built expertise on the topics that affected their members, determined the position of members and subsequently deployed the results in a lobby, couched in an attitude of expertise.

\section{Research Questions}

Business, and more specifically multinationals, have been given a limited role in European integration theory and history. Theorists of integration expected business to shift their lobbying activities from the national sphere to the supranational sphere, or to integrate European economic activity. The actual views of multinational business were unimportant in these investigations. At the most they were seen as participants in the formation of national preferences. How the European multinationals viewed the developments on the European market has received little attention, except for the period of the 1980 s. This is all the more strange as the changes in the organization of the European market were significant during the 1950s and the 1960s. However, the recent transnational turn in the investigation of European history creates opportunities for integrating the history of European business with questions about the shaping of European ideas and meanings. Moreover, historians of business have recently arrived at the insight that European multinationals were confronted with a particularly complex political and economic environment since the 1950s. The proliferation of international institutions and trade blocs offered an uncertain basis to work from, while investments from the United States and Japan were given free reign, upsetting the competitive balance of the European economy.

Differences between industries are significant though, and were caused by specific sector-based challenges. Therefore, the views with regard to the European market may have been very different among different industries. At the same time, given the striking circumstances of the 1950s, during which the national economic environment of most European multinationals became subject to negotiations over the ECSC and the EEC, it is intriguing to see whether multinationals sided with their governments and to what extent this possibly continued in later decades. From these considerations follow two central question that form the heart of the narrative of this book:

How did the views of large European multinational businesses on the European market change between 1950-1980? 
How can we explain differences in views on the European market among multinational businesses? To what extent do national and industrial contexts explain such differences?

The first question particularly acknowledges that the changing circumstances that European corporations experienced may well have changed their outlook on the Common Market. As became clear, these include a changing market organization, the introduction of new institutions, the advent of American and Japanese competition and the uncertainty that the introduction of two trade blocs in Western Europe may have caused. Moreover, this question is also based on the earlier observation that during the 1950s some multinationals were in favour of a larger market, but in the 1980s appeared unsatisfied with how these plans had turned out. How did these views develop in the mean time?

The second question fulfils a different role. As suggested earlier, corporations possibly fostered different views on the European market. Such a differentiation may yield important insights into why these different perceptions gained shape, possibly as a result of differing national and industrial contexts. By answering this question we gain more insight into the factors that co-determined the debates on the organization of the European market.

The previous historiographical discussions have indicated that geopolitical tensions also played a role in the experience of European multinationals. Moreover, the investigated transnational networks were ideal organizations for expressing such geo-political perspectives. Questions of a geo-political nature about the possible conflicts between European, American and Japanese corporations offer an interesting perspective on the formation of the European market. However, as this dissertation is primarily concerned with the views of European corporations on the European market in a context of European integration, these questions will not be treated here or in the following chapters. The concluding chapter will return to the question on whether this investigation has yielded insights of a geopolitical nature.

The next chapters attempt to answer these question by investigating three transnational networks, the European League for Economic Cooperation, the Bilderberg meetings and the Trilateral Commission. The networks will be approached via three themes in three decades between 1950 and 1980; economic integration during the 1950s, East-West trade and American investments in Western Europe during the 1960s, and energy security during the 1970s. 


\section{Chapter 2}

\section{Transnational networks: the participation of businessmen}

\section{Introduction}

The European League for Economic Cooperation, the Bilderberg meetings and the Trilateral Commission were very different organizations. For example, the ELEC was strictly European in scope, the Bilderberg meetings were Transatlantic and the Trilateral Commission combined European, American and Japanese membership. Two of them published policy papers, the third generally did not strive for consensus but was designed to facilitate an exchange of views. This chapter explores these and other differences by separately discussing each group's founding history and subsequent development, their organizational structure, the changes in themes that they studied, and, last but not least, the role played by businessmen in these organizations.

That exploration serves several goals. Before starting the analysis of how businessmen viewed the developments on the European market an understanding of the networks themselves is required. Moreover, by focussing on the different characteristics of these networks, a preliminary interpretation can be offered on the role that businessmen played in their activities. The main question with regard to the comparative perspective is whether businessmen were in a position to pursue different results in different networks? The answer to this question will also have consequences for the analyses put forward in the chapters 4 to 6 .

One element of these networks is of special interest: their different approaches with respect to national representation. All three networks were transnational, in the sense that their members operated beyond their own national environments, with mostly international goals in mind. But national representation was organized differently in each group, from coherent sections to loose contacts. To what extent were national perspectives still relevant in transnational networks like these? ${ }^{64}$

\footnotetext{
64 See for different interpretations of transnational history and the place of national actors in them: Vleuten, E. van der (2008). Towards a transnational history of technology. Meanings, promises, pitfalls. Technology and Culture, 49, 974-994.
} 
These organizations, the Bilderberg meetings and the Trilateral Commission in particular, with their confidential meetings between business-leaders and politicians, have attracted quite some attention in the literature. Several authors have expressed a concern and even suspicion about undue influence of business on politics. Others have argued that such a direct or comprehensive influence is unlikely. Influences of a more subtle nature may have existed however, for example via the establishment of international social relations or as a result of the collective reflection on important international themes. ${ }^{65}$ It is not the primary concern of this book to contribute to the historiography of these organizations as such, nor is it the goal of this chapter. However, as a result of our focus on the role of businessmen in the ELEC, the Bilderberg meetings and the Trilateral Commission, new sources on these networks were consulted, yielding interesting insights on their development. Several of these new insights have found a place in this chapter.

\section{European League for Economic Cooperation, 1946-1980}

The European League for Economic Cooperation was, and still is, a transnational study and lobby network of major European businesses. Considering the lack of attention from historians, even in a time when scholarly interest in transnational lobbies with regard to European integration is growing, one must conclude that it has been largely overlooked.

That may partly have been caused by ELEC's initial activities from 1947 until approximately 1950. In those years the ELEC clearly was not a straightforward business lobby. It was led by personalities from politics and public administration, and it was an integral part of the European Movement. In that setting, according to Heribert Gisch, the ELEC functioned as an unspectacular and seemingly neutral "sub-committee on economic questions", an "informal adviser", to the European Movement which was led by a "body of experts."66

However, Michel Dumoulin and Anne-Myriam Dutrieue investigated the ELEC for the period 1946-1981 and argued that the organization changed considerably after 1950. They conclude that it then became a "study and action movement in European matters." According to them the dominant membership from industry

\footnotetext{
${ }^{65}$ See for example Gijswijt, T. W. (2007). Uniting the West: the Bilderberg Group, the Cold War and European integration, 1952-1966. Unpublished dissertation, Heidelberg, Heidelberg; Gill, S. (1991). American hegemony and the Trilateral Commission. Cambridge: Cambridge University Press; Richardson, I., Kakabadse, A. P. \& Kakabadse, N. K. (2011). Bilderberg people: elite power and consensus in world affairs. London: Routledge.

${ }^{66}$ Gisch, H. (1991). The European League for Economic Co-operation (ELEC). In W. Lipgens \& W. Loth (Eds.), Transnational organizations of political parties and pressure groups in the struggle for European union, 1945-1950 (pp. 186-276). New York: Walter de Gruyter, pp. 189-193.
} 
and banking, and their ideas, made it a "movement of liberal inspiration" and a "movement of employers."67

Despite this awareness of strong business involvement, Dumoulin and Dutrieue failed to seriously employ a business perspective and insufficiently acknowledged ELEC's overbearing identity as a business association. Dumoulin \& Dutrieue did not relate ELEC's work to preoccupations of European business. Moreover Dumoulin \& Dutrieue consciously avoided the dynamic between ELEC's different national sections. This book will attempt to fill these gaps in the empiric sections. The following offers an overview of ELEC's founding period, its reorganization into a business association and the role of businessmen in its work. 68

Founding ELEC, 1946-1949

The ELEC was founded at the initiative of the Polish diplomat Joseph H. Retinger. In May 1946 he approached Paul van Zeeland, a former Prime Minister of Belgium, with the suggestion to create an international organization to advance the future of Europe. Considering Europe's devastated economy after WWII, they concluded that their goal should be to "revive the concept of the unity of Europe by applying it first to the economic field." 69

The cooperation between Retinger and Zeeland rooted in their activities in London during World War II. Both were closely involved in their exiled governments' planning activities on the post-war social order. Retinger was an advisor on international affairs to General Sikorski, Prime Minister of the Polish government in exile. Zeeland led the Commission pour l'Etude des Problèmes d'Après-guerre (CEPAG) from 1941 to 1942, the post-war planning organization of the Belgian government in exile. Their efforts clearly were of value for their later activities in the ELEC. Zeeland's work resulted in a plan for a new international system, involving the reduction of obstacles to trade and the creation of international institutions for overseeing monetary policy and transport. The institutions that Zeeland proposed thus did not yet stress the European dimension. ${ }^{70}$

\footnotetext{
67 Translations by the author of: "un mouvement d'étude et d'action en matières européennes", "mouvement d'inspiration libérale", "Mouvement de patrons" \& "mouvement des patrons." Dumoulin, M., \& Dutrieue, A.-M. (1993). La Ligue Européenne de Coopération Économique (1946-1981): un groupe d'étude et de pression dans la construction européenne. Berne: Lang, p. 257.

68 Ibidem.

${ }^{69}$ Retinger, J. H., \& Pomian, J. (Eds.) (1972). Joseph Retinger: Memoirs of an eminence grise. Brighton: Sussex University Press, p. 210. See also the very informative: Pieczewski, A. (2010). Joseph Retinger's conception of and contribution to the early process of European integration. European Review of History: Revue européenne d'histoire, 17, 581-604.

70 On the CEPAG see: Bellefroid, D. de (2001). The Commission pour l'Etude des Problèmes d'AprèsGuerre (CEPAG) 1941-1944. In M. Conway \& J. Gotovitch (Eds.), Europe in Exile: European Exile Communities in Britain 1940-1945 (pp. 121-133). Oxford: Berghahn Books; Henau, B. (1990). Shaping a New Belgium: The CEPAG. In M. L. Smith \& P. M. R. Stirk (Eds.), Making the New Europe. European Unity and the Second World War (pp. 112-132). London: Pinter.
} 
Joseph Retinger's post-war planning efforts also involved participation by Paul van Zeeland. From 1943 onwards, the Polish government in exile organized meetings with other exiled governments from the continent. The aim was the creation of a post-war bloc of European allies. Paul van Zeeland participated as the Belgian liaison to the Polish government and met Joseph Retinger. Other countries involved were the Netherlands, Greece, Norway, Yugoslavia and Czechoslovakia. ${ }^{71}$

Their joint stay in London had provided Retinger and Zeeland with a range of international contacts which were later mobilized in ELEC's founding phase. In 1946 Retinger met with Pieter Kerstens, a former member of the Dutch exiled government in London, and Roger Motz, one of the directors of the Belgian Commission pour l'Etude des Problèmes d'Après-guerre in London. Kerstens and Motz both would lead the Dutch and Belgian sections of the ELEC. The first formal act of ELEC's founding phase took place on the $17^{\text {th }}$ of October 1946, when Retinger and Van Zeeland created a committee to prepare an association "for the solution of the continental problem of Europe." It was planned to be populated by private citizens with considerable national and international standing from France, Belgium, Luxembourg, the Netherlands, Greece and Poland. This association was to be called the Independent League for Economic Cooperation (ILEC). ${ }^{72}$

Paul van Zeeland's conceptions of post-war global international relations clearly influenced ILEC's initial goals. The association saw Europe as a group of economic regions which should be integrated. Moreover, its members felt that Europe should be integrated in an even larger order of regions under the umbrella of the United Nations Organization, thus achieving a "gradual reconstruction of the world." ILEC was aiming for the reconstruction of the European economy by asking European governments to open their markets. ${ }^{73}$

\footnotetext{
71 In his memoirs, Retinger claimed that the meetings were held with the "underlying idea" to "prepare for the unity of Europe" but according to Polonsky the meetings were designed to create the suggestion of a potential post-war collective strategy of European countries, arguably strengthening the Poles' hand in their relations with Soviet Russia. On Paul van Zeeland as Belgian liaison to the Poles see: Henau, B. (1995). Paul van Zeeland en het monetaire, sociaal-economische en Europese beleid van België, 1920-1960. Brussel: KAWSLK, p. 195. Retinger \& Pomian (1972). Joseph Retinger, p. 106. Polonsky, A. B. (1985). Polish failure in wartime London: attempts to forge a European alliance, 1940-1944. The International History Review, 7, 576-591, pp. 589-91.

72 The Committee was called Association Indépendente d'action européenne. Nationaal Archief, Den Haag, Buitenlandse Zaken, 1945-1954, nummer toegang 2.05.117, inventaris nummer 16814, Pieter Kerstens to the Prime Minister and the Minister of Foreign Affairs, 14 October 1946. With this message Pieter Kerstens informed the Dutch government of what was taking shape and what his role was. Dumoulin \& Dutrieue (1993). La Ligue, pp. 23-24.

${ }^{73}$ In French ILEC was called: Ligue Indépendante de Coopération Européenne. The idea behind ILEC's role in Europe's integration in global relations went quite far: ILEC's Central Council was planned to include members from France, Belgium, The Netherlands, Luxembourg, Norway, Italy, Greece, Yugoslavia, Czechoslovakia and Poland. Moreover members of the United Kingdom, Latin America, specifically Brazil, Canada, the United States of America and the USSR would also be granted a seat. CEHECLIN, LECE, inv. nr. 9, 15-02-1947, Ligue Indépendante de Coopération Européenne, Préambule \& Mémorandum Préliminaire; inv. nr. 1, 2 et 3 mars 1947, Ligue Indépendante de Coopération Européenne. Mémo-
} 
However, ILEC was never realized in this form. The United States intervened in the rapidly worsening economic situation of Europe and offered financial assistance, which became known as the Marshall Plan (5 June 1947). In exchange the American government forced Western European states to jointly plan the allocation of the offered aid. ILEC quickly realized that the impetus for its existence had now been replaced by official governmental action. ${ }^{74}$

ILEC now adopted a different strategy, consisting of active cooperation with several other movements for European unity. As a result, ILEC became one of the movements that collectively organized the well-known European Congress in The Hague in May 1948 and was one of the founding members of the European Movement with Joseph Retinger as its secretary. Furthermore, ILEC was renamed as ELEC.75

Altogether, ELEC's involvement with the European Movement was not a success. It occupied itself with studying and proposing plans on economic cooperation, but in doing so, it had voluntarily curtailed its independence and became associated with quite diverging ideological conceptions of European cooperation. It developed into something of an economic subcommittee of the European Movement, a role which led to tensions towards the end of $1949 .{ }^{76}$

The official installation of the European Council in September 1949, was seized as an opportunity to create some distance between ELEC and the other movements. The British representative to ELEC's Central Council, Edward Beddington-Behrens, proposed to "organize E.L.E.C. on a wider national and international basis. Now that the Assembly is an accomplished fact, it is important to develop an organization [...] with defined economic objectives, on subjects which are essentially practical and non-party." Paul van Zeeland shared the "feeling that E.L.E.C. should increase its activity and independence." 77

Another reason for reclaiming independence was the increasing ideological competition inside the European Movement on how to proceed with regard to Europe's future. Other organizations that participated in the European Movement, such as the Mouvement pour les États-Unis socialistes d'Europe and the European Union of Federalists had become much more active and influential in the course of

randum de la réunion tenue a La Haye les 2 et 3 mars 1947. Translation is partly reproduced in Gisch, H. (1991). The European League, p. 196.

${ }^{74}$ See for the crisis of 1947: Milward, A. S. (1984). The reconstruction of western Europe, 1945-1951. Berkeley: University of California Press, pp. 1-55.

75 CEHECLIN, LECE, inv. nr. 5, 23-06-1947, Independent League of European Co-Operation. Action to be taken on Marshall's Offer. 1st draft, p. 8; inv. 4, 30-06-1947, Independent League for European Cooperation, Paris Meeting, p. 5.

${ }_{76}$ Gisch (1991). The European League, pp. 189-193.

${ }_{77}$ CEHECLIN, LECE, inv. nr. 312, 17-08-1949, Beddington-Behrens to Camu; inv. nr. 312, Camu to Butler, 3rd September 1949. 
1948 and had started a federalist campaign in order to convince European governments of replacing the nation-based pre-war order with a European society. ${ }^{78}$

This was at odds with ELEC's views on the future of Europe. In March 1947, the organization still conceptualized economic cooperation within Europe as something that could be achieved by merely reducing obstacles to trade. At that time the term "integration" was much less commonly used. However, towards the European Congress of May 1948, ELEC's plans had become much more complex. The suggestion of European economic cooperation had given way to a terminology of "economic union." This union would be based on a customs union, with coordinated tariffs and free movement of capital and labour, or, in other words, a Common Market. Moreover, ELEC's leaders had come to believe that a manifold of common policies were required to improve European productivity. They suggested policies on employment, on the coordinated relocation of industry, the stabilization of exchange rates, the removal of quotas on trade and transactions, coordination of credit policy, steel and energy and international control of the Ruhr industries. Finally, they did not believe in one all-embracing move to such an economic union: "The Union cannot be brought about all at once. It will clearly be a gradual and organic process, moving by stages towards the freeing of trade in the territory in accordance with a co-ordinated plan." The ELEC preferred gradual, functional steps, a conception of process that was at odds with the views of the federalists, who wished to make a clean break with the Europe of the past. ${ }^{79}$

Irritation peaked in ELEC during January 1950. The European Movement had planned a vote on a resolution that demanded a federal pact among Western European governments which led to rejection by ELEC. The organization decided to instruct the four ELEC-delegates in the Bureau and Executive Committee of the European Movement to block the vote, joining non-ELEC British representatives in the European Movement who had already rejected the proposal. Furthermore it was unanimously concluded that a constitutional federation for Europe was "a very long term goal." Since then, while never officially leaving the European Movement, ELEC's Central Council hardly ever discussed the actions of the European Movement again. ${ }^{80}$

\section{A new organization}

ELEC's reorganization transformed it into an autonomous transnational study and pressure organization. Its operations were now centralized. Until late 1949, ELEC essentially had been a collection of national organizations within the United King-

\footnotetext{
${ }_{78}^{78}$ Loth, W. (1991). The Mouvement Socialiste pour les États-Unis d'Europe (MSEUE). In Lipgens \& Loth, Transnational organizations (pp. 277-318), pp. 279-281.

79 Gisch, H. (1991). The European League, pp. 189-190, 206. See for the definition of a Common Market Balassa, B. (1969 [1962]). The theory of economic integration. London: George Allen \& Unwin Ltd., p. 2. ${ }^{80}$ Translation of "un objectif à très longue échéance"; CEHECLIN, LECE, inv. nr. 45, 12-01-1950, Conseil Central 12-01-1950, pp. 1-4.
} 
dom, France, the Netherlands, Belgium and Luxembourg. No central body existed. Now a Central Council was founded, which became the main decision-making platform. Its task was to initiate and direct collective studies and to decide on the publication of studies and resolutions. ${ }^{81}$

Since early 1950, the Central Council met about five times a year. It was composed of the President, the Secretary General, the formal representatives of national sections, or Vice-Presidents, and a group of deputy members. It started out as a group of twenty men, which became larger as a result of new national sections that were founded over the next decades. By 1980 it reached the size of 44 members. ${ }^{82}$

In addition to the initial five sections, twelve more were founded between 1950 and 1972 (see table 2.1). Most of them were rather unimportant to ELEC's activities however. They were kept informed of ELEC's work and participated in

Table 2.1: Founding years of ELEC's national sections. ${ }^{83}$

\begin{tabular}{lc}
\hline National Section & Founding Year \\
\hline France & 1946 \\
United Kingdom & 1946 \\
Luxembourg & 1946 \\
Belgium & 1946 \\
Netherlands & 1948 \\
Germany & 1950 \\
Italy & 1950 \\
Austria & 1951 \\
Spain & 1956 \\
Switzerland & 1959 \\
Sweden & 1962 \\
Norway & 1965 \\
Turkey & 1969 \\
Ireland & 1971 \\
Monaco & 1971 \\
Denmark & 1972 \\
Lichtenstein & 1972 \\
\hline
\end{tabular}

meetings but hardly ever played a role in its strategic decisions. The sections that mattered most were those of Belgium, the Netherlands, France, Germany, Italy

${ }^{81}$ The overhaul of ELEC'S organization was decided on the 10 $0^{\text {th }}$ of November 1949 during an Extraordinary General Assembly; CEHECLIN, LECE, inv. nr. 3. 10-11-1949, Assemblée Générale Extraordinaire.

${ }^{82}$ See Table A.8, in the Appendix.

${ }^{83}$ ELEC's publications. Each contained information about the composition of ELEC's Central Council and the leaders of the national sections. See Sources, following chapter 7, for the complete list of all ELEC publications. 
(though not between 1953 and the late 1960s) and the United Kingdom. Their representatives generally determined the content of resolutions and publications (see chapters 4 to 6).

In March 1950, the ELEC also founded three standing commissions that would be devoted to studying current affairs regarding the integration of Europe. The first was the "monetary commission." The second was the "economic commission" which would focus on the reduction, and possible abolishment, of customs tariffs in Europe and overseas. Thirdly, the "commission of institutions" was created, later renamed as the "legal commission." 84

The commission's mandates were determined by the Central Council. Proposals for study mostly originated in national sections, after which the Central Council took a decision. Often the author of the initial proposal assumed the position of rapporteur, who was in charge of processing all the input from the study commissions or the Central Council. In other words: the rapporteur repeatedly consolidated the process of consensus-building into a new, temporary, consensus. Ultimately the Central Council decided on the final text before its publication. ${ }^{85}$

To describe this process of study and negotiation, Dumoulin and Dutrieue use the term "transnational laboratory", referring to a refining process of transforming a diversity of national perspectives into feasible proposals with a European scope. However, this does not mean that everyone inside ELEC always welcomed the endresult: unanimity was not a goal in itself. Interestingly, since real interests were at stake, negotiations about the wording of final texts were common, especially between 1950 and 1958. For some, agreeing to statements that deviated too much from positions within their national government or parliament was unthinkable without carefully weighing the wording, or adding disclaimers. ${ }^{86}$

\section{Business takes over ELEC}

Initially Paul van Zeeland and Retinger intended to shape ELEC as an organization of nationally and internationally well regarded individuals without official functions. The first President of the Dutch section, Pieter Kerstens, a senator and former Dutch minister of trade was such a figure, as was the leader of the Belgian section, senator Roger Motz, a former Minister of the exiled Belgian government in London and President of the Belgian liberal party. The French and British sections were led by former public administrators: Daniel Serruys from France, an experienced negotiator of international economic treaties who had recently become a

\footnotetext{
${ }^{84}$ CEHECLIN, LECE, inv. nr. 45, 25-03-1950, Conseil Central Procès Verbal, pp. 2-3.

${ }^{85}$ See chapters 4 to 6 .

86 Translation by the author of: "laboratoire transnational." Dumoulin \& Dutrieue (1993). La Ligue, p. 258. See for example a discusssion between Edmond Giscard D'Estaing of the French section and the Benelux sections on the European Defence Community. See chapter 2, CEHECLIN, LECE, inv. nr. 45, 1601-1954, Conseil Central.
} 
director at Saint Gobain, and Harold Butler, who had worked on foreign trade strategies before the war. ${ }^{87}$

Over a very short period, this mix of internationally well regarded statesmen and public administrators was almost entirely replaced with leaders from banks, large industrial multinationals, major exporters, and financial-industrial holdings. A selection of members of the most important Belgian, Dutch, German, French and British sections will illustrate this. The database included in the appendix lists all the Central Council members of all the sections. ${ }^{88}$

From about 1950, the Belgian section seized a central role in ELEC by occupying key functions in its organization. Van Zeeland was replaced as President when he became Belgian Minister of Foreign Affairs in 1949. After a short interlude, when the Dutchman Pieter Kerstens held office, the Belgian Baron René Boël took over in 1951 and remained at this post for the next thirty years. He was a major shareholder and member of the executive board of the multinational chemicals producer Solvay \& Cie. and co-owner of several steel producing companies. Other influential business figures were Louis Camu, the vice-president of Banque de Bruxelles who became the Belgian section's representation to the Central Council. Another was Lucien-Léandre Sermon, ELEC's new secretary general, economic advisor to Brufina. Both Banque de Bruxelles and Brufina were key elements of the financial-industrial holding of Baron Paul de Launoit, who partly financed ELEC. A further prominent member of the Belgian section was Pierre de Bonvoison of Banque de la Société Générale de Belgique. However, while the Belgian section as a whole was clearly under control of representatives of basic industries and industrial finance, they did also consult with other groups in society, including senators, and the former minister Paul de Groote, leader of the Belgian socialist party and member of ELEC's Central Council.89

A similar balance between industrial interests and other societal interests could be observed in the Dutch section. After Pieter Kerstens stepped down, Dutch industry re-established the section in 1950. It was presided over by Pieter Bentz van den Berg who was a director of steel producer Koninklijke Hoogovens. The section's executive board consisted of Cornelis Klaasse, Board member of the Amsterdamse Bank-Incasso Bank, Jo Meynen, executive director of the multinational Algemeene Kunstzijde Unie (AKU), a precursor to AKZO, and F. E. Spat, secretary to the board of Philips. Representatives of Shell and Unilever were also members. Besides members of the ELEC, Shell, Unilever, Philips and $A K U$ were at the same time collectively organized in the so-called $A B U P$, a study group that lobbied on

\footnotetext{
${ }^{87}$ Dumoulin \& Dutrieue (1993). La Ligue, pp. 23-31.

${ }_{88}$ The selection of these sections is based on early involvement in the ELEC and active participation throughout the period of 1950-1980. The Italian and the Luxembourg section could have qualified on the grounds of early participation. However, the Luxembourg section ceased active participation for unknown reasons and was reconstituted during the 1970s. The Italian section was in practice nonexistent as from 1953, as will be explained below and was reconstituted in the late 1960s.

${ }^{89}$ Dumoulin \& Dutrieue (1993). La Ligue, p. 34.
} 
Dutch trade policy. Shell, Unilever, Philips and AKU, and Koninklijke Hoogovens shared the total costs of the Dutch ELEC section which amounted to a sum of 14.000 florins a year..$^{90}$

The supervisory board of the Dutch section also involved two governmental agencies, representatives of several unions, and professor of economics Jelle Zijlstra, later a Dutch Minister of Economic Affairs. The executive board however remained firmly in the hands of industrial multinationals and banks. ${ }^{91}$

The German section was only founded in 1950 and was chaired by Hermann J. Abs, a board member of Deutsche Bank since before the war. He was an authoritative advisor to German industry with a range of mandates in advisory councils and he was part of a small circle of advisors to Reichskanzler Adenauer and his Minister of Economic Affairs, Ludwig Erhard. Together with Richard Merton, former chairman of Metallgesellschaft and now chairman of the company's advisory council, he represented the German section in ELEC's Central Council. During the 1950s the German section was almost completely composed of representatives of heavy industry and multinationals, such as the steel producing firm August-Thyssen Hütte, the Vereinigte Glanzstoff-Fabriken (part of Dutch AKU), Farbenfabriken Bayer, the Badische Anilin- und Sodafabrik, Siemens \& Halske, to name a few, and several representatives from banking houses and a small group of academics from several German research institutes on international trade. ${ }^{92}$

The French section was mostly a collection of industry and banking representatives, but differently so than the other sections. The founding of the French section in 1946 was a rather unique move: it consisted of incorporating the entire Comité d'action économique et douanière which was a committee of private commercial origin working for the elimination of international trade barriers. After its founding the French section gradually became more of a mix of liberals, lawyers,

\footnotetext{
${ }^{90} \mathrm{ABUP}=\mathrm{A}(\mathrm{KU}), \mathrm{B}($ ataafsche Petroleum Maatschappij $=$ Shell), U(nilever) and P(hilips). See: Paulussen, J., \& Blanken, I. (2004). Samenwerking tusschen Nederlandsche industrieën met groote internationale belangen. Zaltbommel: Aprilis, pp. 16-18, 38-39. CEHECLIN, LECE, inv. nr. 45. 18-6-1953, Réunion des Secrétaires Généraux, pp. 3, 6, Nationaal Archief, Den Haag, Europese Beweging in Nederland en Voorgangers, 1945-1987, nummer toegang 2.19.109, inventarisnummer 346, 22-4-1950, ELES bestuursleden, Stam-Rutten.

${ }^{91}$ The governmental officials were 'Rijksbemiddelaar' G.M. Nederhorst (installed by the government with the task to broker deals between unions and employers associations in the consultative bodies Stichting van de Arbeid (Labour Foundation) and the Sociaal Economische Raad (SER, the SocioEconomic Council)) and J. Linthorst Homan, president of the 'Rijksdienst voor het Nationale Plan' ( the national geographical planning commission). Nationaal Archief, Den Haag, Europese Beweging in Nederland en Voorgangers, 1945-1987, nummer toegang 2.19.109, inventarisnummer 346, 22-4-1950, ELES bestuursleden, Stam-Rutten.

${ }_{92}$ In 1950 however Deutsche Bank no longer existed as such because the Allies had forced it to split in ten parts. It was re-established in its previous form in 1957, with Abs as Vorstandssprecher. On Abs, see Gall, L. (2004). Der Bankier Hermann Josef Abs: eine Biographie. München: Beck. CEHECLIN, LECE, inv. nr. 371., October 1958, Deutsche Sektion. Merton, R. (1955). Erinnernswertes aus meinem Leben, das über das Persönliche hinausgeht. Frankfurt am Main: Knapp, p. 469. Deutsche Bank A.G. In International directory of company histories (Vol. 2). Chicago: St. James Press.
} 
intellectuals, industrialists, bankers and union members. During the 1950s however, the leadership of the section passed firmly into the hands of representatives of organized industry and banking, typically fulfilling multiple positions in the national business association, the Conseil National de Patronat Français. Key figures participating in the Central Council were Edmond Giscard D'Estaing, President of the French section of the International Chamber of Commerce, a group of French exporters and multinationals; Emmanuel Monnick, honorary governor of the Banque de France, and Président of Banque de Paris et des Pays-Bas; and Pierre Ricard, Vice-President of the Conseil Central de Patronat Français. Additionally, companies frequently represented in the leadership of the French section were Saint- Gobain and Péchiney. ${ }^{93}$

The British section was the only section not led by industry. Its president Edward Beddington-Behrens, though presiding over several companies, was first and foremost an experienced administrator with special experience in international organizations. He had worked for the League of Nations and was deeply involved in all British activities regarding the European Movement. Other leaders were a mix from union-representatives, economists, bankers, public administrators and some industrialists. The Central Council did not include any British industrialists. ${ }^{94}$

With this turn in leadership, ELEC's metamorphosis was complete. It developed from an independent body with a globally perceived strategy for European reconstruction, into a business-led study and pressure group on economic issues with respect to European integration.

\footnotetext{
${ }^{93}$ See for the earliest origins of the French ELEC section: Badel, L. (2001). La vision Européenne du patronat Français mobilisé par Paul van Zeeland en 1945. In G. Duchenne \& V. Dujardin (Eds.), Paul van Zeeland et les questions politiques et économiques de son temps (pp. 35-48). Louvain-la-Neuve: Institut d'études européennes, p. 41; Conseil National du Patronat Français (1955). Annuaire général du patronat français. Paris: CNPF; Ehrmann, H. W. (1957) Organized business in France. Princeton, NJ: Princeton University Press, pp. 392-418. LECE (1957). La L.E.C.E. Dix années d'activité, 1947-1957. Bruxelles: LECE, pp. 27-28; CEHECLIN, LECE, inv. nr. 371, 24-9-1958, Liste des Membres de la section Française de L.E.C.E.

${ }^{94}$ See Appendix.
} 
Table 2.2: Composition of ELEC's Central Council membership in societal spheres, 1950-1980 (absolute figures).$^{95}$

\begin{tabular}{lccccccc}
\hline Societal spheres & 1950 & 1955 & 1960 & 1965 & 1970 & 1975 & 1980 \\
\hline Business & 12 & 15 & 17 & 20 & 25 & 32 & 34 \\
Politics & 5 & 1 & 2 & 1 & 3 & 2 & 4 \\
Public administration & 1 & 0 & 3 & 2 & 2 & 0 & 0 \\
Semi-Public administration & 0 & 1 & 1 & 1 & 2 & 2 & 1 \\
Academic & 0 & 2 & 3 & 4 & 3 & 2 & 1 \\
Military & 0 & 0 & 0 & 0 & 0 & 0 & 0 \\
Labour & 1 & 1 & 1 & 1 & 1 & 1 & 1 \\
Media & 0 & 0 & 0 & 0 & 0 & 0 & 0 \\
Other & 1 & 1 & 1 & 0 & 0 & 1 & 1 \\
\hline Total categorized: & 20 & 21 & 28 & 29 & 36 & 40 & 42 \\
Total membership: & 20 & 21 & 28 & 30 & 38 & 44 & 44 \\
\hline
\end{tabular}

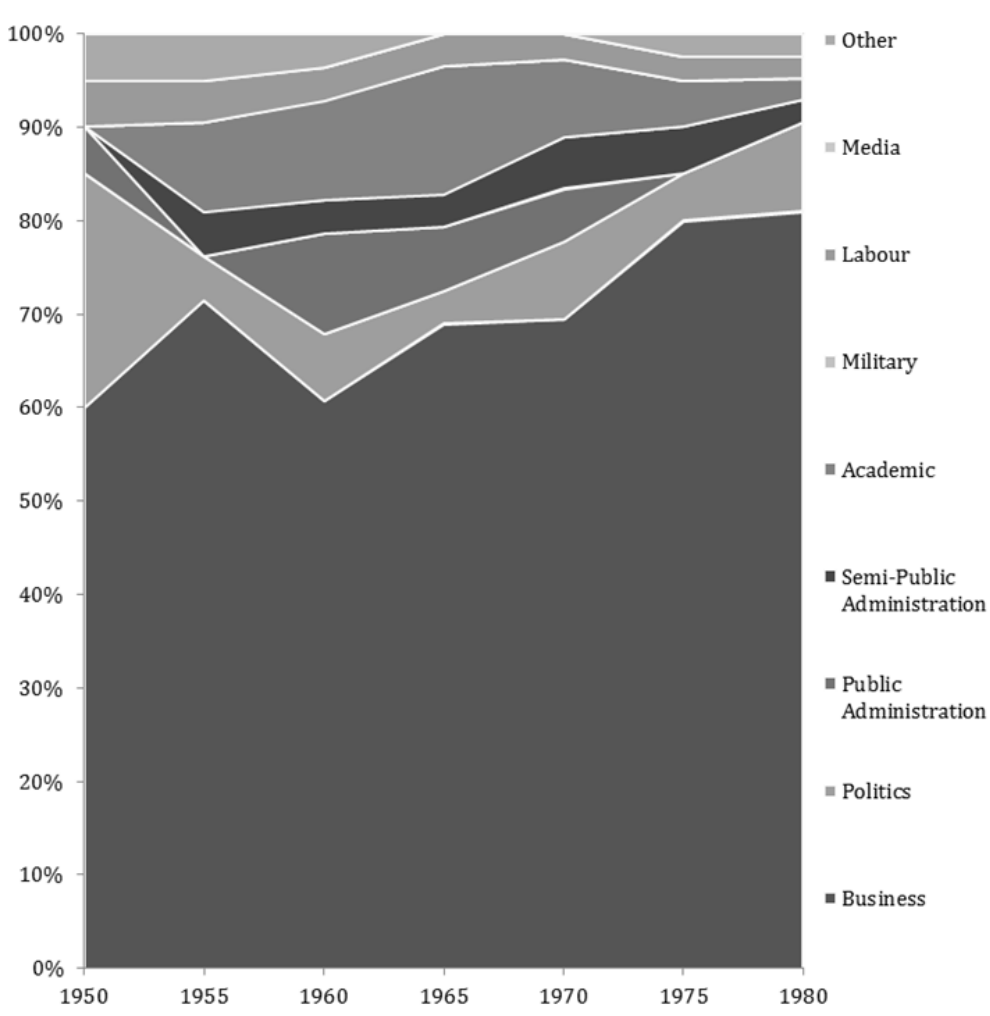

Figure 2.1: Relative composition of ELEC's Central Council membership in societal spheres, 1950$1980 .{ }^{96}$

${ }^{95}$ Source: see the Appendix. For details on the choices in the table, see the Appendix section Tables and figures.

${ }^{96}$ Ibidem. 
ELEC's development into a business-led group would last. The database that is included in the appendix lists the membership of the ELEC's governing body, the Central Council from 1950 until 1980, in seven intervals. Based on individual biographies, each member was categorized as part of a societal sphere, such as business, politics, public administration and others. Considering the membership as shown in table 2.2 and figure 2.1 it becomes clear that the members of the Central Council from the societal sphere of business was consistently above $60 \%$ and from 1960 onwards steadily climbed to approximately 75\%. Other societal spheres such as politics and labour played a nearly marginal role. The only societal sphere that exceeded a share of $10 \%$ for more than one interval were the academics, in this case mainly economists. ${ }^{97}$

The ELEC composition was thus dominated by representatives from business. One aspect of ELEC's membership deserves special consideration however. The League allowed non-business members to be part of their national sections and even included a member of the Belgian socialist party and a British union leader in the Central Council. Several scholars have stressed this aspect and compared this trait of ELEC to the different approach of another transnational voice of European business, the Comité Européen pour le Progrès Economique et Social (CEPES). This was a study and pressure group similar to ELEC, but it only included German, French and Italian sections. ELEC and CEPES became embroiled in a conflict, which was rooted in the double membership of Italians of both organizations. ELEC preferred to absorb CEPES to increase ELEC's representativeness and thus the value of its policy papers. However, CEPES' President, Vittorio Valleta, also President of FIAT, opposed ELEC's practice of including socialist forces into its advisory ranks. CEPES only allowed businessmen and economists as members. The failed attempts at collaboration led to the de-facto discontinuation of the Italian ELEC section between 1953 and the late 1960s. ${ }^{98}$

\footnotetext{
${ }_{97}$ For a complete introduction to the database and all the choices involved in compiling it, see the Appendix.

${ }_{98}$ CEPES requires some further elaboration. Despite similarities between ELEC and CEPES, scholars have stressed their differences. Dumoulin \& Dutrieue claimed that ELEC had a more "federal" and "maximalist" approach to European integration, and CEPES was more "unionist" and "minimalist." Tedeschi pointed out that CEPES, unlike ELEC, preferred to keep the United Kingdom out of the Community. Based on the involvement of socialist thinkers in ELEC, Ramírez Pérez stressed ELEC's neocorporatist outlook, versus a neoliberal outlook among CEPES members. These comparisons imply ideological differences within the European business community that may well be exaggerated. A brief glance over actual CEPES publications leads to questions: they state that the CEPES strove for "die Ausweitung der Europäischen Wirtschaftsgemeinschaft durch den Beitritt Grossbritanniens", not different than ELEC's ambitions. Moreover, the themes and ideas in the publications are similar. The internal differences within CEPES are much more interesting than a comparison between CEPES and ELEC. As explained by Tedeschi and Ramírez Pérez the German, French and Italian sections had trouble accepting each others proposals in the early 1950s. Later CEPES publications point to the continuation of this dynamic, as several were only published in Germany, and several touched solely on national
} 
ELEC itself disagreed internally about the practice of consultation of representatives of labour parties. The French section, as well as ELEC's secretary general Lucien-Léandre Sermon, feared that ELEC would lose access to financial support from business if it would continue with this practice. The issue was put on edge by a request from the British section in 1951 to have the ELEC include more union representatives in the Central Council. The request was declined. ELEC's President Baron Boël simultaneously had to deal with several national contexts, and did not want to run the risk of alienating entire national sections. ${ }^{99}$

It should be remembered that the Western European context of the early 1950s was characterized by reconstruction policies and an associated productivity ideology that was supported by socialists, christian-democrats and liberals alike. However in some countries the capitalist-socialist divide was deeper than in others. Polarization especially occurred in France where the communist party played an influential role, and a similar situation existed in Italy. Against the backdrop of the Korean war, starting in 1950, such tensions were fuelled. These aspects at least partly explain some of the conflicts within ELEC. However, the very limited participation of non-liberal economic ideologues in the Central Council, and the sheer preponderance of industrial and financial interests suggests that this was a nonissue for the longer term: indeed after these conflicts the already minimal consultation of socialists was gradually phased out in ELEC's Central Council's work. ${ }^{100}$

\section{Themes discussed, 1950-1980}

From 1950 onwards, ELEC worked tirelessly on the theme of a European market without internal tariffs. In addition, ELEC also studied monetary questions, agriculture, the organization of transport, and developmental aid for economically weaker regions within Europe. After de Gaulle's rejection of British accession the Common Market in 1963, ELEC felt that new venues of economic integration should be explored. In June 1964 it defined new priorities in the direction of industrial poli-

\footnotetext{
themes. CEPES appears to have been rather ineffective as a transnational study and pressure group in the sense of creating coherent statements geared towards a European polity. Regrettably archives have been unavailable to date. See for CEPES: Tedeschi, P. (2006). Une nouvelle Europe à construire. La section italienne de la LECE, de 1948 à la création du Marché Commun. Journal of European integration history, 12, 87-104. Dumoulin \& Dutrieue (1993). La Ligue, pp. 60-64, 122-127. Ramírez Pérez, S. M. (2010). The European Committee for Economic and Social Progress: Business Networks between Atlantic and European Communities. In K. Wolfram, B. Leucht and M. Gehler (Eds.) (2010). Transnational networks in regional integration. Governing Europe 1945-83 (pp. 61-84). London: Palgrave Macmillan. CEPES (1961). Möglichkeiten und probleme einer Atlantischen Partnerschaft. Arbeitstagung der deutschen CEPES-Gruppe am 16 Februar 1962. Frankfurt a. M.: CEPES, p. 42.

${ }^{99}$ CEHECLIN, LECE, inv. nr. 368, 15-03-1951, Beddington-Behrens to Baron Boël, and, no date, Question of Representation of Trade Union on the Central Council of E.L.E.C. Dumoulin \& Dutrieue (1993). La Ligue, pp. 42-43.

${ }_{100}$ See table 2.2 and figure 2.1. Judt, T. (2005). Postwar. A history of Europe since 1945. New York: Penguin, pp. 203-225, 324-330.
} 
cies mainly in response to external competition. This will be discussed further in chapter 5.101

When after de Gaulle's resignation in 1969 British accession to the Common Market again became feasible, ELEC shortly refocused on the EEC's enlargement. After 1972, it saw the need to respond to the oil crises from a mainly industrial perspective, which also led to a temporary working group on energy policy. Looking at the entire period of 1950 until 1980, the pinnacle of ELEC's activity lies in the 1950s. During the 1970s the declining rate of publications and conferences shows that the urgency of ELEC's vision for Europe's economic organization lost most of its previous drive. But until the end of Baron Boël's presidency of ELEC, in 1981, the ELEC remained on top of European developments. 102

\section{ELEC and businessmen}

After 1950, the ELEC became an organization of European business that studied and lobbied on issues of European integration. For its members the studies on developments of the European market provided basic knowledge for anticipating important changes in the European market organization. At the same time, ELEC was a pressure group that initially approached European governments and later also the European Commission. Viscount Etiènne Davignon, former European Commissioner on industrial affairs, the internal market and energy (1977-1985) characterizes the members of ELEC as "European militants." They were European business leaders who were convinced that "a future within Europe could be better than the traditional means of the member-states." Moreover, according to Davignon, they were a group of people that "understood why they were for such a project", meaning that they could oversee the consequences of such a choice and were also able to convey why they supported certain moves. ${ }^{103}$

ELEC's topics of concern were broader in scope than the liberalization and expansion of international trade: as will be demonstrated in chapter 5, ELEC also treated questions such as how to deal with competition from outside the EEC. However, precisely which message to convey to national governments and later the European Commission was hardly self-evident. Negotiations on the content of ELEC's position papers or resolutions were an inherent part of its meetings. This process of consensus formation required flexibility instead of rigor, as not everybody's demands could be met. Businessmen were therefore also strategically involved: they aimed at shaping ELEC's consensus in the direction of their prefer-

\footnotetext{
${ }^{101}$ Both subjects will be discussed in chapter 5. ELEC's work on US investments was not turned into a publication, but its work on trade relations with Eastern Europe was. For example: ELEC (1969). The Inter-European industrial, technical and scientific agreements : concrete measures with a view to developing them (Vol. 47). Brussels: ELEC. CEHECLIN, ELEC, inv. 748, 19-06-1964, Conclusions de la Table Ronde d'Industriels, pp. 1-2.

102 See Sources for a full list of ELEC publications for the period 1949-1981.

${ }^{103}$ Interview Viscount Etiènne Davignon (Brussels, 8th of September 2010).
} 
ences. The specific role played by industrial and national factors in that process will be analysed in the next chapter.

\section{The Bilderberg meetings, 1952-1980104}

The Bilderberg network was an entirely different organization than ELEC. It did not focus on lobbying institutions or governments, nor did it strive for consensus among its members. Unlike ELEC's focus on Western Europe, the Bilderberg meetings was a Transatlantic organization with North-American and Western European membership. Influential politicians, businessmen, public administrators and policy researchers discussed matters of transatlantic defence and international economic relations. In an abstract and discursive sense, this basic format of the Bilderberg meetings was its key message. The well-prepared discussions between reputable and influential Americans, Canadians and Western Europeans, were organized with the underlying assumption that as long as the Transatlantic dialogue kept going, a bond between the industrialized parts of the world would be sustained. In other words, the simple fact that the meetings took place, realized Bilderberg's intended function. Valérie Aubourg, one of the scholars who investigated the Bilderberg meetings, saw this as Bilderberg's key purpose: nurturing an "Atlantic spirit" and establishing a "common understanding."105

At the same time, it is clear that those that presided over and took part in Bilderberg's activities felt that more was at stake than this primary and at the same time rather general purpose. According to Aubourg, Bilderberg members were political entrepreneurs, who put forward differing conceptions on for example European integration. In doing so, they opened up complex themes for international discussion, and enabled members to test their views in a context of international politics and economics. Thomas Gijswijt has added to this picture that the

104 The only extensive and Bilderberg- focussed archive based study on the Bilderberg meetings is Gijswijt, T. W. (2007). Uniting the West: the Bilderberg Group, the Cold War and European integration, 1952-1966. Unpublished dissertation, Heidelberg, Heidelberg. Other work that places the Bilderberg group in the wider historiography of similar organizations, networks and themes is Aubourg, V. (2003). Organizing Atlanticism: The Bilderberg Group and the Atlantic Institute, 1952-1963. Intelligence and National Security, 18, 92-105; Aubourg, V. (2004). Le groupe de Bilderberg et l'intégration européenne jusqu'au milieu des années 1960. Une influence complexe. In M. Dumoulin (Ed.), Réseaux écononomiques et construction européenne. Economic Networks and European Integration (pp. 411-430). Brussels: PIE Peter Lang; Aubourg V. (2009) Transatlantische Geschäftsbeziehungen. Die BilderbergGruppe. In M. Gehler, W. Kaiser B. \& Leucht (Eds.), Netzwerke im europäischen Mehrebenensystem. Von 1945 bis zur Gegenwart = Networks in European multi-level governance. From 1945 to the present (pp. 69-86). Wien: Böhlau. Contributions that engage less with the historiography have been Aalders, G. (2007). De Bilderbergconferenties: organisatie en werkwijze van een geheim Trans-Atlantisch netwerk. Amsterdam: Van Praag; Thompson, P. (1980). Bilderberg and the West. In H. Sklar (Ed.), Trilateralism: the Trilateral Commission and elite planning for world management (pp. 157-189). Montréal: Black Rose Books.

${ }^{105}$ Aubourg (2003). Organizing Atlanticism, p. 103. 
Bilderberg meetings should also be seen as a platform where individuals "influenced each other."106

Indeed, as will become clear in chapters 4 to 6 some members attempted to use the Bilderberg discussions to influence the international debate on certain themes. Others experimented with their policy views, testing the response of such a diverse yet experienced and responsible audience. Some carefully took notice of the direction in which the international debate on transatlantic defence and international economic relations was going.

\section{Founding the Bilderberg meetings, 1952-1954}

The story of the Bilderberg meetings also starts with Joseph $\mathrm{H}$. Retinger, the same man who laid the basis for the European League for Economic Cooperation. He was concerned about a growing anti-Americanism in Europe. According to him the increasing global policing role of the United States, as a result of Truman's farreaching containment doctrine, in combination with European remilitarization, was causing a rift in Transatlantic relations. He feared that ultimately US support for European unification would be withdrawn. In his view such a move would put the future of European democracy at risk. In 1952 he again turned to relationships from his stay in London, starting with Paul van Zeeland who at that point was still the Belgian Minister of Foreign Affairs. Soon afterwards he contacted Paul Rijkens, Chairman of the British-Dutch multinational Unilever, whom he also knew from London. Retinger proposed to Rijkens to set up a study on European antiAmericanism and to present it to the United States' government. According to him this could provide a basis for a conference to discuss the existing tensions. Rijkens agreed to the suggestion. In May 1952, he subsequently introduced Retinger to HRH Prince Bernhard, Prince-consort of Queen Juliana of the Netherlands, with whom Rijkens had developed close relations since their cooperation in the Dutch Study Group for Reconstruction Problems in London during WWII. A last round of advice with Paul van Zeeland convinced Prince Bernhard to take part in Retinger's initiative. ${ }^{107}$

After Prince Bernhard agreed to Retinger's plan, a group of eminent Europeans was put together from Germany, the United Kingdom, Italy, Denmark, France and Greece, including the Prime minister of Italy, Alcide de Gasperi, and the For-

\footnotetext{
106 Italics are in the original. Aubourg (2004). Le groupe de Bilderberg; Aubourg (2009). Transatlantische Geschäftsbeziehungen; Gijswijt (2007). Uniting the West, p. 293.

${ }_{107}$ Rijkens, P. (1965). Handel en wandel: nagelaten gedenkschriften, 1888-1965. Rotterdam: Donker, p. 137. Retinger \& Pomian (1972) Joseph Retinger, pp. 250-251; Gijswijt (2007). Uniting the West, pp. 1011. For more on the Dutch Study Group for Reconstruction Problems in London during WWII, see: Weenink, W. H. (2005). Johan Willem Beyen, 1879-1976: bankier van de wereld, bouwer van Europa. Amsterdam: Prometheus, pp. 190, 218, 224-225. Paulussen, \& Blanken (2004). Samenwerking tusschen Nederlandsche industrieën, pp. 30-31. Wubs, B. (2008). International business and war interests: Unilever between Reich and empire, 1939-1945. London: Routledge, pp. 137-141.
} 
eign Minister of Denmark, Ole Bjørn Kraft. They decided to investigate the occurrence of anti-Americanism in their respective countries. ${ }^{108}$

The results were included in a report which Retinger presented to the American government in December 1952. Due to national priorities however, the US government was unable to respond in a timely fashion. In September 1953 Charles D. Jackson, Special Assistant to the President for International Affairs, requested John S. Coleman, the chairman of the automotive firm Burroughs Corporation and chairman of the business group Committee on a National Trade Policy to form the so-called American Committee and to respond to the European report. ${ }^{109}$

After the European group received the American report a conference was planned to discuss a synthesis of the main themes of the reports among 50 wellrespected and important participants. It was held from the $29^{\text {th }}$ to the $31^{\text {st }}$ of May in Hotel Bilderberg at Oosterbeek, the Netherlands, thereby starting a tradition of annual conferences until today. The first was called "the Bilderberg Conference", but at the next sessions the name "Bilderberg Group" was adopted until 1959, when it was changed into Bilderberg meetings. The name "Bilderberg Group" had suggested to participants that they would be invited back, but in fact no such guarantee existed. Moreover, Denis Healey, Labour politician and member of Bilderberg's Steering Committee, had signalled that Labour party participants to Bilderberg Group conferences had felt uneasy about being in a "group" with capitalists. ${ }^{110}$

\section{Organization structure}

The organization of the Bilderberg meetings was in the hands of the Steering Committee. It determined the topics for the annual conferences, decided who to

\footnotetext{
${ }_{108}$ The group consisted of mainly European politicians, public administrators and businessmen: Paul van Zeeland (Belgian Foreign Minister, Christian People's Party), Max Brauer (Mayor of Hamburg), Hugh Gaitskell (British Labour Politician), Alcide de Gasperi (Christian Democrat Prime Minister), Major General Colin Gubbins (Former British Special Operations Director, WWII), Ole Bjørn Kraft (Danish Conservative Party and Minister of Foreign Affairs), Guy Mollet (French Socialist Party), Rudolf Mueller (German corporate lawyer), Antoine Pinay (French Conservatives, Prime Minister), Panajotis Pipinelis, Lord Portal of Hungerford (Director Barclays Bank), Pietro Quaroni (Italian ambassador) and Paul Rijkens (Dutch Chairman of the British-Dutch Unilever concern). Gijswijt (2007). Uniting the West, pp. 11-12.

${ }^{109}$ Nationaal Archief, Den Haag, Bilderberg Conferenties, 1952-1999, nummer toegang 2.19.045 inventarisnummer 1 (hereafter, NL-HaNA, Bilderberg Conferenties, 2.19.045, inv. nr.), September 1952, Report No. 1: Report on European-American Relations; December 1953, Report No. 2: Memorandum On American Attitudes Towards Relations with Europe. Gijswijt (2007). Uniting the West, pp. 13-24, 29-32. For details on the Committee for a National Trade Policy, also called the Coleman Committee see: Bauer, R. A., De Sola Pool, I., \& Dexter, L. A. (1972). American business \& public policy: the politics of foreign trade (2 ed.). Chicago: Aldine-Atherton, pp. 30-39, 50, 375-387. See chapter 4 for a discussion of these reports.

${ }^{110}$ Rheinisch-Westfällisches Wirtschaftsarchief Köln, Abt. 72, Nachlass Otto Wolff von Amerongen (hereafter RWWK, NOWA), inv. nr. 72-377-3, 1-01-1960, Meeting of the advisory committee, Soestdijk Palace; 02-02-1960, Otto Wolff von Amerongen to Rudolph Mueller. Gijswijt (2007). Uniting the West, pp. 32-35.
} 
invite and to select authors for introductory papers for the conferences to inform discussion on the major topics. The Steering Committee started as a group of fourteen men in 1954 but grew quickly, reaching the number of thirty members in the early 1960 s. ${ }^{111}$

In addition to the Steering Committee an Advisory Committee was established in 1960 to assist the chairman, the secretaries general for the United States and Europe and the treasurer. While originally this had been a task of the Steering Committee, its size had made it difficult to convene regularly. The advisory committee included representatives of the US, France, the United Kingdom, Germany and Italy. ${ }^{112}$

The annual meetings were very much like regular conferences: they revolved around presented papers and debate. However, the combination of the importance of the guests, the important themes such as transatlantic security and global economic conflict, and the confidential character, turned them into meetings of consultative relevance for foreign policy debates that were taking place in international relations. The conference reports read as an overview of what the different camps in the West were thinking at the time, including a discussion on how consequences of major differences could be minimized. As will be shown in chapters 4 to 6 , reaching consensus or policy instructions between all participants was mostly impossible, positions were simply too divergent.113

Finances for the Bilderberg meetings were mostly arranged by privately owned business. The Ford Foundation paid large sums at several instances. In Europe, contributions were smaller. Wherever a conference took place the national business community was often asked to chip in. For example, for the first conference in Oosterbeek an amount of 27.000 florins was received from ten Dutch companies, among them Philips, AKU and Shell. The conference in Buxton, United Kingdom, relied on thirteen companies, among them British Petroleum, again Shell, Imperial Chemical Industries and Unilever, for an amount of approximately 4700 Pound Sterling. These companies were personally encouraged to contribute by Prime Minister Hugh Gaitskell. Baron de Launoit, a prominent Belgian industrialist, donated an amount of one million Bfr. in 1956 to cover the Belgian share for the following years. ${ }^{114}$

\footnotetext{
${ }^{111}$ See table 2.7, figure 2.2 and the Appendix for the evolving composition of the Steering Committee.

112 The first members of the advisory committee were: Wilfrid Baumgartner, Denis Healey, Rudolph Mueller, Pietro Quaroni, H. J. Heinz II, and George Nebolsine. RWWK, NOWA, inv. nr. 72-377-3, 1-021960, Prince Bernhard to Steering Committee members.

${ }^{113}$ For a list of the meeting reports, see the section Sources, following chapter 7.

114 The Ford Foundation paid in 1957, \$30.000, in 1959, \$48.000, in $1963 \$ 60.000$. Aubourg (2003). Organizing Atlanticism, pp. 96-97. NL-HaNA, Bilderberg Conferenties, 2.19.045, inv. nr. 186, Augustus 1954, Prince Bernhard to boards of Ned. Handel Mij. Amsterdam , K.L.M., Philips, Steenkolen Handelsvereniging, A.K.U., Hoogovens, Staatsmijnen, Standard Vacuum, B.P.M; inv. nr. 48, 11-03-1958, Hugh Gaitskell to Cavendish-Bentinck; inv. nr. 48, 26-8-1958, Bilderberg Conference 1958, Buxton - September 13th, 14th and 15th "The following donations have been received..."; inv. nr. 39, 9-03-1956, Note
} 
Who participated in the Bilderberg meetings? The simple answer is: the Steering Committee. This group visited most of the conferences and co-determined the main direction of the Bilderberg meetings. However, between 1954 and 1980, 1035 different visitors took part in the conferences of which only about 70 people were Steering Committee members. A look at the structure of the membership and their visiting habits reveals interesting results. First of all, table 2.3 shows that participants in conferences were a mix of Americans, Canadians and Europeans

Table 2.3: Start participation of members of Bilderberg meetings, per country, and start Steering Committee membership, 1954-1980. ${ }^{115}$

\begin{tabular}{lcc}
\hline Country & Start Participation since: & Position in the SCM since: \\
\hline Belgium & 1954 & 1954 \\
Denmark & 1954 & 1954 \\
United Kingdom & 1954 & 1954 \\
France & 1954 & 1954 \\
Germany & 1954 & 1954 \\
Italy & 1954 & 1954 \\
Netherlands & 1954 & 1954 \\
United States & 1954 & 1954 \\
Norway & 1954 & 1956 \\
Sweden & 1954 & 1956 \\
Turkey & 1957 & 1958 \\
Greece & 1954 & 1959 \\
Switzerland & 1954 & 1960 \\
Canada & 1955 & 1960 \\
Austria & 1955 & 1973 \\
Iceland & 1966 & 1980 \\
Portugal & 1956 & No SCM \\
Finland & 1962 & No SCM \\
Ireland & 1975 & No SCM \\
Luxembourg & 1977 & No SCM \\
Spain & 1977 & No SCM \\
\hline
\end{tabular}

résument certaines décisions par le Président du Groupe à la suite d'une conversation avec le Prince Bernhard des Pays-Bas, le 1er mars 1956.

115 International Institute of Social History Amsterdam, Archive Max Kohnstamm (hereafter IISGA, AMK), inv. nr. 110, Bilderberg Meetings Alphabetical List of Participants 1954-2001; RWWK, NOWA, inv. nrs. 72-377-3, 72-378-3, 72-378-4, 72-379-2, 72-374-2, 72-374-3, 72-374-4, 72-372-5, 72-968-3, 72-969-1, 72-969-2, 72-969-2, 72-969-3, 72-970-1, Advisory and Steering Committee Minutes From 1959 until 1977 (except for 1966 and 1968 which are not included in the archive); NL-HaNA, Bilderberg Conferenties, 2.19.045, inv. nrs. 30-31-35-41-46. Steering Committee Minutes from 1954 until 1958. Additionally, this data was completed with conference participation lists included in the Bilderberg meetings conference reports of the years: 1954-1959, 1962, 1964, 1967 and 1970-1980. See Sources, section Publications of networks, section Bilderberg meetings publications. 
Table 2.4: All individuals with 11 to 28 visits to Bilderberg conferences, 1954-1980.116

\begin{tabular}{|c|c|c|}
\hline Nationality & Last Name, First Name & Number of conferences \\
\hline Belgium & Snoy et d'Oppuers, Jean-Charles & 16 \\
\hline Canada & Griffin, Anthony G.S. & 16 \\
\hline Denmark & Terkelsen, Terkel M. & 19 \\
\hline England & Bennett, Sir Frederic M. & 20 \\
\hline England & Healey, Lord (Denis W.) & 19 \\
\hline England & Roll of Ipsden, Lord & 14 \\
\hline England & Gubbins, Collin & 11 \\
\hline France & Baumgartner, Wilfrid S. & 15 \\
\hline Germany & Wolff von Amerongen, Otto & 26 \\
\hline Germany & Berg, Fritz & 13 \\
\hline Germany & Erler, Fritz & 12 \\
\hline Germany & Schmid, Carlo & 11 \\
\hline Italy & Agnelli, Giovanni & 19 \\
\hline Italy & Cittadini Cesi, II Marchese & 12 \\
\hline Netherlands & Prince Bernhard of the Netherlands & 24 \\
\hline Netherlands & Beugel, Ernst H. van der & 21 \\
\hline Netherlands & Luns, Joseph M.A.H. & 16 \\
\hline Netherlands & Kohnstamm, Max & 15 \\
\hline Netherlands & Lennep, Emile van & 12 \\
\hline Netherlands & Rijkens, Paul & 12 \\
\hline Norway & Höegh, Leif & 21 \\
\hline Norway & Tidemand, Otto Grieg & 13 \\
\hline Sweden & Wallenberg, Marcus & 21 \\
\hline Switzerland & Umbricht, Victor $\mathrm{H}$. & 12 \\
\hline Turkey & Birgi, M. Nuri & 21 \\
\hline U.S.A. & Heinz II, Henry J. & 26 \\
\hline U.S.A. & Ball, George W. & 26 \\
\hline U.S.A. & Johnson, Joseph E. & 26 \\
\hline U.S.A. & Rockefeller, David & 22 \\
\hline U.S.A. & Hauge, Gabriel & 16 \\
\hline U.S.A. & Collado, Emilio & 16 \\
\hline U.S.A. & Dean, Arthur H. & 13 \\
\hline U.S.A. & Stone, Shephard & 12 \\
\hline
\end{tabular}

116 Ibidem. 
Table 2.5: Number of visitors in relation to the number of conferences visited. ${ }^{117}$

\begin{tabular}{cc}
\hline Conferences visited & Number of visitors \\
\hline 1 & 711 \\
2 & 139 \\
$3-5$ & 107 \\
$6-10$ & 45 \\
$11-20$ & 23 \\
$21-28$ & 10 \\
\hline
\end{tabular}

(including Turkey) from countries not under Soviet communist rule.

A small group of individuals can be described as having a tight knit membership. They are listed in table 2.4, which offers an overview of the persons that visited more than 10 meetings between 1954 and 1980. Table 2.5 clarifies the degree of stability of the Bilderberg meetings membership: 711 of the 1035 visitors only participated once. Only 190 people participated 3 or more times in the total of 28 conferences.

The selection of participants was in the hands of the Steering Committee members who individually arranged invitations per country. For Germany, this was Otto Wolff von Amerongen, President of the steel products trading company Otto Wolff. His practices show that the selection process was mostly based on quality and suitability of an individual with regard to topics on the Bilderberg meetings agenda. However, the national committees were asked to retain the balance suggested by the Steering Committee: politicians from a mix of parties, foreign policy researchers, economists, public administrators and business representatives. ${ }^{118}$

Since 1961 the Steering Committee developed the awareness that the younger generations should increasingly be integrated in its proceedings. Initially nothing came of this, but in 1968, four months after the student protests in Paris and New York, the Secretary for the European members, Ernst van der Beugel, started a more forceful campaign. Claiming that the Bilderberg meetings tended "to be a rather one sided group" and "establishment", he asked of all involved to work towards a $25 \%$ participation from the age group of 25 to 40 years old, since they were "much nearer to the views of the student generation in vital matters of for-

\footnotetext{
117 Ibidem.

${ }^{118}$ See for example a letter of Otto Wolff von Amerongen to Rudolph Mueller in which he succesfully suggested to replace Hans Günther Sohl (leader of Thyssen) for Kurt Birrenbach, also related to Thyssen via its Advisory Board, and member of the Auswärtigen Ausschuss of the German Bundestag as a member of the CDU. Or the suggestion of Ernst Falkenheim instead of Berthold Beitz (leader of Krupp), who combined functions in Deutsche Shell, and the Bund der Deutschen Industrie, making both alternatives broader representatives than merely of two large steel producing companies. RWWK, NOWA, inv. nr. 72-377-3, 02-02-1960, Otto Wolff von Amerongen to Rudolph Mueller.
} 
eign policy and other relevant problems." Women were only invited from 1972 onwards. ${ }^{119}$

Table 2.6 and figure 2.2 show how the Steering Committee membership was distributed across different societal spheres of business, politics, public administration and others. Membership from the societal sphere of business was consistently dominant and almost over the entire period from 1955 to1980 well above $50 \%$. It even reached more than $65 \%$ in 1965 . It is difficult to ignore the temporary importance of the societal spheres of politics and public administration until 1965, which was replaced afterwards by representatives from the societal spheres of academics, particularly think-tank personnel, and media. ${ }^{120}$

Table 2.6: Composition of the Bilderberg meetings' Steering Committee membership in societal spheres, $1955-1980$ (absolute figures). ${ }^{121}$

\begin{tabular}{lcccccc}
\hline Spheres & 1955 & 1960 & 1965 & 1970 & 1975 & 1980 \\
\hline Business & 8 & 16 & 19 & 18 & 22 & 26 \\
Politics & 4 & 4 & 5 & 2 & 2 & 5 \\
Public administration & 2 & 4 & 1 & 0 & 0 & 1 \\
Semi-Public administration & 0 & 0 & 0 & 1 & 1 & 1 \\
Academic & 1 & 1 & 1 & 3 & 3 & 7 \\
Military & 1 & 1 & 0 & 0 & 0 & 0 \\
Labour & 0 & 0 & 0 & 0 & 0 & 1 \\
Media & 0 & 1 & 1 & 2 & 5 & 5 \\
Other & 2 & 1 & 1 & 1 & 1 & 0 \\
\hline Total categorized: & 18 & 28 & 28 & 27 & 34 & 46 \\
Total membership: & 18 & 32 & 30 & 28 & 37 & 50 \\
\hline
\end{tabular}

${ }^{119}$ RWWK, NOWA, inv. nr. 72-379-2, 17-11-1961, Meeting of the Advisory committee at the "Century Club" New York; inv. nr. 72-372-4, 24-09-1968, Ernst van der Beugel to Steering Committee; inv. nr. 72968-3, 5-01-1970, Otto Wolff von Amerongen to Helmut Schmidt; inv. nr. 72-969-1, 24-10-1971, Minutes of the Meeting held by the Steering Committee at Soestdijk Palace.

${ }_{120}$ Table and chart 2.7 are based on the database discussed in Appendix 1. See Appendix 1 for a full consideration of methodology, sources and the database itself.

${ }^{121}$ Source: see the Appendix. For details on the choices in the table, see the Appendix section Tables and figures. 


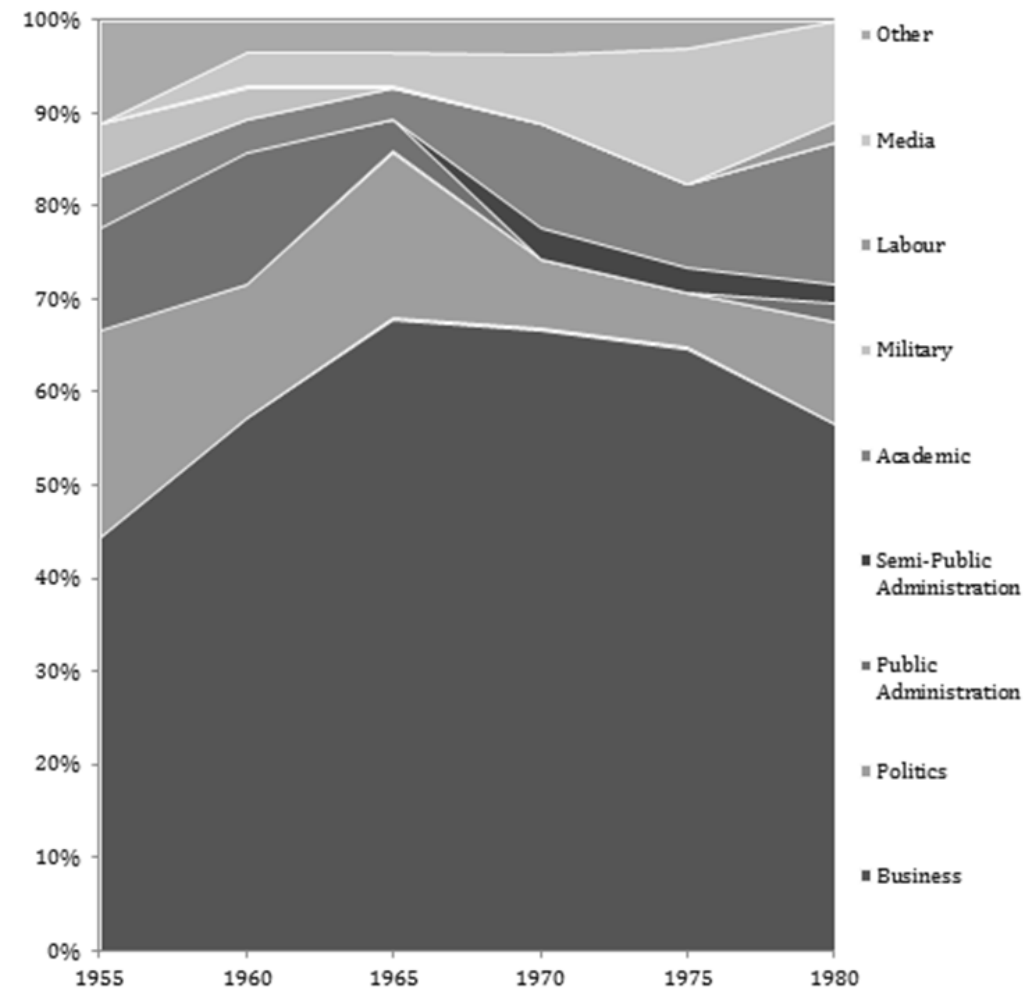

Figure 2.2: Relative composition of the Bilderberg meetings' Steering Committee membership, divided according to societal spheres, 1955-1980.122

Themes discussed, 1954-1980

The first Bilderberg meetings' themes were based on the reports on EuropeanAmerican relations. Simply put, two main subjects dominated the discussion: transatlantic security, and Western economic relations. Transatlantic security was tackled from a multitude of angles, such as NATO strategy and relations, suspicion of Soviet military behaviour or specific communist strategies, the place of nuclear defence in the Transatlantic alliance, etcetera. Western economic relations were mainly discussed from the angle of European integration and the place of the developing countries in Western policy. After de Gaulle blocked British entry into the Common Market in 1963, discussion of European integration stopped to dominate the economic themes and was replaced by topics such as the GATT negotiations, monetary and financial relations and East-West trade. ${ }^{123}$

\footnotetext{
122 Ibidem.

${ }^{123}$ Also see chapter 5. See for an overview of the Bilderberg meetings agenda's from 1954 until 1985 : Nationaal Archief (1988). Inventaris van het archief van de Bilderberg Conferenties: Secretariaat, 1952-
} 
From 1968 onwards the goal to work towards more understanding between the US and Europe appeared to lose its urgency, especially on economic themes. The student protests in Paris and New York in May 1968 had illustrated the need for directing attention to internal Western developments instead of to international relations. The 1969 meeting in Mariënlyst and the 1970 meeting in Bad Ragaz addressed the topics "Elements of instability in Western Society" and the "Future function of the university in our society", both addressing internal political and cultural movements. In May 1970, Steering Committee member Anthony G. S. Griffin of the Canadian Home Oil Company, felt entirely at ease in suggesting a future theme on "urban development", noting that "Bilderberg has already wandered quite far afield from its original subject matter" [...]. He argued that "we are living in an entirely different world now and are absolutely right to be dealing with the kind of questions which we discussed at Marienlyst and Bad Ragaz."124

Bilderberg's original purpose of improving European-American relations was further undermined by a conflict on potential participation of Japanese members in Bilderberg meetings. The Executive Committee had been contemplating the idea of organizing a conference that would focus on the development of Japan into an economic giant. In August 1970, Ernst van der Beugel explained to his colleagues that he felt he had no choice but to invite Japanese participants, seemingly as a form of decorum in international relations. He was not fond of the idea, because he also feared that once the Japanese were invited, the same diplomatic decorum would make it problematic to exclude them from later meetings. The issue led to disagreements within the Steering Committee that resulted in the start of a discussion on the exclusively Transatlantic organization of the Bilderberg meetings. ${ }^{125}$

Nixon's decision in August 1971 to end the dollar-gold convertibility and the subsequent breakdown of the Bretton Woods monetary system, suddenly forced a decision on that subject. The Bilderberg secretaries Joseph E. Johnson for the United States and Canada, and Ernst van der Beugel for Europe, informed the Steering Committee that according to them "the events of this summer had brought about a fundamental change." Bringing back into memory the original purpose of the Bilderberg meetings, namely "to bring about a greater extent of understanding and mutual confidence" they stressed that "since 1945 there hardly has been a situation so conducive to distrust and misunderstanding as exists today." Consequentially, Japanese participation was off the table, since it would only "complicate and hamper the frankness of our discussion." Even David Rockefeller, the influential

2004. Den Haag: Nationaal Archief. Retrieved August 20, 2013, from http://gahetna.nl/collectie/archief/pdf/NL-HaNA_2.19.045.ead.pdf, pp. 7-14.

124 RWWK, NOWA, inv. nr. 72-969-1, 25-05-1970, A.G.S. Griffin to Ernst van der Beugel. Nationaal Archief (1988). Inventaris van het archief van de Bilderberg Conferenties: Secretariaat, 1952-2004. Den Haag: Nationaal Archief. Retrieved August 20, 2013, from http://gahetna.nl/collectie/archief/pdf/NLHaNA_2.19.045.ead.pdf, p. 11.

125 RWWK, NOWA, inv. nr. 72-969-1, 17-08-1970, E.H. van der Beugel to the Members of the Steering Committee; inv. nr. 72-969-1, 30-01-1971, Minutes of the meeting held by the steering committee. 
Chairman of the Chase Manhattan Bank who reintroduced the subject of Japanese membership during the conference of April 1972, was unable to change the minds of his fellows in the Steering Committee. ${ }^{126}$

After 1971, the topics became directed towards the crisis in EuropeanAmerican relations. The oil crisis, starting in October 1973, undermined Western relations even more, which led to the ominous and only subject of the 1974 conference, called "Prospects for the Atlantic world." But also the economic crisis that unfolded during the 1970s became a prominently discussed theme. As a consequence, inflation was a recurrent topic, as was the discussion on the role of the state in the future Western economic structure. Topics of Western defence were part of every conference. ${ }^{127}$

\section{Bilderberg meetings and businessmen}

As mentioned, some scholars have developed insight into what Bilderberg members gained from these meetings. Some participants used their presence to test concepts and strategies in an international environment and others used the opportunity to influence participants from other countries. What did businessmen gain from participation?

One of the most involved people in the Bilderberg meetings was Otto Wolff von Amerongen, Chairman of steel products trading company Otto Wolff (19661986), President of the Deutsche Industrie- und Handelstag (1969-1988) and member of the Bilderberg meetings Steering Committee from 1956 until 1980. He ascribed a double advantage to taking part in the meetings. Apart from creating contacts for his trading firm, he gauged the international perception of German trade policies. This was important for example for his work for the so-called OstAusschuss, a private-public body for the promotion of exports to Eastern Europe, Russia and Asia. ${ }^{128}$

Another German, Fritz Berg, President of the Bundesverband der Deutschen Industrie (BDI) (1949-1971), who took part in meetings during the 1950s, had used them to explain German positions on the EEC and the Free Trade Zone. His participation was thus more aimed at convincing others about German policydirections. ${ }^{129}$

\footnotetext{
${ }^{126}$ RWWK, NOWA, inv. nr. 72-969-1, 28-09-1971, Joseph E. Johnson and Ernst van der Beugel to the members of the Steering Committee, pp. 1-2.

${ }^{127}$ See Nationaal Archief (1988). Inventaris.

${ }^{128}$ Translated from German by the author: "In terms of the economic, and associated political economic tasks of Mister Wolff, the further importance of his participation in the Bilderberg meetings is to be seen in, that in its framework, on an unofficial basis, the reaction on the foreign economic policy of the Federal Republic can be determined, not only of the foreign business world, but also of the foreign governmental circles." RWWK, NOWA, inv. nr. 72-377-3, 2-04-59, Bilderberg-Konferenz in GarmischPartenkirchen September 1955, p. 2.

${ }^{129}$ RWWK, NOWA, inv. nr. 72-377-3, 2-04-59, Bilderberg-Konferenz in Garmisch-Partenkirchen September 1955, p. 2.
} 
Baron Daniel Janssen, President of the chemicals firm Union Chimique Belge (19751984), CEO (1986-1998) and Chairman of Solvay (1998-2006) and member of the Bilderberg meetings Steering Committee (1969-1985) stressed obtaining up to date knowledge as a key interest for businessmen. The Bilderberg meeting of 1973 which discussed possible venues towards a European energy policy was given as an example. The meeting took place only half a year before the first oil crisis would erupt in October 1973. According to Janssen the representatives of major oil companies that participated in the meeting truly brought home the message of what a possible oil shortage would mean. Those present were thus at least enabled to prepare for the worst. However, no scenario had considered a four-fold price increase, as Janssen explained. Even up to date information and well-informed opinion has its limits. ${ }^{130}$

Viscount Etiènne Davignon, former European Commissioner on industrial affairs, the internal market and energy (1977-1985), among others Chairman of the Société de Générale de Belgique (1989-2001) and Chairman of the Bilderberg Meetings (1998-2011), confirms the importance for business to gain an edge in information. According to him it is crucial for business leaders to know that "when there is a crisis, to know how deep it is, what its consequences are in general and for them personally. But also to explain the consequences of their actions to politicians." Thus, the meetings do not merely resolve uncertainty for the participating business leaders. They also provide clarity about their position to other decisionmakers. ${ }^{131}$

With regard to the importance of national viewpoints, Baron Daniel Janssen explained that while the national context mattered in the selection of participants, contributions during the meetings were based on individual experiences. Instead of taking a national position he often found himself defending a European viewpoint. ${ }^{132}$

Viscount Etiènne Davignon stated that "the Bilderberg is a joint structure." Participants "do not require preparatory meetings to determine their position." However, Ernst van der Beugel, the European secretary of the Bilderberg meetings from 1960 until 1980, explained that the nationalist Gaullists could be considered as delegates from the French government. He thought that also the Americans could be seen as a national section, "who convened every morning." Van der Beugel saw those preparatory meetings as a sign of "an American mission" to consistently stress the virtues of European integration, until at least 1968. Thereafter, Henry Kissinger, US National Security Advisor from 1969 until 1975 and Secretary of State from 1973 until 1977, began to deemphasize that policy. Despite those pre-

\footnotetext{
130 Interview with Baron Daniel Janssen. (Brussels, 9th of May 2012).

131 Interview Viscount Etiènne Davignon (Brussels, 8th of September 2010).

132 Interview with Baron Daniel Janssen. (Brussels, 9th of May 2012).
} 
paratory meetings though, the American group still showed internal differences, van der Beugel explained.133

Compared with the ELEC, the Bilderberg meetings emerge as an entirely different organization. It gave priority to the maintenance of Transatlantic relations and focussed on the conflicts of interests between Western Europe and the United States in the global economy and Transatlantic security. Until 1963 European integration was often discussed but it hardly was an all-consuming topic as it was in the ELEC. Moreover, in the Bilderberg meetings European integration was often approached as a strategic goal for the West in a context of Cold War as will be illustrated in chapter 4 . The ELEC was often preoccupied with specific details whereas the Bilderberg meetings focussed on broad ideas. Additionally, in the Bilderberg meetings European integration was placed in a context of Western trade. However, after 1963 the dimension of European integration moved into the background and was replaced by the more general notion of the European market.

Because of the expertise of individuals that were taking part in the conferences, businessmen had access to the most recent information on central topics of the global economy and international security. At the same time participating businessmen themselves fulfilled a similar role of expertise with respect to other spheres of the Transatlantic membership, a position that was used by European business leaders to sensitize Americans to the priorities in international trade for the European market. To European businessmen the Bilderberg meetings can be seen as an ideal platform for participating in international debates and as a context in which business views are taken seriously. ${ }^{134}$

At the same time, national perspectives were important. Both Otto Wolff von Amerongen and Fritz Berg were keen on keeping an eye out for the national interest, at least during the 1950s. Moreover, the motives of French participants under de Gaulle (1959-1969) should be interpreted as outright nationalist which at the time also meant anti-Transatlantic. While expertise may have been an important factor for participation in the meetings, many derived their expertise from intimate involvement with the institutions of national governments. This hybridity of identities creates problems of interpretation which can only be solved by providing ample context in each case. 135

\footnotetext{
133 Nationaal Archief, Den Haag, 357 E.H. van der Beugel, 1946-1990, nummer toegang 2.21.183.08, inventarisnummer 64, p. 692.

${ }_{134}$ Also see chapter 5 .

135 On Gaullism and the criticism of the United States, see for example: Kuisel, R. F. (1993). Seducing the French. The dilemma of americanization. Berkeley. University of California Press.
} 


\section{Trilateral Commission, 1972-1980 136}

The Trilateral Commission was again different from ELEC and the Bilderberg meetings. The membership of the Japanese turned it into a very different organization. That can also be said in relation to ELEC, that lobbied for European economic cooperation in a context of already existing intentions for integration within Western Europe. The Bilderberg meetings on the other hand, tried to improve long-standing Transatlantic relations within the context of a military alliance. As will become clear, the Trilateral Commission tried to do both: just like ELEC it lobbied for economic cooperation, in this case between the United States, Europe and Japan. At the same time, the Trilateral Commission tried to improve Trilateral relations, just as was done during the Bilderberg meetings. However, lobbying for economic cooperation between European countries was different from lobbying for economic cooperation between Europe, Japan and the United States. Moreover improving relations between Japan and the West was more ambitious than improving relations between Europe and the United States, if only due to a lack of cultural similarity, or the limited relations existing until then.

Scholarly analyses of the Trilateral Commission have disregarded that aspect of the complexities of Western-Japanese relations. Instead, they focussed on the motives of businessmen behind the Trilateral Commission's lobbying activities. The best known accounts were characterized by leftist interpretations of the multinational corporation in global power-relations. For example, Stephen Gill's American hegemony and the Trilateral Commission utilized neo-Gramscian theory on the formation of transnational classes to interpret the Trilateral Commission. He depicts the organization's membership as a self-conscious and homogenous, capitalist class, that mobilized the Commission to intentionally forward, legitimize and consolidate their class' hegemony over other classes in the capitalist economic system. Others, such as Holly Sklar, have described the Trilateral Commission in more neutral terms, calling it an elite planning organization. Both approaches stress its elitist character, the supposedly questionable character of its intentions, and the Commission's illegitimate influence over democratic processes. ${ }^{137}$

After an investigation of the Trilateral Commission's archives a less diabolic image of multinational enterprises and their lobbies emerges. The idea of a

\footnotetext{
${ }^{136}$ No archive-based studies on the Trilateral Commission exist to date. Key publications that cover the history of the Trilateral Commission based on published sources are Gill (1991). American hegemony. Sklar, H. (Ed.). (1980). Trilateralism: the Trilateral Commission and elite planning for world management. Montréal: Black Rose Books.

${ }_{137}$ Gill (1991). American hegemony. Others who approached this theme from a similar perspective are Pijl, K. van der (1984). The making of an Atlantic ruling class. London: Verso; Clearfield, F. B. (1985). The trilateral commission: exercising its global influence. Unpublished University Dissertation, University Kentucky, 1985. Lexington, KY: [s.n.]; Sklar (1980). Trilateralism; Beverungen, J. ([2003] 2005). Elite Planning Organizations: Traditionen, Charakteristika, Implikationen der Triateral Commission. University Dissertation Freiburg im Breisgau, 2003. Baden-Baden: Nomos.
} 
planned, self-conscious vehicle for the furthering of the interests of a selfconscious class, or elite planning organization is overstated. Instead, the Trilateral Commission was a rather unstable organization, it seems. Initially, from 1972 to 1974, it had trouble finding its footing because of a lack of enthusiasm for the Commission's cause among European and Japanese members. Later in the 1970s it struggled with upholding the image that its three sections represented a shared worldview while in fact it was internally trying to cope with profoundly differing interests. Some of these aspects will become clear below, others will be explained in more detail in chapter 6 .

\section{Founding the Trilateral Commission, 1972-1973}

The Trilateral Commission was initiated by David Rockefeller who was a member of the prominent Rockefeller oil-family, Chairman of the Chase Manhattan Bank and member of the Bilderberg Steering Committee. David Rockefeller's reasons for founding the Trilateral Commission were primarily aimed at maintaining workable relations between the West and Japan. He personally tried to arrange Japanese participation in the Bilderberg meetings by introducing the topic at the Bilderberg meeting of April 1972. When this failed he decided to create a new organization. ${ }^{138}$

His underlying motives for founding the Trilateral Commission stemmed from worries about the increasing competitive attitudes between the major industrial powers of the world. The sudden breakdown of the Bretton Woods monetary system had shaken relations between the United States, Western Europe and Japan. Rockefeller was mainly concerned about governments neglecting the long term view as they were "compelled instead to concentrate more than ever on issues of the moment", as he explained in July 1972. He added: "Now is a propitious time for persons from the private sector to make a valuable contribution to public policy." 139

In concrete terms the Trilateral Commission was established for developing "practical action" instead of mere research endeavours, and for fulfilling its main purpose of serving "particularly that community of interest which seeks to avoid political conflict between Japan, the European Community, and the nations of North America." The specific mention of the European Community instead of Europe, is noteworthy. It was the result of an intervention by the Dutchman Max Kohnstamm, the European chairman of the Trilateral Commission and a close

\footnotetext{
138 Interview Baron Daniel Janssen (Brussels, 9th of May 2012); Sklar (1980). Trilateralism, pp. 76-82. ${ }^{139}$ Said at the first planning group meeting of the Trilateral Commission. The planning group was composed of seventeen people: C. Fred Bergsten, Robert Bowie, Zbigniew Brzezinski, McGeorge Bundy, Karl Carstens, Guido Colonna di Paliano, Francois Duchêne, René Foch, Max Kohnstamm, Bayless Manning, Kiichi Miyazawa, Kinhide Mushakoji, Saburo Okita, Henry Owen, Tadashi Yamamoto, David Rockefeller, \& George S. Franklin. Rockefeller Archive Center, The Trilateral Commission (North America) Records (hereafter RAC, Trilateral Commission), box 1, folder 1, 23-07-1972, Meeting on proposed Trilateral Commission, p. 1.
} 
associate to Jean Monnet. He felt that European participation in the Trilateral Commission should be limited to people from the European Community. In response to David Rockefeller's surprise about such a request, Kohnstamm stressed that "[...] Europeans of power and influence will serve only if they do not view the Trilateral Commission as a threat to the E.E.C."140

Between the summer of 1972 and October 1973, the planning group built support in their respective national circles and recruited key leaders from Japan, Western Europe and the US for the formation of a leading body called the Executive Committee. The Executive Committee's members on their turn secured funds and established national sections. ${ }^{141}$

The members of the Executive Committee met for the first time on the 21st of October 1973, shortly after the first news of the OPEC oil embargo to the United States and the Netherlands. The first plenary meeting took place as late as May 1975 , the first opportunity for the wider membership to actually meet each other. In other words, the smaller Executive Committee meetings initially formed the core of the Trilateral Commission, and was its only forum until mid-1975.142

\section{Differing assessments of trilateralism}

The Trilateral Commission had trouble finding its footing during its first years. In preparing the first Executive Committee meeting in October 1973, expectations had grown within the planning group for a problem-free and ambitious launch. Their enthusiasm however appeared to be premature. The Europeans were less eager about the Trilateral Commission than the American and Japanese sections. They had not even gone through the trouble of a proper preparation. In spite of some national meetings and a hastily arranged meeting of the European members, they were still unable to speak with one voice, whereas the American and Japanese sections were well-prepared. ${ }^{143}$

The planning group's enthusiasm was however seriously curbed after the first discussions on the actual mandate of the Trilateral Commission, a key point on the first meeting's agenda. According to their draft "statement of purpose", the time had come to institutionalize diplomatic relations between the United States, the European Community and Japan. The Trilateral governments were urged to "com-

\footnotetext{
${ }_{140}$ RAC, Trilateral Commission, box 1, folder 1, 23-07-1972, Meeting on proposed Trilateral Commission, p. 3, 6.

${ }_{141}$ RAC, Trilateral Commission, box 2, folder 22, 25-11-1972, Informal Meeting Geneva, Switzerland, p. 2; box 1, folder 11, 15-10-1973, Full summary of proceedings meeting of the Trilateral Commission of North American, p. 1.

${ }_{142}$ RAC, Trilateral Commission, box 3, folder 41, 20-10-1973, Tadashi Yamamoto to Participants of the Trilateral Commission Tokyo meeting, General Schedule, box 8, folder, 99, no date, The Trilateral Commission Kyoto Meeting, May 1975, Schedule.

${ }_{143}$ RWWK, NOWA, inv. nr. 72-1025-1, 03-10-1973, Bericht zum Stand der Entwicklung der Trilateralen Kommission. Max Kohnstamm to all European members; 05-12-1973, Bericht über die Sitzung des Exekutivausschusses der Trilateralen Kommission vom 21. bis zum 23. Oktober in Tokio.
} 
mit themselves to prior consultation on all decisions which affect their interdependence and to avoid unilateral actions which affect adversely the interests of any of our three areas." Moreover the document stated that "cooperation should be given an organized and continuous framework" and "[c]onsultation should be instituted." The language breathed the atmosphere of essentially problem-free relations between the United States, Europe and Japan. ${ }^{144}$

This was however a bridge too far. No single European or Japanese participant was prepared to urge their governments to follow such guidelines. The European members judged the declaration as too hopeful of trilateralism and deemed the language that was used "euphoric." The Japanese were not convinced either, making clear that they felt that the Trilateral Commission should focus on collective study and discussion, not on putting pressure on their respective governments with respect to a certain political line. ${ }^{145}$

The draft was greatly altered. Any suggestion of the Trilateral Commission's role in multilateral decision-making was painstakingly removed. The proposal of institutionalizing diplomatic relations was reformulated as follows: forwarding of a "sustained process of consultation and mutual education with our countries coming closer together to meet common needs", in which the Trilateral Commission would "promote among Japanese, West European and North Americans the habit of working together", [...] and "generate the will to respond in common." Especially the Americans expressed disappointment about these changes. ${ }^{146}$

The Trilateral Commission clearly meant different things to the different regions. Moreover, the volatile developments in international relations of the last three months of 1973 would place the entire endeavour of the Trilateral Commission in a different perspective. The start of the Yom Kippur war, OPEC's embargo and the reduction of oil exports led to diverging appraisals of the situation by American, European and Japanese governments. Their different responses to the Middle East problems resulted in an atmosphere of reproach. ${ }^{147}$

These developments convinced Max Kohnstamm in early December 1973 of an alternative course for the Trilateral Commission. The original goal of the Trilateral Commission, as he explained, was "the maintenance of the system we had lived in for 25 years" and implied the continuation of the liberal economic order in which American leadership would be replaced with trilateral leadership. However, the unexpected "prudence" of the Japanese and the French during the first Executive Committee meeting and the recent developments in international relations had revealed to Kohnstamm that "there is no preordained harmony between all the many faceted interests of Japan, the U.S. and Europe." He expected that the

\footnotetext{
${ }_{144}$ RWWK, NOWA, inv. nr. 72-1025-1, 25-9-1973. Statement of Purposes, pp. 1-3.

${ }_{145}$ RWWK, NOWA, inv. nr. 72-1025-1, 5-12-1973, Bericht über die Sitzung des Exekutivausschusses der Trilateralen Kommission vom 21. bis zum 23. Oktober in Tokio, pp. 2-3.

${ }^{146}$ Activities of the Trilateral Commission: Statement of Purposes. (1973, November). Trialogue, 2, pp. 12.

${ }^{147}$ See for a broader introduction into the historical context of the early 1970s, Chapter 6 .
} 
Trilateral Commission's focus on action would be void. Instead, Kohnstamm felt that it should "stimulate profound thinking, to search for new ways to mutually inform and enlighten, to point out policy options" and "to be an instrument of mutual education of our members." Through Kohnstamm's reflections the European members had confirmed their collective hesitation about an outspoken lobby and just as the Japanese, they would be satisfied with a focus on study and education. However, the American section was not so easily convinced that this was the right course and as will become clear in chapter six they would mobilize the Trilateral Commission for the purpose of influencing United States policy. ${ }^{148}$

These developments represented more than mere teething troubles and indicate a structural aspect of the Trilateral Commission during the crisis-ridden period of the 1970s. As Rockefeller predicted in the founding process, economic nationalism would and did become the norm. Tense international relations also determined behaviour among the Trilateral Commission members from the private sector. As Baron Daniel Janssen, a member of the Trilateral Commission during the 1970s explained: no shared outlook existed among its members on how to arrange a trilateral order because the different regions were informed by differing priorities. ${ }^{149}$

\section{Organization structure}

The Executive Committee determined the themes of studies and the agenda of the annual plenary meetings in which the entire membership could participate. These were organized from May 1975 onwards. The chairmen of the three regions met several times a year to discuss the Commission's long-term development. Unlike the chairmen and the Executive Committee, the wider membership of about 300350 persons, was not involved in the Commission's current affairs. In cases of special relevance they were consulted by the authors of the Commission's policy reports, or Triangle Papers. They were also consulted as part of regional and even national meetings. Finally, they participated in the annual plenary meetings. The program of these meetings consisted of topical speeches of top-level public administrators and government leaders, informative seminars and planned discussions of the commissioned reports. ${ }^{150}$

For each report the Executive Committee selected a team of three specialists, often academics, to prepare it, from each region one. Typically the scholars were

\footnotetext{
148 IISGA, AMK, inv. nr. 82, 09-12-1973, Max Kohnstamm to Messrs. Smith, Watanabe, Brzezinski, Franklin, Yamamoto, Hager, Colonna, Owen, Bowie.

${ }_{149}$ Interview Baron Daniel Janssen (Brussels, 9th of May 2012).

150 The involvement of regular Trilateral Commission members in the drafting stages of the report, is published in each report, under the heading of 'The Trilateral Process'. See Sources for a list of the Triangle Papers published during the period 1973-1980. See for a typical program of the Trilateral Commission plenary meetings RAC, Trilateral Commission, box 8, folder, 99, no date, The Trilateral Commission Kyoto Meeting, May 1975, Schedule.
} 
not members of the Trilateral Commission. The reports took the form of policy proposals to the governments of the three regions. They mostly summed up the different options with respect to the topic at hand, and it indicated necessary measures to be undertaken by each region. These measures were the result of a process of consultations among members and experts. Finally, the report was discussed at the plenary meetings, and if necessary, adapted afterwards to reflect the thrust of the discussion. ${ }^{151}$

Other scholars have assumed that the Trilateral Commissions' Triangle Papers were a key component in its lobbying properties. However, as became clear, lobbying mainly stood high on the North-American section's agenda. Moreover, when in 1975 the Trilateral Commission discussed cutting its budget, the Europeans were ready to give up the reports. As Max Kohnstamm made clear: "I do not think that our research and our Trilateral working parties are the most essential elements." Similarly, Georges Berthoin, Max Kohnstamm's successor as European chairman, stated in 1976 to the entire European section, that "[w]e should put less emphasis on the academic side of our activities." 152

The businessman Baron Daniel Janssen, from 1975 onwards President of Union Chimique Belge and Trilateral Commission member since 1973, confirmed that the studies were merely a second or even a third priority. According to him, their main use was to provide background information during the plenary meeting discussions. Instead he stressed the importance of the discussions of the reports among participants of different backgrounds. Especially witnessing the process of how certain ideas, suggestions and solutions were recognized, and others were discarded was important to him. The meetings themselves mattered a lot.153

The question arises how the Trilateral Commission was financed. The Executive Committee's members secured funds through their own members, contacts and relations. Main contributors were private foundations and business. For example, between June 1973 and June 1976, the Ford Foundation, the Lilly Endowment, the Rockefeller Brothers Fund, the Charles F. Kettering Foundation and the Fritz Thyssen Foundation granted the Trilateral Commission a total sum of approximately, 1.1 million US dollars. Over the same period, General Motors, Sears Roebuck and Company, Coca Cola Company, Time Incorporated, Caterpillar Tractor Company, Wells Fargo Bank, Exxon Corporation, CBS, and Texas Instruments together contributed 190.000 US dollars to the North American section. ${ }^{154}$

\footnotetext{
151 See the first few pages of each Triangle paper, which introduce the authors and the drafting process. See Sources for a comprehensive list of Triangle papers.

152 For example Gill, S. (1991). American hegemony and the Trilateral Commission. Cambridge: Cambridge University. RWWK, NOWA, inv. nr. 72-1025-3, 12-02-1975, Max Kohnstamm to Gerard Smith, and 14-07-1976, Georges Berthoin to Otto Wolff von Amerongen.

153 Interview Baron Daniel Janssen (Brussels, 9th of May 2012).

${ }_{154}$ RAC, Trilateral Commission, box 358, folder 3586, 30-06-1976, Financial Statements for the three years ended June 30 1976, p. 6; box 2, folder 22, 25-11-1972, Informal Meeting Geneva, Switzerland, p.
} 
The costs for European participation were initially covered through abovementioned grants and were later gradually replaced by European business contributions. Figures for 1979 show key contributing companies such as the Danish Andelsbanken, the Dutch Middenstandsbank (a precursor to the ING bank), Shell, Montedison, and Fiat. The German case was different however. In addition to the key German business associations, paying 40.000 Deutschmark (DM), the German Auswärtiges Amt, the Ministry of Foreign Affairs, also contributed 20.000 DM. Details of the finances of the Japanese section are unknown. ${ }^{155}$

\section{Executive Committee composition, 1973-1980}

Table 2.7 and figure 2.3 show an overview of the composition of the Executive Committee of the Trilateral Commission in terms of societal spheres. Also in this case the dominance of the business sphere is obvious, lying above $50 \%$. The combination of societal spheres of politics, public administration and academics, all policy-making oriented, together make up about $30 \% .{ }^{156}$

Table 2.7: Composition of the Trilateral Commission's Executive Committee membership in societal spheres, 1975-1980 (absolute figures). ${ }^{157}$

\begin{tabular}{lcc}
\hline Spheres & 1975 & 1980 \\
\hline Business & 17 & 20 \\
Politics & 3 & 5 \\
Public administration & 3 & 5 \\
Semi-Public administration & 2 & 1 \\
Academic & 5 & 7 \\
Military & 0 & 0 \\
Labour & 2 & 0 \\
Media & 1 & 0 \\
Other & 1 & 1 \\
\hline Total categorized: & 34 & 39 \\
Of total members: & 34 & 39 \\
\hline
\end{tabular}

2; box 1, folder 11, 15-10-1973, Full summary of proceedings meeting of the Trilateral Commission of North American, p. 1.

155 These German business associations are: Bundesverband Deutschen Banken (BDB), Bund Deutschen Industrie (BDI), Deutsche Industrie- und Handelstag (DIHT), and the Bundesverband des Deutschen Gross- und Aussenhandels (BGA). RWWK, NOWA, inv. nr. 72-1025-3, 14-11-1976, Schoser to Wolff; inv. nr 72-1215-3, 9-05-1979, Income due and pledged. Financial Year 1st October - June 301979.

156 Table 2.8 and figure 2.3 are based on the database discussed in the Appendix. See the Appendix for a full consideration of methodology, sources and the database itself.

${ }^{157}$ Source: see the Appendix. For details on the choices in the table, see the Appendix section Tables and figures. 


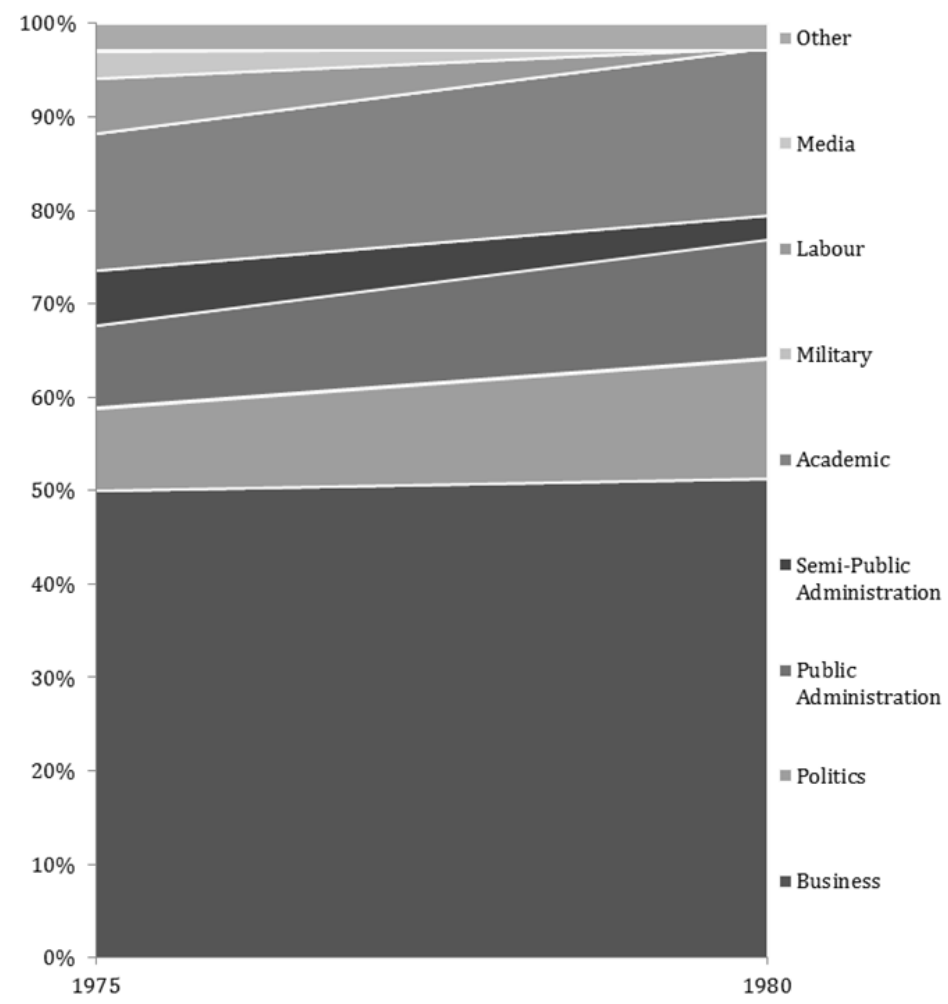

Figure 2.3: Relative composition of the Trilateral Commission's Executive Committee membership in societal spheres, 1975-1980.158

Thematic development, 1973-1980

The main reason for founding the Trilateral Commission was the rejection of international disorder and the uncertainty that it caused. The initial subjects of the Triangle Papers confirm this worrisome outlook. They were preoccupied with the crisis in the monetary system and with the general lack of political will to solve international problems by means of multilateral solutions. The first reports in 1973 collectively pointed out the need for adapting the conduct of international relations to the interdependence that had come about between industrial economies. ${ }^{159}$

158 Ibid.

159 Motoo, K., Cooper, R. N., \& Segré, C. (1973). Towards a renovated world monetary system: a report of the trilateral monetary task force to the Executive Committee of the Trilateral Commission, Tokyo, October 22-23, 1973. New York: The Trilateral Commission; Duchêne, F., Mushakoji, K., \& Owen, H. D. (1974). The crisis of international cooperation: a report of the trilateral political task force to the Executive Committee of the Trilateral Commission, Tokyo, October 22-23, 1973. New York: The Trilateral Commission. 
From 1974 until 1980 Trilateral Commission's studies covered a wide range of topics, including energy policy, North-South and East-West economic and political relations, global tariffs and trade policies, international rules for exploitation of the oceans, the functioning of western democracies, reform of international institutions and diplomatic relations, unemployment, industrial relations and industrial policy. When interpreted from the context of a time of economic nationalism the reports had a rather provocative ring to them. Their consistent global perspective and the technical arguments for international cooperation had little in common with the rekindled expressions of protectionism and icy international relations that left little room for international cooperation. ${ }^{160}$

\section{The Trilateral Commission and businessmen}

The position of businessmen in the Trilateral Commission is not very different from their experiences in the Bilderberg meetings. Participating in the Trilateral Commission on the one hand ensured a source of information on affairs of international economic policy based on the three most important economic regions of the world. For example the former Steering Committee member Baron Daniel Janssen of the Bilderberg meetings explained that when he started to develop activities in Asia, he decided to exchange his position in the Bilderberg meetings for a spot in the Executive Committee of the Trilateral Commission for the purpose of learning about the Japanese and their priorities. Similarly, as mentioned, witnessing the discussions on the Triangle papers was valuable in itself because they provided insight into the dynamic of international problem-solving. ${ }^{161}$

Considering the lobbying aspect it became clear that especially the American section undertook efforts in this direction and that the initial leaders of the European and Japanese sections considered lobbying a bridge too far. Seeking influence was not an important aspect of the Trilateral Commission.

Lastly, as pointed out before, participants from the United States, Europe and Japan, including businessmen, shared only few priorities for the global economic order. This observation severely undermines the idea of a global capitalist class that attempted to forward their joint interests and class' hegemony, as suggested by Gill. It moreover means that the interpretation of business views in the Trilateral Commission may be much more useful if they are investigated on a sectionlevel. ${ }^{162}$

The Trilateral Commission again surfaces as a different organization than the ELEC and the Bilderberg meetings. As mentioned it combined aspects of both, a lobbying role and a role of managing relations, but both took a different form. Lobbying, if pursued, took place in a much less receptive set of relations then the

\footnotetext{
${ }^{160}$ See Appendix 2 for a list of the Triangle Papers published during the period 1973-1980.

161 Interview Baron Daniel Janssen (Brussels, 9th of May 2012).

162 Interview Baron Daniel Janssen (Brussels, 9th of May 2012).
} 
ELEC's work in Western Europe. There was no confessed ambition of European, United States and Japanese governments to cooperate on economic matters. Moreover, the Trilateral Commission was actually a pioneer in building relations between the West and Japan: management of relations could only come later. The Trilateral Commission was, unlike the Bilderberg meetings, hardly concerned with matters of military security.

The Trilateral Commission can best be understood by recognizing the alternative it tried to offer to protectionism and worsening economic relations that were part of the context of the 1970s, along with global monetary disorder, two energy crises, high inflation, and unreceptive attitudes between the main industrial regions of the world. In addition to the requirement for businessmen to have up to date information on international economic developments in such a volatile time, the Trilateral Commission at the same time gave them a platform to clarify what they needed to be successful. That even in such an organization businessmen from different regions had difficulty agreeing on a shared outlook on the world economy implies that they are best seen as in competition with each other.

\section{Joint Membership}

Now that the composition of all three networks' leading bodies has been discussed, a question that remains is to what extent their composition overlapped at any point? As was shown the ELEC, Bilderberg meetings and the Trilateral Commission are related in their origins. The ELEC and the Bilderberg meetings both had the same founders, Joseph Retinger and Paul van Zeeland. The Trilateral Commission was founded by one of the central members of the Bilderberg meetings, David Rockefeller, who drew on the Bilderberg meetings membership for populating the ranks of the Trilateral Commission. This suggests a possible overlap in leadership. Table 2.8 offers an overview of the double or triple memberships across the ELEC Central Council, the Bilderberg meetings' Steering Committee and the Trilateral Commission's Executive Committee for seven selected years between 1950 and 1980. Contrary to popular views that suggest a multitude of ties between these organizations and ascribe world government properties to their joint existence, only minor overlaps existed.

The links between the networks are thus not expressed in their respective leadership. Links across the wider membership of the three networks were in all likelihood more numerous but as mentioned the regular members were less important in directing the groups' purposes. At the same time, the result of little overlap in leadership makes sense, as many overlaps would undermine the reason for the separate existence of the networks. 
Table 2.8: Overlaps between the ELEC, Bilderberg meetings and Trilateral Commission's leading bodies in the years $1950,1955,1960,1965,1970,1975$ and $1980 .{ }^{163}$

\begin{tabular}{lll}
\hline Person & Year & Overlapping membership \\
\hline Paul van Zeeland & 1955 & ELEC, Bilderberg \\
Joseph Retinger & 1955 & ELEC, Bilderberg \\
J.-C. Snoy et D'Oppuers & 1965,1975 & ELEC, Bilderberg \\
Giovanni Agnelli & 1975,1980 & Bilderberg, Trilateral \\
Max Kohnstamm & 1975,1980 & Bilderberg, Trilateral \\
Otto Grieg Tidemand & 1975,1980 & Bilderberg, Trilateral \\
David Rockefeller & 1975,1980 & Bilderberg, Trilateral \\
Leon J. G. Lambert & 1980 & Bilderberg, Trilateral \\
Carlos Ferrer & 1980 & ELEC, Trilateral \\
Henry Kissinger & 1980 & Bilderberg, Trilateral \\
Bruce Maclaury & 1980 & Bilderberg, Trilateral \\
\hline
\end{tabular}

\section{Discussion}

Besides an introduction to the three transnational networks that play a central role in this book, this chapter offers insights in the most important differences between the three organizations. A few aspect should be noted, that are important when reading our analysis in the chapters 4 to 6.

The different levels on which the networks operated are the most important characteristics to take into account. Whereas the ELEC focussed on integration in the European market, the European market was less central to the work of the Bilderberg meetings and the Trilateral Commission. In the last two organizations the European market was discussed in relation to developments in world trade. In chapters 4 to 6 , the investigation of ELEC's activities will likely bring to light the motives of European businessmen with regard to European integration, while an examination of the role of businessmen in the Bilderberg meetings and the Trilateral Commission offers an opportunity to place these seemingly merely Europemotivated views in a Transatlantic and respectively global context.

It is also important to take note of the different priorities of the networks with regard to their national and regional sections. In chapter 4 to 6 especially the interpretation of the debates among businessmen in ELEC requires consideration of nationally formed preferences such as national political-economic priorities. In the Bilderberg meetings and the Trilateral Commission a sensitivity to major differences between the sections of the United States, Western Europe and Japan is required.

${ }_{163}$ Table 2.9 is based on the database discussed in the Appendix. See the Appendix for a full consideration of methodology, sources and the database itself 
Lastly, the European members of ELEC were much more engaged in a strategic process amongst themselves to move consensus in the direction of their priorities. The Bilderberg meetings instead stressed themes that were relevant for Transatlantic relations, which placed European and American business-contexts in conflict with each other. The Trilateral Commission similarly juxtaposed European, American and Japanese business contexts. The investigation of the work of the Bilderberg meetings and the Trilateral Commission in chapters 4 to 6 thus also offers the opportunity to test what remained of European business priorities that were expressed in a context of European integration when they were transferred or elevated to the Transatlantic and global levels of the Bilderberg meetings and the Trilateral Commission. 


\section{Chapter 3}

\section{European multinationals in national and sectoral contexts}

\section{Introduction}

The previous chapter introduced the three transnational networks that are central to this investigation. This chapter introduces the main multinational corporations that were part of the leadership of the ELEC, the Bilderberg meetings and the Trilateral Commission between 1950 and 1980. At the same time they are discussed within their national contexts of economic and industrial policy. Additionally, the second part of this chapter introduces the main dynamics that occurred in the dominant industries to which these firms belonged. The introduction of national and sectoral contexts offers a framework for interpreting the business views on the organization of the European market that are discussed in chapters 4 to 6 . The distinctive settings in which corporations developed and operated play a role in explaining different positions on how European institutions should administer and organize markets.

As became clear in chapter 1 , the context of the national home market has clearly mattered to economic historians and historians of European integration for explaining the motives of European business in the process of European integration. Moreover, the sociologist Richard Whitley has explained how the origin of firms from different national institutional contexts and markets determine the ease with which a firm from one country can transfer its activities to other countries that have a similar business system. He also suggests that these views may have been consistent with preferences of companies with regard to the European market organization when it entered a phase of significant reorganization after 1950. Following this insight this thesis considers the national context as relevant for partly explaining views of European multinationals on aspects of European market integration. ${ }^{164}$

However, these nationally determined perceptions intersect with the sectoral realities that companies are immersed in. Each firm operates as part of one or

\footnotetext{
164 Also see chapter 1. Whitley, R. (1992). The comparative study of business systems in Europe: issues and choices. In R. Whitley (Ed.), European business systems. Firms and markets in their national contexts (pp. 267-284). London: Sage, pp. 267-272, 276-279.
} 
more industries in which it controls, competes or cooperates with other firms. Under the umbrella of his "dynamic market theory" H.W. de Jong introduced the insight that each industry has specific characteristics that co-determine the strategies that firms employ. Following de Jong, this thesis proposes that such sectoral characteristics also informed preferences of firms with regard to the organization of the European market. This chapter intends to offer an introduction into such national and sectoral influences. ${ }^{165}$

\section{Interpreting multinationals in national contexts}

This section discusses a selection of companies that were part of the leadership of the ELEC, Bilderberg meetings and the Trilateral Commission. The selection is based on the database that was created on all members of the leading bodies of the ELEC, Bilderberg meetings and the Trilateral Commission. Some qualifications of the selection should be made. It principally comprises the industrial firms and financial institutions that were based in the Federal Republic of Germany, France, Belgium, the Netherlands, Italy and the United Kingdom. Corporations from other countries were not consistently enough involved in the networks to include them in this analysis. ${ }^{166}$

As mentioned, the following national contexts play a role in explaining how firms viewed certain aspects of European integration. These national settings focus on structural aspects of national economies and the positions of companies in their home markets. The described contexts however do not offer an overview of broad, national or governmental attitudes towards European integration. Such attitudes will be offered in chapters 4 to 6 as they apply to the treated theme.

\section{Federal Republic of Germany}

The post-war trade policies of the Federal Republic of Germany regarding international trade were strongly determined by one key component: exports. Although after WWII almost all countries in Western Europe tried to promote their exports in order to finance their reconstruction programmes, Germany followed a more systematic strategy to regain the position of major exporter that it had before the war. Under pressure of the Allies the government embraced policies that contributed to the liberalization of international trade and it became a strong proponent of organizing conditions for smooth international payments. It subsidized exports

\footnotetext{
165 My translation. Jong, H. W. de (1996). Dynamische markttheorie. Weteringbrug: Eddusa, pp. 3-20. But also see: Jong, H. W. de (Ed.) (1993). The structure of European industry. Dordrecht: Kluwer Academic Publishers.

166 The Appendix is fully devoted to the mentioned database, including its taxonomy, structure, results and sources.
} 
and offered incentives through export insurances. Special subsidies for the improvement of export conditions were offered to the industries of coal mining, iron, steel and chemicals. Additionally, German monetary policy aimed at keeping the Deutsch Mark low. ${ }^{167}$

Of special importance was the German post-war focus on gaining back its markets in Eastern Europe, Russia, and later China. In order to achieve this, the Ost-Ausschuss, or East-Commission, was created. The government cooperated closely with export industries such as steel and chemicals in order to create favourable conditions for Eastern exports. The Germans were committed to expanding their exports. ${ }^{168}$

German corporations that were particularly active in the investigated networks during longer periods of time were strongly connected to heavy industry. Most important were Metallgesellschaft, Thyssen, Otto Wolff and Deutsche Bank. ${ }^{169}$

Already before the second half of the 19th century, the Metallgesellschaft became a multinational. It developed as a trading company in non-ferrous metals such as copper, lead, zinc and aluminium. It also became active in mining and metallurgy. The company created a large, international network of sales subsidiaries and foreign mining operations that mainly supplied the United States and Europe with raw materials. The company also vertically integrated into engineering. Its international position in metal trade was seriously affected by the two world wars. After World War II the firm started to invest in the production of machinery, as well as in research and development. It developed mainly as an exporter of machinery. In addition, the firm realized modest volumes of metal-trade. During the 1960s Metallgesellschaft again began to establish foreign subsidiaries in countries such as France, Brazil and South Africa. ${ }^{170}$

Thyssen was one of the successors to the large pre-war steel producing firm called August Thyssen Hütte. After WWII the Allies blamed Thyssen and other steel producers for aiding the German war effort and destroyed major production assets of the firm and broke it up into 16 companies. In this move, steel production was consciously separated from mining interests. From 1953 onwards the company was able to expand again. In the next twenty years it grew within German borders through investments in steel producing facilities and it merged with other major German steel producing firms. It moreover became active in international sales.

\footnotetext{
167 Braun, H.-J. (1990). The German economy in the twentieth century: the German Reich and the Federal Republic. London: Routledge, pp. 233, 249. Also see: Feldenkirchen, W. (1999). Industrial policy in Germany: the invention of interventionism. In J. Foreman-Peck \& G. Federico (Eds.), European industrial policy. The twentieth-century experience (pp. 98-123). Oxford: Oxford University Press.

168 Spaulding Jr., R. M. (1996). "Reconquering Our Old Position" West German osthandel strategies of the 1950's. In V. R. Berghahn (Ed.) (1996). Quests for economic empire. European strategies of German big business in the twentieth century (pp. 124-143). Providence: Berghahn Books, pp. 132-135, 141-142. ${ }^{169}$ Also see chapter 2.

${ }_{170}$ Achinger, H. (1970). Richard Merton. Frankfurt a. M.: Kramer, pp. 31-43, 57, 130-131; Metallgesellschaft A.G. In International directory of company histories (Vol. 4). Chicago: St. James Press.
} 
Thyssen's production operations remained within German national borders though. ${ }^{171}$

Otto Wolff was a company involved in steel production, the trading of steel products and investment goods. It was not a vertically integrated firm like for example Thyssen, which controlled all dimensions of steel production. Otto Wolff was a loosely connected and decentral group with a variety of activities. Until the early 1960s the group developed within Germany and exported its goods across the globe. But during the 1960s and 1970s the company also founded subsidiaries in Brasil, Hong-Kong, Mexico, Venezuela, Australia and sales agencies in Argentina, Chile, Columbia, Peru, Kenya and Iran. It also owned an international trade organization with branches in Europe, Africa, the United States and Asia. Thyssen and Otto Wolff developed several joint ventures for the production and sales of capital goods, thereby more or less fusing their interests in the export of steel products. ${ }^{172}$

Throughout the post-war era until today, Deutsche Bank has been one of the largest financial institutions of Germany. Shortly after WWII the Allies decided that the bank had been such an important concentration of financial power for the German war effort that it had to be broken up in ten parts. Some reconcentration of these parts was allowed in 1952, but only in 1957 Deutsche Bank regained all of its former constituents. As before the war, it remained a mixed bank. It offered all the services of a deposit bank while owning important shares in German industry. Investing in industry was a major activity and advising those firms a central responsibility: directors of the bank, Hermann Abs in particular, held positions on many supervisory boards such as RWE, Metallgesellschaft, Siemens \& Halske or Deutsche Shell. The bank had retained some portfolio subsidiaries in several South American banks from its sizeable international activities before WWII. From the late 1960s onwards Deutsche Bank started to establish new foreign subsidiaries again. ${ }^{173}$

The German priorities regarding international trade after the war revolved around a continued commitment to exports. In the years after WWII the Allies put the German economy on the path towards a liberally organized market. Under these circumstances, German multinationals were likely to favour similarly liberal conditions on an international level: successful exports required a liberal order of international trade. It is also important to note that German industry had lost many foreign industrial assets, first during WWI and later during WWII. The loss of foreign subsidiaries partly explains the strong focus on exports. Only from the 1960s

\footnotetext{
171 Thyssen A. G. In International directory of company histories (Vol. 4). Chicago: St. James Press. ${ }^{172}$ Soénius, U. S. (2005). Wiederaufbau, Wirtschaftswunder und die Entwicklung im Konzern 1945 bis 1990. In P. Danylow \& U. S. Soénius (Eds.) (2005). Otto Wolff: ein Unternehmen zwischen Wirtschaft und Poltik (pp. 297-384). München: Siedler, pp. 314-316, 327-331.

${ }_{173}$ Deutsche Bank A.G. In International directory of company histories (Vol. 2). Chicago: St. James Press; Tilly, R. (1993). The internationalization of West German banks, 1945-87. In G. Jones \& H. G. Schröter (Eds.), The rise of multinationals in continental Europe (pp. 173-183). Aldershot: Edward Elgar, pp. 174175.
} 
onwards, German foreign investments would pick up again. In other words, the export model was in line with the historical experiences of German industry. ${ }^{174}$

\section{France}

Before 1950 French international trade was strongly dependent on its colonies, which had allowed France to maintain exports during the interbellum, despite contracting international trade. In 1952 the colonies represented a share of $42 \%$ of total French exports. However, this share was halved over the next ten years as a result of decolonization. French exports gradually shifted to Western Europe, mainly the EEC. In maintaining this trade France depended more on protectionism than the rest of Western Europe to safeguard its national industries. ${ }^{175}$

Compared to other Western European countries, the role of the French government in economic planning and industrial policy has been pervasive. After WWII, the government started with comprehensive interventions in the economy and introduced the praxis of devising national economic plans. The plans advised industry on production goals and influenced management decisions in specific industrial sectors. During the 1950s an awareness developed that the protectionist attitude of the French government had resulted in an inefficient business-structure that was unfit for international competition. The government thereupon decided to decrease protectionist measures and increase government planning and assistance to aid companies in the adaptation process. This paradoxical planned liberalization however still included indirect protectionist measures and resulted in deep governmental involvement in entire sectors. For example price controls and foreign investment controls were introduced in the chemical sector. Moreover the nationalized energy sector guaranteed favourable rates for industrial companies. Additionally, during the 1960s the government forced flagship firms to restructure their organizations. In sum French industry originated from a protectionist environment and was accustomed to an interventionist government. As a result, French corporate management maintained close relationships to the government. Topmanagers often were recruited from the civil service and politics. ${ }^{176}$

The list of French multinationals involved in the leadership of the networks examined in this research includes well known industrial firms and industrial-

\footnotetext{
${ }_{174}$ Schröter, H. G. (1993). Continuity and change: German multinationals since 1850. In G. Jones \& H. G. Schröter (Eds.), The rise of multinationals in continental Europe (pp. 28-48). Aldershot: Edward Elgar, pp. 28-35.

175 Adams, W. J. (1989). Restructuring the French economy: government and the rise of market competition since World War II. Washinton, D.C.: The Brookings Institution, pp. 147, 178-179.

${ }_{176}$ Caron, F. (1983). An economic history of modern France. London: Methuen. Particularly chapters 13 (Business Structures) pp. 278-308 and 14 (State Policy and Business Management 1950-1973), pp. 309363, 352. See for the post-war relations between the French government and the national chemical industry: Aftalion, F. (1991). A history of the international chemical industry. Philadelphia: University of Pennsylvania Press, p. 287.
} 
financial dynasties: Péchiney, Saint Gobain, Rhône Poulenc, IMetal and MarineWendel. They were active in the production of chemicals, pharmaceuticals, glass, steel and non-ferrous metals such as aluminium and nickel. Péchiney, was, and still is, one of the largest aluminium producers in the world. Its production sites were predominantly in France, but the company started to expand abroad since the early 1950s, first in the French colonies Cameroon and New Guinea, and later in Argentina, Brazil, Greece and the Netherlands. The firm also actively developed a position in chemicals and mining products such as special metals and uranium. As mentioned, from the 1960s onwards the French government intervened in the structure of French firms. It felt that it was essential for French firms to head of foreign competitors by creating larger industrial groups. Péchiney responded to this policy by absorbing smaller firms in the area of special metals, and undertook a large merger with Ugine Kuhlman in 1971, another aluminium and chemicals producer. The new Péchiney Ugine Kuhlman, or PUK, formed one of the biggest groups of the country. ${ }^{177}$

Throughout the second half of the 20th century, Saint Gobain has been one of the key competing glass producers in Europe, owning many production sites across the continent. It also held a share in the production of chemicals. In 1969 the same government-induced drive towards industrial concentration led Saint Gobain and Péchiney to combine the dominant parts of their chemical operations in a separate group which was bought by Rhône Poulenc. Shortly afterwards, in 1970, Saint Gobain merged with glass and chemicals producer Pont-à-Mousson, together focusing on glass, forming Saint Gobain-Pont-à-Mousson. ${ }^{178}$

Chemicals producer Rhône Poulenc was one of the most research-intensive companies of France, with a strong presence in agricultural chemicals, artificial fibres and pharmaceuticals. After its acquisition of the chemicals divisions of Saint Gobain and Péchiney, it became the largest company of France in 1969. Until then however, Rhône Poulenc had hardly developed its presence and experiences outside France, as it had enjoyed its protected position behind tariff walls. When international competition increased due to the European Common Market and foreign investments, the company started a badly timed phase of international expansion. The 1970s turned out to be a time of general decline of the global chemical sector, due to energy crises and the economic crisis. ${ }^{179}$

Other recurrent companies in the study and pressure networks were mainly involved in mining and metals production. One of them was the Spain-based mining and mainly non-ferrous metals processing company Peñarroya, a world leader in zinc by 1961, but also active in iron and uranium. Another important player was Société Le Nickel, a nickel-treating company. Both heavily drew on Rothschild fami-

\footnotetext{
177 Péchiney S.A. . In International directory of company histories (Vol. 4). Chicago: St. James Press.

178 Compagnie de Saint-Gobain. In International directory of company histories (Vol. 3). Chicago: St. James Press.

${ }^{179}$ Rhône-Poulenc S.A. In International directory of company histories (Vol. 1). Chicago: St. James Press.
} 
ly investments and merged in 1967. After the energy crisis of 1973, the company began to increase its foreign investments. It acquired the iron and uranium mining company Mokta, together forming the group Imetal. Subsequently the United States based Copperweld, the Lead Industries Group based in the United Kingdom, and Compagnie Francaise Minerais d'Uranium were added, competing with Péchiney as provider of uranium fuel for the French government's ambitious plans regarding nuclear energy. ${ }^{180}$

Also leaders of the steel company Sacilor played a role in the study and pressure networks examined in this thesis. It had been created by the De Wendel family in 1973, thereby combining most of the Lorraine steelmaking activities. It was merged with the Marine-Firminy group, the Creusot steelmaking activities, forming the Marine-Wendel group. To restructure the group, the French Government nationalized it in 1975. This is a further illustration of the French interventionist approach towards its basic industries. 181

A firm that arrived on the scene of the study and pressure networks during the 1970s was Electricité de France (EdF). This government-owned company was the result of the nationalization of the entire French electricity industry in 1946. Until the 1960s, EdF had achieved an important share of hydroelectricity in its production methods. Higher and more diversely timed demand led EdF to turn to oil which became the companies' dominant energy source in 1973. The oil crisis of 1973 subsequently sparked a combined ambition of the government and EdF to replace oil with nuclear power. This was the start of the most comprehensive nuclear energy investment plan in Europe. As will be discussed in chapter 6, these plans quickly confronted the company with the international sensibilities regarding uranium supply, which in the French market were largely in the hands of Péchiney and Imetal. ${ }^{182}$

Finally two French banks should be mentioned, due to their early involvement in ELEC: Crédit Lyonnais, an in 1946 nationalized general bank that mainly financed French firms, and the privately owned Banque de Paris et de Pays Bas. This bank was originally mainly active in the former French colonies. ${ }^{183}$

In sum, the French context was thus shaped by an interventionist government and a protected industrial structure, gradually preparing for international competition.

\footnotetext{
${ }^{180}$ IMetal S.A. In International directory of company histories (Vol. 4). Chicago: St. James Press. 181 Usinor S.A. In International directory of company histories (Vol. 4). Chicago: St. James Press.

182 Electricité de France S.A. In International directory of company histories (Vol. 5). Chicago: St. James Press.

${ }^{183}$ Crédit Lyonnais. In International directory of company histories (Vol. 9). Chicago: St. James Press. Compagnie Financière de Paribas. In International directory of company histories (Vol. 2). Chicago: St. James Press.
} 


\section{The Netherlands}

The Dutch economy was mainly characterized by a strong degree of trade liberalism and freedom of entrepreneurship in which trade and exports became the backbone of economic activity. Before WWII, Dutch governments preferred a laissez faire style of economic policy. After 1945 however, the government started to actively intervene in the development of the Dutch economy by creating favourable conditions for industry and the development of the welfare state. However, when in 1949 a comprehensive industrialization strategy was announced, this was done without strong intervention in industry. The government limited itself to offering incentives for investments and tax reductions for industry. The most important aspect of post-war governmental involvement was the system of guided wages, which was the result of institutionalized consultations between employers, unions and the government. The system ensured relatively low wages until well into the early 1960s, which was of key importance to the expansion of exportbased companies within Dutch borders. ${ }^{184}$

The longstanding liberal approach to international trade, as well as the small domestic market, led to the emergence of several successful multinationals. These firms, Royal Dutch/ Shell, Unilever, Philips and AKZO (AKU before 1969), but also Koninklijke Hoogovens, had a determining influence on the Dutch economy. The basis for most of these firms was created before WWI. Their international expansion took off during the 1920s and 1930s. The protectionist measures that were introduced across Europe in that period forced export-focussed firms such as Unilever, Philips and $A K U$ to relocate part of their production to those protected markets. They were also the firms that were involved in the leadership of the study and pressure networks studied in this book. ${ }^{185}$

It is important to stress the degree of international distribution of these firms. Unilever already was a very internationalized company before WWII. Not only was it an Anglo-Dutch merger, it operated production, research and marketing facilities all over Europe, and it sold products and owned productions assets such as plantations all over the world. The product lines were mainly based on margarine and soaps, which shared the feedstocks of edible oils and fats. When the innovation of synthetic detergents since WWII largely replaced soaps, Unilever shifted to the use

\footnotetext{
${ }_{184}$ Sluyterman, K. \& Wubs, B. (2009). Over grenzen: multinationals en de Nederlandse markteconomie. Amsterdam: Boom, pp. 153-160; Zanden, Jan Luiten van (1998). The economic history of the Netherlands, 1914-1995: a small open economy in the 'long' twentieth century. London: Routledge, pp. 129-130, 142-143, 149-150; Iterson, A. van \& Olie, R. (1992). European business systems: the Dutch case. In R. Whitley (Ed.), European business systems. Firms and markets in their national context (pp. 98-116). London: Sage, pp. 108-109.

185 Sluyterman \& Wubs (2009). Over Grenzen. pp. 153-160. Jones, G. G., \& Miskell, P. (2005). European integration and corporate restructuring: the strategy of Unilever, c. 1957-c. 1990. Economic History Review, 28, 113-139.
} 
of petrochemicals as a feedstock. Later it continued to expand and diversified its involvement in foods. ${ }^{186}$

Royal Dutch/Shell similarly was (and is) an Anglo-Dutch merger. Since the 1920s it was, and still is, one of the major private oil companies of the world, owning large reserves in the Middle East, the Americas, and in other regions. In addition to oil it developed a strong natural gas branch. Alongside the delivery of oil products it also developed a second to none petrochemical industry, spread across the world. In the early 1970s circumstances deteriorated. OPEC member states seized control of their national oil assets. With it, they gained the price setting power that formerly had resided with the oil companies. These events ushered in the growth of national oil companies. ${ }^{187}$

AKU, later AKZO, was also active in chemicals, primarily artificial fibres, which remained its key product line until the 1970s. AKU also was the result of a successful international merger, though in this case between the Dutch Nederlandsche Kunstzijdefabriek and the German Vereinigte Glanzstoff-Fabriken. Shortly after WWII the company had production sites in the United States, the Netherlands, Germany, Spain, Italy and Austria, and established factories in Mexico, Columbia and India. In 1969, it merged with the Dutch chemicals, coatings and pharmaceuticals producer Koninklijke Zout Organon, forming the multidivisional company $A K Z O$. Its dependence on petrochemicals for the production of artificial fabrics subsequently forced it to intensify its diversification into coatings, special chemicals and pharmaceuticals. ${ }^{188}$

Leaders of Koninklijke Hoogovens were continuously members of ELEC from 1950 until at least 1980. Hoogovens is a steel producer located at the coast of Ijmuiden, which began production in 1924. After the war the company received governmental support to expand its activities. The company reached an approximate share of 3,5\% of total steel production in 1967 in the European Coal and Steel Community. It diversified by acquiring subsidiaries in aluminium, oil, gas and coal production. In 1966 the firm merged with Hoesch, which in 1972 formed Estel, thereby becoming the fourth steel producer in Europe. However, the steel crisis that began in 1975 forced Hoogovens and Hoesch to de-merge by $1981 .{ }^{189}$

A last major Dutch multinational to be mentioned is Philips, a producer of lighting products and consumer electronics. Although not in a leading position in any of the networks, it is necessary to introduce the firm here due to the important influence of Philips-personnel on the ELEC during the 1950s. ${ }^{190}$

\footnotetext{
186 Unilever. International directory of company histories (Vol. 2). Chicago: St. James Press.

187 Royal Dutch Shell plc. In International directory of company histories (Vol. 4). Chicago: St. James Press. ${ }^{188}$ AKZO Nobel N.V. In International directory of company histories (Vol. 13). Chicago: St. James Press.

${ }_{189}$ Luiten van Zanden, J. (1998). The economic history of the Netherlands, p. 143. Koninklijke Nederlandsche Hoogovens en Staalfabrieken NV. In International directory of company histories (Vol. 4). Chicago: St. James Press.

${ }^{190}$ See Chapter 4 and 5 for Philips activities in the ELEC.
} 
Philips' international expansion also took place before WWII. Originally, the company depended on its exporting capacity. However, as a result of the proliferation of import tariffs during the interbellum, Philips established production facilities across Europe and the United States. It also expanded to Latin America, South Africa and Asia. Philips' post-war development was focussed on its mainly European presence. Its established structure of national production facilities, including country specific marketing strategies, remained a core aspect of the firm until the 1980s. ${ }^{191}$

Two banks also require a short introduction: from 1975 onwards Dutch bankers partly replaced industry in the transnational networks investigated in this thesis. These were $A B N$, a bank with a consistent focus on international financial services, its chief Dutch competitor Amro, which focussed on investments in business in the Netherlands, and Rabobank, which was traditionally focussed on agriculture, an important export sector for the Netherlands. The main developments that governed the financial sector after WWII will receive further attention in the second part of this chapter. ${ }^{192}$

Business historians have identified the international distribution of particularly Philips and Unilever as an important reason for supporting European integration during the 1950s. The senior management of Philips and Unilever thought to be able to take advantage of the resulting large and unified market by reversing the decentralization of these firms during the 1920s and 1930s. Centralization of production would generate economies of scale. Internal conflict within management and unaccommodating unions ultimately prevented a quick implementation of these strategies. However, the experiences of the Dutch multinationals yield important insights: several multinationals based in a small market with liberal traditions as the Netherlands responded in a very specific way to the economic conditions of the Interbellum. This resulted in a similarly specific support for European integration during the 1950s. As such conditions were also prevalent in Belgium such explanations might be generalized to some of those firms as well. ${ }^{193}$

In sum, Dutch multinationals emerged from a non-protectionist, small market environment with a large degree of freedom of entrepreneurship. Moreover the Dutch firms had created many production sites outside the Netherlands, quite different from the German firms that until the late 1960s had mainly developed their industrial structure within German borders.

\footnotetext{
${ }_{191}$ Philips Electronics N.V. In International directory of company histories (Vol. 2). Chicago: St. James Press.

${ }_{192}$ Algemene Bank Nederland N.V. In International directory of company histories (Vol. 2). Chicago: St. James Press. Amsterdam-Rotterdam Bank N.V. . In International directory of company histories (Vol. 2). Chicago: St. James Press. Rabobank Group. In International directory of company histories (Vol. 33). Chicago: St. James Press.

${ }_{193}$ Blanken, I. (2002). Een industriële wereldfederatie. Zaltbommel: Europese Bibliotheek, pp. 259-260. Jones, \& Miskell (2005). European integration.
} 


\section{Belgium}

The Belgian business membership of the transnational networks was formed by a recurrent small group of financial holdings of industry that owned and oversaw the profitability of most of Belgian national heavy industry. These holdings were under control of a few very wealthy families: the Solvay group, the Launoit group, the Lambert group and the Société Générale de Belgique. The Belgian financial holdings of industry developed within a very open economy, with low tariffs. Industry was accustomed to international competition and little intervention by the Belgian government. The proliferation of high tariffs in the 1930s locked Belgian industry in on its small home market and forced it to expand on international markets. Except for the coal sector, industry was strongly geared to foreign markets, with the mentioned holdings controlling or participating in numerous foreign investments. ${ }^{194}$

The holdings are a Belgian phenomenon that emerged in the aftermath of the Great Depression. They were the result of a government decision in 1934 to force mixed banks to choose between deposit and investment banking. One of the countries' major mixed banks was Société Générale de Belgique (SGB). Originally it was founded in the early 19th century to assist the industrialization. It played an important role in developing and controlling the countries' infrastructure, public transport and utilities but it also invested in coal and steel production, the glass industry and the chemical industry. In 1934 these possessions were separated from the deposit branch and continued separately as an industrial investment bank. Its ownership was shared by the prominent families of Belgium, the Solvay's, the Boël's, the Janssen's, the Launoit's, the Empain's and the Lambert's, all having a voice in its investment policies. ${ }^{195}$

Belgium's other pre-1934 major mixed bank was Banque de Bruxelles. It was owned by the Launoit family and presided by Paul de Launoit. The bank was also broken up in a deposit bank, keeping the name Banque de Bruxelles, and a financial holding, Brufina. Brufina absorbed the bank's major investments in coal and steel production, transportation and electric power generation. Paul de Launoit also controlled the important steelworks of Ougrée-Marihaye. ${ }^{196}$

Another group was owned by the Lambert family whose assets were concentrated in the Banque Lambert and the financial holding Compagnie Lambert. The holding had many participations in Congolese firms. Léon Lambert became the

\footnotetext{
${ }_{194}$ Mommen, A. H. (1994). The Belgian economy in the twentieth century. London: Routledge, 34, 76-77. 195 Bank Brussels Lambert. In International directory of company histories (Vol. 2). Chicago: St. James Press.

196 Mommen (1994). The Belgian economy, pp. 21-22. Bank Brussels Lambert. In International directory of company histories (Vol. 2). Chicago: St. James Press. Cockerill Sambre Group. In International directory of company histories (Vol. 4). Chicago: St. James Press. For detailed information on the structure of the dominant Belgian industrial-financial holdings and groups during the 1960s see: CRISP (1962). Morphologie des groups financiers. Bruxelles: Centre de Recherche et d'Information Socio-Politiques.
} 
post-war animator of the group who tried to increase its control over Belgian industry since 1949. Gradually he added industrial participations to his Compagnie. In 1972 he merged his holding with the interest controlled by Paul de Launoit, the Banque Bruxelles and Brufina. ${ }^{197}$

The Solvay group was no bank but a producer of chemicals, founded in 1863 as Solvay \& Cie. Its success was based on the development of an efficient process for the production of soda ash, an important chemical for the production of glass, steel, soap, and other industrial products. Based on its superior process the company expanded in Europe, Russia, Brazil and the United States, becoming one of the largest chemicals producers in the world in 1913. After WWI Solvay diversified into the production of glass and played a role in the establishment of another chemicals production company in 1927, the Union Chimique Belge (UCB), which gained control over the Belgian rayon industry. However, its Russian plants were earlier already lost during WWI, and after WWII the group's investments in Central and Eastern Europe were expropriated, hitting the company hard and in effect concentrating its main operations in Western Europe. Until the 1960s the group mainly produced bulk chemicals, such as soda ash, caustic soda and chlorine. In 1949 the firm began producing plastics and during the 1970s the firm expanded into pharmaceuticals. After the introduction of the Common Market the important advantage of having factories in most Western European countries became a disadvantage as competitors began to found central production-sites for the entire European market. As a result of the Common Market the company's structure became a liability and required a response in terms of cost reduction. The Solvay group has been primarily in the hands of the Solvay family, including the closely related Janssen's and Boël's. ${ }^{198}$

The Belgian holdings share an important feature with Unilever, Philips and Akzo. Between WWI and WWII they also invested abroad to cope with the import barriers that were erected across Europe, which resulted in widely distributed participations in European industry. The Solvay group stands out: already before WWI it developed a widespread, multinational industrial structure around its core activities.

\section{Italy}

Italian membership of the transnational networks from business was limited to two major industrial groups, Fiat and Montedison. In Italy, industry operated under a governmental style that paradoxically combined protectionism with trade liber-

\footnotetext{
197 Bank Brussels Lambert. In International directory of company histories (Vol. 2). Chicago: St. James Press. Mommen (1994). The Belgian economy, p. 190.

198 Bertrams, K., Coupain, N. \& Homburg, E. (2013). Solvay: history of a multinational family firm. Cambridge: Cambridge University Press, pp. 33-95, 328, 334-359, 386-387; Bertrams, K. (2013). A company in history: Solvay, 1863-2013. Cambridge: Cambridge University Press, pp. 58-63, 134-135, 146-149.
} 
alization. While lowering tariffs, the government directly supported national industries. For example during the late 1940s and early 1950s the government created favourable circumstances for Fiat by including it in the allocation of Marshall Plan funds and by offering the company steel at reduced prices through the nationalized steel industry. At the same time the government pursued European trade liberalization to increase exports. During the 1960 s and early 1970s, it subsidized investments in heavy industries in southern Italy to remedy its backward economic development. Fiat and Montedison soon belonged to the top of investors ánd employers of these development projects. Also, during the 1970s, the government made a habit of bailing out industries, especially firms with sizeable employment. Fiat and Montedison fared well under such a governmental safety-net. ${ }^{199}$

Fiat was closely tied to the Agnelli family, which via its financial holding Industrial Fiduciary Institute created a vertically and horizontally integrated industrial conglomerate around its car-making activities. Furthermore, Fiat diversified its investments in related industries. This process started in the 1920s and Fiat has remained the industrial centipede ever since, controlling a plethora of activities in addition to car-production. Since the 1950s, Fiat closely guarded its home market, which it dominated until the 1960s. However, during the 1960s car-makers from the United States began entering the Italian market. The Italian government was convinced of its prerogative to protect the position of national industries and aided Fiat in its campaign to suppress imports from US cars. However, the difficult circumstances of 1970s, with its oil crises and economic stagnation eventually hit Fiat's sales hard on its crucial home market. At same time Fiat was successful with its foreign subsidiaries. The group owned factories in Austria, Germany, France, the United States, Argentina, India, Egypt, Morocco and South Africa. 200

Montedison was the result of a merger between Montecatini and Edison. Montecatini was the largest chemicals producer of Italy during the 1950s, involved in fertilizers, insecticides, pharmaceuticals, artificial fibres and mining. Edison originally was a major electricity producer that diversified into the petrochemical industry during the 1950s. Edison's electricity branch was nationalized in 1962. The merger of 1966 yielded the conglomerate Montedison, active in chemicals and electricity. In 1968, the state took an interest of about $20 \%$ in the firm, via the

\footnotetext{
199 The role of Montedison in the leadership of the transnational networks was hardly as strong as Fiat's. Montedison's place in the database is based on the long tenure of Piero Giustiani as president with Montecatini, until the merger with Edison. Nevertheless, Montedison was certainly also relevant in the Italian national section of ELEC, and the Trilateral Commission, as will become clear in chapter 6. Federico, G. \& Giannetti, R. (1999). Italy: stalling and surpassing. In J. Foreman-Peck \& G. Federico (Eds.), European industrial policy. The twentieth-century experience (pp. 124-151). Oxford: Oxford University Press.

${ }^{200}$ Fiat S.p.A. In International directory of company histories (Vol. 1). Chicago: St. James Press.
} 
national oil company ENI, another sign of the Italian government's tendency to control and safeguard the development of its industry. ${ }^{201}$

Fiat's and Montedison's interests were thus carefully facilitated by the state and one was even partly controlled by it. Especially Fiat, but also Montedison, had grown accustomed to an interventionist industrial policy from governing institutions.

\section{The United Kingdom}

Multinationals from the United Kingdom were hardly involved in the leadership of the transnational networks, and were equally scarce among regular members. This circumstance is probably related to the initial unwillingness of the British government to engage with European integration on continental terms. Instead, British leading figures in the networks were economists, members of parliament and public administrators. Merely one figure from industry, Lincoln Steel participated in the ELEC leadership from 1965 onwards. He was chairman of the overseas committee of the Federation of British Industry (FBI), which dealt with matters of the European market. Before he had been a long-time director of the major chemicals multinational of the country, Imperial Chemical Industries (ICI), and in that role a close colleague of Solvay's René Boël, the president of ELEC. ${ }^{202}$

Further, three London-based merchant banks were members, who all conducted a full range of financial services to business, S.G. Warburg, Schroders and Samuel, Hill \& Co. These banks were involved in all aspects of global finance. They started to participate in the transnational networks around $1965 .{ }^{203}$

Even though British business played a small role in the investigated networks, some introduction to the context of British international trade is useful nonetheless. The post-war market of the United Kingdom was strongly protected by import quotas and tariffs. Moreover, it had an important base of exports in the Commonwealth which it shielded from competition through so-called 'preferences'. Even after the United Kingdom did away with import quotas during the 1950s and significantly reduced tariffs due to its membership of the European Free Trade Area (EFTA) as from the 1960s, compared with the European Community its tariffs remained relatively high. Since the United Kingdom had ample access to the mar-

\footnotetext{
201 Montedison S.p.A. In International directory of company histories (Vol. 1). Chicago: St. James Press. Aftalion (1991). A history, pp. 299-301.

202 Imperial Chemical Industries PLC. In International directory of company histories (Vol. 1). Chicago: St. James Press.

${ }^{203}$ SBC Warburg. In International directory of company histories (Vol. 14). Chicago: St. James Press. LEEST NOG. Schroders plc. In International directory of company histories (Vol. 42). Chicago: St. James Press. Macquarie bank Ltd. In International directory of company histories (Vol. 69). Chicago: St. James Press.
} 
kets of its former empire it was not keen on getting more access to continental markets at the expense of preferential access to the Commonwealth. ${ }^{204}$

\section{Interpreting multinationals in sectoral contexts}

To determine which industries were most prominently involved in the ELEC, Bilderberg meetings and Trilateral Commission a biographical database was created. It includes the members of the three leading bodies of the networks at seven measuring years separated by intervals of five years, for the period 1950-1980. On each individual, information was collected regarding nationality, main professional activity and main affiliation to a company or institution. Based on this information individuals were categorized as part of a societal sphere, such as business, politics, public administration and others. The most important reason to do so already became clear in chapter 2: to assess the dominant character of the ELEC, the Bilderberg meetings and the Trilateral Commission through time. As became clear, the role of business was preponderant in all and only increased as time progressed. Subsequently companies were categorized in industries to determine to what extent the ELEC, the Bilderberg meetings and the Trilateral Commission were geared towards specific industrial sub-interests such as the chemical or automotive industries. Such insights assist in interpreting the views that were discussed in the networks and determine dominant directions. The resulting tables and figures that are presented below represent the industrial composition of the networks in absolute and relative terms. ${ }^{205}$

\footnotetext{
204 Rollings, N. (2007). British business in the formative years of European integration, 1945-1973. Cambridge: Cambridge University Press, pp. 30-33.

205 See Appendix 1 for the database and an introduction into its features.
} 
Table 3.1: Composition of the combined leadership of ELEC, Bilderberg meetings and Trilateral Commission in societal spheres, 1950-1980 (absolute figures). ${ }^{206}$

\begin{tabular}{lccccccc}
\hline Societal spheres & 1950 & 1955 & 1960 & 1965 & 1970 & 1975 & 1980 \\
\hline Business & 12 & 23 & 33 & 39 & 43 & 71 & 80 \\
Politics & 5 & 5 & 6 & 6 & 5 & 7 & 14 \\
Public administration & 1 & 2 & 7 & 3 & 2 & 3 & 6 \\
Semi-Public administration & 0 & 1 & 1 & 1 & 3 & 5 & 3 \\
Academic & 0 & 3 & 4 & 5 & 6 & 10 & 15 \\
Military & 0 & 1 & 1 & 0 & 0 & 0 & 0 \\
Labour & 1 & 1 & 1 & 1 & 1 & 3 & 2 \\
Media & 0 & 0 & 1 & 1 & 2 & 6 & 5 \\
Other & 1 & 3 & 2 & 1 & 1 & 3 & 2 \\
\hline Total categorized: & 20 & 39 & 56 & 57 & 63 & 108 & 127 \\
Of total members: & 20 & 39 & 60 & 60 & 66 & 115 & 133 \\
\hline
\end{tabular}

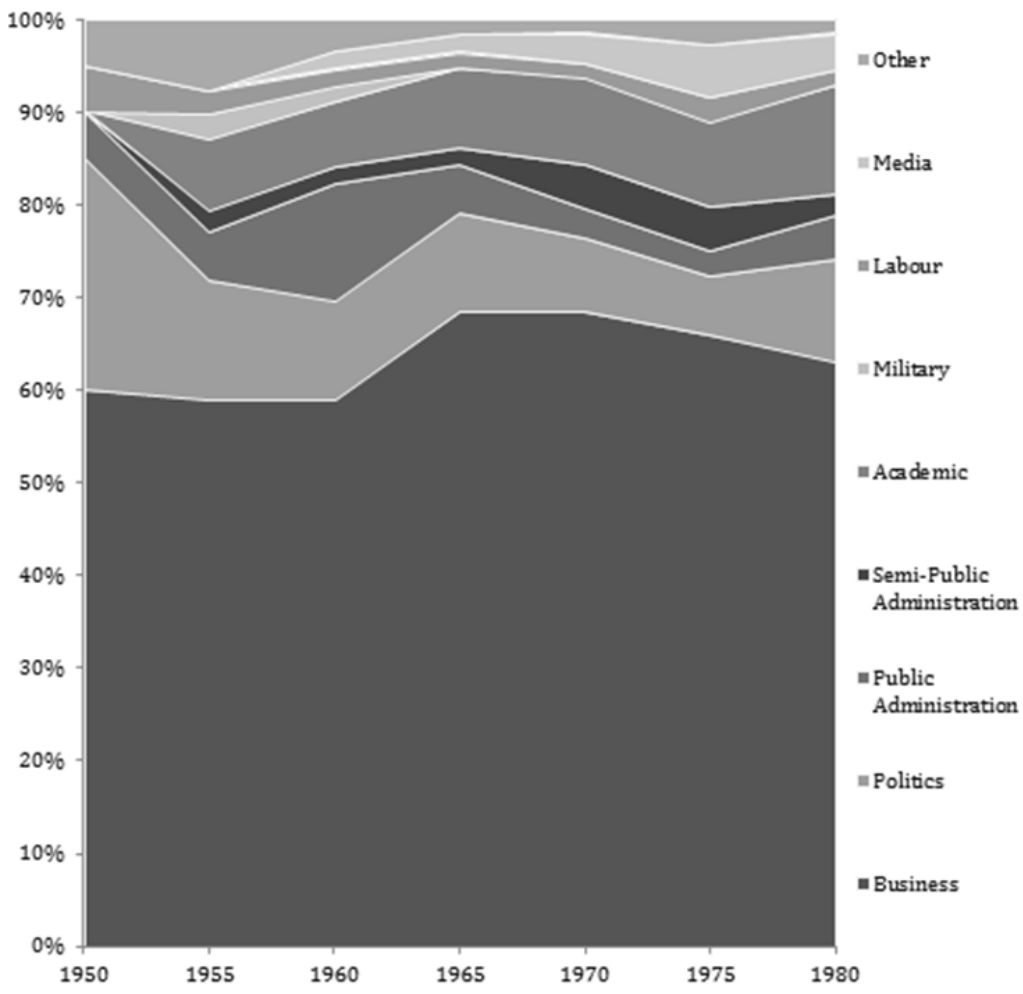

Figure 3.1: Relative composition of combined leadership ELEC, Bilderberg meetings and Trilateral Commission in societal spheres, 1950-1980.207

206 Table 3.1 is in fact the sum of tables 2.2, 2.6 and 2.7: see Chapter 2. For details on the choices in the table, see the Appendix, section Tables and figures.

207 Ibidem. 
Table 3.1 shows the development of the weight of societal spheres for the three networks together. Business involvement fluctuates between $60 \%$ and $70 \%$ from 1950 to 1980 . The other spheres appear as more or less complementary to the business sphere, with hardly ever any larger involvement than 10\%, except for 1950 when the political sphere reached an involvement of 25\%, in ELEC. The business sphere was thus dominant in the population of leading members from the three networks. However, the business sphere itself was rather diverse, including as much as twenty industries. Table 3.2 and figure $3.2 \mathrm{zoom}$ in on the industrial categories of the combined societal business spheres of the networks.

Table 3.2: The representation of different industries in the combined business societal sphere of the ELEC, Bilderberg and Trilateral leadership, 1950-1980 (absolute figures). ${ }^{208}$

\begin{tabular}{lccccccc}
\hline Sectors & 1950 & 1955 & 1960 & 1965 & 1970 & 1975 & 1980 \\
\hline Banking & 3 & 3 & 9 & 10 & 14 & 28 & 32 \\
Multiple & 3 & 6 & 6 & 9 & 5 & 9 & 11 \\
Arms & 0 & 0 & 1 & 0 & 0 & 0 & 0 \\
Automotive & 0 & 1 & 0 & 1 & 2 & 2 & 4 \\
Chemicals & 1 & 2 & 1 & 4 & 7 & 3 & 3 \\
Electrical engin. & 0 & 0 & 1 & 1 & 1 & 1 & 2 \\
Electronics & 0 & 0 & 0 & 0 & 0 & 3 & 2 \\
Foods & 0 & 1 & 1 & 1 & 1 & 1 & 1 \\
Ferrous Metals & 2 & 2 & 2 & 2 & 2 & 3 & 3 \\
Non-Ferrous Metals & 2 & 3 & 1 & 1 & 1 & 0 & 0 \\
Glass & 0 & 0 & 1 & 1 & 1 & 1 & 0 \\
Oil & 0 & 0 & 0 & 1 & 1 & 5 & 3 \\
Pharmaceuticals & 0 & 0 & 0 & 0 & 1 & 1 & 2 \\
Telecommunications & 0 & 0 & 0 & 0 & 0 & 0 & 1 \\
Utilities & 0 & 0 & 0 & 0 & 0 & 2 & 3 \\
Consultancy & 0 & 0 & 0 & 0 & 0 & 1 & 1 \\
Law & 1 & 5 & 5 & 1 & 1 & 4 & 2 \\
Transport & 0 & 0 & 3 & 2 & 1 & 0 & 1 \\
Business associations & 0 & 0 & 1 & 3 & 3 & 3 & 6 \\
Private Foundations & 0 & 0 & 0 & 1 & 0 & 0 & 0 \\
\hline Total categorized & 12 & 23 & 32 & 38 & 41 & 67 & 77 \\
Of total business & 23 & 33 & 39 & 43 & 71 & 80 \\
\hline
\end{tabular}

${ }^{208}$ Source: see the Appendix. For details on the choices in the table, see the Appendix section Tables and figures. 


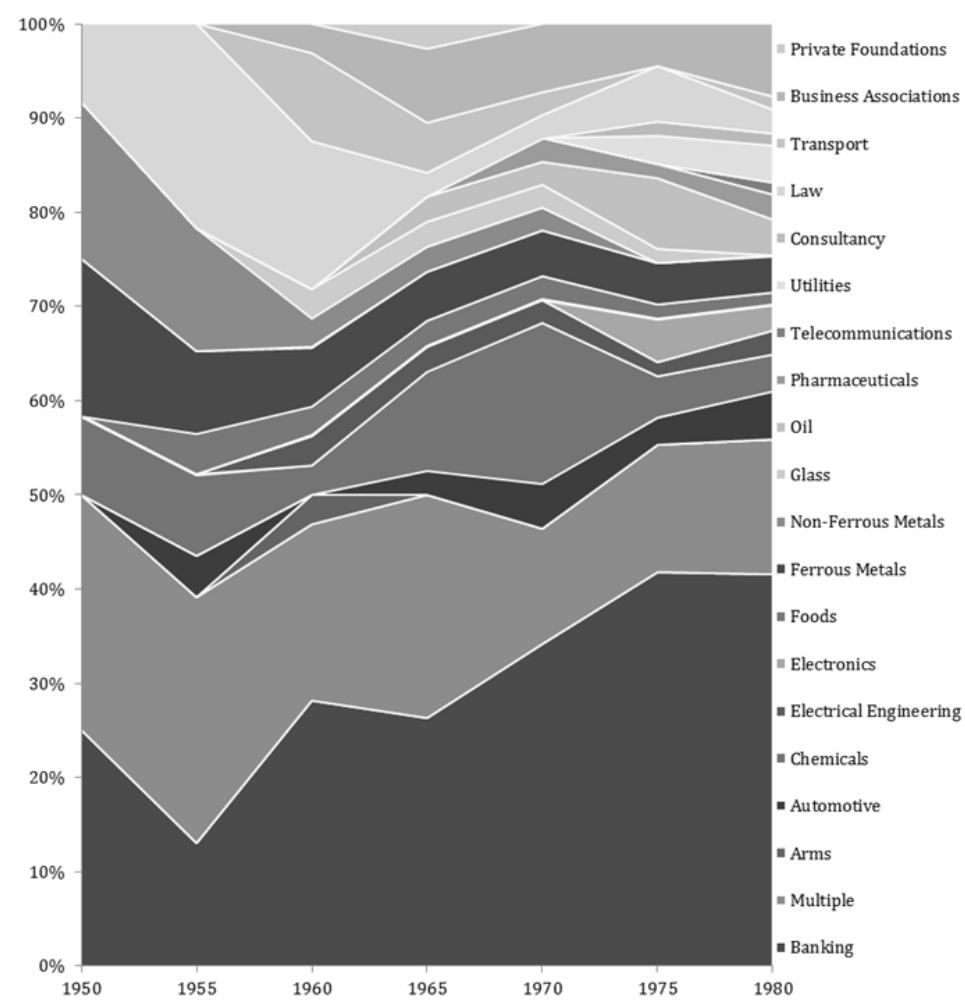

Figure 3.2: Relative representation of different industries in the combined business societal sphere of the ELEC, Bilderberg and Trilateral leadership, 1950-1980.209

Immediately apparent is the large and increasing role of banks in the networks from 1950 to 1980 . The next category that dominates the chart is that of "multiple" which stands for companies with sizeable activities in more than one sector. Examples include financial holdings of industry that branched into almost all kinds of industries, such as Mitsubishi, but also includes Unilever that combined sizeable foods and chemicals branches. This category also includes individuals that combine multiple advisory directorships in several sectors at the same time. Additionally the chemical sector and the metal production sectors (ferrous and nonferrous) appear to be dominant. At the same time one has to conclude that the three networks combined a diverse business membership.

The differences in distribution of the industries in the ELEC, Bilderberg meetings and the Trilateral Commission are shown in tables and figures 3.3, 3.4 and 3.5.

${ }^{209}$ Ibidem. 
Table 3.3: The representation of different industries in the business societal sphere of the ELEC Central Council, 1950-1980 (absolute figures). ${ }^{210}$

\begin{tabular}{lccccccc}
\hline Sectors & 1950 & 1955 & 1960 & 1965 & 1970 & 1975 & 1980 \\
\hline Banking & 3 & 3 & 6 & 7 & 8 & 16 & 16 \\
Multiple & 3 & 4 & 5 & 5 & 3 & 4 & 6 \\
Automotive & 0 & 0 & 0 & 0 & 1 & 0 & 1 \\
Chemicals & 1 & 2 & 1 & 2 & 3 & 1 & 1 \\
Electrical engin. & 0 & 0 & 0 & 0 & 1 & 1 & 2 \\
Ferrous Metals & 2 & 2 & 1 & 1 & 1 & 1 & 1 \\
Non-Ferrous Metals & 2 & 3 & 1 & 1 & 1 & 0 & 0 \\
Oil & 0 & 0 & 0 & 0 & 1 & 1 & 0 \\
Pharmaceuticals & 0 & 0 & 0 & 0 & 1 & 1 & 1 \\
Consultancy & 0 & 0 & 0 & 0 & 0 & 1 & 1 \\
Law & 1 & 1 & 1 & 0 & 0 & 0 & 0 \\
Business associations & 0 & 0 & 1 & 3 & 3 & 3 & 3 \\
\hline Total categorized: & 12 & 15 & 16 & 19 & 23 & 29 & 32 \\
Of total Business & 12 & 15 & 17 & 20 & 25 & 32 & 34 \\
\hline
\end{tabular}

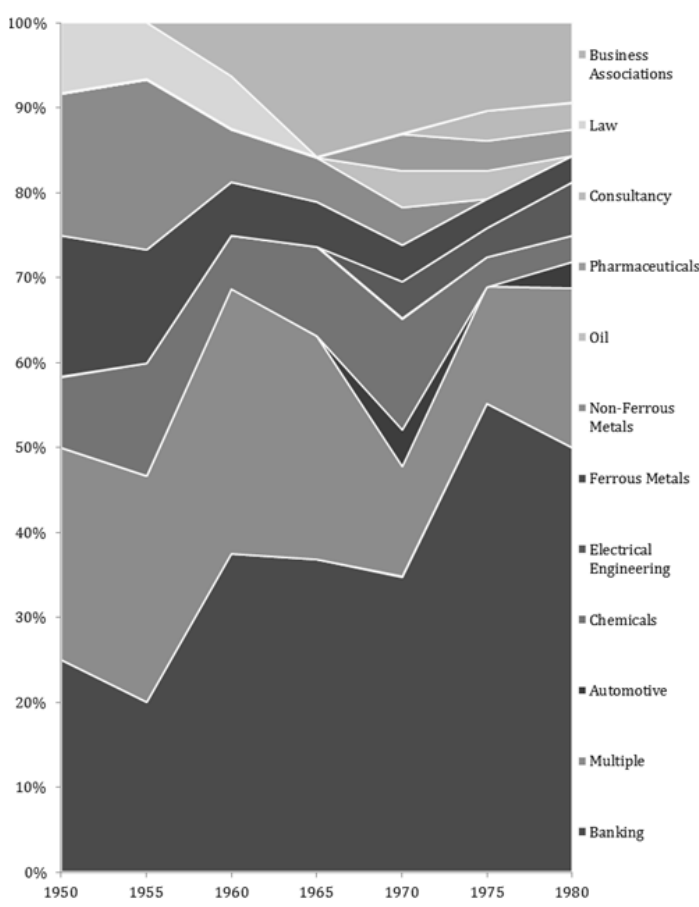

Figure 3.3: Relative representation of different industries in the business societal sphere of the ELEC Central Council, 1950-1980.211

210 Ibidem.

${ }^{211}$ Ibidem. 
As expected, table 3.3 shows that the industry that stands out the most is that of banking. In the ELEC the banking sector was present from the beginning, reaching a temporary peak in 1960 of about $35 \%$ and an absolute peak in 1975, with a weight of even $50 \%$ of ELEC's business membership. The diversity in industries is markedly less than in the total population of business members of table and figure 3.2 , only combining twelve different industries. In addition to the banking industry, the "multiple" sector, the chemical industry and metals industries (ferrous and non-ferrous) were well represented. It is also worth noting that the category of business associations increased in importance in ELEC's leadership. Looking more closely at these, it becomes clear that they were representatives from British, Danish, Norwegian and Swedish national federations of industry, strikingly all countries that formed part of the original membership of the European Free Trade Area in 1960 (see the sector columns for the ELEC entries in tables A.4, A.5, A.6, A.7 and A.8).

Table 3.4: The representation of different industries in the business societal sphere of the Bilderberg meetings' Steering Committee, 1955-1980 (absolute figures). ${ }^{212}$

\begin{tabular}{lcccccc}
\hline Sectors & 1955 & 1960 & 1965 & 1970 & 1975 & 1980 \\
\hline Banking & 0 & 3 & 3 & 6 & 8 & 9 \\
Multiple & 2 & 1 & 4 & 2 & 4 & 3 \\
Arms & 0 & 1 & 0 & 0 & 0 & 0 \\
Automotive & 1 & 0 & 1 & 1 & 1 & 2 \\
Chemicals & 0 & 0 & 2 & 4 & 2 & 2 \\
Electrical Engin. & 0 & 1 & 1 & 0 & 0 & 0 \\
Electronics & 0 & 0 & 0 & 0 & 1 & 1 \\
Foods & 1 & 1 & 1 & 1 & 1 & 1 \\
Ferrous Metals & 0 & 1 & 1 & 1 & 1 & 2 \\
Glass & 0 & 1 & 1 & 1 & 1 & 0 \\
Oil & 0 & 0 & 1 & 0 & 2 & 2 \\
Telecommunications & 0 & 0 & 0 & 0 & 0 & 1 \\
Utilities & 0 & 0 & 0 & 0 & 0 & 1 \\
Law & 4 & 4 & 1 & 1 & 1 & 1 \\
Transport & 0 & 3 & 2 & 1 & 0 & 1 \\
Private Foundations & 0 & 0 & 1 & 0 & 0 & 0 \\
\hline Total categorized & 8 & 16 & 19 & 18 & 22 & 26 \\
Of total business & 8 & 16 & 19 & 18 & 22 & 26 \\
\hline
\end{tabular}

${ }^{212}$ Ibidem. 


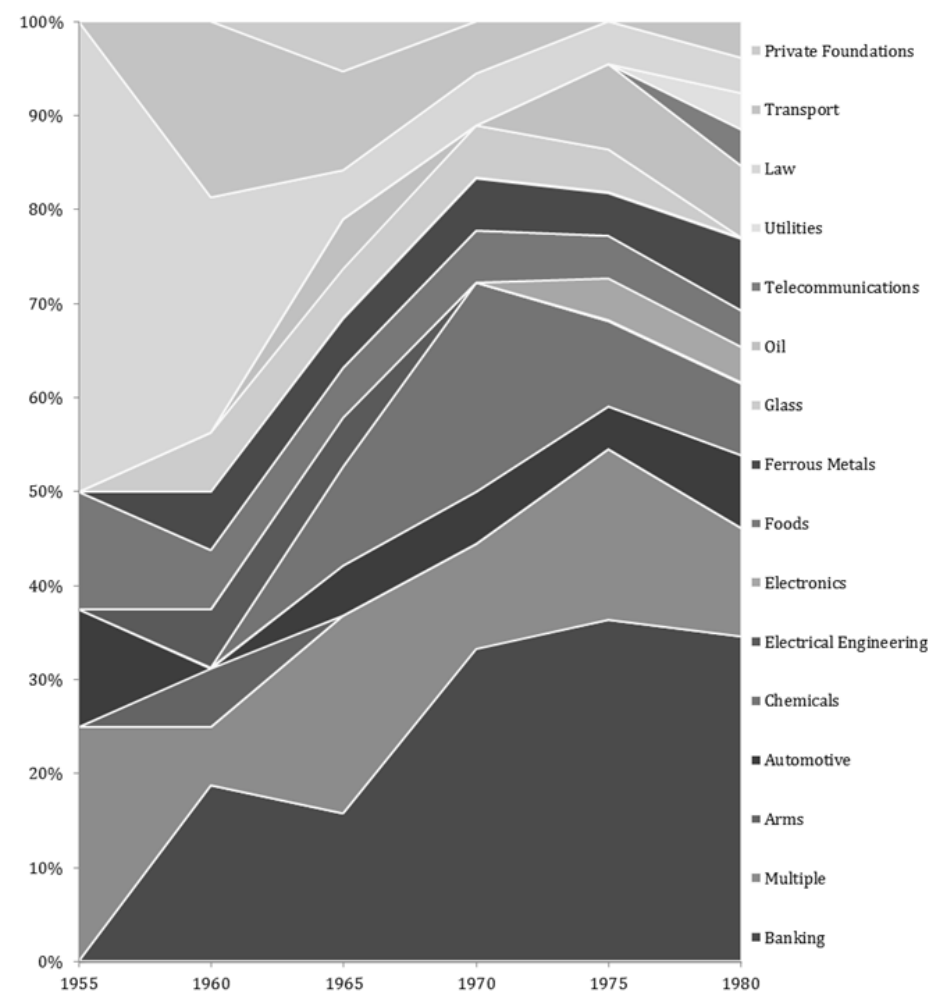

Figure 3.4: Relative representation of different industries in the business societal sphere of the Bilderberg meetings' Steering Committee, 1955-1980.213

Table and figure 3.4 show a more diverse industry composition of the business sphere of the Bilderberg meetings. Banks played a less significant role but still was the most represented industry. The "multiple" category, for lack of a better term, was also strongly represented, whereas the chemical industry only became a wellrepresented sector since the 1960 s.

213 Ibidem. 
Table 3.5: The representation of different industries in the business societal sphere of the Trilateral Commission's Executive Committee, 1975-1980 (absolute figures). ${ }^{214}$

\begin{tabular}{lcc}
\hline Sectors & 1975 & 1980 \\
\hline Banking & 4 & 7 \\
Multiple & 1 & 2 \\
Automotive & 1 & 1 \\
Electronics & 2 & 1 \\
Ferrous Metals & 1 & 0 \\
Oil & 2 & 1 \\
Pharmaceuticals & 0 & 1 \\
Utilities & 2 & 2 \\
Law & 3 & 1 \\
Business associations & 0 & 3 \\
\hline Total categorized & 16 & 19 \\
Of total Business & 17 & 20 \\
\hline
\end{tabular}

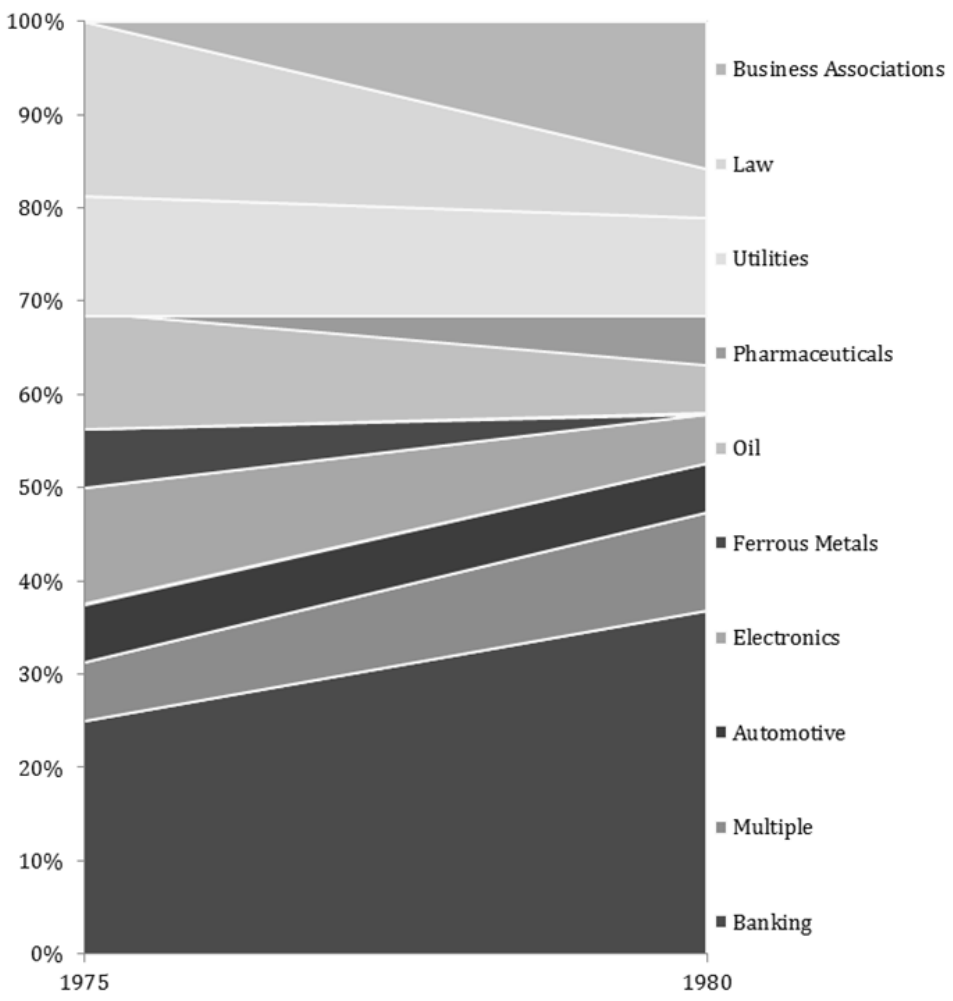

Figure 3.5: Relative composition in sectors of the combined business components of the Trilateral Commission's Executive Committee, 1975-1980.215

${ }^{214}$ Ibidem. 
The least diverse business sphere was that of the Trilateral Commission, as is demonstrated in table and figure 3.5. Again, representatives of banks played a less important role than in the ELEC or the Bilderberg meetings, but still were the most represented industry. The chemical industry, strongly represented in the ELEC and the Bilderberg meetings was not part of the Trilateral Commission leadership.

Clearly the composition of the business spheres of the three networks were cross-sectoral, with a generally large and increasing role for representatives of the banking industry. Besides the banking industry no dominant industry could be singled out, except for perhaps the chemical industry and the metal industry, but to a much lesser degree. It is important to realize however, that although banks were dominant as a single industry, the sum of industrial production companies was in general larger than the sum of banks. Only in the ELEC, from 1970 to 1980, banks had a larger share in membership than industrial firms. It is particularly striking to note which sectors were not included in these networks. Major industries such as agriculture, textiles and, surprisingly, the construction sector play no role at all.

As companies compete with other companies within their industry, they have to respond to strategies of their competitors, and success is ultimately a result of their ability to adapt to new circumstances. Between 1950 and 1980 the pressure to adapt grew as European multinationals were increasingly confronted with international competition. This was the result of two converging developments. There was a gradual process of trade liberalization, firstly within Western Europe through the formation of the EEC and EFTA, and secondly on a global level through multilateral trade negotiations under the framework of the General Agreement on Tariffs and Trade (GATT). Next to that, the EEC became a trade bloc: it installed a Central External Tariff (CET), which led American multinationals to invest in production capacity in the EEC.216

Adjustment to competition became a permanent requirement for European business. There was a constant need to create competitive advantages, but which competitive advantage deserves priority, is a strategic question for each single company. The outcomes varied per sector, depending on many factors, including product properties, the importance of research and development, capital intensity, the availability of resources, investment capacity, cost structures, organization structure, management styles, etcetera. These also result in sector-based priorities and preferences towards the administrative, legal and political organization of the European market. To be able to interpret sector-specific motives on the organization of the European market, below key contexts and properties of some of the

\footnotetext{
215 Ibidem.

${ }^{216}$ Jones, G. G. (2005). Multinationals and global capitalism: from the nineteenth to the twenty-first century. Oxford: Oxford University Press, pp. 31-33.
} 
main sectors in the ELEC, Bilderberg meetings and the Trilateral Commission are discussed: the banking sector, chemicals, steel production and car production. ${ }^{217}$

\section{Banking industry}

Almost during the entire period from 1950 to 1980 the European banking sector was kept on a leash. International competition on the European market was made largely impossible. The main dynamic that structured the experiences of banks was a slow but gradual expansion of the scope for competition through internationalization.

On a national level the European banking sector had inherited strict regulations from the Great Depression period. Many European governments had separated the functions of deposit bank and merchant bank in order to isolate savings from risks originating from investments into industry. During the 1960s these rules were only gradually softened. Moreover, after WWII European governments took a role in the financial sector by nationalizing banks or erecting public savings banks and long-term credit institutions for financing investments. In addition European governments were not willing to transfer national savings to foreign companies and the Rome Treaties did little to change this in the short run. In effect, European capital markets and banks were still mainly organized along national lines, a situation that persisted until well into the 1970s. ${ }^{218}$

Nevertheless ways were explored to circumvent the national organization of European banking. The capital needs during the post-war reconstruction of the European economies laid the basis for one of these. Since WWII the role of European-based capital was very limited in the reconstruction of the European economies. The American capital market provided the required sums instead. However, in the course of the 1950s the flow of dollars out of the US reached such levels that in 1963 the American government introduced a tax on capital exports. The move virtually closed the American capital market to Europe. The European national capital markets were too small to compensate for this and European banks therefore created the Eurodollar. Accumulated dollar reserves deposited outside the United States were transferable throughout Europe without national regulations impeding exchanges. These deposits were floated as short-term loans and during the 1960s they became an alternative capital market that circumvented the limitations of the European national capital markets. ${ }^{219}$

During the 1950s and 1960s some competition among banks developed. American banks founded subsidiaries in Europe, and European banks responded

\footnotetext{
${ }^{217}$ Jones (2005). Multinationals, pp. 7-10; Jong (1996). Dynamische markttheorie, pp. 3-20.

${ }^{218}$ Kurgan-Van Hentenryk, G., Brion, R. and Moreau, J-L. (2000). European banks since the second world war (1944-2000). In H. van der Wee \& G. Kurgan-Van Hentenryk, G. (Eds.). A history of European banking (pp. 363-393). Antwerp: Mercatorfonds, pp. 370-379.

${ }^{219}$ Kurgan-Van Hentenryk (2000). European banks, pp. 365-369.
} 
by merging with other banks on a national level. Later, European partnerships had to fend off American competitive pressures. To reduce risks on the financing of large-scale projects, European banks also engaged in European consortia. Competition further increased by the founding of foreign subsidiaries by European banks. A gradual internationalization of the banking sector started to take place. However direct investments between European countries remained limited. Moreover, national governments could obstruct the creation of a foreign subsidiary or restrict its freedom of activities. This would only change from 1977 onwards when the European Community adopted a directive on a liberalized market, which arranged that foreign subsidiaries could no longer be obstructed. ${ }^{220}$

\section{Chemical industry}

The chemical industry is a quite innovative and research-based industry. The sector has been at the forefront of the development of many substances, several of which have become commonplace by now. A key aspect of the chemical industry has been its capacity to substitute naturally available materials, such as rubber and some natural dyestuffs, by synthesized imitations. Another element is the industries' ability to introduce totally new materials, such as plastics or artificial fibres. Additionally the industry produced basic and special chemicals for a multitude of production processes in other sectors, or produced materials used in industry, such as paints, rubber tires and plastics for the car industry. Moreover, several firms in the sector diversified into biotechnology or pharmaceuticals. But perhaps even more important was the capacity of the industry to invest in research and product development as well as in the development of efficient production processes for mass production. Especially the high investments in research required large-scale enterprises and the ability to respond to the innovations introduced by competitors. ${ }^{221}$

It is important to realize how international the chemical firms already were before WWII. Multinational groups and conglomerates such as Solvay \& Cie already were created during the $19^{\text {th }}$ century. European firms also exported to foreign markets and were accustomed to international competition on their home markets. This competition only increased after the creation of the EEC and GATT rounds. Moreover after WWII European firms started to establish subsidiaries in the United States and vice-versa, causing fierce competition on the European market.222

Another aspect of the chemical industry was its dependence on coal before WWII, and afterwards on oil: both as a resource for energy and as a feedstock for basic chemicals. As coal became relatively more expensive and oil was made more widely, and cheaply, available, the chemical industry successfully switched to the

\footnotetext{
220 Kurgan-Van Hentenryk (2000). European banks, pp. 379-381.

${ }^{221}$ Aftalion (1991). A history, pp. 319-320.

${ }^{222}$ Aftalion (1991). A history, pp. 241-242, 266-269.
} 
new feedstock. When the price of oil quadrupled between 1972 and 1974 the chemical industry entered a difficult time, and started a process of re-orientation. The sector practically breathed with the international energy developments. ${ }^{223}$

\section{Steel industry}

During the period 1950-1980 the European steel sector entered a period with recurrent adaptation crises with regard to their competitive position. Partly this was caused by steel-producing processes, partly it resulted from the steel-sector's dependence on coal. Coalmining, coal-processing and steel production are mutually dependent industries, though today less so than immediately after WWII. Corporations often integrated both activities. Coal was used in the generation of heat in furnaces. In addition coal is a basic resource for the steelmaking process. Both industries were moreover a strategic asset for national governments which resulted in far-reaching protectionist measures. This was one of the aspects which the creation of the European Coal and Steel Community in 1952 intended to remedy: a key condition for the creation of a free market in coal and steel was to pool sovereignty of national governments over these basic industries. ${ }^{224}$

The development of both industries from the 1950s until the 1980s was strongly characterized by international developments. European coalmining was hit hard by the burgeoning oil industry and the improvements in transport services. During the 1950s oil production increased and falling oil prices reduced the use of coal significantly. The chemical industry replaced its coal-feedstock with oil which laid the basis for the petrochemical industry. Also electricity producers shifted from coal to oil and gas. Moreover due to reduced shipping costs European coal-using industries gained access to cheap coal from outside the Community, notably the United States. The European coal industry was therefore dealing with structural contraction and was constantly confronted with the need for rationalization of production methods amidst a demand for protectionism. ${ }^{225}$

These changes in the coal industry also had major consequences for the steel sector. Unlike the use of coal, steel consumption increased between 1950 and 1980 . However, the steel sector experienced intensive competition due to changes in the availability of resources and innovations in production techniques. As mentioned, dropping shipping rates led to cheaply shipped coal ánd high grade ores against acceptable prices. This upset a balance in the sector: it reversed the former advantage of steelworks close to coalmines into a disadvantage, especially while coal was becoming an increasingly protected source of energy, relatively increasing in price against oil. Instead coastal steelworks suddenly came into a favourable posi-

${ }^{223}$ Aftalion (1991). A history, pp. 241, 319.

224 Jörnmark, J. (1993). Coal and steel in western Europe 1945-1993. Innovative change and institutional adaptation. Dissertation, University of Göteborg.

225 Jörnmark (1993). Coal and steel, pp. 62-64, 100-110. 
tion. At the same time scale increases in blast furnaces were realized to improve coal-efficiency. The oxygen-process, which meant blowing pure oxygen into molten pig iron to burn away carbon, was also more efficient in energy use than the formerly widespread air process. Finally, also wide-strip mills were introduced to increase output efficiency. At the same time a development towards higher scale production sites was accompanied by innovations making possible the electricity based and continuously casting mini-mills since the mid-1960s. These permanently changing conditions within the steel industry created strong pressures towards mergers and cooperation and yielded entirely different perspectives on international competition or protectionism within the sector. ${ }^{226}$

\section{Automotive industry}

The European automotive sector shows another side of the European market experience. Whereas European banks and the chemical sector mainly began to experience competition from the United States from the 1950s onwards, European carbuilders were familiar with an American presence in Europe: Ford had several production facilities, two sizeable ones in Germany and the United Kingdom. General Motors owned Adam Opel. However, Ford and General motors were not a major presence. In the EEC their collective market share was approximately $15-16 \%$ between 1958 and 1968. The European car manufacturers were the most sizeable by far. The three largest car producers were Volkswagen, Fiat and Renault, together having a $46 \%$ market share in 1958 , and $56 \%$ in 1968.227

Up to the late 1950s the European automotive producers did not interfere with each others national markets. Each country also carefully protected their car industry. Choices in different models were very limited and was incomparable to the multitude in styles or colours offered today. National markets were also relatively small. As a consequence, producers tended to avoid competition, each specializing on a price range of cars. Not having to compete on different models and price ranges enabled them to produce their cars in larger numbers. ${ }^{228}$

This more or less tranquil balance was upset with the advent of the Common Market introducing a gradual reduction of import tariffs between EEC member states during the 1960s. The removal of tariffs coincided with a strong European increase in car-demand. Between 1959 and 1969, EEC car production nearly doubled, going from 3.1 million to 7.1 million cars. What occurred was a diversification of product lines among the largest producers who engaged in competition between price classes. At the same time intra-European trade of cars rose: European manufacturers began penetrating each other's markets. However, another development

\footnotetext{
226 Jörnmark (1993). Coal and steel, pp. 64-68, 167-171.

${ }^{227}$ Berg, H. (1993). Motorcars: between growth and protectionism. In H. W. de Jong (Ed.), The structure of European industry (pp. 121-146). Dordrecht: Kluwer Academic Publishers, pp. 128-129.

${ }^{228}$ Berg (1993). Motorcars, pp. 125-132.
} 
was taking shape in markets outside the EEC and foreshadowed what was to hit the European market in the 1970s. Japan had emerged as a car-producer, from virtually no production of cars in 1959, to 2.6 million cars in 1969. Approximately 0,5 million of these were exported to the US and elsewhere, but not to the European market. Japanese car-manufacturers were instead building a competitive position in markets outside the EEC to where European manufacturers were exporting about 2.1 million cars. During the 1970s the Japanese exports to the EEC began to increase, forcing European car producers to modernize their plants due to lagging productivity. During the 1980s European governments were forced to take recourse to protectionist measures, brokering deals with the Japanese on maximum import levels. Again global factors strongly shaped the automotive industry from the late 1960s onwards. 229

\section{Conclusion}

This chapter has argued that national and sectoral contexts play a part in the explanation of differing views among European multinationals on the organization of the European market. At the same time this chapter offers national and sectoral contexts that will aid in interpreting the views of European multinationals in next chapters.

The national contexts for European multinationals differed strongly and depended on longstanding national economic policies, strategies and path dependencies. In France, governmental policy regarding the organization of national industry was interventionist and guided by national economic planning. French multinationals were affected by various forms of state intervention but particularly restructuring pressures and nationalization. Ties between the companies and the government were strong. Governments of Belgium, Germany and the Netherlands were much more liberal and largely left businesses to their own devices. The Netherlands and Germany both actively introduced incentives to aid national industrialization and to improve national exports. In the German context, the expropriation of foreign assets in the wake of WWI and WWII resulted in export focussed domestic corporations. Moreover after WWII the de-concentration policy of the Allies forced large German companies to split up in parts, a process which was largely reversed during the 1950s. After reversing de-concentration efforts, German companies started to invest abroad again only from the late 1950s onwards. The Italian government actively aided companies under conditions of steep competition or times of economic decline. Unlike the larger countries, the Netherlands and Belgium included very widespread industrial multinationals and multinational holdings with participations across Europe already since the interbellum. This thesis hypothesises that they were more in favour of unification schemes that

${ }^{229}$ Berg (1993). Motorcars, pp. 128, 132-143. 
harmonized European markets than the firms form larger countries with less foreign assets across Europe: the Dutch and Belgian companies were presented with an opportunity for centralization.

Also sectoral contexts, it is argued, play a part in explaining views of multinational on the European market. A closer look at composition of the transnational networks in terms of industries, revealed that they were cross-sectoral. Banks were the most represented in all networks. The chemical and metals industries were also well represented. Despite the fact that banks were the most represented sector, industrial firms as a group were dominant. Interestingly some rather large economic sectors were absent from the networks, such as agriculture, the textile and construction industries.

Zooming in on the contexts of several important industries that were active in the transnational networks has made clear that each sector had a different outlook. The chemical industry was accustomed to international competition since long before WWII. The steel industry was constantly adapting to international developments since the early 1950s. The car industry was only truly internationalized by the advent of the common market and by Japanese competition. Banks were much less affected by international competition than the car, steel and chemical industries and only saw tangible moves in this direction during the 1970s. What is true for all the industries is the increasing internationalization of the competitive environment during the entire period covered by this thesis. This development was not limited to intra-European changes, but included increasing competition from American and Japanese firms.

The following chapters investigate the debates among European multinationals on the organization of the European market. The differing national contexts and sectoral contexts that were discussed in this chapter are an important tool to understand possible differences in views in those debates. Now this thesis turns to the first empiric chapter, covering the period 1950-1960, addressing the question how European firms viewed the theme of European market integration. 



\section{Chapter 4}

\section{Business leaders and the integration of European markets, 1950-1960}

\section{Introduction}

During the 1950s Western Europe took several large strides towards political and economic integration. Against the background of an emerging Cold War, European governments were dealing with the question to what extent they should integrate and with the even more complicated question about which methods of integration they should follow. The type of market regulations and institutions that were required for such moves were nearly permanently under discussion.

To Western-European corporations such decisions were of utmost significance. Since the end of WWII the United States government was actively pursuing the liberalization of international markets and the Western European response would inevitably affect all kinds of businesses. As will be seen, business leaders seized the moment, organized themselves and expressed their views via the European League for Economic Cooperation and the Bilderberg meetings.

This chapter investigates debates among European multinationals with regard to European market integration. As will be argued the question of economic integration meant much more to them than merely the liberalization of trade. Besides a focus on the views of multinationals on the liberalization and future composition of the European market, this chapter also zooms in on how European corporations valued particular methods of, and paths towards, integration. Moreover the chapter highlights views on the institutional dimension of European economic integration such as the scope and tasks of supranational institutions.

As a result, this chapter uncovers broad concepts put forward by European business on the organization of markets, on the roles of regulatory institutions in markets and on the position of the European market in relation to other markets. All these aspects came together in a complex perspective on European market integration based on the needs of business for stability, flexibility and other aspects of industrial competitiveness in increasingly liberalized, international markets.

At the same time this chapter tries to analyse whether the views of European multinationals were in mutual agreement. Considering their origin in differently 
organized national economies and activities in different sectors, an important question is whether European multinationals had a similar outlook in the first place, and if they did not, along which lines they disagreed. Were differences related to the differing national economies where they had their headquarters or can those differences better be ascribed to the differences between the sectors in which they operated? Lastly, an important aspect throughout the chapter is a comparison between the treatment of the theme of integration by the ELEC and by the Bilderberg meetings.

The first part of the chapter introduces the fragmented conditions of European markets just after WWII and the American pressures to integrate them. Moreover, it introduces the background to the Schuman Plan and the plans for integration during the 1950s. The second and third part of the chapter analyse the discussions within the European League for Economic Co-operation and the Bilderberg meetings on the major plans for economic integration during the 1950s.

\section{International context, 1945-1960}

The ideas of multinationals about the European market developed in a context of far-reaching transformations of western political and economic relations. The emerging Cold War led to new security alliances in the West. Meanwhile the international economy was under reconstruction mainly according to American plans. Simultaneously a continuous diplomatic struggle took place between the United States, the United Kingdom and France on a viable form for a lasting FrancoGerman reconciliation. The resulting Schuman Plan created a foundation for subsequent initiatives towards European economic and political integration. New organizations of the European market were proposed such as a free trade area, a customs union or a Common Market. In a free trade area tariffs and quotas are removed between member states, but members can still determine their external tariffs at will. A customs union differs from a free trade zone because of the existence of common external tariffs. When within a customs union also the constraints on the movement of labour or capital are removed, we speak of a Common Market. These three market designs were an integral part of the post-war debates on how to liberalize the European market. 230

American plans for European trade structures, 1945-1950

In Western Europe, the period 1945-1960 saw multiple initiatives towards decreasing European protectionism. After WWII high import tariffs and trade quotas were the norm in European economic policy. This was the result of a combination

${ }^{230}$ Balassa, B. (1969[1962]). The theory of economic integration. London: George Allen \& Unwin Ltd., p. 2 . 
of war, depression and autarkic economic policy that had characterized the $1920 \mathrm{~s}$ and 1930s. Before WWI a liberal laisser-faire concept of the role of the state characterised economic practice in Europe. International markets were well integrated. Besides the regulation of markets through import tariffs, governments intervened little. However laisser-faire policies lost their appeal after the European war economies had been in operation during WWI: economic planning, the creation of national industries and the drive for national self-sufficiency in strategic goods had demonstrated impressive results. After WWI oversupply and increased competition made that governments decided to protect their national markets. As a result, import tariffs proliferated. From 1929 onwards the Great Depression led to even higher tariffs and the introduction of import quotas. National markets increasingly became isolated from each other and by 1945 the result was a collection of economic islands, each with production structures mainly geared to national needs. ${ }^{231}$

During the 1950s this situation was gradually transformed by means of major schemes of European economic integration. The European Coal and Steel Community (ECSC), the European Economic Community (EEC) and the European Free Trade Association (EFTA) all gradually eliminated tariff walls. Partly, these developments must be seen in the light of the leadership of the United States in reforming postwar international trade in general and the constant pressure it exerted on Western European countries to liberalize their economies. On a domestic level from 1937 onwards the United States government had started a long-term antitrust campaign against international cartels that had proliferated between the wars. American firms were forced to cancel their non-competition agreements on global markets with other firms, particularly in Europe. This cleared the path for American investments in foreign markets and foreign investments in the United States after WWII. In 1944 the United States government took the lead in the introduction of an international payments structure that later became known as the Bretton Woods system. In addition, in 1946 the American government initiated negotiations on lowering tariffs in international trade which laid the basis for a series of conferences under the heading of the General Agreement on Tariffs and Trade (GATT). Moreover the country became the driving force behind the International Trade Organization (IT0), a conference starting in 1947, which aimed for agreements on a liberal international trade order. ${ }^{232}$

The United States government was particularly concerned about the protectionist attitudes in Western Europe and about Europe's fragmented production structure. The Bretton Woods system of multilateral payments that the Americans advocated, required balanced exchanges to function properly. It was hoped that

\footnotetext{
231 Berend, I. T. (2006). An economic history of twentieth-century Europe. Cambridge: Cambridge University Press, pp. 61-73.

232 Wee, H. van der (1987). Prosperity and upheaval: the world economy 1945-1980. Harmondsworth: Penguin Books, pp. 345-350; Taylor, G. D. (1981). Debate in the United states over the control of international cartels, 1942-1950. In The International History Review, 3, 385-398.
} 
Western Europe would become the industrial counterpart of the United States and give the system the necessary durability. To achieve this, Europe would at some point have to achieve parity with the US in terms of productivity. Since the turn of the century however growth figures in Europe had consistently been lagging behind. The American government ascribed this to Europe's fragmented markets. US policy-makers were convinced that Western Europe should emulate the large market of the United States and actively work towards a matching organization of production: large scale industry and mass-production, based on far-reaching standardization in a large market. As part of this plan they hoped that Europe would establish a customs union. ${ }^{233}$

European economic recovery was a prerequisite for realizing that American grand design. When in the spring of 1947 a shortage of dollars obstructed European reconstruction efforts, the US-funded Marshall Plan was introduced. It set out to facilitate European national reconstruction plans with financial aid. In return the European governments were forced to collaborate on the allocation of the funds. At the same time American diplomats started to put pressure on Western European governments to start with the implementation of a European customs union. ${ }^{234}$

As a result, between 1947 and 1950, the Benelux, France Italy and the United Kingdom formed a study group to explore that idea. France used the consultations to convince the United States that, despite its rigid attitude regarding Germany, it could be a constructive partner. Several French proposals for a customs union were introduced, such as a Benelux-France-Italy area (Fritalux), and a FrenchItalian arrangement. But the French did so knowing that the Benelux would never join any collective market without Germany. Moreover, a French-Italian customs union was not seriously pursued by the French government because it would mainly benefit Italy. Moreover during these years the British government came to the conclusion that joining a customs union such as Fritalux, possibly with Germany, would be of little practical use to them. British trade was primarily organized around the Commonwealth and the imperial trade preferences that were in place. This would remain the British position until well into the 1960s. ${ }^{235}$

The ideas on customs unions and common markets that would take hold in Western Europe during the 1950s were thus partly rooted in technical economicmonetary visions of American post-war planning. These ideas were already under consideration by European governments since 1947 and were part of the repertoire of ideas circulating within transatlantic and European transnational discussion networks or other forums interested in European integration. However, the route to a customs union was blocked by France which was worried about the question of how to control Germany in the future.

\footnotetext{
233 Milward, A. S. (1984). The reconstruction of western Europe, 1945-1951. Berkeley: University of California Press, pp. 56-60, 123.

234 Ibidem.

235 Milward (1984). The reconstruction, pp. 232-255.
} 
It took five years after WWII to lay the basis for a durable peace for Western Europe. This was achieved through the Schuman Plan, introduced in May 1950. The plan was the result of an array of evolving strategic motives among Western Allies and the changing Western perception of the threat of the Soviet Union. It is important to shortly introduce these motives and perceptions because they clarify what was at stake with the realization of the European Coal and Steel Community. Moreover, the motives and strategies for reaching a lasting European peace continued to shape the international debate about Western European integration during most of the 1950s. Lastly, an overview of the dominant motives and strategies provides a contrast to the more practical positions that European multinationals took towards the ECSC and the subsequent proposals for integration that will be discussed later in this chapter.

The United States government played a pivotal role in Europe in the first five years after WWII, particularly after the introduction of the Marshall Plan in June 1947. As the Americans had paid a high price for WWI and WWII they had an interest in preventing a European conflict in the future. The key problem for the US government was the containment of Germany. After the war the country was structured in four zones, each separately administered by the United Kingdom, France, the United States and Soviet Russia respectively. Initially US policy was in line with Soviet Union demands and French desires that wished to prevent a German economic revival in order to limit the German capability to wage war. Via the Morgenthau plan the US government even aimed at the destruction of industry in the coalrich Ruhr area. Additionally, in Spring 1946, together with the United Kingdom and the Soviet Union, the United States agreed to impose a policy of punitive reparations on Germany. Moreover the US implemented a policy of decartelization of large German industrial mergers, for example in steel production, chemicals and finance, which they considered important elements of the German war effort. ${ }^{236}$

However, increasing American worries on the policies of the Soviet Union led to a change in attitude. Enabling German revival became more important than maintaining workable US-Soviet relations. In March 1947 President Truman ended the pragmatic approach to the Soviets by announcing his commitment to aid countries financially in order to contain the further spread of Communism. ${ }^{237}$

At roughly the same time Germany's economic revival became seen as a condition for the economic recovery of Western Europe as a whole. During the spring of 1947 European economic reconstruction suddenly stagnated: states had initiated such extensive reconstruction plans that their demand for American exports exceeded their ability to pay in dollars. The resulting balance of payments crisis

\footnotetext{
${ }_{236}$ Gillingham, J. R. (1995). Coal, steel, and the rebirth of Europe, 1945-1955. Cambridge: Cambridge University Press, pp. 97-111.

${ }^{237}$ Gillingham (1995). Coal, steel, pp. 112-117.
} 
threatened to stop the flow of import-payments altogether. Three months later, in June 1947, the Americans launched the Marshall Plan which was meant to relieve the shortage of dollars and thus support the reconstruction efforts. To further aid the Western European reconstruction effort, another three months later the United States and the United Kingdom allowed West-Germany to raise its production levels. ${ }^{238}$

The Marshall plan was not merely an aid package to remove the stifling bottlenecks for European reconstruction. In an attempt to reshape European relations, the American government also used it to force the receiving European countries into an exercise of cooperation. The Americans asked the United Kingdom to chair the negotiation process between the governments on the allocation of aid and on a collective plan for European reconstruction. Under the name of the Committee of European Economic Co-operation (CEEC) sixteen European governments put themselves to that task from July until September 1947. This was continued in the Organization for European Economic Cooperation (OEEC) from March 1948 until August 1949. However, after two years of negotiations the national plans were still too divergent to realize a useful coordination. The United States government blamed the government of the United Kingdom, which had obstructed progress and had failed to fulfil American hopes that it would take the role of European leadership. ${ }^{239}$

The one government most concerned about the outcome of the American suggestions for economic integration was that of France. Since 1944 it was determined to guarantee France's future security by means of neutralizing the German industrial assets that had given that country military edge: the coal-rich Ruhr area and its steel industry. Moreover, France wanted guaranteed access to the Ruhr's resources. To reach this goal the French initially suggested to the United States and the United Kingdom to treat the Ruhr as an internationally controlled and separate entity. During 1948 the French government tried to acquire direct influence on the allocation of Ruhr coal via the proposal for an International Ruhr Authority. To secure such influence the French government wanted the Ruhr Authority to be able to control management decisions of German corporations. The United States' diplomats were however strongly opposed against any intervention in private corporate management. This left the plan for a Ruhr Authority with merely indirect allocation powers over Ruhr resources. Although in this form the International Ruhr Authority did not satisfy French demands, it was still founded in 1949. France was forced to accept that its long-term economic and military security could no longer rely on controlling the Ruhr, but had to be achieved through politi-

238 Gillingham (1995). Coal, steel. pp. 118-120, 126-129.

${ }^{239}$ Milward (1984). The reconstruction, pp. 61-89, 168-211; Gillingham (1995). Coal, steel, pp. 129-136. 
cal and economic integration within Western Europe, including the Federal Republic of Germany, established in 1949.240

The Schuman Plan was the result of the French acceptance of those American initiatives. It proposed a less powerful but enlarged Authority that would include the entire coal and steel industries of all participating countries. To guarantee access to Ruhr coal and steel and the country's own long-term security, France suggested to form a customs union for the French and German coal and steel industries, under control of a supranational High Authority. Such a market and the companies operating on it would be subject to special common policies in order to arrive at a negotiated, balanced, and planned restructuring of the industries that had caused so much mutual mistrust in former decades. Not only would France achieve its main goals, the plan also met the desires of the United States for European economic integration. ${ }^{241}$

The significance of the Schuman Plan was that it worked as a formula for European reconciliation. However, the idea of transferring commercial and industrial powers to the High Authority was unacceptable to the United Kingdom. In June 1950, it declined to take part in negotiations. The Benelux and Italy joined negotiations though, signing the treaty establishing the European Coal and Steel Community in April 1951.242

The liberalization of the Western European market, 1950-1960

The 1950s saw a variety of plans for European integration and the ELEC and the Bilderberg meetings dealt with most of them. Those plans that reached a level of serious consideration at the level of governments will briefly be discussed here. Moreover in order to stress the diversity in plans with which European governments and the members of the ELEC and the Bilderberg meetings were dealing, the following paragraphs also address the different forms of organization of market governance that those proposals implied.

As explained, the European Coal and Steel Community was the result of changing American, French and British foreign policies. At the same time its institutional organization and actions represented a specific form of economic integration. The ECSC only involved the coal and steel industries which was different from the American preference for a customs union that would include all sectors of economic activity. The French government's Schuman Plan introduced a sectoral approach to European economic integration. The ECSC's implicit promise was that other industries could be integrated through a similar approach. Moreover, the ECSC suggested that a larger scale of liberalization of trade could perhaps be achieved by

\footnotetext{
240 Milward (1984). The reconstruction, pp. 141-167, 232-255; Gillingham (1995). Coal, steel, pp. 148163.

241 Gillingham (1995). Coal, steel, pp. 168-177.

242 Gillingham (1995). Coal, steel, pp. 178-183.
} 
means of partial economic communities, possibly each with its own institutions or set of arrangements. ${ }^{243}$

Additionally, through the operations of the High Authority the ECSC introduced a French interventionist approach to economic policy that was at odds with basic ideas on freedom of entrepreneurship. The first President of the High Authority was Jean Monnet, an economic planner who since 1946 had been in charge of the Plan de Modernisation et d'Équippement. This plan, developed by Monnet himself, attempted to restore the industrial competitiveness of France by means of state intervention in the economy. Monnet's ideas on the operations of the High Authority were similar. The ECSC's High Authority would act as an arbitrator and offer general direction. In addition its powers of intervention were comprehensive: it regulated prices and investments, enforced decartelization, adjusted related common external tariffs and bore a responsibility in the coordination of taxes, transport and labour issues. The High Authority was given all the necessary tools to create a level playing field and, paradoxically, plan a liberalized market. Future plans on European economic integration however were very different in both the sectoral approach and the interventionist methods. ${ }^{244}$

The next plan for European economic integration was introduced during the negotiations on the European Defence Community between the ECSC countries. The outbreak of the Korean war in 1950 suddenly shifted attention from the Schuman Plan negotiations to the issue of Western European ánd German rearmament. To address the problem in line with their long-term interest of a pacified Germany, the French Pleven-plan (1950) proposed a European army under collective European authority. Negotiations on the so-called European Defence Community (EDC) began in February 1951 and a treaty was successfully signed in May 1952. The negotiations on the EDC were followed by negotiations on the creation of a European Political Community (EPC) which would be designed to subject a European army to democratic control. ${ }^{245}$

The Dutch Minister of Foreign Affairs, W. J. Beyen, saw in these negotiations an opportunity to realize Dutch goals of economic integration. Claiming that a political unity without economic unity could not work he proposed to include a declaration of commitment to, and obligation for, the EPC to pursue economic integration in the form of a customs union. Moreover in February 1953 he suggested to include a method in the treaty for achieving this goal: he envisioned a progressive removal of tariffs and quotas with a fixed end-date. This would force the EPC to execute the plan. It failed. In August 1954 the French parliament refused to ratify the EDC treaty, rendering void the European Defence Community and its associated initiatives. The problem of German rearmament was subsequently

\footnotetext{
243 Gillingham (1995). Coal, steel, pp. 299-300.

244 Dinan, D. (2004). Europe recast: a history of European Union. Basingstoke: Palgrave Macmillan, pp. 30-39.

245 Dinan (2004). Europe recast, p. 62.
} 
solved by including Germany in the alliances of the Western European Union and NATO. Nonetheless, via Beyen the idea of a customs union was again on the European agenda. ${ }^{246}$

And it remained on the political agenda. During a meeting of the ECSC foreign Ministers in Messina in June 1955 it was decided to install an intergovernmental committee, headed by the Belgian foreign minister Paul Henri Spaak to investigate the viability of the several proposals for economic integration that had been introduced at the meeting. Based on the resulting Spaak report in May 1956 the ECSC foreign ministers decided to establish a Common Market and an atomic energy community. The agreement that resulted from the negotiations from June 1956 until March 1957 also included policies on transport, competition and social and economic affairs. Moreover the treaty established an investment bank to aid the development of backward regions which was important to Italy. The French moreover gained an important concession to offset the consequences that it would incur from the Common Market: the agricultural policy. The treaty was signed in Rome in March 1957. The Commission, the administrating supranational institution of the EEC started its work in January 1958. It lacked the interventionist tools of the ECSC's High Authority but gave the new body significant powers in implementation and enforcement of legislation. From January 1959 onwards the gradual abolishment of tariffs and quotas commenced. ${ }^{247}$

The proposal to create a customs union was contested by the government of the United Kingdom as soon as the Six in 1955 had decided to study the subject. As mentioned above, British trade was much more geared towards the Commonwealth. A small customs union was therefore deemed unattractive. Despite the smaller trade volumes with Western Europe, the British government was concerned about the Common Market's external tariff that could very likely hurt exports. Therefore in November 1956 the British government introduced an alternative scheme in the OEEC to replace the plans for a Common Market by a large European free trade area. It would encompass the entire OEEC and, unlike the Common Market's plan, the free trade area would leave all external tariffs of the member states intact. Additionally agreements for cooperation between member states would be achieved on an intergovernmental basis. Pooling sovereignty in a supranational institution would thus be unnecessary. ${ }^{248}$

The proposal was well-received inside the OEEC. After negotiations on the Common Market were finished, OEEC negotiations on the Free Trade Area (FTA) began in March 1957. In effect they were now transformed into negotiations about a free trade treaty between the non-Community OEEC countries and the EEC. Negotiations were slow and the return to power of the French nationalist de Gaulle in

\footnotetext{
246 Griffiths, R. T. (1997). The Beyen Plan. In R. T. Griffiths (Ed.), The Economic Development of the EEC (pp. 123-140). Lyme: Edward Elgar, pp. 127-128.

247 Dinan (2004). Europe recast, pp. 66-79.

${ }^{248}$ Dinan (2004). Europe recast, pp. 66-79.
} 
June 1958 caused a turn of events. Five months later he decided to pull France back from the negotiations on an EEC-FTA association. De Gaulle was not ready to put at risk the concessions that France had gained during negotiations on the EEC. The United Kingdom, together with Austria, Denmark, Norway, Portugal, Sweden and Switzerland subsequently started negotiations on a free trade area in early 1959 without "the Six" and created the European Free Trade Association (EFTA) in 1960. By then the EEC had already begun with lowering internal tariffs due to which trade diversion between the two European trade blocs became inevitable. ${ }^{249}$

However, despite the different ideas of the United Kingdom about the organization of economic integration, the effects of decolonization suddenly caused a shift in British policy. During the second half of the 1950s British trade with the Commonwealth showed a gradual decline. At the same time trade with the EEC steadily grew. This and many other factors, including concerns about British general decline as a global power, prompted the UK government in July 1961 to request negotiations about the terms for accession to the EEC. Although negotiations were indeed started they were cancelled in January 1963: de Gaulle vetoed the application because he was concerned about the interests of France in the EEC if the United Kingdom would become a member. ${ }^{250}$

To summarize, the international debates between 1947 and 1963 about how to achieve European market integration show several strategies for liberalizing trade relations. A first distinctive aspect were the differences in scale of integration: the Schuman Plan implemented integration on a sectoral level, whereas the EEC integrated all sectors simultaneously, with the exception of agriculture. A second difference involved the powers of the governing institutions: the High $\mathrm{Au}$ thority of the ECSC was given tools to intervene in the operation of markets, government plans and firms, whereas the European Commission in the EEC was not able to steer market developments. Instead it monitored the implementation of the treaties and enforced its rules. A liberalized market had to develop from the application of the rules. A third institutional form was proposed as well: the intergovernmental supervision and decision-making over a free trade area as proposed by the British government, which did not involve at all the creation of new institutions.

From this introduction into European economic integration plans during the 1950s, the chapter now turns to how European multinationals perceived these farreaching changes, starting with the European League for Economic Co-operation.

\footnotetext{
${ }^{249}$ Dinan (2004). Europe recast, pp. 66-79; Gowland, D., Turner, A \& Wright, A. (2010). Britain and European Integration since 1945. On the sidelines. London: Routledge, pp. 42-53.

${ }^{250}$ Dinan (2004). Europe recast, pp. 97-102; Gowland, Turner, Wright (2010). On the sidelines, pp. 53-63.
} 


\section{European League for Economic Cooperation}

The European League for Economic Cooperation, or the ELEC, had only just restructured its entire organization when on the 9th of May 1950 the Schuman Plan was introduced. ELEC's newly adopted course was to respond to developments on European integration in an ad hoc fashion by means of resolutions or booklets on European affairs under its own title, published in appropriate media, or sent to interested governments or relevant organizations. ${ }^{251 / 252}$

A lot had changed for the ELEC since the first months of 1950. Sections were still in the phase of being founded, or even re-founded, and the planned study commissions for the new organization had not convened yet. However, the Central Council, ELEC's main decision-making assembly, was in operation and entirely up to the task. Strikingly, six out of eighteen members were thoroughly immersed in coal and steel interests. They were Pierre Ricard, presiding over several French steel firms, the Italian senator Enrico Falck, member of the steelproducing Falck family, René Boël from Belgium, owner of Usines Gustave Boël, and the Dutchman Pieter Bentz van den Berg, manager at the Koninklijke Hoogovens. Two additional Belgians were directly in the sphere of influence of Paul de Launoit, financier of the ELEC and owner of important steel production and coal extraction. They were the Vice-Chairman of Banque de Bruxelles Louis Camu and Brufina advisor Lucièn Léandre Sermon. ${ }^{253}$

\section{The Schuman Plan}

Less than two weeks after the announcement of the Schuman Plan, the ELEC organized a meeting which resulted in a resolution welcoming the initiative. Particularly the intention to liberalize national markets received ELEC's unequivocal praise.

\footnotetext{
${ }^{251}$ See chapter 2 for the restructering of ELEC. ELEC's first response in this fashion was to the plan for a European Payments Union (EPU). ELEC's position on the Schuman Plan was its second publication. LECE (1949). Un système de convertibilité des monnaies européennes entre elles. Bruxelles: LECE. On the EPU see: Milward (1984). The reconstruction, pp. 299-334. The section Sources, following chapter 7 includes an overview of ELEC publications.

${ }^{252}$ Not all of ELEC's publications during the 1950s are discussed in this chapter. Of the thirty-one reports the ELEC published between 1949 and 1960 the large majority, twenty-one, were explicitly concerned with European market integration. The other ten only did so indirectly. Those discussed monetary and currency issues (4), rearmament, a European institute for business administration, the European Defence Community, a solidarity plan for Southern Europe, the safeguarding of international private investments, indirect fiscal problems in the common market, and investment bank problems in Europe. See Appendix 2 for a full overview of all ELEC publications.

${ }^{253}$ Dumoulin, M. and A.-M. Dutrieue (1993). La Ligue Européenne de Cooperation Économique (19461981): un groupe d'étude et de pression dans la construction européenne. Berne: Lang, p. 59; CRISP (1962). Morphologie des groupes financiers. Bruxelles: CRISP.
} 
The Central Council expressed "great satisfaction" and judged the plan as an "important contribution on the road to the creation of a European single market." 254

Despite the positive reception, ELEC was concerned about the interventionist language of the Schuman Plan though. The Central Council, for example, questioned whether allowing the High Authority to control coal and steel prices would result in a level playing-field. ELEC initially was less opposed to the suggestion of coordination of European investments in the coal and steel sectors. The resolution merely indicated that coordinated investments should constantly keep the coal and steel industries "in the best conditions of efficiency" and improve the productivity of the industry. This attitude would quickly change. ${ }^{255}$

The ELEC also stressed a less obvious point: it was concerned about the structure and functions of the High Authority and its various organs that would be created, more particularly "their relations among themselves and with the existing or future relations with the European authorities." Doubts within ELEC about institutional arrangements particularly involved the relation of industry to the High Authority. Moreover, ELEC expressed uneasiness about how the relations between a supranational institution and European governments with political responsibilities of their own would work and about how these relations would affect the coal and steel industries. Clearly, such concerns illustrate that the ELEC was focussed on more than mere economic factors. ${ }^{256}$

After the first draft treaty for the ECSC became available in late June 1950, the ELEC started an internal review process in order to arrive at a joint policy paper by early August. This centred around a meeting in July, combining several coal and steel interests, particularly from Germany and Belgium. From Germany, Richard Merton of Metallgesellschaft, Hans-Günther Sohl of former Vereinigte Stahlwerke and Carl-Alex Volmer of coal miner Rheinischen AG were taking part. From Belgium Lucien L. Sermon of Brufina and Pierre van der Rest of the Comité de la Sidérurgie belge et du Groupement des Hauts Forneaux et Aciéries belges should be mentioned. The Dutch and Italian sections were not taking part in the meeting at all, probably because firms from those countries were relatively small stakeholders in both sectors. $^{257}$

254 Translation of: "vive satisfaction" \& "contribution importante dans la voie de la création d'un marché européen unique." CEHECLIN, LECE, inv. nr. 45, 1950-05-22, Conseil Central, Annexe, Une résolution internationale sur la proposition Schuman, p. 1.

255 Translation of: "de coordonner les investissements de telle manière que la capacité des industries charbonnières et sidérurgiques de l'Europe soient constamment maintenues dans les meilleures conditions d'efficacité et soient susceptibles de répondre à tous les besoins."LECE, inv. 45, 1950-05-22, Conseil Central, Annexe, Une résolution internationale sur la proposition Schuman, pp. 1-2.

256 Translation of: "leurs relations entre elles et avec les autorités européennes existantes ou à créer." Idem., p. 2.

257 CEHECLIN, LECE, inv. nr. 627, 1950-07-10, Commission spécial du "Plan Schuman", Plan Schuman note introductive du Secrétariat Général de la Ligue, pp. 2-4. Members of the Commission Schuman: with mention of private affiliation in case of steel and coal interests: UK: Lady Rhys-Williams, Edward Beddington-Behrens, Bob Edwards. France: Jean Ducros (Pennaroya), René Fould (Chantier et Ateliers 
According to ELEC the proposed High Authority would gain undue powers over the industries' adaptation process to a liberalized European market. The High Authority's key task would be to create a customs union for coal and steel. Existing import tariffs would have to be removed. At the same time the institution would have to guarantee sufficient production capacity to assist further European recovery against acceptable prices and to respond to increasing demand that was caused by the American involvement in the Korea war, since late June 1950. Additionally, the High Authority had to deal with protectionist policies besides import tariffs. Since long, European steel and coal industries were shielded from international competition in various ways. The Belgian uncompetitive coal-prices, for instance, were compensated by the Belgian government. A liberalized market with unsupported prices would lead to a quick shakeout in the industry, particularly in Belgium, and would cause the overall European production capacity to shrink. In order to avoid a shakeout, the draft treaty proposed an adaptation-period, a three year "péréquation" or equalization phase, that temporarily compensated prices. Less competitive companies, the Belgian ones in particular, would receive financial compensation to neutralize their high cost prices. This would be paid by more competitive companies. In practice those would be the Dutch and German producers. ${ }^{258}$

The proposal to found a supranational institution in order to create a liberalized market via price interventions without coordinating these interventions with the industries themselves was entirely alien to the ELEC. Moreover, according to Sermon it was technically flawed. An international equalization of prices disregarded transport cost-constructions over large distances. In his view a regional price-equalization would be more sensible. Additionally, an international price equalization would also require an international equalization of salaries. Moreover the massive apparatus of officials that would be necessary to supervise companysales in order to calculate a just division of funds, appeared completely unfeasible to him. ${ }^{259}$

Another problem however caused even more frustration. The Schuman Plan had opened the door to one of the biggest fears of the Belgian coal industry, which was well represented in the ELEC. Just after WWII the Belgian government had set out to restructure the Belgian inefficient mine-exploitation and to also lower the

de Saint Nazaire (Naval industry)), Edmond Giscard D'Estaing (Int. Chamber of Commerce), Emmanuel Monick (Banque de Paris et de Pays Bas), René Piaton (Péchiney). Germany: Hermann J. Abs (Süd Deutsche Bank), Richard Merton (Metallgesellschaft), Hans-Günther Sohl (former Vereinigte Stahlwerke), Carl-Alex Volmer (Rheinischen AG). Belgium: Baron Boël (des Usines Gustave Boël), Louis Camu (Banque Bruxelles), Pierre van der Rest (Comité de la Sidérurgie belge et du Groupement des Hauts Forneaux et Aciéries belges). Luxembourg: Jules Hayot, Fernand Loesch.

258 See Milward, A. S. (1992). The European rescue of the nation-state. London: Routledge, pp. 64-83. CEHECLIN, LECE, inv. nr. 627, 1950-07-10, Conseil Central, Plan Schuman note introductive du Secrétariat Général de la Ligue, pp. 6-7. 1950, late July. LECE (1950). Résolution relative au Plan Schuman. Bruxelles: LECE, pp. 8-12.

259 CEHECLIN, LECE, inv. nr. 627, 1950-07-10, Conseil Central, Plan Schuman note introductive du Secrétariat Général de la Ligue, pp. 2-4. 
price-subsidies that it paid to protect the sector. The attempt was successfully resisted by the Belgian private holdings which were unwilling to accept forced mergers and intervention in management decisions. Now, in 1950, they suspected the Belgian government of using the Schuman Plan and the High Authority to finally realize a government-led restructuring. ${ }^{260}$

Instead of price-intervention, the ELEC proposed that the High Authority should embrace cost-price competition. This would force the industries to invest in productivity-improvement themselves. Realizing that Belgian inefficient coal mines would quickly lose the battle with German coal, ELEC's solution was that the least efficient firms should be closed before the start of the customs union and their owners should somehow be compensated by the rest of the entire European coal industry. The remaining firms would then compete under unregulated prices. In other words, via ELEC the Belgian and German coal and steel interests suggested a cartel-agreement to buy out the weakest links in order to keep government intervention at bay. ${ }^{261}$

At the same time, ELEC agreed that the most efficient, or moderately efficient producers should be offered a chance to adapt to the new unregulated prices. A temporary price "péréquation" could be allowed, but only if this would be organized without actual involvement of the coal sector itself. ELEC suggested an alternative system that would equalize prices by taxing coal-consumers. Whenever a coal-consumer from an expensive coal producing country, at that time typically Belgium, would buy coal in a country where coal was cheaper, the consumer would pay a tax. This would be cashed by the government, not the producers, of the expensively producing country, which would be used to reduce the country's coal selling-price. In this way private industry would remain in control of restructuring its own industries while avoiding action by the High Authority. But more importantly: it left the original prices intact and it prevented German and Dutch coal producers from having to subsidize Belgian competitors. Meanwhile, the already existing price subsidies to the Belgian competitors would be left untouched. Merely their source would be re-routed: from the Belgian public to taxes on energy producing corporations and steel makers, the typical coal consumers. ${ }^{262}$

Clearly the industrialists preferred to see as little change as possible in the coal and steel industries. Moreover, they wished to reduce the potential powers of the High Authority where they could. In this vein the ELEC also suggested to let the High Authority play a role of mere coordination over expert committees on coal and steel, guarded by a third committee, composed of members from industry, labour unions and consumers. ${ }^{263}$

\footnotetext{
260 Milward (1992). The European rescue, pp. 54-55, 70-73.

${ }^{261}$ LECE (1950). Résolution, pp. 10-12. Published in 1950, late July.

262 LECE (1950). Résolution, pp. 12-14.

${ }^{263}$ LECE (1950). Résolution, pp. 14-16.
} 
ELEC's proposals on the institutional arrangements of the High Authority were informed by entirely different motives. The French government had insisted that the High Authority should be a supranational institution and that this was to be accepted before negotiations began. As indicated earlier, ELEC wondered whether the relation between the Authority and national governments would complicate the position of the coal and steel industries. However, ELEC truly began to doubt the supranational aspect when in June 1950 the United Kingdom denounced the principle of supranationalism and declined the invitation to take part in the Schuman Plan negotiations. ${ }^{264}$

ELEC as a whole was highly in favour of British membership of a coal and steel customs union, but now that the British government had withdrawn from the plan there was little to be achieved. Precisely at that point, the ELEC's British section began to express strong objections to technical aspects of transport costs and price equalization, even though it was clear that the United Kingdom would not take part in the Schuman Plan negotiations. All of a sudden ELEC's Central Council found itself in an awkward position. Until then, the British section had been of central importance to ELEC's work. If the other sections wanted to retain it as a credible partner, they were forced to accommodate to its views. The British section's technical objections to the Schuman Plan were ignored but instead the ELEC decided to propose a lowering of the threshold for the United Kingdom to take part in the negotiations: in July 1950, the British section, after negotiations with Edmond Giscard d'Estaing of the French section, asked ELEC's Secretary General Louis Camu to include a preamble that proposed to add a ministerial body to control the High Authority. The proposal was the result of a broader preference in the ELEC for the organization of a market with the United Kingdom and internal pressure from the British section. ${ }^{265}$

The proposal for a ministerial body was a new move for ELEC. Earlier that year the Central Council had unanimously expressed a preference for the creation of "specialized institutions" to which "states devolve parts of their sovereignty" instead of veto-based organizations that involve the direct representation of national governments. ${ }^{266}$ Ministerial control over the High Authority however would be very much like a veto-based structure. Although earlier drafts of the policy

\footnotetext{
264 Gillingham (1995). Coal, steel, pp. 178-183.

${ }^{265}$ CEHECLIN, LECE, inv. nr. 627, Rhys-Williams to Camu, 27-7-1950. In Dumoulin \& Dutrieue (1993). La Ligue, pp. 51-52, the interpretation is forwarded that the League was held hostage by the British section to comply with their preferences. The interpretation forwarded here is that the League complied with the British section so that the ELEC could remain a platform for keeping the continent as open as possible to later membership of the United Kingdom.

266 "Formule institutionnelle comportant la création d'institutions spécialisées (principalement de caractère économique) auxquelles les Etats dévoulueraient des parcelles de leur souveraineté." Another route for integration was considered by the Central Council: "Maintien ou formation d'organismes de coordination où s'affronteront les politiques nationales et dont toutes les décisions resteraient passibles du veto des Etats affiliée." This route now seemed to be preferred over the first one. CEHECLIN, LECE, inv. nr. 45, 1950-01-12, Conseil Central, p. 2.
} 
paper included the proposal that the "High Authority would be subject to control by the Governments", they never contained the elaborate proposal for a ministerial body supervising it.267 Louis Camu, an enthusiast for an even further-reaching Atlantic Union, an idea which required closer ties between the continent and the United Kingdom, finally allowed for the preamble to be included. If British membership hung in the balance ELEC was sensitive to British demands. ${ }^{268}$

ELEC continued to suggest courses of actions that were designed to sensitize the negotiating governments to British conceptions of a European market. A later instance in December 1950 illustrates this, and reflects ELEC's frustration over the prospect of an ECSC without the United Kingdom. At that point the Schuman Plan negotiations had progressed to an advanced stage without any changes in attitude in the British government. ELEC blamed the negotiating governments. Addressing them directly in an ad hoc resolution sent to them by letter, ELEC condemned the inability of the negotiating partners to get the United Kingdom to participate, whoever "is responsible for her present forbearance."269 The ELEC thought that without participation of one of the biggest producers of coal and steel in Europe "the chances of this undertaking shall appear limited."270

The ELEC even attempted to involve itself with the most fundamental British arguments against European economic integration; in 1951 it organized a EuropeCommonwealth Conference, which gathered delegations from the Commonwealth to learn about their relation to the United Kingdom. ELEC members thought that the Commonwealth was the main reason why the United Kingdom was not prepared to join. ${ }^{271}$

In the case of the Schuman Plan the views of the ELEC are best explained by the clear interests of coal and steel companies to minimize intervention in price-

\footnotetext{
267 "La Haute Autorité serait soumise au contrôle des Gouvernements." Statement taken from 1950, late July. LECE (1950). Résolution, , but already included in the adopted version during the Central Council meeting of the 10 and 11th of July, 1950.: LECE, inv. nr. 627, 1950-07-11, Translation of the note on the Schuman plan adopted at the meeting of the International executive committee of E.L.E.C. held in Paris on the 10th and 11th of July, 1950, p. 6, §20.

268 [Banque Lambert] (1977). Louis Camu 1905-1976. Banque Lambert: Bruxelles, 56, 59-61.

${ }^{269}$ CEHECLIN, LECE, inv. nr. 685, 02-12-1950, Conseil Central annexe, Une résolution internationale sur la proposition Schuman.

${ }^{270}$ Translation of: "incombe la responsabilité de son abstention actuelle" \& "les chances de l'entreprise apparaitraient restreintes" Ibidem. See for letters to the Belgian government and the instruction to the other ELEC sections to sent resolutions to the relevant ministers of their respective countries, inv. nr. 17, dated 4-12-1950 to 12-12-1950. These letters did not only include the resolution on the Schuman plan, but also a resolution on "la démobilisation tarifaire intra-européenne" which will be discussed below.

${ }^{271}$ LECE (1951). Conférence Europe-Commonwealth - Discours de M. Van Zeeland // EuropeCommonwealth Conference - Speech by Mr Van Zeeland. Bruxelles: LECE, p. 10. Van Zeelands closing speech was revealing; "Of course, when the League invited delegations of so many nations of the Commonwealth, they knew that for a while we were facing a problem. The problem has been studied and if I am right, it has been solved. It was a further reason for hesitation on the part of a certain number of British friends to join fully in the effort to build up Europe, just because they were thinking of their special relations with the Commonwealth."
} 
setting and market-restructuring. They wanted a liberalized market without tariffs and quotas but only if it meant that they, particularly the Belgian and the German companies, would be allowed to restructure that market themselves. ELEC's sensibility to institutional arrangements in order to increase the chances for British association indicates that the ELEC had a very broad conception of the market that they wished to see created in Western Europe. They understood well how certain institutional arrangements would affect the management of their companies in the long run. ELEC's proposals were not realized however: a temporary "péréquation agreement" was included in the ECSC, but not the coal consumers would have to pay the tax, the coal producers would. Moreover, the idea to close inefficient coalmines in return for compensation was not included in the agreement. Instead the rationalization measures for the Belgian coal industry were minimized. ELEC's biggest achievement with regard to the Schuman Plan negotiations however was a constructive agreement between important Belgian and German industrial interests within the coal and steel industries. After the ELEC had dealt with the Schuman plan, the British section, already lacking direct representatives of multinationals or business, would become one of ELEC's least vocal sections. ${ }^{272}$

\section{The many roads to trade liberalization}

As explained in Chapter 2, since its founding in 1947 the European League for Economic Cooperation had proposed the elimination of European import tariffs. Within ELEC the lobby was most zealously carried by Paul van Zeeland and by the French section. Both had raised the issue already since before WWII. In April 1949 the ELEC reached a preliminary climax in that endeavour at the Economic Conference of the European Movement, in Westminster. As chief organizing party the ELEC strongly impressed its views on the preparatory documentation and on the final formulation of resolutions. The resolutions mirrored the proposals for a European customs union by the United States since the announcement of the Marshall Plan and went even further, proposing all characteristics of a Common Market: a customs union including the freedom of movement of labour and capital. Moreover, according to the conference the customs union-element of the Common Market was to be arrived at by removing all quantitative restrictions to trade within a strict, pre-agreed time-frame..$^{273}$

\footnotetext{
272 Milward (1992). The European rescue, pp. 69-73.

${ }^{273}$ Gisch, H. (1991). The European League for Economic Co-operation (ELEC). In W. Lipgens \& W. Loth (Eds.), Transnational organizations of political parties and pressure groups in the struggle for European union, 1945-1950 (pp. 186-276). New York: Walter de Gruyter, pp. 190-191; European Movement (1949). European Economic Conference. Westminster, April 20-25, 1949. Resolutions adopted in plenary session. London: United Europe Movement, pp. 1-3. In fact the resolutions used the terms "economic union", "full customs union" and "customs union" interchangeably. However the characteristics of what was described fitted the definition of a common market as given by Balassa (1969[1962]). The theory, $\mathrm{p}$. 2 .
} 
Throughout the 1950s the idea of a Common Market would remain ELEC's main topic. As will be explained below, ELEC appeared to be in agreement about the fundamental principles of liberalization of European trade. However, at each point when ELEC tried to draft a position paper on the topic it found itself in internal conflict with regard to the methods that should be employed. Particularly the eager Dutch and Belgian sections with direct representation from Europe's largest multinationals and financial holdings with interests all over Western Europe, disagreed with the French section which was more reluctant with respect to liberalization, and more sensitive to general French private interests than merely the interests of its most internationalized corporations.

In 1950 an opportunity presented itself for the ELEC to bring across its views. A failed attempt of the Western European governments at gradually removing European quotas on all goods, suddenly raised attention regarding the topic of trade liberalization. In the years preceding 1950 governments had agreed within the OEEC to begin with removing trade quotas in phases. That process was planned to start in March 1950. However at the first opportunity national governments quickly exploited the technical weaknesses of the agreements in order to leave the quotas virtually unchanged. The plan failed. The result was that from June 1950 onwards the question of how to liberalize European trade was back on the agenda. ${ }^{274}$

Within the ELEC the French section seized the moment to provide an alternative and presented its views to the Central Council. Paul Naudin, the original President of the Comité d'action économique et douanière before it transformed into the French ELEC section in 1946, had drafted a proposal for publication by the ELEC. At most ELEC meetings the French section was composed of representatives from the French national employers association, the Conseil National de Patronat Français (CNPF), and in particular by members from its subcommittees on international trade. Paul Naudin was one of them, being the President of the French-Latin American Chamber of Commerce. His proposal for trade liberalization was written in accordance with the general CNPF perspective of French employers. ${ }^{275}$

In principle the French section subscribed to the idea of a Common Market and the mentioned Westminster approach. However, Naudin was concerned about the cost-price disparities between countries that would remain after the elimina-

\footnotetext{
274 Milward (1984). The reconstruction, pp. 421-424, 443-457.

275 The document was presented during a meeting of the Economic Commission, chaired by Roger Nathan, President of the "Commission de Libre Echange de Conseil National du Patronat Français." Recurrent representatives were the President of the French ELEC section, Edmond Giscard d'Estaing (Président Comité Français Chambre de Commerce International), Jacques Chastenet (a diplomat), René Fould (Chambre Syndicale des Constructeurs de Navire), Emmanuel Monick (Gouverneur Bank de France) and Paul Naudin (Chambre du Commerce France-Amérique-Latin). CNPF (1955). Annuaire Général du Patronat Français. Paris: CNPF, pp. 746-756.
} 
tion of tariffs. ${ }^{276}$ He proposed to add a temporary levy, called the "droit compensateur." 277 The basis for calculation of this levy would be the difference in national cost prices per product group, constituted by several factors of production such as wages or structural social costs. He proposed to levy the rate over imports from the start of a decisive and rapid lowering of the original tariffs. After the original tariffs would be removed, Naudin suggested, the compensating tariffs would be gradually decreased. By proposing this levy Naudin addressed a problem of French employers who were concerned about competition from countries with lower wages. French wages were relatively high, whereas the lowest wages were paid in the Netherlands. The French government was also concerned about these differences. In other words, as part of a plan for tariff reduction Naudin proposed a new tariff to protect French high-cost products from competition based on cheap Dutch labour. ${ }^{278}$

The other sections gave a mixed response. The members of the diversely composed British section were altogether satisfied though they were apprehensive about the complicated nature of the proposal. The Dutch section strongly disagreed and found the Belgian and German sections on its side. ${ }^{279}$

In contrast to the French section, the Dutch section consisted of representatives of large, industrial multinationals. The Dutch section member A. E. J. Simon Thomas of Unilever was convinced that the calculation of such a rate per product group was entirely impossible. Instead Simon Thomas proposed an immediate freeze of existing tariffs and a quick publication of a liberalization scheme. According to him the plan should include stages at which pre-determined percentages of import tariffs would be cut at predetermined dates without any new rates taking their place. Moreover he explained that the scheme should be activated automatically on a fixed date, supervised by a new "High Authority", just like the Westminster resolutions had suggested. Representatives of the Belgian and German sections, leaders and advisors of financial holdings of industry such as Sermon, and the banker Herman J. Abs, subscribed to these proposals. Those sections were

${ }^{276}$ CEHECLIN, LECE, inv. nr. 45, 25-03-1950, Conseil Central, p. 3. The report text by Naudin presented during the Commission Economique of 6-11-1950, is discussed here as it was published in: LECE (1951). La démobilisation tarifaire intra-européenne (Vol. 5). Bruxelles: LECE, pp. 9-17.

277 "droit compensateur: the rate which is calculated to compensate [...] for any price advantages of those inherent costs of national production that are indirectly conferred on external competition." Translation from: "celui dont le taux est calculé pour compenser forfaitairement tout avantage de prix que les charges inhérentes à une production nationale conférent indirectement à la concurrence extérieure." LECE (1951). La démobilisation, p. 12.

${ }_{278}$ Ibidem, pp. 11-14. Especially the French believed that their wages were higher, and production efficiency was lower, than in other OEEC Countries. Lynch, F. M. B. (1997). Restoring France: the road to integration. In R. T. Griffiths (Ed.), The Economic Development of the EEC (pp. 144-172). Lyme: Edward Elgar, pp. 149-150.

${ }^{279}$ CEHECLIN, LECE, inv. nr. 141, 6-11-1950, Commission Economique, procès-verbal, pp. 2-4. 
clearly not prepared to accept new protectionist mechanisms as part of a liberalization scheme. ${ }^{280}$

The Central Council ultimately decided to combine the two plans in one resolution and publish a booklet with separate statements from the French and the Dutch sections. The disagreement illustrates that all sections principally agreed on the need for liberalization but that in the end different economic perspectives informed the method and speed of integration. A split between Benelux and German sections on the one hand and French and UK sections on the other particularly reflects a divide between an accumulation of international trade interests in the first group and more general and diversified interests in the second.281

Attempts were also made to bridge the divide. The very internationalized and highly competitive multinationals from the Netherlands were prepared to deviate from the approach that they preferred if the alternative could convince other sections such as the French to agree to liberalization. In 1951 the plan called "the Promotors Inquiry" was introduced by F. E. Spat, secretary to the board of Philips. In short the idea was to invite individual firms from several industries to collaborate in convincing their governments to reduce tariffs for their industry. Industrybased study groups would have to reach agreements within their industry about the conditions under which tariff-reduction would be acceptable. Certain industries whose resistance to liberalization was now blocking progress on large scale integration schemes could be catered to separately via this approach. The resulting agreements would then be presented to European governments as a basis for negotiations. 282

The plan was initiated in December 1951, but not before the ELEC had agreed to one request from the president of the French section, Edmond Giscard d'Estaing, who was also part of the CNPF as President of the French committee of the International Chamber of Commerce. In principle he supported the plan but he feared that the ELEC stood a chance of loosing control of what it had started. The proposal of sector-based initiatives reminded him of the, by then much derided, Schuman Plan. He wished to impress upon all participants that the ELEC was fighting this "super-

\footnotetext{
280 LECE (1951). La démobilisation, pp. 17-23. CEHECLIN, LECE, inv. nr. 141, 6-11-1950, Commission Economique, procès-verbal, pp. 2-4.

${ }^{281}$ Italian members were not taking part in the meeting. CEHECLIN, LECE, inv. nr. 45, 2-12-1950, Conseil Central; inv. nr. 685, 2-12-1950, Resolution: La démobilisation tarifaire intra-européenne. LECE (1951). La démobilisation.

${ }^{282}$ LECE (1952). Enquête des promoteurs (Vol. 11). Bruxelles: LECE. Originally the plan came from the Rhodius brothers, Dutch wool importers. To get the necessary attention for their plan, the Rhodius brothers approached many companies and officials, among which Philips. Initially, late 1949, the executive director Van Walsem of Philips had turned down their request to go forward with the idea but when the idea started to proliferate in the international business community and in the OEEC, F.E. Spat (secretary of the Philips-board) introduced it to the Dutch ELEC section in January 1951. Blanken, I. (2002). Een Industriële Wereldfederatie. Zaltbommel: Europese Bibliotheek, p. 249, \& Nationaal Archief, Den Haag, Europese Beweging in Nederland en Voorgangers, 1945-1987, 2.19.109, inv. nr. 345, 17-011951, Algemene Ledenvergadering.
} 
dirigisme." According to him the industry-based study groups "should not make new Schuman Plans" and "realise single markets [...] without proposing the unnecessary creation of a high authority." The French section clearly was not prepared to achieve any of its preferences for temporary protection-schemes by means of sector-based institutions. ${ }^{283}$

The response was insufficient for the plan to succeed however. Entrepreneurs were not willing to share sensitive information with each other, nor conclude agreements that would be seen as illegal cartels elsewhere such as in the United States. ${ }^{284}$

\section{The Beyen plan}

The European League for Economic Cooperation again found itself in disagreement in 1954. This time, liberalization of trade as such was not the issue. It was the eagerness that was displayed by the Dutch and Belgian sections in their attempt to push the Beyen plan beyond what was politically prudent for the French section. As explained earlier, the plan of the Dutch Minister Johan Beyen was to link political integration to economic integration. He followed a strategy of indirectly attaching the creation of a customs union to the treaty for a European Political Community (EPC), which itself was attached to the founding of a European Defence Community (EDC) that had been under discussion since 1951. Beyen, a former Unilever director closely adhered to the Westminster method for the formation of a customs union and even tried to fix the terms in the draft treaty of the EPC. He succeeded in attaching the principle of this idea in the draft treaty that was published on the $10^{\text {th }}$ of March 1953. The time scheme was however excluded and merely a gradual development of the market was mentioned. Moreover the draft treaty did not just suggest the founding of a customs union but a Common Market.285

Shortly after the EPC draft treaty was published ELEC tried to use the opportunity to clarify how a European market should be organized according to its members. In a press release they welcomed the prospect of the future founding of a "marché commun", but then quickly followed up to make sure what this should mean exactly. For the first time the ELEC did not just make clear how a market should be liberalized but also how it should work. ELEC stated that the Common

\footnotetext{
${ }^{283}$ Translation: "il ne faut pas faire de nouveaux Plans Schuman" and "réaliser des marchés uniques mais sans proposer la création inutile d'une haute autorité." CEHECLIN, LECE, inv. nr. 716, 15-12-1951, Assemblée Générale, p. 4.

284 On the Promotors Plan also see Dumoulin \& Dutrieue (1993). La Ligue, pp. 74-77. The publication was called LECE (1952). Enquête des promoteurs (Vol. 11). Bruxelles: LECE.

285 Griffiths (1997). The Beyen Plan, pp. 127-128; AEI, Ad hoc assembly instructed to work out a draft treaty setting up a European Political Community (1953). Draft treaty embodying the Statute of the Europan Community. Information and official documents of the Constitutional Committee, October 1952 April 1953. Paris: Secretariat of the Constitutional Committee, p. 102. Retrieved, August 28, 2013, from http://aei.pitt.edu/991/1/poliical_union_draft_treaty_1.pdf.

CEHECLIN, LECE, inv. nr. 45, 27-03-1953, Conseil Central, Annexe, Communiqué de Presse.
} 
Market should "function under a regime of competition" where "the company develops freely within the framework of the law." Moreover, ELEC asked to forego the "dangerous creation of new specialized authorities of a technocratic character", referring to the ECSC's High Authority. Additionally ELEC stated that the market should be as large as possible and that its institutional organization should leave room for expansion to other countries by other means than full membership. In this regard they stressed that there was a serious danger in integrating the Benelux, France, Germany, and Italy without creating ties with the rest of Western Europe, members of the OEEC or the European Payments Union. ${ }^{286}$

ELEC's conceptions of the European market thus went beyond mere liberalization schemes. Earlier the group had made clear that the organization of international markets through artificially created instruments and intervention in investment policies was unacceptable. Now their views were translated into a prescription for an embryonic competition policy, the only regulatory order for the market that was not at odds with the freedom of entrepreneurship that members of ELEC valued so highly. More importantly, ELEC's members were in an ideal position to appreciate the danger of an integrated European market that would ignore its embeddednes in wider European and global trade relations. It was critical to the interests of international traders that the designers of the European market were aware of this dimension. The treaty text lacked such provisions and ELEC felt it had to make clear that a market entailed more than just tariffs.

But tariffs had to be lowered first. The multinationals Philips, Unilever, Shell and $A K U$, of the Dutch ELEC section, were aiding Beyen where they could in the Dutch political arena. In April 1953 they urged the Dutch employers associations to write a general response to back the Beyen plan for a customs union. The employers associations dutifully fulfilled the request. The ABUP also proved instrumental in directing ELEC's attention to the Beyen plan. They met to discuss the details of the plan in June 1953 and decided to introduce them in the ELEC. This prompted the Central Council to take up the plan for study that same month. Broadly supported by all sections, the ELEC even drew up a publication that demanded the definitive and scheduled creation of a customs union after the European Political Community was realized. ${ }^{287}$

However, the combination of economic integration with political integration became a basic controversy within ELEC. The French section thought it was too risky. During the Central Council meeting of January 1954, after months of prepar-

\footnotetext{
286 Translation of: "fonctionner sous un régime de concurrence", "l'entreprise se développe librement dans le cadre des lois", "creation dangereuse de nouvelles autorités specialisées à caractère technocratique", CEHECLIN, LECE, inv. nr. 45, 27-03-1953, Conseil Central, p. 2 \& Annexe, Communiqué de Presse. ${ }_{287}$ Blanken (2002). Een Industriële Wereldfederatie, pp. 251-255; Paulussen \& Blanken (2004). Samenwerking tusschen Nederlandsche industrieën, pp. 45-47, and CEHECLIN, LECE, inv. nr. 45, 19-06-1953, Conseil Central, pp. 3-4. The response that the Dutch employers associations wrote was titled: "Verklaring inzake Europese Integratie, 21 april 1953." The study that they undertook was LECE (1954). La portée économique d'une communauté politique européenne (Vol. 14). Bruxelles: LECE.
} 
ing for the publication of the study, Edmond Giscard D'Estaing explained that he wanted to call it off. The French parliamentary ratification of the European Defence Community was delayed and it was far from obvious that a solution would arise. He feared that a demand by ELEC for the inclusion of a definitive and scheduled creation of a Common Market in the EPC-treaty, would slow down the discussion on the political community, perhaps block them and as a result slow down or block discussions on the EDC." 288 Instead he demanded from the ELEC "to ask the Ministers to sign a strictly political and institutional Treaty."289

The Benelux industrialists responded with agitation. G. A. Kohnstamm of the artificial fibres producer AKU, declared that "[t]he Netherlands have no interest in ratifying a treaty of which the economic provisions do not ensure the formation of common market", a statement underwritten by the Belgians René Boël of Solvay \& Cie. and Lucien L. Sermon of Brufina for the Belgian situation. They nonetheless had to back down after Edmond Giscard d'Estaing stated that the ELEC, being an economic study group, should stay out of matters of a political treaty. The British section moreover indicated that it could not accept the reference to the necessity of a political authority for the formation of Common Market. The original ingredients of the Beyen plan and any references to it were subsequently removed from the study. ${ }^{290}$

The final content of the brochure on the "[t]he economic scope of a European political community", published in March 1954, was thus a compromise which merely tried to remind the negotiating governments that the political community at some point would have to start the implementation of a Common Market ("marché commun"). In addition ELEC also added a sophisticated and complete reworking of its already mentioned ideas on the institutional organization of the market. They demanded a regime of competition, freedom of entrepreneurship and an open character of the community, including the option for other countries such as the United Kingdom to engage in certain forms of association. Moreover they proposed harmonization of national policies on financial, commercial and economicsocial matters. They also offered further reasons for ELEC's denunciation of sectorbased integration under supervision of specialized supranational institutions. They feared that the multiplication of separate institutions would only constrict the freedom of action of member states. ELEC was convinced that each separate insti-

\footnotetext{
${ }_{288}$ Translation: "la discussion nécessaire portant sur les attributions économique ralentit la discussion politique, et va peut-être même l'entraver, ce qui par ricochet ralentit ou entrave la ratification des dispositions militaires." CEHECLIN, LECE, inv. nr. 45, 16-01-1954, Conseil Central, p. 2.

289 Translation: "de demander aux Ministres de signer un Traité strictement politique et institutionnel." CEHECLIN, LECE, inv. nr. 45, 16-01-1954, Conseil Central, p. 2. Also see Dumoulin \& Dutrieue (1993). La Ligue, pp. 67-69 which also zooms in on this discussion.

290 Translation: "les Pays-Bas ne voient aucun intérêt à ratifier un traité politique dont les dispositions économiques n'assurent pas la formation du marché commun." René Boël and Lucien L. Sermon, representing the Belgian section, agreed. CEHECLIN, LECE, inv. nr. 45, 16-01-1954, Conseil Central, pp. 3-4; inv. nr. 720, 31-01-1954, Conseil Central, pp. 1-5. Dumoulin \& Dutrieue (1993). La Ligue, pp. 67-69.
} 
tution would develop different political, economic and monetary views and thus lay the basis for conflicts among them. To their disappointment however the ratification process in the French parliament regarding the European Defence Community faltered nonetheless on the $30^{\text {th }}$ of August $1954 . .^{291}$

It is unlikely that Giscard d'Estaing really saw an ELEC publication as a large risk for the EDC, but within French politics it could likely have backfired on his position as one of the nation's semi-public representatives of international enterprise. In France the discussion about the economic dimensions of the EPC were seen as a nuisance. Moreover, in light of the earlier proposals of the French ELEC section for combinations of trade liberalization schemes and semi-protectionist considerations, the notion of an automatic implementation of a customs union surely was unattractive. Nobody could guarantee that any signatory country would be prepared to re-open negotiations on compensating measures when the customs union was established. Indeed, already in February 1953 the political division of the French Foreign Affairs Ministry was worried about being caught off-guard on economic clauses in the EPC treaty. The fact that within the ELEC the Benelux and German sections so eagerly tried to exploit the opportunity did not help. ELEC affairs in later years however showed that the Benelux sections had learned to be flexible, and to sweeten the deal in order to get the consent they wanted.292

\section{Any market at all...}

By 1954, the ELEC had arrived at a turning point. In April of that year, exactly at the point when the brochure on the economic charter of the EPC was published, the group sensed that the time had come to recapitulate ELEC's ideas on economic and political unification of the six member states of the ECSC. A day before the definitive collapse of the European Defence Community ratification process on the 30th of August, ELEC accepted a draft proposal by its Secretary General, the Belgian Sermon for writing a publication on how a Common Market could best be implemented. However, as will be seen, during the next year ELEC's sections would all be forced to show their true colours on the subject of a Common Market. National governments were suddenly showing a formal interest in the topic. Now that a decision about European economic integration seemed to be in the making, would the section's views regarding a Common Market remain the same?293

The commitment of the Dutch multinationals to the founding of a Common Market remained firm. From August 1954 onwards they began to ask for an ELEC response to the potentially harmful international developments that were undermining the founding of a European Common Market. In August 1954 the secretary

\footnotetext{
291 LECE (1954). La portée économique, pp. 4-10.

292 Griffiths (1997). The Beyen Plan, pp. 128-129.

${ }^{293}$ CEHECLIN, LECE, inv. nr. 45, 15-04-1954, Conseil Central, p. 4; inv. nr. 271, 29-08-1954, Conseil Central, pp. 8-9; inv. nr. 271, 29-08-1954, Conseil Central, Annexe III.
} 
to the board of Philips, F. E. Spat, expressed his concerns about recent tariff increases by the United States on Swiss watches. He proposed a resolution which was personally underwritten by the Dutch Minister of Economic Affairs Jelle Zijlstra, a former ELEC member himself. Moreover Spat had the support of several of the business leaders within the Dutch section. The Central Council agreed to the resolution which condemned "[t]his protectionist measure" through which "America may frustrate Europe's striving for the creation of a common European market." The rationale of this concern was that American protectionism would curb any European willingness to commit to trade liberalization. ${ }^{294}$

Sudden negotiations between the governments of Germany and France triggered a similar response. In October 1954 they concluded agreements on foreign trade and mutual investments. In the pessimistic atmosphere on European integration that had resulted from the EDC debacle, the bilateral agreements triggered the fear that the window for founding a multilateral Common Market had closed. The possibility that European trade would again be organized by means of bilateral agreements suddenly seemed real. As a response in January 1955 the Dutch and Belgian sections asked ELEC's Central Council to condemn the negotiations between Germany and France on the grounds that they might endanger the establishment of a Common Market. However ELEC's French and German sections would not hear of it: they were convinced that such fears were unnecessary. ${ }^{295}$

The fears persisted nevertheless and they strongly affected the drafting of the brochure that was intended to recapitulate ELEC's views on the founding of a Common Market. During the Central Council meeting in January 1955 ELEC's President René Boël explained that the basis for the document was not any longer a customs union but a "free trade area." When the Belgian Secretary General Lucien L. Sermon submitted his draft in ELEC's Economic Committee in March 1955 it indeed committed to a "zone de libre échange" causing frustration among the participants. The move of ELEC's Belgian section had come shortly after a policy change of the Belgian government in January 1955. The Belgian government was also displeased with the Franco-German bilateral initiative and now threatened the protectionist French government to back a free trade area instead of a Common Market. Just as the Dutch ELEC section stood behind the Beyen plan, now the Belgian ELEC section sided with its government.296

\footnotetext{
${ }^{294}$ CEHECLIN, LECE, inv. nr. 35, 19-08-1954, Spat to Sermon, plus annex: draft proposed resolution, pp. 1-2; inv. nr. 271, 29-08-1954, Conseil Central, "E.L.E.C. points out the danger of U.S.A. going back to protectionism", p. 8. (doc. no. 287). The business leaders were P. R. Bentz van den Berg(Koninklijke Hoogovens), M. Klaasse (Amsterdam Bank) and M. Meynen (Algemeene Kunstzijde Unie, A.K.U.).

${ }^{295}$ Milward (1992). The European rescue, pp. 191-192. CEHECLIN, LECE, inv. nr. 39, 29-01-1955, Conseil Central, p. 7; inv. nr. 39, 02-02-1955, Hopes expressed with regard to the Franco-German economic negotiations (doc. 331).

${ }^{296}$ Translation: "zone de libre échange" CEHECLIN, LECE, inv. nr. 39, 29-01-1955, Conseil Central Minutes, p. 36; inv. nr. 39, 29-01-1955, Conseil Central Procès Verbal, p. 4; inv. nr. 151, 12-03-1955, Commission Economique, Le formation du Marché commun européen après les accords de Londres et de Paris, par L. Sermon. Milward (1992). The European rescue, pp. 191-192.
} 
Especially the French section was surprised by the proposal. By now they were thinking about an altogether different proposal as well, one which was also mindful of the views of their new government. The French government was led by Mendès-France (June 1954-February 1955), an outspoken critic of European supranational institutions. As a result the French ELEC section changed its views. Giscard D'Estaing indicated that the section favoured the elimination of tariffs by means of negotiations among industries themselves. This would involve hammering out all sorts of sector-specific deals instead of integrating all sectors at the same time via a Common Market. This was similar to what the ELEC had intended with the "Promotors Inquiry." The French section expected that negotiations on a Common Market would result in negotiations between industries of different countries anyway. The French section moreover stressed that tax harmonization or the equalization of social regimes were not necessary in integration schemes. According to the French, levies could instead be imposed to compensate for the largest disparities between countries, just as the French section had proposed in 1951. By renouncing tax and social regime harmonization the need for a supranational institution was further reduced. ${ }^{297}$

ELEC's Economic Committee met again in July 1955, some weeks after the Messina conference at which the ECSC member states had decided to study the most viable approach to economic integration. Governments were busy devising their strategies, but within the ELEC the tone of debate suddenly changed from a mutual nation-based strategic attitude into a constructive one. The news of a renewed governmental interest in a customs union introduced a careful weighing of options instead of negotiating preferences. The sections took a distanced view of the matter as if they wanted to provide the intergovernmental committee, starting its work in September with as much viable options and techniques that could be useful in achieving a positive result. ${ }^{298}$

The French section for example backed down on the proposals for sectoral agreements and acknowledged that a simultaneous integration of all sectors would be preferable, provided that some sensitivity to specific sector-based problems would be built-in. Moreover they indicated that a customs union and a free trade zone could exist alongside each other for the time being. Also, the French section felt that no preconceived ideas should exist on the size of the market to be created, indicating room for the British to join. The Oxford economist Roy Harrod of the British section favoured a free trade area. The Belgian section agreed with Harrod, as did the German section's secretary Paul Krebs of Deutsche Bank but added that a solidarity plan should aid those countries that would have difficulties in adapting to the reduction of tariffs. The Dutch Pieter Blaisse, member of the General Assembly of the ECSC and member of the Dutch industrialization committee, explained

\footnotetext{
${ }_{297}$ Milward (1992). The European rescue, pp. 191-192. CEHECLIN, LECE, inv. nr. 151, 12-03-1955, Commission Economique, p. 5.

${ }^{298}$ CEHECLIN, LECE, inv. nr. 722, 9-7-1955, Commission Economique.
} 
that the Dutch section had arrived at a point at which it agreed to all the studied possibilities: "a customs union and an economic union, an extension of the ECSC, support the work in Messina, Professor Harrod's project" [...] to "arrive at a result."299

In order to guarantee a result, the Dutch section tried to clear away objections from governments and economic pressure groups against economic integration. Reaching out to French and Italian concerns, they admitted that in view of "significant divergences in financial and social policy in different countries or artificial differences in the cost structure", some harmonization was unavoidable. ${ }^{300}$ To increase the acceptability of a Common Market for both countries, Blaisse proposed a development fund to alleviate adaptation costs, especially for underdeveloped regions and backward sectors. The proposal had been sent in 1954 by Philips lawyer Hein Wertheimer, but the plan was originally rooted in an earlier proposal by Pieter Kuin, an economic advisor to Unilever who had already suggested it late 1953. At the time, Kuin had proposed to the ELEC to investigate in which parts of the European economy the resistance against European integration was located and to find out what could possibly be done about the cause of this resistance. He was explicitly thinking about the limited development of the agriculture sector in France, Italy and Germany and several industries in France, Italy and Belgium. In other words, in order to make economic integration acceptable to even the most backward industries, the Dutch multinationals tried to introduce compensating measures. The Dutch section defended the plan valiantly until it was included in the final document. ${ }^{301}$

ELEC ultimately presented both major options for economic integration that were considered viable within the GATT rules: a Common Market (a customs union including the freedom of movement of labour and capital) and a free trade zone. However the publication indicated that a Common Market would be the more perfect system due to its "common customs tariff and a common commercial policy vis-à-vis third countries" which the free-exchange zone would lack. According to the ELEC the sheer size of the Common Market would offer advantages for devel-

\footnotetext{
299 CEHECLIN, LECE, inv. nr. 722, 9-7-1955, Commission Economique, pp. 4-5.

300 Translation of: "On ne peut négliger les sensibles divergences existant en matière de politique financière et sociale dans les différents pays, ni les écarts artificiels dans la structure des prix de revient", CEHECLIN, CEHECLIN, LECE, inv. nr. 722, 9-7-1955, Conseil Economique, Note Néerlandaise, Programme de Développement Européen, pp. 1-2.

301 CEHECLIN, LECE, inv. nr. 722, 9-7-1955, Conseil Economique, Note Néerlandaise, Programme de Développement Européen; inv. nr. 722, 18-08-1955, Synthèse des remarques relatives au Document No. 340, Projet de déclaration de la L.E.C.E. sur le marche commun. CEHECLIN, LECE, inv. nr. 31, 30-121953, Van Stam to Sermon including “Afschrift van een brief van Prof. Dr. P. Kuin"; inv. nr. 35, July 1954, "Finding the places of resistance. A proposal of the Netherlands section to the Council of E.L.E.C."; inv. nr. 271, 29-08-1954, Conseil Central, p. 7.
} 
opment, rationalization, specialization of production and ultimately an increase of the standard of living. ${ }^{302}$

The fixed time frame for customs reduction, strongly preferred by the Dutch section, now was described in minute detail, suggesting stages over a period of ten years. The ELEC also proposed a method for harmonizing national production costs that stemmed from governmental interventions and a mechanism for alleviating adaptation costs for underdeveloped regions and backward sectors. With regard to the institutional setup ELEC eschewed "putting into operation powers" [...] which "are of a coercive nature" which was in line with its continuing criticism on the institutional style of the ECSC's High Authority. Instead the ELEC preferred a market established by treaty with a small international secretariat and a committee of arbitration, inspired by the Benelux example. This would also make it easier, the publication explained, to allow the association of the United Kingdom, Switzerland and the Scandinavian countries to the Six. These remarks were an expression of ELEC's ultimate goal: a Common Market that would encompass the entire OEEC. 303

The brochure was subsequently produced in haste in order to finish it before September 1955 and thus be in time to present it to the experts of the intergovernmental committee that had been appointed by the Messina Conference to investigate the options for economic integration. ${ }^{304}$

\section{Disappointment and recalibration}

Between 1958 and 1963 ELEC gradually began to realize that their approach to studying practical proposals for market integration was no longer adequate due to changing circumstances. In these years much of ELEC's energy went into a prevention of the impending schism between two major European trade blocs.

As mentioned, in response to the plans for founding a Common Market the United Kingdom proposed an alternative plan in November 1956. It proposed to found a free trade zone for the entire OEEC instead of a Common Market for the Six. The ELEC did not respond to the plan until after the Rome Treaties entered into force in January 1958. Because the EEC at that time had become an established fact the UK proposal now meant to include the EEC in a free trade area of the OEEC. In ELEC's perspective it was imperative to prevent trade diversion between a Britishled free trade area and the Common Market. ELEC's response consisted of solutions to the technical problems that were dominating the negotiations between the OEEC governments. What was considered especially problematic was the potential

\footnotetext{
302 ELEC (1955). Declaration of E.L.E.C. on the creation of a common market (Vol. 18). [s.l.]: [s.n.], pp. 1-4, 5-10.

303 ELEC (1955). Declaration of E.L.E.C., pp. 3-4, 19-20.

304 CEHECLIN, LECE, inv. nr. 722, 9-7-1955, Conseil Economique, p. 5; inv. nr. 722, 20-08-1955, Réunion chez le Baron Boël, p. 3.
} 
diversion of economic traffic as a result from strongly diverging tariffs between the EEC and the rest of he OEEC countries. If ignored, the diversion of trade would affect a whole range of sectors simultaneously. The ELEC presented a system of certification that would treat transferred items based on their origin when they passed through customs. But even ELEC itself doubted its own plan due to the complexity of the European market. Ultimately the ELEC saw only one fool-proof method to prevent trade diversion. It suggested to actually establish a common external tariff with the United Kingdom, with similar harmonization schemes as the EEC. In order to fend off British concerns about a potential loss of sovereignty, it was to be overseen by the OEEC. In fact, ELEC suggested a customs union. 305

In late 1958 de Gaulle withdrew from the OEEC negotiations and as a result the British plan for a free trade zone failed. Subsequently the United Kingdom founded the European Free Trade Association (EFTA) together with Austria, Denmark, Norway, Portugal, Sweden and Switzerland. This did not change the problem of diverging tariffs between the EEC and the EFTA however. The ELEC continued its efforts to minimize trade diversion effects. In October 1960 it organized a conference, aptly titled "The Coming Tasks Europe." A collection of private study groups and public bodies, including representatives of the OEEC and the EEC tried to tackle the problem. Consensus was even reached over a proposition for a European Trade Association comprising the EEC and the EFTA, thus "associating them within a wider system." Its chief goal would be to work towards removing internal tariffs to harmonize external tariffs and the establishment of a common trade policy. ${ }^{306}$

In June 1961 ELEC learned about the British intention to start negotiations on accession to the EEC. The ELEC immediately immersed itself in the problems that were sure to come up in subsequent negotiations and drafted two publications aimed at facilitating a successful outcome. The first, published in January 1962 discussed solutions based on what would in all likelihood become the most contentious elements of the negotiations, namely British trade relations with the Commonwealth and agriculture. The second publication, published in June 1962, was a proposal on how to arrange the tariffs of Commonwealth exports of raw materials to the EEC. The strength of the scheme was that it was based on the input from chief representatives of major industrial corporations from the UK and the EEC which processed the materials themselves. All these efforts would however prove to be pointless: seven months later Charles de Gaulle announced his veto against the British accession to the EEC. ${ }^{307}$

\footnotetext{
305 LECE (1958). Au-delà de la communauté économique européenne. Bruxelles: LECE, pp. 8, 20-22, 30. 306 ELEC (1960). The Coming Tasks of Europe. Synthesis of exchanges of view that took place at the IVth International Conference of the European League for Economic Co-operation (Brussels, October 20th22nd, 1960). Brussels: ELEC, pp. 7-9

307 ELEC (1962). The entry of Great Britain in the European Economic Community. Brussels: ELEC. (Published in January). The materials discussed were zinc, lead, aluminium, paper pulp, textiles, bananas, tea, coffee, cocoa, palm oil and tropical timber. For the discussion on aluminium for example the ELEC
} 
When the ELEC Central Council met for the first time after the French veto, the group was outspoken about its deception. The Belgian Baron Snoy D'Oppuers of the Belgian financial-industrial holding Groupe Lambert called it "the most serious accident which has occurred in Europe since the rejection of the EDC." Similar deception was expressed by the other sections. The French section clearly was on the defensive and attempted to clarify what had gone wrong. ${ }^{308}$

Snoy D'Oppuers was the first to express his doubts about whether the answers that the ELEC had tried to provide during the past fifteen years were still adequate under the present circumstances. Two weeks after de Gaulle's veto, Baron Snoy d'Oppuers stated: "The current situation involves new duties for the ELEC." Indeed, if the French government would not change its mind, little progress towards a more complete economic union was to be expected. During the next two years the ELEC would attempt to renew its purpose and adapt its work to new circumstances. This will be discussed in the next chapter. ${ }^{309}$

In summarizing the views of multinationals on the European market in the ELEC from 1950 until the early 1960s, first the differences deserve attention. Whereas most companies fully supported ELEC's founding idea of liberalization of the European market, strikingly enough the French businesses, ELEC's section with the richest past regarding European tariff reduction, preferred transitional protectionist measures. Representatives of Dutch multinationals were the most outspoken in resisting protectionism. Backed by the Belgian and German corporations, they were strongly in favour of a complete and automatic liberalization of tariffs among the ECSC member states. Moreover, in order to increase the acceptability of that plan, Dutch firms devised compensation measures for European industries and economic areas that resisted integration. The British section included no business representatives.

What became clear was that the views of ELEC's national sections at times remained very close to the positions of national governments. French corporations in 1954 suddenly preferred agreements among sectors as a condition or further economic integration just when the Mendès France government was in power. The Dutch multinationals strongly supported the Beyen plan and the Belgian multinationals quickly supported their government's sudden shift in 1955 towards preferring a free trade area when Germany and France had started to develop their bilateral relations.

brought together experts from Aluminium Français, U.A.W. Bonn, Alcan (UK), Industrie de l'Aluminium (Switzerland), Metallgesellschaft (Germany) and British Aluminium. ELEC (1962). The entry of Great Britain into the European Economic Community. Appendix to publication Nr. 34. Brussels: ELEC. (Published in June).

308 Translation of: "le plus grave accident survenu à l'Europe depuis le rejet de la CED." CEHECLIN, LECE, inv. nr. 746, 1-2-1963, Conseil Central, pp. 3, 5.

${ }^{309}$ Translation of: "La situation actuelle entraine pour le LECE des devoirs nouveau." CEHECLIN, LECE, inv. nr. 746, 1-2-1963, Conseil Central, pp. 3, 5. 
Other views were generally shared among ELEC's multinationals. They resisted the introduction of supranational organizations with the task of regulating corporate behaviour on a sectoral level. Freedom of entrepreneurship was too important to them to allow such external involvement. Instead they preferred competition as an organizing principle, though as became clear, French corporations required transitory measures.

Moreover, corporations in the ELEC were in agreement on the need for an as large, liberalized European market as possible and according to them the institutional structure of the European market should remain as open as possible to allow for expansion, particularly to the United Kingdom. This became all the more clear when the European market was in danger of being split up in two trade blocs. They responded by trying to prevent trade diversion in any way possible.

\section{The Bilderberg meetings}

The Bilderberg meetings also discussed themes of European trade liberalization but these discussions were part of a different dynamic. Unlike the ELEC, the Bilderberg meetings did not operate as a lobby group, nor did they try to appeal to policymakers on specific decisions. A Bilderberg meeting was an organized confrontation of views, where people who were highly informed about international economic or security subjects lobbied each other and sounded each other out on the room for manoeuvring in Transatlantic and European relations. Whereas the ELEC in the 1950s was focussed on European economic unification, the Bilderberg meetings focussed on Transatlantic themes in which security and the global economic system were dominant. The formation of a European market and its institutional organization played a modest part in the meetings. European integration was often discussed as an aspect of transatlantic security or global economic relations.

This had the important consequence that in the Bilderberg meetings the subject of the European market was never merely a European theme. It was discussed as a geopolitical affair which was contextualized by American-led efforts in forging a stable, liberal and multilateral trading system. A useful interpretation of the Bilderberg meetings' discussions is therefore dependent on a simultaneous treatment of tensions among Europeans and tensions between the larger categories of Europeans as a group, ánd Americans.

The initial exchanges that preceded the foundation of the Bilderberg meetings were particularly characterised by a "Europe versus America" dynamic, which placed the discussion of the European market in a context of transatlantic trade. 
European integration: “...dictated by the circumstances of our times...”

The founding phase of the Bilderberg meetings which took place in the years 19521953, revolved around a group of European politicians from several parties and a few European businessmen who wanted to make the United States government aware of an emerging European anti-Americanism. They were especially concerned about the long-term consequences of this development and wanted to illicit a response. According to them, European anti-American perceptions involved two main aspects. The first was the United States' attitude to war. Fears had spiralled high in Europe after the American confrontation with North Korea in 1950 and the subsequent Chinese intervention to stop the American advance. According to the European group, Europeans feared becoming involved in a new war as a result of American actions. The second source of anti-Americanism in their eyes was the United States' irresponsible economic conduct towards Europe. They stated that while Europe was already dependent on the United States for dollar aid regarding imports from the US, the Americans had only increased European frustration by means of adopting the Battle Act (1951). This law made American aid dependent on the suspension of parts of European trade with the Soviet Union and China." 'Where could the Europeans earn their dollars?' ", they asked: "[I]t is America which, while closing to Europe traditional export markets, refuses to open her own; it is thus America which is keeping Europe starved of dollars." According to the European group the dollar gap could be remedied by restructuring trade. They stated that the "Europeans should be allowed to export to the United States as unhindered and unhampered as possible", and thus enable Europe to earn its dollars to pay for its substantial imports from the US. This way the need for aid would be replaced by trade. 310

The European view was transmitted to the American government in December 1952 but only got a response a year later due to other domestic priorities. Eventually the Eisenhower administration (1953-1961) requested the Committee for a National Trade Policy to write a White House sanctioned response to the European inquiry. 311

The Committee for a National Trade Policy was an American lobby group of industrial exporters. It was called into action by Eisenhower's White House itself to support the President's free-trade agenda. George Ball, corporate lawyer who as founding partner of the international law firm Cleary, Gottlieb, Steen \& Ball, served a clientele of American multinationals, was the committee's secretary. He helped businessmen such as John Coleman of the Burroughs Manufacturing Company, Harry Bullis of General Mills, Joseph Spang Jr. of the Gillette Safety Razor Company,

\footnotetext{
310 Nationaal Archief, Den Haag, Bilderberg Conferenties, 1952-1999, nummer toegang 2.19.045 inventarisnummer (hereafter, NL-HaNA, Bilderberg Conferenties, 2.19.045, inv. nr.) 1, September 1952, Report No. 1. Report on European-American Relations, pp. 8-9.

311 See chapter 2 .
} 
John McCloy of Chase National Bank and J.D. Zellerbach of the Crown-Zellerbach Corporation, in lobbying for a policy of reciprocal trade with Europe. 312

Not surprisingly their response to the European report in December 1953 was one of emphatic understanding and acceptance: indeed, they agreed that the US needed to open its markets and enable Europe to earn the dollars it required for imports. But the American group also had a request for the Europeans, which made clear that American views had changed little since the introduction of the Marshall Plan in June 1947. The Europeans were asked to increase their productivity by means of founding a single market, thus "restoring Europe's capacity for selfhelp and a balance in its external accounts." The single market would result in a "more rapid advance of productivity than a narrow and protected one defined by national boundaries." Moreover they explained that in the United States little sympathy existed for the slow progress on creating a "single market", or the ratification of the European Defence Community (EDC). They felt that the pooling of resources was merely a technical problem. To them the creation of a single market or the EDC seemed "dictated by the circumstances of our times", and thus inevitable. ${ }^{313}$

It is important to clarify the American use of the term "single market": in none of the Bilderberg meetings between 1954 and 1963 that will be discussed below did the American group express a specific preference with regard to the precise rules of a European market, such as a customs union, a Common Market or a free trade area. Although a preference among American exporters for low European external tariffs is understandable, the use of the term "single market" was not aimed at conveying this particular preference.

This early exchange of views is telling about how the transatlantic context of the Bilderberg meetings, and the American attitude in particular, forced Europeans to discuss the future of the European market from a geopolitical perspective. In the European League for Economic Cooperation, national sections negotiated about the methods of integration and studied how national differences could be addressed. In a Transatlantic context the European market was however reduced to matters of productivity and balances of payments. At such a level of discussion national idiosyncrasies become a nuisance. Moreover the tendency to discuss problems in geopolitical terms implicitly turned specific national preferences into petty demands whose claimants could be said to have lost sight of the bigger picture.

The discussion on the first two reports resulted in the first Bilderberg meeting, taking place in the Bilderberg Hotel in Oosterbeek (The Netherlands) at the end of

\footnotetext{
${ }^{312}$ See for the so-called Trade Agreement Act and the Randall Commission: Bauer, R. A., De Sola Pool, I., \& Dexter, L. A. (1972). American business \& public policy: the politics of foreign trade (2 ed.). Chicago: Aldine-Atherton, pp. 30-39, 50, 375-387. McCloy also was the former High Commissioner of Bizonia. John Coleman of the Burroughs Corporation was a representative for the automotive industry, concentrated in Detroit, among which the Ford Motor Company. See pp. 251-264.

${ }^{313} \mathrm{NL}-\mathrm{HaNA}$, Bilderberg Conferenties, 2.19.045, inv. nr. 1, Memorandum On American Attitudes Towards Relations with Europe, December 1953, pp. 5, 10-12.
} 
May 1954. In contrast to the urgency that the Americans had attached to the European market in their report on anti-American attitudes, during this meeting they explained that they felt that the European market could wait. George Ball explained "that progress towards political unification was more important than towards economic unification." He was referring to the European Defence Community and the European Political Community that were hanging in the balance at that time. ${ }^{314}$

Moreover, the European and American members alike agreed that the economic problems that were identified in the initial reports were no longer as pressing. They observed that as a consequence of the Korean conflict, war dollars were now pouring into Europe for the sake of rearmament. Moreover, President Eisenhower had managed to realize a reduction of American tariffs. As a result of these developments the Bilderberg participants concluded that the dollar-gap was, at least for now, closed. In addition, during the meeting the efforts by the Committee for a National Trade Policy in support of tariff reduction were explicitly acknowledged. According to Pierre de Bonvoisin, a member of the Belgian section of the ELEC, and also the President of Société Générale de Banque, admired their "courage to go against their own public opinion at home in recommending a lowering of tariffs", adding that it was "evidence of new industrial thinking" in the United States. Meanwhile, the American members repeated their hope that Europe would find a way to unify in one way or another, possibly by means of a federation. According to them the past 100 years had proven that Europe required a new model for its relations. Moreover, in light of the uncertain ratification of the EDC they stressed that "European Union is probably Europe's best weapon against Communism." 315

The next Bilderberg Conference in March 1955 took place in Barbizon (France), and was entirely devoted to Western security in relation to the Soviet Union, more specifically the neutrality of several European countries in the Cold War and infiltration methods of the Communists in Western countries. Matters of European integration were not discussed. However, in September 1955 another Bilderberg meeting was organized in Garmisch-Partenkirchen that did discuss the European market. ${ }^{316}$

\section{A web of high authorities}

Different than in the previous meetings, at Garmisch-Partenkirchen the European market was mainly discussed among European members of the group. The agenda

\footnotetext{
314 Ibidem. p. 47. NL-HaNA, Bilderberg Conferenties, 2.19.045, inv. nr. 3, Bilderberg Summary 6th meeting p. 1, inv. nr. 3, Bilderberg Summary 031, p. 5.

315 NL-HaNA, Bilderberg Conferenties, 2.19.045, inv. nr. 3, Bilderberg Summary m30, p. 12. \& Report Bilderberg Conference May 29th-31st, 1954, p. 37. Bilderberg conference, May 29th-31st, 1954 (1954). Sl.: sn., pp. 46-48.

316 Conférence de Barbizon, 18-20 mars 1955 (1955). Sl.: sn., p. 8. Groupe de Bilderberg (1955). Conférence de Garmisch-Partenkirchen, 23-25 septembre, 1955. Sl.: Groupe de Bilderberg.
} 
featured the topic "European Unity" without further specification, but market integration was the key problem at hand. The meeting was taking place shortly after the start of the European Intergovernmental Committee headed by Paul-Henri Spaak, which was studying the options for Western European economic integration. This added a special relevance to the subject. ${ }^{317}$

Central to the topic was the question of which goal a unified European market should serve and which method of integration best fitted this goal. The theme was introduced by Guy Mollet, the French leader of the socialist party SFIO. In his view the European market should in the first place address the potential scenario of a "reawakening of Germany", which he still felt capable of overpowering France in the future. He stressed that Germany was not won for the West yet, despite its participation in the European Coal and Steel Community and despite its in May 1955 realized membership of NATO. Mollet felt that the Federal Republic of Germany might shift its foreign policies closer to those of the Soviet Union if it would be offered a deal that would make unification with East-Germany possible. To reduce this possibility, Mollet suggested a strategy to lock in Germany, similar to what was attempted with the proposal for the Schuman Plan or the Pleven Plan. ${ }^{318}$

His plan involved a proliferation of sectoral supranational institutions or the expansion of the High Authority to other sectors. According to Mollet, a Common Market could "only be an organized market" in which "necessary powers must be put at the disposal of a common Authority." In his view the High Authority of the Coal and Steel Community had proven that such an institution was necessary and effective, implying that the institutions that would administrate a Common Market would be endowed with similar powers. According to Mollet, an organized European economy was necessary because of France's continuing weakness in dealing with international competition. An intervening High Authority would have the tools of intervention to mitigate the worst effects. Moreover, Mollet felt that there was a limited window for realising a Common Market: he explained that he was observing an increasing reluctance of German industry to unite, "flushed by success and afraid of being tied to the apron-strings of a European system." Mollet further indicated that the six member states of the ECSC, should be the basis of any plan for integration. He felt that they could later strive for the association of other countries, such as the United Kingdom. In his view the participation of the United Kingdom posed too much risk for everything that had already been achieved. Mollet's course was clear: "I am a convinced supporter of the system of "special-

\footnotetext{
317 In addition to "European Unity" and "Reunification of Germany", the following subjects were on the agenda: NATO's non-military development, NATO's nuclear strategy, industrial uses of atomic energy and international trade. Report Conference de Garmisch-Partenkirchen, September 23th-25th, 1955, p. 8.

318 NL-HaNA, Bilderberg Conferenties, 2.19.045, inv. nr. 7, Paper for the Bilderberg Conference Garmisch-Partenkirchen, 23-25 September 1955, Guy Mollet, “The Unification of Europe”, p. 3.
} 
ized Authorities," of "integration by sector", with the underlying goal of binding Germany to the same rules and supranational powers of intervention as France. ${ }^{319}$

This design was unacceptable to several European businessmen. They were very aware that Mollet's proposals represented a multiplication of High Authorities, that, in line with the associated interventionist economic philosophy, would potentially curtail the freedom of enterprise to achieve its goals. The Dutch Paul Rijkens, president of the British-Dutch Unilever, shortly replied being in favour of the Common Market approach as opposed to an institutional setup of specialised communities "because it offers less difficulties." Fritz Berg, the President of the Bundesverband der Deutschen Industrie first defused Mollet's fears concerning any reluctance in German industry to integrate further, but then quickly continued by strongly agreeing with Rijkens. According to Berg an extension of the High Authority, which involved placing more sectors under its control, was not the right course of action. In response to Mollet's concerns about France's competitiveness in international trade, Berg stated that instead of intervening on a sectoral level he preferred to reduce the differences between countries through duties or tax agreements. 320

Louis Camu, a member of the ELEC and President of Banque Bruxelles, believed that a unified market would psychologically be much more important than an extension of the ECSC or the creation of any other institution. He was sure that enlarged markets and options for the rationalization of production would be much more effective. As an alternative to Mollet's proposals he gave an exposé of the ideas that in fact stemmed from the ELEC brochure on the Common Market. Claiming that they had recently presented their report before the Spaak Committee, suggesting "a demobilization of customs through a convention or a treaty between states." Moreover, Camu explicitly denied the requirement for a High Authority. He was convinced that the "Marché Commun", the Common Market, would allow for a much easier inclusion of the United Kingdom at a later stage.321

The Americans George Ball and Paul Hoffman sided with the European industrialists. Ball, still an internationally operating corporate lawyer, attempted to impress upon Mollet that "conditions of competition of the most active kind" would be necessary for raising the standard of living, something which a managed market might miss. Paul Hoffman, the former ECA administrator and at that point active in the automotive industry, advised him to "leave out the ideologies and just stick to straight commercial business and try to see you get more and more goods exchanged." According to him the European debate on the planned economy versus a

\footnotetext{
319 Ibidem, pp. 3-4, 6. Underlining in the original.

${ }^{320}$ NL-HaNA, Bilderberg Conferenties, 2.19.045, inv. nr. 9, Garmisch-Partenkirchen Transcript English IV, pp. 22, 49 .

${ }^{321}$ Translation of: "une démobilisation douanière par l'intermédiaire d'une convention ou d'un traité entre les différents Etats." From the text it becomes clear that Camu used the term "Messina conference" to refer to the Spaak Committee, starting its work in July 1955 until April 1956. NL-HaNA, Bilderberg Conferenties, 2.19.045, inv. nr. 9, Garmisch-Partenkirchen Transcript, French IV, pp. 35-38.
} 
liberal economy would stifle trade instead of forward it. The industrialists and Ball and Hoffman were primarily concerned with the biggest possible growth results and entirely disregarded the political intentions behind Mollet's method, namely to bind Germany to the West. ${ }^{322}$

Within the Bilderberg meetings there was no question about the need for liberalizing trade. Even though Mollet indicated that France required a mechanism to temporarily reduce the impact of a Common Market, he did not wish to forego liberalization. Instead, the method of integration was a main concern. Regarding the method, European but also American businessmen knew very well what Mollet's plans had in store for them. The High Authority of the ECSC had been too unpredictable, and a multitude of High Authorities might turn out to be even worse. Remarkably, Mollet's denunciation of the United Kingdom's participation in a Common Market appeared to be hardly controversial, not even among businessmen such as Rijkens, president of Unilever, a company whose two seats of management were placed on both sides of the Channel. Nobody appeared to be worried if the United Kingdom would join or not.

The Bilderberg conferences in 1956 and early 1957 were not at all concerned with the European market or European integration. The Fredensborg conference, held from the $11^{\text {th }}$ until the $13^{\text {th }}$ of May in 1956 was entirely devoted to discussions on the Western attitude to Asia. The conference of St. Simons Island held from the $15^{\text {th }}$ until the $17^{\text {th }}$ of February in 1957 focussed on the state of the Western Alliance, its security policies towards Europe, and the Middle East. However the Bilderberg conference that followed in October 1957, six months after the signing of the Rome Treaties, did discuss the European market. 323

The meeting foreshadowed a more critical atmosphere between the European and American groups. As part of a general review of developments in the West, members of the American section of the Bilderberg meetings suddenly expressed their concerns about the position of the Common Market in international trade. They claimed to be satisfied that the EEC now was a fact. But the treaty establishing the European Economic Community had left many aspects for later specification, among which the level of the common external tariff. This was not at all appreciated by the American group and they made it clear that postponement should not lead to the formation of a "self-centred economic bloc." They warned that the US would respond through protectionist measures if Western Europe would use the Common Market as an instrument for protectionism. ${ }^{324}$

\footnotetext{
322 Paul Hoffman presided over the Studebaker Company, in the automotive sector. NL-HaNA, Bilderberg Conferenties, 2.19.045, inv. nr. 9, Garmisch-Partenkirchen Transcript English IV, pp. 46, 58.

323 Groupe de Bilderberg (1956). Conférence de Fredensborch, 11-13 mai, 1956. Sl. Groupe de Bilderberg, p. 8. Bilderberg Group (1957). St. Simons Island conference, 13-17 February, 1957. Sl. Bilderberg Group, pp. 7-8.

${ }^{324}$ NL-HaNA, Bilderberg Conferenties, 2.19.045, inv. nr.12, Preliminary Report Fiuggi Conference October 4-6, 1957, p. 7.
} 
On behalf of American exporting corporations, present in the form of members of the Committee for an Economic Trade Policy, the American group explained that they doubted the Common Market's ability to increase trade between the United States and Western Europe. Instead they believed that Europe's industries would concentrate, while simultaneously penetrating the US market. They felt that this dynamic would decrease opportunities for American firms on both sides of the Atlantic. This left them no choice but to buy participations in European businesses in order to increase their ability to compete in Europe. The Americans thus demanded a liberal common external tariff to maintain their existing export position. 325

The Europeans from the Community member states tried to dispel American fears. They assumed that European imports would grow along with intraEuropean trade. Moreover the Europeans wishfully stressed that "the Free Trade Area would be the next step in the process of European economic integration." 326

\section{Mending the Schism}

However, during the Bilderberg meeting in 1958 even the European group was not certain anymore whether further liberalization of the European market was assured. As has been mentioned before, developments between the Common Market member states and the other West-European countries truly brought out the divisive nature of the path to integration that was chosen by the governments of the Benelux, France, Germany and Italy. The Six, as they were called, had shown that they were willing to form a trade bloc against other West European countries in order to secure their own objectives in trade. In the long run these developments appeared to be at odds with the interests of European corporations who had a European market in mind that went beyond merely the Six. ${ }^{327}$

As an alternative to the Common Market for the Benelux, France, Germany and Italy, in June 1956 the United Kingdom introduced a proposal for the creation of a free trade area for the entire OEEC. The proposal was only seriously discussed after the signing of the Rome Treaties. It suggested a free trade area placed on top

\footnotetext{
325 Ibidem. Participating American export interests were George Ball (Committee for an Economic Trade Policy), John D. Ferguson (Cleary, Gottlieb, Friendly, Steen \& Hamilton, a corporate international lawfirm), H. J. Heinz (H. J. Heinz Co.), Paul Hoffman (Studebaker-Packard Co.), David Rockefeller (Chase Manhattan Bank) and J. D. Zellerbach (Crown Zellerbach Corporation). The prophetic quality of this analysis hardly needs clarification: American private investments in Europe would indeed increase to such an extent during the 1960s that in some parts of Europe the fear for an American takeover surfaced. See Chapter 5.

326 Ibidem, p. 8. European representatives of multinationals present were: Belgium: Pierre de Bonvoisin (Banque de la Société Générale de Belgique). Germany: Rudolf Mueller (Corporate Lawyer), Italy: Alberto Pirelli (Pirelli), Giovanni Agnelli (Fiat). Netherlands: Paul Rijkens (Unilever). Obviously not a leader or representative of a multinational was Fritz Berg (Bund Deutschen Industrie), but he was still relevant to these discussions.
}

327 Dinan (2004). Europe recast, pp. 66-79, 97-102. 
of the Common Market structure. Since March 1957 the plan was under serious consideration by the European governments represented in the OEEC. ${ }^{328}$

However, during 1958 problems arose because of the complexities that were involved in combining the Common Market and its special policies with the free trade area. Particularly the governments of France and the United Kingdom were at odds with each other. The French were unwilling to give in to concessions that they had secured in the Rome Treaties, such as the common agricultural policy, the harmonization of social policies, investments in their overseas areas and the European Atomic Energy Community. Moreover the United Kingdom had resisted every suggestion of supranationalism in international treaties over the past eight years and it was unlikely that it would accept French ideas now. By September 1958, when the next Bilderberg meeting took place, the negotiations were stalled. ${ }^{329}$

The Bilderberg meeting paid close attention to the stalled negotiations. An unusual number of leaders of European business had joined the meeting, even including Swedish, Norwegian and British firms and several members from ELEC. The possibility that no agreement would be reached between France and the rest of the OEEC, worried all members. The group as a whole was especially concerned about the possibility of a schism in trade between the EEC and the rest of Western Europe. If negotiations would fail, they all expected the creation of another trade bloc by Austria, Denmark, Norway, Portugal, Switzerland, Sweden and the United Kingdom, dubbed "the Seven". All agreed that a solution should be found to prevent the undesired long-term effect of trade displacement. $330 / 331$

Even Antoine Pinay, a former French Prime Minister, the economist Jacques Rueff, advisor to the since that summer Prime Minister of France, General de Gaulle, and national banker Wilfrid Baumgartner were in favour of finding a way around the emergence of a second European trade bloc. However, they warned that the French government would not be prepared to renegotiate the Rome Treaties. Little

\footnotetext{
328 Ibidem.

329 Ibidem.

${ }^{330}$ Belgium: Paul van Zeeland (Launoit Group, Banque de Bruxelles), Louis Camu (Launoit Group, Banque de Bruxelles), Germany: Rudolf Mueller (Corporate Lawyer), Otto Wolff von Amerongen (Otto Wolff), Fritz Berg (Bund Deutschen Industrie), Hermann J. Abs (Deutsche Bank), Berthold Beitz (Krupp), Hans C. Boden (AEG). Italy: Alberto Pirelli (Pirelli), Giovanni Agnelli (Fiat). The Netherlands: Paul Rijkens (Unilever), P.F.S. Otten (Philips). Norway: Leif Hoegh (Shipping industry). Sweden: Marcus Wallenberg (Enskilda Banken), Erik Boheman (Enskilda Banken) United Kingdom: Edward BeddingtonBehrens of the ELEC, J.L.S. Steel (Imperial Chemical Industries), Victor Cavendish-Bentinck (Unilever) and Henry Tiarks (Schröders Bank).

331 The following ten men from ELEC were participating in the meeting. Hermans Josef Abs (Deutsche Bank), Edward Beddington-Behrens (British industrialist), Henry Tiarks (Schröders Bank), P. A. Blaisse (Dutch Parliamentarian). Louis Camu (Banque Bruxelles), Roger Motz (Belgian Liberal Party) Paul Rijkens (Unilever), J.L.S. Steel (Imperial Chemical Industries).
} 
could be added during the meeting and it would have mattered little: in November 1958 Charles de Gaulle decided to end the negotiations in the OEEC. 332

De Gaulle's decision struck a nerve within the Bilderberg group. The Executive Committee quickly arranged a Greater Steering Committee meeting on the $18^{\text {th }}$ of January 1959 to see if any room for manoeuvring still existed for the creation of a free trade area. The meeting took place in an atmosphere of frustration: Ernst van der Beugel who in 1958 had resigned as the Dutch Deputy Minister for European Affairs and had recently become the President of the Koninklijke Luchtvaart Maatschappij (KLM) opened the meeting with an angry statement. He felt that a community "cannot stand a continuous major influence of the economic conception of one of its members", meaning the French, their protectionist tendencies and their unwillingness to compromise. The Dutch clearly preferred the solution of a free trade area instead of witnessing the first Common Market's external tariff increase vis-à-vis the rest of Europe, only 17 days earlier. ${ }^{333}$

Despite the generally shared frustration among the members, the meeting was characterized by a search for pragmatic solutions to the possible diversion of internal European trade. The group that was gathered would certainly have secured a positive outcome if any room for agreement had existed. They included several decision-makers or those who were expected to know what their governments would agree to. These were the German Alfred Mueller-Armack, the Deputy minister on European Affairs, Reginald Maudling, president of the British Board of Trade, Hubert Ansiaux, the Belgian National Banker, the Italian Ambassador Pietro Quaroni and the recently resigned Dutch Deputy Minister on European Affairs, Ernst van der Beugel. Apart from France, the member-states of the Common Market were well represented. Additionally Raymond Aron, the French liberal philosopher was treated as a go-between for the French government. ${ }^{334}$

The meeting mainly discussed a workable proposal from Fritz Berg of the Bund der Deutschen Industrie. The proposal suggested a minimum-agreement between the Six and the Seven on crucial tariffs where "deflections of trade and diversions of productive capacity are feared." He suggested to abolish tariffs for products that for $90 \%$ or more were produced within the proposed free trade area. He explained that the coverage percentage could gradually be lowered as time would pass and sentiments changed. Especially the industrialists responded enthusiastically: Alberto Pirelli, of Pirelli \& Cie, Paul Rijkens of Unilever, Louis Camu of

\footnotetext{
332 The conference further focussed on the future of Atlantic defence, the Western attitude to Soviet Russia, NL-HaNA, Bilderberg Conferenties, 2.19.045, inv. nr. 13, Groupe de Bilderberg (1958). Conférence de Buxton, 13-15 septembre, 1958. Sl.: Groupe de Bilderberg, pp. 21-23.

333 During the Steering Committee meeting of March 1957 it was decided to use one Steering Committee meeting per year for "more exhaustive studies of various problems", calling it Greater Steering Committee meetings. NL-HaNA, Bilderberg Conferenties, 2.19.045, inv. nr. 41, Steering Committee minutes 1703-1957.

334 NL-HaNA, Bilderberg Conferenties, 2.19.045, inv. nr. 17, Greater Steering Committee 17-18 January 1959, no page nr's., intervention John Ferguson (Cleary, Gottlieb, Friendly \& Ball).
} 
Banque de Bruxelles and the Swiss Walter Boveri of Brown Boveri \& Cie. were all very much in favour. Reginald Maudling even suggested to collectively agree to it, implying that he was witnessing a workable agreement in the making. ${ }^{335}$

However, the Americans H. J. Heinz (H. J. Heinz \& Co.) and George Ball criticized the plan from the perspective of GATT rules. Moreover, Raymond Aron, who was solitarily fending of an atmosphere of reproach directed towards him, made clear that France could only agree to such a proposal if they would have the same guarantees as they had in the Common Market. Clearly the Bilderberg meetings could not add much to this situation. ${ }^{336}$

That is not to say that the Bilderberg would not try again. This was the sole exception to the statement that the Bilderberg meetings were not involved in exerting external influence. At the Bilderberg conference in September 1959 in Yesilkoy, the group tried to bring the French and British governments closer together by arranging a meeting between the European Secretary of the Bilderberg group, Ernst van der Beugel, the economic advisor of President de Gaulle, Jacquess Rueff, and Frederic Bennet, a deputy to Maudling, the President of the British Board of Trade. The meeting resulted in a disappointment however. Ernst van der Beugel's report on the meeting to the Dutch Ministry of Foreign Affairs stated that "the rift between France and England is frighteningly deep", with on the one hand Macmillan who was convinced that France intended to keep the United Kingdom out of European affairs, and on the other hand a suspicious French government that was certain of British intentions to wreck the Common Market. They concluded that only a high level meeting, perhaps initiated by Eisenhower, could restart developments. Nothing of the sort was undertaken. Only two months after the Bilderberg meeting, the United Kingdom, together with Austria, Denmark, Norway, Portugal, Sweden and Switzerland signed the treaty establishing the EFTA trade bloc. ${ }^{337}$

However, in June 1961 the British government announced that it was open to negotiations on the terms of EEC membership. The Bilderberg members remained worried nevertheless. The Bilderberg meeting of May 1962 tried to gauge the likelihood of failure of the UK-EEC negotiations, and more importantly, what failure would mean? The large majority of participants felt that a breakdown in negotiations would have "disastrous consequences": it threatened to damage what had already been achieved in terms of European integration. Moreover, several thought that the momentum in Western liberalization of trade might be lost. The Kennedy administration (January 1961 - November 1963) had only recently started to pursue a proposal for lowering tariffs between the United States and the European

\footnotetext{
335 Ibidem.

336 Ibidem, no page nr's. Both warned that if no free trade area or a Customs Union could be established within a reasonable period of time among the countries in question, agreements as suggested by Fritz Berg would not be admitted by GATT rules.

${ }_{337}$ Nationaal Archief, Den Haag, Ministerie van Buitenlandse Zaken: Code-archief 1955-1964, nr. 2.05.118, inv. nr. 1872, Inlichtingen betreffende de bijeenkomsten van de zogenaamde Bilderberggroep, Letter E. H. van der Beugel to Mr. S. J. Baron van Tuyll van Serooskerken, 25-09-1959.
} 
Community. As was pointed out at the meeting, approval by the American Congress would at least require a reason to believe that Western Europe would remain committed to liberalization. . $^{338}$

The fears for failure appeared to be entirely justified. De Gaulle's veto against British accession to the EEC in January 1963, caused strong disappointment at the Bilderberg meeting in May that year, particularly among the Americans. Congress had granted the Kennedy administration its requested mandate to drastically reduce American tariffs for the European Community, and even remove tariffs entirely on those products that represented $80 \%$ or more of total "free world" exports, as they were called by the Bilderberg American group. This was called the Trade Expansion Act. As several Americans explained, now that the United Kingdom would not become a member of the EEC the mandate was an empty shell with only a few products fitting the prescription. ${ }^{339}$

The Americans now even began doubting the Community's continuing willingness for liberalization, as they called attention to the European keenness to prevent "competition from powerful, aggressive American firms." Moreover, they complained that the strategy of solidifying the West in economic terms was compromised, particularly in light of the Communist challenge. The French participants to the conference confirmed that the size of American firms, but also American governmental aid to corporations via product-orders were standing in the way of far-reaching trade liberalization. Indeed, as was feared the momentum of liberalization appeared to slacken. The Bilderberg commitment to the liberalization drive of the 1950s was no longer evident. The meeting of 1963 marked a shift in themes: a basic consensus about the post-war world order was lost. Subjects with regard to Western trade would instead start to focus on what divided the Americans and Europeans, such as trade with Eastern Europe or the wave of investments by American multinationals. These subjects will be explored in the following chapter. ${ }^{340}$

The Bilderberg meetings' efforts with regard to preventing a European trade schism showed the commitment of industrialists on both sides of the Atlantic to integrate the Common Market with British trade and the larger OEEC area. They particularly wanted to retain the existing trade relations. Moreover, in this case the Bilderberg meetings served as a method for bringing together diverging European standpoints, albeit an unsuccessful one.

\footnotetext{
338 Bilderberg Meetings (1962). Saltsjöbaden conference, 18-20 May, 1962. Sl.: Bilderberg Meetings, pp. 38-39.

${ }^{339}$ RWWK, NOWA, inv. nr. 72-374-2, Bilderberg Meetings (1963). Cannes conference, 29-31 May, 1963. Sl.: Bilderberg Meetings, pp. 27-30. Wee, H. van der (1987). Prosperity and upheaval. The world economy, 1945-1989. Harmondsworth: Penguin Books, pp. 382-387.

${ }^{340}$ RWWK, NOWA, inv. nr. 72-374-2, Bilderberg Meetings (1963). Cannes conference, 29-31 May, 1963. Sl.: Bilderberg Meetings, pp. 32-33. The twelve French participants were Maurice Faure, Guy Mollet, Antoine Pinay, Jacques Piette, Wilfried Baumgartner, Guillaume Guindey, Jacques Baumel, Pierre Uri, André Fontaine, René Massigli, René Pleven and René Sergent.
} 
A summary of the role of representatives of multinationals and companies with a multinational outlook in the Bilderberg meetings results in the following. From the early 1950s onwards a general agreement could be noted regarding the liberalization of trade between Western Europe and the United States. After the French parliament's failure to ratify the European Defence Community in August 1954, a first sign of a conviction of the need for a European Common Market emerged. Corporations in the Bilderberg meetings at the same time resisted the idea of a Common Market that would be organized by several supranational institutions with powers of intervention. Initially, doubts whether the United Kingdom would or should join the Common Market were not addressed. However, after the signing of the Rome Treaties in early 1957, attention shifted to the United Kingdom government's proposal for a European free trade area. Representatives of European corporations in the Bilderberg meetings were strongly in favour of the realization of a European free trade area and were worried about the potential for trade diversion between the Common Market and a possible second European trade bloc if the OEEC free trade area would fail to come about. The resistance against intraEuropean trade diversion and the fear of loosing the momentum of post-war trade liberalization further motivated their support for the United Kingdom's accession to the Common Market.

\section{Conclusion}

The main question of this investigation is focussed on learning the views of multinationals on the European market. The main methodological device for answering this question is formed by the networks in question. When we compare European League for Economic Cooperation and the Bilderberg meetings are compared it becomes clear that they approached the idea of a European market in entirely different ways which shapes the interpretation of the multinational's views. The ELEC started from a shared desire for a European economic union. While that union may have meant different things to different members, the motive of closer economic integration was shared by all. Other than the Bilderberg meetings ELEC worked towards that goal through national groups. The League's organization structure in fact mimicked negotiations between governments: each section had their set of demands, or specific requirements, on the one hand determined by knowledge about what their national government could go along with, and on the other hand by their own interests based on their national context. The negotiation process was slow but the practice of seemingly preparatory negotiations for real negotiations between nation states led to useful results vis-à-vis decision-makers.

The Bilderberg meetings had a different aim: transatlantic cooperation. The main motive within the Bilderberg meetings was not European integration but the transatlantic security agenda. The theme of economic integration as such was 
submerged in a much larger conception of transatlantic cooperation, anchored in shared security goals and a mutually beneficial international system of economic exchange that required productive and politically stable units. While indeed European market integration was discussed at several moments it was not a priority for discussions between Americans and Europeans. If debated with Americans, the theme of the European market was, by Europeans and Americans alike, instantly transformed to issues on balances of payments and demands for liberalized trade. Therefore, the most interesting examples of debate about the formation of a European market were those held between Europeans, with an incidental American as commentator. In fact, the Bilderberg meetings developed as an ad hoc platform for Europeans to discuss possible solutions for trade diversion between the Common Market and the United Kingdom largely amongst themselves. Besides the ELEC, which focussed on the technical aspects of this problem, not many other forums for discussions on such themes existed.

The main focus of this investigation is about the views of multinationals on the European market and how possible differences in views can be explained. The debates both in ELEC and the Bilderberg group show that most multinationals favoured the liberalization of intra-European trade. However among French corporations a clear preference for protectionism predominated. Regarding the question of the organization of the European market, all corporations resisted the introduction of interventionist supranational institutions, even the French corporations who were originally accustomed to technocratic intervention. A multiplication of High Authorities, each intervening in their respective industries was very undesirable to them. Most multinationals also opposed a sectoral approach to economic integration. Instead there was a general preference for treaty-based integration that involved the removal of tariffs and quotas through fixed, predictable steps for all sectors simultaneously. The French corporations however again had a specific preference in this regard. Despite their apprehension about several sectoral supranational institutions and acceptance of integration for all sectors simultaneously, French corporations felt that European sectors should negotiate amongst themselves in order to arrive at agreements on how the main national disparities could be addressed. French business was trapped between the rejection of supranational interventionism and the need for protectionism. Instead of organizing the European market through interventionist supranational institutions ultimately all subscribed to the mechanism of competition as organizing principle, to clearly retain a basic freedom of entrepreneurship vis-à-vis European institutions. Lastly, a general point can be made about the preference of European multinationals for the most largest market as possible. This was particularly expressed in the efforts to creating favourable conditions for the United Kingdom to associate itself with the Community or join integration plans.

How can these views be explained? The overall accepted view of liberalizing trade on the European market can be understood by considering international 
political and economic circumstances. The aftermath of the Great Depression, the run up to WWII and the war itself had resulted in a widespread protectionist organization of European markets in which international trade was minimized to the benefit of an autarkic organization of national markets. After WWII, under leadership of the United States, a debate was sparked among Western European governments on the liberalization and integration of European markets which characterized the entire 1950s. At the same time the organization of international markets through business-led cartels was severely undermined by American anti-trust campaigns, requiring a new approach to international competition. At the same time, companies were presented with the prospect of more opportunities for larger sales. Moreover, as was introduced in chapters 1 and 3, for multinationals with multiple subsidiaries across Europe, liberalization offered an opportunity for scale advantages. A large market made it possible to rationalize the dispersed production structure. This is consistent with the strong preferences for liberalization of the Dutch and Belgian multinationals and industrial holdings that were discussed in this chapter.

As became clear, corporations however held different views, even with regard to liberalization which was supported by most. To a very large extent these differences can be explained by national contexts. The continuous attempts of French industry to include forms of protectionism such as delays in liberalization of trade for France or tailored private agreements between sectors can be understood as a result of the dominant national view of lacking international competitiveness in domestic industries, and a relatively more costly national social system than the rest of Western Europe. French industry drew the same conclusions as the French government: transitional protectionist measures were needed to give firms the time to adjust to a more competitive business environment. Within the large groups of multinationals that did favour liberalization several options were considered: a customs union, a Common Market, a free trade area or sectoral integration by means of High Authority-like institutions. The Dutch multinationals were ultimately prepared to accept each of these options as long as this would yield results. To make liberalization more acceptable to the French and Italians they were moreover prepared to suggest several compensatory mechanisms. As the French, the Dutch corporations also remained very close to the interests of their governments. The same is true for the Belgian multinationals which just after the failure of the EDC shifted from a preference for a customs union to a free trade area, just as their government did. German corporations were the least outspoken until a stand had to be taken. They opted for a free trade area, a decision that fitted the national structure of their international trade very well ánd also remained very close to the assessment of their government. Corporations located in the United Kingdom were not represented in the ELEC, except via the Dutch section; Unilever, which also was well represented in the Bilderberg meetings. Except for Unilever, no other firms expressed concrete views, though it became clear in the section on 
the Bilderberg meetings that they too were worried about a schism in European trade.

Another key question in this research is whether views of multinationals can be explained through sector-based contexts? In contrast to our findings in later chapters, these played a minor role in relation to the negotiations on the Schuman Plan. The ELEC assembled expertise from representatives of the coal and steel sectors. They proposed a sectoral solution for the national problems of the Belgian coal industry suggesting the closure of inefficient European coal mines, to be compensated by the sector as a whole. However this proposal did not originate from a competitive aspect of the European coal and steel industries vis-á-vis competing non-European coal and steel industries. Instead the proposal was an expression of the wish to exclude the High Authority from restructuring processes.

Turning to the role of business in European integration historiography, it becomes clear that the generally followed approach by authors such as Gillingham (1991), Milward (1992) or Moguen-Toursel (2002) to interpret the preferences of European industry and business during the 1950s through a national perspective is the most useful. Multinationals perceived European integration through the perspective of their own home markets and the conditions under which they had been forced to adapt their organizations and the specific competitive qualities which they developed under those circumstances. They wanted the European market to be organized accordingly. This was furthermore expressed through their support for the positions of their national governments in negotiation processes on treaties. ${ }^{341}$

Lastly the question arises whether these activities of European multinationals are better understood through conceptualizing them as active lobbies on developments in European integration or as expressions of uncertainty reduction, as proposed by Rollings and Moguen-Toursel? A mixed conclusion can be drawn. Whereas the entire organization of the ELEC was structured to generate representativeness and influence, it certainly also functioned as a source of information on new developments. The Bilderberg meetings however were not aimed at exerting any form of external influence on decision-making. It facilitated a way of learning about views of others and assessing new developments and how serious they might turn out to be. Reduction of uncertainty was likely to be a result of debate among highly informed professionals. Formal intentions with regard to Transatlantic mutual understanding aside, the Bilderberg meetings primarily functioned as a barometer on the state of the Transatlantic consensus. The fact that a group of people met did

\footnotetext{
${ }^{341}$ Gillingham (1991). Coal, steel; Milward (1992). The European rescue; Moguen-Toursel, M. (2002). L'ouverture des frontières européennes dans les années 50 : fruit d'un concertation avec les industriels? Bruxelles: P.I.E. Lang.
} 
not mean that they had the same convictions or would be prepared to adopt convictions of others. ${ }^{342}$

On a whole, European multinationals in the ELEC and the Bilderberg meetings, save the French which required temporary transitional measures, were in favour of an as large as possible, liberalized market without interventionist, supranational institutions. The Common Market largely was a realization of these views. In the next chapter we will see whether the liberalized European market indeed turned out to be a favourable development.

342 Rollings, N. \& Moguen-Toursel, M. (2012). European organised business and European integration in the post-Second World War period. Jahrbuch für Wirtschaftsgeschichte, 53, 103-123. 



\section{Chapter 5}

\section{Facing challenges from the West and the East, 1960-1970}

\section{Introduction}

In the previous chapter the actions of Western European companies have been discussed in relation to European integration during the 1950s. In the 1960s however, circumstances changed. The removal of quotas and tariffs that was initialized so successfully during the 1950s lost its impetus. Disagreement among Western European governments undermined further plans for integration. Expansion of the EEC and the introduction of new integration schemes ceased to dominate political discourse. Besides the completion of the Common Market's tariff structure and the common agricultural policy, little was achieved

At the same time, European companies were confronted with collective problems that required solutions by different means than a reduction of tariffs. During the 1960s, large and technologically advanced corporations from the United States increasingly directed their investments towards Western Europe. As a result, Western European companies were threatened by increased competition. Moreover, competition on the Western European markets was paralleled by a breakdown of Western consensus on the provision of export credits for trade with Eastern European states. Through their involvement in the European League for Economic Cooperation and the Bilderberg meetings European companies responded to these problems and used these networks to address their worries.

The present chapter investigates whether these appeals represented a new approach towards the organization of the EEC and its place in the wider Western European market and international trade relations. It will be argued that the combination of a blocked agenda with regard to liberalization and European integration, the effects of American investments in Western Europe, and the slipping consensus on credit extensions to the East-bloc, forced European corporations to take a stand on how the European governments and the European Commission were dealing with issues in the sphere of EEC external trade. As a result, this chapter also explores to what extent European companies could actually turn to the European Commission for addressing such EEC-transcending problems that affected all of Western Europe. Finally, this chapter analyses to what extent the responses of 
European companies differed. Special attention is being paid to national contexts, and to differences between industrial sectors.

\section{European and transatlantic tensions}

During the 1960s Western European and transatlantic relations were characterised by a weakening consensus on liberalization and integration. The European League for Economic Cooperation and the Bilderberg meetings adjusted the scope of their activities accordingly. Changes in Western political relations undermined ideas that were so successfully pursued during the 1950s. An important reason for that change lies in the politics of the French President Charles de Gaulle who in 1958 unexpectedly re-entered the arena of active politics after his retirement in 1953. Following the mutiny of the French army against orders to give up the colony of Algeria, de Gaulle was given a mandate to lead the country and draft a new constitution. He became President in late 1958 and stayed on until 1969.343

Under the new constitution the position of President granted de Gaulle full authority in foreign affairs and defence. He believed in the importance of the nation-state and he rejected France's involvement in supranational institutions within the European Community. Nevertheless he accepted the EEC and Euratom and their supranational institutional organization because they represented a means to reach important national goals, such as a European policy on agriculture. Still, over the next years he antagonized the rest of the EEC member states. De Gaulle blocked new and far-reaching initiatives of European economic integration by ending negotiations on the European Free Trade Zone in late 1958 and he refused to allow British accession to the Common Market during his Presidency until 1969. Moreover, in July 1965 de Gaulle de facto immobilized Community decision-making by suspending French participation in the Council of Ministers for three months to force through a suspension of qualified majority voting on agricultural and trade issues. In January 1966 the member states agreed to continue the Council's decision-making on the basis of unanimity. This became known as the Luxembourg Compromise. ${ }^{344}$

Instead of trying to advance European integration via the supranational European Commission, de Gaulle pursued a different route. He introduced the so-called Fouchet-plan on Political Union. The Fouchet plan proposed to superimpose a new intergovernmental structure for Community decision-making on the existing institutions of the European Communities. Through increased cooperation in foreign affairs, defence and economic policy he intended to re-establish a European inde-

\footnotetext{
343 Palmer, R. R. \& Colton, J. (1995). A history of the modern world. New York: McGraw-Hill, pp. 889-891. 344 Dinan, D. (2004). Europe recast: a history of European Union. Basingstoke: Palgrave Macmillan, pp. 83-84, 94-96, 102-108; Kuisel, R. F. (1993). Seducing the French. The dilemma of Americanization. Berkeley. University of California Press, pp. 138-139.
} 
pendent role in international politics under French leadership and strove for equal roles for Western Europe and the United States in NATO. Community negotiations on how such a structure would work started in September 1960.345

By pursuing the Fouchet plan, de Gaulle consciously opposed the United States. His plan was at odds with an American proposal to bring the European Community into a Transatlantic partnership. In August 1961 the Kennedy administration proposed to organize equal economic and military relations between an enlarged EEC and the United States, though under American political leadership. Furthermore, the American government had economic goals in mind. In order to exploit the technological lead of American over European companies, Kennedy wanted to lower tariffs between the EEC and the US market. In 1962 Kennedy asked Congress for the Trade Expansion Act, which gave the President the mandate for cutting tariffs substantially and even to completely abolish tariffs on products of which USEEC trade represented 80 per cent of the worldwide total. However, only few products would fall in this category if the United Kingdom would not become a member of the EEC. ${ }^{346}$

De Gaulle's plan for a Political Union was not realized. The Dutch feared the prospect of Franco-German dominance and demanded the inclusion of a counterweight: the United Kingdom. This was unacceptable to de Gaulle, as the United Kingdom would in all likelihood demand close relations with the United States, which would be incompatible with his plans for an independent Western Europe. At the same time de Gaulle frustrated Kennedy's plans by blocking the accession of the United Kingdom to the EEC in January 1963. The move caused deep frustration in the United States. The EEC without British membership effectively rendered the Trade Expansion Act and the associated Transatlantic partnership futile. De Gaulle's move was also taken badly among the member states of the European Community. They were particularly baffled by the abruptness and unilateralism of his actions. ${ }^{347}$

French resistance against the expanded powers for the institutions of the European Community, but also against American dominance and transatlantic security structures, had a detrimental effect on Western political relations. Further steps of economic integration were blocked for the duration of de Gaulle's term. As will become clear, these developments would also affect the agendas of the ELEC and the Bilderberg meetings.

\footnotetext{
345 Dinan (2004). Europe recast, pp. 97-100.

346 Wee, H. van der (1987). Prosperity and upheaval. The world economy, 1945-1989. Harmondsworth: Penguin Books, pp. 382-387; Dinan (2004). Europe recast, pp. 97-102.

347 Dinan (2004). Europe recast, pp. 97-102, 112; Gowland, D., Turner, A \& Wright, A. (2010). Britain and European Integration since 1945. On the sidelines. London: Routledge, pp. 53-63.
} 


\section{Emerging challenges for business in European markets}

The dissension in Western relations stood in contrast with the general Western economic success. Global, and particularly Western, economic expansion between 1950 and 1970 reached the highest growth rates in history: global production annually increased with a rate of 5,6 per cent. During the 1960s average growth rates were the highest. Post-war trade liberalization schemes, for example through the GATT conferences, were an important cause of this unprecedented growth. Western Europe grew faster, which was partly a result of the mixed economy: governments, unions and corporate management jointly determined policies in pursuit of maximizing growth. Moreover, in Europe the optimism that followed from the founding of the EEC and EFTA led to high investments during the 1960s, mainly from the United States. As will be shown however, the persistence of growth also resulted in a destabilization of competitive positions for certain European companies. One of these destabilizing factors was the growth of Western European trade relations with Eastern Europe. ${ }^{348}$

\section{Complexities in East-bloc trade}

Trade between Western Europe and the East-bloc had to be redeveloped during the 1950s. As a result of policies of the United States, the existing Western European trade relations with the East-bloc had crashed around 1950. As the Cold War emerged during the late 1940s, the United States initialized a strategy of economic warfare with the Soviet Union and its satellites. In order to prevent unintentional facilitation of the East-bloc's capacity to militarize, the Americans limited exports to Eastern Europe and the Soviet Union. The US government asked Western European exporters to follow suit, but they initially refused. To Western European exporters Eastern Europe represented traditional export areas and they depended on the revenues from those markets. The start of the Korea war in June 1950 suddenly shifted Western European sentiments. Cooperation with the United States quickly took shape within a multilateral agreement to limit the exports of strategic materials and sensitive technology. The Co-ordinating Committee agreement (CoCom), as it was called, was activated in the summer of $1951 .^{349}$

However, already shortly after the end of the Korea war in 1953 Western Europe was given more freedom to restart exports. Negotiations with the United States in 1958 generated more options. Many products that were prohibited before, such as ships and steel, but also technological know-how, could again be exported. From 1959 onwards only the strategically most important goods were withheld

\footnotetext{
348 Van der Wee (1987). Prosperity and upheaval. Harmondsworth: Penguin Books, pp. 48-56. 349 Mastanduno, M. (1992). Economic containment. CoCom and the politics of east-west trade. Ithaca: Cornell Press University, pp. 68-92.
} 
from Eastern Europe and the Soviet Union. However, American exporters still were not allowed to trade with the eastern bloc. ${ }^{350}$

As a result, Western European trade with the East-bloc boomed: EC exports to Eastern Europe and the Soviet Union increased from \$ 626 in 1958 to \$992 million in 1960. Between 1956-1971, exchanges between developed capitalist countries and the Comecon area, the Soviet Union and Eastern Europe, annually grew with more than $11 \%$. Admittedly, East-West trade remained limited to only 2-3 per cent of world trade until the early 1970s, and 3-4 per cent of EC trade. It is important to note that trade increased despite hostile Cold War confrontations between the United States and the Soviet Union, culminating in the Cuban Missile Crisis (October 1962).351

Not surprisingly, the United States' government continued to express reservations against Western trade with the East-bloc, and particularly against Western exports of sophisticated capital goods. Western Europe had begun exporting entire factories and other production equipment to the Communist bloc under generous, government-backed export loans. The Communist-bloc was chronically short on convertible currencies and was therefore dependent on the ability of Western firms to provide export credits. Naturally, the East-bloc countries preferred firms that offered the favourable loans. The Americans perceived the increasingly milder repayment conditions as a form of aid to the Communist bloc. In 1960, the United States asked its Western European allies to limit the duration of export finance loans on capital goods. This was arranged via the so-called International Credit Insurers Union, or the Berne Union, a public-private association that determined financial rules for international credit insurances. Over the next years the member countries, almost all of the OECD members, voluntarily adhered to the rule that export credits on large capital equipment would have to be repaid within a maximum of five years. ${ }^{352}$

However, Western European engineering contractors and other capital goods exporters challenged the agreement in 1963. They were experiencing competition from American engineering contractors on their own home markets. In response, aided by government guarantees they began to redevelop their exports to the Eastbloc against more generous repayment terms. Trade relations that thus developed would upset a balance in several markets, with different consequences for specific

\footnotetext{
350 Mastanduno (1992). Economic containment, pp. 94, 107-108.

351 Eastern Europe: Albania, Bulgaria, Czechoslovakia, East Germany, Hungary, Poland \& Rumania. Yugoslavia was only an observer in ComeCom, and the only Eastern European country having OECD observer status. Mastanduno (1992). Economic containment, p. 112. Schlaim, A. \& Yannopoulos, G. N. (Eds.) (1978). The EEC and Eastern Europe. Cambridge: Cambridge University Press, p. 7; Lavigne, M.(1974). The socialist economies of the Soviet Union and Europe. London: Martin Robertson, p. 334; Feld, W. (1983). The European Community in World Affairs. Boulder: Westview Encore, p. 214.

352 Mastanduno (1992). Economic containment, pp. 124-126; Feld, W. (1967). The European Common Market and the World. Englewood Cliffs, N.J.: Prentice Hall, 154.
} 
sectors. These imbalances were primarily initiated by the wave of investments by American multinationals, which will be discussed now. ${ }^{353}$

\section{American investments in Western Europe}

Between 1957 and 1967, foreign direct investments from the United States in Western Europe more than quadrupled, going from $\$ 4.2$ billion to $\$ 18.2$ billion per year. The growth of the investments in the EEC jumped from $\$ 1.7$ billion to $\$ 8.1$ billion per year; and the US investments in the rest of Western Europe, notably the United Kingdom, grew from $\$ 2.5$ billion to $\$ 10.1$ billion per year. As a share of US total foreign direct investments the annually invested capital in Western Europe nearly doubled from approximately 16 to 32 per cent. American corporations could exploit their generally more advanced production technology and management techniques while at the same time profiting from the growing sales of durable consumer goods in the EEC. Investments were particularly made in growth industries such as the automotive, electronics and petrochemicals industries. ${ }^{354}$

All over Europe these developments resulted in worries and in France they even led to a protectionist reflex. The unprecedented size and the corresponding large financial capacity of American multinationals were experienced as unfair competition. The American subsidiaries in Europe moreover ignored European mores in dealing with labour unions and national governments. ${ }^{355}$

American investments were also perceived as a cause for the widening of the so-called "technology gap." Industrial research and development by private companies had surged after WWII. Companies created in-house laboratories to boost product innovation. American industrial research dwarfed the Western European counterpart: from 1957 until 1967, American spending amounted to slightly over \$ 155 billion dollar against \$ 50 billion in Western Europe. Particularly in France the growing investments by large American multinationals was associated with this technological gap. De Gaulle claimed that Americans were buying French research-intensive firms, which in his view prevented France from developing and exploiting new technologies itself. 356

\footnotetext{
353 Zaleski \& Wienert (1980). Technology transfer, p. 47; Mastanduno (1992). Economic containment, pp. 125-126; Marsh, P.(1978). Development of Relations between the EEC and CMEA. In A. Schlaim \& G. N. Yannopoulos (Eds.), The EEC and Eastern Europe. Cambridge: Cambridge University Press, p. 38; Rooij, A. van \& Homburg, E. (2002). Building the plant. A history of engineering contracting in the Netherlands. Zutphen: Walburg, pp. 61-65, 106.

354 United Nations (1993). From the Common market to EC 92: regional economic integration in the European Community and transnational corporations. New York: United Nations, pp. 29-30. Wee (1987). Prosperity and upheaval, pp. 197-198.

355 Kindleberger, C. P. (1969). American business abroad. Six lectures on direct investment. New Haven/London: Yale University Press, pp. 74- 82.

356 Kindleberger (1969). American business, pp. 83-88, 103-105; Wee (1987). Prosperity and upheaval, pp. 200-213; OECD (1968). General Report: Gaps in Technology. Paris: OECD, pp. 9, 12-13, 30-31.
} 
Some efforts were undertaken to provide an answer to the American investments. During the 1960s the French government developed itself as a very assertive and critical defender of the interests of French, and partly as a result, European corporations. In early 1963 it began delaying the provision of permits on investments from US companies. In February 1965 de Gaulle began attacking the reserve currency role of the dollar in the Bretton Woods monetary system for creating an unfair investment advantage to American corporations. In March 1965, in order to facilitate European companies to merge into larger units across national borders the French government proposed a European company law, claiming that the legal disparities between national company laws were discouraging mergers. Additionally, the American investments elicited a further response on a separate track: in 1969 the European Commission tried to harmonize European taxation rules for companies because it considered double taxation to be the main threshold to transnational mergers. ${ }^{357}$

In 1970 the European Commission combined all these proposals and other related themes in an agenda for a European industrial policy. This was the socalled Colonna memorandum, named after the European Commissioner for Industrial Affairs (1967-1970), Guido Colonna di Paliano. The central idea of the proposal was that European industry should be enabled to seize the opportunities of the large Common Market. It suggested that in order to realize the concentration and transnationalization of European industrial structures, the provision of a legal and fiscal system was required, including a European company law. Moreover it proposed to increase access to capital for European industry. Still these aspects of industrial policy were not accepted by the Council during the 1970s, except for the Commission's proposal on the coordination and funding of Community-wide research which will be discussed in chapter $6 .^{358}$

As will be demonstrated below, European multinationals were consistently ahead of the French government and the European Commission in the formulation of options to improve their position in relation to American firms.

\footnotetext{
${ }^{357}$ Kuisel (1993). Seducing the French, pp. 163-164, 171-178. Rollings, N. (2007). British business in the formative years of European integration, 1945-1973. Cambridge: Cambridge University Press, pp. 242246. Thompson, D. (1969). The Proposal for a European Company. London: Chatham House, pp. 9-13, 39-42

${ }^{358} \mathrm{AEI}$, Commission of the European Communities (1970). Industrial policy in the Community. Memorandum from the Commission to the Council. Brussel: Commission of the European Communities, Retrieved, September 6, 2013, from http://aei.pitt.edu/38638/1/A3443.pdf, pp. 19, 23-24, 26-27.; Winter, H. (1994). Interdependenzen zwischen Industriepolitik und Handelspolitik der Europäischen Gemeinschaft. Baden-Baden: Nomos, pp. 64-65.
} 


\section{Changing circumstances, new priorities}

Before turning to how these challenges affected the ELEC and the Bilderberg meetings, it is important to explain why these themes entered their agendas. For both networks the new themes were a reflection of changing circumstances. With regard to the Bilderberg meetings the effects of changing circumstances were already illustrated in the previous chapter. De Gaulle's rejection of British accession to the EEC in 1963 had produced severe tensions between Americans and Europeans. The Americans expressed serious doubts about whether the European Community could resist the influence of de Gaulle. They wondered whether the Community would remain committed to the post-war consensus on liberalisation. When formerly transatlantic trade relations were discussed in a congenial atmosphere, now contention was creeping in. The discussed themes would develop accordingly. 359

For the European League for Economic Cooperation the French rejection of the United Kingdom's membership of the EEC also was a turning point. It resulted in a consciously initialized re-evaluation of its priorities. There was a distinct feeling that de Gaulle would block any initiative on further expansion of the Community which led to the question what the League should focus on instead. In December 1963, Baron René Boël announced a round table meeting with 15 prominent industrialists based in the EEC and the EFTA to discuss "the most important issues to be resolved to advance European integration."360

The industrialists met in June 1964 at the OECD in Paris. Prominent companies were participating, such as Solvay \& Cie. (Baron Boël), Pirelli (Emanuele Dubini), Unilever (Pieter Kuin), Shell International Petroleum Co. (Pierre Escoffier), Bayer (Hanns Gierlichs) and Stockholms Enskilda Bank (Marcus Wallenberg). Interestingly, they were joined by men from key organizations in the international business dialogue: one was Lincoln Steel, a former Imperial Chemical Industries director who now presided over the International Chamber of Commerce, a global agenda setting body on business interests. Also George Villiers took part, the influential President of the Conseil National du Patronat Français. Moreover, two officials from the EEC and the EFTA were attending. 361

\footnotetext{
359 See chapter 4.

360 CEHECLIN, LECE, inv. nr. 746, 1-2-1963, Conseil Central, pp. 3, 5. "les questions les plus importantes à résoudre pour faire progresser l'intégration européenne"; inv. nr. 747, 10-12-1963, Conseil Central, p. 13.

${ }^{361}$ Further participants; Austria: Herbert Koller (VÖEST), Hans Poppovic (Bunzl \& Biach). Belgium: Emile Bernheim (Grands Magasins "A L'Innovation"), Pol Provost (Soc. Générale de Belgique), Baron Snoy et d'Oppuers (Compagnie d'Outre-Mer pour le Financement et l'Industrie). France: Jean Délorme (l'Air Liquide), Jean Dupin (L'Aluminium France). Italy: Faina (Società Montecatini) Luxembourg: Gabriel Chretien (H.A.D.I.R.), Richard Herlin (Minière et Metallurgique de Rodange). The Netherlands: P. R. Bentz van den Berg (Ned. Hoogovens en Staalfabrieken), J. Zijlstra (Bank voor Handel en Scheepvaart). Spain: Juan Bertrand y Mata (La Catalana de Gas y Electricidad), Pedro Ibarra Mac-Mahon (Banco de Viscaya et Babcock et Wilcox). Sweden: Ingmar Eidem (Stockholms Superfosfat Fabriks), Curt R.
} 
The meeting resulted in a suspension of ELEC's original activities on liberalization of European markets by means of tariff elimination. De Gaulle's rejection of British membership for now had ruled out further political initiatives between the EEC and EFTA. ELEC decided that any further action on the matter had to remain limited to the Kennedy Round, the General Agreement on Tariffs and Trade negotiation-round that was planned for the near future. Snoy D'Oppuers summarized: "[I]f we are blocked on the customs side, [...] the opening is to start with the other chapters of the economic union." Instead of continuing to work on the minimization of tariffs between the EEC and the EFTA the participants at the meeting of June 1964 decided to focus on the reduction of differences in policies in the EEC and the EFTA such as transport policies, agricultural policies or non-tariff discrimination. ${ }^{362}$

However, the main issue that the industrialists wanted ELEC to respond to was competition from outside the Community. The group signalled problems in trade with Eastern Europe, which resulted in a new priority for the League: lobbying for a Community trade policy for third countries. Moreover the participants expressed concerns about the lack of concentration of European industry in comparison to the large US corporations that were currently investing in Europe. Particularly CNPF President George Villiers expressed doubts about whether the small European firms could withstand giant groups such as General Motors and General Electric. The industrialists concluded that the European economy had to be prepared to "withstand the shock of competition from large American companies" by an induced concentration process. They proposed the investigation of a fiscal and legal framework to facilitate transnational mergers among European companies to "achieve the optimum dimensions in a very short time."363

\section{Eastern European markets and the Bilderberg meetings}

The Bilderberg meetings engaged with the subject of East-West trade only shortly after the agreement on export credit facilities for the East-bloc had been struck. As explained, two measures limited Western European trade with the East-bloc. In 1960 the government of the United States pressured European governments and exporters to abide by an international agreement on repayment terms of export credits for capital goods. At the same time, the CoCom agreement was still in place

Nicolin (A.S.E.A.), Philip Göran Philipson (Svenska metallverken). Switzerland: Hans Schindler (Ateliers de Construction Oerlikon). EEC: J. Paelinck (Direction Générale des Affaires Economiques). EFTA: Charles Muller (Ass. Secr. Gen. EFTA). CEHECLIN, LECE, inv. nr. 105, 19-06-1964, "L'investissements et L'Europe de demain": liste des participants, pp. 1-5.

362 "[S]i nous sommes bloqués du côté douanier, [...] le débouché c'est de commencer par les autres chapitres de l'union économique." CEHECLIN, LECE, inv. nr. 748, 19-06-1964, Conclusions de la Table Ronde d'Industriels, pp. 1-2.

363 CEHECLIN, LECE, inv. nr. 107, 19-06-1964, Table Ronde Minutes, p. 15. Inv. 748, 19-06-1964, Conclusions de la Table Ronde d'Industriels, pp. 1-2. 
for certain sensitive goods. As will become clear there was little sympathy for this agreement among Western European exporters of capital goods. The Bilderberg meetings were the ideal forum for discussing misgivings about such a sensitive Transatlantic issue.

East-West trade first appeared on the Bilderberg agenda in 1961, a year after the five-year credit agreement for capital goods was agreed on. The meeting bore the title: "The impact of Communist economic penetration in the Western World." The meeting took place against a disturbing background. It was held from the $21^{\text {st }}$ until the $23^{\text {rd }}$ of April, only days after the failed Bay of Pigs invasion of Cuba. This was the wrong moment to make an appeal to Americans to end security-based trade barriers for the communist East-bloc. ${ }^{364}$

This was nonetheless precisely what two business leaders did. Both were important figures in the Western capital goods industry. The first was the Canadian James S. Duncan who was a former CEO at Massey-Ferguson, a producer of agricultural machinery. The second was the German Otto Wolff von Amerongen, president of Otto Wolff, a company that produced and traded in steel, semi-finished and finished steel capital goods such as container cranes and industrial machinery. Otto Wolff was strongly geared towards Eastern Europe. Additionally, Wolff von Amerongen himself was a highly visible proponent and expert on trade with the Eastbloc. As the chairman of the so-called German "Ost-Ausschuss", the East Committee, he embodied the Federal Republic's strategy to gain back control over Germany's pre-WWII export markets in Eastern Europe and Russia. In this role Wolff von Amerongen operated as a diplomat-businessman, personally closing trade agreements on behalf of the Federal Republic with countries with which regular diplomatic relations were too sensitive. ${ }^{365}$

The views of Duncan and Wolff von Amerongen on trade with Eastern Europe were remarkably similar in their opposition to official American policy. Duncan represented a Canadian viewpoint and tried to convince the Americans that the strategy of embargoes of the United States government should be cancelled. According to him the CoCom-agreement was unjustly blocking the trade of certain goods. Instead, he felt that trade with the Communist bloc should be expanded in order "to increase the dependence of Communist countries on international trade and to help them to increase the living standards of their people." At the same time he explained that the Communist-bloc was taking advantage by demanding in-

\footnotetext{
${ }_{364}$ Rossem, M. van (2001). De Verenigde Staten in de twintigste eeuw. Den Haag: Sdu Uitgevers, p. 240. IISGA, Collectie Cees Wiebes, inv. nr. 70, Bilderberg Meetings (1961). St. Castin Conference, 21-23 April, 1961. Sl.: Bilderberg Meetings, pp. 41-44.

365 Soénius, U. S. (2005). Otto Wolff von Amerongen: Kundschafter der Marktwirtschaft. In P. Danylow \& U. S. Soénius (Eds.), Otto Wolff: ein Unternehmen zwischen Wirtschaft und Politik (pp. 385-435). München: Siedler. Spaulding Jr., R. M. (1996). "Reconquering our old position" West German osthandel strategies of the 1950's'. In Berghahn, V. R. (Ed.), Quests for economic empire. European strategies of German big business in the twentieth century (pp. 124-143). Providence: Berghahn Books, pp. 132-135, 141-142.
} 
creasingly beneficial terms and conditions from Western companies that wanted to increase their exports. They were being played out against each other and according to Duncan this had to stop. In other words, he wanted "regulatory rather than prohibitionary ground rules." He felt that the embargoes should be replaced with an internationally agreed code of conduct for trade with the Communist-bloc to aid Western business to resist request for even better terms and conditions. ${ }^{366}$

Otto Wolff von Amerongen was the author of the European paper presented at the April meeting. Just as James Duncan he proposed to do away with any securitybased barriers to trade, and stressed that the East-bloc represented traditional markets for Western Europe. Now trade with these markets was partially blocked via the CoCom-agreement, though. Wolff felt that by removing these artificial barriers "[i]n the field of trade we would do openly what we now do half-heartedly." Moreover he asked to combine the lifting of the embargo with a new export credit agreement for the West. According to him, the rule of a maximum of five-year-term credits for exports of capital goods to state trading countries that was agreed to in 1960, was already being transgressed by several private firms. ${ }^{367}$

Duncan's and Wolff von Amerongen's request to lift the trade embargo to the Communist-bloc should be seen in the light of competition by American corporations in Western Europe. Whereas American competitors were free to export to Canada or Western Europe, they were prohibited from trading with the Communist bloc. The Canadians and Western Europeans therefore could take advantage of that situation by exporting to the Communist bloc, if allowed.

These two requests for better credit regulations had different reasons. Duncan's position was clearly rooted in the idea that companies in the capital goods sector were being played out against each other by Eastern European states. Wolff von Amerongen's argument for renewed credit regulations was double-layered. On the one hand the sectors involved in the production of capital goods such as steel, engineering and construction preferred a strengthened negotiation position with the East-bloc too, but Wolff von Amerongen's request also carried a specifically German dimension. Due to foreign policy decisions the Federal Republic of Germany had no trade agreements with Eastern European countries until 1963. As a result, unlike other Western European countries, the German government was not able to guarantee export credits of banks for its capital goods industry. Under close supervision by Wolff von Amerongen himself the Federal Republic closed the required agreements during 1962 and 1963. Wolff von Amerongen's request for a new credit agreement therefore had little to do with the capital goods producers as

\footnotetext{
366 Haycraft, W. R. (2000). Yellow steel: the story of earthmoving equipment industry. Urbana: University of Illinois Press, p. 154. RWWK, NOWA, inv. nr. 72-378-4. James S. Duncan: The impact of Communist economic penetration in the Western World (April 1961), pp. 2-3, 14-15, 18-19.

${ }^{367}$ RWWK, NOWA, inv. nr. 72-378-4. Otto Wolff von Amerongen: Impact of Soviet Economic Penetration in the Western World (1961), pp. 10-11.
} 
a whole but was related to the inability of the German government to support its industries. ${ }^{368}$

In the next years however the Western agreement on the repayment terms for capital goods exports was severely challenged. As part of an investment wave by American corporations in Western Europe since the mid-1950s, U.S. engineering contractors had seized the opportunity to exploit their competitive advantage over European firms. During WWII they had developed a lead in management techniques and expertise in building installations for petrochemical production processes. Particularly these were required in Western Europe as during the 1950s the chemical industry began to switch from coal-based processes to oil-based feedstocks. As a result Western European engineering contractors soon turned to the East-bloc markets, where the Americans were not allowed to exploit their expertise. ${ }^{369}$

The export credit agreement quickly became an empty shell. Entire factories, including installations and process technology were exported to the East-bloc. The required export loans were financed by Western European banks which on their turn were guaranteed by Western European governments. The exporters, banks and governments together exceeded the agreed maximum five-year repayment term by far. In 1963 a ten-year Belgian credit of \$ 7.2 million was granted to Hungary to buy a turnkey chemical plant. The loan was guaranteed by the Belgian government. In 1964 the United Kingdom also breached the agreement through the provision of two loans, one of twelve years for Czechoslovakia to build fertilizer plants, and one of $\$ 300$ million for a period of fifteen years for the Soviet Union to build chemical factories. France soon followed, as did Italy with a deal involving FIAT. Abruptly, Western Europe was engaged in a minor bidding war to gain a share of the East-bloc market for capital goods. The government of the Federal Republic of Germany however was not prepared to follow this practice, which reduced the ability of German exporters to compete. 370

Under these circumstances, the topic of East-West trade quite unexpectedly returned to the agenda of the Bilderberg meeting of March 1964. A last minute change was made because the United States government suddenly showed an interest in allowing the resumption of American trade with the Communist-bloc. It had concluded that the CoCom embargo had little effect on the Soviet economy and on its capacity to fight a war. Moreover, the export credit agreement was being challenged. The result was that the government now wanted American firms to

\footnotetext{
368 Wolff von Amerongen, O. (1992). Der Weg nach Osten. Vierzig Jahre Brückenbau für die deutsche Wirtschaft. Droemer: Knaur, pp. 93-96.

${ }^{369}$ Rooij, A. van \& Homburg, E. (2002). Building the plant. A history of engineering contracting in the Netherlands. Zutphen: Walburg, pp. 61-65, 106.

370 Zaleski \& Wienert (1980). Technology transfer, p. 47; Mastanduno (1992). Economic containment, pp. 125-126; Marsh, P.(1978). Development of relations between the EEC and CMEA. In A. Schlaim \& G. N. Yannopoulos (Eds.), The EEC and Eastern Europe. Cambridge: Cambridge University Press, p. 38; Wolff von Amerongen (1992). Der Weg, pp. 93-96.
} 
start exporting eastward. George Ball, recently appointed Under-Secretary of State, confirmed this but stressed that the export of know-how remained curtailed. Moreover, China and, especially, Cuba would be considered off-limits to US exporters. $^{371}$

Otto Wolff von Amerongen immediately embraced the new American position as an opening to develop a coordinated approach which could level the playing field with the rest of Europe for him and his fellow exporters of capital goods from the Federal Republic. He explained that he and his colleagues had abided by the credit agreement out of necessity, even when others in the EEC had not done so and that they were suffering accordingly. Coordination was badly needed and he hoped to develop a feasible approach with the Americans. He even proposed to include the governments of the United States and Britain in the coordinative talks on the East-bloc that had started in the EEC in 1961.372

Wolff von Amerongen received support from American businessmen such as John McCloy, the chairman of the Ford Foundation and Jack Heinz II of Heinz and several US foreign policy specialists. They demanded a clear line of conduct to prevent the Communist bloc from pushing through its politically motivated strategies. They proposed fair play rules, arbitration and rules on the exploitation of patents by the East bloc. Now that the Americans realized that the previous restrictive policies had failed they were ready to take the lead in establishing a level playing field for East-West trade. ${ }^{373}$

However, the Belgian, French, Italian and British participants disagreed on the need for a new set of agreements and felt that the existing agreements were sufficient. In their view the playing field did not suddenly require levelling just because the United States had decided to let its exporters compete in Eastern markets. The Americans were unable to convince European governments to close a new credit agreement in the next years. After repeated requests from Wolff von Amerongen's East Committee, the German government ultimately began backing export credits exceeding the five-year term from March 1965.374

\footnotetext{
${ }^{371}$ RWWK, NOWA, inv. nr. 72-374-3. Diskussion über den Ost-West-Handel anlässlich der Bilderberg Konferenz in Williamsburg am Freitag, dem 20. März 1964. Mastanduno, M. (1992). Economic containment, pp. 135-139.

${ }^{372}$ RWWK, NOWA, inv. nr. 72-374-3. Diskussion über den Ost-West-Handel anlässlich der Bilderberg Konferenz in Williamsburg am Freitag, dem 20. März 1964; inv. nr. 72-374-3. Bilderberg Meetings (1964). Williamsburg conference, 20-22 March, 1964. Sl.: Bilderberg Meetings, pp. 24-27. See for the response of the European Community to developments in East-West trade: Feld (1983). The European Community, pp. 217-219.

${ }_{373}$ RWWK, NOWA, inv. nr. 72-374-3. Diskussion über den Ost-West-Handel anlässlich der Bilderberg Konferenz in Williamsburg am Freitag, dem 20. März 1964. The Americans speaking on the subject were Jacob K. Javits, John McCloy, Jack Heinz, C. D. Jackson and Dean Acheson; inv. nr. 72-374-3. Bilderberg Meetings (1964). Williamsburg conference, 20-22 March, 1964. Sl.: Bilderberg Meetings.

${ }^{374}$ RWWK, NOWA, inv. nr. 72-374-3, Bilderberg Meetings (1964). Williamsburg conference, 20-22 March, 1964. Sl.: Bilderberg Meetings, pp. 24-27. Wolff von Amerongen (1992). Der Weg, pp. 93-96.
} 
In sum, in order to withstand competition with American capital goods exporters in their own markets, Western European capital goods exporters tried to remove export barriers to the East-bloc. Moreover, they preferred a maximization of the repayment-terms of export credits to retain a strong negotiation position vis-à-vis the East-bloc. However, when the agreement of export credits ceased to play a role after 1963, it became clear that particularly German exporters of capital goods required such forms of coordination because the national government was not willing to aid national industry in trade with Eastern Europe. Other Western European governments preferred to have a free hand in determining the degree of their involvement in the East-bloc and to aid their industries in competing with American capital goods exporters where possible.

\section{Eastern European markets and the ELEC}

Between 1964 and 1969 the European League for Economic Cooperation responded to the same problems. That response was motivated by a different perception of trade with the East-bloc though. Not the capital goods sector but mainly the producers of industrial goods, such as chemicals and metals, but also banks, were influencing ELEC's perceptions and responses. That resulted in an entirely different analysis of the issues involved in East-West trade: the ELEC members were worried about Western European imports from the East-bloc that resulted from the exports of capital goods exports to that region. ${ }^{375}$

\section{The Western European chemical industry and Eastern Europe}

A good example of how the export of capital goods to the East-bloc affected Western Europe's goods industries can be drawn from Baron René Boël's experiences in the Western European chemical sector. Since January 1964 Boël was Executive President of the chemicals producing multinational Solvay \& Cie. In that position he also chaired an informal association of the European chemical industry, the Club de l'Industrie Chimique. The Club was founded in 1959 to discuss the sector's strategic interests and exclusively consisted of leaders of major European chemical firms such as Solvay, Péchiney, Rhône Poulenc, Montecatini, Hoechst, Bayer and Imperial Chemical Industries. 376

\footnotetext{
375 On ELEC's work on East-West trade also see Dumoulin, M., \& Dutrieue, A.-M. (1993). La Ligue Européenne de Coopération Économique (1946-1981): un groupe d'étude et de pression dans la construction européenne. Berne: Lang, pp. 158-164.

${ }^{376}$ The Club de l'Industrie Chimique had developed from the Consultative Commission of the Employers of the Chemical Industry, founded in 1950. In this body, the European chemical industry coordinated strategy towards the International Labour Organization in Genève. When this function was absorbed in 1959 by the European federation of national employer associations of the chemical industry CEFIC (Conseil Européen des Fédérations de l'Industrie Chimique), the industrialists decided to continue the
} 
From July 1963 to July 1966 the Club de l'Industrie Chimique was paying attention to strategic problems in East-West trade. The producers of chemicals had worries about the effects of cheaply priced imports from the East-bloc. In 1963 they were particularly concerned about the role of their own governments in closing trade agreements in which industrial goods from East-bloc countries were accepted against dumping prices in exchange for exports of capital goods. The dumped goods were driving down the prices on Western European markets. In July 1964 a different worry surfaced in the Club. The industrialists concluded that the Eastbloc export market was deteriorating because Western European exporters were selling their products below market prices. They particularly blamed governments for competing for the exports of capital goods by means of guaranteeing increasingly longer-term export loans. By July 1966 the chemical industrialists noted that the government-supported export of capital goods had laid the basis for even worse dumping effects then before. Boël warned for a "boomerang effect": the East-bloc factories that were being built by Western European engineering contractors and machinery producers would begin selling their surplus products on Western European markets. Moreover, the Club had information about a new development in the export of turnkey production plants to the East-bloc. Until then it was common to include a non-export clause for Western Europe in the building contracts. But in the summer of 1966 the chemicals producers learned that such clauses were becoming less and less acceptable to the East-bloc. Western Europe was creating its own competition and East-bloc surplus production capacity would soon start flooding the West, according to Boël. He concluded that an urgent need for effective anti-dumping laws had emerged. In addition he and his colleagues felt that indirect governmental support of the capital goods industry should be suspended, or at least limited, by reducing the guarantees on export credits to fiveyear-loans. ${ }^{377}$

Clearly the strategies of the Western European capital goods industry conflicted with the interests of the Western European chemical sectors. Whereas the exporters of capital goods tried to compensate for the loss of market-share to American firms, the European chemical industry had to endure the effects of falling prices, the disappearance of export markets, and dumping of East-bloc goods.

meetings in the Club de l'Industrie Chimique. Private Archive Solvay S.A., Club de l'Industrie Chimique C2-1: Fondation du Club et ses Principes, 3-7-1973, "Historique de la Constitution du Club de l'Industrie Chimique."

377 Private Archive Solvay S.A.., Binder Cercle PV1, 11-07-1963, Minutes Club de l'Industrie Chimique, Réunion de Bruxelles, le 5 juillet 1963, pp. 16-17; 24-07-1964, Minutes Club de l'Industrie Chimique, Réunion de Francfort, le 3 juillet 1964, pp. 7-9; 05-07-1966, Minutes Club de l'Industrie Chimique, Réunion A Londres, le vendredi 1er juillet 1966, pp. 7-8. In the economic system of the East-bloc, imports of Western capital goods forced the Eastern European countries to realize balanced exports in order to acquire foreign currencies. In the economic planning practices of the East-bloc, exports were import-driven: exports served for the payment of imports. Therefore, in return for imports of capital goods, low priced industrial goods were exported to Western European markets against dumping prices. See Lavigne (1974). The socialist economies, pp. 341-342. 
These effects were of course not exclusive to the chemical industry. Car-factories or steelworks were also being built in the East-bloc under Western supervision. From mid-1964 onwards the ELEC would attempt to normalize relations with Eastern European industry under Boël's leadership. ${ }^{378}$

\section{Overcoming narrow bilateralism}

When in June 1964 the ELEC directed its attentions to the emerging problems in East-West trade relations, Boël steered the debate in the direction of the problems that were preoccupying the chemical sector. During informal strategy meetings with his fellow chemical industrialists in July 1964, Boël had learned that NATO formally adhered to the policy of export loans for capital goods with a maximum repayment term of five years. Moreover, the Club de l'Industrie Chimique had decided to address the issue of the competitive behaviour of national governments, and started to lobby for a general commitment to the internationally agreed credit policy. Boël combined both aspects by arranging a meeting with the Permanent Belgian Delegate to NATO, André de Staercke, to whom he proposed collaboration on the organization of an ELEC roundtable meeting on East-West commercial relations. ${ }^{379}$

Since NATO itself was officially prohibited from working on East-West economic relations, the Belgian delegation to NATO was very interested in cooperating with ELEC. They were convinced that improved economic relations between East and West would reduce the Cold War hostility. The delegation wondered whether the views of industrialists could provide help in overcoming "the narrow bilateralism which governs exchanges between East and West." They hoped it would result in collective action and a western front, among others in credit-policy. They moreover proposed that Western European industry should approach the East-bloc directly and begin negotiations on all sorts of commercial arrangements. The League would take up both suggestions in the following years. ${ }^{380}$

\footnotetext{
${ }^{378}$ For more on these investments see: Zaleski, E. \& Wienert, H. (1980). Technology transfer between East and West. Paris: OECD.

379 Private Archive Solvay S.A., Binder Cercle PV1, 24-07-1964, Minutes Club de l'Industrie Chimique, Réunion de Francfort, le 3 juillet 1964, pp. 7-9. CEHECLIN, LECE, inv. nr. 276, 12-10-1964, Correspondence René Boël-André de Staercke.

380 The members of the Permanent Belgian delegation to NATO were: G. de Brouwere, economic advisor to the Permanent Belgian Delegation to NATO, and the deputy director of the Economic department of NATO, Oscar Debunne "Pour différentes raisons, l'O.T.A.N. ne peut envisager de traiter officiellement la question et souhaiterait que d'autres organisation le fassent." "La délegation belge à l'O.T.A.N. est convaincue de l'importance que présente un accroissement des relations économiques entre l'Est et l'Ouest, pour favoriser la détente", CEHECLIN, LECE, inv. nr. 276, 04-11-1964, Wergifosse-Boël, Note Pour le Baron Boël: Table Ronde sur les Relations Economiques Est/Ouest, p. 1. "L'obstacle fondamental est le bilateralisme étroit qui règle les échanges entre l'Est et l'Ouest"; inv. nr. 276, 12-11-1964, Brouwere-Wergifosse, p. 1.
} 
In October 1964 Boël was able to persuade the ELEC to organize a round-table meeting in May 1965. The goal of the meeting was "to arrive at common conceptions, particularly with regard to the credit policies for countries of the Western World." In the past the ELEC had focussed on Western European topics and was particularly geared to issues concerning the Common market. However, the European Commission had no means at its disposal to regulate governments or market players regarding trade with the East-bloc. The Soviet Union refused to recognize the European Community, making collective negotiations with the Comecon impossible. The only alternative had been to conclude bilateral agreements, assisted by consultations among Community member states. Moreover, an agreement on the level of the European Community alone would not be enough as each Western country was contributing to the problem. Non-Community members that would not adhere to the agreement could simply offer more attractive loans to Eastern Europe and profit from the Communities' willingness to prevent internal competition. Instead, ELEC's goal was similar to that of Wolff von Amerongen in the Bilderberg meetings: to bring about a consensus on credit policy for Eastern Europe in the entire West, including the United States. This was new territory for ELEC. 381

The round-table meeting took place in Brussels on the 14th and 15th of May 1965. ELEC had successfully invited representatives from the European Commission, the OECD, NATO and the United Nations Economic Commission for Europe. The European business community was represented by about fifty participants from national ELEC sections, some observers from CEPES, UNICE, and members of the national federations of industries of the EC member states. Particularly European banks were well represented. This is not surprising since the insurance of export loans to the East-bloc was a central subject. The selection of visitors shows ELEC's ability to assemble the required international institutions and expertise to address issues that went beyond the EEC. Still, it is important to understand that ELEC organized the round table to address the issue in the business community, and on the level of Western supranational and international institutions, to exchange ideas on the problems at hand. The resulting resolution however was not a collective agreement but merely represented ELEC's views on the subject. ${ }^{382}$

\footnotetext{
381 CEHECLIN, LECE, inv. nr. 749, 02-10-1964, Conseil Central, pp. 7-8. On the Community's trade policy regarding the Comecon see: Feld (1983). The European Community, pp. 217-219.

382 Participants from the European Commission: Member of the European Commission, Jean Rey, "Administrateur Principal" Louis Kawan, "Directeur" Wolfgang Ernst. NATO: Francois D. Gregh and Gérard de Brouwere. OECD: M. de Gianella. United Nations Economic Commission for Europe: Melvin M. Fagen. Financial Institutions: France: Crédit Lyonnais, Banque de Paris et des Pays-Bas. Belgium: Caisse générale d'Epargne et de Retraite, Banque Bruxelles. Austria: Association of Austrian Banks and Bankers. Germany: Deutsche Bank. Sweden: Swedish Bankers Association, Svenska Handelsbanken and Stockholms Enskilda Bank. UK: Henry Schroder, Wagg and Co. Nederland: Algemene Bank Nederland. ELEC (1965). East-west commercial relations: study conference, opening speech, introductory report, resolutions, list of participants, Brussels, May 14th and 15th, 1965 (Vol. 40). Brussels: ELEC, pp. 63-70. Also see section "Resolutions of ELEC resulting from the Round Table on East-West Commercial Relations”, pp. 57-62.
} 
As Boël and the Club de l'Industrie Chimique preferred, the ELEC concluded from the round table meeting that Western governments should cease to guarantee increasingly longer termed export loans and set up a "coordinated policy" on credit terms and a "good conduct code" on commercial practices such as the classification of goods, importation safety clauses, and protection of industrial property. Additionally it became clear during the round-table that the member-states of the European Community had decided not to develop a joint policy. Individually the countries could obviously still contribute to a pan-Western agreement. According to the ELEC though, the OECD should shape the coordinative efforts as it was composed of all the major economic interests of the West, including the United States. ${ }^{383}$

What does ELEC's work on this matter tell us about views within European multinationals on the European market? The ELEC responded to the destabilization of markets for Western Europe's basic industries. They were worried about the export of factories and industrial machinery to the East-bloc and the resulting competition on Western European markets and wished to see it curtailed. The fact that ELEC's banks active within ELEC agreed to this approach can be understood from the viewpoint of increasing risks that were de facto unnecessary if the West could conclude an agreement. The capital goods exporters on the other hand required the successful exploitation of alternative markets beyond that of Western Europe to survive American competition. In contrast to the goods producers and banks, they preferred continued support from their governments. These different conceptions on the organization of the European market emerged from different sectoral priorities.

The European Commission proved to be unable to fulfil a role in establishing a level playing field. In such global issues the Community represented too few countries for setting an example for the rest of the world: too many OECD countries would benefit from such voluntary restraint. The EEC was part of a larger set of competitive forces that paradoxically made a coordinated EEC policy unattractive. Instead the ELEC approached NATO and the OECD to address Western trading practices. However, as explained earlier, Western governments were unable to achieve a new credit term agreement for Eastern Europe.

\section{Organizing international markets}

After the spring of 1965 the ELEC wanted to continue its work on the normalisation of trade relations with Eastern Europe. In June 1966 it decided upon a strategy that could mitigate the East-bloc exports against dumping prices, which the Club de I'Industrie Chimique was so worried about. The ELEC tried to create opportunities for direct cooperation between Western and East-bloc companies. The idea was proposed to the ELEC by an unexpected party, the European Commission. Louis

383 Ibidem, pp. 46, 59-61. 
Kawan, a Commission-expert on East-bloc affairs saw a clear link between the problems of the companies active in ELEC and the issues that he as a Commissionrepresentative tried to achieve. The European Commission wanted to engage Eastern European governments directly to reach agreements on technical matters of economic exchange. However, since the East-bloc did not officially recognize the European Community, the European Commission was unable to undertake action. Louis Kawan proposed that the ELEC should mobilize its "ideally placed" position in economic, scientific and technical matters to open discussions with Eastern European governments. At the same time ELEC would operate as an intermediate for the European Commission. It was imagined that via one or more round-table meetings the ELEC could facilitate cooperation between Western and Eastern industrial corporations. ${ }^{384}$

These agreements were necessary because the economic systems of Western and Eastern Europe were too far apart for engaging in workable East-West joint ventures or other forms of cooperation. The concept of the company in East-bloc economies was incomparable to that in Western economies. Before 1965 East-bloc companies were fully subordinate to the national economic administration and sector-based ministries that planned and directed their activities. By 1965 several Eastern European countries such as Hungary and Czechoslovakia changed the position of the industrial firm in their economies. These new policies gave companies more freedom to co-determine and realize national and sector-based production plans. Moreover, selected firms were given more access to international trade. However, although East-bloc firms were gradually given the means for collaboration with Western firms, in many respects Eastern European business functioned quite differently from the Western market economy. These differences included rules on the use of patents, price setting practices, and many other technicaleconomic matters and severely complicated East-West collaboration between companies. 385

As will become clear, the ELEC developed plans to reduce those differences. It is important to realize that ELEC's efforts in this regard followed from requests from the European Commission. The Commission convinced European business to cooperate on proposing new forms of integration with the East-bloc.

\footnotetext{
384 Koeune, J. C. (October 23rd, 2006). Interview with Yvonne de Wergifosse, Secretary General of ELEC (1962-1988), acquired from http://www.elec-lece.eu/documents/div/origin-deWergifosse-E.pdf, on the 26th of September 2011, p. 4; Bossuat, G. \& Legendre, A. (2007). De rol van de Commissie in buitenlandse betrekkingen. In M. Dumoulin (Ed.), De Europese Commissie, 1958-1972: geschiedenis en herinneringen van een instelling (pp. 361-402). Luxemburg: Bureau voor Officiële Publicaties der Europese Gemeenschappen, p. 388. CEHECLIN, LECE, inv. nr. 752, 09-05-1966, Réunion du Comité Préparatoire de la Deuxième Table Ronde Est/Ouest, le 19 avril 1966, p. 3.

385 Palmer \& Colton (1995). A history of the modern world, p. 912. Judt, T. (2005). Postwar. A history of Europe since 1945. New York: Penguin, pp. 312-318. Lavigne (1974). The socialist economies, pp. 49-89, 334.
} 
The first of these proposals, however, initially led to some uneasy feelings among the corporate leaders inside ELEC. Some questioned whether it was appropriate for "free enterprise country industrialists, to have officials from the East as interlocutors." The majority nonetheless perceived it as an opportunity that could result in "beneficial effects on the evolution of minds and on the economic systems of state trading countries." 386

A round table took place in late February 1967, in Brussels. The meeting involved an initial exchange of ideas between government officials from Bulgaria, Hungary, Poland, Romania, Czechoslovakia and Yugoslavia, and forty representatives of Western European companies. Of these companies two groups were actively contributing to the East-bloc's industrialization: the commercial banks (10) and capital goods producers (18). A third group was formed by producers of industrial goods (12) in which the chemical industries were well represented (6). As mentioned, these firms were confronted with exports to the EEC against dumping prices. Additionally, in order to observe the progress on potential agreements, representatives of the GATT, the European Commission, the EFTA secretariat and the United Nations were taking part. ${ }^{387}$

The meeting resulted in a strong awareness that indeed, despite reforms, the economic systems of East and West were still far apart. Representatives of Eastern European states wanted to be persuaded of the benefits of cooperation. In response, a basis for continuing the meetings was found in a format of exchange, in which Western companies would offer technology under licence, technical assistance, and commercial access to western markets, while in return Eastern companies would offer cheap labour and commercial and logistic knowledge of Eastern markets. However, the next step required overcoming practical issues that often stemmed from basic differences in economic ideology and practice: information on price formation processes, industrial ownership, intellectual property rights, arbitrage, and several other issues, first had to be exchanged before any progress could be made. ${ }^{388}$

Two further meetings were required before the introduction of a draft cooperation agreement between Eastern and Western companies was possible. A smallscale preparatory meeting was organized in Prague from the 2nd to the 4 th May 1968. It coincided with the high time of the Czech liberalization movement, the Prague Spring. The meeting resulted in the concrete investigation of cooperation agreements. The third and last meeting again took place in Brussels in December

\footnotetext{
386 "industriels de pays de libre entreprise, auraient comme interlocuteurs des représentants officiels des pays de l'Est", \& "peuvent avoir des effets bénéfique sur l'évolution des esprits et des systèmes économiques des pays à commerce d'état", CEHECLIN, LECE, inv. nr. 752, 28-01-1966, Conseil Central Élargi, p. 6; inv. nr. 752, 11-07-1966, Conseil Central Élargi du 24 Juin 1966, pp. 3-4.

387 ELEC (1967). Economic, industrial, scientific and technical cooperation between the countries of Eastern and Western Europe : Round Table, organized in Brussels, February 24th and 25th, 1967 (Vol. 41), pp. 105-117. Jean-Claude Koeune (October 23rd, 2006), Interview with Yvonne de Wergifosse.

388 ELEC (1967). Economic, industrial, scientific.
} 
1969, with similar participants to the meeting in 1967. Boël explained what was at stake: the West wished "to develop their exports", the socialist countries were, besides exports, also interested in the "exchange of technical data and a reduction of production cost", in other words, more efficient production techniques. The meeting revolved around an elaborate treatment of technical, legal, commercial and financial aspects of cooperation between Western and Eastern firms. Several proposals for model-contracts for industrial cooperation were discussed. The ELEC had laid the basis for industrial collaboration between Western Europe and Eastern Europe, which in the following years would actually take shape. ${ }^{389}$

The involvement in this endeavour of both producers of industrial goods and the producers of capital goods, despite their conflicting interests, can be understood by revisiting the worries of the Club de l'Industrie Chimique in July 1966. Through cooperative agreements with East-bloc corporations the effects of the export of East-bloc overproduction could be mitigated: ELEC's efforts made it possible to replace dumping by productive exchanges. In exchange for knowledge about an industrial chemical production process from Solvay \& Cie. for example, a Hungarian firm could start the production of the resulting product for sales on the Hungarian market. By engaging in such joint ventures with Eastern European companies, Western European companies could lay a foundation for East-West integration. In sum, the strategic behaviour of Western European capital goods exporters and of the planners of the East-bloc governments was coordinated in several ways, thereby replacing the preceding dumping practices by mutual beneficial agreements. On a more abstract level ELEC's initiatives expressed a demand for predictable and controllable markets in which governments were expected to defend the interests of European industries instead of fuelling competition.

In the discussion on East-West trade one factor remained underexposed: the investments by American corporations that had been the initial factor that destabilized the Western European market for capital goods, with all the East-West consequences discussed above. It is indeed the case that the Western European basic industries were also directly confronted with competition as a result of very substantial American investments. The following section will discuss how European industry tried to deal with these developments.

\section{American investments in Europe and the ELEC}

From the second half of the 1950s onwards, American companies bought participations in existing European firms, or established on a large scale their own subsidiaries. By 1963 the investments started to result in expressions of concern in

389 ELEC (1969). The Inter-European industrial, technical and scientific agreements : concrete measures with a view to developing them (Vol. 47). Brussels: ELEC, pp. 9-10, 167-168, 205-219. See for more details on such forms of cooperation: Zaleski \& Wienert (1980). Technology transfer. 
Western Europe. As discussed above, initially the French government but later also voices in other Western European countries began to perceive the size of American companies as a threat. The much smaller European companies were thought to be unable to withstand such competition. The successful liberalization movement of the 1950s, fully in line with the dominant ideas in ELEC and the Bilderberg meetings, had now resulted in a large European market that formed an excellent basis for competition from companies from the United States. ${ }^{390}$

In 1967, the French press tycoon Jean-Jacques Servan-Schreiber published a widely read book, titled Le Défi américain that offered an alarming analysis of what he called the American takeover of European industry. According to him, Europe's approach to organization, management and innovation was hopelessly out-dated and was unable to cope with American dynamism. The book was a response to the French President's protectionist reflex. Since 1963, de Gaulle had tried to obstruct American investments. According to Servan-Schreiber Europe should instead improve its capacity to compete. According to him a clear choice existed between protectionism and taking up the challenge posed by the American firms. ${ }^{391}$

ELEC started working on these questions even before Servan-Schreiber conveyed his worries. Its work on this subject developed along two parallel tracks from 1964 onwards. The first was concerned with the creation of larger European firms, or in other words, on how to initialize an industrial concentration process in the European market. The second involved the question whether American investments could be slowed down or at least American use of European capital could be reduced.

\section{European industrial concentration}

The initial request to investigate how to kick-start industrial concentration on the European market came from Jean Dupin, leader of the aluminium and chemicals producer Péchiney, and president of ELEC's economic commission. In October 1964 he asked the Central Council to study the introduction of a new European company law. The idea of a European company law was not new or innovative and originally stemmed from the Dutch professor Pieter Sanders who had first proposed it in 1959. However, at that time it was not associated with the need for industrial concentration. The plan involved a new legal structure for European companies and was designed to simplify transnational mergers by laying down a European Community-wide body of rules. In legal terms it enabled actual transnational mergers instead of the until then customary transnational holding constructions. The framework was meant to exist alongside the differing national laws that were already in place. The plan proposed to leave firms the choice to adopt the

\footnotetext{
390 On ELEC's work on American investments, also see Dumoulin \& Dutrieue (1993). La Ligue, pp. 154157.

${ }^{391}$ Servan-Schreiber, J. J. (1967). Le Défi américain. Paris: Denoël.
} 
legal structure that suited their purposes. It was presented as an option instead of a requirement. 392

Already in June 1960 the Central Council of ELEC had asked its national sections to become involved in exploring the subject during the International Congress for the creation of a European commercial company type. The national sections however regarded this more as a technical issue of integration than as a requirement for their operations. All sections had reservations, but the German and Dutch sections were outright opposed. The German section wondered whether it fulfilled a need at all, since industry itself was not asking for a new corporate law. Additionally, on behalf of the Dutch section, Hein Wertheimer, legal advisor to the Dutch electronics firm Philips raised issues of legal practice. According to him the introduction of a European company law hardly meant that it would be applied equally in national courts. More importantly however, he feared that a European company law might open the door to elevating to a European level the German practice of giving rights of co-determination to employees. Additionally, because the Dutch ELEC section also included representatives of Dutch unions who favoured such a development, Wertheimer rejected any association of ELEC with the Congress. He feared the emergence of political issues within his section, which he wished to avoid at all costs. ${ }^{393}$

Despite the strong opposition, Jean Dupin in October 1964 insisted on repeating the investigation. This time he felt it should be studied in the light of the new circumstances of growing American investments and the required response of European industrial concentration. Personally asking the national sections to consider his idea once more, he presented them with a questionnaire that was permeated with Euro-protectionist sentiments: "Would it [the European company type] constitute a means of defence against the outside threats of invasion?"394

However, with the exception of the French section all important national sections once again turned down the idea. The UK section simply declined and the Dutch and Belgian sections conveyed their unchanged views. Paul van Reepinghen, the legal advisor of the Fédération des Industries Belges, had characterized the "creation of a new European company type of a supra national character" as a project which [...] "marks a utopian cult." Instead he preferred a different approach,

\footnotetext{
392 CEHECLIN, LECE, inv. nr. 749, 13-10-1964, Conseil Central du 02-10-1964, pp. 6. Thompson (1969). The Proposal, pp. 9-10, 39.

393 Wertheimer even implied that Pieter Sanders himself was a proponent of introducing codetermination on a European scale via the European company law. CEHECLIN, LECE, inv. nr. 660, 2906-1960, Congress International pour la création d'une société commerciale de type Européen, Palais de Justice de Paris, 16, 17, 18 juin 1960, pp. 2-3, 22-12-1960, Yvonne de Wergifosse to Paul Krebs, \& 2803-1960, Hein Wertheimer to Lucien L. Sermon, 19-04-1960, Hein Wertheimer to Lucien L. Sermon, pp. $2-3$.

${ }^{394}$ CEHECLIN, LECE, inv. nr. 749, 13-10-1964, Conseil Central du 02-10-1964, pp. 6. "Constituerait-elle un moyen de défense contre les menaces d'envahissement extérieur?; inv. nr. 749, 13-10-1964, Questionnaire adressé aux Comités nationaux. Creation de Sociétés de Type Européen, p. 3; inv. nr. 661, 17 12-1964, Yvonne de Wergifosse to Jean Dupin, p. 2.
} 
the harmonization of national company laws. On behalf of the German section, Paul Krebs of Deutsche Bank expressed fears that if the plan was presented as overtly directed against American investments, it might evoke a response in the United States that could hurt investments of German multinationals abroad. Moreover, he explained that American companies "would not hesitate to make use of this instrument, thereby even more being able to strengthen their power of competition vis-à-vis companies of genuine European origin." He did not imply that a European company law wás a protectionist instrument, but the fear that it might come across as such was larger than the benefits it might pose. Krebs remarks reveal a taboo on suggesting even the smallest hint of protectionism vis-à-vis the American government. 395

Instead of pursuing the proposal of a European company law further the Central Council launched an investigation on the views of company experts on industrial concentration. From February 1965 onwards, ELEC's Economic Commission contacted the management of several companies and organized sessions in which recent experiences with mergers and extensive corporate cooperation within the EEC were shared. The investigation took more than a year and was concluded in March 1966. An interesting outcome was that often psychological problems between the different nationalities and related misunderstandings about daily practicalities stood in the way of the well-functioning of industrial cooperation or mergers. The main result was that fiscal differences between countries were seen as the biggest stumbling bloc, particularly the issue of double taxation. ${ }^{396}$

Indeed, double taxation could make transnational mergers unattractive. When companies merged across borders they were liable to taxes for capital moving from one balance sheet to the other. Moreover, subsidiaries were taxed locally on generated profits and again on capital transferred from subsidiaries to the parent firm. According to the ELEC the removal of fiscal obstacles would be the quintessential problem-solver for the European concentration process. ${ }^{397}$

The consensus within ELEC came about despite the alternative proposed by Jean Dupin of Péchiney, which was supported by René Boël, president of the ELEC and of Solvay \& Cie. When the investigation on concentration started Boël personally wrote to Max Nokin, Governor of the Société Générale de Belgique, and expressed his regret that the ELEC had not agreed on proposing a European company law but

\footnotetext{
395 “Personnellement, j'estime que la création d'une société nouvelle de type européen, de caractère supra national ou venant s'ajouter aux variétés de sociétés déjà existantes, et, aujourd'hui, marquée du culte de l'utopie." CEHECLIN, LECE, inv. nr. 661, 04-11-1964, Paul van Reepinghen to Grosfils, p. 1; inv. nr. 661, 23-12-1964, Paul Krebs to Yvonne de Wergifosse, pp. 4-5; inv. nr. 661, 3-12-1964, H. W. Wertheimer to Yvonne de Wergifosse.

${ }_{396}$ CEHECLIN, LECE, inv. nr. 750, 18-02-1965, Conseil Central Elargi du 6 Février 1965, p. 8; inv. 752, 24 03-1966, Réunion Commission Économique 18-02-1966, pp. 5-6; Economic Commission, 18-02-1966, Concentration of Enterprises: Presentation by Mr. Hooglandt, p. 7; 24-03-1966, Synthèse des Réponses au Questionnaire sur la Concentration des Entreprises, p. 9; 24-06-1966, Conseil Central Elargi, pp. 8-9, including, Resolution La Dimension Des Entreprises, pp. 1-2.

${ }^{397}$ Rollings, N. (2007). British business, pp. 246.
} 
instead was exploring different means to stimulate industrial concentration. Even after ELEC's consensus on fiscal harmonization emerged, both Boël and Dupin remained interested in a European company law. ${ }^{398}$

To explain their views, some insights from the Club de l'Industrie Chimique are again helpful. Already during meetings in July 1963 and 1964, the leaders of the chemical industry had expressed concerns about the American investments in the European chemical sector. In March 1965 the French government requested the European Commission to develop a European commercial company law. It was meant to provide an alternative to the diverging national company laws which according to the French government were inhibiting transnational mergers. The resulting concentration of European industry would be required for competing with the large American firms. The Club de l'Industrie Chimique responded promptly and started a study on the ins and outs of the French proposal. A year later, in July 1966, Boël made clear why he had been pushing for a European company law in the European League for Economic Cooperation since 1960. He "insisted" on its importance: "In effect, the [chemical] companies must be of such a size that they can finance the heavy spending of research to address the American competitors, which would be difficult if there were no European company law."399

The European chemical sector was convinced that only a far-reaching step of European integration would enable them to compete with American firms. By legally integrating their subsidiaries within the EEC they could limit costs and easily merge operations. In other words, now that the European market was more and more liberalized, they required the legal flexibility to adapt their organizations to the changing circumstances.

\section{Financial protectionism}

Besides the question of European industrial concentration, the European League for Economic Cooperation also paid attention to the financial dimension of the large amounts of dollars that were pouring into Europe. In that process however, industry and the financial sector found themselves in opposite camps. A reason for the ELEC to investigate the subject emerged with a speech that the French President

\footnotetext{
398 CEHECLIN, LECE, inv. nr. 661, 17-12-1964, Yvonne de Wergifosse to Jean Dupin, p. 2.

${ }^{399}$ For the same reason Boël made Solvay a joint stock company. See Bertrams, K., Coupain, N. \& Homburg, E. (2013). Solvay: history of a multinational family firm. Cambridge: Cambridge University Press, Chapter 17. Private Archive Solvay S.A., Binder Cercle PV1, 11-07-1963, Minutes Club de l'Industrie Chimique, Réunion de Bruxelles, le 5 juillet 1963, pp. 9-11, \& 24-07-1964, Minutes Club de l'Industrie Chimique, Réunion de Francfort, le 3 juillet 1964, pp. 3-5.20-07-1965, Aide-Mémoire, p. 1. 05-07-1966, Minutes Club de l'Industrie Chimique, Réunion á Londres, le vendredi 1er juillet 1966, pp. 1-5. "Le Baron Boël insiste sur l'importance de l'élaboration d'un statute pour une société européenne. En effet, les enterprises doivent être d'une dimension telle qu'elles puissent financer les lourdes dépenses de recherche pour faire face aux concurrents américains, ce qui serait difficult s'il n'existait pas de société de droit européen"; Rollings (2007). British business, pp. 242-245; Thompson (1969). The Proposal, pp. 9-13, 39.
} 
Charles de Gaulle gave on the 4th of February 1965 about the increasing deficit on the US balance of payments. As a result of dollar-gold convertibility in the Bretton Woods monetary system, the United States were in a position to maintain deficits on their balance of payments without immediate effects. De Gaulle linked this circumstance to the capacity of American companies to invest in Europe and reasoned that therefore they had more access to capital than European companies. De Gaulle felt this was a form of unfair competition. The ELEC immediately instructed its monetary commission to investigate the relation between movements of capital and American investments in Europe. The commission was headed by Hermann J. Abs, chairman of the board (Vorstandsprecher) of the investment bank Deutsche Bank and one of the most influential bankers in Europe at the time. Boël stipulated that Abs should focus the work of his commission on European problems and a monetary union of the six. ${ }^{400}$

However, approximately four months later in June 1965, Boël intervened. He demanded from Abs to transfer the topic that he was studying in the monetary commission to the more industry-focussed economic commission of ELEC. Boël no longer believed that the investments from the United States required a monetary approach, and felt that the resulting study had to be compatible with two other explorations that were being conducted within the ELEC; the previously described study on the concentration of enterprises and one on European company law, which Boël did not rule out yet. The Frenchman Jean Dupin of the aluminium and chemicals firm Péchiney, Boël's colleague in the chemical sector, would then in effect inherit the study. ${ }^{401}$

The reason for Boël's intervention becomes clearer if we look to his activities within the Club de l'Industrie Chimique. As explained, the competition by American firms was high on its agenda. In July 1963 and 1964 leaders of the European chemical industry complained that American competition was disturbing European cartels and created scarcity in the labour force. Moreover, they deplored the fact that European governments were offering incentives to attract American competitors. As a result, Boël and others started contemplating the option of somehow limiting or channelling the investments from the United States, but out of fear of an American protectionist response to their own investments in that country, the matter was not pursued. 402

In July 1965 however, the chemicals producers discussed the effects of a policy of the American government that had been introduced in 1963: the interest

\footnotetext{
400 Kuisel (1993). Seducing the French, pp. 171-175. CEHECLIN, LECE, inv. nr. 750, 18-02-1965, Conseil Central Elargi du 6 Février 1965, p. 4. On Hermann J. Abs see Gall, L. (2004). Der Bankier Hermann Josef Abs: eine Biographie. München: Beck.

${ }^{401}$ CEHECLIN, LECE, inv. nr. 554, 30-04-1965, Hermann J. Abs to René Boël; inv. nr. 554, 22-06-1965, René Boël to Josef Hermann Abs.

${ }^{402}$ Private Archive Solvay S.A.., Binder Cercle PV1, 11-07-1963, Minutes Club de l'Industrie Chimique, Réunion de Bruxelles, le 5 juillet 1963, pp. 9-11; 24-07-1964, Minutes Club de l'Industrie Chimique, Réunion de Francfort, le 3 juillet 1964, pp. 3-5.
} 
equalization tax on portfolio investments. Dollars flowing out of the United States were taxed if they were intended for taking participations in companies abroad. In this way the American government had hoped to limit the growing shortages on the US balance of payments. The availability of dollars for investments in Western Europe dropped sharply. However, the law did not stop American multinationals from continuing to invest in Europe. Instead, they were increasingly taking recourse to European capital which triggered a price increase, so the European chemical industry noted. By July 1966 the shortage of European capital was causing frustration inside the Club. Boël explained that all the members of the club should start active lobbies via the European industrial federations in order to "draw attention to the importance of American investments in Europe and to demand that the European capital markets would be more protected against the Americans." 403

These preoccupations of the European chemical industry places Boël's intervention in Abs' monetary commission in a different light. As one of the leaders of the chemical sector he wanted the ELEC to consider the industrial viewpoint on European monetary relations and capital markets, instead of the banker's perspective. Abs refused. He would only accept a transfer of the mission of his commission to an ad hoc panel with another banker in charge, the Belgian Louis Camu of Banque de Bruxelles. 404

As a result the Ad Hoc Commission on American investments was created. However only few industrialists were included and it was still dominated by industrial investors and bankers. The subject that underpinned its assignment was the question whether and how intervention in the European capital market should be organized to limit the American investments. Within ELEC the decision-making on the subject remained firmly in the hands of the banking sector. ${ }^{405}$

The Ad Hoc Commission met in October 1965. Surprisingly, despite concerns about American competition all participants agreed that the European economies required American investments. However, several of them felt mistreated by their own governments. Particularly men from the chemical industry, Bakker from the Dutch artificial fibres producer $A K U$, and Noan, of the French Péchiney, but also Meimberg of Deutsche Bank and Pulinckx of the Federation of Belgian industry, indicated their frustration with government-subsidies to attract American firms.

\footnotetext{
403 "attirer l'attention sur l'importance des investissements américaines en Europe et demander que les marchés européens des capitaux soient plus protégés contre les Américains." Private Archive Solvay S.A., Binder Cercle PV1, 20-07-1965, Aide-Mémoire, p. 1; 05-07-1966, Minutes Club de l'Industrie Chimique, Réunion á Londres, le vendredi 1er juillet 1966, pp. 9-11. Kurgan-Van Hentenryk, G., Brion, R. \& Moreau, J-L. (2000). European banks since the second world war (1944-2000). In H. van der Wee \& G. Kurgan-Van Hentenryk, G. (Eds.). A history of European banking (pp. 363-393). Antwerp: Mercatorfonds, p. 367.

${ }^{404}$ CEHECLIN, LECE, inv. nr. 554, 22-07-1965, Y. de Wergifosse to René Boël.

${ }^{405}$ CEHECLIN, LECE, inv. nr. 554, 21-10-1965, Compte rendu Résumé de la réunion du 19 octobre sur les investissements étrangers en Europe, p. 1.
} 
According to them European governments should at least guarantee equal treatment of all firms. That conclusion was shared by James van Luppen, an administrator for the American Ford cooperation in Belgium. He agreed that American investments should not be stimulated by governments, but he also warned against any government interference against investments. According to him these investments were improving the European living-standard and the productivity of European enterprises. As a result, the removal of all governmental incentives, or in other words, the creation of a level-playing field, was one of the main conclusions of the meeting. ${ }^{406}$

However, the key issue discussed during the meeting was the effect of American investments on the European capital markets. The Frenchman Geniteau from the Banque Nationale pour le Commerce de l'Industrie (BNCI) explained that multinationals from the United States had more access to capital from their home market, while simultaneously they were also creating shortages on European national capital markets, for example in France, where savings were insufficient to fulfil increasing demands in industrial finance. He asked for improvements on the European capital market so that European firms would have less disadvantages vis-àvis the Americans. Camu however explained that this was not such a simple endeavour, as most appeared to think. According to him numerous adaptations and cooperation in national economic policies would be required to create a working capital market in the first place. To his frustration, the European Community member states refused such measures. Finally, backed by Meimberg of Deutsche Bank, Camu firmly denounced to solve the industrialists' problems by rushing into the creation of an imperfect European capital market. He moreover felt that the American move to restrict the export of dollars should be seen as an attempt to contribute to a solution of a complex problem of global dimensions: the increasing shortage on the American balance of payments. He brushed aside the implicit and explicit suggestions of protectionist elements in a future European capital market,

\footnotetext{
${ }^{406}$ CEHECLIN, LECE, inv. nr. 554, 21-10-1965, Compte rendu Résumé de la réunion du 19 octobre sur les investissements étrangers en Europe; inv. nr. 554, 28-10-1965, Commission Ad Hoc sur les investissements. The Ad Hoc Commission involved the following participants: Austria: Georg Zimmer-Lehmann (Creditanstalt-Bankverein). Belgium: Louis Camu (Banque de Bruxelles), Snoy et d'Oppuers (Groupe Lambert), Michel Grosfils (Banque de Bruxelles), René Lamy (Société Générale de Banque), Raymond Pulinckx (Fédération des Industries belges), Van Luppen (Ford Belgium). France: Pierre Dieterlen (Centre National de la Recherche Scientifique), Geniteau (Banque Nationale pour le Commerce de l'Industrie), Gildas le Noan (Péchiney). Germany: Rudolf Meimberg (Deutsche Bank), Kurtz (unknown). The Netherlands: E. Bakker (AKU), M. van der Velden (Algemene Bank Nederland). Spain: Ismael LopezNugnoz (unknown), Felipe Navalpotro (Banco Central), Julio Tejero (Banco Hispano Americano). Sweden: Bengt Rydén (Economist). Switzerland: Jakob Ittensohn (Schweizerischen Bankverein). United Kingdom: F. V. Corfield (Member of Parliament Conservative Party), Edward Hulton (publisher), Geoffrey Rippon (Member Conservative party, currently no position), Dennis Walwin Jones (ELEC); inv. nr. 751, 3-11-1965, Commission Ad Hoc sur les investissements étrangers en Europe, pp. 1-2.
} 
as if they were an inappropriate response to measures of such a global magnitude. 407

Camu's response can moreover be seen as an expression of the conditions under which the European banking sector was operating. Since the 1950s American banks had established subsidiaries in Western Europe with which the European banks were in competition. In such a context it was difficult to envisage how preferential access to capital for European industry would work. Moreover, European banks were also in a position to provide capital to American corporations. Preferential access to capital for European firms would put the American customers at a disadvantage. ${ }^{408}$

What then were the conclusions of this exchange of views? In effect, Camu had personally shielded ELEC's monetary commission from future involvement by European industrialists and by French financiers of industry who wished to explore protectionist options through the organization of a European capital market. Instead he, and his colleague at Banque de Bruxelles, Michel Grosfils, concluded that the problem that could actually be addressed was the size of American firms. They proposed two approaches to remedy the resulting competition problems in Europe. The first was to request from American multinationals to follow certain game rules or develop cooperation, about which Louis Camu felt that it would have to be addressed on a transatlantic level, perhaps even through NATO diplomacy. The second suggestion effectively transferred back the entire matter of American investments to the study on industrial concentration in the economic commission: to resolve fiscal, legal and administrative disparities within and outside the EEC in order to facilitate a European concentration process. 409

The ELEC did not adopt a protectionist attitude even though there were pressures from France and the chemical industry which found itself in open competition with American multinationals. When options or views that vaguely referred to a protectionist attitude were on the table, they were quickly renounced out of fear to stir up counter-protectionist sentiments across the Atlantic. The achievements of the liberalization drive of the 1950s were ultimately not undermined.

\section{American Investments in Europe and the Bilderberg meetings}

In the Bilderberg meetings the key questions were similar to those in the European League for Economic Cooperation: to accept the American challenge as articulated by Servan-Schreiber, and to protect European corporations against the giant US-

\footnotetext{
407 CEHECLIN, LECE, inv. nr. 554, 21-10-1965, Compte rendu Résumé de la réunion du 19 octobre sur les investissements étrangers en Europe, pp. 1-5; inv. nr. 554, 28-10-1965, Commission Ad Hoc sur les investissements, pp. 1-26.

${ }^{408}$ Kurgan-Van Hentenryk, Brion \& Moreau (2000). European banks, p. 380.

${ }^{409}$ CEHECLIN, LECE, inv. nr. 554, 28-10-1965, Commission Ad Hoc sur les investissements, pp. 20-21, 25-26.
} 
companies. As discussed in chapter 4, some doubts had emerged during the Bilderberg meetings of the early 1960s when the issue was raised whether the transatlantic post-war consensus about liberalizing markets was still intact. The meetings of 1965, 1967 and 1968 discussed the American investments. At these occasions, tensions emerged between the European and the United States' members as a result of entirely different perceptions of how multinational companies ought to behave when operating abroad. ${ }^{410}$

\section{Capital markets}

The first time that tensions on the topic of American investments emerged in the Bilderberg meetings, was in April 1965. The conference discussed only two subjects: the security related "State of the Atlantic Alliance", and "Monetary Cooperation in the Western World", which was of course linked to the subject of American investments in Western Europe. Also in the Bilderberg meetings the growing deficit of the US balance of payments motivated the choice of that topic. The Dutchman Emile van Lennep, chairman of the OECD working party on international balance of payments-problems, explained in an introduction that the deficit was mainly caused by the American expenditures for the Vietnam war and by developmental aid. The deficit posed a threat to the long-term stability of the monetary system and the meeting was geared towards identifying possible solutions. ${ }^{411}$

Nonetheless, the subject was repeatedly hijacked by French participants. They disagreed with van Lennep's interpretation of the main reasons for the United States' deficit-problems. They attempted to frame the deficit as an expression of out of control private US investments in Europe. The French were not against investments: they agreed with the rest of the speakers that they were "wholesome", thereby particularly welcoming the export of American "know-how." Nevertheless one of the French speakers asked the conference to consider restricting those investments, or limit them selectively. According to him, the dollars should be directed "to fields where new techniques and means of production were necessary, while avoiding those where fresh investments in markets already saturated were likely to disrupt the economy unduly." These remarks most probably must have come from Jacques Baumel, an important Gaullist, who fully confirmed the interventionist and protectionist style of de Gaulle's actions against American investments since 1963.412

\footnotetext{
${ }^{410}$ Servan-Schreiber (1967). Le Défi américain.

${ }^{411}$ NOW, abt. 72 RWWA, inv. 72-374-4, Bilderberg Meetings (1965). Villa d'Este conference, 2-4 April, 1965. Sl.: Bilderberg Meetings, pp. 22-24.

412 It is not possible to verify whether the remark indeed was made by Jacques Baumel. Kuisel (1993). Seducing the French, pp. 163-164, 171-173. The French participants were:, Jacques Baumel (politician, important organizer of the Gaullist Movement), Wilfrid S. Baumgartner (Rhône Poulenc), Paul Huvélin (Société générale d'exploitations industrielles), Jean A. F. Lecanuet (Politician, Centre Démocrate), Robert E. Marjolin (European Commissioner Economy and Finance) and Pierre-Paul Schweitzer (Direc-
} 
Other Europeans were more keen on improving circumstances in the European economy in order to equip firms better for competition, instead of blocking American competitors. Participants from Belgium and Norway for example proposed to realize an actual European capital market to utilize surplus savings more effectively, and decrease Western European dependence on dollars. A Dutchman and an Italian confirmed this attitude of independence: "While many European industrialists might see cause for anxiety in certain American investments, the answer to the challenge should be found by Europe in her own energy and potentialities." They felt that mergers and European cooperation in scientific and technical research were the solution for withstanding American competition. In other words, a commitment to free competition was affirmed. Reservations about the liberal economic order between the European and American markets remained limited to the French Gaullists. ${ }^{413}$

\section{Strength through unity}

Different than in 1965, the Bilderberg meeting of April 1967 addressed the transatlantic tensions through a planned and dedicated session. European worries about American investments had not subsided but had shifted to the question whether Europe itself was still capable of doing original and path-breaking research when American corporations were buying their assets? The American section of the Bilderberg meetings saw this as an opportunity to set the record straight. In October 1966, George Ball pushed the steering committee to select this topic for the next meeting, as he aimed at forestalling European worries. Strikingly, roughly a third of European and American participants of the conference were leaders of multinational industry and finance. ${ }^{414}$

tor of the IMF). NOW, abt. 72 RWWA, inv. 72-374-4, Bilderberg Meetings (1965). Villa d'Este conference, 2-4 April, 1965. Sl.: Bilderberg Meetings, p. 23.

${ }^{413}$ NOW, abt. 72 RWWA, inv. 72-374-4, Bilderberg Meetings (1965). Villa d'Este conference, 2-4 April, 1965. Sl.: Bilderberg Meetings, p. 24.

${ }^{414}$ RWWK, NOWA, inv. nr. 72-372-5, 10-10-1966. Otto Wolff von Amerongen-Fritz Erler pp. 3-4. Belgium: J. C. Snoy et d'Oppuers (Banque de Lambert). France: Wilfrid Baumgartner (Rhône Poulenc), Ambroise Roux (Compagnie Générale d'Electricité). Germany: Otto Wolff von Amerongen (Otto Wolff), Kurt Birrenbach (August-Thyssen Hütte) Hans L. Merkle (Robert Bosch). Greece: Stavros Niargos (Shipowner). Italy: Giovanni Agnelli (Fiat), Aurelio Peccei (Italconsult), Leopoldo Pirelli (Pirelli), Netherlands: Ernst H. van der Beugel (multiple companies), Johannes Meynen (AKU). Norway: Leig Höegh (shipowner), Otto Grieg Tidemand (shipowner). Sweden: Marcus Wallenberg (Skandinaviska Enskilda Banken). United Kingdom: Charles R. Wheeler (Associated Electrical Industries), Lord Roll of Ipsden (S. B. Warburg \& Co.), Lord Kearton of Whitchurch (Courtaulds), Arnold Hall (Hawker Siddeley Group), David H. Barran (Shell Transport and Trading Company), Lord Shawcross (Morgan Guranty Trust Company of NY). 21 of 59. USA: Henry J. Heinz (Heinz), George W. Ball (Lehmann Brother Kuhn Loeb), David Rockefeller (Chase Manhattan), Robert D. Murphy (Corning Glass), Arthur H. Dean (Sullivan \& Cromwell), Emilio Collado (Exxon), Harold van B. Cleveland (First National City Bank), Antonie T. Knoppers (Merck Sharpe \& Dohme), John Diebold (Diebold Group), Emanuel R. Piore (IBM). (10 of 29) 
The subject was introduced by an Americanized Dutchman, Antonie Knoppers, of the company Merck Sharp and Dohme that was active in the research intensive pharmaceutical sector. Having little sympathy for European vulnerabilities vis-àvis US investment power, his message was clear: Europe should remain open to US investments. While he understood the "anxiety of foreign (U.S.) dominance" as a result of a " 'take over' of national industries by [...] U.S. world companies", he believed that the deterrence of US investments would hamper the transfer of technological knowledge. He was convinced that Western Europe required American investments to learn how to manage research and how to exploit research through product development. Moreover, according to Knoppers, Europeans should emulate the American system of education: instead of catering to the elites, it should offer opportunities to a larger group. Furthermore, he considered it essential to increase the dimensions of European companies through mergers. Similar to his sector-colleagues Baron Boël and Jean Dupin in the ELEC, he felt that mergers should be facilitated by a uniform European company law, including harmonization of taxes, monetary conditions and other regulations. According to Knoppers American investors were unduly asked to soften their aggressive approach. Instead Western Europe should adapt its market to help European industry face these developments. 415

The Europeans were agitated. They felt that Knoppers had left out from his analysis a crucial source of American scientific and technological progress. According to them corporations from the United States were taking advantage of the innovations that were fuelled by government expenditures for the purpose of defence and the space program. Otto Wolff von Amerongen observed that the leaders of American business disliked being reminded about the fact that 60 per cent of total American expenditures on research and development came from government programmes. ${ }^{416}$

Despite this disagreement on the cause of the differences between Western Europe and the United States, a shared outlook developed about how the transatlantic industrial disparities should be equalized. Several approaches were discussed like countering the European brain-drain to the United States, Knoppers' suggestion to change the European approach to education, or to actively pursue European "spin-off" effects from large-scale government-sponsored research. However, the approach on which all participants settled was "European unity": to continue on the path of integration! Nobody doubted that Europe required a large

\footnotetext{
415 RWWK, NOWA, inv. nr. 72-372-5. Knoppers, Antonie: The technological gap between America and Europe with special reference to American involvement in Europe (1967), pp. 2-3, 5, 21-22.

416 From 1957 and 1966, total expenditures in the United States on industrial research and development amounted to \$ 157.7 billion, against \$ 50 billion in Western Europe. However, 57\% of American expenditures was spent by the US Department of Defence, NASA and the Atomic Energy Commission. According to Van der Wee, no direct link existed between this source of funding and American industry, but it "broadened and deepened the scientific base of industry." Wee (1987). Prosperity and upheaval, pp. 202-203. RWWK, NOWA, inv. nr. 72-372-5, 03-04-1967, Otto Wolff - Dr. Billigmann, etc.
} 
market area and far-reaching common policies which in combination would create the appropriate pressures for a concentration process. Moreover, in light of encouraging European transnational mergers, the need for improved European capital markets, and indeed, a European common market as had been intended in the Rome Treaties, was generally acknowledged. But these could only become a reality if the Western European states, not just the member states of the European Communities, would find unity in their political affairs. The American participants made one thing absolutely clear though: according to them "political union" should not include any interventionist action that would involve forcing the different national industries into pan-European industries. Instead, they wanted enterprises to act on their own. So, the Western European and American multinationals agreed on increasing competition and flexibility on the European market in order to facilitate European corporations to grow and increase their ability to do research. ${ }^{417}$

\section{A code for multinationals}

During the meeting in April 1968 the problem of American investments was again on the agenda, but this time it was informed by a debate on the effects that American multinationals were having on the sovereignty of states. The discussion revolved around the possibility of establishing a code of conduct for multinationals. This time, nearly half of all the participants from Europe and the United States were leaders of large companies. 418

George Ball again played a role in the conference and delivered the introductory paper. Recently his career as advisor to the Presidents John F. Kennedy and Lyndon B. Johnson had ended, and he now had taken a position at the investment bank Lehmann Brothers Kuhn Loeb. From his frank, direct and nearly euphoric presentation of free trade conceptions it seems that his positions in the highest circles of government had muzzled him at earlier occasions. For those familiar with

${ }^{417}$ RWWK, NOWA, inv. nr. 72-372-5. Bilderberg Meetings (1967). Cambridge conference, 31 March- 2 April, 1967. Sl.: Bilderberg Meetings, pp. 30-31, 35-36.

${ }^{418}$ Belgium: Louis Camu (Banque de Bruxelles), J. C. Snoy et d'Oppuers (Banque Lambert), Jacques E. Solvay (Solvay \& Cie.). France: Wilfrid M. Baumgartner (Rhône Poulenc), Edmond de Rothschild (Compagnie Financière du Groupe), Jacques Fouchier (Banque de Paris et des Pays-Bas). Germany: Otto Wolff von Amerongen (Otto Wolff). Fritz Berg (Bund Deutschen Industrie), Kurt Birrenbach (August-Thyssen Hütte), Dieter Spethmann (August-Thyssen Hütte). Greece: Stavros Niarchos (Shipowner). Italy: Aurelio Peccei (Italconsult), Leopoldo Pirelli (Pirelli), Umberto Agnelli (Fiat), Roberto Olivettie (Olivettie \& Co.). Netherlands: Ernst H. van der Beugel (multiple companies), Frits C. Karsten (AMRO Bank), Norway: Leif Höegh (shipowner), Otto Grieg Tidemand (shipowner). Sweden: Björn Lundvall (Telefonaktiebolaget/Ericsson). Switzerland: Victor H. Umbricht (Ciba Geigy). United Kingdom: Duncan M. Oppenheim (British American Tobacco, rtrd. 1966), Maurice Bridgeman (British Petroleum). 23 of 54 Europeans. USA: Henry J. Heinz (Heinz), George W. Ball (Lehmann Brother Kuhn Loeb), David Rockefeller (Chase Manhattan), Gabriel Hauge (Manufacturers Hanovers Trust Co.), Robert D. Murphy (Corning Glass), Arthur H. Dean (Sullivan \& Cromwell), Emilio Collado (Exxon), Henry Ford II (Ford Motor Company), Thomas S. Gates, (Morgan Guarantee Trust), J. Ward Keener (B.F. Goodrich Company) John T. Ryan (Mine Safety Appliances Company). 11 of 22. 
public criticisms directed at multinationals, Ball's contributions come across as a hagiography of the virtuous characteristics that multinationals had to offer the world. He used the term "world companies" and praised their ability to shape "policies not in terms of national economies but in terms of the overall world economy." Nevertheless, he understood the need for reconciliation between international firms and national interests and asked the question: "where was there a legitimate base for the power of corporate management to make decisions that could profoundly affect the economic life of nations"? 419

However, instead of acknowledging the state's prerogative to force companies to follow certain rules, he proposed to create the missing legitimate base: lifting the multinationals and their subsidiaries out of national legal frameworks and to subject them to an "international companies law" instead. This law would be established by treaty and enforced by an international body of national representatives from countries that had signed the treaty. In combination with widely dispersed shareholder ownership the legal framework would start a process of "internationalizing or denationalizing the parent", to reduce suspicion about the loyalty of any firm to any state. Ball believed in the force of such "new world instrumentalities" [...] "to stimulate mankind to close the gap between the archaic political structure of the world and the visions of commerce that vault beyond confining national boundaries." In fact, he wanted to free the multinationals from national differences and particularities, to create the ultimate level playing field, for all multinationals at the same time. George Ball's code was to replace all potential codes with one, thereby significantly simplifying the international landscape. Needless to say this vista would strengthen the already favourable position of the giant American corporations. On the other hand, in Ball's proposal the fact that they were American multinationals would de jure seize to have any relevance at all. ${ }^{420}$

In light of this utopian dream of the ultimate freedom of entrepreneurship, Ball pleaded for more European integration on social, fiscal and legal regulations, to facilitate international mergers so that "European companies will achieve the scope and resources needed to serve our modern world economy with full efficiency." Additionally, he stressed the need for a European "counter invasion" by investing in the United States which would relieve the disequilibrium of the US balance of payments. A Dutch participant however criticized Ball's remarks, and stressed that the United States itself still had significant regulations in place that were discouraging European investments. ${ }^{421}$

\footnotetext{
${ }_{419}$ Ball, G. (1982). The past has another pattern. New York: Norton. NOW, abt. 72 RWWA, inv. 72-373-1, Bilderberg Meetings (1968). Mont Tremblant conference, 26-28 April, 1968. Sl.: Bilderberg Meetings, p. 38.

420 Ibidem, pp. 37-39.

${ }^{421}$ RWWK, NOWA, inv. nr. 72-373-1. Ball, George W. : Some implications of the world company (1968), p. 8. From the Dutch participants, three active businessmen were present, one of them probably responsible for the remark: Pieter Kuin (Unilever), Frits Karsten (Amsterdam-Rotterdam Bank) and Ernst van der Beugel (multiple companies).
} 
Ball's code also received a reply by Jacques de Fouchier, banker and vice-chairman of the state controlled investment bank La Banque de Paris et des Pays-Bas. Although admitting his satisfaction with the internationalization of business, Fouchier disagreed with Ball about the basic intentions that should underlie an international agreement on multinational corporations. While Ball regarded an international code for multinationals as an instrument to free the world corporations from excessive governmental interventionism, Fouchier wished to use it "to emphasize their duties as citizens of the individual countries in which they were operating." He explained the problems that American companies were causing, such as large investments in industries of strong national interest, thereby endangering the existence of national firms in those sectors, reserving higher management jobs for American employees, concentrating research in the companies' home country, the repatriation of multinationals' profits to the home country, leaving behind the host countries with a vulnerable balance of payments, and unstable capital markets. ${ }^{422}$

Indeed, he pleaded for an international agreement on multinationals that did not merely improve the position of the company, but also the position of the countries where they invested. According to Fouchier, foreign companies should embrace competition instead of engaging in its elimination and they should grant their national competitors access to their scientific and technological advances. He also demanded more relevant jobs for employees of foreign affiliates, such as management positions and research. Additionally, and of key importance, companies should change their financial structures in such a way that their capital would become distributed globally instead of mainly in the companies' home country. He complained that American companies with subsidiaries in France were transferring funds back to the United States instead of investing it in France. In other words, what Fouchier proposed was to curtail the intense competitive behaviour of American firms on European soil. By forcing American firms to act in the local interest, a level playing field would be created between European and American firms in European markets. According to Fouchier the European firms were forced to consider their local environment and now Americans ought to learn their place within the national context. ${ }^{423}$

The proposal by Fouchier only was supported by the Belgian delegation. This consisted entirely of Belgian businessmen, including Jean Charles Snoy d'Oppuers of Groupe Lambert, Jacques E. Solvay of Solvay \& Cie. and Louis Camu of Banque de Bruxelles, in sum a representation of the major industrial holdings of the country. Fouchier's code resembled the conclusions that had been reached by the ELEC working group headed by Louis Camu, about the need for an international code for multinationals. They stressed that a code was necessary but first "a European code for European companies" should be established, thus a code for companies operat-

422 RWWK, NOWA, inv. nr. 72-373-1, Bilderberg Meetings (1968). Mont Tremblant conference, 26-28 April, 1968. Sl.: Bilderberg Meetings, pp. 42-43, 46.

${ }^{423}$ Ibidem, pp. 43, 44 \& 46. 
ing in Europe. In the past years particularly the Belgian government had offered incentives on American investments. As a result Belgium had experienced a high influx of American companies, which explains the position of the Belgian holdings. The rest of the participants to the meeting thought that the enforcement of such a code would be highly problematic. Ultimately the majority declined the option of any code, even George Ball's suggestion of a global level-playing field for multinationals. ${ }^{424}$

Despite the diverging views between the European and American members on how to deal with the imbalances between American firms and European firms, a consensus was closer than would appear from the introductory papers: widespread agreement was expressed about the phenomenon of the multinational company in general. Americans on their part stressed the multinationals' potential to advance economic welfare. More importantly, several unnamed European heads of companies made clear that the phenomenon of the multinational was no "object of controversy." After all they were leaders of multinationals themselves. The commitment to liberal relations between the Western markets remained firm. ${ }^{425}$

\section{Conclusion}

During the 1960s the European League for Economic Cooperation and the Bilderberg meetings explored comparable themes that involved sensitivities among European corporations. But the approach of both networks to the idea of the European market was based on diverging outlooks. In the Bilderberg meetings the European market was no longer discussed as part of the economic pillar of the Western Cold War strategy. Instead the organization of the European market became a contested issue for diverging European and American interests. The Transatlantic membership disagreed on the insurance of export credits to Eastern Europe and the European membership repeatedly felt the need to question the activities of American multinationals on the European market. The ELEC instead discussed how the organization of the European market could be changed to help European corporations to adapt to external competition.

How did the European multinationals' views on the European market change during the 1960s? The focus on liberalization of European and particularly Transatlantic markets was replaced by a new priority: the equalization of conditions of competition on international playing fields. Four different expressions of this pri-

\footnotetext{
${ }^{424}$ RWWK, NOWA, inv. nr. 72-373-1, Bilderberg Meetings (1968). Mont Tremblant conference, 26-28 April, 1968. Sl.: Bilderberg Meetings. Wilkins, M. (1974). The maturing of multinational enterprise: American business abroad from 1914 to 1970. Cambridge: Harvard University Press, p. 343. See for the interrelations between Belgian financial holdings in the early 1960s: CRISP (1962). Morphologie des groupes financiers. Bruxelles: CRISP.

${ }^{425}$ RWWK, NOWA, inv. nr. 72-373-1. Bilderberg Meetings (1968). Mont Tremblant conference, 26-28 April, 1968. Sl.: Bilderberg Meetings, pp. 47, 50-53.
} 
ority can be distinguished. The first was a lobby on reducing the repayment terms for government insured export credits that governments and banks offered to European capital goods producers. Particularly the chemical sector and the ELEC as a whole, including industrial goods producers and banks, lobbied against a preferential treatment of the export interests of the capital goods producers, because that was fuelling the industrialization of the East-bloc at the expense of Western industrial interests. They demanded a limitation of export credit insurance. Because the German government did not offer similar insurance for export loans the German capital goods exporters agreed with the suggestion to limit these facilities in the entire West.

A second expression of this attempt to equalize playing field also concerned trade with the East-bloc and involved the coordination between the economic systems of the East-bloc and Western European markets to enable joint ventures or other forms of collaboration. The goal of these agreements was to involve Eastern European companies and states into good relations with Western European corporations so that they would have less reasons to dump their products on the European market.

Further expressions were related to the dominance of American corporations on the European market. European firms agreed that Western European governments should abolish investment incentives for US companies. Another example lies in the general suggestion within the ELEC to investigate the possibility of code of conduct for American multinationals with activities on the European market. Such a code was thought to reduce the aggressive competitive behaviour of American companies. However, when the subject reached the Transatlantic Bilderberg meetings only the representatives of the major Belgian holdings of industry were committed enough to pursue such a code.

Moreover, it is interesting to note that there wás a broad agreement on levelling playing fields, instead of outright protectionist responses. Whenever a protectionist attitude reared its head, it was quickly brushed aside. The case on the improvement of access to capital for European firms is telling in this regard. Some representatives of European industry felt that European companies should have more access to European capital than American firms. However, European banks refused such discriminatory measures.

In addition to the reduction of inequalities in international competition, European firms also saw a need for transnational concentration of European industry. In order to improve conditions for transnational mergers European multinationals attempted to convince the European Community to adopt new measures in order to facilitate such mergers. Most European corporations agreed that national tax schemes for company mergers in the Community should be reformed and aim at preventing double taxation. However, particularly the European chemical sector preferred the creation of a European company law which would enable to create 
actual European companies in legal terms. Most corporations strongly declined the option of a European company law however.

These changing views vis-à-vis the European market can firstly be explained through changed circumstances in international political economic developments. The French government, which in the 1950s still had been a major driving force behind European integration, obstructed further liberalisation between the European Community and the rest of Western Europe. This forced members of the ELEC and the Bilderberg meetings to rethink their expectations of the European Community and the European market. At the same time the prospect of a large EEC market with a collective external tariff wall led to increased investments from large American multinationals. Their aggressive competition and size forced European multinationals to rethink their priorities. Additionally, competition emerged from the East-bloc by means of state trading companies.

In addition to these changing political and economic circumstances the changes in views can also be explained by an emerging awareness about significant imperfections of the common market. The resulting competition by large American firms required European companies to increase their scale, for instance by transnational mergers. The structure of European firms was originally based on their relatively small national markets. American competition now forced European companies to restructure and adapt to the new reality of a large market. However, the European Community had not provided the necessary transnational legal framework for such solutions. Mergers between companies from different member states were problematic as a result of differing national legal contexts and taxation practices. European firms were thus obstructed in the adaptation process to the new circumstances. As a result, the European chemical industry demanded a uniform company law. Other firms demanded a reduction in taxation. Member states of the European Community however refused to go along with such measures. Path dependencies of European companies ánd a lack of consensus in European Community decision-making therefore prevented that those companies could make a head start: while they were originally ideally attuned to the typically European national idiosyncrasies they now struggled to achieve the same dimensions as their American competitors.

European companies seldom achieved a general consensus on how new developments should be approached. How can such differences be explained? In comparison to the 1950s, the national contexts of firms ceased to really dominate the debates, but they were still relevant for the explanation of some differences. The position of the Dutch multinationals on a European company law can be explained by considering the freedom of entrepreneurship that they depended on. Out of fear that the German policy of co-determination of company decisions by company personnel might be introduced via such a European company law, the Dutch firms held off any involvement with the issue. The views of the German capital goods producers represented by Otto Wolff von Amerongen were also de- 
termined by the national context. The German government refused to offer insurance for export loans to the East-bloc going beyond a repayment term of five years. Other European governments however did insure export loans for longer periods than five years. As a result German capital goods exporters, as already stated above, had a unique perspective on the subject and demanded that other governments adhered to the internationally agreed standard of five years. The support of Belgian holdings for a behavioural code for American multinationals can be explained by the relatively large share of American investments that Belgium experienced.

Several differences in views of multinationals can certainly be explained by the type of industries in which they were operating. Representatives from the chemical sector pushed for a European company law, in order to achieve centralized organisations. Moreover, they were prepared to think along lines of protectionist measures against American investments if this could slow down the advance of their American competitors. At the same time, the banking sector counterbalanced such desires, pointing out the unfeasibility of such plans on a European level. Additionally, tensions developed on export loans for capital goods exports to the East-bloc between producers of industrial products, exporters of capital goods, and the financial sector.

These sector-based differences can be explained through sectoral competitive pressures and specific sectoral features. The chemical industry was already a highly internationalized sector, and since long competed on the basis of innovation capability. The emergence of large American competitors on their European home market forced them to achieve similarly large organisations within the European Community. Only in this way, they thought, the high expenditures on research and development could be financed.

The European banks' unwillingness to contemplate preferential access to capital for European firms can be explained by the competition they experienced from American banks on the European market. On their turn, producers of industrial goods wished to see export guarantees abolished since the financially riskfree capital goods exports were literally building the production facilities of their competition. Such opposed perspectives of sectors make clear that views of business on the organization of the European market often obscure in fact very different interests.

Finally the question arises how these findings relate to the historiography on the place of European business in European integration theory and history? During the 1960s the dominant voice in integration theory was that of Stanley Hoffmann, who argued that European integration solely progressed through intergovernmentalist decision-making processes. According to him, member states, especially the large ones, were in full control of the direction that the European Community would take. This chapter indeed shows that national governments were in a position to resist the requests that European corporations formulated. Even when the multinationals fully agreed, as on the subject of double taxation, they were unable 
to steer the Community in their preferred direction. However, this does not mean that European multinationals were totally absent. As we have seen, they were very capable of connecting to and engaging with the European Commission. A symbiotic relation grew between the ELEC and the Commission, in which the ELEC found a receptive attitude towards their views on European company laws and double taxation. These views inter alia found their way to the earlier mentioned Colonna memorandum on the need for an industrial policy for the European Community in 1970. An important part of this memorandum was the appeal for a transnationalization of European industry via mergers and other forms of collaboration, which required harmonization on company laws and fiscal rules. In fact these were the complaints of European industry that would only be addressed by the European Community during the 1980s in the Single European Act and the resulting Single Market Program. ${ }^{426}$ In the 1960 s there was not enough support within the Council to adopt such measures.

At the same time, the interaction with the multinationals was also beneficial for the European Commission. The latter was able to rely on the ELEC for shaping informal relations of economic diplomacy with East-bloc countries. This permitted to circumvent the formal limits that Community member-states had imposed on the European Commission with regard to matters of external trade policy. In this role the European Commission was also able to shape the attitudes of European multinationals towards a cooperative strategy amongst themselves and with Eastbloc competitors.

Despite this mutually beneficial interaction, the European Commission was however not able to assist European multinationals in their pursuit of international level-playing fields. Mere EEC agreements were not sufficient because Europewide and even Transatlantic agreements were required. Moreover, such agreements would be ineffective because non-EEC countries could take advantage of the constraints that the EEC member-states would place on themselves. European multinationals were therefore forced to turn to the OECD and NATO to cover all the politically sensitive issues and create an as large level-playing field as possible.

\footnotetext{
${ }^{426}$ Hoffmann, S. (1964). De Gaulle, Europe, and the Atlantic alliance. International Organization, 18, 128; Hoffmann, S. (1964). The European process at Atlantic crosspurposes. Journal of Common Market Studies, 3, 86-101; Hoffmann, S. (1966). Obstinate or obsolete? The fate of the nation state and the case of Western Europe. Daedalus, 95, 862-915.
} 


\section{Chapter 6}

\section{European multinationals during the oil crises, 1970-1980}

\section{Introduction}

In the 1950s European multinationals supported the liberalization of Western markets and European economic integration. During the 1960s, in the face of competition on the Common Market, they tried to adapt their own organizations and relevant European regulations, to those new circumstances. The 1970s however posed entirely different challenges. During the economic boom of the 1960s, economic and monetary disequilibria developed that resulted in a monetary crisis, an oil crisis and an economic crisis. Especially the emerging energy shortages and price rises led to upheaval and intense debates between Europe, the United States and Japan. A lack of international consensus on the solutions for international problems raised the spectre of uncertain economic conditions for years to come. The Trilateral Commission was founded in response to the inability of the major industrialized regions to cooperate.

The outcomes of those international debates were of paramount importance for European multinationals as they affected the stability of the international system in which their businesses had developed. Unstable international relations posed significant problems for the oil, petrochemicals and automotive industries especially. These industries were well represented in the ELEC, the Bilderberg meetings and the Trilateral Commission, during discussions on how international energy policies and economic relations could be improved. That circumstance provides an ideal case for gaining a better understanding on how the views of business developed in relation to the European market, in an international context.

The present chapter investigates how industries responded to those uncertain and problematic circumstances. Did their requests to the European Community change? How should the European Community, according to business leaders, act in international economic affairs? Moreover, did the atmosphere of crisis increase the importance of national contexts with respect to the views that European multinationals held? And to what extent did the context of crisis affect the views of business on the freedom of entrepreneurship, which they guarded so closely during the 1950s? This chapter argues that under the pressure of the globalization of 
their sectors and the worsening international circumstances the views of multinationals on the European Community and its institutions changed considerably.

\section{Economic circumstances during the early 1970 s}

As was discussed in previous chapters, during the 1950s and 1960s the Western economies flourished under a relatively stable political, economic and military order that was enforced by the United States. The foundations of that order were laid during and in the wake of WWII. They included the implementation and maintenance of the Bretton Woods monetary order, the gradual materialization of an Atlantic military alliance that included Western Europe, and the economic and military power of the United States. As will be explained below, this order was fundamentally challenged during the 1970s, with profound consequences for the international outlook of the European multinationals.

\section{The monetary crisis}

The post-war economic order was severely shaken by the collapse of the Bretton Woods monetary system in 1971. The monetary system was based on fixed exchange rates in relation to the dollar and on the exclusive dollar-exchangeability with gold. However, a combination of expansive policies of the US government during the 1960s, the financing of the Vietnam war, and foreign investment by US multinationals, undermined the value of the dollar and thereby the viability of the system. Because the exchange rate of the dollar was fixed against gold, holders of dollars began to increasingly exchange dollars for gold. To solve that problem the United States asked for a controlled revaluation of the Japanese and Western European currencies against the dollar. Those governments refused though, feeling that this would endorse the disruptive expansive monetary policies that the US had practiced over the past decade. A further deterioration of the US gold-position ultimately led President Nixon to unilaterally force a revaluation by cancelling dollar-gold convertibility on the 15th of August 1971. The move severely damaged transatlantic relations and affected the United States' international standing. Attempts to mend the system were fruitless and by March 1973 most governments had decided to allow their currencies to float. ${ }^{427}$

\section{The oil crises of the 1970 s}

The transformed monetary order that unfolded from August 1971 onwards, resulted in the first oil crisis. As intended, Nixon's decision devalued the dollar. The

427 Wee, Herman van der (1987). Prosperity and upheaval: the world economy 1945-1980. Harmondsworth: Penguin Books, pp. 475-494. 
terms of trade for oil exporting countries were immediately affected. A lower dollar decreased their returns on oil exports. Moreover, a global boom had simultaneously driven up prices of food and industrial products, which further decreased the import power of oil producing countries. As most of these countries were strongly dependent on imports, the monetary upheaval crippled their economies. In order to guard their common interests, the oil exporting countries had already in the 1960s organized themselves in the Organization of Petroleum Exporting Countries (OPEC). But until 1971 OPEC had failed to force the major Western oil companies to raise the price of oil. However, from August 1971 onwards OPEC started to demand higher returns on oil exports in order to finance their sizeable imports. Up to October 1973, several rounds of price increases were dictated to the oil companies and company assets were nationalized by OPEC countries. The oil-majors were defenceless as their home governments refused to accept a confrontational approach in order to prevent the risk of a shutdown in oil supplies. ${ }^{428}$

Additionally, the OPEC resorted to the use of an oil-embargo to force Western countries to change their policies as regards Israel during the Arab-Israeli Yom Kippur war. Egypt and Syria attacked Israel on the 6th of October, after which OPEC immediately increased oil-prices by 70 per cent. That month, Arabian OPEC countries imposed embargoes on the United States, and subsequently also on the Netherlands, because these countries refused to cancel their support for Israel. OPEC imposed another price increase by 125 per cent in January 1974. From February 1974 onwards most cuts were reversed and the shortages abided. During the following six months the embargoes for the US and the Netherlands were lifted. Prices however were not reduced which caused payments imbalances and severe inflation throughout the world. ${ }^{429}$

The oil crisis of 1979 was not the result of a monetary crisis but of a sudden reduction in the availability of oil. From August 1978 onwards the Islamic Revolution of Iran and its associated strikes caused a sharp drop in Iranian oil production. It caused chaotic competition for oil supplies in the West and rising prices, resulting in similar economic effects as the first oil crisis. ${ }^{430}$

\footnotetext{
${ }^{428}$ Ghosh, A. (1983). OPEC, the petroleum industry, and United States energy policy. Westport: Quorum, pp. 23-26; Wee (1987). Prosperity and upheaval, pp. 378., 494-495. For details on the OPEC negotiations with the international oil-majors see: Bamberg, J. (2000). British Petroleum and global oil, 1950-1975. The challenge of nationalism. Cambridge: Cambridge University Press, pp. 447-474. Sluyterman, K. (2010). Keeping competitive in turbulent markets, 1973-2007. A history of Royal Dutch Shell (Vol. 3). Oxford: Oxford University Press, pp. 14-19.

${ }^{429}$ Licklider, R. E. (1988). Political power and the Arab oil weapon. Berkeley: University of California Press, pp. 12-13. Ghosh (1983). OPEC, pp. 27-28, 41.

430 Lieber, R. J. (1983). The oil decade: conflict and cooperation in the West. New York: Praeger, pp. 27-29, 35.
} 


\section{Economic crisis and protectionism}

Particularly in Western Europe the combination of a collapsing monetary order and the oil crisis of 1973 converged with another development. The strong growth of Western Europe during the 1950s and 1960s was not merely a result of liberalization but also followed from growing productivity. Production increased notably as a result of internal European labour transfers from agricultural labour into industrial production. By the late 1960s however, the supply of labour-migrants was depleted and the growth of production began to level off. Despite dropping profits, wages continued to rise as had been the practice during the long boom, thus draining the capacity of businesses to invest. Moreover, in the early 1970s the long period of growth had resulted in temporary overcapacity. Investments declined and unemployment began to rise. When this stagnation was confronted with surging inflation due to rising oil prices, "stagflation" was the result, and an economic crisis set in from which recovery was only achieved during the 1980s. ${ }^{431}$

At the same time, Western Europe, but also the United States, found themselves confronted with increasing economic competition by Japan. Between 1950 and 1973 that country had caught up with the West through a state-managed and export-led model of growth. The state facilitated industry in areas such as industrial strategy, foreign exchange policy, protectionism, and technology licencing. In that period Japan achieved the unprecedented average growth of more than 10 per cent per year, increasing its GNP from $\$ 11$ billion to $\$ 320$ billion, turning it into the third-largest world economy in $1973 .{ }^{432}$

When the economic, monetary and energy crises successively took hold between 1970 and 1974, protectionist tendencies that had been reduced since 1945 now resurfaced. The United States, the European Community and Japan put in place non-tariff barriers and arranged subsidies to assure the survival of domestic industries. As a result the model of liberal international trade that had served the United States and Western Europe so well since WWII came under severe pressure during the 1970s. ${ }^{433}$

\section{Responses to the oil crisis of October 1973}

The energy crisis of 1973 caused significant damage to international relations and highly determined international debate on how to approach the issue of oil scarcity. From 1969 onwards however, relations within the European Community were

\footnotetext{
431 Judt, T. (2005). Postwar. A history of Europe since 1945. New York: Penguin, pp. 456-464; Wee (1987). Prosperity and upheaval, pp. 300-301.

432 Gordon, A. (2003). A modern history of Japan. From Tokugawa times to the present. Oxford: Oxford University Press, pp. 245-250; Wee (1987). Prosperity and upheaval, pp. 81-87.

${ }^{433}$ Wee (1987). Prosperity and upheaval, pp. 386-389.
} 
turning a corner following de Gaulle's resignation in 1969. That year the freshly elected President of France George Pompidou lifted two of Charles de Gaulle's veto's that had stifled European integration on key subjects: negotiations on an independent budget for the Community, and the accession of the United Kingdom to the Community. The United Kingdom joined in January 1973, together with Ireland and Denmark. The move not only significantly expanded the Community, it also affected the comprehensiveness of a new mechanism in the making: European Political Cooperation (EPC). In exchange for progress in matters of Community expansion, the French government had been granted an opening to introduce its longstanding wish of an intergovernmental form of European foreign policy coordination. From October 1970 onwards, bi-annual meetings of EC foreign ministers and regular meetings of foreign policy officials were introduced. When the oil crisis emerged in October 1973, major deficiencies in European integration, coordination and cooperation appeared to have been remedied. 434

At the same time, relations between Western Europe and the United States were burdened with frustration just before the oil crisis escalated. The American government's role in the collapse of the Bretton Woods system in 1971 had shocked the European and Japanese governments. The US Secretary of State Henry Kissinger tried to mend relations with the European Community by announcing the need for a "New Atlantic Charter" during the US "Year of Europe" in 1973, but the invitation was declined. 435

With the advent of the oil-crisis, European progress in integration had little effect on crisis management. The Americans, but also the Dutch, were blamed by their European partners for rigidly holding on to their support to Israel during the OPEC oil embargo. European solidarity was a hollow phrase: the French and British governments even complied with the Arab embargo and agreed to halt the reexport of oil to the United States or the Netherlands. At the same time the European oil multinationals Shell and British Petroleum were experiencing pressure from the British government to uphold normal supplies. Based on their commercial motives, the companies preferred to distribute the available oil equally among its customers instead. Nonetheless, British Petroleum secretly gave in to the government's demands. Still, the potential shortages of oil were alleviated by the oilsharing strategy of the oil companies. ${ }^{436}$

European relations with the United States further deteriorated when the French government began demonstrating its weight in the newly established EPC mechanism. From November 1973 onwards, Henry Kissinger tried to unite Western Europe, the United States and Japan into an oil-consumer collective against

\footnotetext{
434 Dinan, D. (2004). Europe recast: a history of European Union. Basingstoke: Palgrave Macmillan, pp. 126-144; Nuttal, S. J. (1992). European Political Co-operation. Oxford: Clarendon Press, pp. 30-45.

435 Dinan, (2004). Europe recast, p. 153.

${ }_{436}$ Lieber (1983). The oil decade, pp. 17-19, 52, 84; Lucas, N.J.D. (1977). Energy and the European Communities. London: Europa Publications, p. 59. Bamberg (2000). British Petroleum, pp. 474-485. Sluyterman (2010). Keeping competitive, pp. 27-29.
} 
OPEC interests. The French government preferred a different approach, because of its strong dependence on oil from the Middle East. Moreover, France convinced its European counterparts to aim for a dialogue with the oil exporting countries instead of supporting a consumer-nations collective. The country also pressed for a joint European declaration that condemned American support for Israel. The United States actively attempted to limit the success of the French government, resulting in an isolation of French diplomats during the Washington Energy Conference of February 1974. Unlike its European counterparts France subsequently declined membership of the International Energy Agency, established in November 1974, which studied means for collective action of the oil consuming countries. At the same time however, European governments did start a dialogue with the oil exporting countries, particularly the Arab countries. The dialogue involved the question of how to help oil exporting countries to reduce their dependence on imports, which was one of the causes of their need for a high oil price. ${ }^{437}$

The response of the United States, Western Europe and Japan to the oil crisis involved far reaching choices regarding their energy policies. To adequately interpret the position of European multinationals in these international energy debates a short overview is appropriate.

\section{Western European energy policy response}

The Western European energy policy context was characterized by two main features: the dependence on the Middle East to the extent of 60 percent of the energy requirements, and, secondly, diverging national energy strategies. ${ }^{438}$

Examples of French, British and German policy responses show how different European countries responded to the oil crisis. In 1974 the French government initialized a national nuclear energy project that involved the construction of sufficient nuclear plants over the next decades to achieve national energy independence. It united national industries around unprecedented goals of nuclear energy capacity. The policy was moreover supplemented by severe energy saving measures. Alternatively, the United Kingdom decided to depend on recently discovered reserves: natural gas and oil deposits were discovered in the North Sea between 1960 and 1973. At the same time the United Kingdom had maintained a significant coal mining industry, which made the country less dependent on imports in the short term in comparison to other European countries. Germany in its turn, had a declining coal industry similar in size to that of the United Kingdom. New closure of mines was stopped immediately. Moreover, plans for nuclear energy were initialized. Germany had still to replace imported oil by natural gas though, due to the time that was required for the construction of nuclear energy plants.

437 Ibidem.

${ }^{438}$ Lieber (1983). The oil decade, p. 14. 
Only during the early 1980s, nuclear energy began replacing oil up to slightly over 10 per cent of Germany's needs. 439

As a whole the European Community was unable to arrive at a collective energy policy during the 1970s. Attempts had been undertaken since 1960, but the contradictory interests of the involved institutions, the High Authority, the European Commission and Euratom, undermined those initiatives. Only after the merger of these three institutions into one Community, in January 1967, the European Community was able to start a comprehensive approach. Since 1967 the driving force behind that approach became the fear for oil blockades, because OPEC had tried that policy instrument that year for the first time. To reduce the effects of a possible second blockade, the European Commission proposed a regulated energy market with incentives for internal oil exploration. This should alleviate the European import dependency. No Council agreement on the plans could be reached though, except in 1972, on a minor directive for storing emergency oil to supply the European economies for 90 days if necessary. In May 1973 similar proposals on an energy market failed again, notably due to opposition by the Dutch and British governments that felt that Shell and British Petroleum ought to remain exempt from Common Market regulations. Only an agreement on non-binding resolutions could be achieved, in December 1974, which merely formalized existing energy policies of the Community member states on energy mix diversification and on reduction of energy consumption. 440

\section{The United States energy policy response}

Unlike Western Europe, the United States had significant domestic oil reserves and coal deposits at its disposal. As a result, interruptions of supply did not affect the United States much in 1973. However, prices of domestically drilled oil rose along with the OPEC-dictated prices. To encourage domestic oil exploration, the American government allowed oil from new wells to be sold at the higher OPEC prices. That policy had an unintended effect. Oil companies began to replace oil from existing wells by oil from new wells to reap higher profits. As a result, American domestic oil production decreased. At the same time, the US Congress consistently blocked energy saving policies and allowed the increase of oil consumption. Combined with the aforementioned decreasing domestic production the American dependency on imported oil from the Middle East increased by 28 per cent be-

\footnotetext{
${ }^{439}$ Lieber (1983). The oil decade, pp. 76-92. Also see Saumon, D. \& Puiseux, L. (1977). Actors and decision in French energy policy. In L. N. Lindberg (Ed.), The energy syndrome: comparing national responses to the energy crisis (pp. 119-172). Lexington: Heath; Chesshire, J. H., Friend, J.K, Pollard, J. de B., Stringer, J. \& Surrey, A. J. (1977). Energy policy in Britain: a case study of adaptation and change in a policy system. In Lindberg (Ed.), The energy syndrome, (pp. 33-62); Michaelis, H. (1993). Energiewirtschaft der Bundesrepubliek Deutschland. In Hohensee, J. \& Salewski, M. (Eds.), Energie-Politik-Geschichte: nationale und internationale Energiepolitik seit 1945 (pp. 51-74). Stuttgart: Steiner.

${ }^{440}$ Lucas (1977). Energy, pp. 34-56, 65-68.
} 
tween 1973-1978. Such results were in conflict with the energy reduction policies that the US government had agreed upon with Western Europe and Japan. During the same period Europe and Japan reduced their dependency on imports by 2,2 per cent. The Community and Japan criticized the US for exposing them to new oil shocks. That criticism only grew louder when in May 1979 the United States suddenly decided to subsidize oil imports by 5 dollar per barrel, thereby further stimulating dependence on Middle East oil. ${ }^{441}$

\section{Japanese energy policy response}

Japan, had few local energy resources available and had become almost entirely dependent on imported oil during its prolonged economic boom of the 1960s. In 1973 Japan imported 93 per cent of its energy requirements. At the same time oil represented 75 per cent of the national energy mix, and came largely from the Middle East. When the embargo and price increases began, Japan gave in to Arab demands and adapted its policy towards Israel. Moreover, a dialogue was started with particularly the Middle East countries in order to arrive at higher prices and supplies. This went against the preferences of the United States of forming a consumers bloc. Energy saving policies were implemented while at the same time Japan opted for an increasing role of imported natural gas and of nuclear energy in its electricity production. In that process Japan initialized a comprehensive statefacilitated nuclear industry capable of building the numerous plants that the electricity producers required. Similar to France, Japan was aiming at a strong nuclear energy based economy. ${ }^{442}$

\section{Energy security and the European League for Economic Co- operation}

As discussed, several developments converged during the 1970s. The breakdown of the Bretton Woods system and the resulting devaluation of the dollar led to demands from OPEC countries for higher returns on oil. During 1971-1973 oil prices rose and private oil companies lost their privileged position as industry leaders. The European Community lacked an energy policy, despite repeated proposals by the European Commission since 1967. From October 1973 oil prices soared and supply was reduced, suddenly undeniably bringing home Western

441 Ghosh (1983). OPEC, pp. 149-187; Lieber (1983). The oil decade, pp. 32, 96-97.

${ }_{442}$ Clark, J. G. (1990). The political economy of world energy: a twentieth century perspective. New York: Harvester Wheatsheaf, pp. 106, 108, 261-264; Morse, R. A. (1982). Japanese energy policy. In W. L. Kohl, (Ed.), After the second oil crisis: energy policies in Europe, America and Japan (pp. 255-269). Lexington: Lexington Books. 
Europe's dependency on Arabian oil. Meanwhile an economic crisis emerged that was deepened by the high inflation resulting from risen oil prices.

As will be discussed below, even before the oil crisis escalated Western European multinationals made several attempts to convince the European Community of vigorous concerted action in the sphere of energy. Also after October 1973 they continued to approach European policy makers and took position in the international debate on either forming a Western bloc against the Arab world or starting consultations with the Middle East on the reduction of their import dependency via industrialization. These actions were also caused by growing industrial overcapacity and by the economic crisis that hit Western Europe during the 1970s. Finally, European multinationals were confronted with a renewed American commitment to nuclear non-proliferation policy as a result of French, British, German and Japanese commercial nuclear energy strategies.

As a result, certain sectors of European industry began to appeal to the European Community to help them in protecting European industrial competitiveness and to support them by safeguarding minimal conditions of stability and predictability of international markets.

During 1972-1973 the European League for Economic Cooperation developed a policy paper on the establishment of a European energy policy. The time was ripe for action. Already since February 1971 Western oil companies were forced to accept higher oil prices as agreed in the so-called Tehran agreement, formally the result of negotiations between them and OPEC. In fact they had no choice but to go along with OPEC's wishes. The companies were not prepared to accept OPEC's terms but the American and Western European governments had urged them to arrive at an agreement instead of risking a shutdown of oil supplies. In January 1972 prices were again raised by 20 per cent under the similarly imposed Geneva agreement. Moreover, from late 1971 onwards oil companies were confronted with the nationalization of their oil fields and production facilities. In December 1971, the Libyan government nationalized assets of $B P$, and in 1972 the Iraqi government nationalized the Iraq Petroleum Company, a joint-venture of Western oil companies. Many other nationalizations followed. The loss of such key assets transformed oil producers into mere distributors of oil. Meanwhile the European Community, showed no willingness to undertake action on matters of European energy security. 443

\section{European energy policy, 1972-1974}

It thus should not be a surprise that the first request within ELEC to develop a proposal on a European energy policy came from the oil industry. In July 1972,

${ }_{443}$ Jacoby, N. H. (1974). Multinational Oil: a study in industrial dynamics. New York: Macmillan publishing, pp. 257-263. Also see for a very detailed account: Bamberg (2000). British Petroleum, pp. 447-474. Sluyterman (2010). Keeping competitive, pp. 14-19. 
Bernardo Lopez Majano, the general director of the Spanish nationalized oil company Campsa, contacted key-persons within ELEC. 444

Normally ELEC's Economic Commission would first discuss an initial draft and hold sessions between representatives of national sections to arrive at a common position. However, the newly appointed president of ELEC's Economic Commission, Guido Colonna di Paliano, felt that a different approach was required. Colonna had been European Commissioner for Industrial Affairs from 1967 until 1970, and was responsible for the so-called Colonna-memorandum of 1970 on the need of a comprehensive industrial policy for the European Community. As a former central figure in Community affairs Colonna was an ideal person to direct the drafting process of a resolution on energy affairs. Moreover his involvement in European industrial affairs had resulted in positions as director of the Belgian chemicals producer Solvay \& Cie and the Italian FIAT concern. ${ }^{445}$

The reason why Colonna preferred a different approach also lies in his experience with the affairs of the European Community. As former Commissioner, Colonna di Paliano knew the issues that ELEC's Economic Commission was going to handle. Its membership was based on the national sections, who sent representatives based on the dominant theme under discussion. Colonna feared that the combination of the inherent political aspects of a European energy policy and the representation from the national sections would result in a lack of focus. Instead he proposed "a very restricted group of experts" [...] with the assignment to "delimit the field of the investigation and to define the guidelines." His decision led to the establishment of an "Energy Panel" in which Colonna himself played no further role. ${ }^{446}$

The panel was formed early 1973 and Colonna's preference for "experts" resulted in a nearly exclusive representation from the Western European energy industry. The national sections had made the selection and they had done so in accordance with major national energy interests. The Dutch section opted for oil company Shell, the British section selected British Petroleum, as well as the National Coal Board, the supervisory body of the nationalised coal industry. The Belgian representation also was a mix of longstanding Belgian energy interests: Banque de Bruxelles, via its financial relations with Brufina committed to the Belgian coalmining industry; the Belgian petrol federation and the Belgian federation of electricity

${ }^{444}$ CEHECLIN, LECE, inv. nr. 272, 30-06-1972, Bernardo Lopez Majano to Yvonne de Wergifosse, including 18-07-1972, Bernardo Lopez Majano, Necessité d'une politique énergétique commune dans l'Europe des dix. For the activities of ELEC on energy policy also see: Dumoulin, M., \& Dutrieue, A.-M. (1993). La Ligue Européenne de Cooperation Économique (1946-1981): un groupe d'étude et de pression dans la construction européenne, pp. 185-189.

${ }_{445}$ LECE (1972). Rapport du sécretaire général sur l'activité de la LECE en 1971. Bruxelles: LECE, p. 13.

${ }_{446}$ Tanslation: "Le problème est sans doute très actuel: mais il est aussi très compliqué, car on y retrouve des éléments économiques et politiques dont il n'est pas facile de faire le départage" \& "il serait préférable de confier à un Groupe très restraint d'experts le soin de délimiter le domaine de l'enquête et d'en définir les orientations. CEHECLIN, LECE, inv. nr. 272, 23-11-1972, Guido Collona di Palliano to Yvonne de Wergifosse. 
producers and distributors. The German section, by mistake only present at the second meeting, had chosen the Rheinische Braunkohlenwerke, an RWE subsidiary. The Austrian section sent the Österreichische Mineralölverwaltung, the national oil company. The rather large French delegation was formed by the coalmines of Lorraine and a group of semi-governmental atomic energy interests: the Atomic Energy Commission (CEA) and the state-owned utilities company Electricité de France (EdF). Lastly, the in 1971 largest private industrial conglomerate of France, Péchiney-Ugine-Kuhlman (PUK) took part: a major aluminium producer (a very energy intensive industrial process) and a producer of metals, chemicals and pharmaceuticals. PUK was also active throughout the entire nuclear fuel cycle, making it part of the public-private partnership of the French government in nuclear energy. Strikingly, the French delegation was the only group to include two senators and a former French delegate to European energy affairs. This circumstance was in line with the French practice of fusing political governance and industrial strategy when that served their needs. Also a minority of energy consuming industries participated, such as FIAT and Solvay \& Cie., via René Boël, now Honorary President of the firm. The energy consuming industries only played an observing role. 447

The panel met in February and May 1973. Although the producers of energy and energy-resources clearly represented important national interests, the meeting's minutes and the accompanying correspondence make clear that they thought and cooperated along lines of the energy resource-sectors: coal, oil and nuclear energy. Starting with the oil companies, the fact that the initial proposal came from a president of a Spanish oil firm is an odd occurrence since Spain was not a member of the European Community. Why would a Spanish oil firm involve itself with a Community policy? ${ }^{448}$

The draft proposal of the Campsa director for the energy panel provides an answer. Departing from Europe's dependence on imported oil, he proposed to stimulate EC-internal oil exploration by lifting Community restrictions on oil ex-

\footnotetext{
${ }^{447}$ Members of the energy panel (over two sessions): The Netherlands: C. A. Ruys (Shell) United Kingdom: Alan Hart Dutton (British Petroleum), M. J. Parker (National Coal Board). Belgian section, Banque de Bruxelles: Conrad Reuss \& Gh. Havelange, Fédération Pétrolière Belge: E. Struyf, Fédération Professionnelle des producteurs et Distributeurs d'Electricité de Belgique: R. Pacquet. German section, Rheinische Braunkohlenwerke AG: F.J. Schmitz-Josten, Austrian section, Österreichische Mineralölverwaltung A.G: F. Hochreiter. French section, Houillères du Bassin de Lorraine: M. Halff, Commissariat à l'Energie Atomique (CEA): Mr. Berges, Electricité de France (EdF): Mr. Hector, PUK: Georges Desbrières. Senators: E. Bonnefous \& Y. Coude du Foresto. Further: Pierre Olivier Lapie. CEHECLIN, LECE, inv. nr. 272, 23-021973 Proces-Verbal de la Réunion Panel Energétique, pp. 1-2 \& 02 05-1973, Proces-verbal du Panel Energétique, p. 1. Boël presided over the first meeting, and left this task to Pierre Olivier Lapie during the decisive meeting. Further members were: the Belgian Leo Deschuyteneer of Sofina, Danis Koper from Turkey and Mr. Baumberger of Motor-Columbus from Switzerland.

448 CEHECLIN, LECE, inv. nr. 272, 30-06-1972, Bernardo Lopez Majano to Yvonne de Wergifosse, including 18-07-1972, Bernardo Lopez Majano, Necessité d'une politique énergétique commune dans l'Europe des dix.
} 
ploration by companies from third countries, such as Spain. The international oil companies Shell and British Petroleum agreed, stressing that no energy source would be able to significantly replace oil during the next decade. Additionally, the oil companies also had a unique outlook that had not been heard before in the Europe-focussed ELEC. C. A. Ruys, of Shell was of the opinion that any endeavour regarding oil supply security should not be dealt with on a European level but on a global level, because of the "international nature of the oil industry." Moreover, he proposed coordination with the USA and Japan to "avoid a scramble" for available oil. Ruys thus wanted the European Community member states to collectively coordinate their external political-economic relations, so that they could be of service to his internationalized sector as a bloc of governments. It is important to stress that they did not want the European Commission to play a role in their affairs. Dutton from British Petroleum illustrated the extent to which Shell and $B P$ had transcended mere Europe-focussed perspectives. According to him the proposals should not include references to a "supranational regime" for energy policy. He rejected the proposal of "direct negotiations between the EEC and producer governments" [oil exporting countries, RG]. Instead of involvement with supranational arrangements within the Common Market, Shell and BP preferred harmonized national policies, alongside a strengthened European hand in international negotiations, but always in coordination with the USA and Japan. ${ }^{449}$

The European coal-producers on the other hand tried to save what was left of their industry. The sector had been in decline since oil and cheap American coal had begun flooding European markets since the 1950s. For them the current circumstance of rising oil prices was a welcome change in the energy landscape. French and British coal exploiters explained that under further oil price increases, coal might even regain a competitive position. Moreover, they made clear that unlike oil, coal was locally and immediately available providing an element of "security" that under present conditions would justify an elevated coal price. Their main goal however was to keep open their mines. ${ }^{450}$

Lastly the electricity and uranium producers had a different view of what an energy policy should contain. They felt that Community support for nuclear energy should be stressed especially. The French representatives from $E d F$ and the $C E A$,

${ }^{449}$ CEHECLIN, LECE, inv. nr. 272, 30-06-1972, Bernardo Lopez Majano to Yvonne de Wergifosse, including the document: 18-07-1972, Bernardo Lopez Majano, Necessité d'une politique énergétique commune dans l'Europe des dix; 23-02-1973 Proces-Verbal de la Réunion Panel Energétique; approx. 031973 (no date), C. A. Ruys to Yvonne de Wergifosse; 10-03-1973, Projet de Déclaration soumise aux participants a la réunion du panel énergétique du 23-2-1973 à Bruxelles. Necessité d'une politique énergétique commune dans l'Europe des neuf; 02-04-1973, A. H. Dutton to Yvonne de Wergifosse.

${ }^{450}$ See for a short overview of the experiences of the coal sector since WWII: Chapter 3. CEHECLIN, LECE, inv. nr. 272, 23-02-1973 Proces-Verbal de la Réunion Panel Energétique; 10-03-1973, Projet de Déclaration soumise aux participants a la réunion du panel énergétique du 23-2-1973 à Bruxelles. Necessité d'une politique énergétique commune dans l'Europe des neuf; 26-03-1973, Maurice Halff to Yvonne de Wergifosse; 29-03-1973, M. J. Parker to Yvonne de Wergifosse. The citation of "security" is a translation from French, of "sécurité." 
and Roger Paquet of the Belgian federation of electricity producers and distributors, insisted on a European strategy with regard to uranium supply and enrichment to enable higher production levels of nuclear energy. For the Belgian electricity producers the motive was particularly sector based, because of the importance of nuclear energy for electricity production. The French however were pushing a nuclear strategy also for national reasons. The development of nuclear energy had been a national project since WWII, which was carefully fostered by the French government. Since 1960, the CEA and French industry had focussed on the development of a single uranium enrichment method: gaseous diffusion. In 1970 however a competing enrichment method was introduced. Germany, the United Kingdom and the Netherlands established URENCO in order to develop and exploit enrichment by means of ultra-centrifuges. The CEA subsequently developed a strategy to bind the founders of URENCO to the successfully operating French nuclear fuel cycle. In February 1973, the same month when the CEA proposed a European enrichment strategy in the ELEC, the CEA assembled a group of European countries for a collective enrichment study, with the aim to include the shareholders of URENCO into a new company based on gaseous diffusion enrichment: Eurodif. The URENCO members declined. The French proposal in ELEC to arrive at a collective strategy on uranium supply and fuel enrichment should thus be interpreted as an expression of a national goal to make the European nuclear sector dependent on the advanced fuel cycle developed by the French. ${ }^{451}$

ELEC's energy panel thus represented diverse and competing interests with regard to how a European energy policy should be shaped. The result of the panel's meetings was a hybrid request from the Community governments for stimulating the further development of all three energy sectors simultaneously, in the form of subsidies for coal mines, encouragement of oil-exploration, access to nuclear plants for electricity producers, and the swift completion of a European nuclear fuel cycle. However, what is much more important than the different sector-based preferences is the collective expression of a necessity for intervention and an embryonic sign for the need for a European industrial policy. One difference stands out between the coal and nuclear industries operating mainly in Europe, and the international oil firms: as $B P$ and Shell had requested, the document asked for an international agreement with the US and Japan that would ensure the correct distribution of oil in times of crisis. Unlike the Europe-based coal industry and the still infant nuclear industry that preferred a European approach and supranational policies, the internationalized oil companies required the Community member states to take a global approach to oil policy and preferred harmonized policies

\footnotetext{
451CEHECLIN, LECE, inv. nr. 272, 23-02-1973 Proces-Verbal de la Réunion Panel Energétique; 10-031973, Necessité d'une politique énergétique commune dans l'Europe des neuf, p. 4; 22-03-1973, Roger Paquet to Yvonne de Wergifosse. Pringle, P. \& Spiegelman, J. (1981). The nuclear barons. London: Michael Joseph, p. 344. Also see Uitham, C., Vries, B. de, \& Zijlstra J. (1977). Kernenergie in Nederland: een onderzoek naar machtstructuren. S.l.: Stichting Uitgeverij Xeno, p. 36.
} 
across the member states. The oil companies' international, global structure and the severe problems that the sector was dealing with required international action. Although the European Political Cooperation framework was gradually taking shape, the European Community for now still was ill equipped to negotiate as a collective on a global level. This can explain the oil companies' attitude in this regard. 452

The proposal for a European energy policy was sent to the Council of Ministers, which was scheduled to meet on the 22nd of May 1973. However, no Community energy policy was agreed upon, nor on any later occasion during the $1970 \mathrm{~s}^{453}$

\section{Economic crisis}

When Western Europe was confronted in October 1973 with the oil embargo and price rises, it was already struggling with an economic downturn for several years. Since 1970 the European economies had been showing signs of slacking growth, which was unrelated to the developments in the oil industry. Western European productivity growth was stagnating. At the same time, putting trust in the two past decades of growth, wages were allowed to rise and investments continued. The resulting overcapacity required a consolidation, a process that set in when energy prices began to rise. In January 1974, only three months after the beginning of the oil embargo, ELEC started working on a publication on the very vulnerable situation that was now arising for two particularly oil-dependent industries: the petrochemical and automotive industries. As a whole the study, named Conjunctural and structural problems of the European industry, tried to drive home the message of the vulnerability of those sectors in a context of international competition and political-economic upheaval and proposed a facilitation of industrial restructuring. 454

The study was conducted under chairmanship of the earlier mentioned Italian representative Guido Colonna di Paliano. When he joined ELEC in 1971, he had agreed to reorganize the Italian section. As a result he was able to involve the Italian section in active ELEC-work for the first time since 1952. Representatives of two prominent Italian businesses executed the study: car-maker Fiat and the pet-

\footnotetext{
452 CEHECLIN, LECE, inv. nr. 272, 11-05-1973, Déclaration sur la necessité d'une politique énergétique commune dans l'Europe des neuf.

${ }^{453}$ CEHECLIN, LECE, inv. nr. 272, 14-05-1973, Yvonne de Wergifosse to 'sécretaires géneraux et, pour information, aux Présidents des comités nationaux'. Lucas (1977). Energy, pp. 34-56.

${ }_{454}$ Judt, T. (2005). Postwar, pp. 456-464; Wee (1987). Prosperity and upheaval, pp. 81-87. ELEC (1975). Report of the Secretary General on the activities of E.L.E.C. in 1974. Brussels: ELEC, pp. 4-5. CEHECLIN, LECE, inv. nr. 140, 22-10-1974, Commission Economique, p. 2. ELEC (1975). Conjunctural and structural problems of the European industry: the automotive, chemical, and machine-tool industry. Brussels: ELEC. Also on this publication see Dumoulin \& Dutrieue (1993). La Ligue, pp. 189-191.
} 
rochemicals and utilities firm Montedison. They chaired panels consisting of major European corporations in those sectors and authored the final results. ${ }^{455}$

The analyses of the panels sketched the consequences of both the oil crisis and the overcapacity crisis. According to them the present circumstances could only result in an "adaptation of the European industrial apparatus", and in a geographical redistribution of production. The reasons for this were a combination of international competition, rising oil prices and the uncertain provision of oil. The European automotive industry was competing with lower American production costs due to energy price controls. The petrochemical industry was partly driven to invest in oil-producing countries where process and energy feedstocks were cheaper. At the same time the panels complained about inflexible industrial relations: according to them social demands and the norm of full employment were making a European adaptation to new international competitive pressures impossible. ${ }^{456}$

To remedy these obstacles, both panels proposed an industrial policy on Community level that would enable a dialogue between industry and the trade unions. Moreover, the necessary geographical redistribution also required the elimination of fiscal and regulatory obstacles to create a homogenous area for investment decisions. It is important to note, with hindsight, that within ELEC this was the first concrete proposal that came close to the intentions of the Single European Act Community treaty of 1986, namely to finalize the single market. Furthermore the panels asked the Community to cultivate, encourage, and "foster" research in the direction of anti-pollution technology, new materials, propulsion and foodstuffs and provide coordination on a European level to achieve greater efficiency. In this way the industries could retain their technological edge. ${ }^{457}$

The chairmanship of Guido Colonna di Paliano automatically places the outcome of this study in light of the memorandum Industrial policy in the Community which appeared in 1970 under his responsibility as the European Commissioner of Industrial Affairs. As discussed in chapter 5 this memorandum already included remarks on industrial restructuring, transnational mergers, and on the minimization of fiscal and regulatory obstacles that were advocated by the ELEC since 1965. Together, ELEC's earlier work, Colonna's memorandum, and the new ELEC study indicate a continuity of ideas and solutions advocated by parties from the Europe-

\footnotetext{
455 More as an afterthought, also the European machine tools industry was added to the study in a later stage. Chairman automotive panel: Hubert Carniaux. Authors report: Alberto Tiazoldi and Allesandro Giraudo, Fiat. Report author chemical industry: Aldo Romoli, Montedison, for the machine tools industry, no panel was created but a report was written by Roberto Taranto of Ucimi. CEHECLIN, LECE, inv. nr. 140, 22-10-1974, Proces-Verbal de la Réunion de la Commission Economique, p. 1 and ELEC (1975). Report of the Secretary General on the activities of E.L.E.C. in 1974. Brussels: ELEC, pp. 4-5. LECE (1972). Rapport du Secrétaire Général sur l'activité de la L.E.C.E. en 1971. Bruxelles: LECE, p. 13. ELEC (1975). Conjunctural. See Chapter 2 for remarks on the Italian section in the early $1950 \mathrm{~s}$.

456 ELEC (1975). Conjunctural, pp. 10-11, 25, 37-38.

${ }^{457}$ ELEC (1975). Conjunctural, pp. 8-13, 16.
} 
an industry from the mid-1960s to the mid 1970s. That continuity will be further discussed below. 458

Coming back to the energy crisis, the high oil prices also posed a long-term strategic challenge for the chemical and automotive industries. Leaders from those industries wondered where the OPEC oil revenues would be invested? The ELEC publication summarized the two available options: the Arabs could invest directly in Western European and Japanese assets, such as real estate or industry, thus allowing funds to flow back. The second option involved the so-called petrodollar recycling: the OPEC countries could transfer their surpluses back to Western Europe and Japan in return for the development of the industrial base in the OPEC countries, in order to limit their import needs. This implied the transfer of industrial and technological know-how and plants, in return for oil.459

Particularly the chemical industry had learned its lesson with regard to these matters. During the 1960s exports of industrial know-how and plants to Eastern Europe by the capital goods industry had raised the spectre of a boomerang effect of the dumping of chemical products on European markets. Now similar worries existed. In Conjunctural and structural problems of the European industry Aldo Romoli of Montedison stated on behalf of the European chemical sector that Western Europe should cooperate with the OPEC countries in order to secure oil supplies and "to re-establish monetary, economic and political stability, all features to which the chemical industry is particularly sensitive." The chemical sector also acknowledged the need for either direct investments in Western Europe or petrodollar recycling to normalize the balances of payments. Nonetheless, the European chemical industry preferred direct investments in Western Europe. The report made clear that petrodollar recycling, or technology transfers, should only be undertaken against the highest possible return of oil and that when recycling would nonetheless be the result of a European-OPEC dialogue, particularly overcapacity in the Middle East should be prevented. Otherwise Community policies would once more create dumping effects for the Communities' own chemical industry. According to Romoli, each move in this regard should take into account the consequences for Western European industry. 460

From October 1974 onwards René Boël, the President of ELEC, repeatedly attempted to organize a technology transfer dialogue with OPEC countries, particularly with those in the Middle East. The Director-General of Energy in the European Commission, Fernand Spaak, urged him to take the lead in organizing a corporate

\footnotetext{
${ }^{458}$ AEI, Commission of the European Communities (1970). Industrial policy in the Community. Memorandum from the Commission to the Council. Brussel: Commission of the European Communities, Retrieved, September 6, 2013, from http://aei.pitt.edu/38638/1/A3443.pdf, pp. 19, 23-24, 26-27; Winter, H. (1994). Interdependenzen zwischen Industriepolitik und Handelspolitik der Europäischen Gemeinschaft. Baden-Baden: Nomos, pp. 64-65.

459 ELEC (1975). Conjunctural, pp. 14-15, 38-39. On petrodollar recycling and import substitution also see: Clark (1990). The political economy, pp. 291-296.

${ }^{460}$ Italics are mine. See chapter 5. ELEC (1975). Conjunctural, pp. 14-15, 38-39.
} 
version of the Europe-Arab dialogue, alongside what was being undertaken on the Community member state level. Boël approached the national sections of ELEC at several occasions but only the British section was enthusiastic enough to take up the initiative. In 1976 that section organized a conference with Arab governmentrepresentatives and British industrialists and bankers without the other ELEC sections being present.461

As a result of global economic pressures, both the chemical and automotive sectors were in effect asking for an industrial policy. They wanted the Community to think about industrial policy in terms of global competition. Just as Shell and $B P$ they demanded new policies because they were so internationalized. However, unlike Shell and BP they were mainly based within Europe and required the Community to take action on a supranational basis because the problems they were experiencing had transcended national policymaking. Additionally, they wanted the Community to defend the positions of European multinationals in international markets.

\section{European energy policy, 1978-1981}

During the late 1970s and early 1980s, the European League for Economic Cooperation continued to work on two new proposals for a European energy policy. These proposals followed two major incidents that shook the world and the European energy industries. The first was the recurrence of oil shortages as a result of the Islamic revolution in Iran, triggering a veritable oil crisis and accompanying price rises from August 1978 onwards. The second event was the Three Mile Island nuclear power reactor accident in the United States in March 1979. The accident caused strong uncertainties with regard to the future of nuclear energy and resulted in widespread public debate about nuclear technology and in strong resistance by anti-nuclear activists. ${ }^{462}$

The first of these proposals was published in December 1979. The month before the ELEC had founded a small committee to prepare a new resolution demanding a Community energy policy. The most notable members of that committee were Baron Pierre Snoy of the Belgian branch of oil giant Shell and the German Paul Dax of Siemens. Among many things, Siemens was a builder of power plants and together with its partner $A E G$ the company was deeply involved in nuclear energy via their joint venture Kraftwerk Union. Other members included M. Pouly, a representative of the Swiss nuclear power-plant constructor Motor Columbus,

\footnotetext{
461 CEHECLIN, LECE, inv. nr. 272, 19-07-1974/24-09-1974, René Boël to Fernand Spaak, October 1974, Fernand Spaak to René Boël; 18-10-1974, Note pour le Comte Boël. Entretien du 18 octobre 1974 avec M. Fernand Spaak, pp. 1-2. See for the efforts of Boël to interest ELEC's other national sections to participate in a Europe-Arab dialogue: inv. 681, Dialogue Euro-Arabe, Nord Sud 1976-1978. ELEC (British Section) (1976). Europe and the Arab world: report of the London conference organised by the British section of the European League for Economic Co-operation. London: ELEC, British Section.

462 Clark (1990). The political economy, pp. 255-258, 320-329.
} 
and Michel Gras, director of the French Commission for Atomic Energy (CEA), the institution overseeing the French government's public-private nuclear energy ambitions. René Boël himself chaired the meetings. ${ }^{463}$

The statement that resulted from these meetings largely resembled the energy policy requests from 1973. The Iranian oil crisis had again brought home the message of the dependence of the European Community on Middle East oil. The energy industries collectively requested the European Commission to stimulate the further development of all non-oil energy sources. Particularly the coal and nuclear industries saw an opportunity for Community level support. The ELEC committee advised that coal should be imported as well as extracted domestically, and that the construction of nuclear plants should be continued with speed. Further the document stated that the Community should investigate all possible innovative energy resources. The resolution also asked for a pricing of natural gas that would be more in line with the prices of other energy sources. In the Netherlands domestic natural gas was sold for very low prices to industry. According to Snoy, all energy resources should be priced in correspondence with international prices and therefore nearer to the price-level of oil. In other words, Snoy advocated a levelplaying field for oil. He argued that this would lead to a downward pressure on oil prices. He also included a request for a foreign policy of the Community related to energy, based on consultation with the oil-producers, the developing countries and the United States. According to oil major Shell the new problems in Iran again necessitated a European foreign policy response. It is significant that only the European oil majors and as became clear in the former section of this chapter, the European chemical industry, demanded such a policy. The dependency of both industries on oil and oil derivatives in a time of oil-scarcity explains this attitude. At the same time, both industries had in common that they were very internationalized, owning multiple production facilities outside Western Europe. As a result they required stable international arrangements and hands-on international coordination where necessary, factors in which a Community policy could make a difference. ${ }^{464}$

The committee members connected to nuclear plant constructors, namely Dax (Siemens), Pouly (Motor Columbus) and Gras (CEA), stressed that the speed of nuclear investments ought to be increased. A stunning proposal was Gras' request that the European Community should start a campaign towards the European public on the merits of nuclear energy. The events at Three Mile Island had caused a decisive blow to the nuclear industry's public image: new orders for nuclear power stations had been rare since then. The idea was immediately embraced by

\footnotetext{
${ }^{463}$ See table 6.1 on the next page.

464 CEHECLIN, LECE, inv. nr. 273, 13-11-1979, Groupe Ad Hoc Sur l'Energie, Proces Verbal de la Réunion tenez chez le Comte Boël, pp. 2-3; inv. nr. 272, 28-05-1979, [Belgian section proposal, RG] Elements for a revival of the Community Energy Policy, for the first time proposed during the Central Council -29th June 1979, p. 4; inv. 273, Resolution pour la poursuite d'une politique Européenne de l'energie, pp. 1-2; inv. 66, 14-12-1979, Process Verbal du Conseil Central, pp. 2-3.
} 
all the members of the committee, convinced that the public needed to be educated on one of the key solutions to Europe's energy shortages. ${ }^{465}$

Again, it is striking that the dominant view on the organization of the European market of the 1960s, the creation of level playing fields, was replaced by a preference for intervention by the Community. A preference for Community directed industrial policy with regard to the energy industry was a key element of these proposals. The participation of such a variety of energy branches can be explained by the scarcity of energy resources on the European market: all were in position to take advantage of the situation, with the exception of the oil companies perhaps. The fact that an oil multinational such as Shell supported an educational campaign on the desirability of nuclear energy is not as surprising as it may sound. In 1969, Shell became a shareholder of the public-private holding Ultracentrifuge Nederland N.V. which on its turn took a share in the British-Dutch-German Uranium Enrichment Corporation (URENCO), founded in 1971. Moreover, in 1973 Shell bought half of the shares of General Atomics, co-owned by the American oil major Gulf Oil, with the goal of developing Very High Temperature Nuclear Reactors. In other words, Shell had broadened its strategic scope from oil to energy. Educating the public on nuclear energy was therefore no strange move for Shell.466

Based on the outcomes of the small ad hoc energy committee ELEC's Central Council decided in December 1979 to found a permanent Energy Committee to further elaborate ELEC's position. Table 6.1 offers an overview of its membership, which also includes the membership of the ad hoc small committee that preceded it. From the oil industry only Belgian Shell participated. Expertise on the gasindustry came from the Nederlandse Gasunie, and the coal-industry was represented by the German Saarbergwerke and the British National Coal Board. The nuclear industry was overrepresented. Several utilities and nuclear engineering firms took part. The Belgian section included the holding Sofina and Société Générale de Banque, which under an umbrella of cross-ownerships represented the dominant Belgian energy industries: the oil company Petrofina, the utilities holding Electrobel and the industrial engineering firm Tractionel that was involved in building nuclear facilities. Together they were involved in a strategy to redirect their coal and oil-based electricity operations towards nuclear-based energy production. The French representatives again included the Atomic Energy Committee (CEA) and Electricité de France, while the German section was once more represented by Paul Dax from Siemens. The Swiss Motor Columbus and the Italian Montedison, both involved in the construction of nuclear reactors, were also included. An advisor to

465 CEHECLIN, LECE, inv. nr. 273, 13-11-1979, Groupe Ad Hoc Sur l'Energie, Proces Verbal de la Réunion tenez chez le Comte Boël, pp. 1-2; inv. nr. 273, no date, Section Francaise de la Ligue Européenne de Coopération Économique, Recommandations pour des actions Européennes communes en matière énergétique, p. 9; inv. nr. 273, Resolution pour la poursuite d'une politique Européenne de l'énergie, pp. 1-2; inv. nr. 66, 14-12-1979, Process Verbal du Conseil Central, pp. 2-3.

${ }^{466}$ Uitham, Vries, de \& Zijlstra (1977). Kernenergie, pp. 36, 42. 
the Director General of DG Energy of the European Commission, Robert de Bauw, took part in the sessions. ${ }^{467}$

From April 1980 until September 1981 the group worked on a final report. In October 1980 the ELEC organized a colloquium on a European energy policy. The outcome foreshadowed the outcome of the Energy Committee, in which the nuclear industry was so strongly represented. The colloquium included representatives from all energy sectors and dealt with all energy sources and aspects, but nuclear energy dominated the discussion. The participants of the colloquium were frustrated about the popular attacks on nuclear energy, and about the attack on coalbased energy as well. According to them a campaign of misinformation was being fuelled by "a small nucleus of people", [...] at whom "operations of control and resistance" should be aimed. ${ }^{468}$

When the committee finally produced a report in September 1981, which was sent to the Community member states and the European Commission, it became clear that the Three Mile Island nuclear plant accident had strongly influenced the outcome. All important sources of energy received their share however and the requests for industrial policy-like interventions persisted. Coal was considered an important resource in securing Western Europe's energy independence, warranting further subsidies, as the document stated. The oil interests were included solely through an appeal for a focus of Community actions in order to create conditions to develop oil or gas sources outside OPEC or the Eastern World. The request originated from Pierre Snoy representing Shell. This also included European action on enforcing respect for contract-relations and preventing nationalizations such as had taken place in the Middle East. In other words, the international oil industry did not ask for internal European policies, but external representation to support their international expansion. ${ }^{469}$

\footnotetext{
${ }^{467}$ Tractebel S.A. In International directory of company histories (Vol. 20). Chicago: St. James Press. Mommen, A. H. (1994). The Belgian economy in the twentieth century. London: Routledge. CEHECLIN, LECE, inv. nr. 66, 14-12-1979, Process Verbal du Conseil Central, pp. 2-3; inv. nr. 273, 13-11-1979, Groupe Ad Hoc Sur l'Energie, Proces Verbal de la Réunion tenez chez le Comte Boël; 29-04-1980, Commission de L'Energie Proces-Verbal, 04-12-1980; Meeting of the Energy Commission; inv. nr. 274, $02-$ 04-1981, Proces-Verbal de la Réunion de la Commission "Energie."

468 Translation of: "ces jeunes pour la plupart, sont abusés par un petite noyau de gens qui eux sont les vrais coupables, et je pense qu'il y a vraiment, dans un certain nombre de domaines, des incitations à ces mouvements qui entraînent les jeunes gens de bonne foi. Mais ceux qui les manipulent sont très loin eux d'être innocents et c'est certainement là que devraient se porter les actions destinées à de véritables opérations de contrôle et de lutte contre cette anti-idéologie", LECE (1980). Pour une politique Communautaire de l'énergie. Colloque du 10 octobre 1980 Paris salle Médici du Sénat. Paris: LECE, pp. 8283. CEHECLIN, LECE, inv. nr. 273, Colloque "Pour une Politique Energétique Commune" Liste des Participants, pp. 1-9.

${ }^{469}$ CEHECLIN, LECE, inv. nr. 274, 19-08-1981, DOCUMENT 3091/BIS and Complement coordinated text 19-8-81, Central Council - Athens, May 14, 1981 (Item 5. -2 of the agenda). For a European Energy Policy, pp. 5-6; inv. 273, 10-12-1980, External Aspects of European Energy Policy, pp. 4-6; inv. 273, 2904-1980, Commission de L'Energie Proces-Verbal.
} 
Table 6.1: Participants in the small ad-hoc ELEC Energy Committee (November 1979) and the permanent ELEC Energy Committee thereafter (April 1980, December 1980, April 1981). ${ }^{470}$

\begin{tabular}{|c|c|c|c|c|c|c|c|}
\hline Country & Last Name, First Name & Company & Sector & Nov79 & Apr80 & Dec80 & Apr81 \\
\hline Belgium & Bauw, Robert de & Commission of the EC & Public Admin. & & $\mathrm{x}$ & $\mathrm{x}$ & $\mathrm{x}$ \\
\hline Belgium & Berghe, Adrien van den & Shell & Oil & & & & $\mathrm{x}$ \\
\hline Belgium & Boël, René & Solvay & Chemicals & $\mathrm{x}$ & & $\mathrm{x}$ & \\
\hline Belgium & Cayron, Robert & Belgo-Nucléaire & Nuclear Energy & & $\mathrm{x}$ & $\mathrm{x}$ & $\mathrm{x}$ \\
\hline Belgium & Hatry, Paul & Fédération Pétrolière Belge & Business Ass. & $\mathrm{x}$ & $\mathrm{x}$ & $\mathrm{x}$ & \\
\hline Belgium & Henrard, Jacques & $\begin{array}{l}\text { Com. de Contrôle de l'Electri- } \\
\text { cité et du Gaz }\end{array}$ & Public Admin. & & $\mathrm{x}$ & $\mathrm{x}$ & $\mathrm{x}$ \\
\hline Belgium & Snoy, Pierre & Shell & Oil & $\mathrm{x}$ & $\mathrm{x}$ & $\mathrm{x}$ & $\mathrm{x}$ \\
\hline Belgium & Ugeux, Georges & Societé Générale de Banque & Banking & & $\mathrm{x}$ & $\mathrm{x}$ & $\mathrm{x}$ \\
\hline Denmark & Breitenstein, Finn & Fed. of Danish Industries & Business Ass. & & $\mathrm{x}$ & $\mathrm{x}$ & $\mathrm{x}$ \\
\hline France & Couture, Jean & Societé Générale & Multiple & & $\mathrm{x}$ & $\mathrm{x}$ & $\mathrm{x}$ \\
\hline France & Jacquier, Armand & Electricité de France & Utilities & & & & $\mathrm{x}$ \\
\hline France & Royere, Olivier de & Rhône-Poulenc & Chemicals & & $\mathrm{x}$ & & \\
\hline France & Thierry Djaparizde, A. & Electricité de France & Utilities & & $\mathrm{x}$ & $\mathrm{x}$ & $\mathrm{x}$ \\
\hline France & Gras, Michel & Comm. de l'Energie Atom. & Public Adm. & $\mathrm{x}$ & $\mathrm{x}$ & & \\
\hline Germany & Dax, Paul & Siemens & Electrical Eng. & $\mathrm{x}$ & $\mathrm{x}$ & $\mathrm{x}$ & $\mathrm{x}$ \\
\hline Germany & Jorzyk, Sigurd & Saarbergwerke AG & Coal & & $\mathrm{x}$ & & \\
\hline Germany & Schmidt, Hans Peter & Siemens & Electrical Eng. & & & $\mathrm{x}$ & \\
\hline Italy & Romoli, Aldo & Montedison & Multiple & & $\mathrm{x}$ & & \\
\hline Netherlands & Plouvier, L.J.M. & Nederlandse Gasunie & Gas & & $\mathrm{x}$ & $\mathrm{x}$ & $\mathrm{x}$ \\
\hline Spain & Lopez Majano, B. & Asfaltos Espagnoles & Asfalt & $\mathrm{x}$ & & $\mathrm{x}$ & \\
\hline Switzerland & Baumberger, $\mathrm{H}$. & Motor Columbus & Automotive & & & $\mathrm{x}$ & $\mathrm{x}$ \\
\hline Switzerland & Pouly, M. J. & Motor Columbus & Automotive & $\mathrm{x}$ & $\mathrm{x}$ & $\mathrm{x}$ & \\
\hline Switzerland & Zwahlen, Jean & & & & $\mathrm{x}$ & & $\mathrm{x}$ \\
\hline U. K. & Jenssen, W.G. & National Coal Board & Coal & & & $\mathrm{x}$ & \\
\hline U. K. & Mabon, J. Dickson & Former Minister of Energy & Politician & & $\mathrm{x}$ & & \\
\hline U. K. & Rhys-Williams, B. & European Parliament & Politician & $\mathrm{x}$ & & & \\
\hline
\end{tabular}

However, the key part of the report was devoted to nuclear energy. In addition to the chemical industry and the oil industry in earlier reports and resolutions, the nuclear industry also appealed to the European Community for more support in foreign relations, outside the EC. In this case this involved in particular an issue of United States-European Community relations, namely non-proliferation. During

\footnotetext{
${ }^{470}$ Sources table 6.1: November 1979: CEHECLIN, LECE, inv. nr. 273, 13-11-1979, Groupe Ad Hoc Sur l'Energie, Proces Verbal de la Réunion tenez chez le Comte Boël. April 1980; 29-04-1980, Commission de L'Energie Proces-Verbal. December 1980; 04-12-1980, Meeting of the Energy Commission. April 1981; inv. nr. 274, 02-04-1981, Proces-Verbal de la Réunion de la Commission "Energie." Jean Zwahlen's biography could not be located. René Boël no longer had an executive position in Solvay \& Cie. His long tenure with the firm however, from 1931 until 1971, justifies his further categorization as part of the firm.
} 
the 1970s, the development of commercial nuclear reprocessing plants and the emerging technology of the fast breeder reactors also gave rise to nonproliferation risks. The reprocessors were designed to extract residual plutonium from spent uranium. The fast breeder reactors were designed to produce plutonium from uranium, for the purpose of immediately used fuel. While both were designed with energy production and environmental goals in mind, the installations offered the possibility of acquiring weapons-grade fissile material for anyone who was able to order such plants commercially. At the same time companies from several European countries were willing to build them. In 1976, the United States Carter administration therefore demanded a renewed non-proliferation treaty, which was concluded in 1978. American pressure had forced Western European countries to accept controls on proliferation. In return for American and Canadian controlled access to uranium, a prohibition for sales of reprocessing plants and breeder reactors was agreed upon. In other words, the European countries were forced to accept a further energy dependence besides the already high degree of dependence on Middle East oil. As a result the ELEC asked for a common action to "remove the political constraints on uranium supply." Additionally, in order to reduce the dependence on uranium from the United States and Canada the report asked to cooperatively realize the demonstration projects for the efficient fast breeder reactor. ${ }^{471}$

ELEC's proposal did not affect decision-making on energy policy though. The energy shortage disappeared due to a decreased demand for oil in industrial countries following the widespread economic slowdown of the 1970s and early 1980s. Moreover, the oil industry was confronted with an abundance of oil from 1982 onwards. Meanwhile, orders for new nuclear reactors stagnated, and did not pick up later. The energy crisis was over and, as a result, this drastically reduced the need for Community member states to develop a common energy policy. ${ }^{472}$

The views of the oil industry, nuclear industry, automotive industry and chemical industry illustrate a growing desire for intervention by the European Community in the areas of industrial policy and foreign policy. The automotive and chemical industries demanded support in scientific research and assistance in improving the relations with unions on a European level. At the same time the chemical, oil and nuclear industries stressed the need for Community representation on a global level to protect their interests overseas in terms of stable conditions, controlling the direction of investments (chemical industry) respect for contract relations, and support for the expansion of the oil industry. Additionally the

\footnotetext{
471 CEHECLIN, LECE, inv. nr. 274, 19-08-1981, DOCUMENT 3091/BIS and Complement coordinated text 19-8-81, Central Council - Athens, May 14, 1981 (Item 5. -2 of the agenda). For a European Energy Policy, pp. 5-7. On the topic of non-proliferation and commercial nuclear enrichment technology, see: Krass, A. S., Boskma, P., Elzen, B. \& Smit, W. A. (1983). Uranium enrichtment and Nuclear Weapon Proliferation. London: Taylor \& Francis, pp. 202-207.
}

472 Clark (1990). The political economy, pp. 352-357. 
nuclear industry demanded a diplomatic effort in EC-US relations aimed at lifting blockades on the global commercialization of nuclear technology.

In a period of international upheaval and increasing international pressures on European multinationals, the views that were expressed by the ELEC changed into an interventionist direction in terms of industrial policies. Moreover, an increasing desire for external representation can be noted. In the Bilderberg meetings particularly this last aspect would dominate.

\section{Bilderberg meetings}

Over the course of the 1970s the Bilderberg meetings discussed several themes related to the energy crisis. However, only in 1973, the annual Bilderberg meeting focussed on the issue of a European energy policy and energy security. In the followings years the energy crisis was mainly discussed in terms of financial consequences, particularly inflation.

The decision to discuss the topic of a European energy policy in May 1973 was based on requests by representatives of European industries that depended on stable oil prices for their activities: the petrochemical and automotive industries. Already in September and October 1972, three appeals were made to discuss the deteriorating situation with regard to oil. As explained, since 1971 OPEC had forced Western oil companies to accept higher oil prices and during 1972, individual OPEC member in Northern Africa and the Middle East had begun nationalizing Western oil assets such as oil field concessions. The first request came from the Belgian Baron Snoy et d'Oppuers, Minister of Finance from 1968 until 1971. Snoy et d'Oppuers was also active in the ELEC, but was not related to the Belgian Baron Pierre Snoy of Shell who was also a member of the ELEC. Before Snoy et D'Oppuers was the Minister of Finance he had several directorships in the Belgian energy sector (BP Belgium, Electrogaz, Intercom) and recently had again taken on directorships for BP Belgium and Fiat Auto Belgio. But also Daniel Janssen, director of Union Chimique Belge and Giovanni Agnelli, President of Fiat had expressed their preference for a discussion on the Middle East, both in relation to the security of energy supplies for Western Europe. During two Steering Committee meetings in October 1972 the decision was reached to put following topic on the agenda: The possibilities of the development of a European energy policy, and the consequences for European-North American relations. ${ }^{473}$

\footnotetext{
${ }^{473}$ The present American members were Joseph E. Johnson, Arthur H. Dean, James A. Perkins and Shepard Stone. RWWK, NOWA, inv. nr. 72-969-2, 28-09-1972, Joseph E. Johnson \& Ernst H. van der Beugel to the Steering Committee. The alternative topics were: Urban development and the Club of Rome and MIT report on the limits of growth (Johnson and Beugel); 13-10-1972, Daniel Janssen to Ernst van der Beugel; 17-10-1972, Giovanni Agnelli to Ernst van der Beugel; 21/22-10-1972, Minutes of 2 Meetings of the Steering Committee, p. 2. Bilderberg Meetings (1973). Saltsjöbaden Conference, May, 11-13 May, 1973. Sl.: Bilderberg Meetings, p. 13.
} 
The conference of May 1973 included a strong participation of the oil and petrochemical industries. Of the 80 participants only seventeen were from the USA, of which four were active in business: two longstanding Bilderberg members, Henry J. Heinz II of the multinational Heinz and the former Under-Secretary of State George W. Ball, now an investment banker with Lehman Brothers Kuhn Loeb, and two oil company executives: Emilio Collado of Exxon and Robert O. Anderson of Arco. ${ }^{474}$

The Europeans had invited 54 participants of which fifteen were from industry (Table 6.2) They mainly came from the oil and petrochemical industries. The Belgian representations included the Union Chimique Belgique (UCB), BP Belgium and Fiat Auto Belgio. The French group was built around energy intensive industry and energy producers: Rhône Poulenc which was one of the largest chemicals producing groups in Europe, the public utilities company Electricité de France and the commercial oil company Compagnie Française des Pétroles. The Dutch and British representatives included the chairmen of Shell and British Petroleum. The Norwegian representatives were the recently installed chairmen of the state oil companies Statoil and Saga Petroleum established in 1972, after major oil discoveries The Swiss group included the chemical firm Ciba-Geigy, and the Swedish delegation included utilities company Sydkraft. Non oil dependent, but most certainly oil \& energy - interested firms were electronics multinational Philips, part of the Dutch group, and FIAT, part of the Italian group. 475

${ }^{474}$ IISGA, AMK, inv. nr. 110, Bilderberg Meetings Alphabetical List of Participants 1954-2001.

475 The conference included the following nationalities: Belgium (3) , Canada, (4), Denmark (3), United Kingdom (8), Finland (1), France (6), Germany (6), Iceland (1), Italy (7), the Netherlands (8), Norway (3), Sweden (5), Switzerland (3), Turkey (2), the USA (17) and participants from an 'international' category (3). Bilderberg Meetings (1973). Saltsjöbaden Conference, May, 11-13 May, 1973. Sl.: Bilderberg Meetings, pp. 5-7. 
Table 6.2: Overview European participants from business, Bilderberg Saltsjöbaden Conference, May 1973.476

\begin{tabular}{llll}
\hline Country & Name & Company & Energy/Oil relation \\
\hline Belgium & Janssen, Daniel E. & Union Chimique Belge & Petrochem. \\
Belgium & Snoy et d'Oppuers, J.-Ch. & BP Belgium \& Fiat Auto Belgio & Oil prod.-Automotive \\
France & Baumgartner, Wilfrid S. & Rhône Poulenc & Petrochem. \\
France & Boiteux, Marcel & Electricité de France & Utilities \\
France & Lilliac, Granier de & Comp. Française des Pétroles & Oil prod. \\
Netherlands & Wagner, Gerrit A. & Royal Dutch Shell & Oil prod. \\
U.K. & Drake, Eric & British Petroleum & Oil prod. \\
Norway & Lied, Finn & Statoil & Oil prod. \\
Norway & Tidemand, Otto Grieg & Saga Petroleum & Oil prod. \\
Switzerland & Umbricht, Victor M. & Ciba-Geigy & Petrochem. \\
Sweden & Björgerd, Anders & Sydkraft & Utilities \\
Netherlands & Philips, Frits J. & Philips & Electronics \\
Italy & Agnelli, Giovanni & FIAT & Automotive \\
Germany & Wolff von Amerongen, Otto & Otto Wolff & Steel \\
\hline
\end{tabular}

\section{To block or absorb the Arabs?}

The Bilderberg debate on a European energy policy was very different from that inside ELEC in 1973. Instead of a focus on how the European energy industry could decrease Europe's dependency on Arabian oil, it revolved around a controversy between oil multinationals and Fernand Spaak, the Director-General of Energy in the European Commission on how to organize a European response to OPEC's actions.

Fernand Spaak opened the conference with an explanation of the point of view of the European Commission. His remarks breathed the caution that any representative of the European Commission had to observe: many aspects of energy policy overlapped with foreign policy, a domain that had almost entirely remained outside the Commission's mandate. Since 1970 an intergovernmental foreign policy framework, European Political Cooperation, was being developed, initially also shutting out involvement by the European Commission. Indeed, during his introduction Spaak limited himself to the relation between energy security and the European market, which was a central responsibility of the European Commission. He offered an elaborate explanation of how to stimulate, harmonize and coordinate all sorts of aspects of the Communities' energy market. Nevertheless, he felt that

${ }_{476}$ Bilderberg Meetings (1973). Saltsjöbaden Conference, May, 11-13 May, 1973. Sl.: Bilderberg Meetings, pp. 5-7. 
"one of the principal factors at issue" were Community-relations with energy importing countries and the Middle East. ${ }^{477}$

According to Spaak it was of central importance that Europe, the United States and Japan would develop a basis for cooperation on energy issues. He feared that if oil supplies would suddenly drop, harmful outbidding on the oil market would be the result. Cooperation should prevent such a situation according to him. At the same time however, he sketched the European Community's vulnerability within such a cooperative constellation. Western Europe's dependency on the United States was not to be underestimated, as Spaak indicated: American oil companies, holding a third of the European market, could be prompted by American incentives to redirect activities to the US market. He also pointed out European worries about the dominant position of the United States in nuclear technology and its role as price-setter and setter of terms for the sale of enriched uranium. ${ }^{478}$

The truly important issue to Spaak however were relations with the Middle East. He explained that if any consultation were to take place between Europe, the United States and Japan, these countries "should not look as if they were creating a bloc of energy importing countries as against the bloc of energy exporting countries", [...] or, "as if they were a defensive reaction." According to Spaak the European Community should aim at "stability and controlled development" in its approach of the Middle-East. As a result, Spaak explained that the oil companies, which had been conducting all the negotiations with OPEC countries in the past, could not any longer keep the Western oil-dependent nations in the dark about their intentions "before and during any negotiations." In Spaak's view the oil companies should retain the role of negotiating party, but facilitated by consultations between the United States, Japan and the European Community. In other words, he preferred a commercial approach of oil supplies to Western Europe, thereby avoiding direct involvement of European governments in negotiations. ${ }^{479}$

Spaak encountered strong opposition from participants close to, or part of, the oil industry. The American Walter J. Levy, an authoritative oil industry consultant, was invited to respond to Spaak's views. He was defensive of the oil companies, and stressed their inability to represent the interests of the West by themselves any longer. The Arab countries had taken control of pricing and had nationalized oil concessions formerly owned by Western oil companies. Thereby, he explained, the Arab countries had reduced them to "junior partners" and [...] "service companies", who were no longer capable of acting as an "independent-intermediary

\footnotetext{
${ }_{477}$ Fernand Spaak's (son of Paul-Henri Spaak) paper was reprinted in the Saltsjöbaden Bilderberg Meeting report. In October 1972, Daniel Janssen and Max Kohnstamm were instructed to contact Fernand Spaak to invite him for presenting an introductory paper. RWWK, NOWA inv. nr. 72-969-2, 21/2210-1972, Minutes of 2 Meetings of the Steering Committee, p. 2. Bilderberg Meetings (1973). Saltsjöbaden Conference, 11-13 May 1973. S.l.: Bilderberg Meetings, pp. 15-16.

${ }^{478}$ Bilderberg Meetings (1973). Saltsjöbaden Conference, 11-13 May 1973. S.l.: Bilderberg Meetings, pp. 17-18.

${ }^{479}$ Ibidem., pp. 18-19.
} 
commercial force" as Spaak still had implied. According to Levy, the West had to utilize its political and military strength to remedy the "imbalance of negotiating power" and enforce "respect for the dignity of agreements." 480

Leaders of the oil industry attending the meeting agreed with that analysis, and demanded support given their new position. Eric Drake, chairman of British Petroleum, posed a particularly forceful request. ${ }^{481} \mathrm{He}$ felt that no such thing as an oil crisis existed; according to him the current situation of OPEC-imposed prices was a political crisis. As he explained, agreements on oil supply could not be enforced and thus had ceased to be a commercial matter, with the consequence that "it was now essential that consuming governments become involved in what was essentially a political confrontation." 482

Drake had no time for extensive rounds of consultations as Spaak had proposed. He felt that the situation required immediate action. European, American and Japanese agreements could take years, while "oil companies were 'in the firing line,"“ in their relations with the Arab countries. He therefore proposed a farreaching and unprecedented oil-industry-empowering collaboration with the biggest three industrial blocs (USA, Europe and Japan). Drake pleaded for the quick establishment of an "action committee", consisting of nine delegates of international oil companies and nine delegates of the three importing blocs who were fully authorized ("plenipotentiary") to represent their governments, which would be "able when necessary to provide decisions in a week's time or less." 483

Moreover, one of the representatives of American oil companies that was taking part expressed a deep concern about the political pressure that would be mounted against oil companies in the case of suddenly dropping oil-supplies. The allocation of scarce supplies in an emergency situation would result in a political confrontation between importing countries, and the oil companies did not wish to

${ }^{480}$ Ibidem., pp. 28, 34. Walter J. Levy's paper was titled: “An Atlantic-Japanese Energy Policy", pp. 22-34 as included in the Bilderberg Meetings report, but also RWWK, NOWA inv. nr. 72-969-2, Walter J. Levy: An Atlantic-Japanese Energy Policy, March 27, 1973.

481 Interpretation of who contributed to the debates in the Bilderberg Meetings reports is not unproblematic. Statements of participants in the published reports are not linked to individuals. Moreover, statements are a mix of citation and paraphrase. Only the nationality is indicated. In rare cases however, by carefully combining insights about national delegations and the content, it is possible to link statements to anonymous individuals. In the case of Eric Drake, besides him the British delegation (8) only included public officials. Statements of the British delegation that contained specialist knowledge of the oil industry and its recent activities, and a strikingly defensive attitude of the oil industry, could only be ascribed to Drake. Similarly the American delegation only included three specialists on the American oil industry, the leaders of Arco and Exxon and Walter J. Levy, of whom the last one was at each instance identified as the American rapporteur. A similar situation fortunately existed in the case of the Dutch delegation that included G. A. Wagner, the Dutch President of Shell. Also in these cases statements that indicated specialist knowledge of or specific commitment to the oil industry were ascribed to oil industry representatives.

482 Bilderberg Meetings (1973). Saltsjöbaden Conference, 11-13 May 1973. S.l.: Bilderberg Meetings, p. 36. ${ }^{483}$ Ibidem, p. 42. 
be caught in the middle. They felt that governments ought to devise oil-sharing arrangements to deal with such emergencies. ${ }^{484}$

Emile van Lennep, secretary-general of the OECD, explained that his organization would be well suited to "associate the efforts of governments and the petroleum companies." As an intergovernmental consultative and coordinative body on economic matters for the US, Europe and, since 1964, Japan, the OECD indeed seemed ideal for serving the interests of the importing countries. Spaak's proposals for a non-confrontational attitude towards OPEC countries were largely ignored. None of the delegations that included petrochemical industry opposed the proposal put forward by Drake. There appeared to be widespread agreement that the Western private oil companies had to be supported by their governments in attempts to counter the OPEC assertiveness. ${ }^{485}$

This debate is a further confirmation of what could be observed with respect to the European League for Economic Cooperation. The internationalized oil companies wanted governments to engage in multilateral consultation and collaboration. Specifically for the European market this meant that the oil industry was in favour of international representation by the Community, capable of acknowledging on the one hand the shared interests of the Community and at the same time the worldwide interests of European ánd American oil-multinationals. In other words, the oil companies demanded political actions from the Community for which it was not prepared yet, namely the combination of a foreign economic policy, a strategic energy policy, and a collective external representation to take a stand against what the oil companies clearly saw as a form of economic insubordination by the OPEC.

As can be told from the discussions, the May 1973 meeting signalled an atmosphere of crisis several months before the oil crisis would actually escalate in October 1973. Given OPEC's recent assertiveness, that was not showing signs of coming to an end soon, the Bilderberg meeting also considered long-term implications, such as the consequences for balances of payments in the case that such a vastly traded resource would become even more expensive. Moreover, the participants considered the possible results of an enormous accumulation of oil-dollars in Arab countries, whose economies were incapable of absorbing the surplus dollars through internal investments. Already at this point ideas were developed to let the importing countries actively aid the Arabian countries in developing their own economies by, for example, building petro-chemical complexes. These complexes would be constructed by Western contractors, and as a result the Arabian oil dollars could flow back to the oil importing countries. ${ }^{486}$

During the following years the Bilderberg meetings would pay little attention to energy problems. The oil crisis that escalated in October 1973, only worsened

\footnotetext{
${ }^{484}$ Ibidem, pp. 42, 44, 46-47.

${ }_{485}$ Ibidem, pp. 42, 46-48.

${ }^{486}$ Ibidem, pp. 64-69.
} 
already damaged Trans-Atlantic political relations. In the context of the Bilderberg network, which was originally founded to address such Western tensions, these relations took precedence over issues of crisis-management. In April 1974 the Bilderberg meeting featured only one subject: "Prospects for the Atlantic world." The oil crisis was only discussed as a symptom of deteriorated Western relations. Furthermore, a key oil-crisis topic such as the founding of the International Energy Agency was not addressed. ${ }^{487}$

In fact, during the following years the economic subjects on the Bilderberg agenda transformed into more general concerns about the future structure of the Western economies. Hyperinflation preoccupied the Bilderberg meeting of 1975 , and the meeting of 1976 was cancelled due to the involvement of -the founder and chairman of Bilderberg meetings, Prince Bernhard, in the Lockheed-affair. When the second oil crisis developed in early 1979, the Bilderberg meeting considered the recurrent frustrating effects of instability in the Middle East and Africa. ${ }^{488}$

At two instances however, debates about energy security resurfaced. The meeting of April 1977 resulted in a short disagreement between Americans and Europeans on nuclear proliferation. The issue centred around criticism from the German delegation against actions of the Carter administration with regard to a commercial nuclear reprocessor that the Siemens-AEG combine Kraftwerk Union wished to sell to Brazil. On the 7th of April 1977, shortly before the Bilderberg meeting took place, President Carter had announced a new policy on nuclear proliferation. The policy involved placing controls on the commercial sale of nuclear energy plants and fuel-cycle processes, designed in such a way that weapons grade plutonium would be excluded as a fuel for energy-generation. Since the Carter administration had taken office in 1976, the American government had already insisted on negotiations on the commercial sale of nuclear enrichment plants, capable of producing weapons grade plutonium. Similarly, the reprocessor could be operated to extract weapons grade plutonium from spent uranium. In other words, on grounds of fear for proliferation of access to plutonium, the United States blocked European and Japanese sales of the nuclear technology that was considered proliferant. At the Bilderberg meeting the Germans asked for close collaboration between France, Germany and Japan, all three builders of nuclear installations, to reach a solution. ${ }^{489}$

Three years later, the meeting of April 1980 featured a similar outburst of criticism by Europeans towards the American government, this time from indus-

\footnotetext{
${ }_{487}$ Bilderberg Meetings (1974). Megève Conference, 19-21 April, 1974. Sl.: Bilderberg Meetings.

488 Bilderberg Meetings (1975). Cesme Conference, 25-27 April, 1975. Sl.: Bilderberg Meetings. Bilderberg Meetings (1978). Princeton Conference, May, 21-23 April, 1978. Sl.: Bilderberg Meetings. Bilderberg Meetings (1979). Baden Conference, 27-29 April, 1979. Sl.: Bilderberg Meetings, pp. 87-97.

489 Bilderberg Meetings (1977). Torquay Conference, 24-25 April 1977. Sl.: Bilderberg Meetings, pp. 8485. Goldschmidt, B. (1982). The atomic complex. A worldwide political history of nuclear energy. La Grange Park: American Nuclear Society, pp. 399-415; Krass, etc. (1983). Uranium enrichment and nuclear weapon proliferation, pp. 202-207.
} 
trialists. The meeting as a whole considered a variety of current affairs from political, security and economic angles, while shortly touching on the energy situation that had developed since the Islamic Revolution in Iran. Belgian and German delegations seized the opportunity to express their misgivings. They were agitated about the lack of success of the American government to truly affect oil price regulation policies. In 1971 the American government had introduced domestic price regulations for oil, designed to compensate for the OPEC determined price rises. The Belgian representatives of business included Daniel Janssen, president of petrochemicals and pharmaceuticals firm Union Chimique Belge, and Léon Lambert, chairman of Groupe Bruxelles Lambert, owner of significant shares in the Belgian energy industry. The group of nineteen German participants largely consisted of politicians, including Federal Chancellor Helmut Schmidt, but also some of the most prominent industrialists of the country: Otto Wolff von Amerongen, president of the Deutsche Industrie und Handelstag, and still chairman of the steel goods trading Otto Wolff company, Karlheinz Kaske, president of electric engineering firm Siemens, Gerhard Prinz of carmaker Daimler Benz, Herbert Grünewald, chairman of chemicals and pharmaceuticals firm Bayer, Thyssen's chairman Dieter Spethmann and banker Alfred Herrhausen of Deutsche Bank, all involved in energy intensive industry the energy industry or widespread. They complained that the US was artificially keeping prices low for American industry while European industry had to work under free market price conditions. In other words, according to them European industry was finding itself in a position of unfair competition with the United States since the early 1970s. European industry had irreversibly entered a mode of global competition in which since the advent of the oil crisis differences between energy prices posed a challenge to their competitive position in the global market. ${ }^{490}$

Similar as in the ELEC, the Bilderberg meetings debates illustrated how changing global circumstances forced major private oil companies and other industries, to view the European market as strongly influenced by economic policies from other countries and markets. To counter this situation the oil companies required

\footnotetext{
${ }^{490}$ Belgian participants: Jean-Charles Snoy et d'Oppuers (Rtrd, former Minister of Finance (1968-1971), former Groupe Bruxelles Lambert), Henry Francois Simonet, Daniel E. Janssen (Union Chimique Belge), Léon J. G. Lambert (Groupe Bruxelles Lambert), Etiènne Davignon (European Commissioner Internal Market, Customs Union and Industrial Affairs). German participants: Otto Wolff von Amerongen (Otto Wolff AG/DIHT), Helmut Schmidt (SPD, Chancellor), Peter Corterier (Politician, SPD), Theo Sommer (Publisher, "Die Zeit"), Birgit Breuel (Politician, CDU), Walter Leisler Kiep (Politician, CDU), Christoph Bertram (International Institute for Strategic Studies), Alfred Herrhausen (Deutsche Bank), Helmut Haussman (Politician, FDP), Guido Brunner (European Commissioner Science, Education and Technology), Herbert Grünewald (Bayer AG), Gunter Huonker (Politician, SPD), Karlheinz Kaske (Siemens AG), Helmut Kohl (Politician, CDU), Otto L. Lambsdorf (Politician, FDP), Gerhard Prinz (Daimler Benz AG), Gerhard Schmidt (Politician, SPD), Rüdiger Freiherr von Wechmar (Ambassador), Dieter Spethmann (Thyssen AG). Bilderberg Meetings (1980). Bad Aachen Conference, 18, 19 and 20 April 1980. Sl.: Bilderberg Meetings, pp. 105-106. International Institute of Social History Amsterdam, Archive Max Kohnstamm, inv. nr. 110, Bilderberg Meetings Alphabetical List of Participants 1954-2001.
} 
the Community to engage in multilateral, strategic action together with the other industrialized regions of the world. Adaptation was not an acceptable approach, the position of the oil industry had to be protected via diplomatic channels. However, for the oil companies the European market was not an area in itself. The companies were too interconnected with the energy markets of the United States and Japan to limit themselves to mere European diplomacy. The debates in the Bilderberg meetings therefore also aid this investigation in the interpretation of the same oil companies' views in the ELEC that were discussed earlier. The further discussed energy debates in the Bilderberg meetings were less instructive about what European corporations expected from European Political Cooperation or Community institutions. It is nevertheless clear that they used the Bilderberg meetings to bring across their views to American circles of influence.

\section{Trilateral Commission}

While the ELEC and the Bilderberg meetings were already addressing problems in relation to rising oil prices, expropriations of Western oil company assets by OPEC members and a potential supply crisis during 1972 and early 1973, the Trilateral Commission was still in the process of being founded. The reasons for founding the Trilateral Commission initially did not lie in a concern with energy but in the deterioration of monetary relations since the Nixon shock of decoupling the dollar from gold in 1971. The first Trilateral studies initialized in the Spring of 1973 offered solutions for the international monetary disorder and addressed the lacking international will to solve problems on a multilateral basis. As explained however, the escalation of the oil crisis in October 1973 functioned as an accelerator of tensions between governments of Western Europe, the United States and Japan and exacerbated already existing animosity on monetary affairs. The Trilateral Commission tried to remedy the deteriorating international collaboration and coordination. For this reason the conflicts that followed the first oil crisis triggered a prolonged interest in the energy theme. Oil and energy supply became a topic of interest from late 1973 onwards, right after the crisis had taken on full blown proportions. Between 1973 and 1980 the Trilateral Commission recurrently debated the political economic structure of energy relations. As a result, studies and debates on trilateral energy policies and related topics began appearing from 1974 onwards. Before turning to these studies and debates however, an overview of Trilateral Commission members which were involved in energy related subjects is required to gauge the balance of interests involved in these discussions. ${ }^{491}$

\footnotetext{
491 Also see the section on the Trilateral Commission in Chapter 2. Motoo, K., Cooper, R. N., \& Segré, C. (1973). Towards a renovated world monetary system: a report of the trilateral monetary task force to the Executive Committee of The Trilateral Commission, Tokyo, October 22-23, 1973. New York: The Trilateral Commission; Duchêne, F., Mushakoji, K., \& Owen, H. D. (1974). The crisis of international cooperation: a
} 
As discussed in chapter 2, the Executive Committee of the Trilateral Commission consisted of a diverse group of businessmen, policy experts, politicians, exministers, lawyers and public administrators. This composition does not provide any clues for the interpretation of the Trilateral Commission's work in general.

However, when interpreting the Executive Committee's membership within the context of the gradually developing oil crisis and energy security more broadly, a pattern emerges. Table 6.3 presents the membership of the Trilateral Commission Executive Committee in 1975. It shows that the Canadian, European, and the Japanese delegations had several members from strong energy-related interests. Strikingly, these were absent in the American section. The concentration of energy related interests is most obvious in the European membership: key industry leaders with high stakes in the oil industry, energy industry or in oil dependent developments such as fuel prices, were part of the European leadership. These include the French Paul Delouvrier, chairman of the public corporation Electricite de France, the Dutch chairman of the supervisory board of the Dutch-British Royal Dutch Shell, John Loudon and the Italian Giovanni Agnelli, president of Fiat.

Canadian energy related members included the chairman of utilities company $B C$ Hydro and a director of the nuclear-energy technology heavyweight Westinghouse. The Japanese Trilateral Commission's leadership included the largest industrial conglomerate of Japan, Mitsubishi, which was active in oil production and development of nuclear energy but also energy intensive metals production and petrochemicals. 
Table 6.3: Overview of the members of the Trilateral Commission Executive Committee in $1975 .{ }^{492}$

\begin{tabular}{|c|c|c|c|c|}
\hline Country & Last Name, First Name & Societal Sphere & Sector & Company/Institution \\
\hline Belgium & Eyskens, Marc & Academic & University & Catholic Univ. Louvain \\
\hline Canada & Bonner, Robert W. & Business & Utilities & Brit. Col. Hydro Company \\
\hline Canada & Pepin, Jean-Luc & Business & Electronics & Westinghouse Canada \\
\hline France & Berthoin, Georges & Other & Other & Other \\
\hline France & Delouvrier, Paul & Business & Utilities & Electricité de France \\
\hline Germany & Birrenbach, Kurt & Business & Ferrous Metals & August Thyssen-Hütte \\
\hline Germany & Ehrenberg, Herbert & Politics & Parliament & SPD (social-democratic) \\
\hline Ireland & Robinson, Mary T.W. & Politics & Senate & Independent \\
\hline Italy & Agnelli, Giovanni & Business & Automotive & Fiat \\
\hline Italy & Compagna, Francesco & Politics & Parliament & Partito Repubblicano Italiano \\
\hline Japan & Fujino, Chujiro & Business & Multiple & Mitsubishi \\
\hline Japan & Haraguchi, Yukitaka & Labour & Labour & Fed. of Metal Mine Labor Unions \\
\hline Japan & Hirasawa, Kazushige & Media & Media & Japan Broadcasting \\
\hline Japan & Kashiwagi, Yusuke & Business & Banking & Bank of Tokyo \\
\hline Japan & Mushakohji, Kinhide & Academic & Pol. Res. Inst. & Instit.of Intern. Relations \\
\hline Japan & Okita, Saburo & Academic & Pol. Res. Inst. & Japan Econ. Rese.Center \\
\hline Japan & Takeuchi, Ryuji & Publ. Adm. & Foreign Affairs & Ministry Foreign Affairs \\
\hline Japan & Ushiba, Nobuhiko & Publ. Adm. & Foreign Affairs & \\
\hline Japan & Watanabe, Takeshi & Business & Banking & Bank of Tokyo \\
\hline Netherlands & Kohnstamm, Max & Semi Publ. Adm. & University & European Univ. Institute \\
\hline Netherlands & Loudon, John & Business & Oil & Royal Dutch Shell \\
\hline Norway & Tidemand, Otto G. & Business & Oil & Saga Oil \\
\hline U.K. & Younger, Kenneth & Business & Law & \\
\hline U.K. & Zulueta, Philip de & Business & Banking & Hill, Samuel \& Co. \\
\hline U.S.A. & Abel, I. W. & Labour & Labour & United Steelworkers of America \\
\hline U.S.A. & Brown, Harold & Semi Publ. Adm. & University & California Institute of Technology \\
\hline U.S.A. & Brzezinski, Zbigniew & Academic & University & $\begin{array}{l}\text { Columbia Res. Inst. on Intern. } \\
\text { Change }\end{array}$ \\
\hline U.S.A. & Haggarty, Patrick E. & Business & Electronics & Texas Instruments \\
\hline U.S.A. & Reischauer, Edwin 0. & Academic & University & Japan Institute Harvard University \\
\hline U.S.A. & Rockefeller, David & Business & Banking & Chase Manhattan Bank \\
\hline U.S.A. & Roth, William M. & Business & & Roth Properties \\
\hline U.S.A. & Scranton, William W. & Publ. Adm. & Security & $\begin{array}{l}\text { GAC Arms Control and Disarma- } \\
\text { ment }\end{array}$ \\
\hline U.S.A. & Smith, Gerard C. & Business & Law & Wilmer, Cutler and Pickering \\
\hline U.S.A. & Warnke, Paul C. & Business & Law & Clifford \& Warnke \\
\hline
\end{tabular}

492 This table is based on the table A1.14, included in Appendix 1. The main source for the information in this table is Sklar, H., \& Everdell, R. (1980). Who's who on the Trilateral Commission. In H. Sklar (Ed.), Trilateralism: the Trilateral Commission and elite planning for world management (pp. 90-130). Montréal: Black Rose Books. 
A similar picture emerges in table 6.4. The table presents an overview of the members of the entire Trilateral Commission between 1973 and 1980 that were involved in the production of energy feedstocks, energy producers, energy-intensive industries, oil-related industries or energy policy specialists. Energy intensive industry typically comprises the production of basic-chemicals and metals. The American membership only included six members in this category with little continuity in membership. In comparison with the European (22), Japanese (18) and even Canadian (8) energy related memberships, American energy interests were poorly represented. Particularly striking is the multiple appearance (4) of Shell representatives.

In other words, the European and Japanese energy intensive or oil dependent industry made sure to be involved in the international study and lobby platforms of the industrialized world, whereas their American counterparts appeared to be less interested. One exception to this situation was oil giant Exxon Corporation, which was involved in the American membership since 1974. This did not mean that American industry was not interested in the Trilateral Commission. Particularly companies from the emerging information-technology firms were represented: General Electric, Texas Instruments, Hewlett Packard, Honeywell and IBM.493

A lack of interest of American industry in the oil subject can be explained through the specific domestic context. Prices of domestically drilled oil were placed under government control since 1972, guaranteeing continued access to cheap energy. Moreover, the Americans never developed a high realization of dependence on OPEC oil as in contrast to Western Europe or Japan, the United States had large amounts of energy resources at their disposal on their own territory.494

\footnotetext{
${ }^{493}$ The representatives from the American information-technology firms were John F. Burlingame (General Electric Co., member from 1980 onwards), Patrick E. Haggerty (Texas Instruments, member between 1973-1975), David Packard (Hewlett Packard, member from 1973), Mark Shepherd Jr. (Chairman, Texas Instruments, member from 1977), Edson W. Spencer (President, Honeywell Inc., member from 1977). Moreover, several European directors of IBM were members. See Sklar \& Everdell (1980). Who's who.

${ }^{494}$ Ghosh (1983). OPEC, pp. 149-187
} 
Table 6.4: Overview of Energy/Oil Related Members of the Trilateral Commission 1973-1980.495

\begin{tabular}{|c|c|c|c|c|c|c|c|c|c|c|}
\hline Country & Name & $\begin{array}{l}\vec{\omega} \\
\text { w }\end{array}$ & $\vec{v}$ & $\begin{array}{l}\vec{\varphi} \\
\text { जे } \\
\text { v }\end{array}$ & ॠु & $\begin{array}{l}\overrightarrow{\mathrm{U}} \\
\text { J }\end{array}$ & 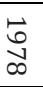 & 它 & చ̋ Company & Energy/Oil relation \\
\hline Belgium & Janssen, Daniel E. & $\mathrm{x}$ & $\mathrm{x}$ & $\mathrm{x}$ & $\mathrm{x}$ & $\mathrm{x}$ & $\mathrm{x}$ & $\mathrm{x}$ & $\mathrm{x}$ Union Chimique Belge & Petrochem. \\
\hline Belgium & Lambert, Leon J.G. & $\mathrm{x}$ & $\mathrm{x}$ & $\mathrm{x}$ & $\mathrm{x}$ & $\mathrm{x}$ & $\mathrm{x}$ & $\mathrm{x}$ & x Group Bruxelles Lambert & Multiple, Utilities \\
\hline Belgium & Rey, Jean & $\mathrm{x}$ & $\mathrm{x}$ & $\mathrm{x}$ & $\mathrm{x}$ & $\mathrm{x}$ & $\mathrm{x}$ & $\mathrm{x}$ & $\mathrm{x}$ Sofina & Utilities \\
\hline Canada & Bonner, Robert W. & $\mathrm{x}$ & $\mathrm{x}$ & $\mathrm{x}$ & $\mathrm{x}$ & $\mathrm{x}$ & $\mathrm{x}$ & $\mathrm{x}$ & x British Columbia Hydro Company & Utilities \\
\hline Canada & Pepin, Jean-Luc & $\mathrm{x}$ & $\mathrm{x}$ & $\mathrm{x}$ & & & & & $\begin{array}{l}\text { Westinghouse Can., Power Corp. } \\
\text { Can. }\end{array}$ & Utilities, Nucl. Energy \\
\hline Canada & Murray, J. R. & $\mathrm{x}$ & & & & & & & Hudson's Bay Oil \& Gas. Co. & Oil, Gas prod. \\
\hline Canada & Nielsen, Arne R. & & $\mathrm{x}$ & & & & & & Canadian Superior Oil Ltd. & Oil prod. \\
\hline Canada & Strong, Maurice F. & & & & $\mathrm{x}$ & $\mathrm{x}$ & & & Petro-Canada & Oil prod. \\
\hline Canada & Harvie, Donald S. & & & & & & $\mathrm{x}$ & $\mathrm{x}$ & x Petro-Canada & Oil prod. \\
\hline Canada & $\begin{array}{l}\text { Macdonald, Donald } \\
\text { S. }\end{array}$ & & & & & & $\mathrm{x}$ & $\mathrm{x}$ & x Shell Can. Ltd., Dupont Can. Ltd. & Oil prod., Petrochem. \\
\hline Canada & Mckeough, Darcy & & & & & & & & x Union Gas Ltd. & Gas prod. \\
\hline France & Delouvrier, Paul & $\mathrm{x}$ & $\mathrm{x}$ & $\mathrm{x}$ & $\mathrm{x}$ & $\mathrm{x}$ & $\mathrm{x}$ & $\mathrm{x}$ & x Electricité de France & Utilities, Nucl. energy \\
\hline France & Marjolin, Robert & $\mathrm{x}$ & $\mathrm{x}$ & $\mathrm{x}$ & $\mathrm{x}$ & $\mathrm{x}$ & $\mathrm{x}$ & $\mathrm{x}$ & x Royal Dutch Shell France & Oil prod., Petrochem. \\
\hline France & Martin, Roger & & $\mathrm{x}$ & $\mathrm{x}$ & $\mathrm{x}$ & $\mathrm{x}$ & $\mathrm{x}$ & $\mathrm{x}$ & x Saint-Gobain & Petrochem.-Glass-Nucl. \\
\hline France & Bonety, Rene & & $\mathrm{x}$ & $\mathrm{x}$ & $\mathrm{x}$ & $\mathrm{x}$ & & & Electricité de France & Utilities, Nucl. energy \\
\hline France & Jouven, Pierre & & $\mathrm{x}$ & $\mathrm{x}$ & & & & & Pechiney-Ugine-Kuhlmann Co. & Petrochem. \\
\hline France & Boiteux, Marcel & & & & & & & $\mathrm{x}$ & x Electricité de France & Utilities, Nucl. Energy \\
\hline Germany & Birrenbach, Kurt & $\mathrm{x}$ & $\mathrm{x}$ & $\mathrm{x}$ & $\mathrm{x}$ & $\mathrm{x}$ & $\mathrm{x}$ & $\mathrm{x}$ & x August Thyssen Hütte & Metal prod. \\
\hline Germany & Sohl, Hans-Günther & $\mathrm{x}$ & $\mathrm{x}$ & $\mathrm{x}$ & $\mathrm{x}$ & $\mathrm{x}$ & $\mathrm{x}$ & $\mathrm{x}$ & x August Thyssen Hütte & Metal prod. \\
\hline Italy & Agnelli, Giovanni & $\mathrm{x}$ & $\mathrm{x}$ & $\mathrm{x}$ & $\mathrm{x}$ & $\mathrm{x}$ & $\mathrm{x}$ & $\mathrm{x}$ & $\mathrm{x}$ Fiat & Automotive \\
\hline Italy & Colombo, Umberto & $\mathrm{x}$ & $\mathrm{x}$ & $\mathrm{x}$ & $\mathrm{x}$ & $\mathrm{x}$ & $\mathrm{x}$ & $\mathrm{x}$ & $\begin{array}{l}\text { x Montedison, Nat. Comm. for Nucl. } \\
\text { En. }\end{array}$ & Petrochem., Utilities \\
\hline Italy & $\begin{array}{l}\text { Colonna di Paliano, } \\
\text { G. }\end{array}$ & $\mathrm{x}$ & $\mathrm{x}$ & $\mathrm{x}$ & $\mathrm{x}$ & $\mathrm{x}$ & $\mathrm{x}$ & $\mathrm{x}$ & x Fiat, Solvay, CGE, Exxon & Multiple \\
\hline Japan & $\begin{array}{l}\text { Ashihara, Yoshishi- } \\
\text { ge }\end{array}$ & $\mathrm{x}$ & $\mathrm{x}$ & $\mathrm{x}$ & $\mathrm{x}$ & $\mathrm{x}$ & $\mathrm{x}$ & $\mathrm{x}$ & x Kansai Electric Power Co. & Utilities \\
\hline Japan & Fujino, Chujiro & $\mathrm{x}$ & $\mathrm{x}$ & $\mathrm{x}$ & $\mathrm{x}$ & $\mathrm{x}$ & $\mathrm{x}$ & $\mathrm{x}$ & x Mitsubishi Corp. & Multiple \\
\hline Japan & $\begin{array}{l}\text { Hasegawa, Norishi- } \\
\text { ge }\end{array}$ & $\mathrm{x}$ & $\mathrm{x}$ & $\mathrm{x}$ & $\mathrm{x}$ & $\mathrm{x}$ & $\mathrm{x}$ & $\mathrm{x}$ & $\begin{array}{l}\text { x Nippon Alum., Sumitomo Chem. } \\
\text { Co. }\end{array}$ & Metal prod., Petrochem. \\
\hline Japan & Inayama, Yoshihiro & $\mathrm{x}$ & $\mathrm{x}$ & $\mathrm{x}$ & $\mathrm{x}$ & $\mathrm{x}$ & $\mathrm{x}$ & $\mathrm{x}$ & x Nippon Steel Corp. & Metal prod. \\
\hline Japan & Kawamata, Katsuji & $\mathrm{x}$ & $\mathrm{x}$ & $\mathrm{x}$ & $\mathrm{x}$ & $\mathrm{x}$ & $\mathrm{x}$ & $\mathrm{x}$ & x Nissan Motor Co. & Automotive \\
\hline Japan & Kobayashi, Koji & $\mathrm{x}$ & $\mathrm{x}$ & $\mathrm{x}$ & $\mathrm{x}$ & $\mathrm{x}$ & $\mathrm{x}$ & $\mathrm{x}$ & x Nippon Electric Co. & Utilities \\
\hline
\end{tabular}

495 The column "Energy/Oil relations" contains the category "multiple”, typically including conglomerate corporations. This indicates that the company was involved in most or even all of the other mentioned industrial categories. The term "multiple" also covers corporate advisors or directors that were affiliated with multiple energy or energy-intensive industries. Sklar, H., \& Everdell, R. (1980). Who's who on the Trilateral Commission. In H. Sklar (Ed.), Trilateralism: the Trilateral Commission and elite planning for world management (pp. 90-130). Montréal: Black Rose Books. 


\begin{tabular}{|c|c|c|c|c|c|c|c|c|c|c|c|}
\hline Country & Name & $\begin{array}{l}\vec{v} \\
w\end{array}$ & $\underset{v}{\vec{v}}$ & $\begin{array}{l}\overrightarrow{0} \\
\text { v }\end{array}$ & $\begin{array}{l}\vec{\sigma} \\
\text { ă }\end{array}$ & $\begin{array}{l}\vec{v} \\
\text { V }\end{array}$ & 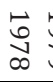 & 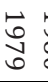 & $\begin{array}{c}\bullet \\
\infty \\
\infty\end{array}$ & Company & Energy/Oil relation \\
\hline Japan & Kono, Fumihiko & $\mathrm{x}$ & $\mathrm{x}$ & $\mathrm{x}$ & $\mathrm{x}$ & $\mathrm{x}$ & $\mathrm{x}$ & $\mathrm{x}$ & $\mathrm{x}$ & Mitsubishi Heavy Industries & Multiple \\
\hline Japan & Ohjima, Yoshihisa & $\mathrm{x}$ & $\mathrm{x}$ & $\mathrm{x}$ & $\mathrm{x}$ & $\mathrm{x}$ & $\mathrm{x}$ & $\mathrm{x}$ & $\mathrm{x}$ & Arabian Oil Co. Ltd. & Oil prod. \\
\hline Japan & Toyoda, Eiji & $\mathrm{x}$ & $\mathrm{x}$ & $\mathrm{x}$ & $\mathrm{x}$ & $\mathrm{x}$ & $\mathrm{x}$ & $\mathrm{x}$ & $x^{\prime}$ & Toyota Motor Company & Automotive \\
\hline Japan & Hotta, Shozo & $\mathrm{x}$ & $\mathrm{x}$ & $\mathrm{x}$ & $\mathrm{x}$ & $\mathrm{x}$ & $\mathrm{x}$ & & & Sumitomo Bank & Multiple \\
\hline Japan & Komai, Kenichiro & $\mathrm{x}$ & $\mathrm{x}$ & $\mathrm{x}$ & $\mathrm{x}$ & $\mathrm{x}$ & $\mathrm{x}$ & & & Hitachi Ltd. & Multiple \\
\hline Japan & Kikawada, Kazutaka & $x$ & $\mathrm{x}$ & $\mathrm{x}$ & $\mathrm{x}$ & & & & & Tokyo Electric Power Co. Inc. & Utilities, Nucl. energy \\
\hline Japan & Kondo, Shinichi & $\mathrm{x}$ & $\mathrm{x}$ & $\mathrm{x}$ & $\mathrm{x}$ & & & & & Mitsubishi Corp. & Multiple \\
\hline Japan & Miyazawa, Kiichi & $\mathrm{x}$ & $\mathrm{x}$ & & & $\mathrm{x}$ & & $\mathrm{x}$ & $\mathrm{x}$ & Nippon Steel Corp. & Metal prod. \\
\hline Japan & Hyuga, Hosai & & & & & $\mathrm{x}$ & $\mathrm{x}$ & $\mathrm{x}$ & $\mathrm{x}$ & Sumitomo Metal Ind. Ltd. & Metal prod. \\
\hline Japan & $\begin{array}{l}\text { Shibusawa, Masa- } \\
\text { hide }\end{array}$ & & & & & & $\mathrm{x}$ & $\mathrm{x}$ & $\mathrm{x}$ & Sumitomo Corp. & Multiple \\
\hline Japan & Oshima, Keichi & & & & & & & $\mathrm{x}$ & $x^{\prime}$ & $\begin{array}{l}\text { Tokyo University, Nucl. Engineer- } \\
\text { ing }\end{array}$ & Nuclear energy \\
\hline Japan & $\begin{array}{l}\text { Yoshiyama, Hi- } \\
\text { rokichi }\end{array}$ & & & & & & & $\mathrm{x}$ & $\mathrm{x}$ & Hitachi Ltd. & Multiple \\
\hline Neth. & Loudon, John & $\mathrm{x}$ & $\mathrm{x}$ & $\mathrm{x}$ & & & & & & Royal Dutch Shell & Oil prod., Petrochem. \\
\hline Neth. & Fibbe, Karel & & & & & & $\mathrm{x}$ & $\mathrm{x}$ & $\mathrm{x}$ & $\begin{array}{l}\text { Overzeese Gas en Electriciteits- } \\
\text { bedrijf }\end{array}$ & Utilities \\
\hline U.K. & McFadzean, Frank & & $\mathrm{x}$ & $\mathrm{x}$ & $\mathrm{x}$ & & & & & Shell Transport and Trading Co. & Oil prod., Petrochem. \\
\hline U.K. & Grierson, Ronald & & & & & $\mathrm{x}$ & $\mathrm{x}$ & $\mathrm{x}$ & $\mathrm{x}$ & General Electric Co. & Nuclear energy \\
\hline U.K. & Littman, Mark & & & & & $\mathrm{x}$ & $\mathrm{x}$ & $\mathrm{x}$ & $\mathrm{x}$ & British Steel Corp. & Metal prod. \\
\hline U.K. & Shackleton, (Lord) & & & & & $\mathrm{x}$ & $\mathrm{x}$ & $\mathrm{x}$ & $\mathrm{x}$ & Rio Tinto Zinc Corporation & Metal prod., Uranium \\
\hline U.K. & Smith, J. H. & & & & & & $\mathrm{x}$ & $\mathrm{x}$ & $\mathrm{x}$ & British Gas Corp. & Gas prod. \\
\hline U.K. & Turner, Mark & & & & & & & $\mathrm{x}$ & $\mathrm{x}$ & Rio Tinto Zinc Corporation & Metal prod., Uranium \\
\hline U.S.A. & Anderson, John B. & $\mathrm{x}$ & $\mathrm{x}$ & $\mathrm{x}$ & $\mathrm{x}$ & $\mathrm{x}$ & $\mathrm{x}$ & $\mathrm{x}$ & $\mathrm{x}$ & Joint Committee Atomic Energy & Nuclear energy \\
\hline U.S.A. & Wilson, Carroll L. & $\mathrm{x}$ & $\mathrm{x}$ & $\mathrm{x}$ & $\mathrm{x}$ & $\mathrm{x}$ & $\mathrm{x}$ & $\mathrm{x}$ & $\mathrm{x}$ & $\begin{array}{l}\text { Alfred Sloan School: Alt.Energy } \\
\text { Strat. }\end{array}$ & Policy Research \\
\hline U.S.A. & Jamieson, J. K. & & $\mathrm{x}$ & $\mathrm{x}$ & $\mathrm{x}$ & & & & & Exxon Corp. & Oil prod., Petrochem. \\
\hline U.S.A. & Sawhill, John C. & & & & & $\mathrm{x}$ & $\mathrm{x}$ & $\mathrm{x}$ & & Aspen Inst. Comm. On Energy & Policy Research \\
\hline U.S.A. & Caldwell, Philip & & & & & & & $\mathrm{x}$ & $\mathrm{x}$ & Ford Motor Company & Automotive \\
\hline U.S.A. & Schaetzel, J. Robert & & & & & & & $\mathrm{x}$ & $\mathrm{x}$ & Cummins Engine Inc. & Automotive \\
\hline U.S.A. & Burlingame, John F. & & & & & & & & $\mathrm{x}$ & General Electric & Nuclear energy \\
\hline
\end{tabular}

This imbalance between regional energy interests in the Trilateral Commission provides a frame for interpreting the different positions that were taken in the debates that will be presented below.

\section{The energy debates}

The Trilateral Commission's debates on the oil crisis and its effects took place in two main phases, from 1973 to 1975 and from 1977 to 1979. In both phases a 
different assessment was made of the oil and energy crisis. During the first period the Commission's discussions were characterized by three different yet entangled subjects that came together in one main argument on how to approach the OPEC members. Initially the Trilateral Commission worked on formulating a collective American, European and Japanese approach towards a reduction of dependence on OPEC oil. Secondly, these questions quickly became inseparable from the Trilateral Commission's concern with regard to the projected long-term financial effects of the accumulation of surplus foreign capital in OPEC countries. Thirdly, proposed strategies to deal with the financial effects of the oil crisis were entangled with the question on how to integrate the oil-exporting countries in international institutions. Fourthly, all these questions were ultimately connected to a controversy about the attitude that should be taken towards the oil exporting countries. Between 1977-1979 little innovation was introduced in the consideration of these problems. Instead the debate was supplemented with an entirely different dimension of the international energy supply balance, namely the combination of the United States' nuclear proliferation policy and oil policy that were damaging the European and Japanese energy positions.

On all these subjects, as will become clear, the Trilateral Commission tried to achieve a consensus among the different sections of how the several dimensions of energy supply should be approached. Participating multinationals were implicitly involved in the attempt to build consensus. In the following the extent and nature of this involvement will be explained.

In the beginning of the Trilateral Commission's work in 1973 however it initially appeared to be very difficult to start any discussions on the energy subject at all. Even within the Trilateral Commission in which like-minded members had committed themselves to improving the conditions for cooperation among their governments, the international distrust of late 1973 had a paralysing effect. When in October and November 1973 tensions escalated between Western Europe, Japan and the United States, the American membership felt that the Trilateral Commission had to act. However, during the first Executive Committee meeting in October 1973 the European and Japanese sections denounced the idea of an internationally conceived lobby towards their governments. Instead they wanted the Trilateral Commission to operate as a study organization in the service of mutual understanding and long-term education on international cooperation. ${ }^{496}$

In December 1973 the American members grew restless about these attitudes. In the course of November, the oil crisis had shown its potential risk for undermining all prospects for cooperation within the industrialized world, the primary purpose of the Trilateral Commission. At that time, the OPEC oil embargo to the United States and the Netherlands was activated and prices had surged. The North Ameri-

\footnotetext{
${ }^{496}$ See Chapter 2. Rockefeller Archive Center, The Trilateral Commission (North America) Records (hereafter RAC, Trilateral Commission), box 2, folder 23, 8-12-1973, Planning Committee meeting [American section RG].
} 
can Chairman Gerard Smith proposed to the European and Japanese sections to issue a joint statement that urged their governments to start consulting each other on "common arrangements on energy to prevent the economic collapse of any of the countries in our regions." To the frustration of the American members, the European and Japanese Executive Committee members declined the proposal. In a meeting of the Trilateral Commission's chairmen, Gerard Smith (North America), Max Kohnstamm (the European Community), and the banker Takeshi Watanabe (Japan) in December 1973, it became clear that not even a statement that urged governments to refrain from taking unilateral action was an option. Watanabe explained that in Japan such a statement would be considered "an attempt to impose American policy on them." Kohnstamm repeated the approach of long-term education on international cooperation instead of statements. A further proposal by Brzezinsky to devote a special conference to the energy problem was also rejected. In other words, the Japanese and European Trilateral Commission members wanted to stay out of their government's ways. As a result, the Trilateral Commission had nothing to contribute. ${ }^{497}$

However, parallel to these fruitless efforts, the chairmen did initialize two studies that laid a basis for discussion on the energy situation between the sections. The first report, Energy: The Imperative for a Trilateral Approach focussed on the immediate necessary action, and the second report, Energy: a strategy for international action focussed on long-term strategy. They primarily functioned as an advice to the Executive Committee. They were designed as an overview of the evolution of the oil crisis and proposed courses of action for the industrialized world. The two resulting reports were written by a group of experts: the American John C. Campbell, a research fellow with the Council on Foreign Relations, the French Guy de Carmoy, a professor at the European Institute of Business Administration (INSEAD), and Shinichi Kondo a former ambassador to Canada and advisor to the Japanese conglomerate Mitsubishi. ${ }^{498}$

Despite the different setup of the studies the recommendations were very similar. Fundamentally both argued for a American-European-Japanese approach with shared policies in order to take away any further upward pressures on the oil price: collective energy-use-reduction, collective increases in energy-efficiency, coordinated policies to maximize their bargaining power with OPEC countries, a

\footnotetext{
${ }^{497}$ RAC, Trilateral Commission, box 2, folder 23, 8-12-1973, Planning Committee meeting [American section RG], Annex; box 3, folder 32, 16/20 December 1973, The Trilateral Commission meeting of Chairmen.

${ }^{498}$ Campbell, J. C., Carmoy, G. de, \& Kondo, S. (1974). Energy: the imperative for a trilateral approach: a report of the trilateral task force on the political and international implications of the energy crisis to the executive committee of the Trilateral Commission, Brussels, June 23-25, 1974 (Vol. 5). New York: The Trilateral Commission; Campbell, J. C., Carmoy, G. de, \& Kondo, S. (1974). Energy: a strategy for international action: a report of the trilateral task force on the political and international implications of the energy crisis to the executive committee of The Trilateral Commission, Washington, D.C., December 8-10, 1974 (Vol. 6). New York: The Trilateral Commission.
} 
comprehensive oil-sharing plan for new supply crises and the sharing of technology and research \& development aimed at unlocking new energy resources. The root of the problem, the dependence of Western Europe and Japan on Middle Eastern oil, was also acknowledged. These measures were hardly controversial and could be easily backed by the different sections of the Trilateral Commission, which they did. After the Executive Committee meeting in June 1974, the Trilateral Commission finally was able to issue a collective statement on a trilateral approach to the global energy problem. One sensitive subject which had featured prominently in the reports however was left out: economic cooperation with the OPEC countries and the required cooperative attitude towards them in solving the long term issues of oil trade. ${ }^{499}$ The next section will discuss this sensitive issue in more detail.

\section{Economic cooperation with OPEC, 1974}

The advisory reports to the Executive Committee of 1974 were very outspoken on what the oil consuming countries ought to do in response to the actions of OPEC. Instead of advising assertive action as major oil companies had indicated during the Bilderberg meeting in the Spring of 1973, the Trilateral Commission reports asked for a cooperative attitude and investments in OPEC countries. The logic underlying this response was a financial one. The quadrupling of oil prices in the last months of 1973 had started a flow of billions of extra dollars into OPEC hands. This resulted in large deficits in the balances of payments of Western Europe and Japan. The outflow of oil dollars could not be kept up indefinitely, nor could the OPEC countries endlessly accumulate dollars. To balance financial flows, or in other words, to pay the oil bill, the reports stressed the requirement of exports to the OPEC countries. Moreover, because the overall small sized OPEC economies had limited import requirements, the reports also stressed the responsibility of the industrialized world to aid in diversifying the OPEC economies, particularly by assisting in establishing basic industries within their borders. The reports particularly stressed the inevitability of the building of refineries and petrochemical plants in OPEC countries, close to the basic resource of petroleum. This way the OPEC countries' import capacity would grow, enabling a more balanced structure of international financial relations. Even though such exports in the form of capital goods and industrial knowledge would create competition for particularly Western European and Japanese oil-based industries, the authors of the reports deemed it

\footnotetext{
${ }^{499}$ Campbell, Carmoy, Kondo (1974). Energy: the imperative, pp. 8-9, Campbell, Carmoy, \& Kondo (1974). Energy: a strategy, pp. 34, 40-42. Trilateral Commission (1974). Trialogue. 5th Issue. New York: Trilateral Commission, pp. 6-8.
} 
necessary in the service of the functioning of the international financial structure. 500

As mentioned these reports principally played an advisory role. Nevertheless these views were also held by financial and industrial members of the Executive Committee. When the first report was discussed during the Executive Committee meeting in June 1974, David Rockefeller expressed a strong preference for cooperation with the OPEC countries. He viewed the energy crisis as an opportunity to realize a new international cooperative structure that had crumbled during the past four years. To him the "cement" for post-war unity had been the collective stance against Soviet expansion, but now that relations with Soviet Russia were normalizing, the "energy crisis [...] could provide this kind of unifying force." In Rockefeller's view the crisis played the role of obstacle that could only be overcome by acting in unison. The Japanese members, government advisors in this particular case, took a more cautious view and merely expressed their interest in creating the conditions under which cooperation could develop. They were taking care not to force anything upon the OPEC countries that might make them less willing to be lenient in on-going negotiations. On the European side, the Dutch chairman of the Shell supervisory board, John Loudon, explained that cooperation with the Arab countries was inevitable: "OPEC countries will demand refining, petrochemical industry and other manufacturing and [...] they will get it", he stated, adding that it was important to help in these "natural aspirations." Now that Shell had lost its oil field assets in OPEC countries, the corporation could alternatively expand its sizeable petrochemical branch near the sources of oil. Kurt Birrenbach, a German member of parliament and a director of steel producer Thyssen, referred to a different aspect of cooperation with the OPEC countries. According to him their economies could impossibly absorb the enormous funds that they were accumulating. Only by means of foreign direct investments or by importing capital goods to build an industrial base and infrastructure could the funds be put to use, he explained. In other words, cooperation with the OPEC countries was a result of financial, nearly technical necessity. ${ }^{501}$

In October 1974 the chairmen of the Trilateral Commission actively pursued a practical method to provide a solution for these imbalances. They requested Lehman Brothers Kuhn Loeb investment banker and former Under Secretary of State George Ball to take part in their plan. Ball had recently presented a scheme for a Bank for Fund Recycling which he, despite his membership of the Trilateral Commission, had developed independently. The proposed bank was intended to activate OPEC capital. Under equally shared control of oil-consuming and producing countries the bank would borrow capital from OPEC countries and lend it to oil

\footnotetext{
${ }^{500}$ Campbell, Carmoy, \& Kondo (1974). Energy: the imperative, pp. 25-26; Campbell, Carmoy, \& Kondo (1974). Energy: a strategy, pp. 31-34.

${ }^{501}$ RAC, Trilateral Commission, box 4, folder 44, 23/24-06-1974, Executive Committee Meeting, Brussels, Discussion on Energy, pp. 3-6
} 
consumer countries that were facing problems in their payments balances. The OPEC countries would receive income over these possibly "perpetual" loans in the form of interest. Ball felt that this way the oil consuming countries would maximize the OPEC countries' willingness to invest their funds in the trilateral regions instead of elsewhere. The chairmen asked him present his proposal at the next Executive Committee meeting, flanked by carefully prepared co-sponsor statements elsewhere in the world and important invitees to lend an aura of significance to the plan. The plan was further prepared through consultation with the Japanese and European Executive Committee members in view of publishing a joint resolution. Important French and Japanese members, Paul Delouvrier, chairman of Electricité de France and Takeshi Watanabe from the Bank of Tokyo indicated the need for an extremely careful approach in proposing such a bank. According to both the resolution should in no way suggest already thought-out goals or mechanisms so that OPEC governments could be given the chance to formulate their own preferences. The Western European and Japanese members were afraid to trigger anything that might cause further price increases or damage an atmosphere of cooperation. Thus adapted, the resolution was agreed upon and published.502

The most remarkable aspect of these and other Trilateral Commission reports was their consistent, implicit criticism of United States foreign policy. From October 1973 onwards, Secretary of State Henry Kissinger had tried to build a coalition of oil consuming countries in a collective stand against rising oil prices. This confrontationist approach had been resisted strongly by the Japanese and French governments respectively, who, based on their dependency on oil from the Middle East stressed cooperative strategies and dialogue. The Trilateral Commission collectively and openly adopted this critical approach and under David Rockefeller's guidance actively approached the American Secretary of State with their different assessment. Rockefeller personally organized a dinner-meeting between the Executive Committee and Henry Kissinger on the 9th of December 1974 for a discussion. To make absolutely clear to the outside world what message they wanted to convey to the Secretary of State, the Trilateral Commission organized speeches on the preceding day: the Japanese Ambassador to the United States, Nubohiko Ushiba, Electricité de France chairman Paul Delouvrier, and investment banker George Ball, openly opposed the United States strategy of forcing OPEC to lower prices. After the meeting, Rockefeller explained in his thank-you-note to Kissinger, that the meeting had "clearly eased some of the worries they had had on the question of

\footnotetext{
${ }_{502}$ RAC, Trilateral Commission, box 6, folder 68, 8-12-1974, The Hon. George Ball, former Under Secretary of State of the United States. Energy and Middle East Crises. Trilateral Commission meeting held in Washington, pp. 1-24; 19-11-1974, Memorandum, George Franklin to Dr. Brzezinsky; 11,-8-1974, George Ball, Draft of statement regarding recycling proposal; box 70, folder 786, 11-10-1974, Memorandum, Charles Heck to Zbigniew Brzezinsky/George Franklin. "Decisions" from October 6-7 Chairmen Meeting. Trilateral Commission (1975). Trialogue. 6th Issue. New York: Trilateral Commission, pp. 3-4, 6. RWWK, NOWA, inv. nr. 72-1025-3, 8-12-1974, Executive Committee meeting. Ambassador Nobuhiko Ushiba. Remarks on the Energy Problem (pp. 1-3).
} 
cooperation versus confrontation with the OPEC countries", particularly for the European and Japanese members. ${ }^{503}$

These views on cooperation with the OPEC countries were supplemented with the conviction that they should be integrated in international institutions and subsequently take responsibility for their new-found role in the international economy. These ideas were advised to the Executive Committee in two reports by the American Richard Gardner, professor of Law at Columbia University, Saburo Okita, the chairman of the Japan Economic Research Center, and the Dutch Berend Udink, former Minister of Development Aid and Transport and at that time managing director of the construction and energy holding OGEM. The writing process of these reports was, unlike the energy reports, however hardly rooted in advice from business circles. Instead circles involved in aid and development were consulted. 504

The reports were titled A Turning Point in North-South Economic Relations, published in 1974, and OPEC, the Trilateral World and the Developing Countries: New Arrangements for Cooperation, 1976-1980, published in 1975. Both more specifically featured the question on how to involve OPEC countries in a shared responsibility for the plight of the developing countries which due to higher oil prices and subsequent inflation in the West had been hit the hardest by the combination of a monetary and oil crisis. The Executive Committee accepted the proposals of the reports: they advised a restructuring of the international institutions by increasing OPEC members' voting rights in the World Bank and the International Monetary Fund. Moreover, a plan was presented to invite OPEC countries to share in the cost of a development fund for developing countries. ${ }^{505}$

The logic that underlay the Trilateral Commission's views with regard to the energy crisis was the necessity of stability and the realization that economic conflict with global repercussions was unacceptable. Its leaders were convinced of the need for absorbing the new political-economic reality instead of opposing it and incorporating the financial imbalances that had occurred in the global capital flows, by including the OPEC countries in the international financial framework instead of

\footnotetext{
${ }^{503}$ RAC, Trilateral Commission, box 6, folder 69, 16-07-1974, David Rockefeller to Henry A. Kissinger; 13-12-1974, David Rockefeller to Henry A. Kissinger. Trilateral Commission (1974). Trialogue. 5th Issue. New York: Trilateral Commission, pp. 6-8. Trilateral Commission (1975). Trialogue. 6th Issue. New York: Trilateral Commission, pp. 3-4, 6.

504 Gardner, R. N., Okita, S., \& Udink, B. J. (1974). A turning point in north-south economic relations: a report of the trilateral task force on relations with developing countries to the executive committee of the Trilateral Commission, Brussels, June 23-25, 1974 (Vol. 3). New York: The Trilateral Commission; Gardner, R. N., Okita, S., \& Udink, B. J. (1975). OPEC, the trilateral world and the developing countries: new arrangements for cooperation, 1976-1980: a report of the trilateral task force on relations with developing countries to the executive committee of the Trilateral Commission (Vol. 7). New York: The Trilateral Commission.

505 Trilateral Commission (1974). Trialogue. 5th Issue. New York: Trilateral Commission, pp. 6-8. Report discussed at the Executive Committee meeting of 23rd-25th of June 1974: Gardner, Okita \& Udink (1974). A turning point, pp. 14-19; Gardner, Okita \& Udink (1975). OPEC, pp. 17-20.
} 
keeping them at arms length. Keeping in mind ELEC's reservations against aiding the development of the OPEC economies out of fear for creating competition for the European market, or the American Foreign Policy reservations against cooperation with OPEC countries, it becomes clear that in the Trilateral Commission there was no room for regional preferences. The Trilateral Commission employed a perspective that presupposed cooperation, burden sharing, the possibility of a global economic architecture in which the greater good ignored local specificities.

\section{Criticizing American energy policy}

In the next years the Trilateral Commission's treatment of the energy theme became characterized by strong European and Japanese criticism of American policy on the two subjects of price controls on oil and nuclear proliferation policy. The debates were less informed by a world view that characterized the Trilateral Commission as a whole. Instead the debates mainly became an expression of criticisms on the inability of the United States, Western Europe and Japan to coordinate and facilitate each other's strategies.

The debates on energy and oil were temporarily replaced by other subjects after 1975, but the theme re-emerged in 1977 under entirely different circumstances. The reason for this was a sudden policy shift from the United States with regard to international nuclear non-proliferation. The shift was caused by an American reassessment of the advances in nuclear enrichment technology. In Western Europe and Japan, the oil crisis of 1973 had resulted in an increasing commitment to nuclear energy. Especially France, Germany and Japan had engaged in comprehensive national public-private nuclear projects. Moreover, in Europe commercial parties were developing stakes in enrichment technologies. British, Dutch and German companies participated in the ultra-centrifuge enrichment company Urenco, and French, Belgian, Italian and Swedish firms participated in Eurodif. By 1975 both companies had begun selling entire nuclear fuel cycles in the form of process machinery. These sales were made within the rules of existing non-proliferation treaties. However, the international policy-landscape on proliferation shifted. To the surprise of the United States government India tested a nuclear bomb in 1974, pointing out the failure of non-proliferation policies. Shortly afterwards the American government began to openly question the commercial exports of nuclear enrichment technologies and nuclear reprocessing technology. This change in policy was motivated by the fact that these exports potentially gave access to limited amounts of weapons grade plutonium. . $^{506}$

In 1975 American pressure forced non-proliferation treaty members to accept stricter rules on the export of enrichment technology. Two years later, in April 1977, President Carter decided that the reprocessing of spent uranium for residual plutonium was no longer acceptable. This particularly angered the American allies.

${ }^{506}$ Krass, etc. (1983). Uranium enrichment, pp. 202-207. 
The national nuclear projects in France, Germany and Japan now lost the prospect of further commercialization of their efforts in research \& development. Moreover, France, Germany, the United Kingdom and Japan were all aiming at increasing the efficiency of their respective national fuel cycles by using reprocessing technology to acquire residual plutonium from spent uranium as recycled fuel. However, in the eyes of the United States' non-proliferation efforts, a commercialization of such reactors and facilities was unacceptable. ${ }^{507}$

The new stance of the Carter administration on reprocessing technology caused intense discussion at the Trilateral Commission plenary meeting of October 1977, in Bonn, and of June 1978, in Washington. One of the speakers at the meeting in Bonn was Gerard Smith, former chairman of the Trilateral Commission American section, but now US Ambassador at-Large for Non-Proliferation Matters. He was recruited by Jimmy Carter himself who until his election as President had been a member of the Trilateral Commission. Another speaker at the meeting was Zbigniew Brzezinsky, the former Trilateral Commission director and now National Security Advisor to President Carter. According to Smith, non-proliferation now took precedence over energy matters. Brzezinsky, whose ideas on international economic interdependence formed an important basic concept that lay at the basis of the Trilateral Commission, now stressed how nuclear proliferation was an expression of political interdependence which required a joint approach. What had moved the secretaries and chairmen of the Trilateral Commission to arrange these speeches and subsequent discussions was to "get our grip on the issues involved, and find constructive and cooperative ways to proceed."508

Nonetheless, the remarks made by Smith and Brzezinsky were difficult to accept for Kinya Niizeki, Commissioner of Japan's Atomic Energy Commission. According to him Japan required reprocessing technologies to make their nuclear fuel cycle more efficient. Since they depended on other nations for their uranium, this was of capital importance. Another speaker, André Giraud the leader of the French atomic program and director of the French Atomic Energy Commission thought it unacceptable that negotiations were taking place under pressure from the United States. According to him vital European interests were at stake in relation to the European energy supply and energy dependence. Both Niizeki and Giraud were central figures in their national public-private endeavours into nuclear energy and both represented the interests of their respective states, the nuclear industry and energy dependent industries. The intense debate that followed was dominated by

\footnotetext{
507 Ibidem.

508 RAC, Trilateral Commission, box 12, folder 158, 25-10-1977, Gerard Smith, Remarks on nonproliferation for Trilateral Commission; (no date), André Giraud, Energy and nuclear weapon proliferation; 2510-1977, Zbigniew Brzezinski, remarks The Trilateral Commission Bonn, p. 19-20; box 12, folder 163, 14-09-1977, Charles Heck to George Frankin, Francois Sauzey and Madeleine Jablonski, Subject: Gerard Smith's Presentation in Bonn.
} 
critical European and Japanese members who demanded a predictable playing field in which they could develop their own ambitions. 509

This criticism directed at the United States continued during the plenary meeting in June 1978 in Washington. A new report, Energy: Managing the Transition, centred around an evaluation of the achievements of American, European and Japanese energy policies since the oil crisis. What again emerged from the discussion was a frustration about the lack of cooperation that the industrialized nations had been able to achieve. The criticism was particularly directed at the new status of the United States as the largest global importer of oil, thereby causing extra pressure on international oil prices. Up until 1973 the United States were only minimally dependent on imported oil. The reason for this turnaround lay in the price-control measures that were initiated in 1972 for all oil produced from domestic oil wells. The immediate result was a decline in oil production from those wells. In order to maintain the level of their profits, oil companies became more keen on delivering oil to the United States from wells outside the country. The report asked the US to cancel the local price controls, which was expected to lead to more domestic supply, thus decreasing the pressures on international oil prices. The debate on the report made clear that many participants criticized United States policy, asking for a long-term policy orientation instead of the out-dated short-term energy crisis based orientation. ${ }^{510}$

What do these debates on energy security in the Trilateral Commission teach us about the views of European multinationals on the European market? As became clear, participation in the Trilateral Commission represented the acknowledgement of a need for global and international stability. Members believed that disparities in decision-making between the major industrialized areas of the world would result in undesirable upheaval and instability, negatively affecting their operations. Seen from this angle, the European market was viewed as deeply integrated with and affected by global economic relations. Moreover, they embraced the idea that the political-economic governance of the European market should be geared towards a maximum degree of international stability. However, this basic attitude did not mean that the different industrial regions and their business representatives by default agreed on how to organize the global economy, or on which interests took precedence over others. On the contrary: similar to the Bilderberg meetings the ingrained model of discussion, debate and disagreement points in the direction of an organization in which learning about each others different standpoints was the main function.

\footnotetext{
${ }^{509}$ RAC, Trilateral Commission, box 12, folder 160, (no date), Kinya Niizeki, 'Energy and nuclear weapon proliferation, A Japanese point of view'; box 12, folder 158, André Giraud, 'Energy and nuclear weapon proliferation Trilateral Commission'.

510 Sawhill, J. C., Oshima, K., \& Maull, H., W. (1978). Energy: managing the transition: report of the trilateral energy task force to the Trilateral Commission (Vol. 17). New York: The Trilateral Commission. pp. x-xiv. Trilateral Commission (1978). Trialogue. 18th Issue. New York: Trilateral Commission, pp. 3-4.
} 


\section{Conclusion}

During the 1970s the ELEC, the Bilderberg meetings and the Trilateral Commission all had their own way of dealing with the global challenges that were posed to their members from business. The ELEC went from an agenda for a European economic union in the 1950s, finally to a more interventionist agenda for Community policies for industry and for international representation by the Community to safeguard European corporate interests on foreign territory. The Bilderberg meetings, by contrast, forced by the deteriorating Transatlantic relations of the 1970s, returned to the original purpose for which they had been founded: namely of enabling mutual understanding between the different US and European memberships. The Trilateral Commission introduced a new agenda altogether. Concerned as its founders were about the deteriorating consensus that had characterised the postwar liberal economic order, the Trilateral Commission tried to propose new angles for a new consensus. Its basic assumption was that a global economic architecture belonged to the realm of possibilities and was fundamentally important for the prevention of economic conflict with global repercussions.

The views of European multinationals on the European market changed during the 1970s. The tendency of the 1960s to resolve international economic disparities between regions via the equalization of playing fields was replaced by a policy of paying attention to the possible roles of the European Commission and the Community member states to support their sectors. In the ELEC the energy industries requested stimulation of coal mining, oil-exploration and aid in the completion of a European nuclear fuel cycle in order to reduce the Communities' dependency on oil. Also in the ELEC the automotive and chemicals sectors asked support for research and development in industries that were experiencing strong international competition. Moreover, to improve the competitiveness of European industry as a whole, business leaders requested from the European Community to organise workable relations between employers and unions to enable a restructuring process of European industry. Whereas European corporations had tried to avoid interventionist Community institutions during the 1950s, by the 1970s they obviously had changed their minds.

Moreover, a significant group of multinationals asked for international representation by the Community. Oil firms wanted the Community to take a position in upholding commercial law also outside the Community. They found themselves confronted with hostile nationalizations of their assets. The European chemical sector demanded active involvement by the Community in developmental questions regarding the Middle East. The prospect of industrializing OPEC countries to balance their import capacity with their export capacity worried them because it could result in strong competition. Engineering firms involved in nuclear reactor and nuclear enrichment technology demanded that the Community would take a role in the negotiation of treaties that negatively affected European firms. 
A final occurrence of changing views could also be identified both in the Bilderberg meetings and the Trilateral Commission. In the Bilderberg meetings, oil firms requested consultation between the largest industrialized areas of the world. In fact, this was the basic rationale behind the Trilateral Commission. In that view the European market was perceived as a part of a global interdependent economy in which the European Community should play a role in developing international policies together with the other major industrialized regions.

An explanation for these changed views firstly lies in changed circumstances. The monetary crisis that escalated in 1971 marked the end of a historic economic boom that began in the 1950s. The economic decline of the 1970s was aggravated by rising oil prices which particularly affected energy intensive industries. Moreover the on-going competition by American corporations on the European market was joined by increasing exports from Japan.

The changed views can moreover be explained by the on-going cumbersome adaptation process of European industry to international competition already discussed in chapter 5 . The crisis intensified the need for more flexibility of European industry to allow companies to restructure their operations by making use of the opportunities offered by the size of the European market. By transnational mergers and relocation of production greater efficiency and competitiveness could be achieved. In addition to the differences between national tax laws and company laws, according to European industry a further threshold to such a restructuring process was the resistance of trade unions.

The present chapter again confirms that European corporations did not selfevidently agree on how the European market should be organized. Looking more closely at how these differences in views were structured, it becomes clear that the national perspective that dominated ideas on the European market in the 1950s, disappeared almost during the 1970s. Sectoral motives began to inform European industrial views instead. Within the energy sector, oil companies, coal miners and nuclear energy producers took position depending on their key business and in relation to their specific challenges of their sector within the Community. The oil companies stood out in this regard. The international nature of their sector resulted in two striking preferences that differed from other sectors. Firstly they preferred a strengthened role for the European Community in consultation with the governments of the main industrial regions of the world, the United States and Japan. At the same time they rejected supranationally organized policies or a supranationally organized market for energy. They instead preferred a European coordination of policies by means of harmonization of national policies. This paradox of an internationalized sector preferring harmonization of national policies instead of supranational arrangements may be explained by the oil companies' main interests in foreign relations of the European Community since they were being confronted, as we have seen, with the hostile appropriation of their assets by OPEC countries. 
The European chemical and automotive sectors similarly departed from their specific sectoral contexts. In contrast with the oil corporations, these sectors however did favour a supranational approach with regard to industrial policy. The reason for demanding Community action however was the same as with the major oil firms. International competition within their sectors required adaptation on a sectoral level.

One exception to the dominance of the sectoral context can be noted in the case of French nuclear energy interests. Electricité de France (EdF), the state owned French utility corporation gave more weight to the context of the national nuclear industry. This can be explained by the fact that EdF was a state owned corporation that represented the main investments in French nuclear power plants as part of the French government's nuclear ambitions. The French nuclear project was a national endeavour in which national motives informed a strategy to Europeanize the French nuclear fuel cycle.

How do the insights provided in this chapter relate to the historiography discussed in chapter 1? During the 1970s political scientists with a focus on European integration such as Feld, Häckel and Axt were interested in the role of multinationals in the dynamics of the integration process. They all defended the view that European economic integration could only succeed if multinationals would realize a transnationalization of European capital and economies. They considered transnational mergers and less intensive forms of transnational collaboration between European firms as the key route to turning national economies into a European market. They also concluded that this was not taking place. Multinationals were investing outside the Community and national governments were obstructing mergers and collaboration. European companies were willing to organize mergers and collaboration, but European national governments were not prepared to think of the European market in European terms, these political scientists argued. The results from this chapter and the previous chapter largely confirm the basic insight of barriers to European corporate transnational collaboration. However, the authors were mainly interested in how transnational collaboration could contribute to political integration. In contrast, chapter 5 and 6 show the extent to which European multinationals wanted political assistance in maintaining a viable European industrial apparatus. According to firms, corporate transnational collaboration was a practical necessity instead of a prerequisite for European integration. ${ }^{511}$

This chapter also provides important insights into the historical background that induced the European Round Table of Industrialists (ERTI) to support the Single European Act in 1986, the European treaty that provided the basis for complet-

\footnotetext{
511 Feld, W. J. (1970). Transnational business collaboration among common market countries. Its implication for political integration. New York: Praeger; Häckel, E. (1975). Multinationale Konzerne und Europäische integration. Bonn: Europa-Union Verlag; Axt, H.-J. (1978). Staat, multinationale Konzerne und politische Union in Westeuropa: ein Beitrag zur Staatstheorie und Analyse regionaler Integration. Köln: Pahl-Rugenstein.
} 
ing the single market by 1992. Both Sandholtz \& Zysman and Cowles argued how international competition since the late 1970s forced European developers of telecommunications and chips technologies to demand a European single market. As these scholars explained, the large European market in fact still was a collection of smaller markets as a result of non-tariff discrimination. The corporations required larger sales and a rationalized company structure. The Single market would remove national protectionism and strip national governments of their vetoes on market-related directives. Chapters 5 and 6 enrich these insights. A continuity between the experiences of industrial corporations represented in the European League for Economic Cooperation and the ERTI emerges. Already since the mid1960s European businesses were aiming at transnational mergers and joint ventures in response to American competition. To facilitate such cross-border undertakings they demanded a response from national governments on harmonization of European company laws and on ending the phenomenon of double taxation. During the 1970 s no progress was made while the circumstances continued to worsen as a result Japanese competition, rising oil prices and an economic crisis. In addition to the still existing legal and tax barriers to transnational mergers, multinationals in chemicals and automotive industries identified Community-wide frustrated relations between industry and the unions. Attempts at adapting the European industrial structure to the new challenges were being blocked. It is argued here that the root cause for the ERTI's support regarding the Single European Act in 1986 stemmed from the longstanding need for industrial restructuring on a European level. Their support for the Single European Act was the result of a deficiency of the Common Market that had caused problems for European industries since its inception in 1957: the barriers to a transnational rationalization and amalgamation of European company structures. ${ }^{512}$

\footnotetext{
512 Sandholtz, W., \& Zysman, J. (1989). Recasting the European Bargain. World Politics, 42, 95-128. Green Cowles, M. (1995). Setting the agenda for a new Europe: the ERT and EC 1992. Journal of Common Market Studies, 33, 501-526. Green Cowles, M. (1996). Business means Europe. Who built the market? In M. Bond, J. Smith \& W. Wallace (Eds.), Eminent Europeans: personalities who shaped contemporary Europe (pp. 192-213). London: The Greycoat Press.
} 



\section{Chapter 7}

\section{Changing views on a changing European market}

The first research question addressed in this volume is how views of European multinationals in the European market have changed between 1950 and 1980. It is answered by describing the dominant views that leaders of European companies put forward in the ELEC, the Bilderberg meetings and the Trilateral Commission.

During the 1950s most European multinationals were strong proponents of liberalization of the Western European market. In their view tariff walls, import quotas and other trade restrictions should be abolished in order to achieve an as large market as possible, preferably including the United Kingdom. Moreover a broad consensus took shape on the organization of the market. Multinationals opposed regulation by interventionist supranational institutions and rejected the idea of a multiplication of sectoral institutions. The companies felt that supranational institutions instead should guarantee the freedom of entrepreneurship and enforce conditions of competition. According to them freedom of entrepreneurship and competition were the main organizing principles of the European market. European multinationals were also persistent about the predictability of the implementation of liberalization processes. Instead of ad-hoc determination of successive steps, they wanted a predetermined and a well-defined time-schedule and roadmap for the removal of trade barriers.

In the 1960s most European multinationals continued to support and advocate liberal European and Trans-Atlantic trade relations. New however was that European multinationals felt that the European Community should play a role in levelling international playing fields. They turned against what they saw as competition distorting measures within and outside the European Community that affected their ability to compete internationally. For example, investment incentives for American companies by Community member states were mostly rejected, and attempts were undertaken to curb Eastern European dumping practices by starting coordination efforts between the Western European and the East-bloc economic systems.

During the 1970s the views of the investigated multinationals changed with regard to the role of the European Community in the markets. The demand of international level playing fields was replaced by requests for intervention. This was 
expressed in two ways. Multinationals asked the Community to actively secure and defend the international interests of European industry outside the European market. Major oil firms for example wanted the Community to consult with other major industrialized areas in the world on concerted, international interventions in order to create stability in global trade relations. Engineering firms in nuclear technology also turned to the Community, asking to reopen negotiations on international treaties on non-proliferation where these harmed their interests. A further expression of the new take on Community intervention was that European business requested an active industrial policy. Energy corporations for example were looking for a policy that would aid them in developing more energy sources. Chemical companies and carmakers asked for support in financing and coordinating industrial research. By supporting technological development, the international competitiveness of European multinationals could be maintained, the multinationals argued (Table 7.1).

Table 7.1: Schematic overview of changes in views on the European market among European multinationals.

\begin{tabular}{ll}
\hline Period & Views of European multinationals on the European market \\
\hline $1950-1960$ & $\begin{array}{l}\text { Enlargement of the European market, opposition to intervention. } \\
1960-1970\end{array}$ \\
$\begin{array}{l}\text { Demand for international level playing fields, facilitation of transnational mergers. } \\
\text { Intervention via international interest-representation on a European Community level } \\
\text { and by means of a European industrial policy. }\end{array}$ \\
\hline
\end{tabular}

How can these changes be explained? On the one hand the explanation lies in changes in international political and economic circumstances. On the other hand the answer can be found in the difficulties experienced by European multinationals in adapting to changes in the European market.

\section{Changing circumstances}

During the 1950s West European corporations adopted a new economic direction that was coherent with an American view on the development of international trade. In the first few years after WWII the United States government firmly shaped its future role as one of the two superpowers on the world stage. At the same time Western Europe entered a phase of economic reconstruction which in 1947 reached a bottleneck. The main problem was a shortage of dollars which were badly needed for imports from the United States. The Marshall Plan provided the necessary import power, but in return the United States government used its leverage to manoeuvre Western Europe into a restructuring of its internal relations. The Americans applied pressure on European governments, demanding cooperation, integration of their national economies, and increased European productivity within the fragmented Western European markets. According to the 
American government a large, liberalized European market would develop more balanced import and export relations with the American market. This was seen as the main underpinning of the in 1944 established multilateral Bretton Woods monetary system. The project of liberalization and European integration held the promise of large markets. European multinationals in the ELEC consistently supported these views. For the already large and widely distributed corporations larger markets provided circumstances in which they could centralize their organizations in one headquarter. For smaller corporations larger markets were an opportunity for growing their scale which was becoming a necessity for withstanding competition from large American firms. Moreover, in the Bilderberg meetings, American and European multinationals mutually affirmed their preference for increased access to each other's markets, further bringing about balanced exchanges in the new Western economic order.

The project of liberalization of the European market was undermined during the early 1960s though. The French government blocked further initiatives for liberalizing trade between the Common Market and the European Free Trade Association, established in 1960, and it blocked the accession of the United Kingdom to the Community. At the same time the conditions on the European market began to change. European multinationals were increasingly facing competition from outside Western Europe. The prospect of a European market without internal tariff barriers, but with a common external tariff wall, attracted large investments by major American companies. This resulted in strong competition for European corporations. In addition several European industries encountered competition from the East-bloc. Eastern European state trading companies started offering basic industrial products against dumping prices. These new circumstances focussed the attention of European multinationals on distorted competition and on strategies designed for neutralizing such international unbalances. In response to American investments for example, companies in the ELEC and the Bilderberg meetings proposed a code of conduct for American corporations to limit their aggressive competitive behaviour on the European market. In response to competition from the East-bloc, European corporations tried to develop a framework of agreements to enable joint ventures between Western European and Eastern European companies.

Three related crises dominated the developments in the West during the 1970s. In 1971 the post-war monetary system collapsed, which resulted in significant instability in currency markets. The consequential changing terms of trade for OPEC countries caused them to increase oil prices, triggering a second crisis, which resulted in high inflation. The simultaneous stagnation of European productivity growth and the occurrence of overcapacity marked the end of the global economic boom that had taken place since the 1950s. It introduced the novelty of stagflation, which rigorously affected European economies. Moreover, the unilateral response to these events by the governments of the United States, France and the United 
Kingdom resulted in a crisis in international, Western relations. The option of solving international problems on a multilateral basis was severely undermined. In the midst of this cocktail of instability and uncertainty European multinationals demanded from their governments to pursue international stability and to organize collective European representation of business interests in external markets. Moreover, as a result of diverging energy prices in the world, particularly the European chemical industry warned for an international restructuring process whereby companies would move production capacity to regions with the cheapest sources of energy, such as the United States that artificially held down prices, or the Middle East, with an abundance of oil. However these developments were intimately connected with another process that began to take hold since the early 1960s.

\section{Adaptation problems}

The views of multinationals on the European market were also shaped by adjustment problems related to the changes of this very market. As explained, during the 1950s several large European corporations were strong supporters of the removal of internal barriers to trade in order to create an as large as possible market for their goods. But for the earliest European multinationals, that had already developed before WWII, this perspective also created problems. During the protectionist interbellum Dutch and Belgian multinationals such as Philips, Unilever and Solvay had expanded their firms outside their small home markets. They established subsidiaries in the Western European national markets, decentralizing production, marketing and research and development. To them the establishment of the Common Market represented an enlarged market in which companies could realize mass production at more centrally located and cost-efficient sites. The Common Market was an opportunity to recentralize. ${ }^{513}$

In the 1960s it became clear that the prospect of the Common Market attracted investments of very large American industrial corporations. American corporations had achieved their position within a large American market and had grown to corresponding dimensions. European companies instead had developed in smaller, national home-markets. As a result their production units often were much smaller than those of the American companies that began investing in Europe. Moreover, unlike the European multinationals that had expanded internationally during the Interbellum, the American firms were not tied to already existing investments that first required restructuring and centralization before the scale advantages of the

\footnotetext{
513 Blanken, I. (2002). Een industriële wereldfederatie. Zaltbommel: Europese Bibliotheek, pp. 262-280; Jones, G. G., \& Miskell, P. (2005). European integration and corporate restructuring: the strategy of Unilever, c. 1957-c. 1990. Economic History Review, 28, 113-139; Tolliday, S. (2003). The origins of Ford of Europe: from multidomestic to transnational corporation. In H. Bonin \& Y. Lung (Eds.), Ford, 19032003: the European history (pp. 153-242). Paris: P.L.A.G.E.
} 
Common Market could be reaped. To summarize, quite some European companies had remained relatively small and they were challenged by American firms in terms of sheer size. A small group of early European multinationals was held back by the path-dependency of their since long existing investments and they were challenged by American firms in terms of company structure. In order to at least approach the size of American companies European multinationals proposed harmonization of national taxation systems to encourage transnational mergers. ${ }^{514}$

The need for adaptation only grew larger during the crises of the early 1970s. The combination of industrial overcapacity and growing wage demands was untenable and further increased the need for restructuring the European companies. At the same time, international competition only increased, as a result of Japanese exports, for example. But the rigid conditions on the European labour market made restructuring an impossible task. Moreover, the requests for improved circumstances for transnational mergers still had not been met. Whereas the European multinationals had resisted interventionist governments and supranational institutions in the 1950s, they were now prepared to accept intervention to enable the necessary restructuring. European automotive and chemical multinationals for example demanded an active involvement of the European Community in arranging European industrial relations in order to achieve flexibility in relocating their production sites. In their view, unions were obstructing a restructuring process of European industry. An industrial policy was badly needed.

The European Commission was a powerless partner for European multinationals though. It indeed presented proposals in line with the wishes of European multinationals, including a memorandum for a Community industrial policy by Commissioner Guido Colonna di Paliano. However, member states were unwilling to accept them. The de facto veto structure of Community decision-making that had emerged since the Luxembourg compromise in 1966, obstructed far reaching decisions. Moreover, European multinationals appeared to gain little from cooperation with the European Commission in matters of international trade diplomacy with the United States and European countries outside the Community. The Commission merely represented a small group of countries in a large international playing field. The European Community was not in a position to commit to level playing fields in an early stage, because non-Member States could easily benefit from the possible self-restraint of the Community. In such cases, the European companies turned to the OECD, or even NATO, to devise arrangements with a wider representation of Western governments. ${ }^{515}$

In that process European multinationals found themselves trapped between international competition, a supranational system of governance that was unable to cater to their needs for restructuring, and an accumulation of crises during the

\footnotetext{
514 Jones \& Miskell (2005). European integration. 515 See chapter 5 .
} 
1970s. This unfortunate combination of affairs reached a peak in the early 1980s and will be discussed in more detail in the section on historiography.

\section{Explaining diverging views: national and sectoral contexts}

The dominant views among the investigated European multinationals described above conceal subtle differences. The second research question of this study is which differences existed among the views of multinationals and how they can be explained? Chapter 3 introduced an interpretative framework that proposed an explanation of those differences by considering the diverse national and sectoral contexts in which companies operated. .516

\section{National views}

As was described above the 1950s were characterized by a broad consensus among the investigated multinationals on the necessity of liberalizing the European market. At the same time, there were differences of opinion on how liberalization should be realized and they mainly differed along national lines. French corporations for example preferred a special brand of liberalization. They were of the opinion that the largest share of differences in cost-prices between countries should be harmonized through compensation rates. The French companies launched the plan to hold negotiations within European sectors in order to arrive at proposals for economic integration that included specific measures to overcome resistance from unfavourably positioned companies. Multinationals from the other countries saw little use for such de facto protectionist temporary measures. German companies preferred a free trade area (without a common external tariff) rather than a Common Market (with a common external tariff wall). The Dutch and Belgian companies were pushing for any form of liberalization that had a realistic chance of success. The British representation in the ELEC and the Bilderberg meetings hardly represented multinationals that were established in the United Kingdom. Therefore it is not possible to sketch a clear picture of the views of British multinationals. Shell and Unilever however were established both in the United Kingdom and the Netherlands and were part of the Dutch section, which at least gives some insight into views held by British firms.

These differences can be explained by the national contexts of economic structure, competitive position and path-dependencies, and the consequences of these factors for opportunities in the European market. The French context was strongly determined by the large role of the state in national economic planning. With regard to the liberalization drive of the 1950s, the wishes of French corporations on cost-price harmonization can moreover be understood by considering the relative-

516 See chapter 1. 
ly high French wages and the costs that companies incurred from the French social system. When as a result from the Common Market import-tariffs would be dropped, the competitive strength of French firms would be eroded. The attitude of German companies regarding the preference for a free trade area without a common external tariff wall can be explained by the broad orientation of German trade outside the Benelux, France and Italy. Germany already had a relatively low tariff wall. The projected higher external tariff wall of the Common Market would make their exports more expensive. Finally the views of the Dutch and Belgian multinationals were based on a path dependency that resulted from the small size of their markets. Already before WWII companies from these countries had expanded outside their small domestic markets. As a result to them the liberalization of European markets meant opportunities for economies of scale. Moreover, as a result of prolonged liberal policies by both governments the multinationals from the Benelux were since long exposed to external markets and had developed a strong competitive position. In a liberalized market they would benefit from that position. With regard to the decision how to shape a Common Market during the 1950s it is also important to stress that the views of the investigated European companies in the European League for Economic Co-operation can be largely explained by considering the negotiating positions of their national governments. They remained very close to positions held by their governments in negotiations.

In the 1960s the diverging views that were based on a national context cannot be so clearly explained by nationally differing economic structures, competitive position and path-dependencies. The explanations seem to be more idiosyncratic than structural. As became clear in the Bilderberg meetings, the temporary demand of German capital goods exporters for a virtually OECD-wide limitation of terms for export loans to the East-bloc originated from the unwillingness of the German government to follow the practices of guaranteeing export loans in the rest of Western Europe. Western European governments took on a competitive attitude versus Germany over a share in these exports and were prepared to go beyond the maximum period of guarantees that the German government was prepared to offer. Therefore a level-playing field on such terms would be beneficial to German companies. Similarly nationally informed was the rejection by the Dutch multinational companies in the ELEC of a uniform company law for the European Community. Their refusal to cooperate in this regard stemmed from the fear of inadvertently introducing German participation rules in the Dutch economy.

In the 1970s in the ELEC a pronounced national attitude could be noted among French companies who were active in the sector of nuclear energy. Their attempts to elevate the nuclear fuel cycle that they had developed, as the dominant European standard would further strengthen their leading role in nuclear technology in Europe. More importantly, the Commissariat à l'Énergie Atomique, a semipublic administrative institution and the state company Électricité de France played a leading role in the pursuit of this strategy. The explanation of this attitude 
here also lies in the role of the state in France's economic management. The government's consistent role in planning and stimulating the nation's scientific and industrial control over nuclear energy since the 1950s illustrates that the national attitude of French firms in this case was an example of path dependency.

\section{Sectoral views}

Views that differed along lines of sectoral interests resulted mostly from sector specific challenges. In the 1960s, for example, representatives of the European chemical industry favoured the creation of a European company law instead of harmonization of national taxation schemes. Additionally, in the 1960s clear differences of opinion emerged on the organization of the European market with regard to aiding exports of capital goods to the Eastern European bloc. The remaining European industry, especially the chemical industry, opposed indirect government-support to exporters of capital goods because it facilitated emerging competition by the East-bloc. European banks also fulfilled a separate role in this dispute. They provided the export loans to the East-bloc countries but were only willing to do so if governments provided guarantees. Each sector had different ideas about how to organize these aspects of external trade. Some banks such as Banque Bruxelles and Deutsche Bank were also confronted with increasing demands from European industry to reform the nationally still very separated European capital markets in such a way that European industry would gain more access to affordable capital.

Also in the 1970s industries developed different ideas about the organization of the European market. Among the energy industries an interesting difference emerged. The commercial oil industry requested international representation by the European Community in strategic and commercial affairs. The coal and nuclear industry instead preferred Community support for the further development of their industries. However, around 1980 the European nuclear industry changed its position and joined the oil industry in a demand for external representation by the European Community.

Those sectoral differences can be explained by a combination of the internationalization of markets and specific sectoral responses to changing circumstances. Increasing competition by American companies played a decisive role. The activities of large American chemical companies on the European market forced the European chemical industry to increase their scale and efficiency in research and development. According to the European chemical industry mergers and centralization of European companies could only be stimulated by the adoption of a uniform legal structure for European companies. The research intensity of their operations was the main rationale behind that preference for mergers and enlargement of scale. Other sectors were satisfied with the abolishment of double taxation that occurred in transnational mergers. 
During the 1960s the increased industrial competition on the Western European market also led to competition with respect to capital. When in 1963 the export of dollars to Europe was limited by an American tax, American multinationals turned to the European capital market, which resulted in rising prices of capital. European industry and European banks disagreed on how this scarcity of capital should be approached. Industry wanted a European capital market that would be predisposed to European industry. The bankers however were opposed to any suggestion of a preferential treatment for European industry and saw no quick solution in terms of a European capital market, as they were convinced that European governments were not prepared to follow through on all the required adaptations for such an undertaking. A further explanation was that European banks were in competition with American banks which made discrimination between European and American clients undesirable.

In the 1970s the degree of internationalization of companies explains differences in attitude towards to the organization of the European market. Globalised oil companies in the Bilderberg meetings attempted to organize European, American and Japanese governments around an assertive policy to counter OPEC's increasing control of oil price-formation and on-going nationalization of industryassets. They wanted a predictable environment instead of the chaos that the oilexporting countries were causing and perceived any effort by the European Community in this area as a step in the right direction. Instead the Europe-based coal and nuclear industries were not concerned with these problems since their activities were focussed on the domestic market.

The views of European multinationals on the organization of the European market were thus not only determined by national circumstances and pathdependencies. They were also determined by competition within their own sectors and the specific characteristics of each sector. Studying European business on a transnational level therefore requires both a national and a sectoral perspective. In addition, it became clear that the liberalization and internationalization of the European market led to adjustment problems, forcing sectors to demand much more intervention from the European institutions than they preferred to accept in the first place when the European institutions were being founded.

\section{Transnational networks}

A key element of this investigation is its comparative perspective on the ELEC, the Bilderberg meetings and the Trilateral Commission. Studying these organizations has resulted in new insights into how they operated, their different roles and the different setting that each provided for multinational companies. 


\section{European League for Economic Co-operation}

The ELEC was already thoroughly investigated by Michel Dumoulin and AnneMiriam Dutrieue. Still, even though similar sources were used in the present investigation new insights could be gained. The investigation of Dumoulin and Dutrieue mainly focussed on individuals. Although the authors acknowledged a dominant role of European business in the ELEC, they disregarded corporate interests in explaining the formation of ideas in the organization. The present study has shown though that the ELEC is eminently suited to be studied from a business history perspective. The large European companies played an all-decisive role in the ELEC: they financed it, set the agenda and contributed to the content of publications. In addition, the milieu of large European companies and multinationals formed the primary environment in which the ELEC tested how it should shape its role. Finally, it became clear how ELEC reformulated its mission when initiatives for liberalization of the European market stalled. The original priority of liberalizing the European market was moved into the background in favour of the new priority of devising a response to external competition. The ELEC asked for attention for a broad range of ideas emerging from European business. 517

\section{Bilderberg meetings}

Research on the Bilderberg meetings by Valérie Aubourg and Thomas Gijswijt remained limited to the period 1952-1966. Both concluded that the Bilderberg meetings enabled an exchange of ideas between Americans and Europeans and agreed that the organization was not geared to generating any influence as a group. According to Gijswijt the encounters functioned as a sort of pressure valve for the transatlantic alliance in which differences of opinion could be freely expressed without self-censorship. With regard to the topic of European integration, according to Aubourg the Bilderberg meetings were particularly distinctive compared to other networks or groups because the members showed great willingness to include the United Kingdom into the Common Market. 518

For the period 1952-1966 our investigation has shown the extent to which the economic dimension of the Bilderberg meetings was characterized by views cherished by the American government on the European market. According to the Americans, Western Europe had to develop economic cooperation, liberalize their markets, integrate, and increase productivity in order to arrive at a stable equilib-

\footnotetext{
517 Dumoulin, M., \& Dutrieue, A.-M. (1993). La Ligue Européenne de Coopération Économique (19461981): un groupe d'étude et de pression dans la construction européenne. Berne: Lang.

518 Aubourg, V. (2009). Transatlantische Geschäftsbeziehungen. Die Bilderberg-Gruppe. In Gehler, M., Kaiser, W. \& Leucht, B. (Eds.), Netzwerke im europäischen Mehrebenensystem. Von 1945 bis zur Gegenwart = Networks in European multi-level governance. From 1945 to the present (pp. 69-86); Wien: Böhlau; Gijswijt, T. W. (2007). Uniting the West: the Bilderberg Group, the Cold War and European integration, 1952-1966. Unpublished dissertation, Heidelberg, Heidelberg, pp. 294-298.
} 
rium in exchanges within the in 1944 established multilateral Bretton Woods monetary system. The discussions during the Bilderberg meetings on the need for European economic integration match this context. The repetitive mutual reaffirmation between Europeans and Americans about the importance of avoiding protectionism moreover fits this grand scheme. Particularly during the 1950s the Bilderberg meetings were an instrument for both Americans and Europeans to continuously evaluate whether they still agreed on the economic foundation of the military alliance. ${ }^{519}$

The positive attitude in the Bilderberg meetings with regard to the accession of the UK to the Common Market and other forms of integration between the UK and the EEC should also be seen in light of the liberalization and productivity agenda. The Bilderberg meetings were however not unique in this regard. Dumoulin and Dutrieue had already identified a similar attitude in the ELEC, which is confirmed by our investigation. ${ }^{520}$

Both Aubourg and Gijswijt also argued that the Bilderberg meetings should be seen as a continuous effort to strengthen Transatlantic ties, and that the participants used the encounters to influence each other. In the previous chapters several examples of those efforts have been discussed. However, an additional function of the Bilderberg meetings was identified for the leaders of multinational companies. Through their participation in these meetings they were able to satisfy their needs regarding up to date knowledge about international developments. As members they were better informed about changes that the international system was undergoing, or might undergo. The meetings provided an opportunity for gathering new perspectives and for monitoring the international debate by leading experts on the liberal order.521

Particularly interesting were the results for the period after 1966. The leaders of the Bilderberg meetings developed a concern about the too homogeneous composition of the membership. After the turbulent period of student protests around May 1968, they began to actively invite younger participants, especially from circles of the New Left. These doubts were accompanied by a more fundamental sense of a lacking legitimacy for continuing the exchange of ideas on a strictly Transatlantic level. A disagreement on the possible participation of Japanese members undermined the group's original goals. That dispute was finally settled in the wake of President Nixon's decision to suspend dollar-gold convertibility in 1971: the monetary and political upheaval that followed, suddenly convinced the leaders of the Bilderberg meetings that future transatlantic relations would con-

\footnotetext{
519 Milward, A. S. (1984). The reconstruction of western Europe, 1945-1951. Berkeley: University of California Press.

520 Dumoulin \& Dutrieue (1993). La Ligue.

521 Aubourg (2009). Transatlantische Geschäftsbeziehungen; Gijswijt (2007). Uniting the West. Also see Chapter 2.
} 
tinue to require an informal exchange of ideas without participation of other regions. 522

\section{Trilateral Commission}

Previous research on the Trilateral Commission by Stephen Gill was informed by a neo-Marxist reading of globalization. Gill considers the Trilateral Commission as an expression of a transnational class struggle in which multinationals attempt to realise their superiority on a global scale. That view is similar to the approach by Holly Sklar, who also published a critical analysis in which the supposedly undemocratic nature of the Trilateral "elite" is emphasized. Both consider the fact that so many representatives of multinational companies were members of the Trilateral Commission as evidence of a broad similarity in interests. But we have shown that this was not the case.

Particularly during the first years after the Trilateral Commission was founded in 1973, and throughout the 1970s, substantial differences emerged between the American, Japanese and European members. The three regional sections made diverging assessments about the tense circumstances of the 1970s. Trilateralism, the idea that the three major industrialized regions of the world together would take on global leadership, was a wishful interpretation of world affairs on the part of the American initiators and was approached very critically by the European and Japanese sections until at least the early 1980s. Although the Trilateral Commission aimed at real trilateral cooperation, in reality the Trilateral Commission had no choice but to settle for a modus operandi similar to that of the Bilderberg meetings. ${ }^{523}$

\section{Comparisons}

The comparative perspective on these three networks was very useful for understanding the views of multinationals on the European market. The simultaneous investigation of the selected themes via the ELEC, the Bilderberg and Trilateral Commission meetings, results in the insight that in each group each subject manifested itself in a different way. The composition of the membership of the networks, and their diverging missions, played a role in how a topic was treated. Compare for example the ELEC and the Bilderberg meetings: European national differences were more pronounced in the ELEC due to the presence of Europeans only. However, in the Bilderberg meetings European national positions remained more in the

\footnotetext{
522 See Chapter 2.

523 Gill, S. (1991). American hegemony and the Trilateral Commission. Cambridge: Cambridge University Press, pp. 90-93 and 96-98; Sklar, H. (1980). Trilateralism: Managing Dependence and Democracy. In H. Sklar (Ed.), Trilateralism: the Trilateral Commission and elite planning for world management. (pp. 1-57). Montréal: Black Rose Books, pp. 4, 8, 21.
} 
background due to the confrontation of Europeans with Americans. In order to accomplish a sensible discussion the Europeans were forced to think in more or less European terms instead of continuously stressing national idiosyncrasies.

Additionally, the different contexts of the networks mattered for how a topic was treated. For example, in the ELEC in the 1950s the subject of liberalization of the European market was repeatedly discussed in terms of lower tariffs. In the Bilderberg meetings the subject of liberalizing the European market instead took on the contours of an element of the American strategy for the West against the Soviet Union. ${ }^{524}$

In the 1960s the ELEC and the Bilderberg meetings fulfilled different roles for European business, even when on the same subjects. In the ELEC the topics of EastWest trade and American investments were solely treated from a European perspective and revolved around safeguarding the position of West European companies. In the Bilderberg meetings however, East-West trade was approached from a Transatlantic perspective which was still strongly determined by Cold War sensitivities. The American members preferred to limit Western export credits for the export of turn-key factories and production machinery to the East-bloc in order to prevent that Soviet Russia would benefit from Western know-how. The theme of American investments was mainly turned into an opportunity to once more mutually reaffirm the importance of a liberal attitude towards American investments. The Bilderberg members decided that the only answer to American investments would be increased European unity. ${ }^{525}$

Also in the 1970s similar subjects manifested differently across the organizations. In the ELEC the activities were mainly directed at improving Community policies to the benefit of European industry. In the Bilderberg meetings and the Trilateral Commission the members focused on shaping opportunities for international cooperation and tried to actively address global problems and to promote international stability. ${ }^{526}$

The combination of the ELEC, the Bilderberg meetings and the Trilateral Group has played a complementary role in this investigation. The ELEC offered a broad perspective on the developments that took place within the European market. At the same time the debates taking place in the Bilderberg meetings and the Trilateral Commission illustrated how these developments were linked with the internationalization of the world economy. The juxtaposition and comparison of these three organizations yielded a fuller picture of the motives behind the views of European multinationals.

\footnotetext{
${ }_{524}$ See Chapter 4.

525 See Chapter 5.

${ }^{526}$ See Chapter 6.
} 
The selection of these particular transnational networks and the focus on corporations, begs the question about whether these organizations had any influence or not? Although this investigation was never designed to answer this question, some insights can be offered.

The activities of the Bilderberg meetings and the Trilateral Commission make it difficult to characterize them as lobbying groups. And even though ELEC clearly lobbied via its publications and resolutions it is still not possible to identify concrete examples of policy influence emerging from these networks. The relation between the networks' activities and policy outcomes was not investigated. It is important however to make a distinction between the largely absent lobbyactivities of the networks and lobby-activities that firms undertook outside the networks.

One could consider possible similarities between the networks' preferences and immediate policy outcomes as instances of influence. In that case ELEC's views throughout the 1950s come very close to the decision to found the Common Market in 1957. But to ascribe influence to the ELEC based on such a similarity would be a gross misrepresentation of the complexity of the actors and parties involved in the decisionmaking process towards the signing of the Rome Treaties. The ELEC however was able to change attitudes in Eastern Europe, by proposing practical collaboration schemes. ELEC's other activities did not result in the preferred outcomes.

Although outcomes remained largely unaffected, aspects of influence existed in other ways. Clearly the ELEC was seen as an important interlocutor for the European Commission on topics in which they shared a common goal. The Bilderberg meetings' members were in the position to arrange a meeting between governmental representatives from France and the United Kingdom on the vetoed British accession to the Common Market. At times the networks acquired a role of discussion partner.

\section{Relation to historiography}

The questions addressed in this book are related to the historiography on European business in the three disciplines that were discussed in chapter one: European integration theory, history of European integration, and business history. To what extent do the insights from this study enrich the historiography of these disciplines? 


\section{Business and European integration theory}

Since the 1950s European integration theorists have tried to understand and predict how European integration would proceed. The Americans Ernst Haas and Leon Lindberg, two neofunctionalist integration theorists, defined integration as a shift in political activity of elites towards newly created supranational institutions. The logic inherent in this perception of integration is that society redirects itself to a new institutional reality. It precludes that elites can be initial actors in starting the integration process before the existence of supranational institutions. The activities of multinationals in the ELEC and the Bilderberg meetings show however that companies were already lobbying national governments to take steps towards integration, even before supranational institutions existed. Moreover, companies took part in debates on how supranational institutions should organize the European market before the institutions were founded. Still, as stated by neofunctionalist theorists, particularly the ELEC developed loyalties, expectations and political activity towards the supranational institutions. ELEC's position papers and publications were aimed both at member states and the European Commission. The European Commission on the one hand became a source of proposals for ELEC's agenda, for example with regard to seeking cooperation with East-bloc states, or on starting a dialogue with OPEC countries. On the other hand, the European Commission tried to mobilize the ELEC in areas where it could not act itself. The European Commission also showed sensitivity to ideas that emerged from the ELEC, for example on tax harmonization and industrial restructuring.527

Implicitly ingrained in integration theory is the question of how actors influence the European integration process. In neofunctionalist theory, elites and supranational institutions play a central role. In intergovernmentalist theory, member states are considered the main decision makers. Although the present investigation was not designed for studying decision-making dynamics, still, by considering the preferences of European multinationals and the degree of success they had in seeing their views realized, the following general conclusions can be drawn.

In the 1970s political scientists such as Werner Feld and Erwin Häckel ascribed an important role to multinationals in breaking down the national structures of the European economy. To do so these multinationals had to engage in transnational mergers and joint ventures. The neo-marxist Heinz-Jürgen Axt was also convinced that in order to achieve deeper market integration, national capital had to become increasingly transnationalized. All three authors concluded that the Community member states were blocking such developments. That conclusion

\footnotetext{
527 Also see chapter 1. Haas, E. B. ([1958]1968). The uniting of Europe: political, social and economical forces, 1950-'57. London: Stevens, pp. 9-10, 16-17; Lindberg, L. N. (1963). The political dynamics of European economic integration. Stanford: Stanford University Press, pp. 10-11. Commissioner Guido Colonna di Paliano included ideas that emerged in the ELEC in his 1970 memorandum on industrial policy. See chapter 5 .
} 
agreed with intergovernmentalist integration theory, based on the work of Stanley Hoffmann that claims that European integration proceeds when national governments allow it to proceed: governments remained in full control of the preservation of sovereignty. The results in this book confirm that conclusion. It appeared that already since the mid-1960s European multinationals had a different view on the organization of the European market than Community member states. As an answer to American competition companies required a larger scale of operation. However, transnational mergers were unattractive due to major differences between national legal systems, particularly with regard to taxation. Even though the European Commission adopted the ideas of mitigating these obstacles, member states were not willing to accept reform proposals during the 1960s and 1970s.528

Further advances in integration theory acknowledged a role for business in explaining European integration, albeit on the national level. Andrew Moravcsik's liberal intergovernmentalism went beyond Hoffmann's state-centric explanation of integration in that he explicitly recognized that states develop their position towards integration in domestic preference formation processes. However, although business interests played a role in national debates, according to Moravcsik the state remained the only aggregator of interests in relation to state bargaining processes. What liberal intergovernmentalist theory does not acknowledge however is the potentially transnational nature of business interests. Chapter 4 showed a mixed message in this regard. During the 1950s the ELEC published papers that received transnational approval, but these were the result of nationally diverging business views. However, chapter 5 on the 1960s and chapter 6 on the 1970s showed the emergence of sector-based preferences on a European, transnational scale: chemical industries, major oil firms, carmakers across Europe attained a consensus on the main issues for their sectors. National representatives of these industries conveyed those views to their national governments. In this way transnational views were introduced in national preference formation processes. In other words, Moravcsik's implicit argument that domestic preference formation processes are closed off to transnational ideas is too simplistic. ${ }^{529}$

\footnotetext{
${ }^{528}$ Hoffmann, S. (1964). De Gaulle, Europe, and the Atlantic alliance. International Organization, 18, 128; Hoffmann, S. (1964). The European process at Atlantic crosspurposes. Journal of Common Market Studies, 3, 86-101; Hoffmann, S. (1966). Obstinate or obsolete? The fate of the nation state and the case of western Europe. Daedalus, 95, 862-915. See Chapter 4. Feld, W. J. (1970). Transnational business collaboration among common market countries. Its implication for political integration. New York: Praeger; Häckel, E. (1975). Multinationale Konzerne und europäische Integration. Bonn: Europa-Union Verlag; Axt, H.-J. (1978). Staat, multinationale Konzerne und politische Union in Westeuropa: ein Beitrag zur Staatstheorie und Analyse regionaler Integration. Köln: Pahl-Rugenstein.

${ }_{529}$ Moravcsik, A. (1998). The choice for Europe: social purpose and state power fom Messina to Maastricht. Ithaca: Cornell University Press, pp. 22-25. 35-41.
} 


\section{History of European integration}

The literature on the history of European integration lacks a broad perspective on business. This book is a first attempt to add that perspective to the research agenda.

Nonetheless, to a certain degree European industry has been given a role in the history of European integration, mainly by economic historians. In the 1990s Alan Milward and John Gillingham included the interests of business in their seminal works on European integration. More recently scholars such as Marine Moguen-Toursel and Neil Rollings, who are interested in the crossover between business history and European integration, focussed on how national industrial sectors, nationally organized industrial federations, or employers' associations, perceived economic integration. By focussing on national settings, naturally their results were nationally formulated business views on the European market. The investigation of transnational business organizations to date remained limited to the Council of European Industrial Federations (CEIF), which mainly functioned as an instrument to forward the goals of national associations on a European level. Moreover, the organization knew no direct business representation. ${ }^{530}$

The investigation of transnational networks offered the opportunity to deviate from a strictly national perspective and allowed room for discovering crossindustry and industrial transnational perspectives. What were the results of this approach?

It appeared that in the 1950s multinationals approached European integration from a national perspective, similar to what the aforementioned authors have found. Remarkably so, particularly in the ELEC the firms investigated closely adhered to the views defended by their national governments. In all cases it was difficult to distinguish between positions of the companies and those of the national governments. It is argued here that the prospect of trade liberalization in Western Europe represented an opportunity for all parties to push for a specific version of trade liberalization. Each national group fended for an organization of the European market that remained the closest to the market organization from which they had expanded their firms. ${ }^{531}$

Whereas in the 1950s the national contexts offer the best explanation for business views on the Common Market, during the 1960s the growth of external

\footnotetext{
530 Milward, A. S. (1992). The European rescue of the nation-state. London: Routledge; Gillingham, J. R. (1991). Coal, steel, and the rebirth of Europe, 1945-1955. Cambridge: Cambridge University Press; Rollings, N. (2007). British business in the formative years of European integration, 1945-1973. Cambridge: Cambridge University Press; Moguen-Toursel, M. (2002). L'ouverture des frontières européennes dans les années 50: fruit d'un concertation avec les industriels? Bruxelles: P.I.E. Lang. See Chapter 1 for more examples of this national perspective on European business. Rollings, N. \& Kipping, M. (2008). Private transnational governance in the heyday of the nation-state: the Council of European Industrial Federations (CEIF). Economic History Review, 61, 409-431.

${ }^{531}$ See chapter 3 for an explanation of the different national contexts.
} 
competition by the United States and the East-bloc countries resulted in transnational industry-specific challenges. Business views on the European market were increasingly formulated in terms of interests of entire European industries or groups of industries. During the 1970s transnational sectoral preferences became much more pronounced as a result of deteriorating international competitiveness. The emergence of transnational industry-based views suggests that the European market at least was transnationalizing in terms of a European industrial business identity. Histories of European integration should start taking into account such transnational industry-specific concerns and their specific agenda's regarding European integration. Moreover, investigations of business views on European integration should focus on how post-war transnational industrial identities were shaped in the first place.

Since the mid-2000s various authors have developed a transnational approach to European integration history. In 2006, Thom Misa and Johan Schot proposed to write a transnational history of the technological integration of Europe. In 2009 Wolfram Kaiser, Brigitte Leucht, Michael Gehler and Morten Rasmussen proposed the investigation of transnational political networks and the supranational European polity that they shaped. Ulrike von Hirschhausen and Kiran Patel additionally proposed in 2010 to write a transnational history of Europe by investigating processes of Europeanization. A transnational history of European business in relation to European integration history is a natural component of these endeavours and this book has made a first contribution in this direction. A particularly interesting dimension of Misa and Schot's and Hirschhausen and Patel's proposals is the acknowledgement that ideas and meanings that shaped the transnational history of Europe were also shaped by global influences. As this book has shown, the history of the changing views of business on the European market cannot be understood from a strictly European perspective. By focussing on the European Community from a perspective of European multinationals it became clear that the need for harmonization of trade rules, codes of conduct, and international economic policies was part of processes that went beyond the integration of European markets. Because of the fact that European companies were more and more confronted with competition from the United States, the East-bloc, Japan and potentially the Middle East, the need arose to pursue international level playing fields and to convince Western governments of the need to undertake strategic action. Such international agreements however could only be arranged via connections with NATO and the OECD, which in these cases functioned as platforms for consultation. A transnational history of European business inevitably also shows how such global challenges affected its identity. ${ }^{532}$

${ }^{532}$ Especially see chapter 5. Misa, T. J. \& Schot, J. (2006). Inventing Europe: technology and the hidden integration of Europe. History and Technology, 21, 1-19, also see www.tensionsofeurope.eu; Hirschhausen, U. von \& Patel, K. K. (2010). Europeanization in history: an introduction. In M. Conway \& K. K. Patel (Eds.), Europeanization in the twentieth century. Historical approaches (pp. 1-18). Basing- 


\section{Business history}

Business historiography in relation to European integration has taken two forms. The first consists of individual company histories that partly zoom in on the specific challenges of restructuring a multinational firm with multiple subsidiaries in the European market since 1950. The second approach of business historians consists of studying business associations in the context of European integration.

Researchers of individual businesses like Geoffrey Jones and Peter Miskell who investigated Unilever, and Ivo Blanken, who investigated Philips, made clear that these companies initially saw great potential for economies of scale in an integrated European market, due to the prospect of amalgamating the hundreds of factories that they controlled across Europe. Plans for such reorganizations failed however during the 1960s and 1970s. National governments resisted relocation of production and local management preferred national sales and marketing strategies. Moreover, Steven Tolliday showed that also an originally American multinational with several production sites in European markets, the car manufacturer Ford for example, had to overcome major challenges to integrate these. Local marketing needs and different production practices complicated technical interchangeability of parts between the different factories. The rationalization of widespread production structures of multinational companies on the European market was a difficult and lengthy process. ${ }^{533}$

The present investigation adds to these insights. The competition from American companies on the European market especially caused a need for mergers for European companies. European business tried to convince European governments to simplify tax rules or to consent to a Community-wide company law. In the cases of multinationals such as Unilever and Philips the need for mergers was less of an issue since they had already achieved a large size by expanding across Europe. The suggestion then is that companies with different structures used different strategies to cope with increasing competition in the European market. Extensive and widespread European multinationals ended up in a complicated reorganization process aimed at centralization and harmonization. European companies that in comparison to American companies were relatively small and had not expanded beyond national borders were forced to enter into national or transnational mergers to obtain the appropriate scale. How the integration of the European market

stoke: Palgrave Macmillan; Gehler, M., Kaiser, W. \& Leucht, B. (2009). Networks in informal European governance. Diachronic perspectives on the European Union as a multi-level polity. In M. Gehler, W. Kaiser, \& B. Leucht (Eds.), Netzwerke im europäischen Mehrebenensystem. Von 1945 bis zur Gegenwart = Networks in European multi-level governance. From 1945 to the present. (pp. 9-26). Wien: Böhlau, p. 23; Kaiser, W., Leucht, B \& Rasmussen, M. (2009). Origins of a European polity. In W. Kaiser, B. Leucht \& M. Rasmussen (Eds.), The history of the European Union: origins of a trans-and supranational polity 19501972 (pp. 1-11). New York: Routledge, pp. 6-7.

${ }_{533}$ Blanken (2002). Een industriële wereldfederatie, pp. 262-280; Jones \& Miskell (2005). European integration; Tolliday (2003). The origins of Ford of Europe. 
exactly forced companies from various industries and company structures to respond remains an exciting direction for future research. In any case it became clear that adjustment problems of European business to the new size of the European market was a widely shared experience. ${ }^{534}$

Business historians who have recently studied European business associations put forward a different take on the relation between business and European integration. Neil Rollings, Matthias Kipping and Marine Moguen-Toursel resist the dominant approach in political science to study business associations in terms of their influence on the policy-making aspects of European integration. According to them, the existence of business associations at a European level should be interpreted as stemming from the uncertainty that was caused by the stream of integration plans during the 1950s. Moreover, they argue that business associations should be investigated as examples of the formation of ideas about European integration. As shown, this dissertation demonstrates the value of investigating associations in which business played a large role as places where ideas on European integration took shape. However, the suggestion by the abovementioned authors that investigating business associations as examples of formation of ideas is different from investigating influence can be qualified on the basis of this dissertation's findings on the ELEC. Certainly the ELEC contributed to the formation of ideas on European integration. On the other hand the ELEC pro-actively chose position and its primary goal was to gain influence on policy making. If the ELEC had influence, it was via the ideas that it forwarded, not through concrete pressure. Its proposals for economic integration stemmed from 1949 and in 1955 the group was actually ahead of consensus with their agenda for a Common Market between the ECSC states. Moreover, ELEC's early ideas on the need for harmonized taxation measures and a European company law both in the service of adaptation of European industry to external competition ended up in Commission memoranda on industrial policy. Ultimately, as explained below, these suggestions were realized via the European Commission's White Paper following the Single European Act in 1985. The investigation of influence of business associations cannot be so easily separated from investigating them as examples of the formation of ideas. ${ }^{535}$

In conclusion, it is important to explain how this investigation offers more clarity about the activities of the European Round Table of Industrialists (ERTI) towards the realization of the Single European Act in 1986. In other investigations on European integration this subject would probably be dealt with in a section on European integration theory. However, the contribution of this study to a better understanding of the ERTI lies in the area of the history of business associations

\footnotetext{
534 Blanken and Jones \& Miskell note no pressure for mergers for Philips and Unilever. Blanken (2002). Een industriële wereldfederatie. Jones \& Miskell (2005). European integration.

535 Rollings, N. \& Kipping, M. (2008). Private transnational governance in the heyday of the nation-state: the Council of European Industrial Federations (CEIF). Economic History Review, 61, 409-431; Rollings, N. \& Moguen-Toursel, M. (2012). European organised business and European integration in the postSecond World War period. Jahrbuch für Wirtschaftsgeschichte, 53, 103-123.
} 
and the themes they placed on the political agenda. The Single European Act (SEA) amended the Treaties of Rome of 1957. The intention behind the SEA was to eliminate protectionism within the Community and to initialize the formation of a truly uniform single market. The Common Market had abolished all internal import tariffs by 1969, but non-tariff trade barriers had proliferated since. Each member state had devised specific exceptions that determined which products could be imported and which could not. The SEA also abolished these trade barriers. Moreover, the SEA replaced the veto-based voting system with a qualified majority voting system for market related policies in order to simplify and accelerate decision-making. Wayne Sandholtz, John Zysman and Maria Green Cowles ascribed a crucial role to European industry in bringing about this treaty. According to them the European Round Table of Industrialists, founded in 1983, had set up a successful lobby on national and supranational levels in order to convince governments and to assist the European Commission where needed. According to these authors the involvement of European industry was a result from international competition since the 1970s, particularly from companies that were active in advanced information technology. ${ }^{536}$

This investigation shows why the creation of the ERTI and its lobby were the result of longer standing problems originating from a broadly shared business experience since the early 1960s. Particularly the ELEC clearly has functioned as a precursor to the ERTI. The ELEC dedicated itself to the realization of the Common Market during the 1950s. During the 1960s it surfaced that European companies were facing strong foreign competition. Efforts to promote the concentration of European industry by means of transnational mergers encountered the lacking political will of Community member states. At the advent of the crisis years of the 1970s, competition intensified as a result of quickly growing Japanese exports. Suddenly an urgent need for rationalization of particularly the automotive sector presented itself. European business even requested a European industrial policy in order to speed up the required restructuring of European companies so that full advantage could be taken of the scale economies that the Common Market had to offer. The main topic of the ERTI, the single market, was a consistent and coherent result from these developments.

The European integration theorist Andrew Moravcsik argues in his book The choice for Europe, that the industrialists of the ERTI presented their ideas only after Community member states had expressed their willingness to change Common Market policies and therefore were too late to influence the decision-making process with regard to the Single European Act. This argument should be turned

536 Sandholtz, W. \& Zysman, J. (1989). Recasting the European bargain. World Politics, 42, 95-128; Green Cowles, M. (1995). Setting the agenda for a new Europe: the ERT and EC 1992. Journal of Common Market Studies, 33, 501-526; AEI, Commission of the European Communities (1985). Completing the internal market. White paper from the Comission to the European Council (Milan, 28-29 June 1985). Brussels: Commission of the European Communities. Retrieved September 23, 2013, from http://aei.pitt.edu/1113/. 
upside down: European business had forwarded multiple suggestions to address the issue for the past twenty years but governments had not acted. The governments were only now taking up a problem that had been spelled out by the European Commission since the late 1960s. In fact the establishment of the ERTI should be seen as an expression of continuity, continuing the work of the European League for Economic Cooperation on a different scale: it represented a resumption of earlier efforts by leading European corporations to convince Community member states to follow through on their initial decision in 1957 to create the Common Market. 537

\section{Geo-political insights}

This investigation was not designed for answering questions about geo-political dynamics between powerblocs. However, as explained in chapter 1, the combined historiographical overviews did indicate that geopolitical tensions played a role in the experience of European multinationals. The following geo-political insights with regard to the West-European and American powerblocs can be deduced from the results of this dissertation.

Clearly a competitive dynamic existed between American and West-European corporations. This dynamic can be explained by structural differences between the American and European market circumstances. The structure of European corporations was attuned to the smaller national markets. During the 1950s, European multinationals were favourably positioned towards realizing a large, European market, because scale advantages would likely improve their ability to compete abroad. However, European corporations were not counting on the competition of large American corporations on their still poorly integrated market. The American multinationals had a significant structural advantage: unlike the European corporations, the American companies originated from a large, integrated home-market. As a result, when they began to increase their European investments in the early 1960s, they were much larger than most of their European counterparts who were still mainly geared towards their much smaller home-markets. Moreover, this circumstance enabled American companies to spread their costs across a large market, something European companies were unable to do. The same advantage can be noted for corporations from Japan. The adverse starting position of European corporations determined this development and also explains why they favoured a continuing integration but also enlargement of the Common Market.

${ }_{537}$ Moravcsik (1998). The choice for Europe, pp. 355-356. 


\section{Reflection on methodology}

While the design of the study and the choices that were made yielded significant results, they also pose limitations that have to be taken into account when assessing the results. The main pillars of the design are the choice for a longitudinal investigation from 1950 until 1980, the themes for the sub-periods' cases, and the selection of the three transnational networks.

The investigation of the period from 1950 to 1980 made it possible to examine the views of European multinationals in relation to changing circumstances. Additionally it offered the opportunity to identify gradual changes in views. Moreover, the long timeline made visible that the Common Market was no undivided blessing to European multinationals. Companies were confronted with adaptation problems as a result of changing conditions of competition, which were only resolved in policy changes during the 1980s. That picture would not have emerged if we would have limited ourselves to the 1950s or the 1960s. Finally, the examination of the period 1950-1980 resulted in insights on how the relationship between European multinationals and the institutions of the European Community changed and how other organizations such as the OECD and NATO played a complementary role when the European Community was unable to act.

As explained in chapter 1, the choice for a longitudinal approach was complemented by a selection of major themes. It is important to realize that that selection inevitably underexposed other topics that were of relevance to European industry and finance. Additional investigations of those topics will undoubtedly enrich the findings of this study. The challenge in such endeavours is to determine which sectors and actors were affected most by the chosen topics. In the present investigation the choice for a representative and typical theme for the 1970s, energy security, did not turn out to be as representative of the priorities of European industry and finance as initially expected. While the subject of economic integration for the 1950s, and East-West trade and U.S. investment for the 1960s resulted in involvement of several sectors, energy security in the 1970s was mostly just discussed by parties connected to the energy sector.

The value of the selection of the transnational networks has already been addressed in relation to the selected comparative approach. There are also drawbacks to investigating such networks. Indeed, representatives of multinationals played an important role in the networks. However, the available archival material not always allowed the identification of particular views that could be associated with single firms. The identification of national groupings and industries was possible however, offering a more general approach to the experiences of European multinationals. As a result, this research design has also demonstrated that the investigation of business views is very well possible through transnational networks such as the ELEC, the Bilderberg meetings and the Trilateral Commission. 
That insight provides opportunities for further research on other transnational networks of business.

\section{Opportunities for further research}

As a result of the dynamics caused by the implementation of the Common Market, European multinationals were confronted with difficulties in adapting their organizations to the new circumstances. Academic attention for this restructuring process has to date primarily focussed on the decision-making processes on the level of the European Community during the 1980s. Still, the roots of this problem for European business seem to lie in the 1960s when the European Community was unable to introduce new policies. It appeared that the need for the restructuring of European industry became tied up with other difficulties. The European technological gap with the United States during the 1960s and energy scarcity in the 1970s were also translated into restructuring problems. The single market program following the Single European Act in the 1980s merely was the provisional endpoint in these developments. The theme of the adaptation and restructuring process of European business in relation to European economic integration is connected to many aspects of the wider European business experience. The restructuring process can function as a focal point for a research agenda on the business experience of the European Community. Such an approach will moreover contribute to research agendas that endeavour towards a transnational history of Europe.

Various sub-areas can be identified for the investigation of European industrial restructuring. It is important to stress the potential for business historians to contribute to such a perspective. Relatively few business histories position companies in the wider European political economic landscape. As became clear in chapter 1 and 3, histories of single multinational companies can have an impact on our understanding of how European business experienced the profound changes in the European market organization since WWII. But also views of management on European integration and strategies in lobbying in the European Community are valuable for understanding how business has co-shaped the present system. The investigation of the transnational organization of European industries since the founding of the Common Market should result in particularly interesting contributions.

Such a research agenda would moreover include the relations between institutions and European business. This includes the investigation of the contacts between the European Commission and European business, as well as the contacts with business from other regions, from a European Commission perspective. In what way did the European Commission try to manage the European restructuring process, what policy angles did it employ in this regard, and how did it deal with 
the implicit tension between European business and American and Japanese business?

Moreover, as became clear European multinationals at times turned to the OECD and incidentally even mobilized relations within the NATO for consultations on establishing international level playing fields. The suggestion is that particularly the OECD has repeatedly played a role in organizing global markets for European as well as American and Japanese business. Whether European business attempted to manage aspects of the restructuring challenge on a global scale via the OECD and whether this resulted in tangible agreements, can be a productive angle for future investigations.

These agendas should particularly acknowledge the importance of changing circumstances, the national and industry-based contexts of multinationals, the differences in structure and resulting path dependencies and the increasingly global nature of competition that demanded a response from all actors involved. 



\section{Sources}

\section{Archives}

European League for Economic Cooperation

European League for Economic Cooperation - Ligue Européenne de Coopération Économique (ELEC-LECE)

Institution: $\quad$ Centre d'étude d'histoire de l'Europe contemporaine Louvain-la-Neuve (CEHECLIN).

Collection name: $\quad$ Ligue européenne de coopération économique (1946-1985) (LECE).

Collection number:

Abbreviation:

CEHECLIN, LECE

Content:

This extensive archive contains the documents of ELEC's "Sécretariat Général" from 1946 until 1985. It contains minutes of the Central Council and all the standing and ad hoc study committees, including extensive correspondence between the Secretariat and members of national sections.

\section{Europese Beweging Nederland en voorgangers}

Institution: Nationaal Archief, The Hague, The Netherlands.

Collection name: Europese Beweging in Nederland en Voorgangers, 19451987.

Abbreviation: $\quad$ NL-HaNa, Europese Beweging Nederland.

Collection number: 2.19 .109

Content: The archive contains documents with regard to the founding of the Dutch ELEC section (ELES) in 1950-1951.

\section{$\underline{\text { Private Archive Drs. Matthijs van der Velden }}$}

Location: Rotterdam, The Netherlands.

Content: $\quad$ ELEC publications. 


\section{Bilderberg meetings}

\section{$\underline{\text { Secretariat Bilderberg Conferences Archive }}$}

Institution: Nationaal Archief, The Hague.

Collection name: Bilderberg Conferenties, 1952-1999

Abbreviation: NL-HaNA, 2.19.045.

Collection number: 2.19 .045 .

Content: The archive contains documents on the organization of all conferences, correspondence of the secretariat and Steering Committee minutes. In some cases verbatim minutes of conferences are available. Conference summaries and/or reports are included.

Remarks on access: Only the documents from the period 1952 until 1963 were accessible for research due to a 50 -years period embargo on the documents.

\section{Nachlass Otto Wolff von Amerongen}

Institution: Stiftung Rheinisch-Westfälisches Wirtschaftsarchiv zu Köln, Cologne, Germany.

Collection name: $\quad$ Nachlass Otto Wolff von Amerongen

Collection number: Abt 72

Abbreviation: RWWK, NOWA.

Content: With regard to the Bilderberg meetings the collection contains documents on the period from 1955 until 1985. It contains correspondence on the organization of all conferences that were organized during that period, including reports and Steering Committee minutes. Moreover, Wolff von Amerongen's personal correspondence on meetings is included.

\section{$\underline{\text { Archief Max Kohnstamm }}$}

Institution: Internationaal Instituut Sociale Geschiedenis, Amsterdam.

Collection name: Archief Max Kohnstamm

Abbreviation: IISGA, AMK

Content: $\quad$ With regard to the Bilderberg meetings, the archive contains a complete membership list for the period 1954 until 2001.

\section{Ernst van der Beugel}

Institution: $\quad$ Nationaal Archief, The Hague. 
Collection name: Collectie 357 E. H. van der Beugel

Collection number: 2.21 .183 .08

Content:

This archive contains a verbatim transcription of a set of interviews that were conducted with Ernst van der Beugel for the purpose of an oral history account of his professional experiences, including his experiences as the European secretary of the Bilderberg meetings.

\section{$\underline{\text { Ministerie van Buitenlandse zaken }}$}

Institution: $\quad$ Nationaal Archief, The Hague.

Collection name: $\quad$ Ministerie van Buitenlandse zaken Code-archief 1955-1964

Collection number: 2.05.118

Content With regard to the Bilderberg meetings the archive contains a (very) small amount of correspondence. See reference in chapter 4 .

\section{Collectie Cees Wiebes}

Institution: Internationaal Instituut Sociale Geschiedenis, Amsterdam.

Collection name: Collectie Cees Wiebes

Content: With regard to the Bilderberg meetings, the archive contains several Bilderberg meetings reports on conferences.

\section{Trilateral Commission}

The Trilateral Commission (North America) Records

Institution: $\quad$ The Rockefeller Archive Center, Sleepy Hollow, NY, USA.

Collection name: The Trilateral Commission (North America) Records

Abbreviation: RAC, Trilateral Commission.

Contents:

The archive ranges from 1972-2001 and contains Executive Committee meeting reports, plenary meeting reports, correspondence on the organization of meetings, writing and drafting processes of publications. The documents were amassed by the American section of the Trilateral Commission. It is important to note that this archive also includes the documents of the initial Trilateral Commission director Zbigniew Brzezinsky and deputy director Christopher Makins, the later American coordinator of the Trilateral Commission, George Franklin and later officers of the Trilateral Commission (but see "Remarks on access" below). Therefore the 
archive is probably the only collection of documents that comes close to an institutional archive of the Trilateral Commission. Nonetheless, only a very small collection of the European section documents are part of the archive. Moreover, the archive contains no documents of the Japanese section.

Remarks on access: Several subseries were not accessible due to "temporary preservation concerns." These series include the files of key individuals of the Executive Committee: Zbigniew Brzezinsky, Christopher Makins, but also early general correspondence from 1972 until 1975. Moreover, a sixteen-year embargo is in place.

\section{Nachlass Otto Wolff von Amerongen}

Institution: Stiftung Rheinisch-Westfälisches Wirtschaftsarchiv zu Köln, Cologne, Germany.

Collection name: $\quad$ Nachlass Otto Wolff von Amerongen (NOWA)

Collection number: Abt 72

Abbreviation: RWWK, NOWA.

Content: Contains correspondence, reports on Executive Committee meetings, minutes of the European group, speeches, Executive Committee correspondence and some correspondence among the German members of the Trilateral Commission, from 1973 to 1995.

\section{Archief Max Kohnstamm}

Institution: Internationaal Instituut Sociale Geschiedenis, Amsterdam.

Collection name: Archief Max Kohnstamm

Collection number:

Abbreviation: IISGA, AMK

Content: The archive contains some of Kohnstamm's correspondence during his role as the European Chairman of the Trilateral Commission from 1972 until 1975.

Other archival sources

Archive of European Integration

Institution: $\quad$ University of Pittsburgh, Pittsburgh, PA, USA.

Online Repository: aei.pitt.edu

Abbreviation: AEI 
Content: An electronic repository and archive of official EC/EU documents on European integration.

Private Archive Solvay S.A.

Location: Brussels

Content: $\quad$ The content of the archive used for this investigation was limited to the documents on the Club de l'Industrie Chimique.

\section{Interviews}

- Max Kohnstamm (Fenffe, 23rd of October 2009).

- Coen Ramaer (Hoeilaart, June 2010).

- Matthijs van der Velden (Rotterdam, 14th of June 2010).

- A. S. Friedeberg (Rotterdam, 1st of July, 2010).

- Viscount Etiènne Davignon (Brussels, 8th of September 2010).

- Erik Hugenholz (Son \& Breugel, 15th of October 2010).

- Victor Halberstadt (Amsterdam, 3rd of November 2010).

- Baron Cardon de Lichtbuer (Brussels 22nd of March 2011).

- Jacques Delacave (Brussels, 16th of December 2011).

- Baron Daniel Janssen (Brussels, 9th of May 2012).

\section{Publications of networks}

European League for Economic Cooperation (1949-1980)

A note on the ELEC publications: the ELEC publications were published in French and often also in English. In cases where an English version was available, the titles are mentioned in English. The publications mentioned here are all the publications that were edited by the ELEC, in chronological order. A volume number is mentioned for the numbered series, the documents that were intended for external distribution. Lastly, when in the references below the authoring organisation and the publisher were Ligue Européenne de Coopération Economique or European League for Economic Co-operation, they have been abbreviated as LECE or ELEC respectively.

\section{Periodicals}




\section{$\underline{\text { Brochures }}$}

LECE (1949). Un système de convertibilité des monnaies européennes entre elles (Vol. 1). Bruxelles: LECE. LECE (1950). Résolution relative au plan Schuman (Vol. 2). Bruxelles: LECE.

LECE (1950). Vers la liberté des transferts internationaux de devises (Vol. 3). Bruxelles: LECE.

ELEC (1950). The rearmament of western Europe and its economic unification (Vol. 4). Brussels: ELEC.

LECE (1951). La démobilisation tarifaire intra-européenne (Vol. 5). Bruxelles: LECE.

LECE (1951). Conférence europe-commonwealth - résolutions (Vol. 6). Bruxelles: LECE.

LECE (1951). Conférence Europe-Commonwealth - Discours de M. Van Zeeland // Europe-Commonwealth conference - speech by Mr Van Zeeland. Bruxelles: LECE.

LECE (1951). Conférence Europe-Commonwealth - Discours (Vol. 7). Bruxelles: LECE.

LECE (1951). La mobilité des travailleurs en Europe occidentale (Vol. 8). Bruxelles: LECE.

LECE (1951). L'organisation des transports en Europe occidentale (Vol. 9). Bruxelles: LECE.

ELEC (1952). European institute for advanced business management (Vol. 10). Brussels: ELEC.

ELEC (1952). The promoters' inquiry (Vol. 11). Brussels: ELEC.

ELEC (1952). The role of agriculture in the formation of a single European market (Vol. 12). Brussels: ELEC.

ELEC (1953). The monetary reconstruction of Europe and its contribution to economic and social progress : introductory report of the monetary conference of E.L.E.C. (Brussels, the 29th, 30th and 31st January 1953) (Vol. 13). Brussels: ELEC.

LECE (1954). La portée économique d'une communauté politique européenne (Vol. 14). Bruxelles: LECE.

LECE (1954). Incidences économiques de la CED: objections et réponses (Vol. 15). Bruxelles: LECE.

LECE (1954). Les discriminations d'ordre économique envers les étrangers (Vol. 16). Bruxelles: LECE

ELEC (1955). A European solidarity plan to aid the depressed areas of southern Europe (Vol. 17). Brussels: ELEC.

ELEC (1955). Declaration of E.L.E.C. on the creation of a common market (Vol. 18). [s.l.]: ELEC.

ELEC (1955). 1st supplement to publication no. 18 published under the title: Declaration of E.L.E.C. on the creation of a common market (Vol. 19). [s.l.]: ELEC.

ELEC (1956). The common market to promote social prosperity : introductory report for the IIIrd international conference of E.L.E.C. (Brussels, June, 20th, 21st and 22nd, 1956) (Vol. 20). Brussels: ELEC.

ELEC (1956). The common market to promote social prosperity : resume of the work of the IIIrd international conference of E.L.E.C. (Brussels, June, 20th, 21st and 22nd, 1956) (Vol. 21). Brussels: ELEC.

LECE (1956). Le marché commun facteur de prospérité sociale - Discours prononcés au cours de la IIIe conférence internationale de la LECE (Vol. 22). Bruxelles: LECE.

ELEC (1957). European integration and social security (Vol. 23). Brussels: ELEC.

LECE (1957). La formation du Zollverein (1815-1867) Une leçon pour l'Europe contemporaine (Vol. 24). Bruxelles: LECE.

ELEC (1958). Common protection for private international investments (Vol. 25). Brussels: ELEC.

LECE (1958). Au-delà de la communauté économique européenne (Vol. 26). Bruxelles: LECE.

Ligue Européenne de Coopération Économique (1958). La L. E. C. E. : dix années d'activité 1947-1957 | La Ligue Européenne de Coopération Économique. Bruxelles: Ligue Européenne de Coopération Économique.

ELEC (1959). European co-operation in relation to a world recession (Vol. 27). Brussels: ELEC.

LECE (1959). La fiscalité indirecte dans le marché commun (Vol. 28). Bruxelles: LECE.

ELEC (1960). Topical tasks of monetary policy in Europe (Vol. 29). Brussels: ELEC.

ELEC (1960). European investment bank problems (Vol. 30). Brussels: ELEC.

ELEC (1960). The coming tasks of Europe : introductory reports for the IVth international conference of E.L.E.C. : (Brussels, October 20th, 21st and 22nd, 1960) (Vol. 31). Brussels: ELEC.

ELEC (1960). The coming tasks of Europe : synthesis of exchanges of views that took place at the IVth international conference of the European League for Economic Co-operation(Brussels, October 20th-22nd, 1960). Brussels: ELEC. 
LECE (1960). Les tâches prochaines de l'Europe - Discours prononcés à la IVe conférence internationale de la LECE. Synthèse des échanges de vues à la IVe conférence internationale de la LECE (Vol. 32). Bruxelles: LECE.

ELEC (1960). E.L.E.C. 1946-1960. Brussels: ELEC.

ELEC (1961). The developing countries of Europe and European integration (Vol. 33). Brussels: ELEC.

ELEC (1962). The entry of Great Britain into the European Community (Vol. 34). Brussels: ELEC.

LECE (1962). La politique agricole dans la communauté économique européenne (Vol. 35). Bruxelles: LECE.

ELEC (1962). The entry of Great Britain into the European Community : appendix to publication nr. 34 (Vol. 36). Brussels: ELEC.

Bachmann, H. (1962). The European Economic Community and the three neutrals Austria, Sweden, Switzerland (Vol. 37). Brussels: ELEC.

ELEC (1963). Latin America and the European experience (Vol. 38). Brussels: ELEC.

ELEC (1963). Strengthening economic co-operation in Europe : opening speech, introductory reports, conclusions, list of participants for the fifth international conference, Brussels, June 20th-22nd, 1963 (Vol. 39). Brussels: ELEC.

ELEC (1965) East-west commercial relations: study conference, opening speech, introductory report, resolutions, list of participants, Brussels, May 14th and 15th, 1965 (Vol. 40). Brussels: ELEC.

ELEC (1966). E.L.E.C.: 1946-1966. Brussels: ELEC.

ELEC (1967). Economic, industrial, scientific and technical cooperation between the countries of Eastern and Western Europe : round table, organized in Brussels, February 24th and 25th, 1967 (Vol. 41). Brussels: ELEC.

Snoy et d'Oppuers, J.-C. (1967). Institutional problems arising from an enlargement of the European Communities (Vol. 42). Brussels: ELEC.

Boël, B. (1967). XXe Anniversaire de la LECE : discours / prononcés au diner du XXe Anniversaire par le Baron Boël, president de la LECE. XXth Anniversary of ELEC : speeches (Vol. 43). Bruxelles: Ligue Européenne de Coopération Économique.

ELEC (1968). The organization of a European monetary order : VIth international conference introductory report, comments, resolution, list of participants (Vol. 44). Brussels: ELEC.

ELEC (1969). The common policy for transport in Europe (Vol. 45). Brussels: ELEC.

ELEC (1969). The inter-European industrial, technical and scientific agreements : concrete measures with a view to developing them (Vol. 47). Brussels: ELEC.

ELEC (1970). A program for monetary integration within the E.E.C : feasibility study and proposals as to the measures to be taken (Vol. 46). Brussels: ELEC.

LECE (1970). La Ligue Européenne de Coopération Économique, 1946-1969. La L.E.C.E. - 1946-1969. Bruxelles: LECE.

Binswanger, H. C., \& Mayrzedt, H. (1972). L'élargissement des communautés européennes et la position des pays non-candidats faisant partie de l'Aele (six non-six), (Autriche, Finlande, Islande, Portugal, Suède et Suisse) : propositions et perspectives (Vol. 48). Bruxelles: LECE.

Colonna di Paliano, G. (1972). Europe and the world: the external relations of the community (Vol. 49). London: [s.n.].

ELEC (1972). Summary of activities in 1971: brief account of ELEC's influence on European development, 1946-1970. Brussels: ELEC.

Oslizlok, J. S. (1973). Regional policy in the economic and monetary union (Vol. 50). Brussels: ELEC.

LECE (1973). XXVe anniversaire de la LECE // XXVth Anniversary of ELEC. Bruxelles: LECE.

LECE (1974). Pour une réforme du fonctionnement des institions des communautés européennes: propositions d'améliorations pratiques à court terme. For a reform of the functioning of the European Community institutions: proposals for practical short term improvements. (Vol. 51). Bruxelles: LECE.

ELEC (1975). Conjunctural and structural problems of the European industry (autumn 1974): the automotive, chemical, and machine-tool industry (Vol. 52). Brussels: ELEC.

ELEC [British Section] (1976). Europe and the Arab world: report of the London conference organised by the British section of the ELEC. London: ELEC [British Section]. 
ELEC (1977). Towards a united Europe: an ELEC enquiry (Vol. 53). Brussels: ELEC.

LECE (1978). La relance économique en Europe: le rôle primordial du Parlement Européenne. A new economic impetus for Europe: the fundamental role of the European Parliament (Vol. 54). Bruxelles: LECE.

Bauer, B. (1979). Europe?: yes, Europe! : guide for the candidates. Brussels: ELEC.

LECE (1980). Pour une politique communautaire de l'énergie. Colloque du 10 octobre 1980 Paris salle Médici du Sénat. Paris: LECE.

\section{Bilderberg meetings (1954-1980)}

A note on the Bilderberg meetings' publications: the Bilderberg meetings' publications were in fact unpublished reports of the annual conferences and were only distributed among the participants. They summarized introductory papers and subsequent debate. The reports do not link statements to individuals, instead the nationality of contributors is mentioned. The reports also include lists of participants to the conferences. The listed titles include the reports of all conferences between 1954 and 1980, except for the 1966 Wiesbaden and the 1969 Marienlyst reports, which were not available. No conference was organized in 1976. During the 1950s the reports were printed in French and English. When no English copy was available, the French title is listed. The titles below can either be accessed through the Secretariat Bilderberg Conferences Archive and the Nachlass Otto Wolff von Amerongen or international interlibrary loans.

Bilderberg conference, May 29th-31st, 1954 (1954). Sl.: sn.

Conférence de Barbizon, 18-20 mars 1955 (1955). Sl.: sn.

Groupe de Bilderberg (1955). Conférence de Garmisch-Partenkirchen, 23-25 septembre, 1955. Sl.: Groupe de Bilderberg

Groupe de Bilderberg (1956). Conférence de Fredensborch, 11-13 mai, 1956. Sl. Groupe de Bilderberg. Bilderberg Group (1957). St. Simons Island conference, 13-17 February, 1957. Sl. Bilderberg Group. Le groupe de Bilderberg (1957). Conférence de Fiuggi, 4-6 octobre, 1957. Sl.: Le groupe de Bilderberg. Groupe de Bilderberg (1958). Conférence de Buxton, 13-15 septembre, 1958. Sl.: Groupe de Bilderberg. Bilderberg Group (1959). Yesilkoy conference, 18-20 September, 1959. Sl.: Bilderberg Group. Bilderberg Meetings (1960). Bürgenstock conference, 28-29 May, 1960. Sl.: Bilderberg Meetings Bilderberg Meetings (1961). St. Castin conference, 21-23 April, 1961. Sl.: Bilderberg Meetings. Bilderberg Meetings (1962). Saltsjöbaden conference, 18-20 May, 1962. Sl.: Bilderberg Meetings. Bilderberg Meetings (1963). Cannes conference, 29-31 May, 1963. Sl.: Bilderberg Meetings. Bilderberg Meetings (1964). Williamsburg conference, 20-22 March, 1964. Sl.: Bilderberg Meetings. Bilderberg Meetings (1965). Villa d'Este conference, 2-4 April, 1965. Sl.: Bilderberg Meetings. Bilderberg Meetings (1967). Cambridge conference, 31 March- 2 April, 1967. Sl.: Bilderberg Meetings. Bilderberg Meetings (1968). Mont Tremblant conference, 26-28 April, 1968. Sl.: Bilderberg Meetings. Bilderberg Meetings (1970). Bad Ragaz conference, 17-19 April, 1970. Sl.: Bilderberg Meetings. Bilderberg Meetings (1971). Woodstock conference, 23-25 April, 1971. Sl.: Bilderberg Meetings. Bilderberg meetings (1972). Knokke conference, 21-23 April, 1972. Sl.: Bilderberg Meetings. Bilderberg Meetings (1973). Saltsjöbaden conference, May, 11-13 May, 1973. Sl.: Bilderberg Meetings. Bilderberg Meetings (1974). Megève conference, 19-21 April, 1974. Sl.: Bilderberg Meetings. Bilderberg Meetings (1975). Cesme conference, 25-27 April, 1975. Sl.: Bilderberg Meetings. Bilderberg Meetings (1977). Torquay conference, 24-25 April 1977. Sl.: Bilderberg Meetings. Bilderberg Meetings (1978). Princeton conference, May, 21-23 April, 1978. Sl.: Bilderberg Meetings. Bilderberg Meetings (1979). Baden conference, 27-29 April, 1979. Sl.: Bilderberg Meetings. 
Bilderberg Meetings (1980). Bad Aachen conference, 18, 19 and 20 April 1980. Sl.: Bilderberg Meetings.

\section{Trilateral Commission (1973-1980)}

\section{$\underline{\text { Periodicals }}$}

Trialogue: the Trilateral Commission's quarterly of North American - European - Japanese affairs (1973-...). New York: The Trilateral Commission.

\section{$\underline{\text { Brochures }}$}

Motoo, K., Cooper, R. N., \& Segré, C. (1973). Towards a renovated world monetary system: a report of the trilateral monetary task force to the executive committee of the Trilateral Commission, Tokyo, October 22-23, 1973 (Vol. 1). New York: The Trilateral Commission.

Duchêne, F., Mushakoji, K., \& Owen, H. D. (1974). The crisis of international cooperation: a report of the trilateral political task force to the executive committee of the Trilateral Commission, Tokyo, October 22-23, 1973 (Vol. 2). New York: The Trilateral Commission.

Gardner, R. N., Okita, S., \& Udink, B. J. (1974). A turning point in north-south economic relations: a report of the trilateral task force on relations with developing countries to the executive committee of the Trilateral Commission, Brussels, June 23-25, 1974 (Vol. 3). New York: The Trilateral Commission.

Colonna di Paliano, G., Trezise, P. H., \& Ushiba, N. (1974). Directions for world trade in the nineteenseventies: a report of the trilateral task force on trade to the executive committee of the Trilateral Commission, Brussels, June 23-25, 1974 (Vol. 4). New York: The Trilateral Commission.

Campbell, J. C., de Carmoy, G., \& Kondo, S. (1974). Energy: the imperative for a trilateral approach: a report of the trilateral task force on the political and international implications of the energy crisis to the executive committee of the Trilateral Commission, Brussels, June 23-25, 1974 (Vol. 5). New York: The Trilateral Commission.

Campbell, J. C., de Carmoy, G., \& Kondo, S. (1974). Energy: a strategy for international action: a report of the trilateral task force on the political and international implications of the energy crisis to the executive committee of the Trilateral Commission, Washington, D.C., December 8-10, 1974 (Vol. 6). New York: The Trilateral Commission.

Gardner, R. N., Okita, S., \& Udink, B. J. (1975). OPEC, the trilateral world and the developing countries: new arrangements for cooperation, 1976-1980: a report of the trilateral task force on relations with developing countries to the executive committee of the Trilateral Commission (Vol. 7). New York: The Trilateral Commission.

Crozier, M., Huntington, S. P., \& Watanuki, J. (1975). The crisis of democracy: report on the governability of democracies to the Trilateral Commission (Vol. 8). New York: New York University Press.

Oda, S., Johnston, D. M., Holst, J. J., Hollick, A. L., \& Hardy, M. (1976). A new regime for the oceans: a report of the trilateral task force on the oceans to the executive committee of the Trilateral Commission (Vol. 9). New York: New York University Press.

Beigie, C. E., Hager, W., \& Sekiguchi, S. (1976). Seeking a new accommodation in world commodity markets: a report of the trilateral task force on commodities issues to the executive committee of the Trilateral Commission (Vol. 10). New York: The Trilateral Commission.

Bergstein, C. F., Berthoin, G., \& Mushakoji, K. (1976). The reform of international institutions: a report of the trilateral task force on international institutions to the Trilateral Commission (Vol. 11). New York: The Trilateral Commission.

Ortona, E., Schaetzel, J. R., \& Ushiba, N. (1976). The problem of international consultations: a report of the trilateral task force on consultative procedures to the Trilateral Commission (Vol. 12). New York: The Trilateral Commission.

Hosoya, C., Owen, H., \& Shonfield, A. (1977). Collaboration with communist countries in managing global problems: an examination of the options: a report of the trilateral task force on constructive trilat- 
eral-communist cooperation on global problems to the Trilateral Commission (Vol. 13). New York: The Trilateral Commission.

Cooper, R. N., Kaiser, K., \& Kosaka, M. (1977). Towards a renovated international system (Vol. 14). New York: The Trilateral Commission.

Azrael, J. R., Löwenthal, R., \& Nakagawa, T. (1978). An overview of east-west relations: report of the trilateral task force on east-west relations to the trilateral commission (Vol. 15). New York: The Trilateral Commission.

Colombo, U., Johnson, G. D., \& Shishido, T. (1978). Reducing malnutrition in developing countries: increasing rice production in south and southeast Asia: report of the trilateral north-south food task force to the Trilateral Commission (Vol. 16). New York: The Trilateral Commission.

Sawhill, J. C., Oshima, K., \& Maull, H., W. (1978). Energy: managing the transition: report of the trilateral energy task force to the Trilateral Commission (Vol. 17). New York: The Trilateral Commission.

Roberts, B. C., Okamoto, H., \& Lodge, G. C. (1979). Collective bargaining and employee participation in western Europe, North America and Japan: report of the trilateral task force on industrial relations to the Trilateral Commission (Vol. 18). New York: The Trilateral Commission.

Pinder, J., Hosomi, T., \& Diebold, W. (1979). Industrial policy and the international economy: report of the trilateral task force on industrial policy to the Trilateral Commission (Vol. 19). New York: The Trilateral Commission. 


\section{Bibliography}

Aalders, G. (2007). De Bilderbergconferenties: organisatie en werkwijze van een geheim Trans-Atlantisch netwerk. Amsterdam: Van Praag.

Achinger, H. (1970). Richard Merton. Frankfurt a. M.: Kramer.

Adams, W. J. (1989). Restructuring the French economy: government and the rise of market competition since World War II. Washinton, D.C.: The Brookings Institution.

Aftalion, F. (1991). A history of the international chemical industry. Philadelphia: University of Pennsylvania Press.

Apeldoorn, B. van (2002). Transnational capitalism and the struggle over European integration. London: Routledge.

Aldrich, R. J. (1997). Oss, CIA and European unity: The American Committee on United Europe, 19481960. Diplomacy \& Statecraft, 8, 184-227.

Aubourg, V. (2003). Organizing Atlanticism: The Bilderberg Group and the Atlantic Institute, 1952-1963. Intelligence and National Security, 18, 92-105.

Aubourg, V. (2004). Le groupe de Bilderberg et l'intégration européenne jusqu'au milieu des années 1960. Une influence complexe. In M. Dumoulin (Ed.), Réseaux écononomiques et construction européenne. Economic Networks and European Integration (pp. 411-430). Brussels: PIE Peter Lang.

Aubourg, V. (2009). Transatlantische Geschäftsbeziehungen. Die Bilderberg-Gruppe. In M. Gehler, W. Kaiser \& B. Leucht (Eds.), Netzwerke im europäischen Mehrebenensystem. Von 1945 bis zur Gegenwart = Networks in European multi-level governance. From 1945 to the present (pp. 69-86). Wien: Böhlau.

Axt, H.-J. (1978). Staat, multinationale Konzerne und politische Union in Westeuropa: ein Beitrag zur Staatstheorie und Analyse regionaler Integration. Köln: Pahl-Rugenstein.

Badel, L. (2001). La vision Européenne du patronat Français mobilisé par Paul van Zeeland en 1945. In G. Duchenne \& V. Dujardin (Eds.), Paul van Zeeland et les questions politiques et économiques de son temps (pp. 35-48). Louvain-la-Neuve: Institut d'études européennes.

Balassa, B. (1969[1962]). The theory of economic integration. London: George Alllen \& Unwin Ltd.

Ball, G. (1982). The past has another pattern. New York: Norton.

Bamberg, J. (2000). British Petroleum and global oil, 1950-1975. The challenge of nationalism. Cambridge: Cambridge University Press.

Bauer, R. A., De Sola Pool, I., \& Dexter, L. A. (1972). American business \& public policy: the politics of foreign trade (2 ed.). Chicago: Aldine-Atherton.

[Banque Lambert] (1977). Louis Camu 1905-1976. Banque Lambert: Bruxelles.

Bellefroid, D. de (2001). The Commission pour l'Etude des Problèmes d'Après-Guerre (CEPAG) 19411944. In M. Conway \& J. Gotovitch (Eds.), Europe in exile: European exile communities in Britain 1940-1945 (pp. 121-133). Oxford: Berghahn Books.

Berend, I. T. (2006). An economic history of twentieth-century Europe. Cambridge: Cambridge University Press.

Berg, H. (1993). Motorcars: between growth and protectionism. In H. W. de Jong (Ed.), The structure of European industry (pp. 121-146). Dordrecht: Kluwer Academic Publishers.

Berger, F. (2011). Premières approches historiques sur l'intégration économique européenne: une réflexion sectorielle. In Badel, L. \& Michel, H. (Eds.), Patronats et intégration européenne: pour un dialogue disciplinaire raisonée (pp. 17-40). Paris: Harmattan.

Bertrams, K. (2013). A company in history: Solvay, 1863-2013. Cambridge: Cambridge University Press.

Bertrams, K., Coupain, N. \& Homburg, E. (2013). Solvay: history of a multinational family firm. Cambridge: Cambridge University Press.

Beverungen, J. ([2003] 2005). Elite planning organizations: Traditionen, Charakteristika, Implikationen der Trilateral Commission. University Dissertation Freiburg im Breisgau, 2003. Baden-Baden: Nomos.

Blanken, I. (2002). Een industriële wereldfederatie. Zaltbommel: Europese Bibliotheek. 
Bossuat, G. \& Legendre, A. (2007). De rol van de Commissie in buitenlandse betrekkingen. In M. Dumoulin (Ed.), De Europese Commissie, 1958-1972: geschiedenis en herinneringen van een instelling (pp. 361-402). Luxemburg: Bureau voor officiële publicaties der Europese Gemeenschappen.

Braun, H.-J. (1990). The German economy in the twentieth century: the German Reich and the Federal Republic. London: Routledge.

Brodkey, R. M. (1964). U.N.I.C.E. in European integration. Princeton: Woodrow Wilson School of public and international affairs, Princeton University.

Bührer, W. (1986). Ruhrstahl und Europa. Die Wirtschaftsvereinigung Eisen- und Stahlindustrie und die Anfänge der europäische Integration (1945-1952). Munich: Oldenburg.

Bührer, W. (1992). Der Bundesverband der Deutschen Industrie und die Aussenpolitik der Bundesrepublik in den fünfziger Jahren. In Viertelsjahrshefte für Zeitgeschichte, 40, 241-261.

Bührer, W. (1995). German industry and European Integration in the 1950's. In C. A. Wurm (Ed.), Western Europe and Germany: the beginnings of European integration, 1945-1960. Oxford: Berg Publishers. Leitolf, J. (1996). Wirtschaft, Verbände, Integration: britische Industrie und westeuropäische Integration von 1945 bis 1975. Bochum: Brockmeyer.

Bussière, E., \& Dumoulin, M. (Eds.)(1998). Milieux économiques et intégration européenne en Europe occidentale au XXe siècle. Arras: Artois presses université.

Bussière, E., Dumoulin, M., \& Schirmann, S. (Eds.) (2006). Milieux économiques et intégration européenne au XXe siècle: la crise des années 1970. Bruxelles: P.I.E. Peter Lang.

Bussière, E., Dumoulin, M., \& Schirmann, S. (2009). The development of economic integration. In Wilfried Loth (Ed.), Experiencing Europe. 50 years of European construction, 1957-2007 (pp. 45-101). Baden-Baden: Nomos.

Cantwell, J., Dunning, J. H. \& Lundan, S. M. (2010). An evolutionary approach to understanding international business activity: The co-evolution of MNEs and the institutional environment. Journal of International Business Studies, 41, 567-586.

Caron, F. (1983). An economic history of modern France. London: Methuen.

CEPES (1961). Möglichkeiten und probleme einer Atlantischen Partnerschaft. Arbeitstagung der deutschen CEPES-Gruppe am 16 Februar 1962. Frankfurt a. M.: CEPES.

Chandler, A. D. (1977). The visible hand. The managerial revolution in American business. Cambridge: Harvard University Press.

Chesshire, J. H., Friend, J.K, Pollard, J. de B., Stringer, J. \& Surrey, A. J. (1977). Energy policy in Britain: a case study of adaptation and change in a policy system. L. N. Lindberg (Ed.), The energy syndrome: comparing national responses to the energy crisis (pp. 119-172). Lexington: Heath.

Clark, J. G. (1990). The political economy of world energy: a twentieth century perspective. New York: Harvester Wheatsheaf.

Clearfield, F. B. (1985). The trilateral commission: exercising its global influence. Unpublished University Dissertation, University Kentucky, 1985. Lexington, KY: [s.n.].

Coen, D. (1997). The evolution of the large firm as a political actor in the European Union. Journal of Public Policy, 4, 91-108.

Conseil National du Patronat Français (1955). Annuaire Général du Patronat Français. Paris: CNPF.

CRISP (1962). Morphologie des groups financiers. Bruxelles: Centre de Recherche et d'Information SocioPolitiques.

Delanty, G. (1995). Inventing Europe. Idea, identity, reality. Basingstoke: Macmillan.

Dinan, D. (2004). Europe recast: a history of European Union. Basingstoke: Palgrave Macmillan.

Dumoulin, M., \& Dutrieue, A.-M. (1993). La Ligue Européenne de Coopération Économique (1946-1981): un groupe d'étude et de pression dans la construction européenne. Berne: Lang.

Dunning, J. H. \& Lundan, S. M. (2008). Multinational enterprises and the global economy. Cheltenham: Edgar Elder.

Dutrieue, A.-M. (1993). Le CEPES, un mouvement patronal européen? (1952-1967). In M. Dumoulin \& R. Girault (Eds.), L'Europe du patronat: de la guerre froide aux années soixante: actes du colloque de Louvain-la-Neuve des 10 et 11 mai 1990 (pp. 213-230). Berne: Lang.

Ehrmann, H. W. (1957) Organized business in France. Princeton, NJ: Princeton University Press. 
European Movement (1949). European Economic Conference. Westminster, April 20-25, 1949. Resolutions adopted in plenary session. London: United Europe Movement.

Federico, G. \& Giannetti, R. (1999). Italy: stalling and surpassing. In J. Foreman-Peck \& G. Federico (Eds.), European industrial policy. The twentieth-century experience (pp. 124-151). Oxford: Oxford University Press.

Feld, W. (1967). The European common market and the world. Englewood Cliffs, N.J.: Prentice Hall.

Feld, W. J. (1970). Transnational business collaboration among common market countries. Its implication for political integration. New York: Praeger.

Feld, W. (1983). The European Community in world affairs. Boulder: Westview Encore.

Feldenkirchen, W. (1999). Industrial policy in Germany: the invention of interventionism. In J. ForemanPeck \& G. Federico (Eds.), European industrial policy. The twentieth-century experience (pp. 98123). Oxford: Oxford University Press.

Gales, B. P. A. \& Sluyterman, K. E. (1993). Outward bound. The rise of Dutch multinationals. In G. Jones \& H. G. Schröter (Eds.), The rise of multinationals in continental Europe (pp. 65-98). Aldershot: Edward Elgar, p. 91.

Gall, L. (2004). Der Bankier Hermann Josef Abs: eine Biographie. München: Beck.

Gehler, M., Kaiser, W. \& Leucht, B. (2009). Networks in informal European governance. Diachronic perspectives on the European Union as a multi-level polity. In M. Gehler, W. Kaiser, \& B. Leucht (Eds.), Netzwerke im europäischen Mehrebenensystem. Von 1945 bis zur Gegenwart = Networks in European multi-level governance. From 1945 to the present. (pp. 9-26). Wien: Böhlau.

Gerring, J. (2007). Case study research: principles and practices. Cambridge: Cambridge University Press.

Gijswijt, T. W. (2007). Uniting the West: the Bilderberg Group, the Cold War and European integration, 1952-1966. Unpublished dissertation, Heidelberg, Heidelberg.

Gill, S. (1991). American hegemony and the Trilateral Commission. Cambridge: Cambridge University Press.

Gillingham, J. R. (1991). Coal, steel, and the rebirth of Europe, 1945-1955. Cambridge: Cambridge University Press.

Ghosh, A. (1983). OPEC, the petroleum industry, and United States energy policy. Westport: Quorum.

Gisch, H. (1991). The European League for Economic Co-operation (ELEC). In W. Lipgens \& W. Loth (Eds.), Transnational organizations of political parties and pressure groups in the struggle for European Union, 1945-1950 (pp. 186-276). New York: Walter de Gruyter.

Goldschmidt, B. (1982). The atomic complex. A worldwide political history of nuclear energy. La Grange Park: American Nuclear Society.

Gordon, A. (2003). A modern history of Japan. From Tokugawa times to the present. Oxford: Oxford University Press.

Gowland, D., Turner, A \& Wright, A. (2010). Britain and European integration since 1945. On the sidelines. London: Routledge.

Green Cowles, M. (1995). Setting the agenda for a new Europe: the ERT and EC 1992. Journal of Common Market Studies, 33, 501-526.

Green Cowles, M. (1996). Business means Europe. Who built the market? In M. Bond, J. Smith \& W. Wallace (Eds.), Eminent Europeans: personalities who shaped contemporary Europe (pp. 192-213). London: The Greycoat Press.

Green Cowles, M. (2009). The European Round Table of Industrialists and the single market programme. From political to policy network. In M. Gehler, W. Kaiser, \& B. Leucht (Eds.), Netzwerke im europäischen Mehrebenensystem. Von 1945 bis zur Gegenwart = Networks in European multi-level governance. From 1945 to the present. (pp. 139-150). Wien: Böhlau.

Greenwood, J., \& Aspinwall, M. (Eds.) (1998). Collective action in the European Union: interests and the new politics of associability. London: Routledge.

Greenwood, J. (2007). Interest representation in the European Union. Basingstoke: Palgrave.

Griffiths, R. T. (1997). The Beyen plan. In R. T. Griffiths (Ed.), The Economic development of the EEC (pp. 123-140). Lyme: Edward Elgar.

Haas, E. B. ([1958]1968). The uniting of Europe: political, social and economical forces, 1950-'57. London: Stevens. 
Häckel, E. (1975). Multinationale Konzerne und europäische Integration. Bonn: Europa-Union Verlag.

Haycraft, W. R. (2000). Yellow steel: the story of earthmoving equipment industry. Urbana: University of Illinois Press.

Henau, B. (1990). Shaping a new Belgium: The CEPAG. In M. L. Smith \& P. M. R. Stirk (Eds.), Making the new Europe. European unity and the Second World War (pp. 112-132). London: Pinter.

Henau, B. (1995). Paul van Zeeland en het monetaire, sociaal-economische en Europese beleid van België, 1920-1960. Brussel: KAWSLK.

Hirschhausen, U. von \& Patel, K. K. (2010). Europeanization in history: an introduction. In M. Conway \& K. K. Patel (Eds.), Europeanization in the twentieth century. Historical approaches (pp. 1-18). Basingstoke: Palgrave Macmillan.

Hoffmann, S. (1964). De Gaulle, Europe, and the Atlantic alliance. International Organization, 18, 1-28.

Hoffmann, S. (1964). The European process at Atlantic crosspurposes. Journal of Common Market Studies, 3, 86-101.

Hoffmann, S. (1966). Obstinate or obsolete? The fate of the nation state and the case of western Europe. Daedalus, 95, 862-915.

International directory of company histories (1988-...). Chicago: St. James Press.

Iterson, A. van \& Olie, R. (1992). European business systems: the Dutch case. In R. Whitley (Ed.), European business systems. Firms and markets in their national context (pp. 98-116). London: Sage.

Jacoby, N. H. (1974). Multinational oil: a study in industrial dynamics. New York: Macmillan publishing.

Jones, G. \& Schröter, H. G. (Eds.) (1993). The rise of multinationals in continental Europe. Aldershot: Edward Elgar.

Jones, G. G. (2005). Multinationals and global capitalism: from the nineteenth to the twenty-first century. Oxford: Oxford University Press.

Jones, G. G., \& Miskell, P. (2005). European integration and corporate restructuring: the strategy of Unilever, c. 1957-c. 1990. Economic History Review, 28, 113-139.

Jörnmark, J. (1993). Coal and steel in western Europe 1945-1993. Innovative change and institutional adaptation. Dissertation, University of Göteborg.

Jong, H. W. de (1996). Dynamische markttheorie. $4^{\text {th }}$ edition, Weteringbrug: Eddusa.

Jong, H. W. de (Ed.) (1993). The structure of European industry. Dordrecht: Kluwer Academic Publishers.

Judt, T. (2005). Postwar. A history of Europe since 1945. New York: Penguin

Kaiser, W. (2007). Christian democracy and the origins of the European Union. Cambridge: Cambridge University Press.

Kaiser, W. \& Leucht, B. (2008). Informal politics of integration: Christian Democratic and Transatlantic networks in the creation of ECSC core Europe. Journal of European integration history, 14, 35-50.

Kaiser, W., Leucht, B \& Rasmussen, M. (2009). Origins of a European polity. In W. Kaiser, B. Leucht \& M. Rasmussen (Eds.), The history of the European Union: origins of a trans-and supranational polity 1950-1972 (pp. 1-11). New York: Routledge.

Kaiser, W. (2009). Bringing people and ideas back in: Historical research on the European Union. In D. Phinnemore \& A. Warleigh-Lack (Eds.), Reflections on European Integration: 50 Years of the Treaty of Rome (pp. 22-39). Basingstoke: Palgrave Macmillan.

Kindleberger, C. P. (1969). American business abroad. Six lectures on direct investment. New Haven/London: Yale University Press.

Koeune, J. C. (October 23rd, 2006). Interview with Yvonne de Wergifosse, secretary general of ELEC (1962-1988), acquired from http://www.elec-lece.eu/documents/div/origin-deWergifosse-E.pdf, on the 26th of September 2011.

Krass, A. S., Boskma, P., Elzen, B. \& Smit, W. A. (1983). Uranium enrichtment and nuclear weapon proliferation. London: Taylor \& Francis

Kuisel, R. F. (1993). Seducing the French. The dilemma of americanization. Berkeley. University of California Press.

Kurgan-Van Hentenryk, G., Brion, R. \& Moreau, J-L. (2000). European banks since the Second World War (1944-2000). In H. van der Wee \& G. Kurgan-Van Hentenryk, G. (Eds.). A history of European banking (pp. 363-393). Antwerp: Mercatorfonds. 
Lanzalaco, L. (2008). Business interest associations. In G. G. Jones \& Zeitlin, J. (Eds.), The Oxford handbook of business history (pp. 293-315). Oxford: Oxford University Press.

Lavigne, M.(1974). The socialist economies of the Soviet Union and Europe. London: Martin Robertson.

Licklider, R. E. (1988). Political power and the Arab oil weapon. Berkeley: University of California Press.

Lieber, R. J. (1983). The oil decade: conflict and cooperation in the West. New York: Praeger.

Lindberg, L. N. (1963). The political dynamics of European economic integration. Stanford: Stanford University Press.

Loth, W. (1991). The Mouvement Socialiste pour les États-Unis d'Europe (MSEUE). In W. Lipgens \& W. Loth (Eds.), Transnational organizations of political parties and pressure groups in the struggle for European union, 1945-1950 (pp. 277-318). New York: Walter de Gruyter.

Lucas, N. J. D. (1977). Energy and the European Communities. London: Europa Publications.

Marsh, P. (1978). Development of relations between the EEC and CMEA. In A. Schlaim \& G. N. Yannopoulos (Eds.), The EEC and Eastern Europe. Cambridge: Cambridge University Press.

Mastanduno, M. (1992). Economic containment. CoCom and the politics of east-west trade. Ithaca: Cornell Press University.

Matvia, M. (1999). Der Einfluss der Vereinigung der Industrie- und Arbeitgeberverbände Europas (UNICE) auf den Entscheidungsprozess der Europäischen Union. Bern: Lang.

Merton, R. (1955). Erinnernswertes aus meinem Leben, das über das Persönliche hinausgeht. Frankfurt am Main: Knapp.

Michaelis, H. (1993). Energiewirtschaft der Bundesrepubliek Deutschland. In Hohensee, J. \& Salewski, M. (Eds.), Energie-Politik-Geschichte: nationale und internationale Energiepolitik seit 1945 (pp. 51-74). Stuttgart: Steiner.

Milward, A. S. (1984). The reconstruction of western Europe, 1945-1951. Berkeley: University of California Press.

Milward, A. S. (1992). The European rescue of the nation-state. London: Routledge.

Mioche, P. (1988). Le patronat de la Sidérurgie francaise et le Plan Schuman en 1950-1952: les apparences d'un combat et la réalité d'une mutation. In K. Schwabe (Ed.), Die Anfänge des SchumanPlans. 1950/51 (pp. 305-318). Baden-Baden: Nomos.

Misa, T. J. \& Schot, J. (2006). Inventing Europe: technology and the hidden integration of Europe. History and Technology, 21, 1-19.

Mommen, A. H. (1994). The Belgian economy in the twentieth century. London: Routledge.

Moguen-Toursel, M. (2002). L'ouverture des frontières européennes dans les années 50: fruit d'un concertation avec les industriels? Bruxelles: P.I.E. Lang.

Moguen-Toursel, M. (Ed.) (2007). Stratégie d'entreprise et action publique dans l'Europe intégrée (19501980). Affrontement et apprentissage des acteurs (pp. 47-86). Bruxelles: PIE-Peter Lang.

Moravcsik, A. (1991). Negotiating the Single European Act: National interests and conventional statecraft in the European Community. International Organization, 45, 19-56.

Moravcsik, A. (1993). Preferences and power in the European Community: a liberal intergovernmentalist approach. Journal of Common Market Studies, 41, 473-524.

Moravcsik, A. (1998). The choice for Europe: social purpose and state power fom Messina to Maastricht. Ithaca: Cornell University Press.

Morse, R. A. (1982). Japanese energy policy. In W. L. Kohl (Ed.), After the second oil crisis: energy policies in Europe, America and Japan (pp. 255-269). Lexington: Lexington Books.

Murmann, J. P. (2003). Knowledge and competitive advantage: The coevolution of firms, technology, and national institutions. Cambridge: Cambridge University Press.

Nuttal, S. J. (1992). European Political Co-operation. Oxford: Clarendon Press.

OECD (1968). General report: gaps in technology. Paris: OECD.

Pagden, A. (Ed.). (2002) The idea of Europe. From antiquity to the European Union. Cambridge University Press.

Palmer, R. R. \& Colton, J. (1995). A history of the modern world. New York: McGraw-Hill.

Patel, K. K. \& Schot, J. (2011). Twisted paths to European integration: comparing agriculture and transport policies in a transnational perspective. Contemporary European History, 20, 383-403. 
Paulussen, J., \& Blanken, I. (2004). Samenwerking tusschen Nederlandsche industrieën met groote internationale belangen. Zaltbommel: Aprilis.

Pieczewski, A. (2010). Joseph Retinger's conception of and contribution to the early process of European integration. European Review of History: Revue européenne d'histoire, 17, 581-604.

Pijl, K. van der (1984). The making of an Atlantic ruling class. London: Verso.

Polonsky, A. B. (1985). Polish failure in wartime London: attempts to forge a European alliance, 19401944. The International History Review, 7, 576-591.

Pringle, P. \& Spiegelman, J. (1981). The nuclear barons. London: Michael Joseph.

Ramírez Pérez, Sigfrido M. (2009). Transnational business networks propagating EC industrial policy: The role of the Committee of Common Market Automobile Constructors. In W. Kaiser, B. Leucht \& M. Rasmussen (Eds.), The history of the European Union: origins of a trans- and supranational polity 1950-1972 (pp. 74-92). New York: Routledge.

Ramírez Pérez, S. M. (2010). The European Committee for Economic and Social Progress: business networks between Atlantic and European communities. In K. Wolfram, B. Leucht and M. Gehler (Eds.) (2010). Transnational networks in regional integration. Governing Europe 1945-83 (pp. 6184). London: Palgrave Macmillan.

Ranieri, R. (1988). The Italian steel industry and the Schuman Plan negotiations. In K. Schwabe (Ed.) (1988). Die Anfänge des Schuman-Plans. 1950/51 (pp. 345-356). Baden-Baden: Nomos.

Rasmussen, M. (2010). European rescue of the nation-state? Tracing the role of economics and business. In W. Kaiser \& A. Varsori (Eds.), European Union history: themes and debates (pp. 128-149). Basingstoke: Palgrave Macmillan.

Retinger, J. H., \& Pomian, J. (Eds.) (1972). Joseph Retinger: Memoirs of an eminence grise. Brighton: Sussex University Press.

Rhenisch, T. (1999). Europäische Integration und Industrielles Interesse. Die Deutsche Industrie und die Gründung der Europäische Wirtschaftsgemeinschaft. Stuttgart: Franz Steiner.

Richardson, I., Kakabadse, A. P. \& Kakabadse, N. K. (2011). Bilderberg people: elite power and consensus in world affairs. London: Routledge.

Rietbergen, P. (1998). Europe. A cultural history. London: Routledge.

Rijkens, P. (1965). Handel en wandel: nagelaten gedenkschriften, 1888-1965. Rotterdam: Donker.

Rollings, N. (2007). British business in the formative years of European integration, 1945-1973. Cambridge: Cambridge University Press.

Rollings, N. \& Kipping, M. (2008). Private transnational governance in the heyday of the nation-state: the Council of European Industrial Federations (CEIF). Economic History Review, 61, 409-431.

Rollings, N. \& Moguen-Toursel, M. (2012). European organised business and European integration in the post-Second World War period. Jahrbuch für Wirtschaftsgeschichte, 53, 103-123.

Rooij, A. van \& Homburg, E. (2002). Building the plant. A history of engineering contracting in the Netherlands. Zutphen: Walburg.

Rosamond, B. (2000). Theories of European integration. Basingstoke: Macmillan Press.

Rossem, M. van (2001). De Verenigde Staten in de twintigste eeuw. Den Haag: Sdu Uitgevers.

Sandholtz, W. \& Zysman, J. (1989). Recasting the European bargain. World Politics, 42, 95-128.

Saumon, D. \& Puiseux, L. (1977). Actors and decision in French energy policy. In L. N. Lindberg (Ed.), The energy syndrome: comparing national responses to the energy crisis (pp. 119-172). Lexington: Heath.

Schlaim, A. \& Yannopoulos, G. N. (Eds.) (1978). The EEC and Eastern Europe. Cambridge: Cambridge University Press.

Schröter, H. G. (1993). Continuity and change: German multinationals since 1850. In G. Jones \& H. G. Schröter (Eds.), The rise of multinationals in continental Europe (pp. 28-48). Aldershot: Edward Elgar, pp. 28-35.

Servan-Schreiber, J. J. (1967). Le défi américain. Paris: Denoël.

Sklar, H. (1980). Trilateralism: Managing dependence and democracy. In H. Sklar (Ed.), Trilateralism: the Trilateral Commission and elite planning for world management. (pp. 1-57). Montréal: Black Rose Books. 
Sklar, H., \& Everdell, R. (1980). Who's who on the Trilateral Commission. In H. Sklar (Ed.), Trilateralism: the Trilateral Commission and elite planning for world management. (pp. 90-130). Montréal: Black Rose Books.

Sluyterman, K. (2010). Keeping competitive in turbulent markets, 1973-2007. A history of Royal Dutch Shell (Vol. 3). Oxford: Oxford University Press.

Sluyterman, K. \& Wubs, B. (2009). Over grenzen: multinationals en de Nederlandse markteconomie. Amsterdam: Boom.

Soénius, U. S. (2005). Otto Wolff von Amerongen: Kundschafter der Marktwirtschaft. In P. Danylow \& U. S. Soénius (Eds.), Otto Wolff: ein Unternehmen zwischen Wirtschaft und Politik (pp. 385-435). München: Siedler.

Soénius, U. S. (2005). Wiederaufbau, Wirtschaftswunder und die Entwicklung im Konzern 1945 bis 1990. In P. Danylow \& U. S. Soénius (Eds.) (2005). Otto Wolff: ein Unternehmen zwischen Wirtschaft und Poltik (pp. 297-384). München: Siedler.

Spaulding Jr., R. M. (1996). "Reconquering Our Old Position” West German osthandel strategies of the 1950's. In V. R. Berghahn (Ed.), Quests for economic empire. European strategies of German big business in the twentieth century (pp. 124-143). Providence: Berghahn Books.

Taylor, G. D. (1981). Debate in the United states over the control of international cartels, 1942-1950. In The International History Review, 3, 385-398.

Tedeschi, P. (2006). Une nouvelle Europe à construire. La section italienne de la LECE, de 1948 à la création du marché commun. Journal of European integration history, 12, 87-104.

Thompson, D. (1969). The proposal for a European company. London: Chatham House.

Thompson, P. (1980). Bilderberg and the West. In H. Sklar (Ed.), Trilateralism: the Trilateral Commission and elite planning for world management (pp. 157-189). Montréal: Black Rose Books.

Tilly, R. (1993). The internationalization of West German banks, 1945-87. In G. Jones \& H. G. Schröter (Eds.), The rise of multinationals in continental Europe (pp. 173-183). Aldershot: Edward Elgar.

Tolliday, S. (2003). The origins of Ford of Europe: from multidomestic to transnational corporation. In H. Bonin \& Y. Lung (Eds.), Ford, 1903-2003: the European history (pp. 153-242). Paris: P.L.A.G.E.

Uitham, C., Vries, B. de, \& Zijlstra J. (1976). Kernenergie in Nederland: een onderzoek naar machtstructuren. S.l.: Stichting Uitgevery Xeno.

United Nations (1993). From the common market to EC 92: regional economic integration in the European Community and transnational corporations. New York: United Nations.

Vleuten, E. van der (2008). Towards a transnational history of technology. Meanings, promises, pitfalls. Technology and Culture, 49, 974-994.

Waarden, F. van (1995). Employers and employers' associations. In J. Ruysseveldt, R. Huiskamp \& J. van Hoof (Eds.), Comparative industrial and employment relations (pp. 68-108). London: Sage.

Wee, H. van der (1987). Prosperity and upheaval: the world economy 1945-1980. Harmondsworth: Penguin Books.

Weenink, W. H. (2005). Johan Willem Beyen, 1879-1976: bankier van de wereld, bouwer van Europa. Amsterdam: Prometheus.

Whitley, R. (1992). The comparative study of business systems in Europe: issues and choices. In R. Whitley (Ed.), European business systems. Firms and markets in their national contexts (pp. 267284). London: Sage.

Wilkins, M. (1974). The maturing of multinational enterprise: American business abroad from 1914 to 1970. Cambridge: Harvard University Press.

Winter, H. (1994). Interdependenzen zwischen Industriepolitik und Handelspolitik der Europäischen Gemeinschaft. Baden-Baden: Nomos.

Wolff von Amerongen, O. (1992). Der Weg nach Osten. Vierzig Jahre Brückenbau für die deutsche Wirtschaft. Droemer: Knaur.

Wubs, B. (2008). International business and war interests: Unilever between Reich and empire, 1939-1945. London: Routledge.

Zanden, Jan Luiten van (1998). The economic history of the Netherlands, 1914-1995: a small open economy in the 'long' twentieth century. London: Routledge. 



\section{Appendix - The leadership of the ELEC, Bilderberg meetings and the Trilateral Commission, 1950-1980: a database}

\section{Introduction}

This chapter presents a database of the individual professional affiliations of the leadership of the ELEC, Bilderberg meetings and the Trilateral Commission. The database is included in this appendix in tables A.2 to A.15. Its structure is designed to answer questions about:

- $\quad$ The networks' main members and their professional affiliations.

- The size of the networks' business membership.

- The industrial composition of the networks' business components

- The overlap between the networks' leaders

The data is analysed in tables and figures included in chapter 2 and 3. Also see the section "Tables and figures" below.

The database has one important additional asset. It offers an overview of the distribution of nationalities and indicates the distribution of other societal spheres than business. This feature offers unprecedented transparency about the composition of these networks and the changes in composition through time. As a result the database has become a resource for future investigations on the ELEC, Bilderberg meetings and the Trilateral Commission. Moreover, it supplements the necessarily limited selection of individuals that occur in the main text.

\section{Content and creation of the database}

For the period 1950-1980, measuring points at 5-year intervals were selected. This resulted in the years, 1950, 1955, 1960, 1965, 1970, 1975 and 1980. For these years the database offers details on each individual member of the ELEC's Central Council, the Bilderberg meetings' Steering Committee and the Trilateral Commission's Executive Committee, with regard to: 
- Nationality

- Name

- Societal Sphere

- Industry

- Company/Institution for which they worked.

The process of data-compilation consisted of two phases with each phase involving the compilation of a different set of data. The first phase and set of data was "membership", the second phase and set of data was "affiliation." Both sets of data required different types of sources.

\section{Membership}

Firstly three sub-datasets were compiled for each group. The datasets included the details on membership, name, nationality and timing of membership of the ELEC's Central Council, the Bilderberg meetings' Steering Committee and the Trilateral Commission's Executive Committee.

\section{Members of ELEC's Central Council:}

The data on ELEC's Central Council's membership is based on ELEC's frequent publications which included updated member-lists. For the year 1980 it was not possible to use information from a publication of that exact year. Instead a list of members from 1979 was used. Because the ELEC Central Council had a limited turnover of members over the years, the short time-gap was considered acceptable. The "affiliation" data for the 1979 group was still based on the year 1980.

\section{Members of the Bilderberg meetings' Steering Committee}

The data on the Bilderberg meetings' Steering Committee's membership is based on a hardcopy list from the Max Kohnstamm archive that compiles the Bilderberg meetings' conference visitors and Steering Committee members for the period 1954 to 2001 . The list includes information on conference participation and Steering Committee membership. It is safe to assume that list originated from the Bilderberg meetings secretariat itself, as Max Kohnstamm has been a member of the Steering Committee himself.

The hardcopy list was photographed and turned into an excel spreadsheet via Optical Character Recognition software. The spreadsheet was subsequently proofread and supplemented with further data about Steering Committee membership in minutes of the Steering Committee meetings, from 1954 until 1977. Individuals who participated in the Steering Committee meetings only once between 1954- 
1980 were not included in the database because they typically stood-in for official members. ${ }^{538}$

\section{Members of the Trilateral Commission Executive Committee}

The data on the Trilateral Commission's Executive Committee's membership is based on the work of Holly Sklar: she compiled an elaborate "who's who" on the Trilateral Commission for the period 1972-1980, which was gratefully used for the purpose of this database. Note that Sklar's interpretations were not reproduced here. The membership-information and the biographical information included in her book was used to make a new assessment. ${ }^{539}$

The resulting sub-datasets were then combined, constituting the basis for the next step.

\section{Affiliation}

The database was subsequently complemented with information about the main professional affiliation of each individual member. Data like this is typically available in biographical sources such as biographical dictionaries, encyclopaedias, online databases etcetera. In the case of the Trilateral Commission the required biographical information was already compiled by Holly Sklar. ${ }^{540}$

The selection of the main appointment or professional affiliation of each individual requires interpretation. Often the individuals in this database held several positions at the same time. The rule that informed the decisions was to choose the most likely main professional activity. The company or institution that appears in the "Company/Institution" column is the person's main affiliation for that year. On the more specific problems of interpretation and classification in this database, see the sections on the "Company/Institution" column and the "Remarks" column below, in the discussion of the database's structure and taxonomy of the database.

The affiliation of each individual was further categorized in terms of "societal sphere" and "sectors." The taxonomy involved in making these choices is also explained below.

\footnotetext{
538 IISGA, AMK, inv. nr. 110, Bilderberg Meetings Alphabetical List of Participants 1954-2001. For details on the sources on the Steering Commitee see the section "Sources database - Membership sources per group" of this appendix.

539 See the section "Sources database - Membership sources per group" of this appendix.

${ }^{540}$ See the sections "Sources database - Membership sources per group" and Sources Database - "Professional Affiliations" sources per country of this appendix.
} 


\section{Structure and taxonomy}

The following explains the decisions and interpretations that were involved in compiling and structuring this database. The eight columns of the database will be discussed separately. Additionally, the use of the category "Other" is explained. The eight columns of the database are:

\begin{tabular}{|l|l|l|l|l|l|l|}
\hline Group & Country & Name & Societal Sphere & Sector & Company/Institution & Remark \\
\hline
\end{tabular}

\section{Group}

The column indicates whether the respective individual in the "Name" column was a member of the ELEC Central Council, the Bilderberg meetings Steering Committee or the Trilateral Commission Executive Committee.

\section{Country}

This column indicates the nationality of the individual in the "Name" column.

\section{Name}

The names of the database entries are stripped of titles such as "Lord", "Baron", "Viscount" and "Sir." The exception to this rule are royal titles that belong to the direct line of succession in relation to the head of state, such as Crown Prince, Prince, Queen, King. Last names are followed by a comma, which is followed by first names as they appeared in the original sources.

Some names appear twice in a single measuring year. As the "group" column will indicate, these persons are members of two different networks at the same time. Some names are stricken through: their biographies could not be located and membership sources did not provide additional information. Per interval the following amount of individuals have remained uncategorized:

Table A.1: Percentage of uncategorized members in database in relation total member in database.

\begin{tabular}{lccc}
\hline Year & $\begin{array}{c}\text { Number of individuals } \\
\text { without biographies: }\end{array}$ & Of total members: & $\begin{array}{c}\text { Percentage of } \\
\text { uncategorized members }\end{array}$ \\
\hline 1950 & 0 & 20 & 0 \\
1955 & 0 & 39 & 0 \\
1960 & 4 & 60 & $6,70 \%$ \\
1965 & 3 & 60 & $5 \%$ \\
1970 & 3 & 66 & $4,50 \%$ \\
1975 & 7 & 115 & $6,10 \%$ \\
1980 & 6 & 133 & $4,50 \%$ \\
\hline
\end{tabular}




\section{Societal Sphere}

The column "Societal Sphere" is a general categorization of the entry in the "Company/Institution" column. The categories that are distinguished within the "Societal Sphere" column pertains to the following broad ideal types:

- Business: the individual in the name column works in a private or stateowned corporation active in any possible sector (but see "Media").

- Media: media corporations are part of the business sphere. However, considering the organizations under scrutiny it makes sense to reserve a category for media alone. Popular publications about the Bilderberg meetings or the Trilateral Commission often imply a close relationship between them and media. In such publications "the media" are accused of failing to pay due attention to the networks.

- Labour: this societal sphere solely pertains to persons active in national unions or international federations of national unions.

- Politics: the individual in the name column performs a function which is primarily related to party politics such as a membership of parliament and government, either in a national or international context. Ministers are considered to primarily fulfil a political function that informs their role as public administrators. With regard to the "Company/Institution" column, the political parties that the ministers represent are included.

- (Semi-)Public Administration: any person who performs a function in public administration or semi-public administration, either in a national or international context. The difference between public administration and semi-public administration lies in a larger degree of autonomy for the latter, despite its dependence on public funds: examples are hospitals or universities.

- Academic: this category is not perfect. It tries to capture several professional activities that go beyond (but include) work in academia in a narrow sense. The persons in this category are all involved in studyorganizations, policy research institutes or universities.

\section{Sector}

The column sector specifies in which industries the corporations from the business sphere were active. For the other societal spheres the column offers further specification on organizations or institutions to which the individual members were affiliated.

- Societal Sphere Business: for the business sphere, the column "Sector" lists the area in which the firms were active. The industries "Arms", "Automotive", "Banking", “Consultancy", "Electrical Engineering”, “Electronics", "Law", "Foods", "Glass", “Oil”, "Telecommunications", "Transport”, "Utili- 
ties", could be attributed to companies without strong potential for overlap or other difficulties of interpretation. However, the following attributions of industries require some explanation ${ }^{541}$ :

- "Business Associations": business associations obviously do not form an industry. Within the sphere of business however, the business association is a type of business-involvement in the networks under scrutiny. In the database the business associations typically appear in the form of national federations of industry.

o "Chemicals" versus "Pharmaceuticals": a single terminology for the chemical industry and the pharmaceutical industry is problematic. Chemical firms often diversified into the production of pharmaceuticals for example. To tackle this problem of overlap, the sector "Pharmaceuticals" was only attributed to firms that unmistakeably focussed on the production of pharmaceuticals.

o "Ferrous Metals" versus "Non-Ferrous Metals": ferrous metals (mostly steel, in this database exclusively steel) differ from nonferrous metals (aluminium, copper, tin, zinc, etc.) in that they contain iron. In this database the distinction is made to single out the steel industry, particularly because the sector was directly involved in a specific phase of integration of European markets in the early 1950s: the Schuman Plan and the resulting European Coal and Steel Community.

o "Multiple": the term "Multiple" stands for activities in multiple sectors. Examples include financial holdings of industry that branched into almost all imaginable sectors (Mitsubishi for example), but also Unilever that combines sizeable foods and chemicals branches. The category also includes individuals that combine multiple advisory directorships in several sectors at the same time.

○ "Private Foundations": again, not an industry, but nonetheless a relevant category to single out within the business sphere because of their pursuit of ideological goals. The Ford Foundation is a familiar example: it is a private fund used for private means on a number of issues: education, research, and among others, funding the Bilderberg meetings or the Trilateral Commission in their start-up phases.

- Societal Sphere Media: in terms of the goals of this database, companies within the "Media" sphere require no further specification or division. The term "Media" is repeated in the "sector" column.

${ }^{541}$ For the categorization of business sectors the following encyclopedic source was consulted: International directory of company histories (1988-...). Chicago: St. James Press. 
- Societal Sphere Labour: the societal sphere "Labour" only pertains to representatives of unions. The sphere "Labour" is further specified as "Unions" in the "sector" column.

- Societal Sphere Politics: the "sector" column further specifies a role in government, house of representatives or the senate.

- Societal Sphere (Semi-)Public Administration: The "sector" column further specifies the area of expertise of the person or company/institution, in this database limited to "Economic Affairs", "Foreign Affairs" and "Security."

- Societal Sphere Academic: the organization or institution is further specified in terms of "University" and "Policy Research Institute" in the "sector" column: only Universities are actually called "Universities" in the "sector" column. One exception to this rule was allowed for the French Centre Nationale Recherche Scientifique, which is not a University as such but an organization created to strengthen University research. It nonetheless received the category "University." All the others are categorized as "Policy Research Institutes."

\section{Company/Institution}

This column states the main affiliation of the individuals in the database by listing the corporation or institution for which they worked or participated in. Components of corporate names that express details about the legal structure of the firm, such as N.V., A.G., Incorporated or Corporation, were not included. In the case of European political parties a rough characterization was added between brackets to provide added usability for future users of the database.

In some cases the selection of "main affiliation" was problematic. At times, more then one option was available. In these instances the criterion of most likely main professional activity was not helpful. Specific problem-cases and the choices that were involved in solving them are explained in the footnote. ${ }^{542}$

\footnotetext{
542 Beugel, Ernst van der $(70,75,80)$ : the choice was made to include his multiple advisory board functions in corporations instead of his extraordinary professorship at Leiden University on Post-war Western Cooperation. Van der Beugel himself claimed that half of his time went to advisory board work, the rest to all his other (multiple) duties. Therefore he is classified as part of the societal sphere of business. Nationaal Archief, Den Haag, 357 E.H. van der Beugel, 1946-1990, nummer toegang 2.21.183.08, inv. nr. 64, p. 478.

Edwards, Robert (all intervals): the choice was made to include his role as union leader, instead of his membership of Parliament. He took on his role as union leader earlier and remained union leader throughout his membership of Parliament. As a result he was qualified as part of the societal sphere of Labour.

Birrenbach, Kurt $(75,80)$ : the choice was made to stress his role in the steel-producing firm Thyssen, instead of his position in the German Reichstag as a Foreign Affairs expert. It appeared impossible to determine which role consumed the most time. His affiliation with Thyssen combined with his advisory role towards businesses, was the longest standing one. Therefore he is qualified as part of the societal sphere of business.
} 


\section{Remark}

The remark column provides extra information, including the following types of entries:

- Relevant previous appointments, typically leading roles in national governments.

- Relevant previous or current internal positions in ELEC, the Bilderberg meetings or the Trilateral Commission (such as Chairman, or European Secretary etc.).

- Extra information regarding the entry in the Company/Institution column where it was considered helpful.

- Deviating source rules. Three forms of deviating source rules exist:

- A single *-sign indicates that the person in question already retired from the affiliation listed in the Company/Institution column. Nevertheless the affiliations are listed because of the continuing importance for a correct interpretation of the person in the current measuring year. Typically this method is used for indicating individuals with a particularly long involvement in big multinational firms on a top executive level, who after retiring remained active in ELEC, the Bilderberg meetings and the Trilateral Commission.

○ A double ${ }^{* *}$-sign followed by a number, representing a year: ${ }^{* *} 62$, for example. This means that the entry in the Company/Institution column is based on information for the year mentioned. In these cases there was no biographical source available to give information about a measuring year. In the case of biographical encyclopaedia one can then normally use a later edition (if available) and use the updated biography entry. One exception that occurs at times is that the individual's biography does not recur in later editions. In these cases individuals may have deceased in the interval between editions, or have withdrawn from professional activities.

○ ***-signs means that no entry could be included in the Company/Institution column, but that information with regard to "Societal Sphere" was available from the source material that was used to establish the membership of ELEC, Bilderberg meetings and the

Tidemand, Otto Grieg $(75,80)$ : Tidemand had since long been an owner of ships, and between 1965 and 1971 he was the Norwegian Minister for Defence, Trade and Shipping. When he left public office in 1971 he became chairman of the in 1972 created Saga Oil, a state-oil-company. Because this was a full time function, it was Tidemand's most important activity. Therefore he was included in the societal sphere of business.

Zellerbach, J. D. (60): the choice was made to include his diplomatic career as a US ambassador to Italy instead of his leading position in the Crown-Zellerbach Corporation. In the late 1950s this became his main career activity. Therefore he's categorized as part of the societal sphere of public administration. 
Trilateral Commission: if an affiliation was missing in such documents, in some cases at least mention was made of the individual being an "Industrialist", or "Banker." This particularly occurred in the ELEC publications.

\section{Other}

The entry "Other" appears in some special cases of persons whose work or affiliation is difficult to categorize. This entry was used with members of royal families. The entry was further used in two cases: Joseph Retinger and Georges Berthoin. Both did not perform clearly distinguishable professional roles but were very active in the networks under scrutiny.

\section{Tables and figures}

This section explains the content and composition of the tables and figures in this book that are based on this database.

\section{Societal Spheres}

The tables 2.2, 2.6, 2.7 and 3.1 and figures 2.1, 2.2, 2.3 and 3.1 compile the information in the societal spheres-column of the database from 1950-1980. The tables offer insight into the absolute distribution of spheres in the different networks. The figures graphically display the relative distribution of the categorized members across the societal spheres. As mentioned, not all members included in the database could be categorized due to a lack of sources. This small group (see table A.1) was left out of the graphs.

\section{Sectors}

Tables and figures 3.2, 3.3, 3.4 and 3.5 compile the information in the sectorcolumn of the database, but only for the business sphere. The tables offer insight into the absolute distribution of the industries in all networks. The figures graphically display the relative distribution of the categorized sectors of the business sphere. In rare cases the company at which an individual worked could not be determined, which made it impossible to add an industry in the sector column. These were left out of the graphs. 


\section{Results}

Results can be distilled from the database on three levels. The first level of results is obtained through the unprecedented overview that the database offers on the structure of the ELEC, the Bilderberg meetings and the Trilateral Commission leadership in terms of membership, nationality, societal spheres and sectors. The second level of results is obtained by comparing the ELEC, the Bilderberg meetings and the Trilateral Commission on these aspects. Those are discussed in chapter 2 and 3. Results regarding the distribution of nationality are mentioned here.

\section{Country database table}

The database offers a good overview of the countries that were involved in the leadership of the networks. Several aspects are worthwhile noting here. The involvement of Italian members was very limited until 1970. More importantly, the weight of the Dutch members in the Bilderberg group and Belgian members in the ELEC, is striking. Both countries were more strongly represented in the networks than should be expected based on the size and importance of their countries in international affairs. Moreover, both achieved this position through similar means. The initiative to found the ELEC originated with the Belgian Paul van Zeeland. Subsequently, the Belgians secured central positions within the ELEC (President/Secretary general) and managed to hold on to them for a long time. Similarly, the Dutch carried the initiative for the Bilderberg meetings and also secured central positions within the network (Chairman, European secretary, Treasurer). The Dutch for example consistently selected the Bilderberg treasurers from the leadership of Dutch multinationals. The group of Belgian and Dutch leaders clearly were the driving forces behind both organizations. The Dutch nonetheless lost the chairmanship in the Bilderberg meetings in 1976 when Prince Bernhard was forced to resign. ${ }^{543}$

Additionally, it is worth noting that the American position in the Bilderberg meetings is small compared to that of the Europeans, even taking into account that the Europeans require extra representation to cater to national sentiment. This strengthens the idea that the Bilderberg meetings ultimately was and remained a European initiative. It was initiated and continued by Europeans, with European chairmen. In this perspective, Americans formed the main invitees.

543 See chapter 2. 


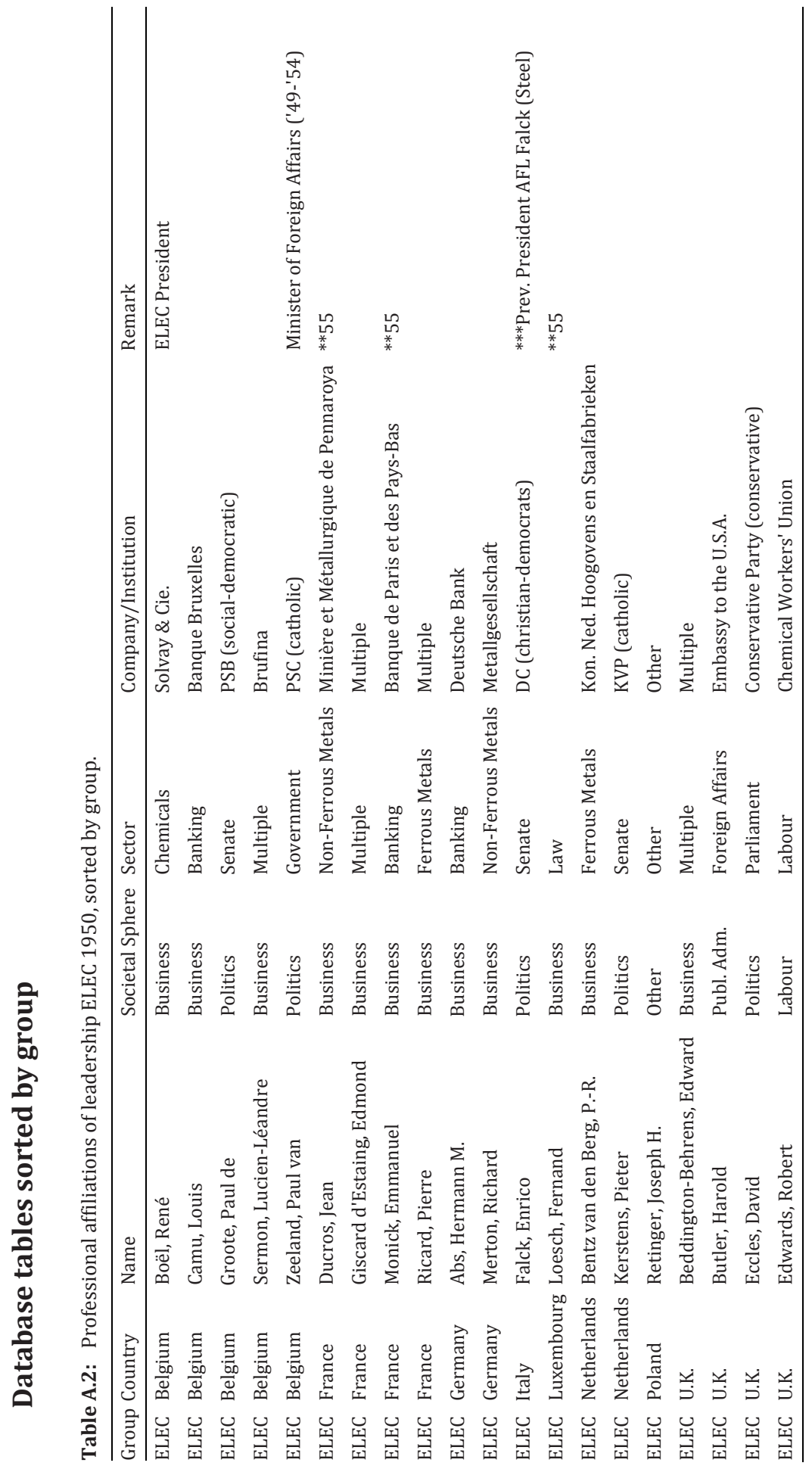




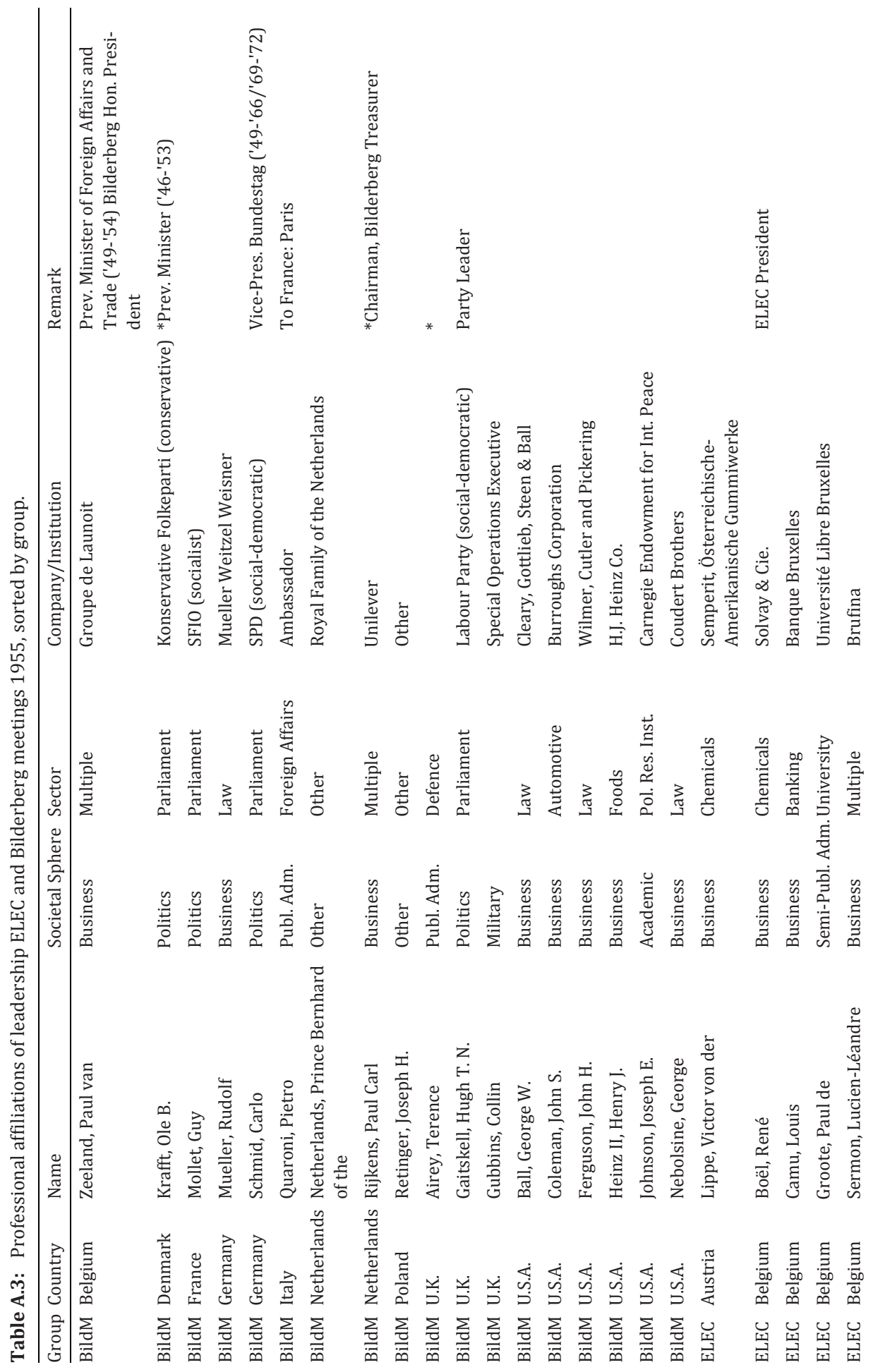




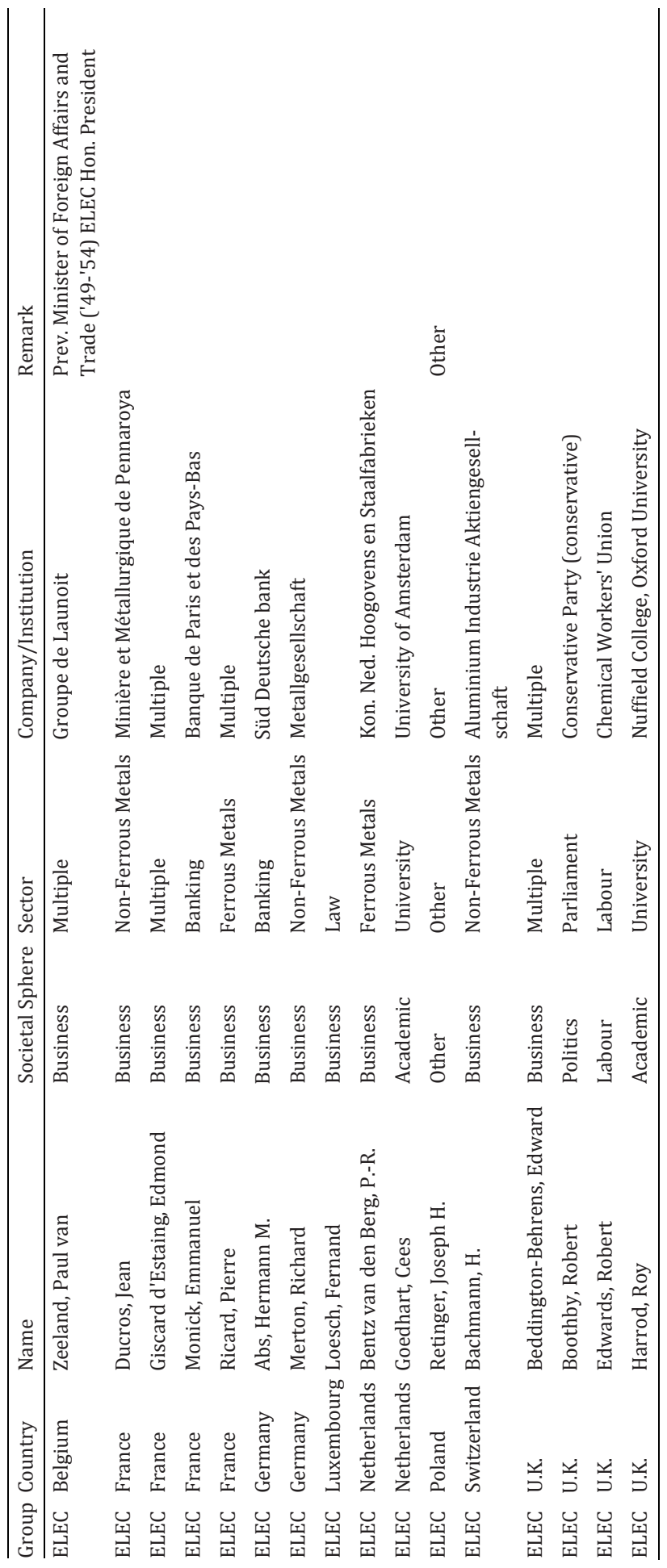




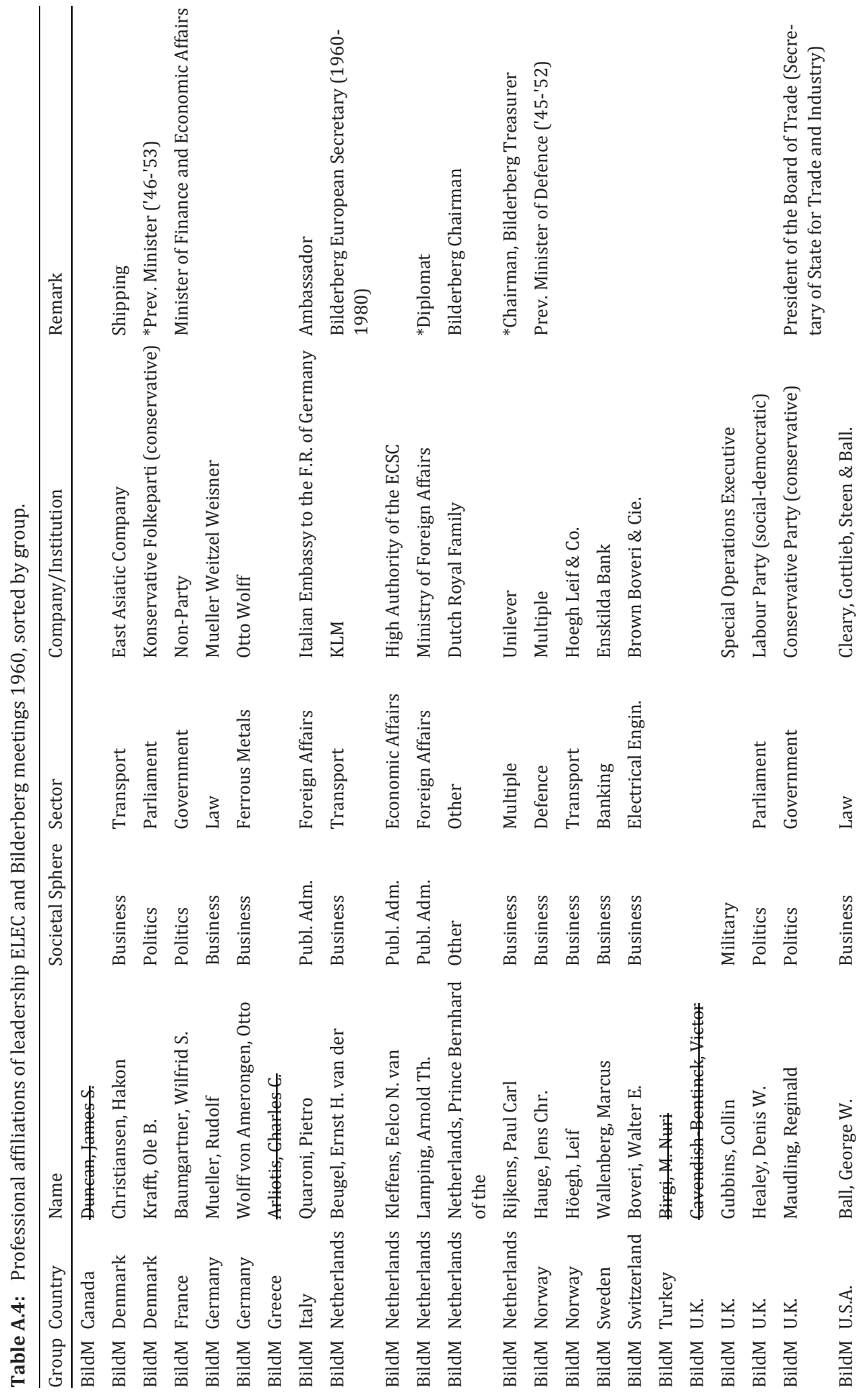




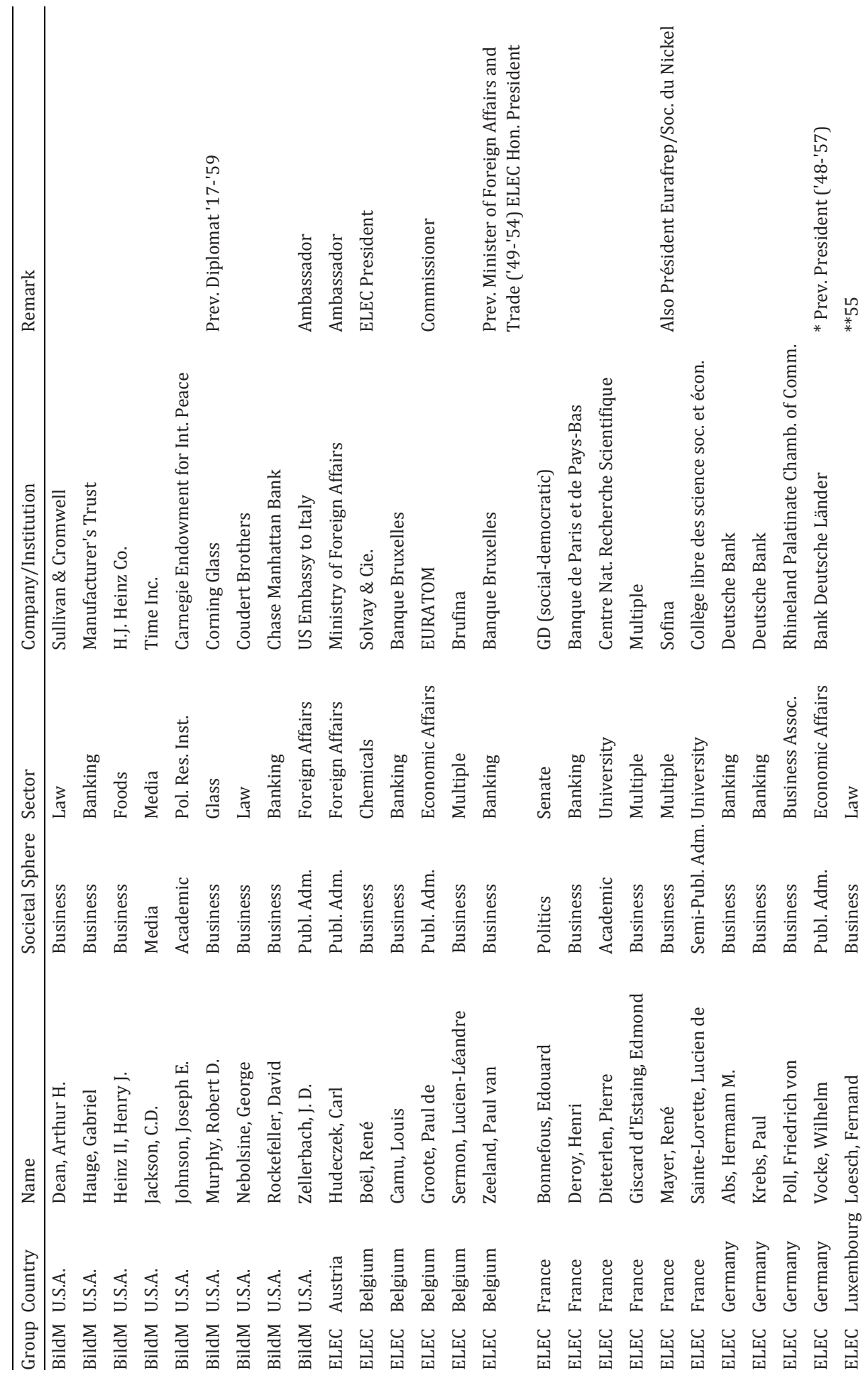




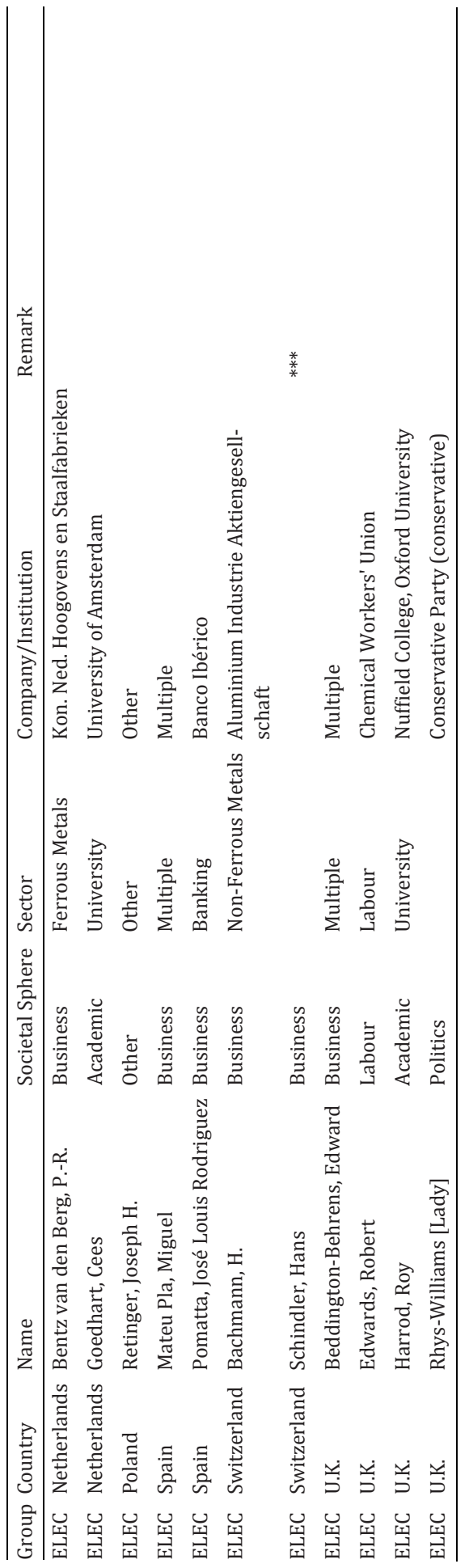




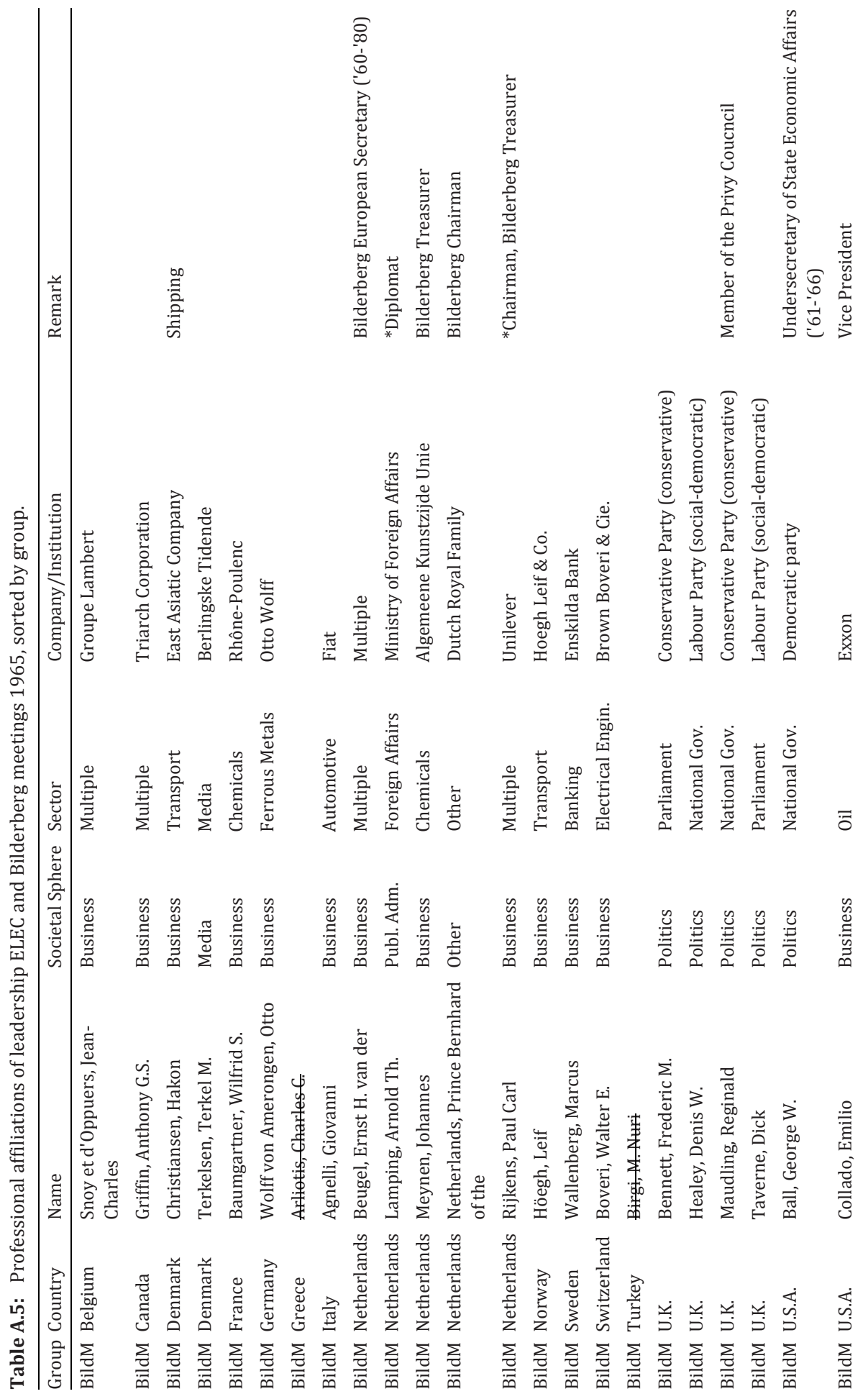




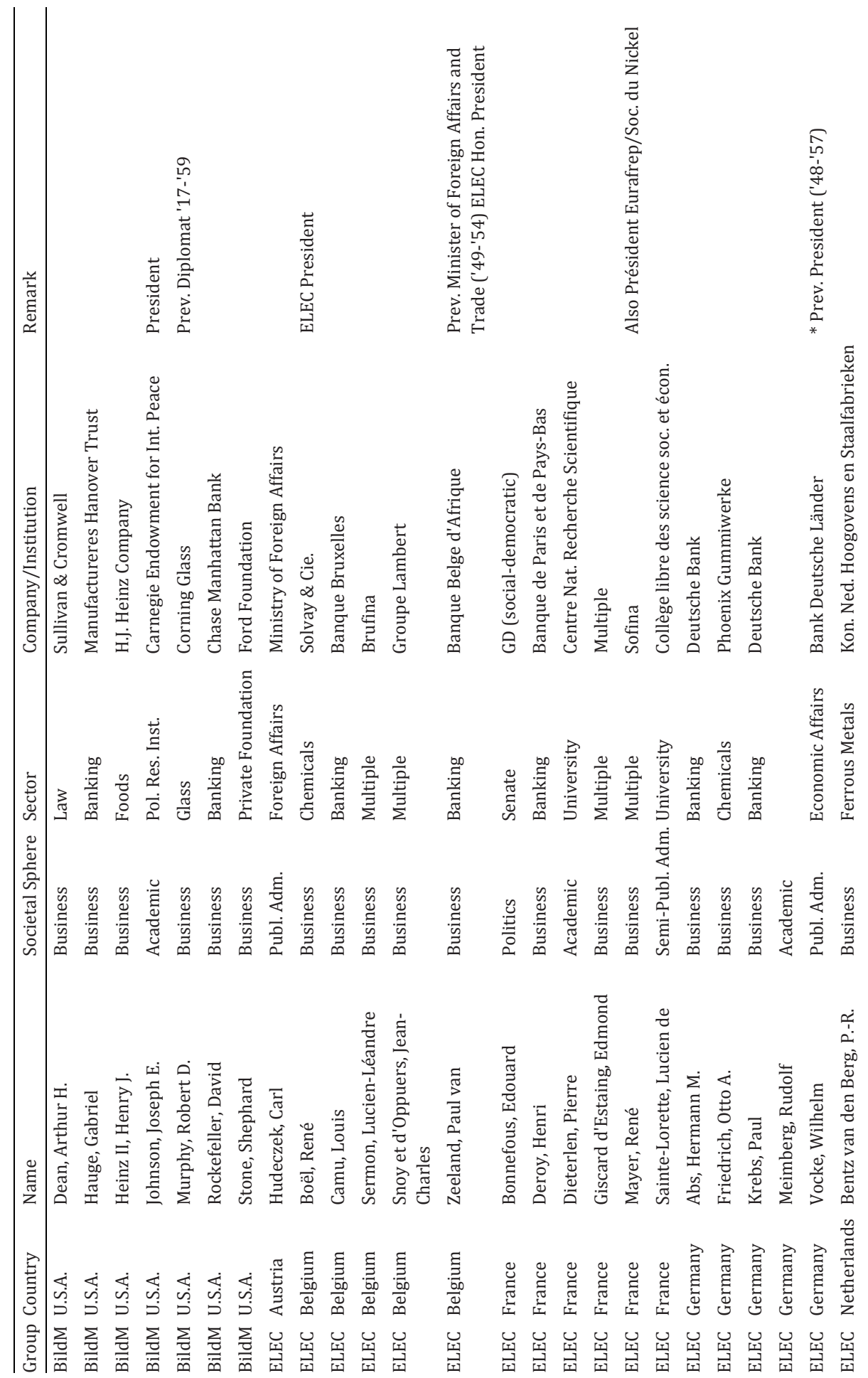




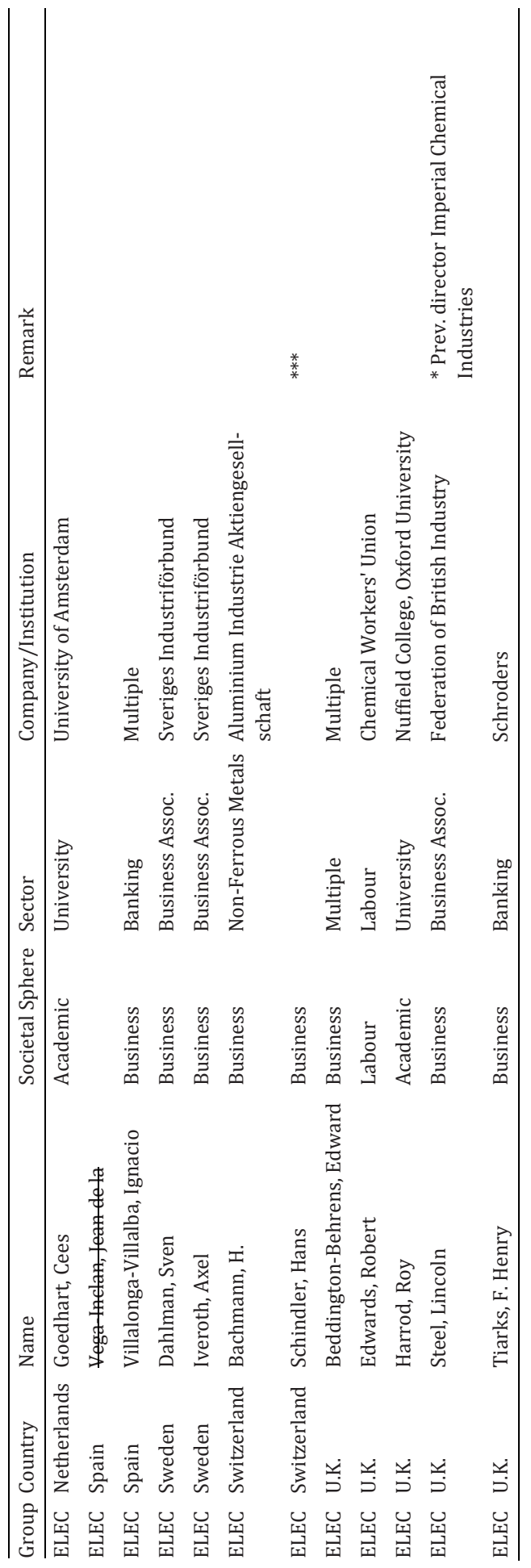




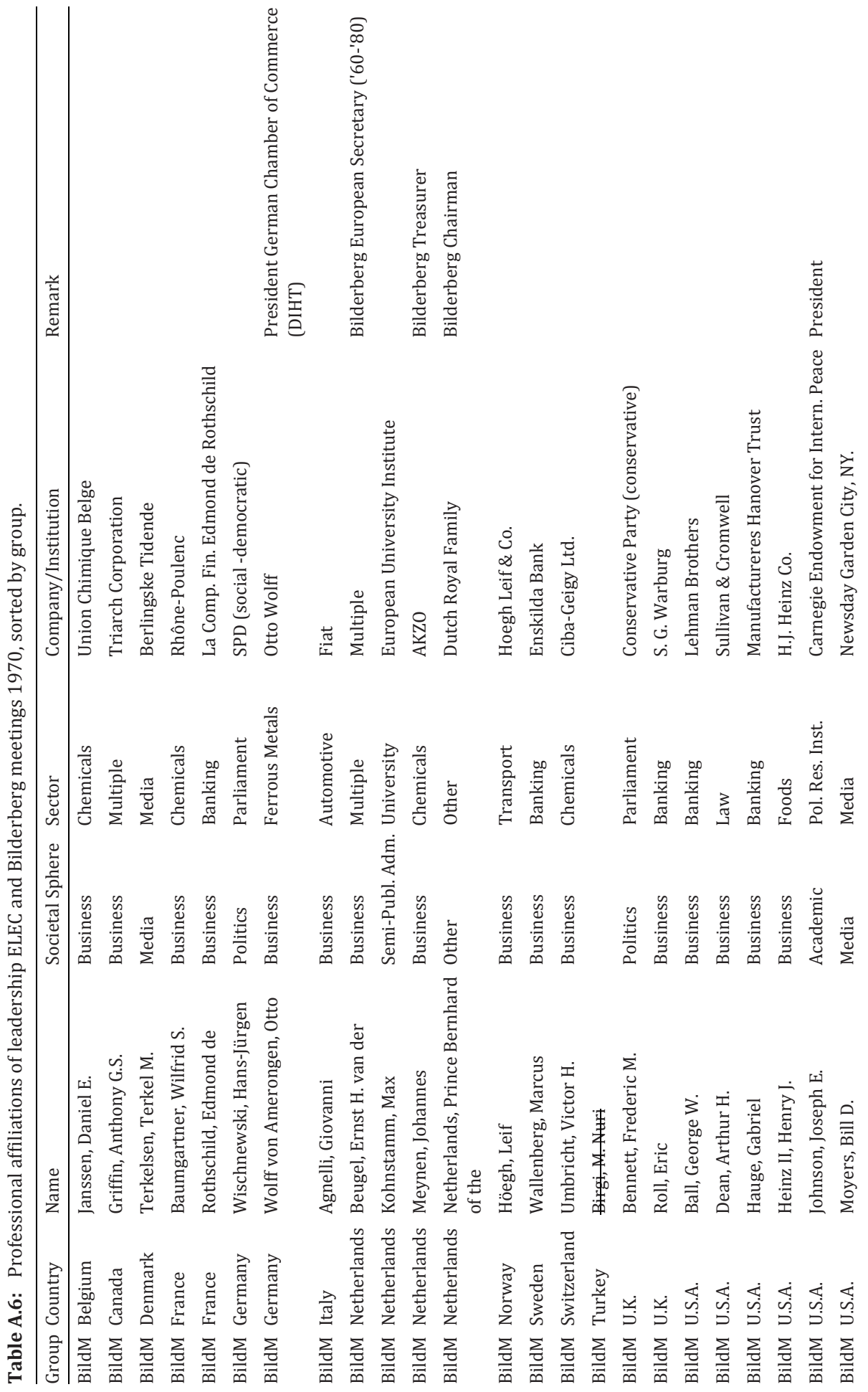




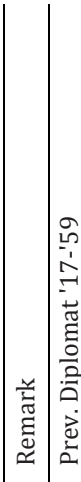

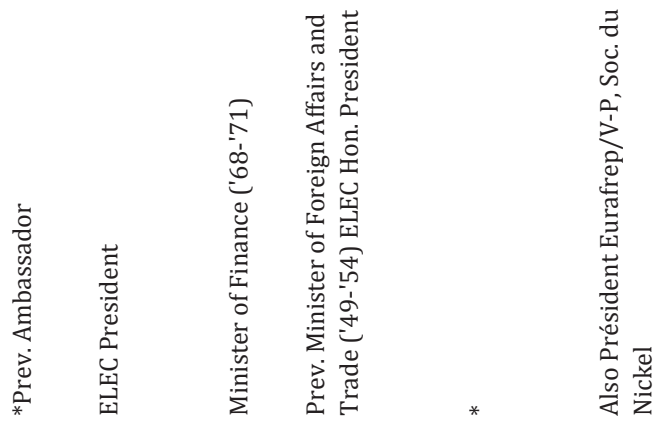

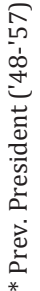

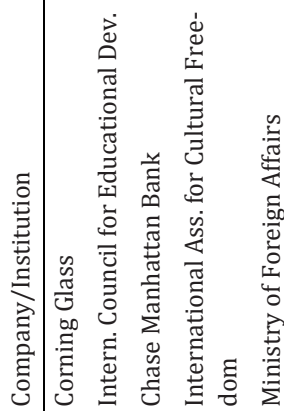

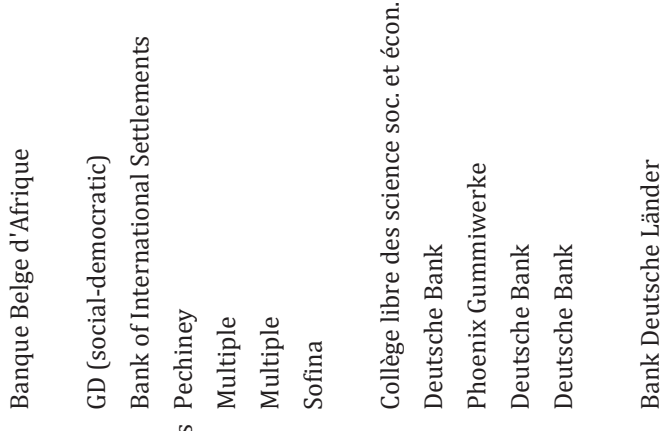

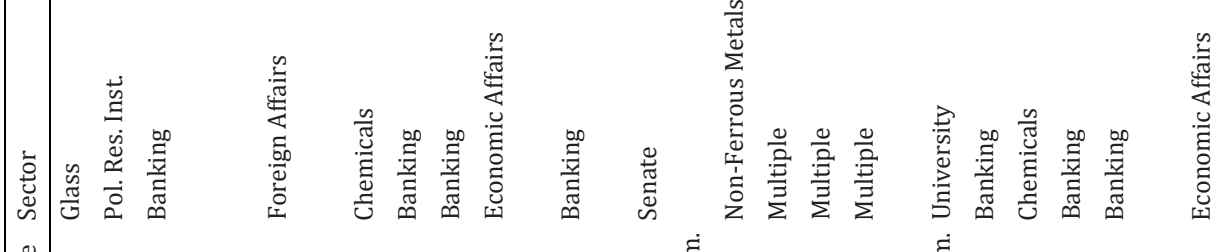

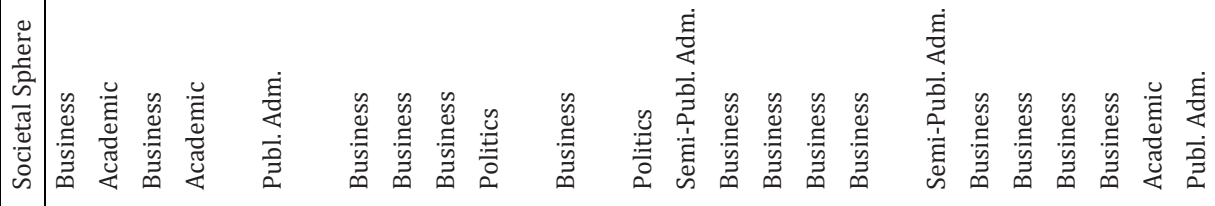

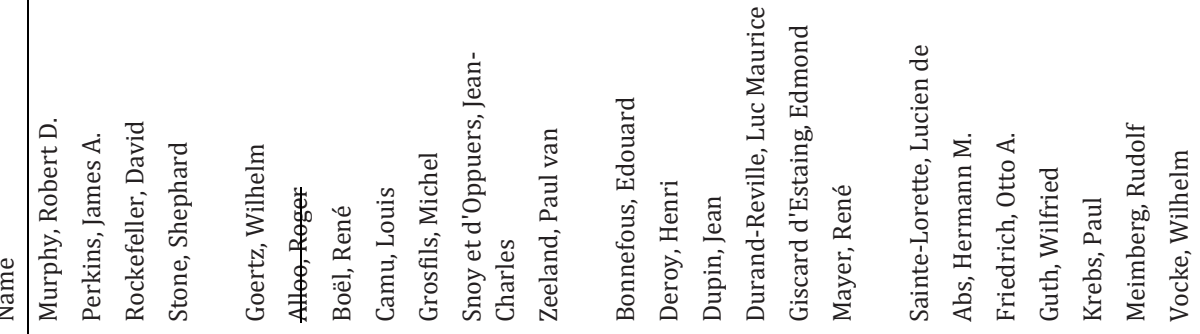

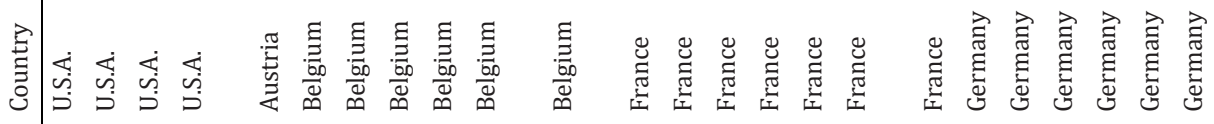

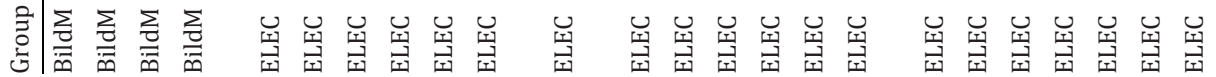




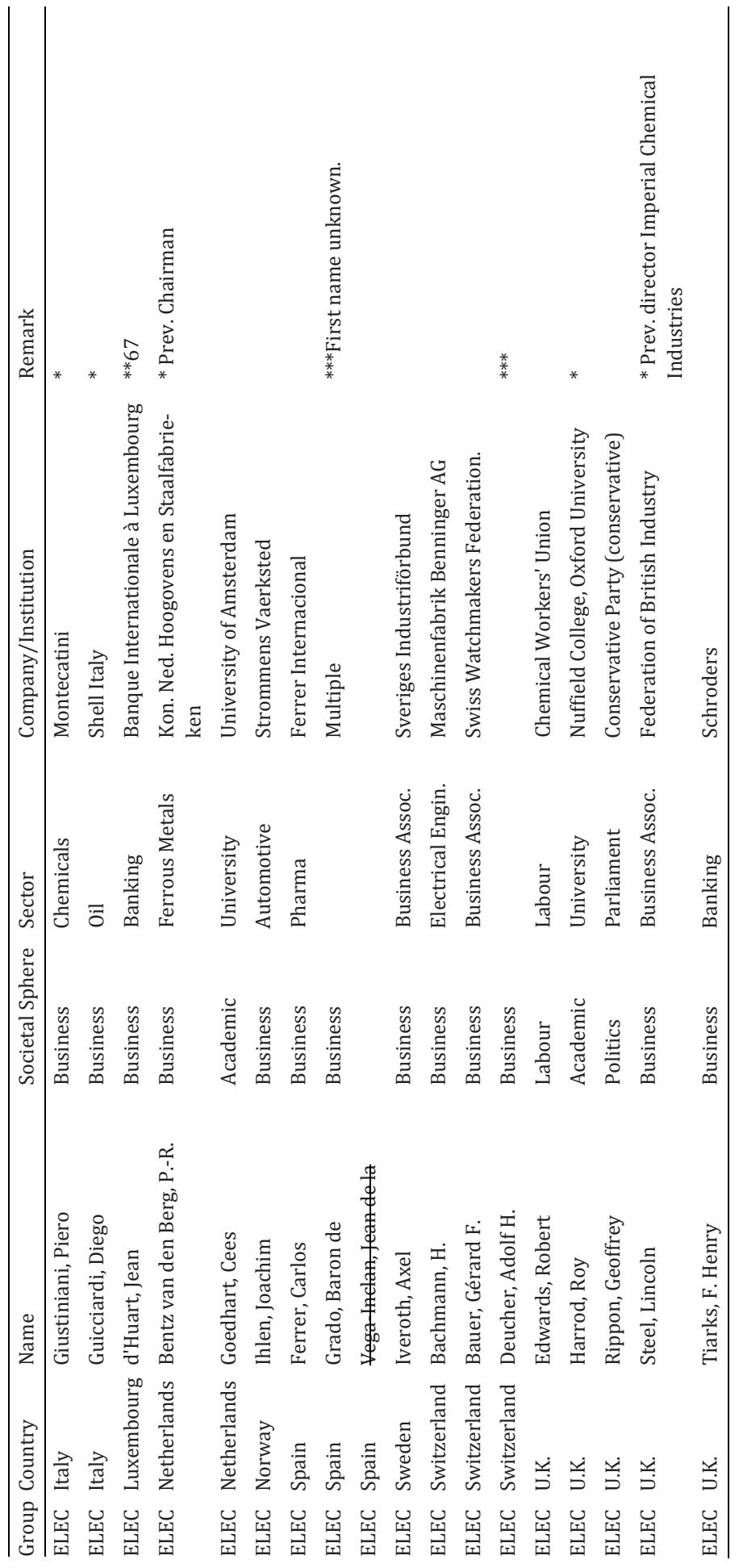




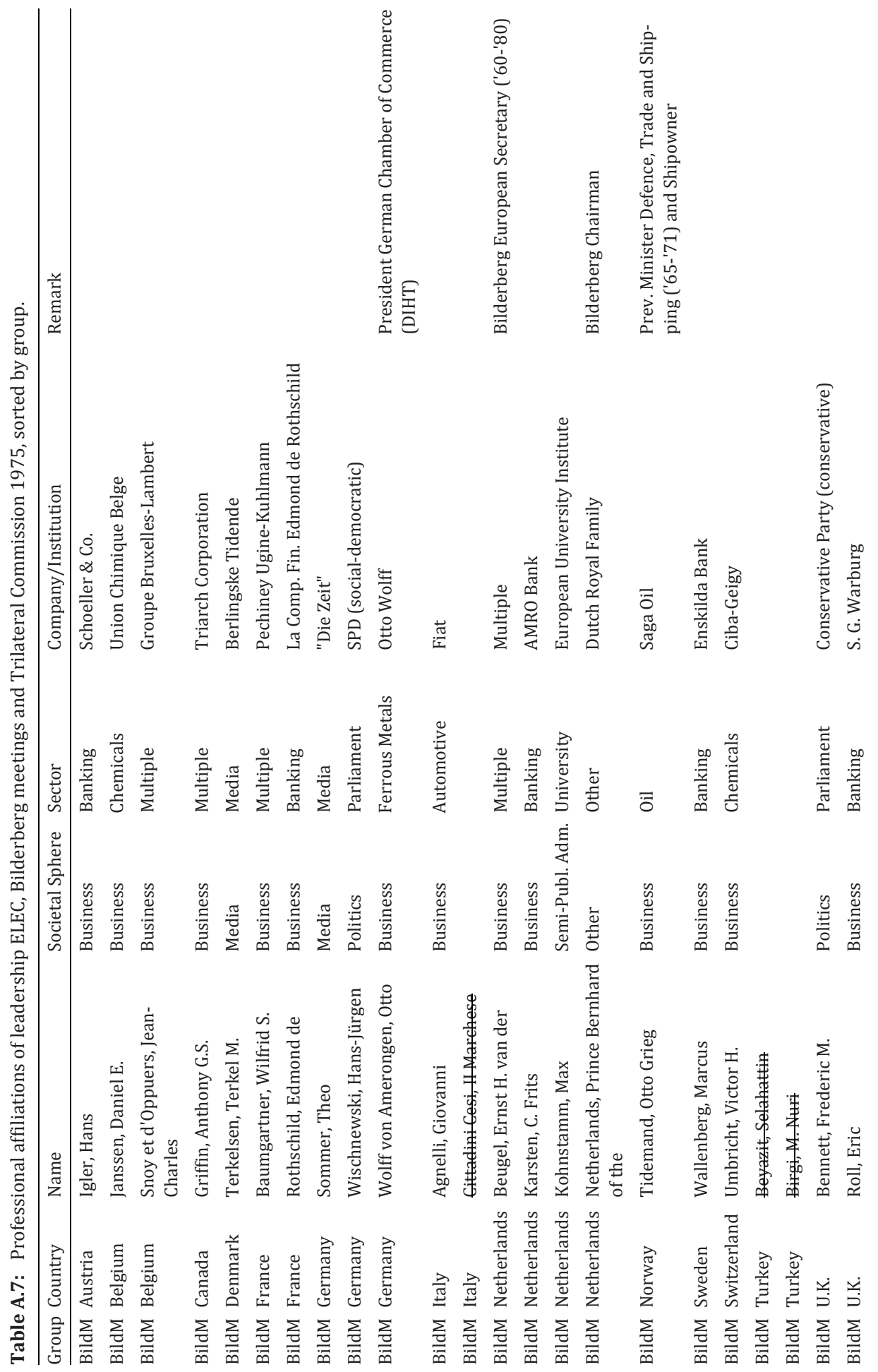




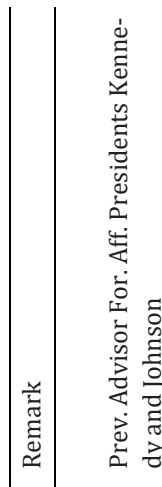

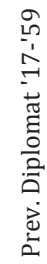

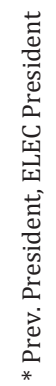

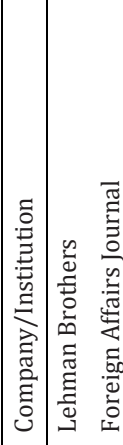

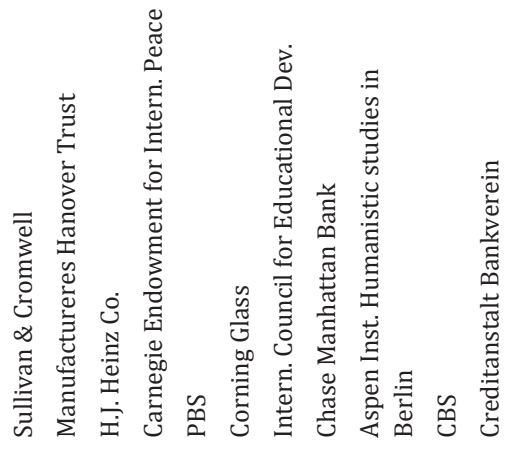

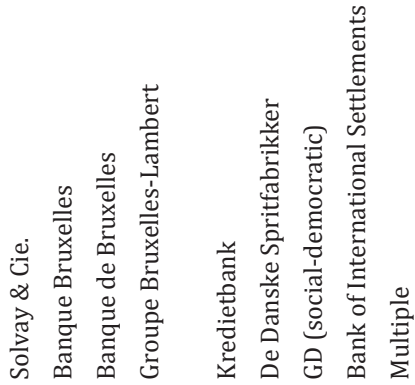

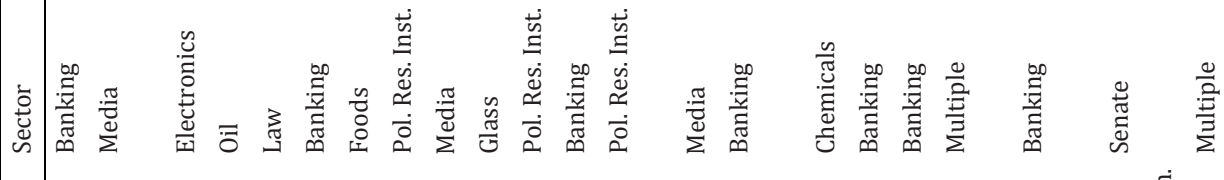

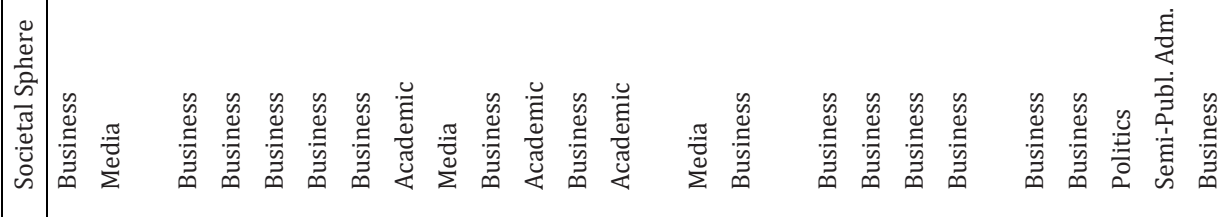

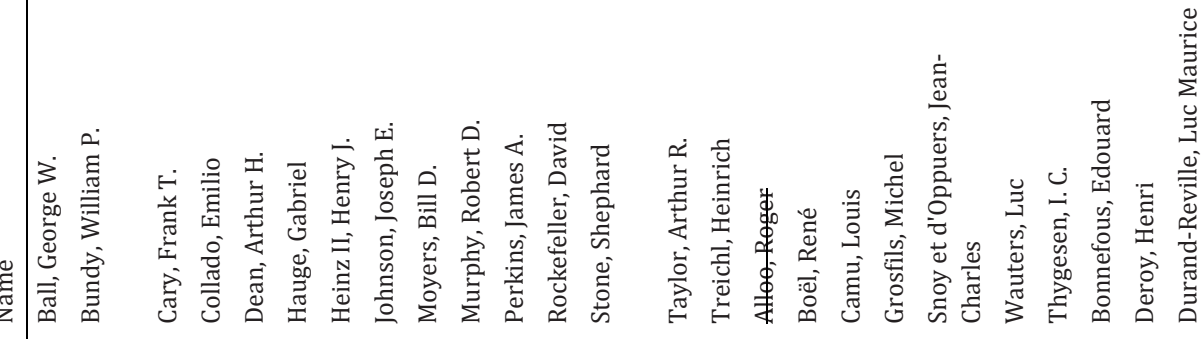

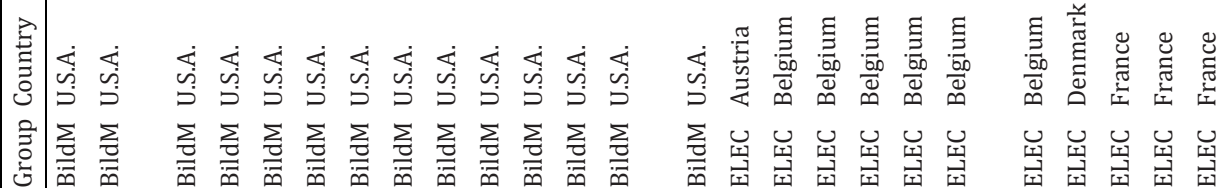




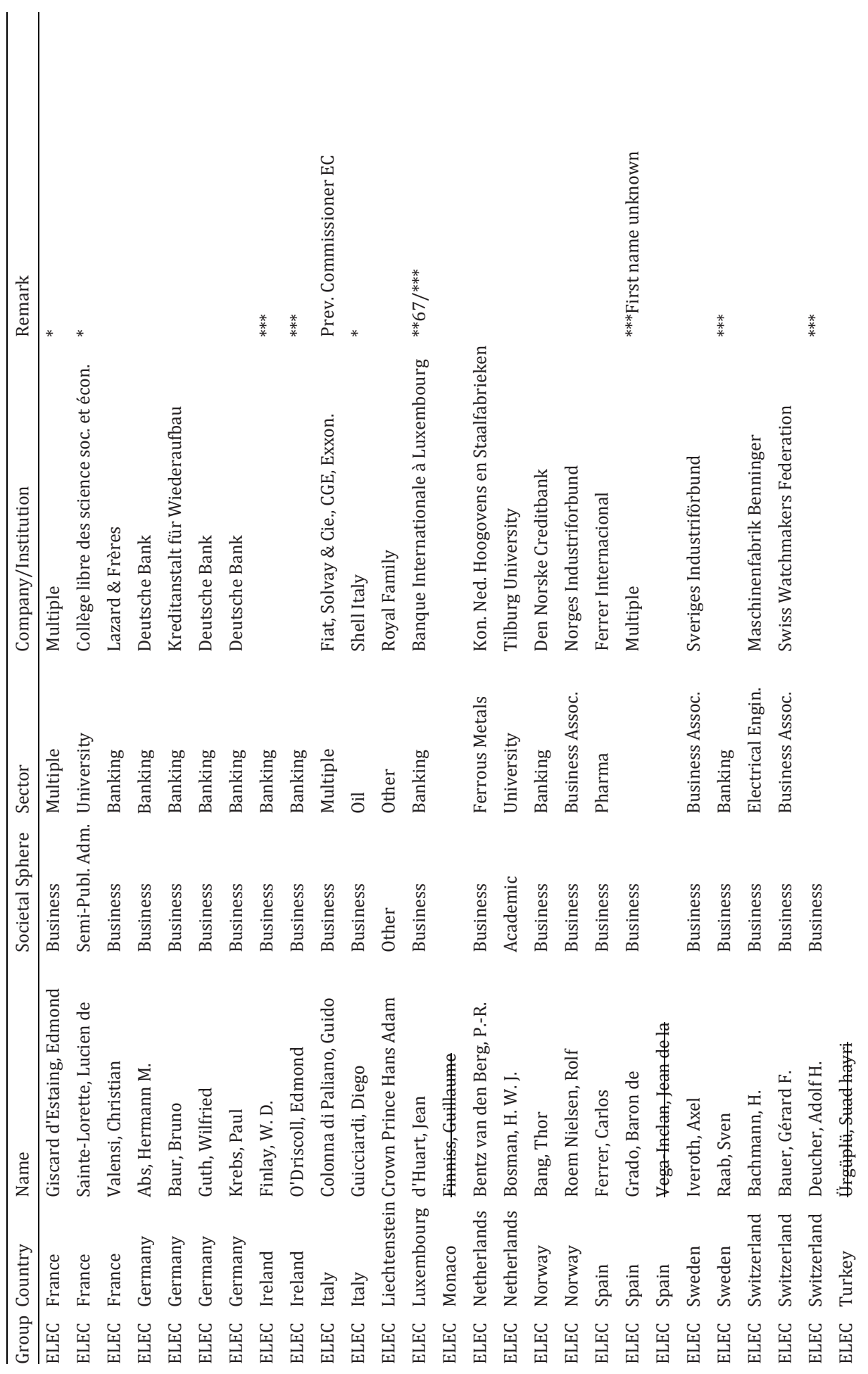




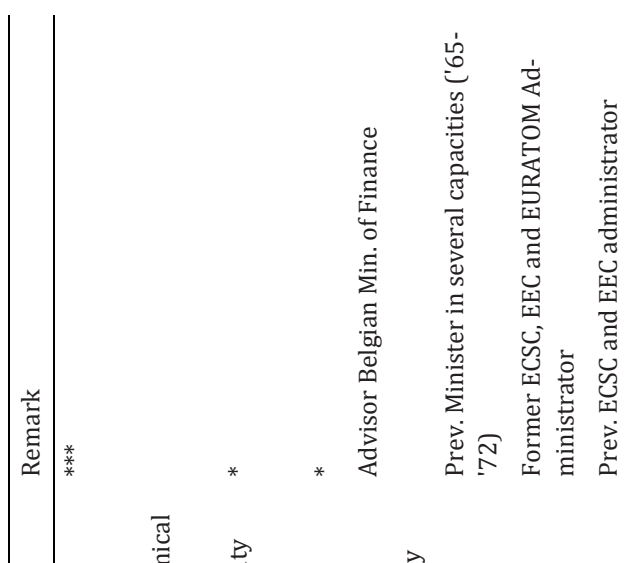

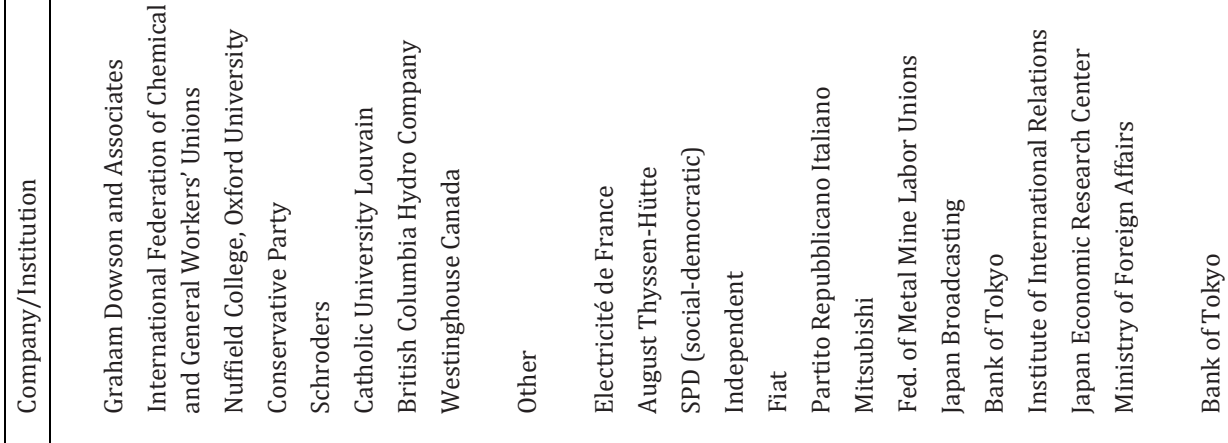

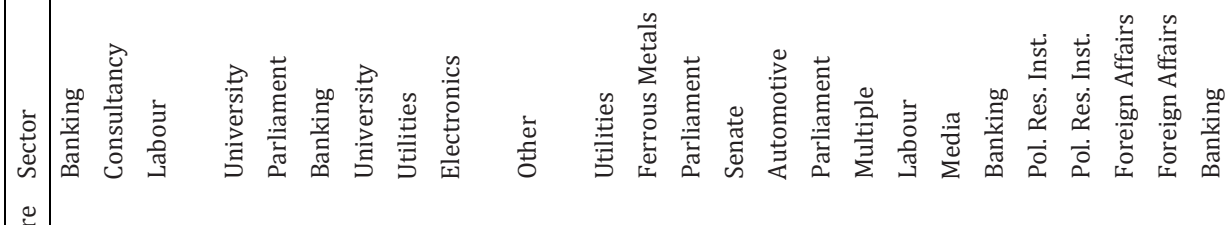

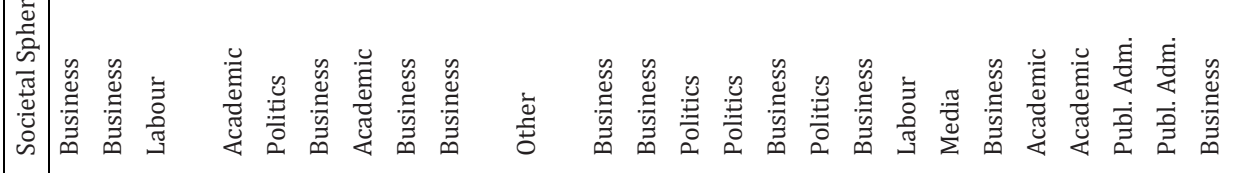

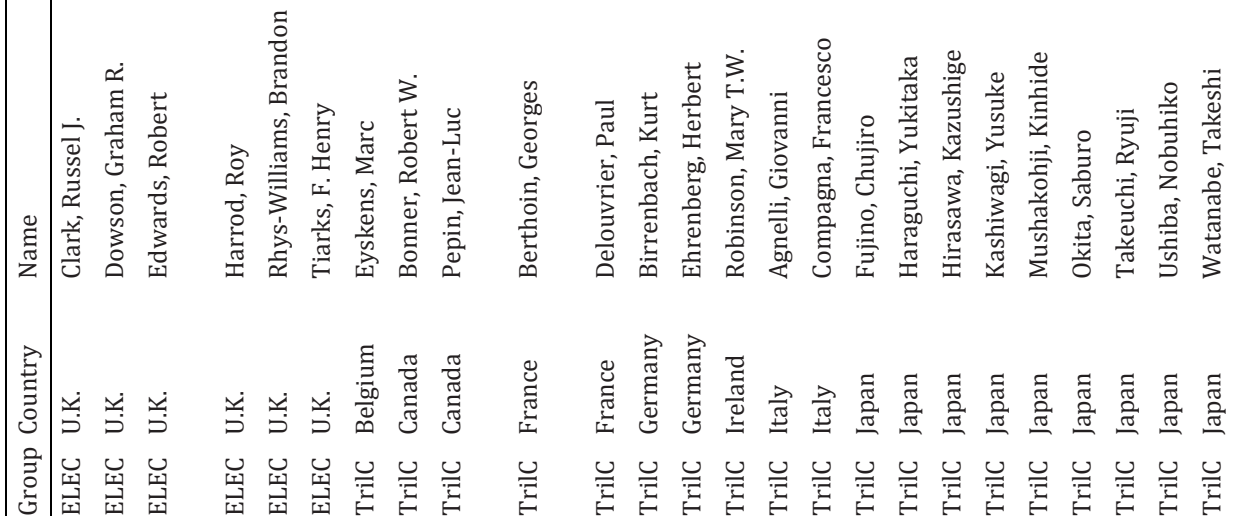




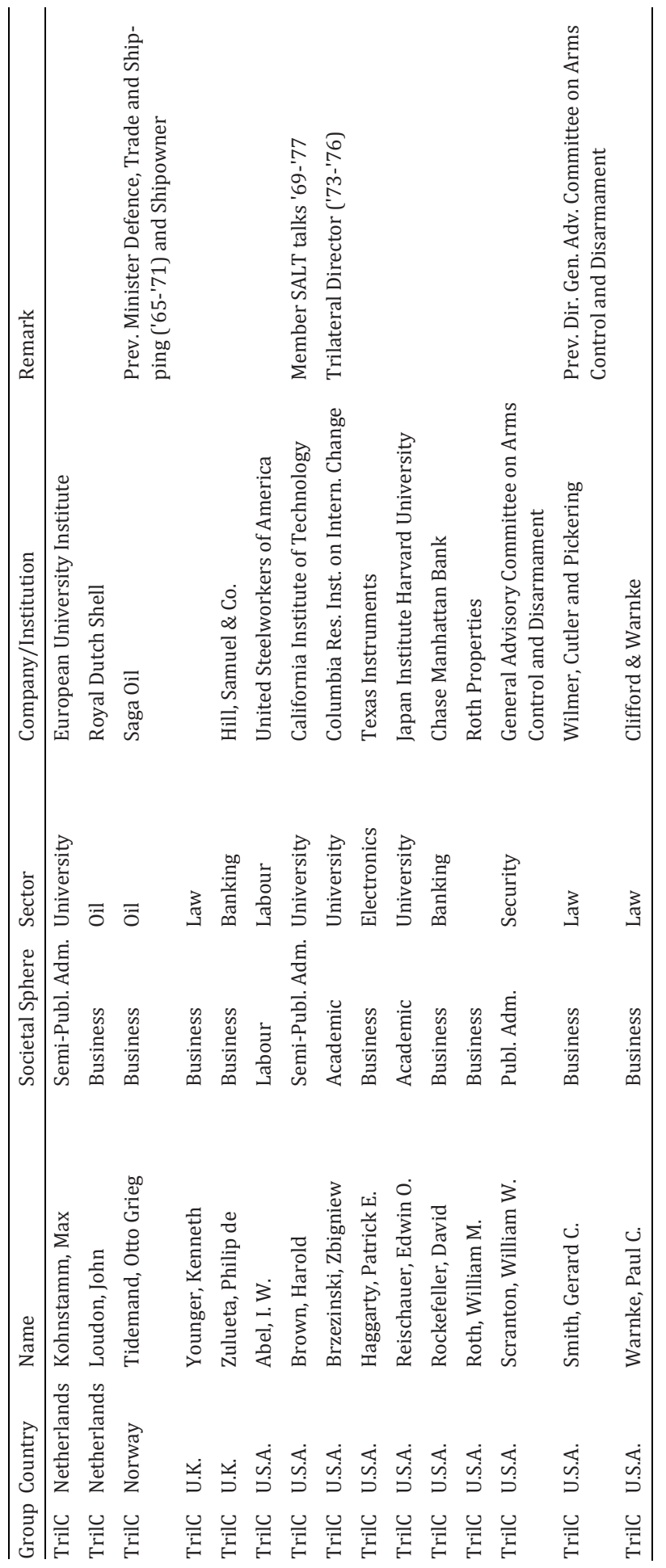




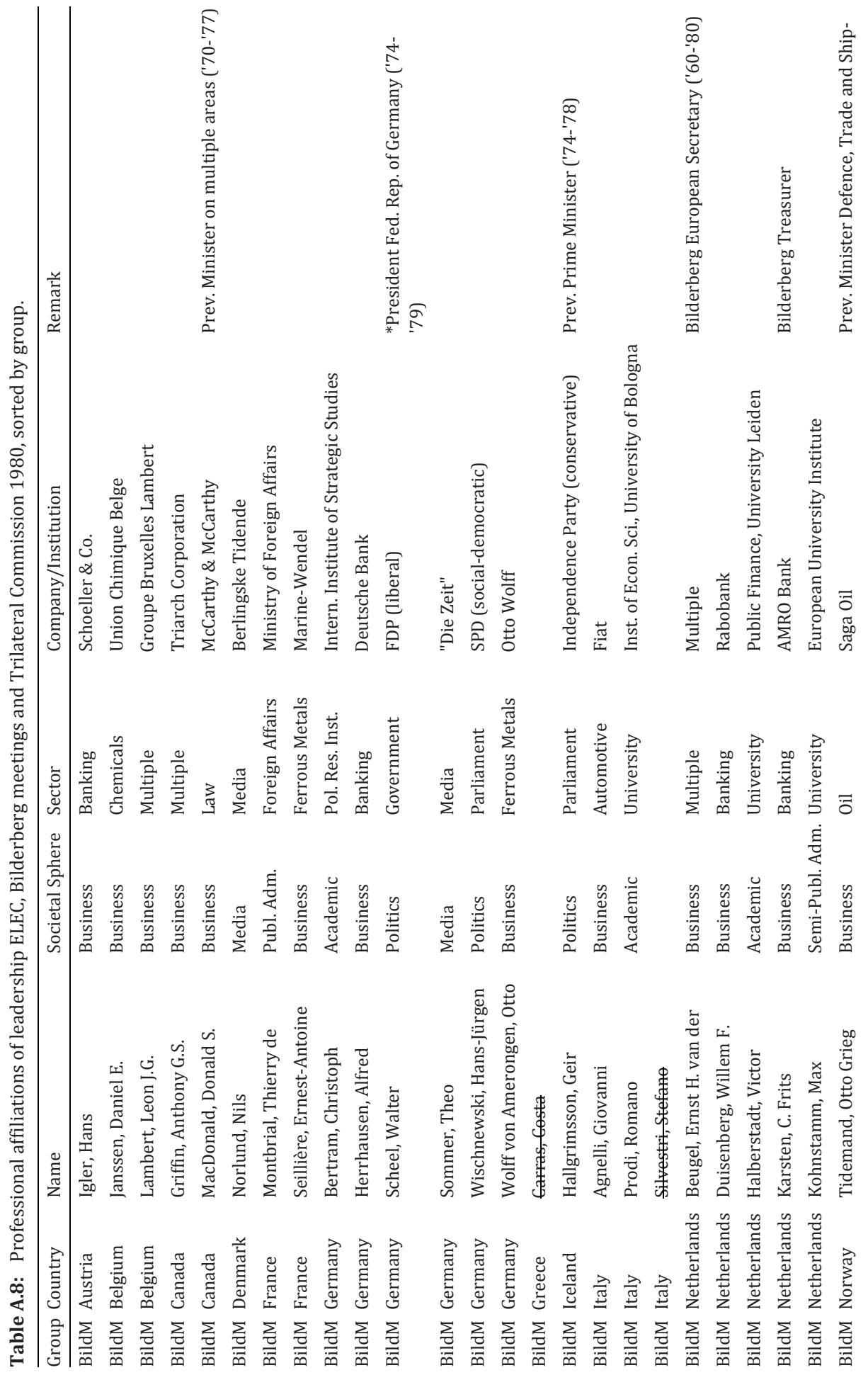




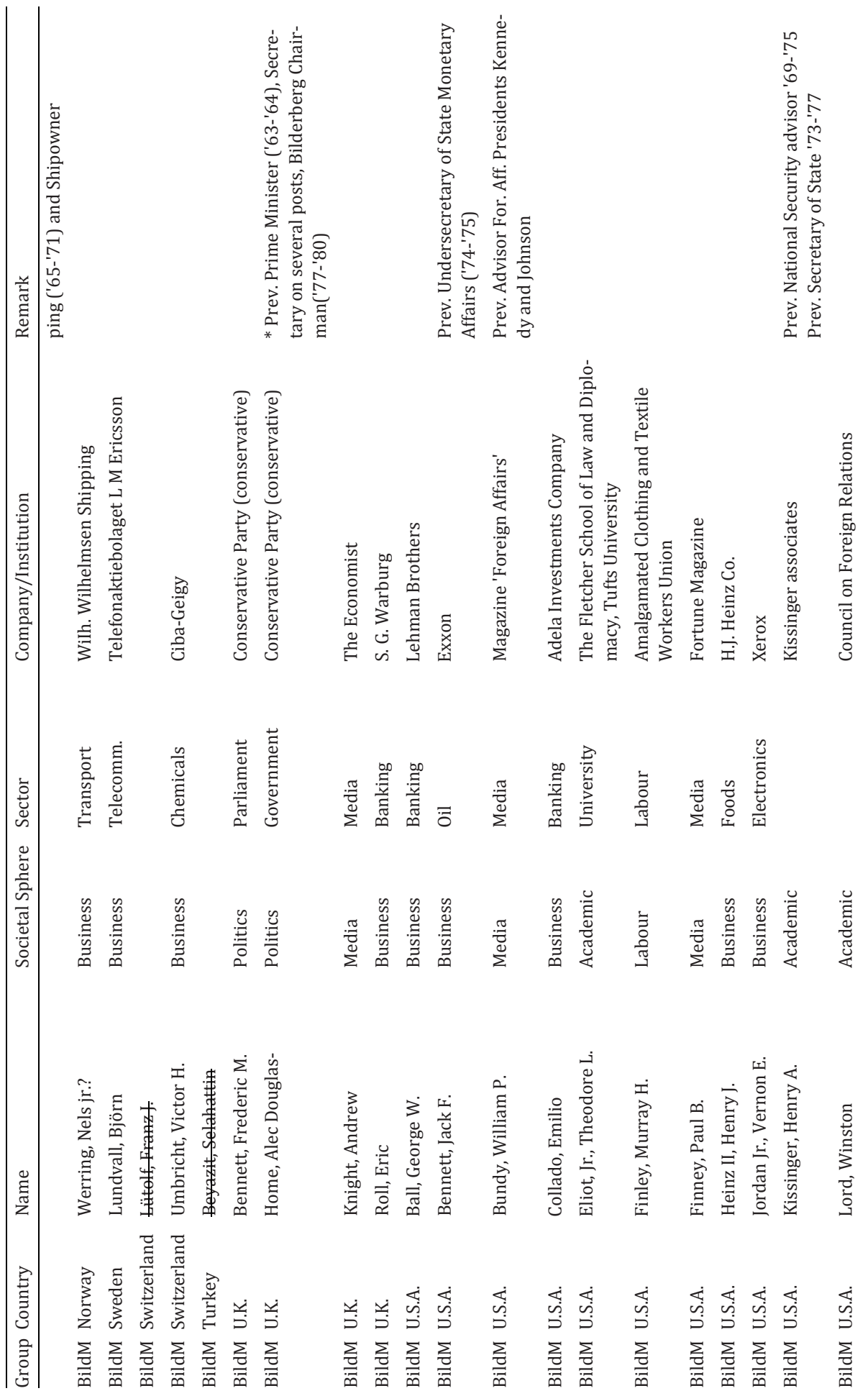



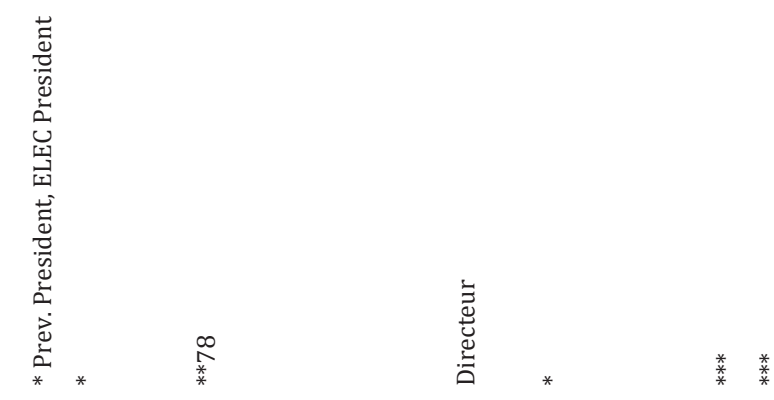

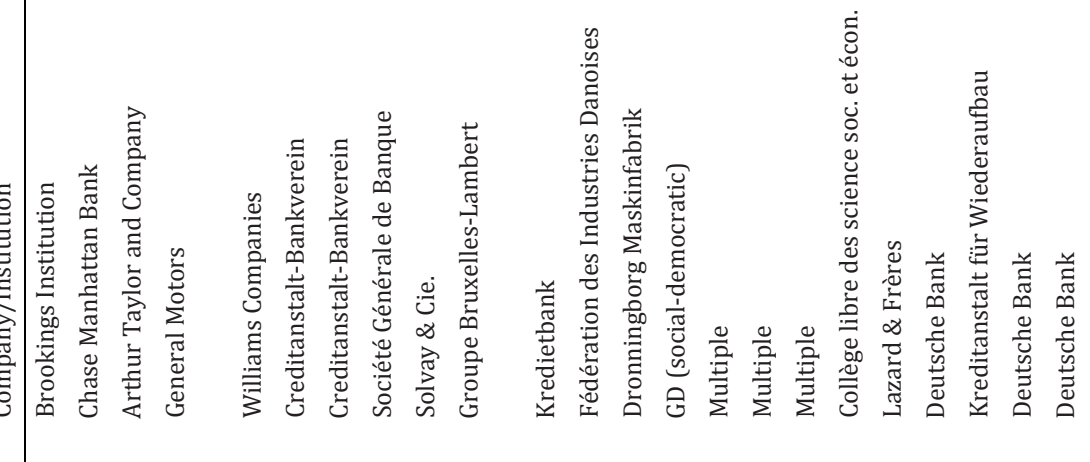

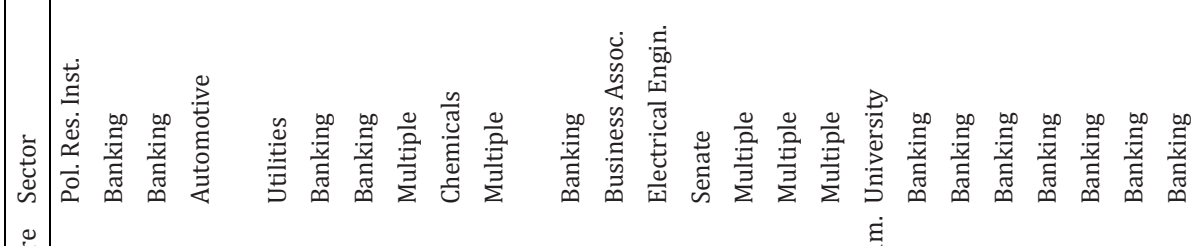

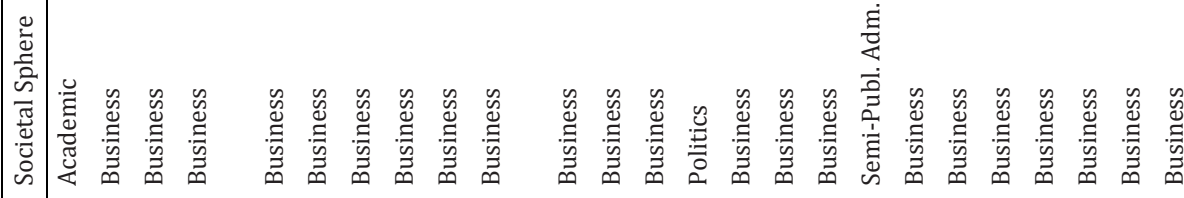

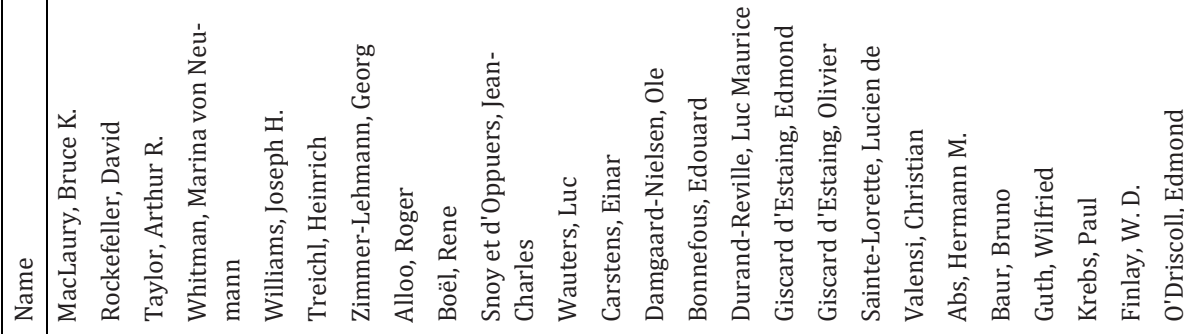

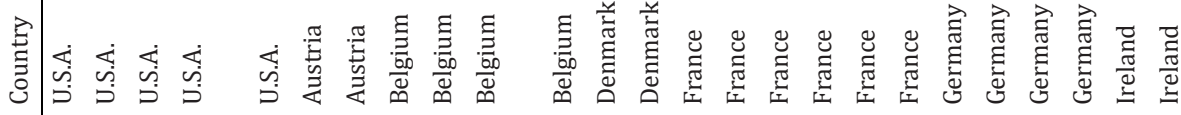

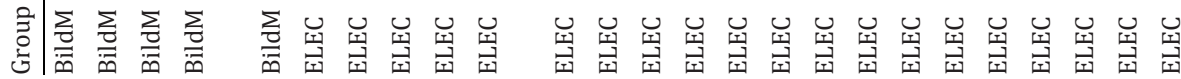




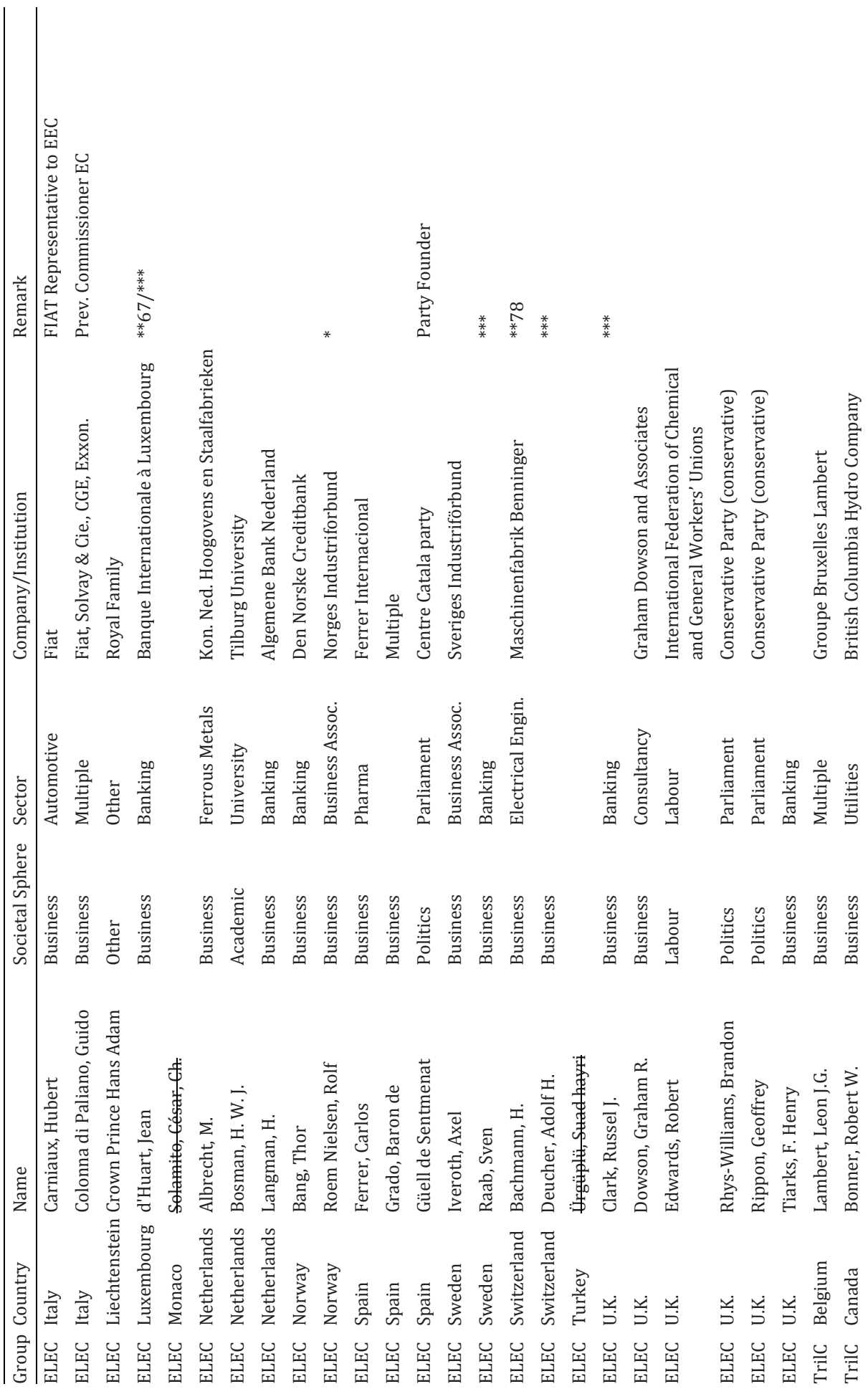




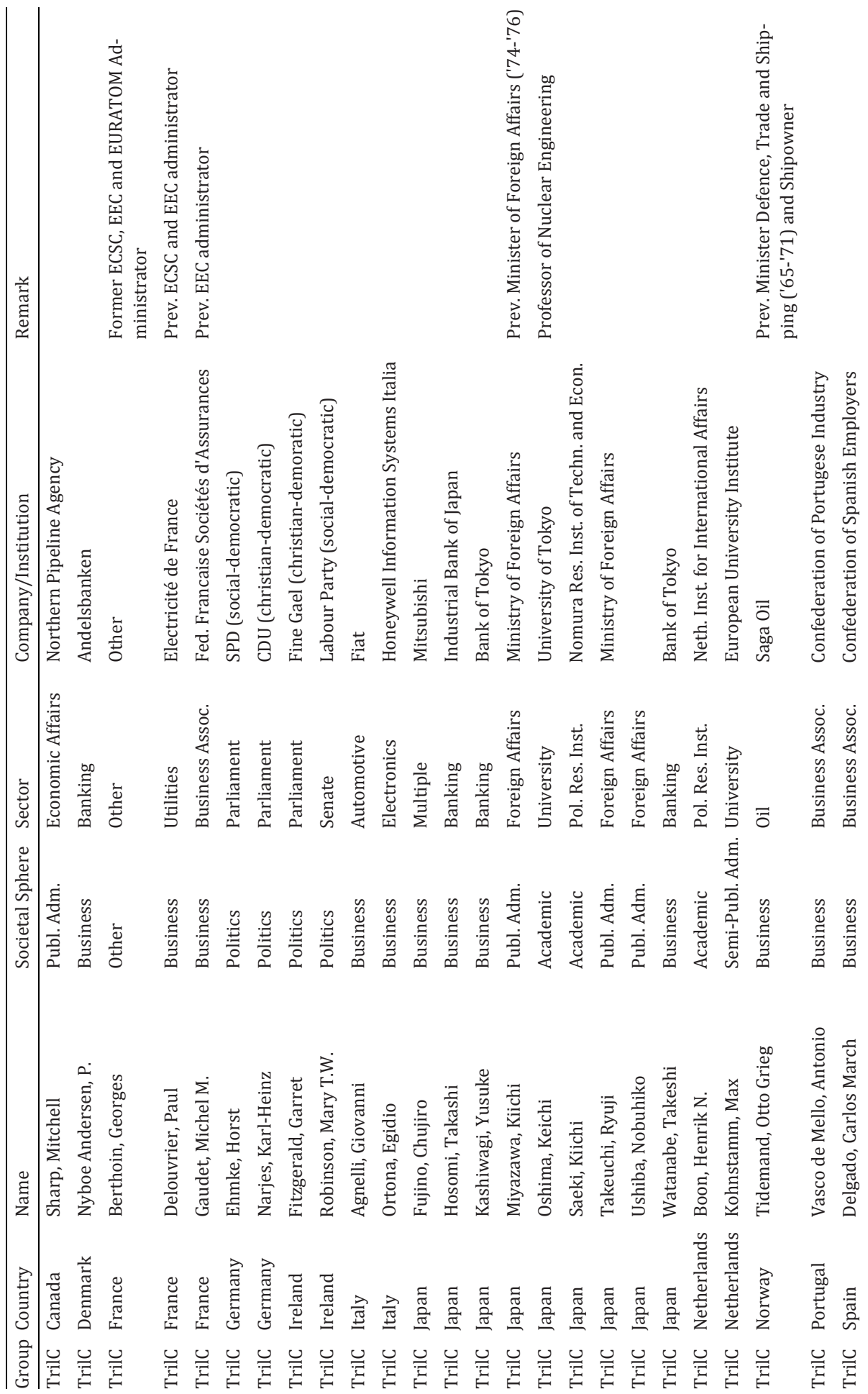




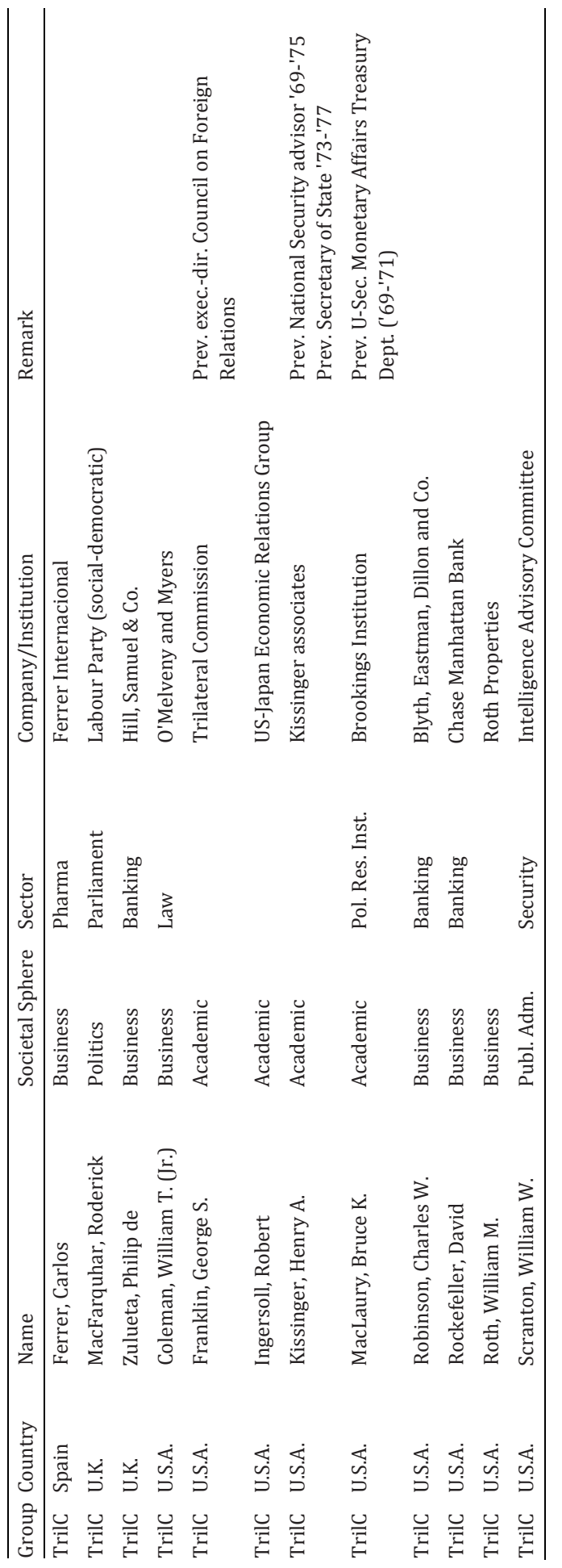




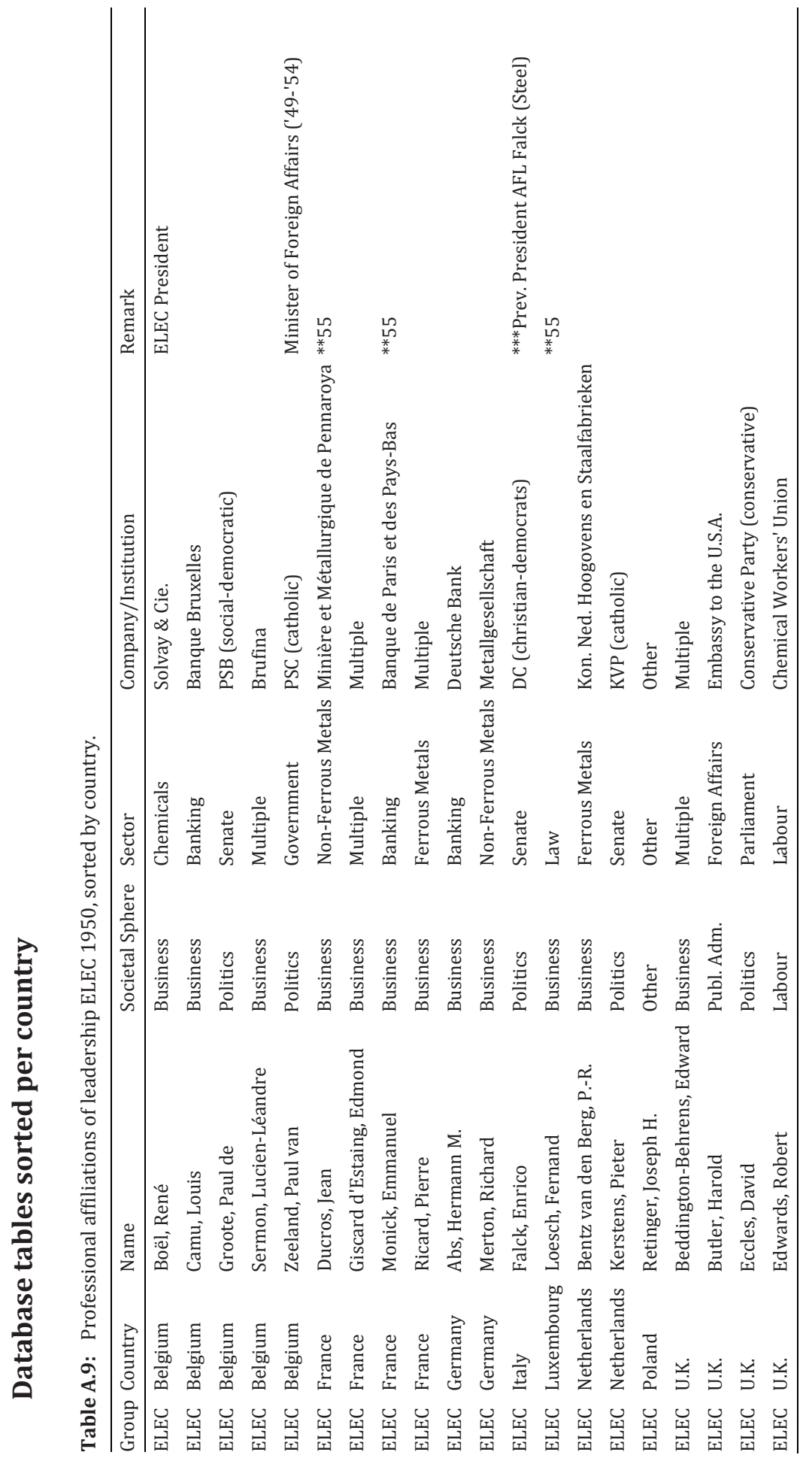




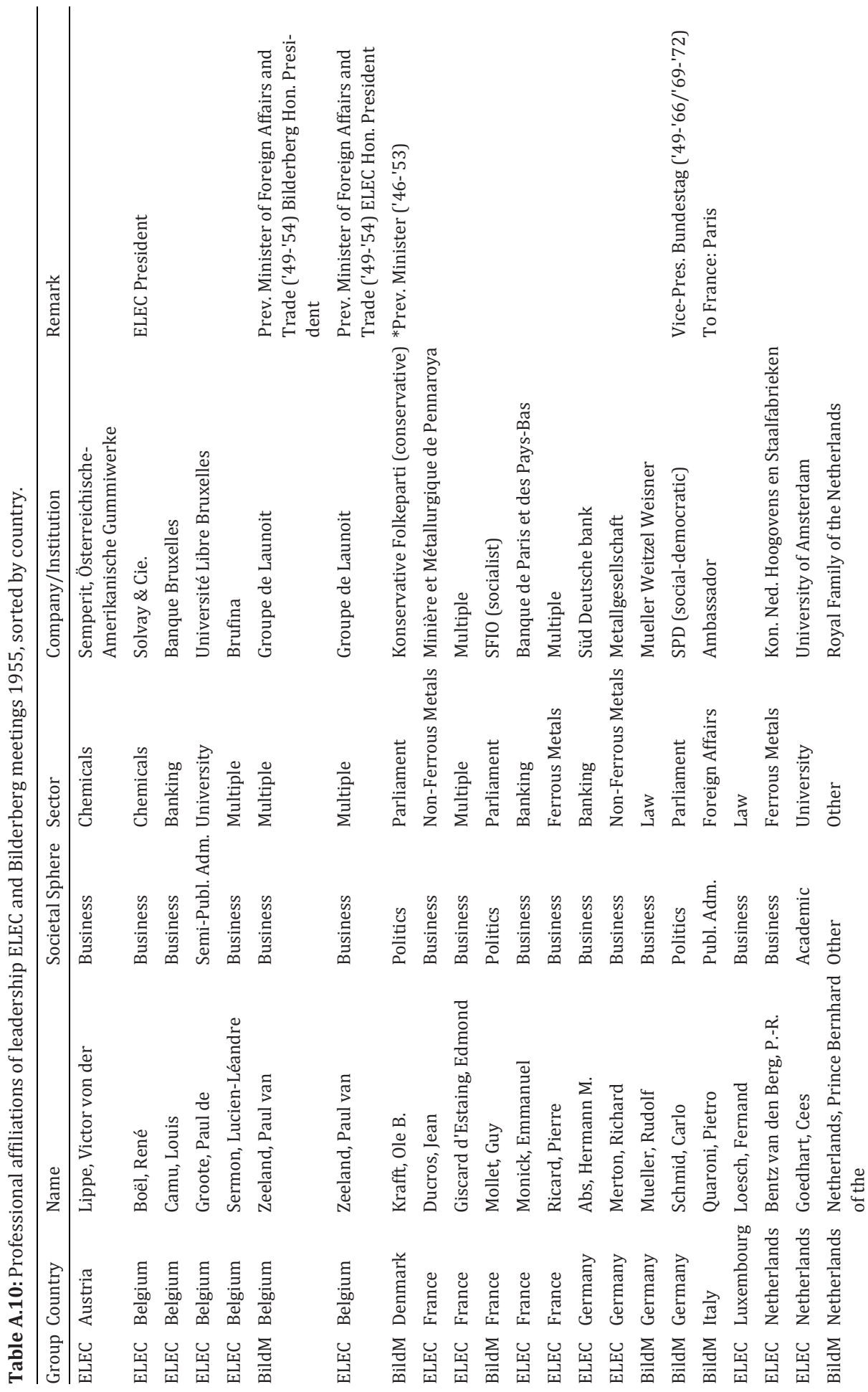




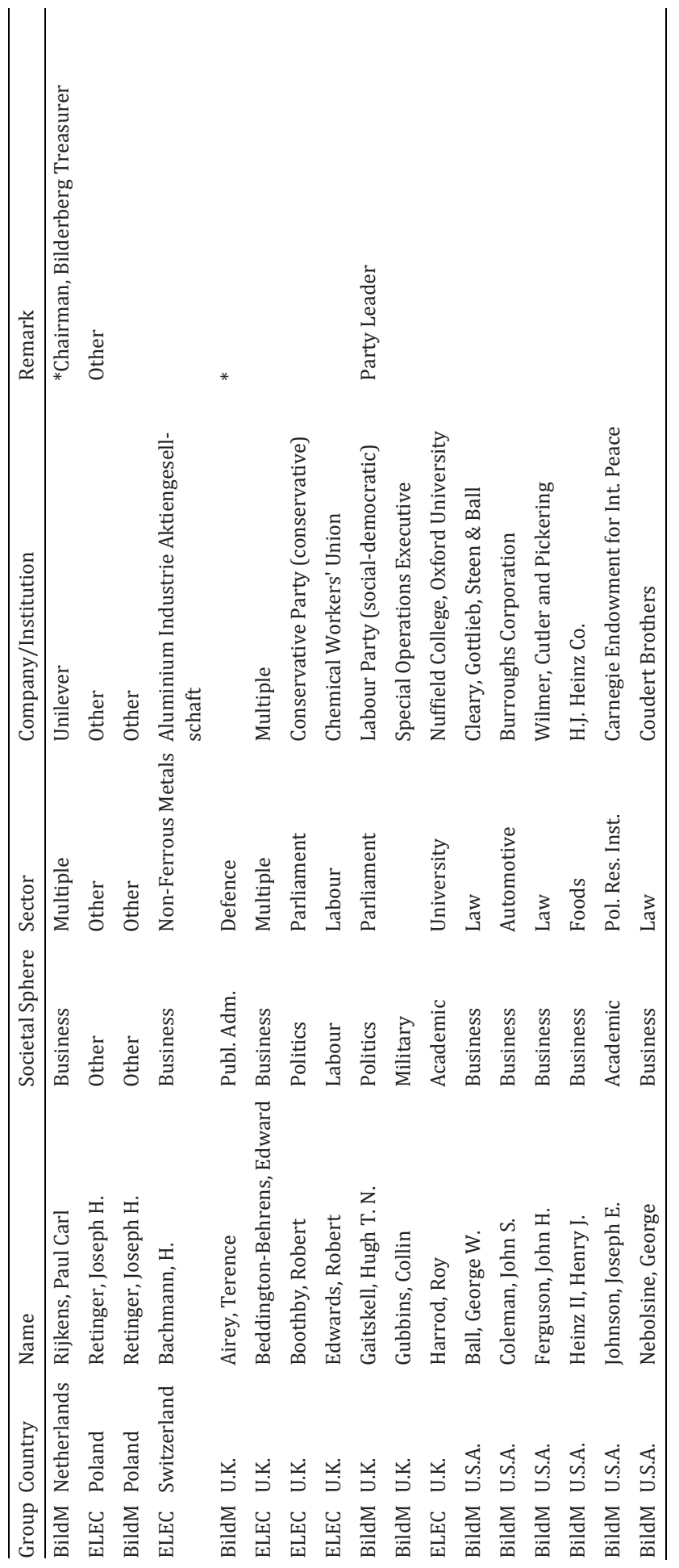




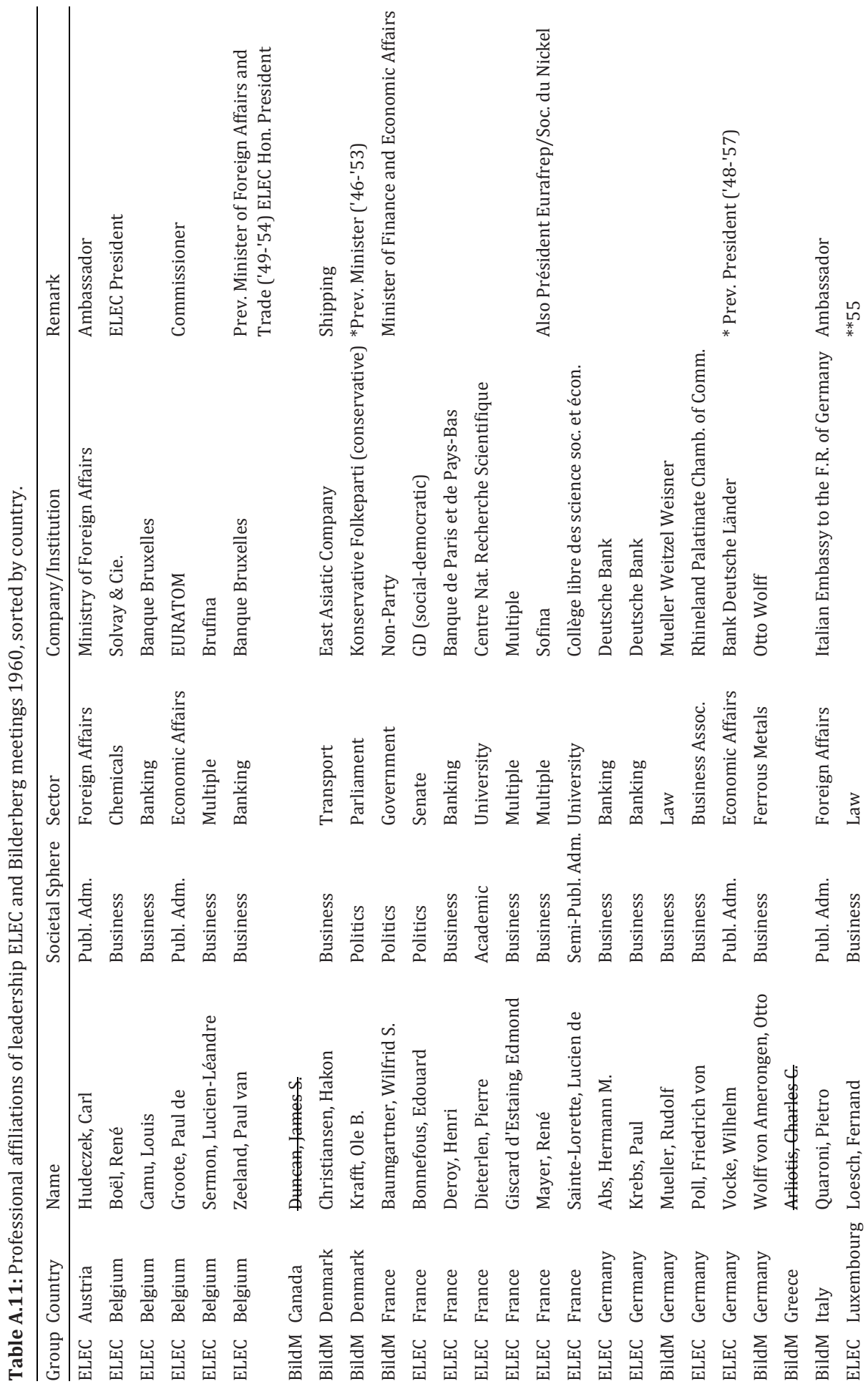




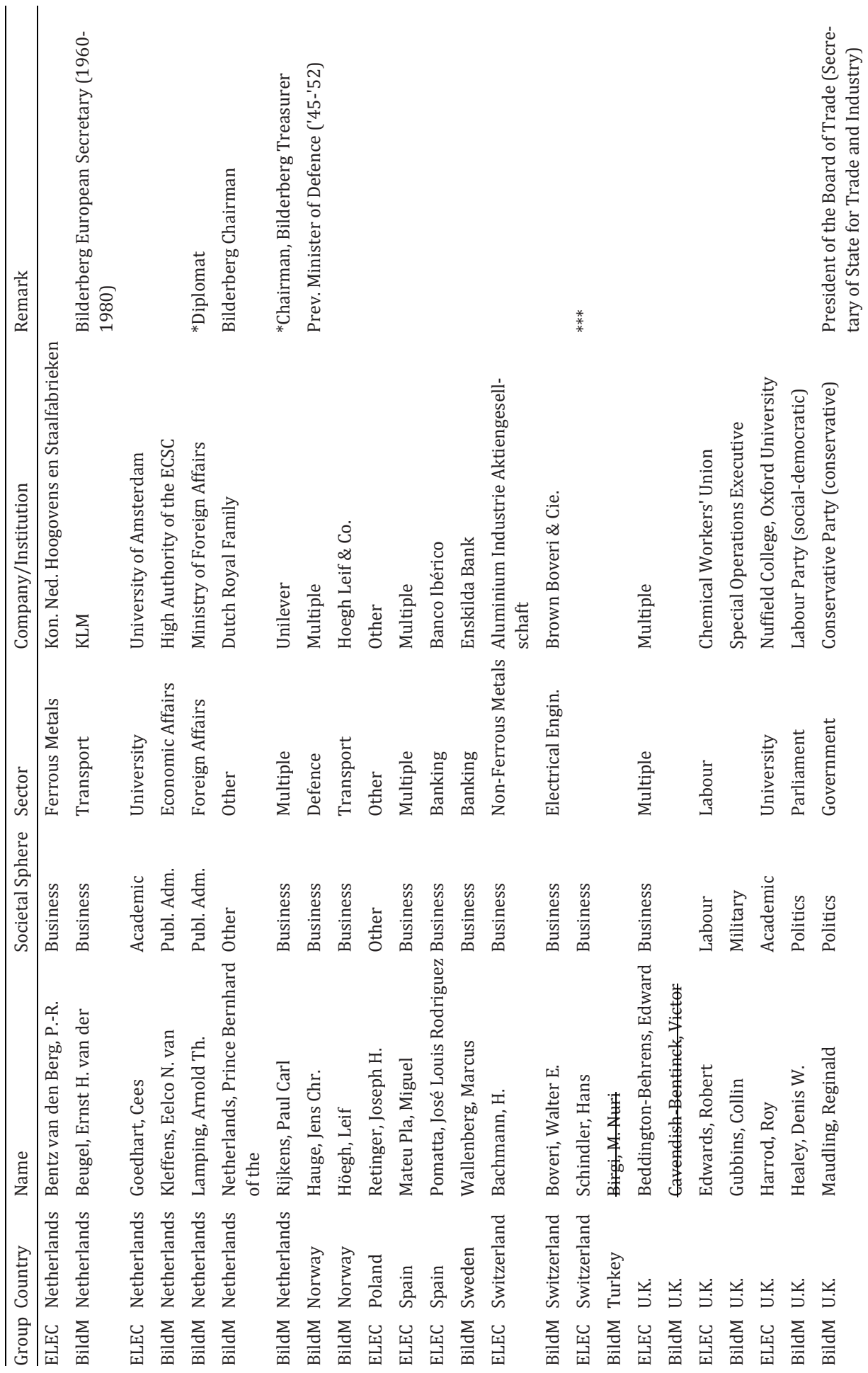




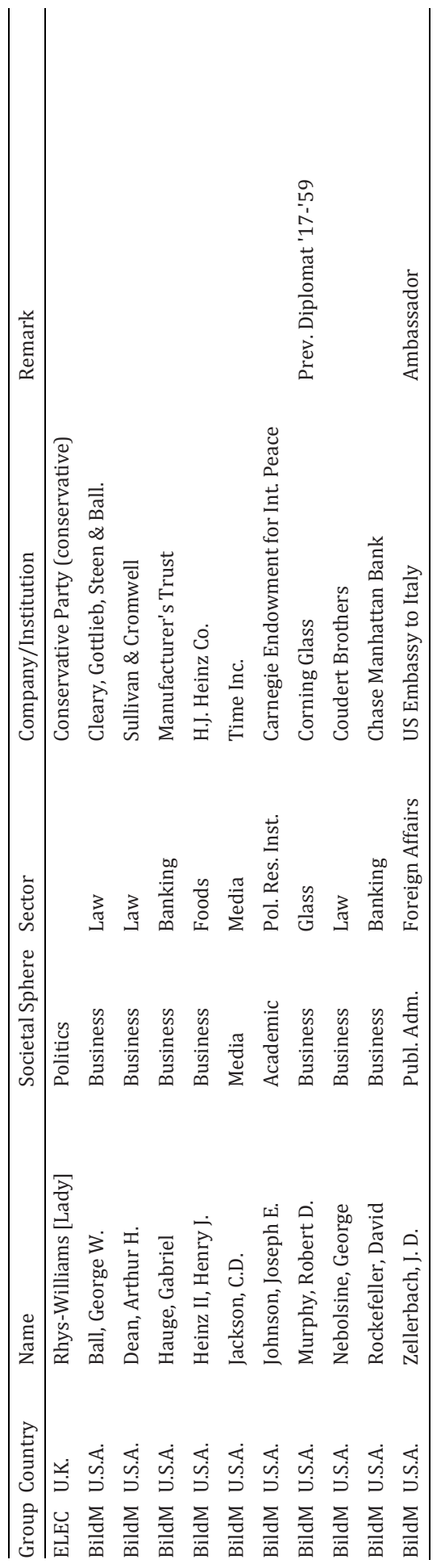




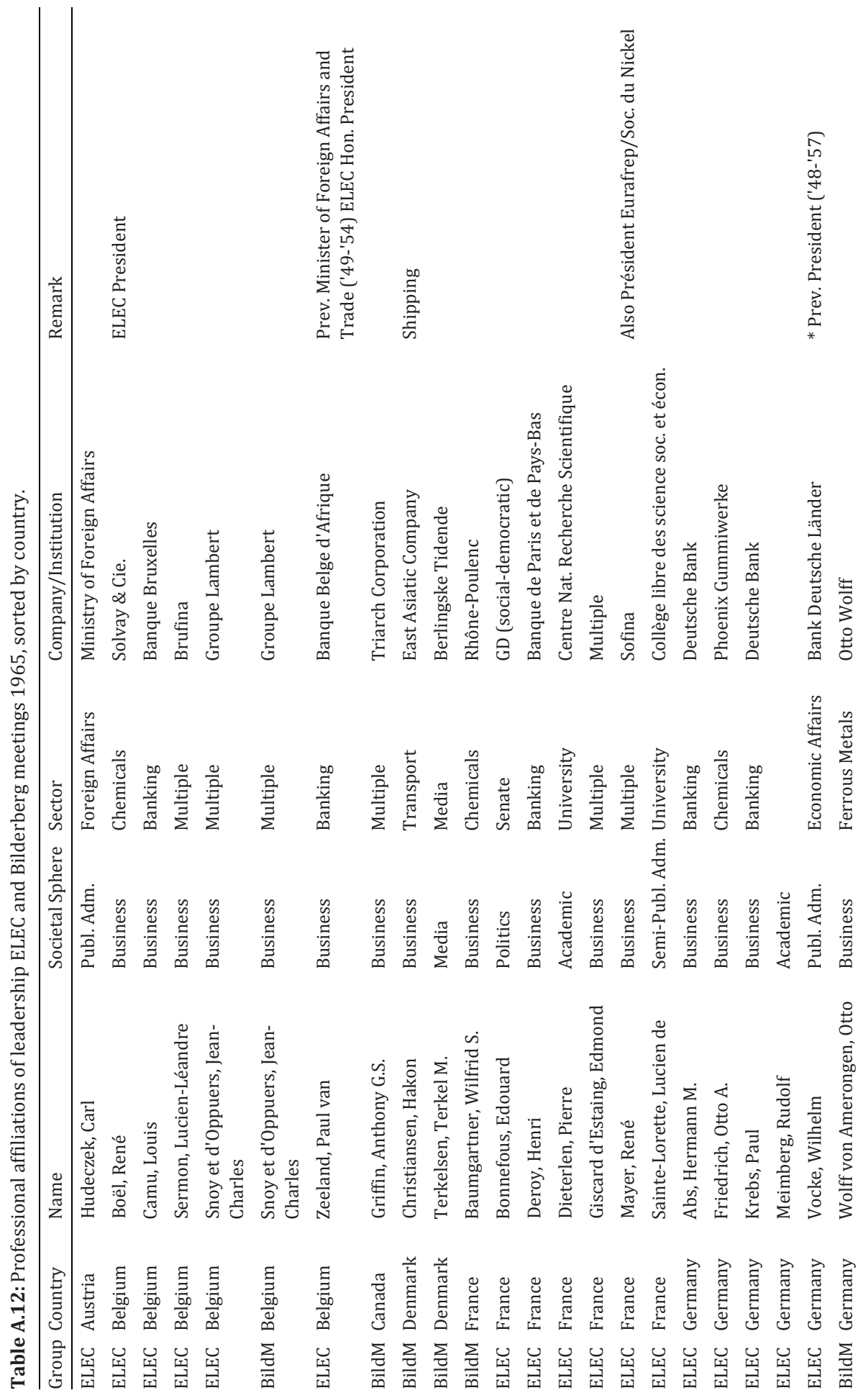




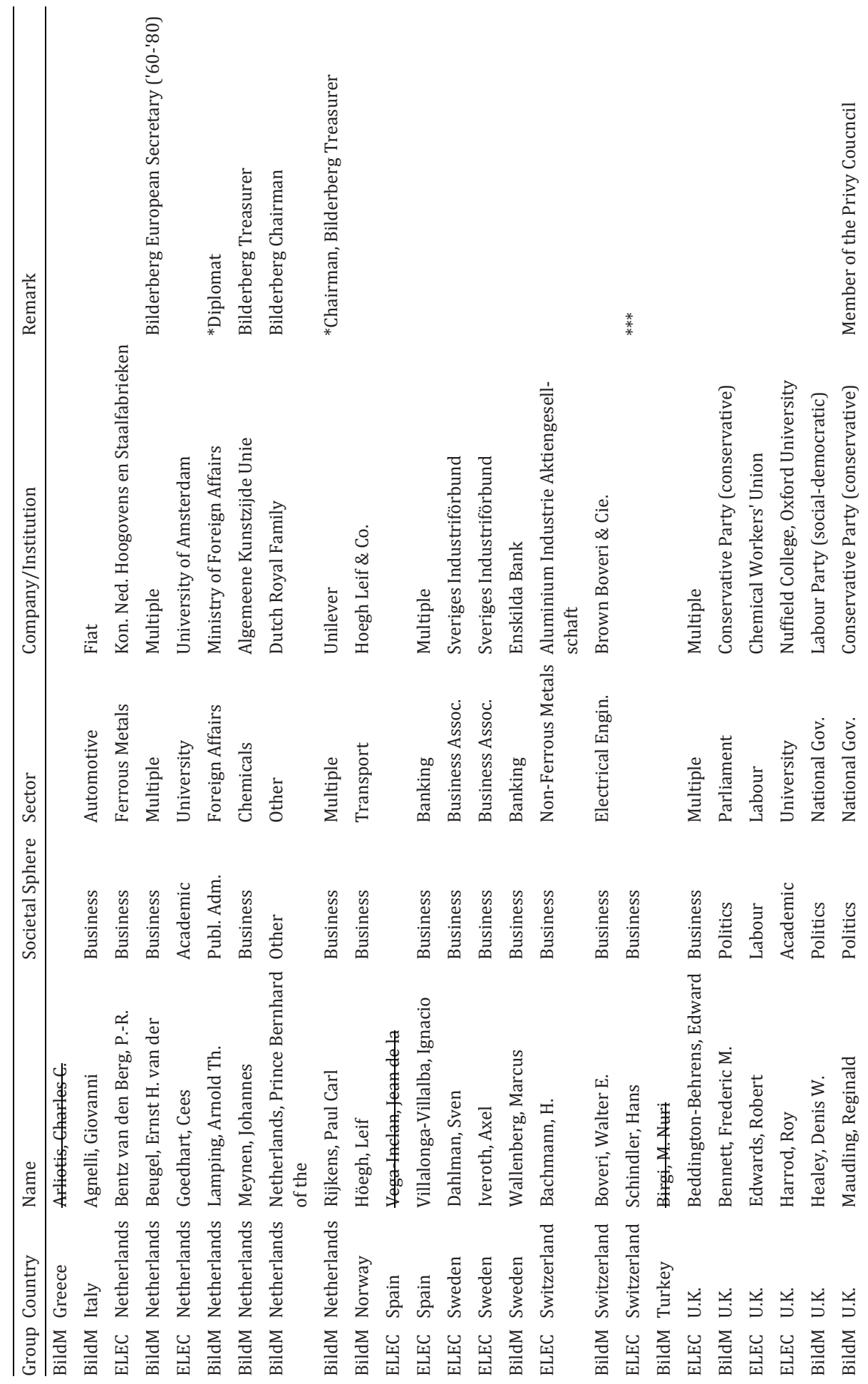




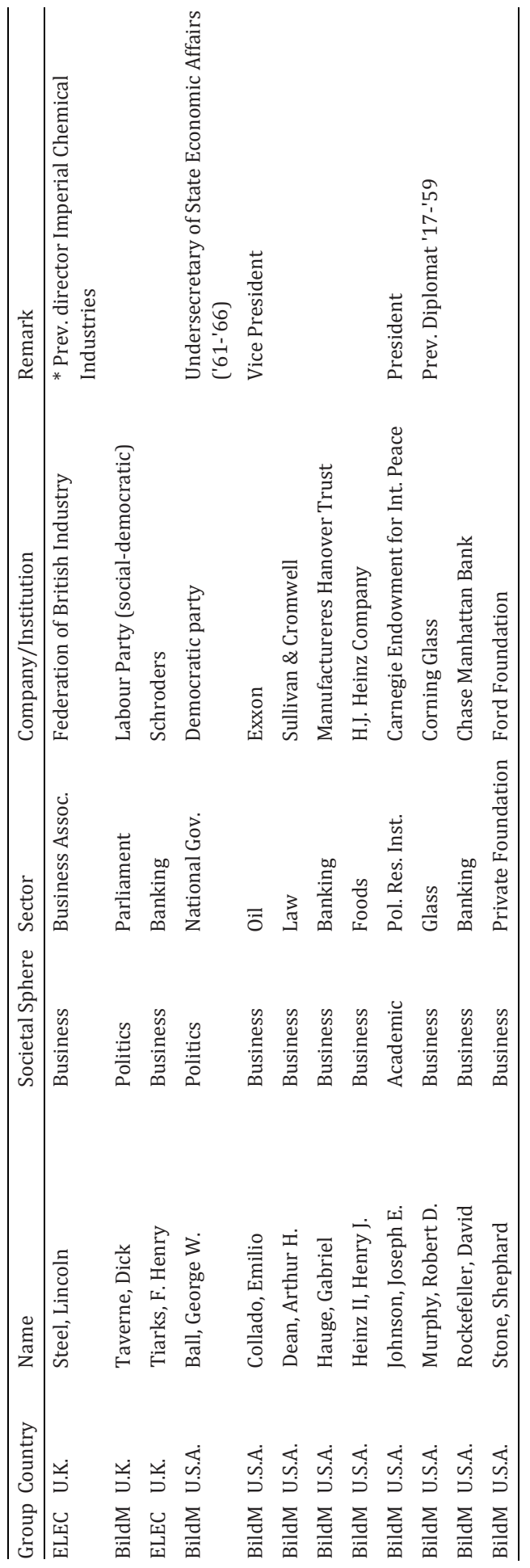




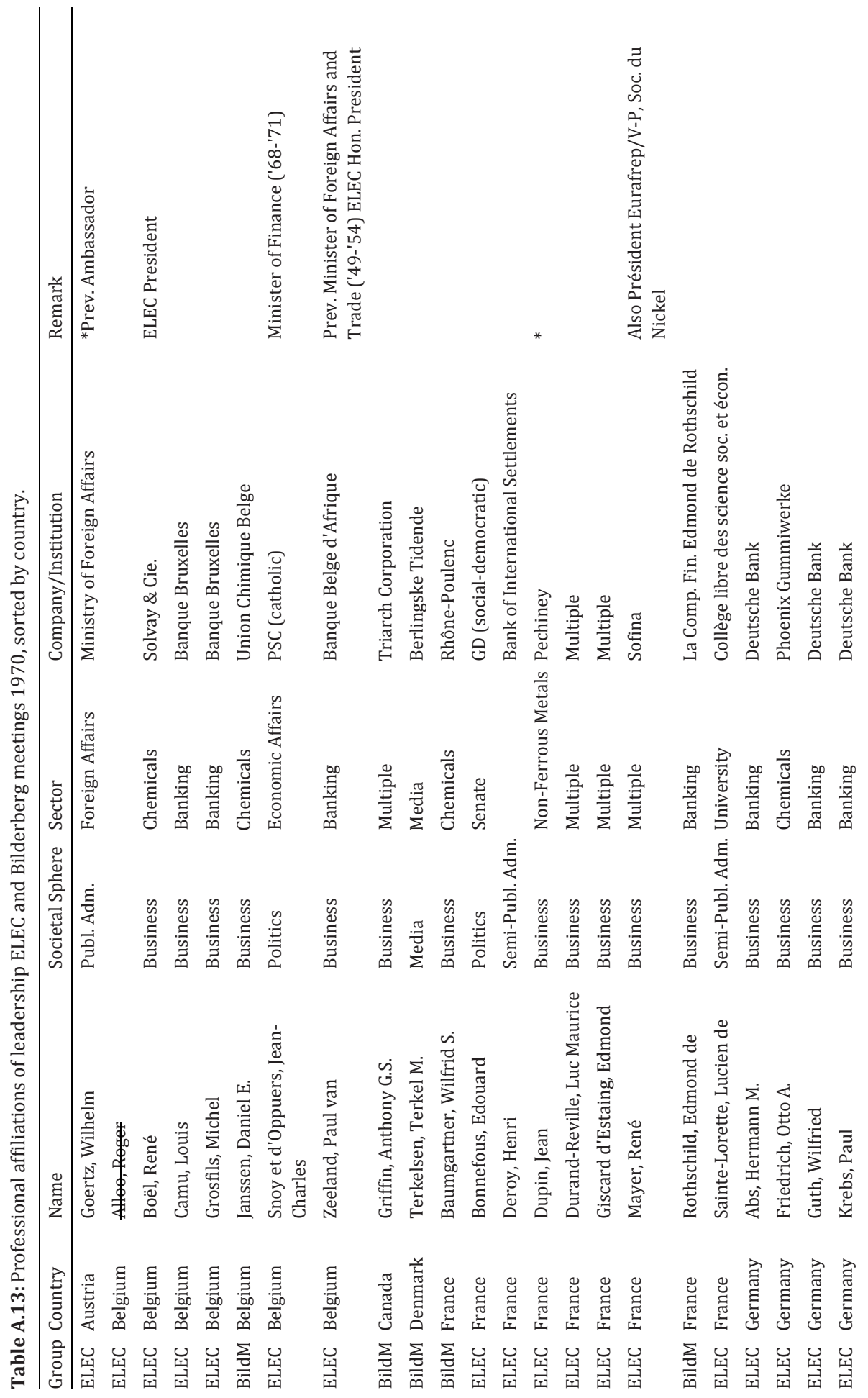




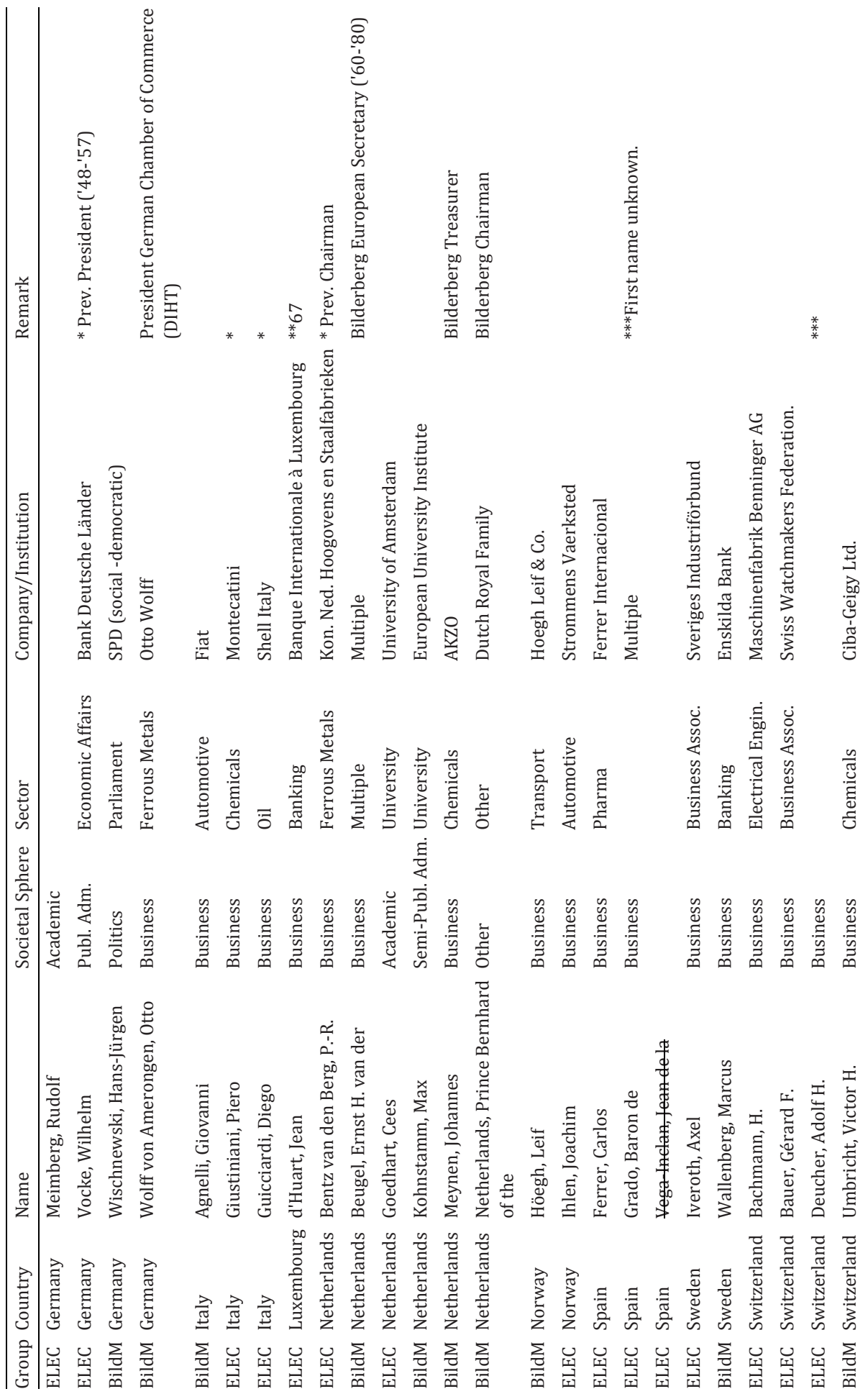




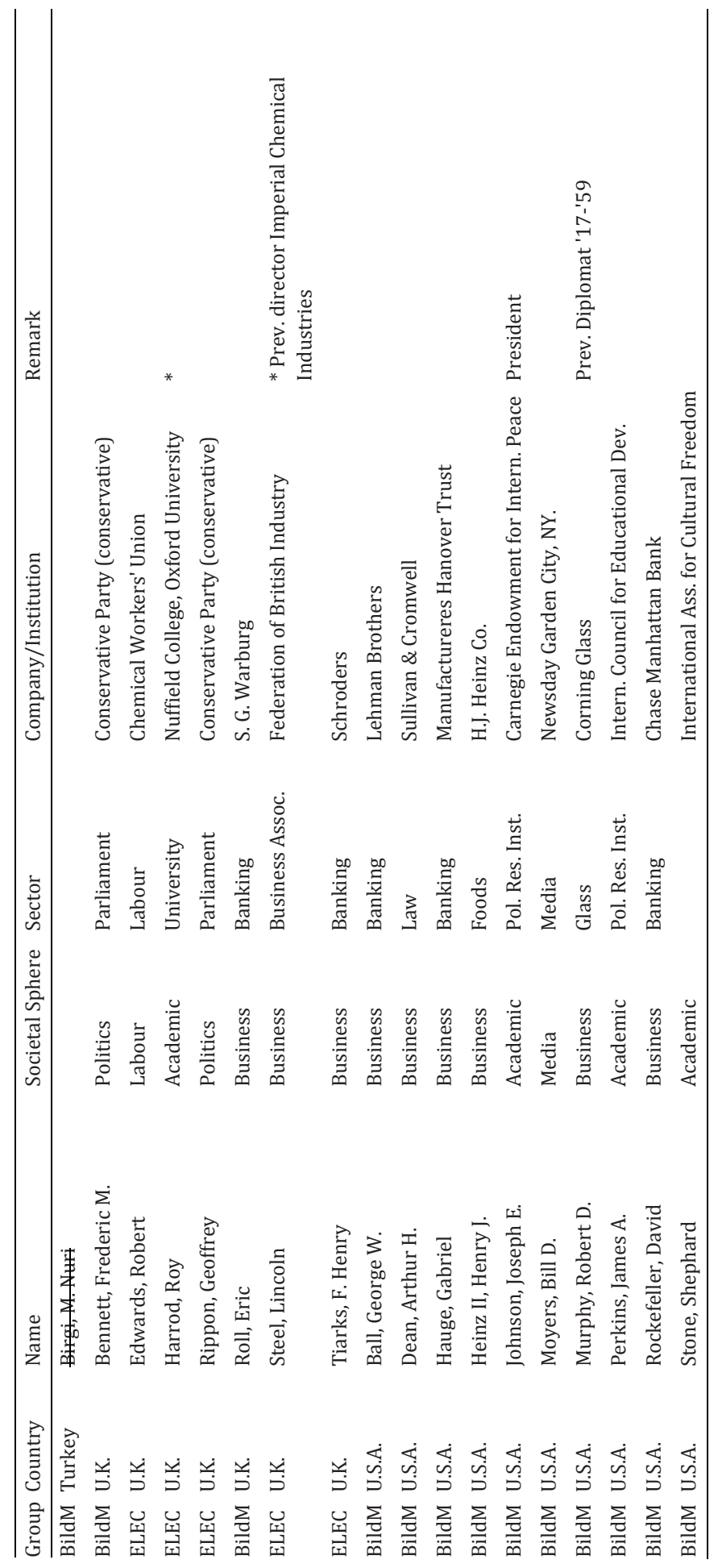




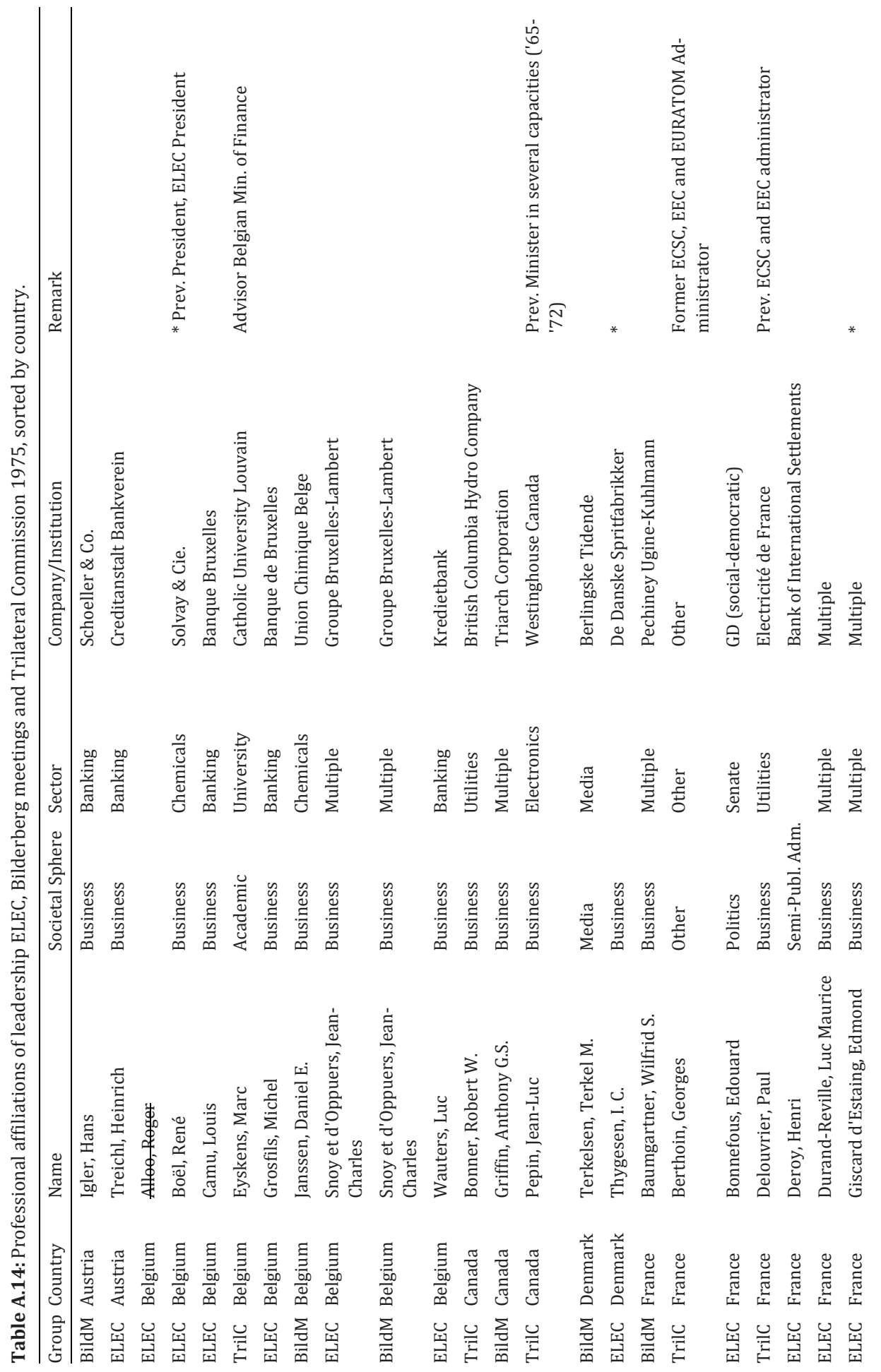




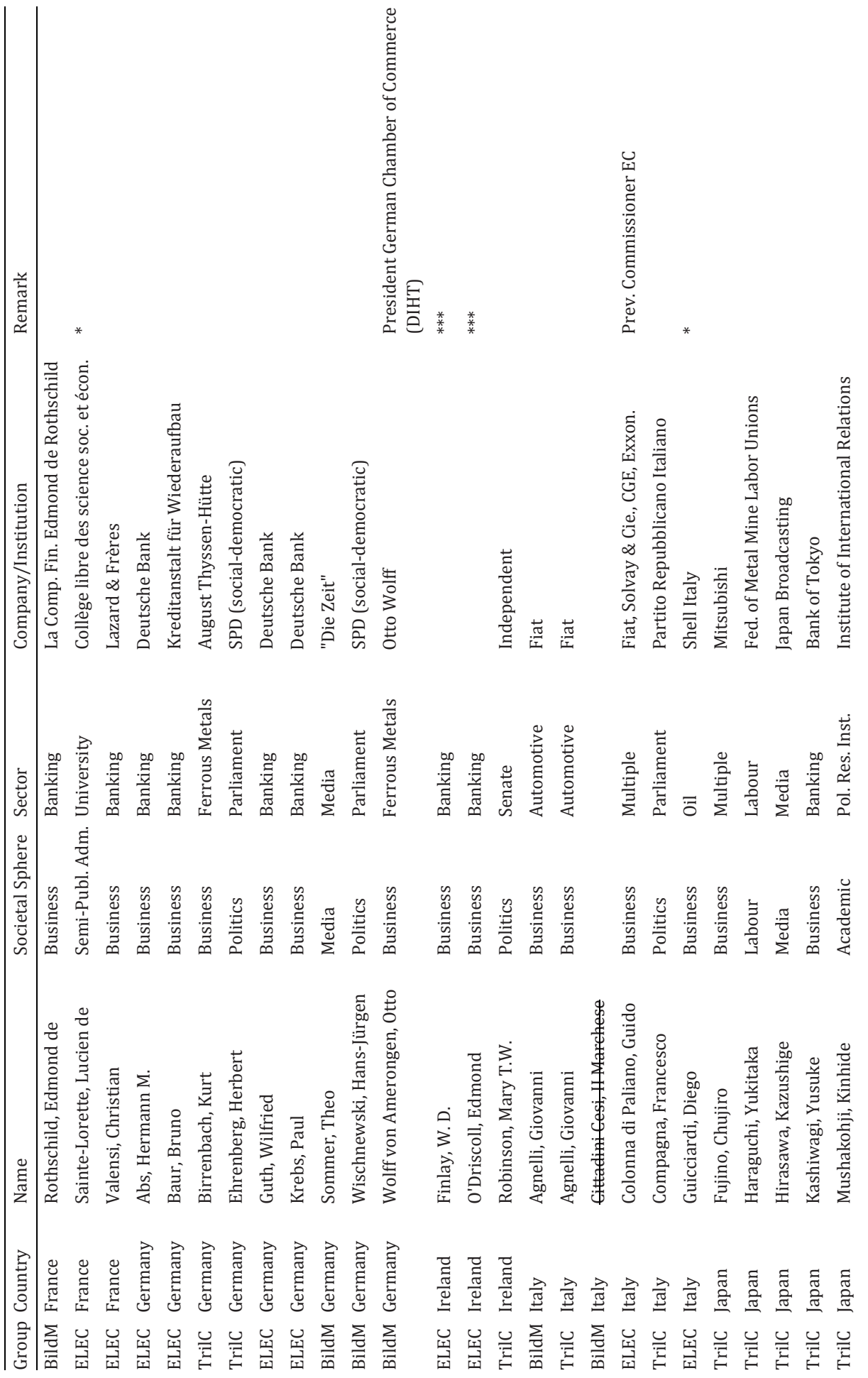




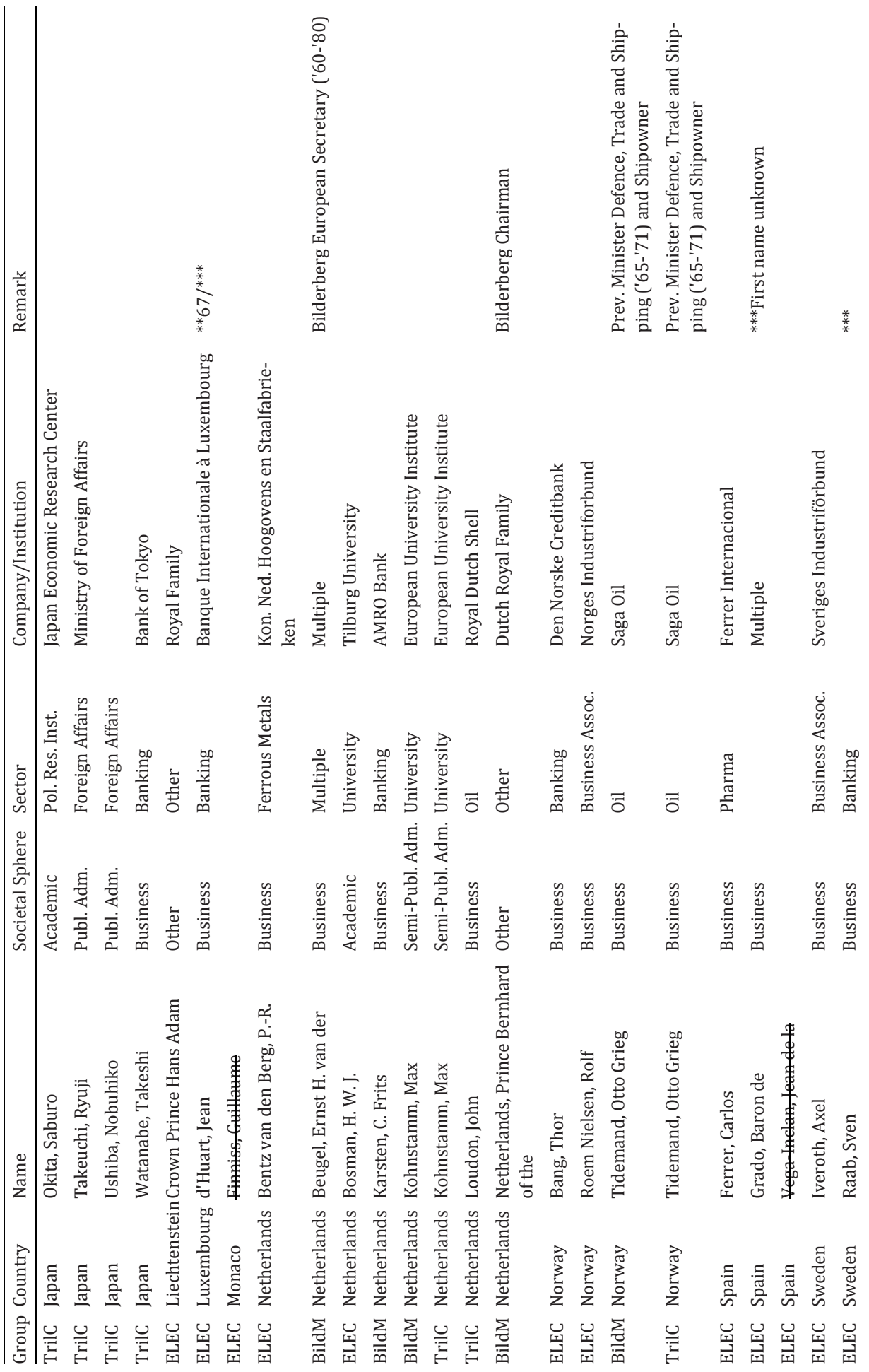




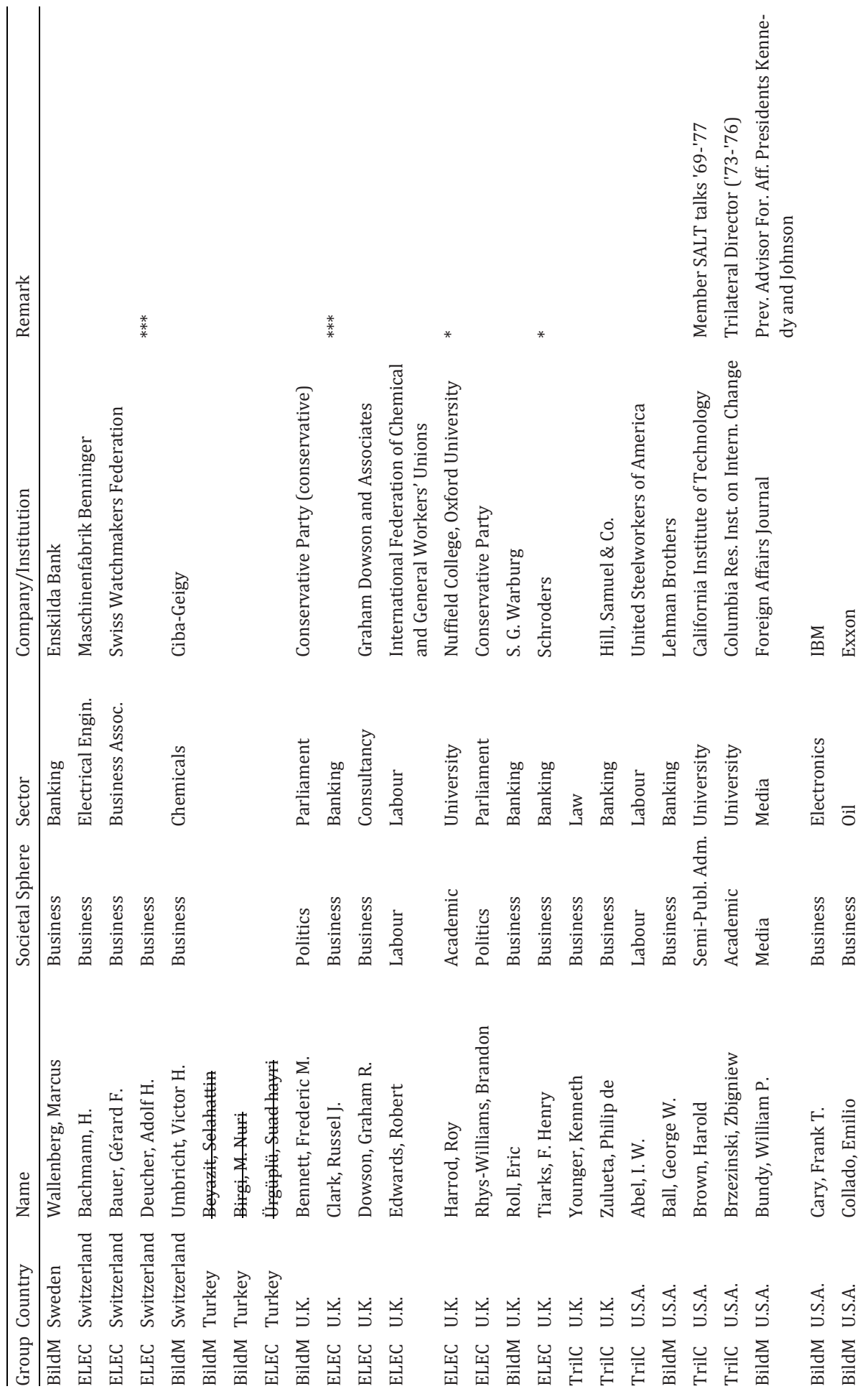




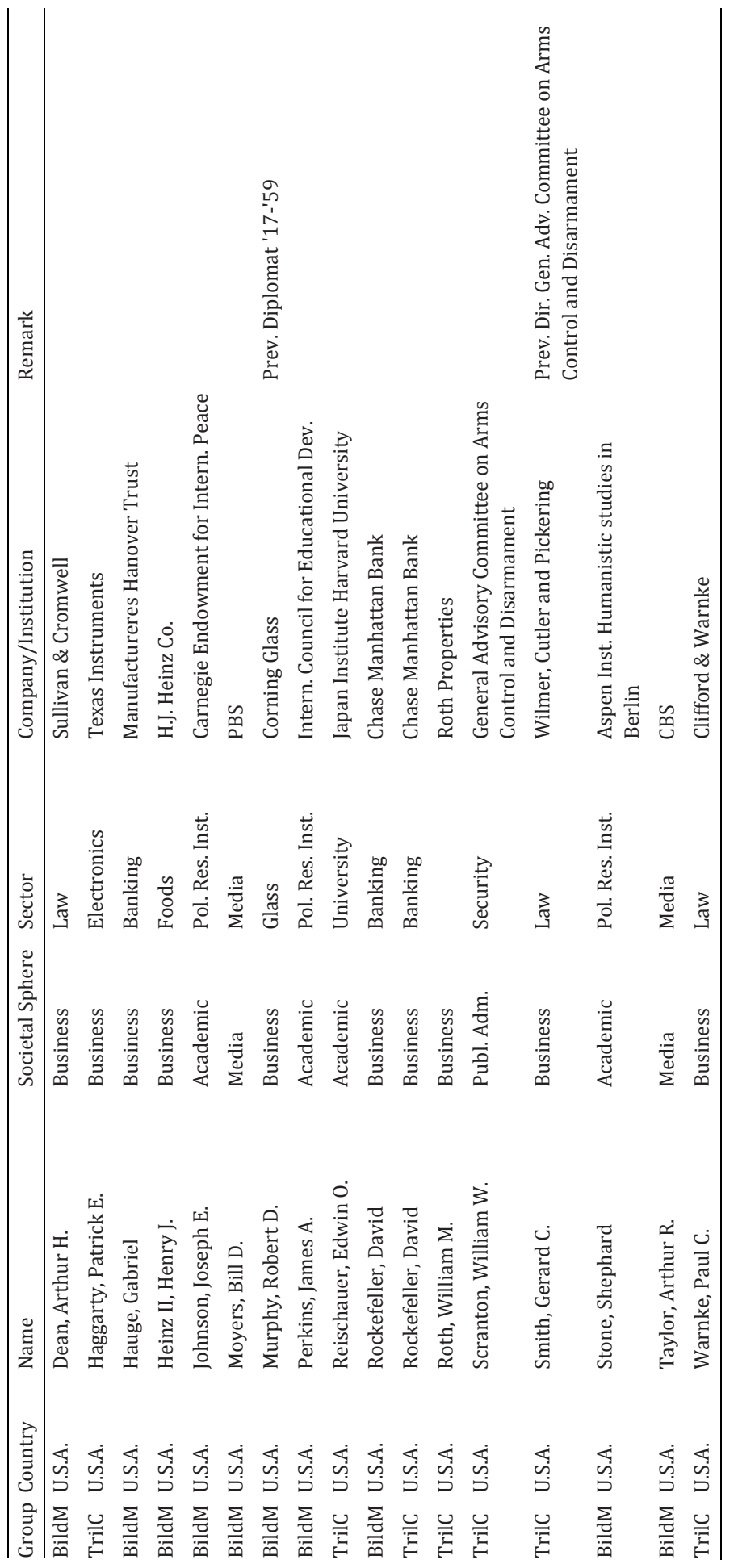




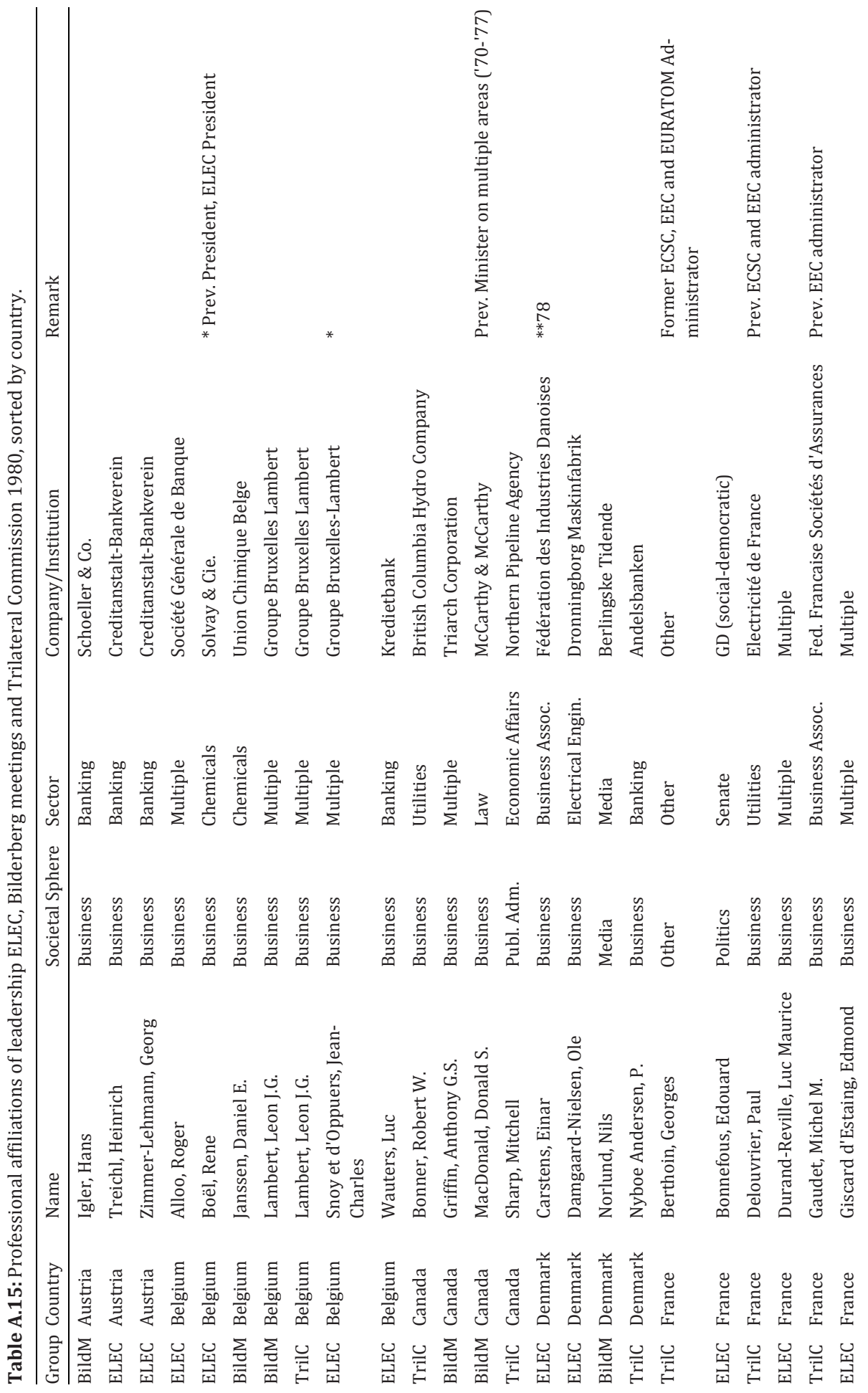




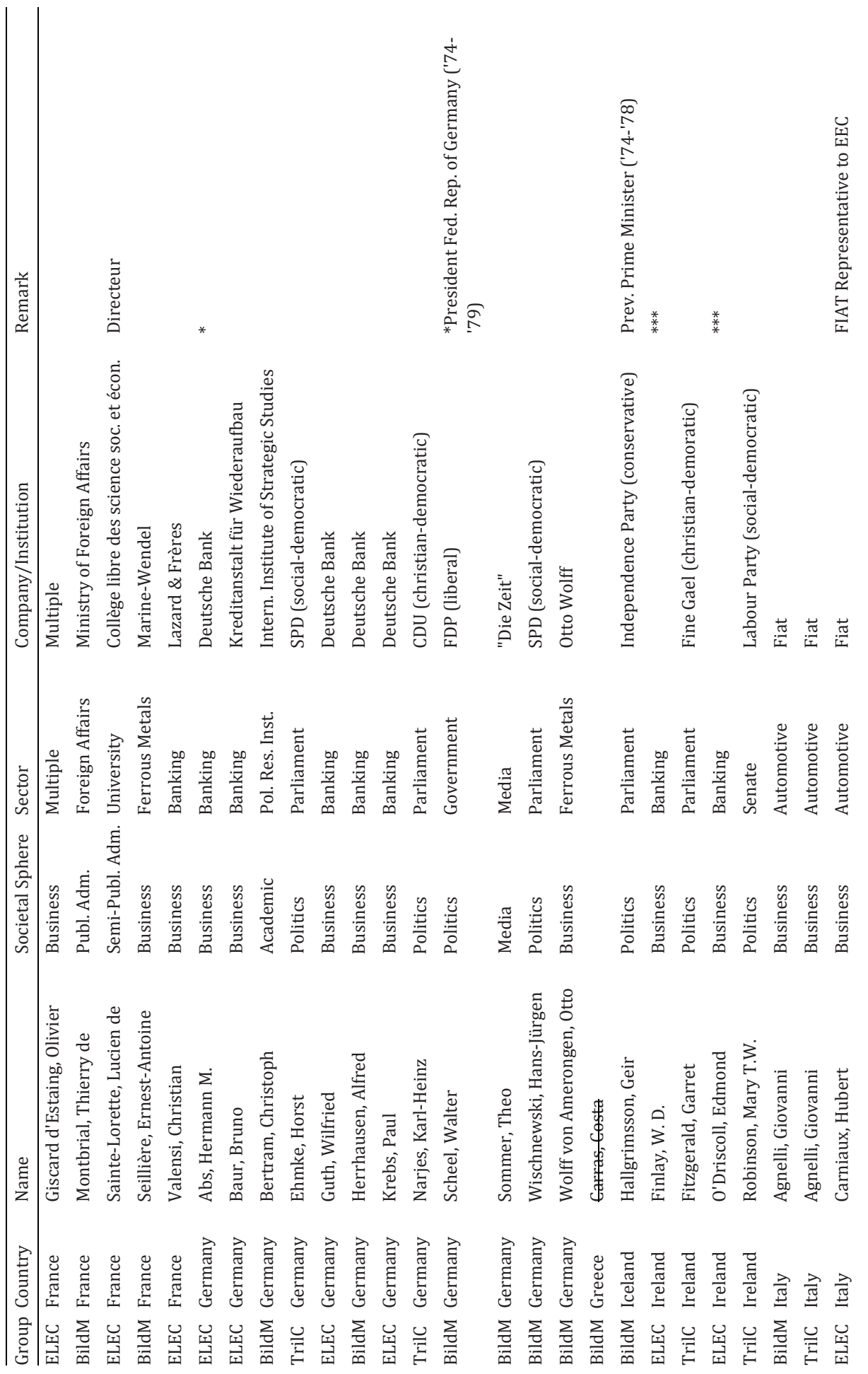




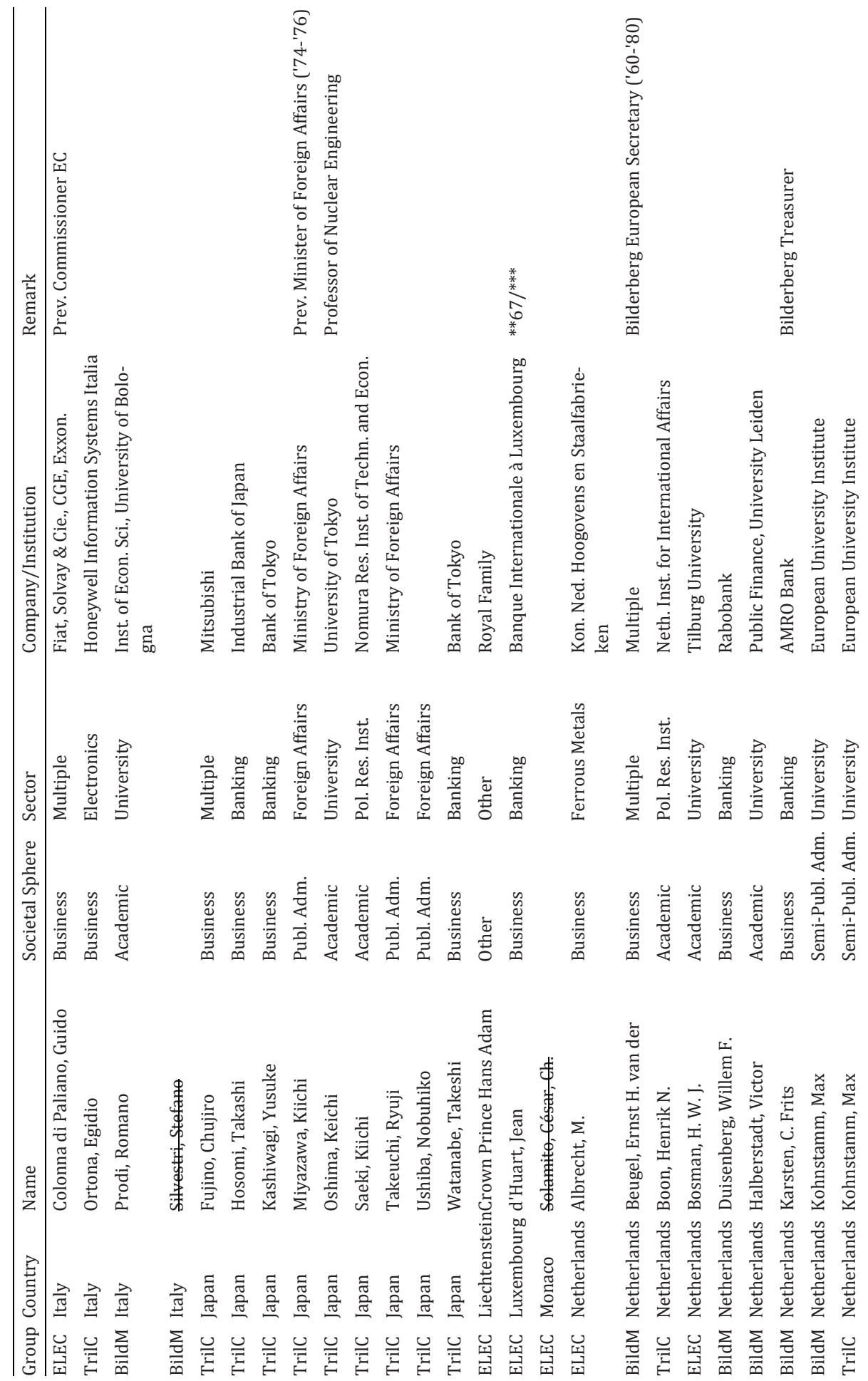




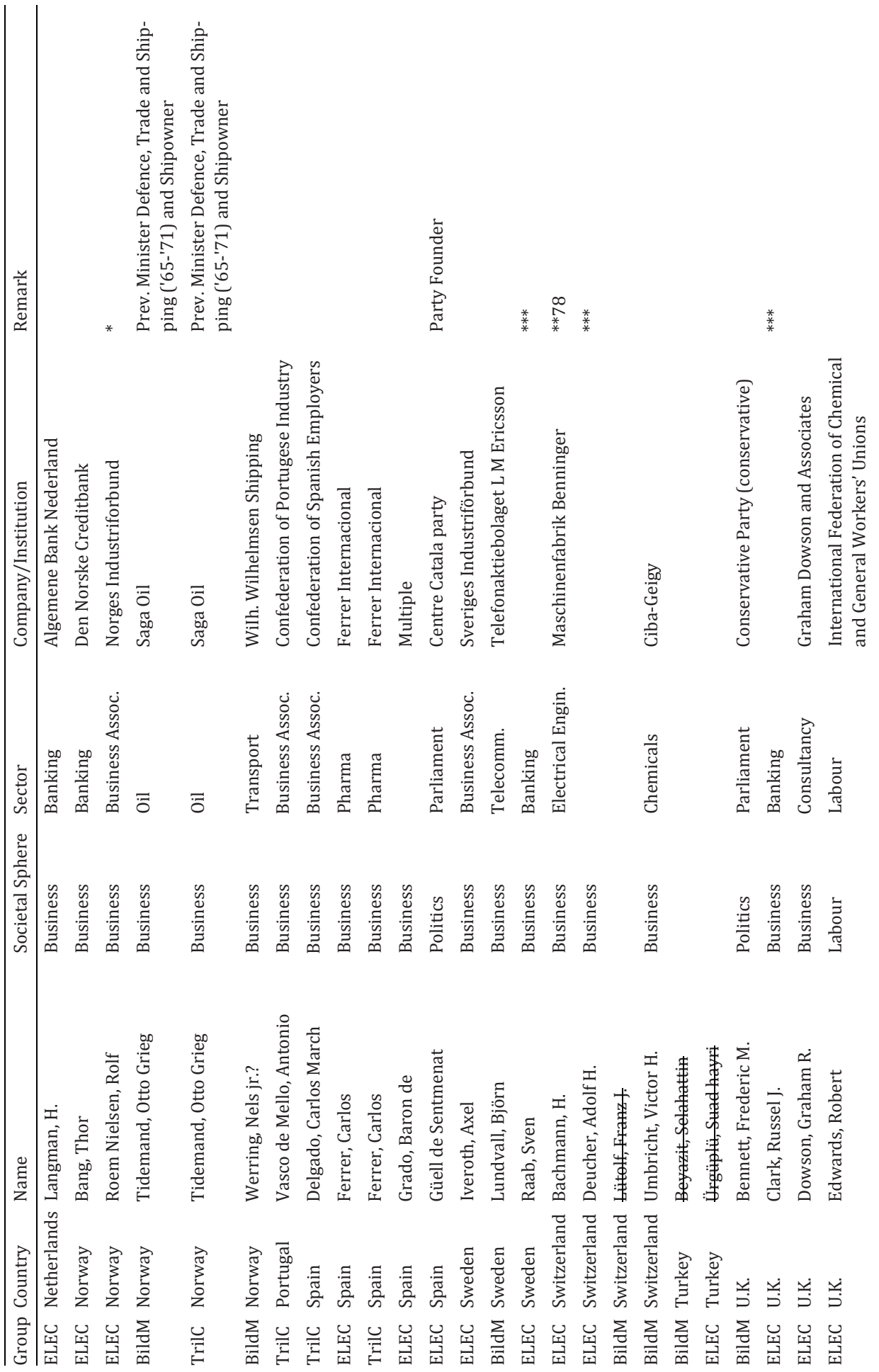




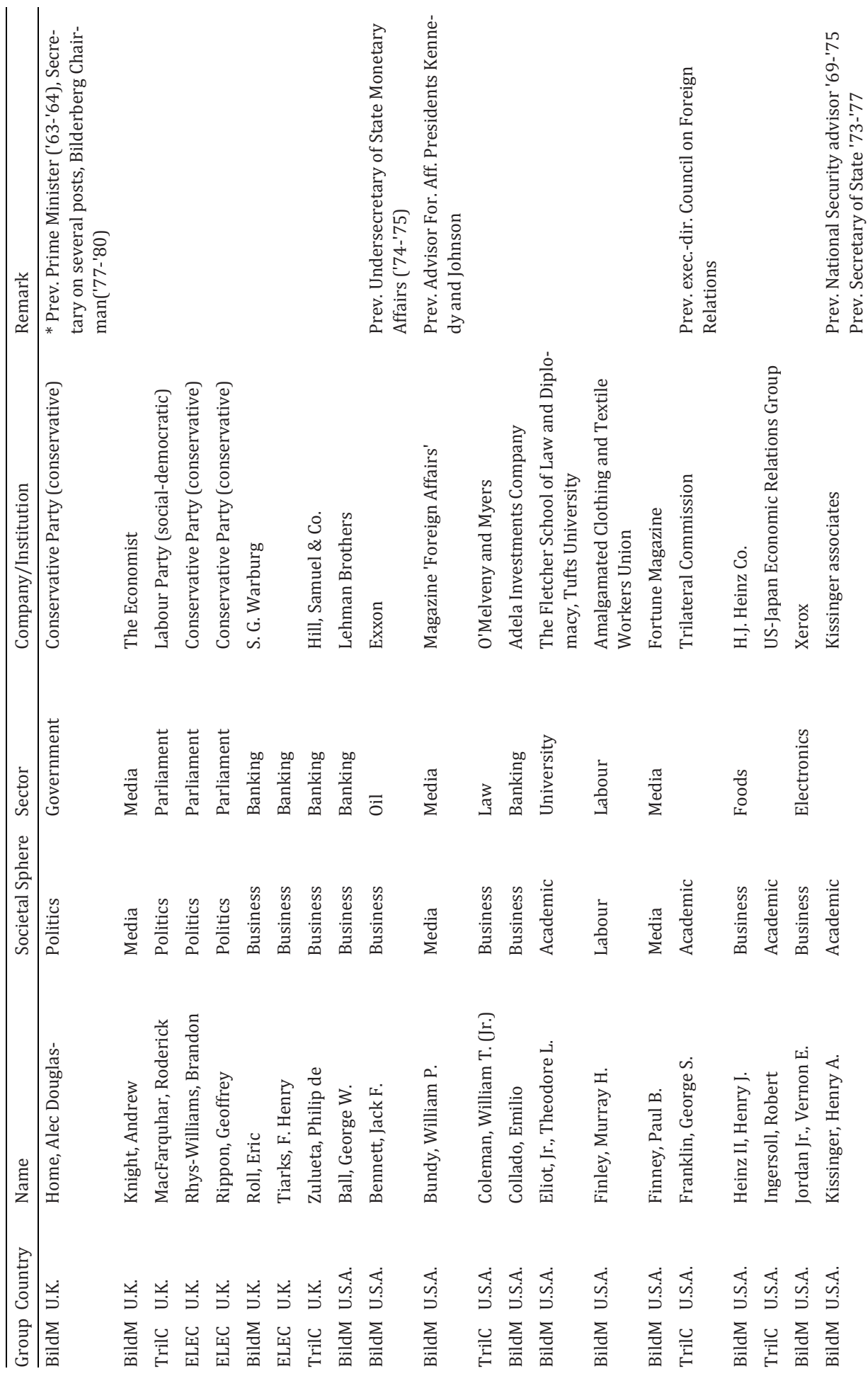




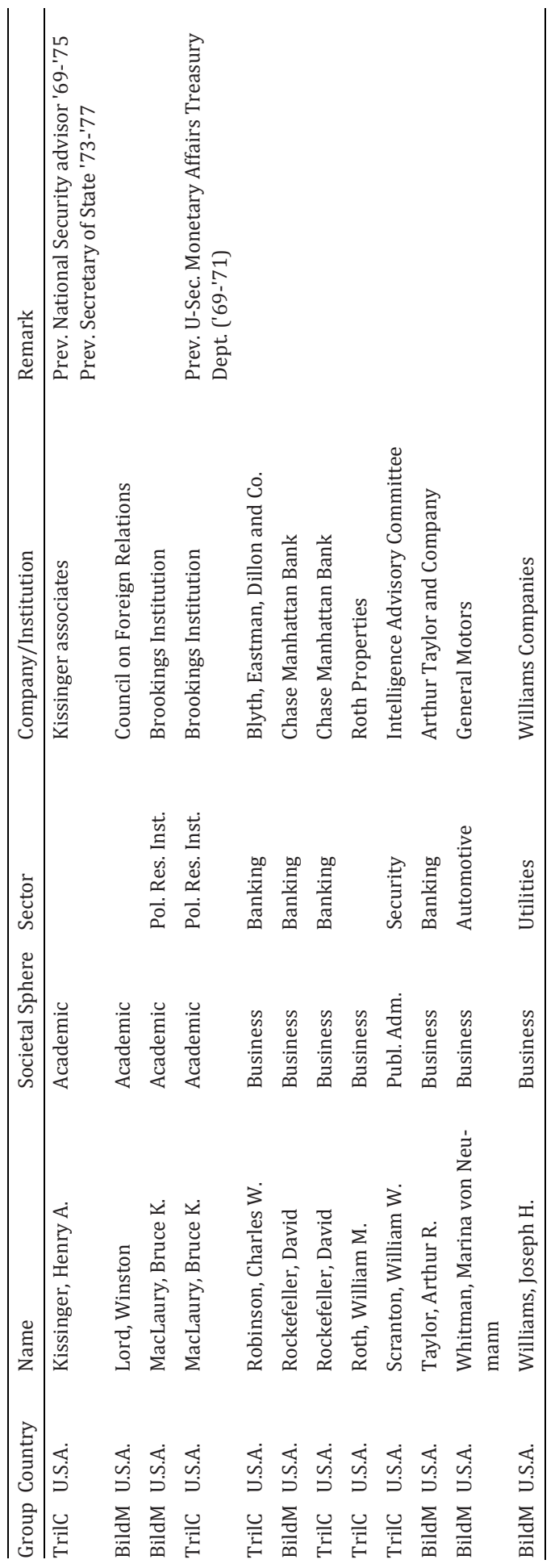




\section{Sources database}

The database "Professional Affiliations of Leadership ELEC-Bilderberg meetingsTrilateral Commission 1950-1980", is created from two source-types: membership sources, and biographical sources, mainly biographical dictionaries.

\section{Membership-sources per group}

\section{$\underline{\text { ELEC }}$}

LECE (1950). Résolution relative au Plan Schumann. Bruxelles: LECE.

ELEC (1955). A European solidarity plan to aid the depressed areas of southern Europe. Brussels: ELEC.

ELEC (1960). Topical tasks of monetary policy in Europe. Brussels: ELEC, p. 0.

ELEC (1965). East-west commercial relations: study conference, opening speech, introductory report, resolutions, list of participants, Brussels, May 14th and 15th, 1965. Brussels: ELEC, p. 71.

LECE (1970). Rapport du Sécretaire Général sur l'activité de la L.E.C.E. en 1969. Bruxelles: LECE.

ELEC (1975). Report of the Secretary General on the activities of ELEC in 1974. Brussels: ELEC, pp. 26-27.

ELEC (1979). Report of the Secretary General on the activities of ELEC in 1978. Brussels: ELEC.

\section{Bilderberg meetings}

IISGA, AMK, inv. nr. 110, Bilderberg Meetings Alphabetical List of Participants 1954-2001.

NL-HaNA, Bilderberg Conferenties, 2.19.045, inv. nrs. 30-31-35-41-46. Steering Committee Minutes from 1954 until 1958.

RWWK, NOWA, inv. nrs. 72-377-3, 72-378-3, 72-378-4, 72-379-2, 72-374-2, 72-374-3, 72-374-4, 72372-5, 72-968-3, 72-969-1, 72-969-2, 72-969-2, 72-969-3, 72-970-1, Advisory and Steering Committee Minutes From 1959 until 1977 (except for 1966 and 1968, which could not be located).

\section{$\underline{\text { Trilateral Commission }}$}

Sklar, H., \& Everdell, R. (1980). Who's who on the Trilateral Commission. In H. Sklar (Ed.), Trilateralism: the Trilateral Commission and elite planning for world management (pp. 90-130). Montréal: Black Rose Books.

\section{"Professional affiliations" sources per group}

\section{$\underline{\text { Trilateral Commission }}$}

Sklar, H., \& Everdell, R. (1980). Who's who on the Trilateral Commission. In H. Sklar (Ed.), Trilateralism: the Trilateral Commission and elite planning for world management (pp. 90-130). Montréal: Black Rose Books. 


\section{"Professional affiliations" sources per country}

AUSTRIA

Bohman, R. \& Taylor, S. S. (Eds). (1964/1967). Who's who in Austria. Montreal: Intercontintenal Book and Pub. Co.

Strute, K. \& Doelken, T. (Eds.) (1969/1977). Who's who in Austria. Wörthsee: Who's who, the International Red Series Verlag.

Taylor, S. S. (Ed.) (1955). Who's who in Austria: a biographical dictionary. Montreal: Intercontinental Book and Publishing.

\section{BELGIUM}

Decan, R. G. A. (1981). Qui est qui en Belgique francophone 1981-1985. Encyclopédie biographique de la Belgique francophone 1981-1985. Bruxelles: Éditions BRD.

ELEC (1970). A programme for monetary integration within the E.E.C : feasibility study and proposals as to the measures to be taken (Vol. 46). Brussels: ELEC, p. 5.

ODIS (2007). Databank Intermediaire structuren in Vlaanderen 19e-20e eeuw. Retrieved October 9, 2012, from www.odis.be.

Kurgan-Van Hentenryk, G. \& Puissant, J. (Eds.) (1996). Dictionnaire des patrons en Belgique: les hommes, les entreprises, les réseaux. Bruxelles: De Boeck Université.

Michielsen, F. \& Taylor, S. S. (Eds.) (1962). Who's who in Belgium and Grand Duchy of Luxembourg. Les Editions Biographiques: Brussels.

\section{CANADA}

Lumley, E. (Ed.) (1997). Canadian Who's Who. Toronto: University of Toronto Press.

Simpson, K. (Ed.) (1986). Canadian Who's Who. Toronto: University of Toronto Press.

\section{DENMARK}

(1974). Kraks Blaa Bog: ... nulevende Danske mænds og kvinders levnedsløb. Retrieved, October 9, 2012. From www.rosekamp.dk/kbb_74_ALL/N.htm

Cedergreen Bech, Svend et al. (Eds.)(1979-1984). Dansk Biografisk Leksikon. Kopenhagen: Gyldenhal, published as online database on Den Store Danske (2011). Retrieved October 9, 2012, from www.denstoredanske.dk/Dansk_Biografisk_Leksikon.

ELEC (1978). A new economic impetus for Europe. The Fundamental role of the European Parliament. ELEC Conference on December 14th 1978. Brussels: ELEC.

\section{FRANCE}

ELEC (1970). A programme for monetary integration within the E.E.C : feasibility study and proposals as to the measures to be taken (Vol. 46). Brussels: ELEC, p. 5.

Who's who in France = Qui est qui en France (1955/1967/1980). Paris: Lafitte.

\section{FEDERAL REPUBLIC OF GERMANY}

Kliemann, H. G. et al. (Eds.) (1964/1972/1980). Who's who in Germany. Wörthsee near Munich: Who's who, the international red series Verlag GmbH.

Pöllath, R. \& Heukamp, M. (2009). 200 Jahre Wirtschaftsanwälte in Deutschland. Baden-Baden Nomos 2009.

\section{ICELAND}

Strute, K. \& Doelken, T. (1981). Who's who in Scandinavia. Zürich: Who's who. 
ITALY

Aftalion, F. (1991). A history of the international chemical industry. Philadelphia: University of Pennsylvania Press, pp. 223, 225.

GEHECLIN, LECE, inv. nr. 370.6, 2-10-1967, Reconstitution d'un comité Italien de la Ligue Européenne de Coopération Economique.

GEHECLIN, LECE, inv. nr. 273, 10-10-1980, Colloque “Pour Une Politique Energétique Commune”, Liste des Participants (see Appendix 2 for details on archival sources).

Giordani, I. \& Taylor, S. S. (Eds.) (1958). Who's who in Italy. Zürich: Sutter's International Red Series.

Groeg, O. J. (Ed.) (1980). Who's who in Italy. Zürich: Sutter's International Red Series.

\section{LUXEMBOURG}

CEHECLIN, LECE, inv. nr. 370.1 , 23-09-1955, Extrait du “Memorial” (Recueil Spécial) No. 70.

CEHECLIN, LECE, inv. nr. 371, 30-03-1967, 20ème anniversaire du plan Marshall. Membres de la LECE, qui pourraient y être invités.

\section{THE NETHERLANDS}

Algemeen Nederlands Persbureau (1977-2005). A.N.P. Biodienst. Den Haag: ANP.

Egmond, Frans van (Ed.) (1984). Wie is wie in Nederland, 1984/1988. 's-Gravenhage: Pragma Nederland. Instituut voor Nederlandse Geschiedenis (no year). Biografisch Portaal van Nederland. Retrieved, October 9, 2012, from www.biografischportaal.nl

Parlementair Documentatie Centrum Universiteit Leiden (no year). Biografisch Archief Online. Retrieved October 9, 2012, from www.parlementairdocumentatiecentrum.nl

\section{NORWAY}

Steenstrup, B. (1973). Hvem er Hvem? Oslo: Aschehoug.

Steenstrup, B. (1984). Hvem er Hvem? Oslo: Kunnskapsforlag

Strute, K. \& Doelken, T. (1981). Who's who in Scandinavia. Zürich: Who's who.

SPAIN

Dove, J. C. (Ed.)(1987). Who's who in Spain. [s.l.]: [s.n.].

Olives Canals, S. \& Taylor, S. S. (Eds.) (1963). Who's who in Spain. Barcelona: [s.n.]

\section{SWEDEN}

Lagerström, S. \& Sölvén, E. (Eds.) (1969). Vem är det, Svensk biografisk handbok. Stockholm: P A Norstedt \& Söners Förlag. Retrieved, October 9, 2012, from runeberg.org

Strute, K. \& Doelken, T. (1981). Who's who in Scandinavia. Zürich: Who's who.

Vem är det, Svensk biografisk handbok. (1985). Stockholm: P A Norstedt \& Söners Förlag. Retrieved, October 9, 2012, from runeberg.org

\section{SWITZERLAND}

Historisches Lexicon der Schweiz Online (no year). Retrieved October 9, 2012 from http://www.hlsdhs-dss.ch/index.php

Who's who in Switzerland, including the Principality of Liechtenstein, (1968). Zürich: Orell Füssli.

Who's who in the World, 1978-1979 (1978). Chicago: Marquis Who's who.

\section{UNITED KINGDOM}

Who Was Who, A \& C Black, 1920-2008; online edition. Oxford University Press (2007). Retrieved October 9, 2012, from www.ukwhoswho.com 
UNITED STATES OF AMERICA

(1943). Who was who in America. Chicago: Marquis Who's who. (Volumes 7-17).

(2012). Who's who in America. Chicago: Marquis Who's who. 


\section{Samenvatting}

Na 1945 bleef in Europa de lappendeken van nationale markten aanvankelijk gehandhaafd. Maar mede onder druk van de Amerikaanse regering bewoog een groep van zes West Europese overheden zich vanaf 1947 langzaam naar overeenstemming over het wegnemen van de onderlinge handelsbelemmeringen. België, de Bondsrepubliek Duitsland, Frankrijk, Italië, Luxemburg en Nederland besloten in 1952 de nationale handelsbelemmeringen op kolen en staal op te heffen met het vormen van de Europese Gemeenschap van Kolen en Staal. In 1957 breidden de landen deze markt uit met de oprichting van een gemeenschappelijke markt voor industriële goederen. De handelsquota en importtarieven verdwenen geleidelijk en een gezamenlijk importtarief werd opgezet. Beide besluiten resulteerden tevens in aparte supranationale instellingen om de overeengekomen verdragen uit te voeren, respectievelijk de Hoge Autoriteit en de Europese Commissie. Vanaf 1959 werd er ook een begin gemaakt met het zoeken naar oplossingen voor de grote administratieve en juridische verschillen tussen de lidstaten welke een soepele integratie van markten in de weg stonden.

De geleidelijke verandering van een nationale ordening van markten naar een supranationale ordening van één markt roept vragen op over bedrijven die al vertakt waren in een aantal van deze landen. Van multinationale ondernemingen zoals Unilever en Philips, twee van de meest internationaal vertakte ondernemingen in de jaren vijftig, is bekend dat zij voordelen zagen in een zo groot mogelijke markt en probeerden in de decennia daarna ook te profiteren van de geboden mogelijkheid tot schaalvergroting.

Eerder onderzoek toont ook aan hoe Europese multinationals dachten over de Europese Economische Gemeenschap in de jaren tachtig. In 1983 startten grote, toonaangevende bedrijven een lobby om de gemeenschappelijke markt eindelijk volledig in te voeren. Onder de noemer van de European Round Table of Industrialists constateerden ze dat de Europese markt onvoldoende was geharmoniseerd sinds haar oprichting vanaf 1957. De blijvende grote verschillen tussen de markten verhinderde de ondernemingen nog altijd om gebruik te maken van de schaalvoordelen van de Europese markt, zo claimden ze. Onder invloed van Amerikaanse en Japanse concurrentie was de resterende nationale marktordening gaan knellen.

De aanvankelijk positieve houding onder enkele multinationale ondernemingen in de jaren vijftig en de kritische houding van een forse groep in de jaren tachtig doet de vraag reizen hoe hun visies op de Europese markt zich hebben ontwikkeld in de tussenliggende periode? Tegelijkertijd is de term "multinational" een noemer voor bedrijven met grote onderlinge verschillen. Zo komen zij voort uit diverse nationale contexten met eigen beleidsrichtingen, economische pad- 
afhankelijkheden en bedrijfsculturen. Ook opereren zij in sterk verschillende sectoren. Zodoende onderzoekt deze dissertatie ook hoe eventuele verschillen in opvattingen onder multinationals kunnen worden verklaard.

Tenslotte wil dit onderzoek bijdragen aan een alternatief voor de veelal nationale benaderingen in het onderzoek naar de geschiedenis van Europese integratie. De visies van ondernemingen worden onderzocht via hun rol in drie transnationale netwerken waarin bedrijven uit heel West Europa ideeën uitwisselden over de plek van de Europese markt in internationale economische verhoudingen. Zo draagt dit proefschrift bij aan een transnationale geschiedenis van de plek van Europese, multinationaal georganiseerde en georiënteerde bedrijven in de geschiedenis van de Europese integratie.

De bedoelde drie transnationale netwerken die zijn onderzocht zijn: de European League for Economic Cooperation (ELEC), de Bilderberg meetings en de Trilateral Commission. Om de ontwikkelingen tussen circa 1950 en 1980 te onderzoeken zijn voor de jaren vijftig, de jaren zestig en de jaren zeventig dominante debatten geselecteerd die enerzijds een vergelijking tussen de netwerken mogelijk maakten en anderzijds een belangrijke rol vervulden voor de betrokken bedrijven in relatie tot hun positie op de Europese markt.

Het boek bestaat uit twee delen. Samen met het inleidende hoofdstuk vormen hoofdstukken twee en drie een introductie tot de geselecteerde netwerken en tot de diverse contexten waarin Europese multinationals opereerden. Hoofdstukken vier, vijf en zes vormen samen het empirische hart van het boek. De hoofdstukken bespreken achtereenvolgens de onderzochte debatten per decennium. Hoofdstuk 7 bespreekt de conclusies.

Om de debatten goed te kunnen plaatsen binnen de activiteiten van de ELEC, de Bilderberg meetings en de Trilateral Commission onderzoekt hoofdstuk 2 allereerst hoe deze netwerken functioneerden. De ELEC is een in 1947 opgerichte West-Europese studie- en lobby-organisatie welke zich richtte op onderwerpen van economische integratie. De organisatie bestond uit nationale secties, waarin België, de Bondsrepubliek Duitsland, Frankrijk, Nederland en het Verenigd Koninkrijk de belangrijkste waren. De ELEC volgde debatten over de ordening van de Europese markt en deed voorstellen tot aanpassing. De Bilderberg meetings is een in 1953 opgerichte Trans-Atlantische studiegroep die zich als doel stelde het wederzijdse begrip tussen Europeanen en Amerikanen te verdiepen. Eens per jaar besprak een, veelal stabiele, groep van voornamelijk vertegenwoordigers van het bedrijfsleven met een groot aantal goed ingevoerde genodigden over veiligheidsvraagstukken en de internationale economie. Deelnemers aan de Bilderberg meetings waren tijdens de bijeenkomsten verwikkeld in lopende internationale debatten. De Trilateral Commission is een in 1973 opgerichte Europees-AmerikaansJapanse studie-organisatie van privépersonen die de internationale politieke en economische samenwerking weer op de agenda probeerde te krijgen nadat deze aan het begin van de zeventiger jaren onder druk was komen te staan. Op basis van 
een in de appendix opgenomen biografische database biedt hoofdstuk 2 tevens een gedetailleerde analyse van de rol van het bedrijfsleven in die drie netwerken.

In hoofdstuk 3 staat de vraag centraal hoe eventuele verschillende opvattingen over de ordening van de Europese markt onder bedrijven verklaard kunnen worden. Het voorgestelde raamwerk benoemt twee dominante contexten waarin multinationals opereerden voor wat betreft de samenvoeging van nationale markten tot een Europese: de nationale context en de sectorale context van een bedrijf. Verschillen in nationale contexten waaruit de diverse Europese multinationals oorspronkelijk vandaan kwamen bepalen mede hoe zij aankeken tegen marktintegratie. Zo kwamen Belgische en Nederlandse multinationals voort uit kleine markten en stonden in het protectionistische Europa van de jaren dertig onder druk om zich internationaal te vertakken. Tegelijkertijd waren zij onder een economisch liberale politiek en beperkt overheidsingrijpen tot bloei gekomen. Bedrijven uit de Bondsrepubliek Duitsland raakten na WOII geënt op het Duitse exportbeleid en vormden zich naar liberale importtarieven en een goedkope Deutsch Mark. Bedrijven in Italië en Frankrijk hadden daarentegen te maken met interventionistische en plannende nationale overheden. De Franse economie genoot bovendien forse afscherming van buitenlandse concurrentie. Deze verschillen deden er toe bij het bepalen van de kaders waarbinnen de Europese markt zou worden opgezet. Zo zouden Nederlandse bedrijven minder profiteren van een Europese markt die de Franse voorkeur voor protectionisme volgde, en zouden Franse multinationals zich moeilijker redden in een sterk geliberaliseerd Europa.

Naast andere nationaal gemotiveerde voorkeuren kunnen verschillen in visies op de Europese markt ook begrepen worden vanuit een sectorale context. Bedrijven concurreren met hun sectorgenoten waarin sectorspecifieke concurrentievoordelen een grote rol spelen. Europese banken opereerden als gevolg van nationale afscherming vooral nationaal gedurende de periode 1950-1980. Concurrentie van nieuw opgerichte dochters van Amerikaanse banken noopte echter tot samenwerking onder Europese banken waardoor een geleidelijke internationalisering op gang kwam. De chemische industrie was meer aan internationale concurrentie onderhevig. Na WOII vestigden Amerikaanse en Europese chemische multinationals zich in elkaars markten, waarbij forse investeringen in onderzoek en ontwikkeling een noodzaak tot steeds grotere organisaties tot gevolg hadden. Daarnaast speelden energiekosten een rol voor de chemische industrie. De staalindustrie raakte verwikkeld in intense competitie als gevolg van herhaaldelijke innovaties in het productieproces en internationale veranderingen in de beschikbaarheid van grondstoffen. De daaruit volgende druk tot rationalisering van de productie leidde tot verzoeken om bescherming en tot een golf van fusies. De Europese auto-industrie ontwikkelde pas onderlinge concurrentie vanaf de oprichting van de Gemeenschappelijke Markt. Vanaf de jaren zeventig groeide de Japanse concurrentie op de Europese markt waardoor forse modernisering van productie nood- 
zakelijk werd. De bijzonderheden van elke sector spelen een rol in de verklaring van hun visie op de Europese markt.

Hoofdstukken 4, 5 en 6 vormen de kern van het proefschrift en behandelen elk een debat over een dominant thema in zowel de ELEC, de Bilderberg meetings als de Trilateral Commission. Hoofdstuk vier onderzoekt de periode 1950 tot 1960 en zoomt in op de vraag hoe Europese multinationals aankeken tegen economische integratie in West Europa. Deze visies op integratie gingen veel verder dan liberalisering op zichzelf. Binnen de European League for Economic Cooperation werd er langs nationale lijnen verschillend gedacht over hoe de Europese markt moest worden ingericht. Vooral vertegenwoordigers van de Nederlandse multinationals Philips, Unilever, AKU (later AKZO), en het Belgische Solvay \& Cie., de Launoit holding en Société Générale de Belgique, maar ook bedrijven in de Duitse groep wilden de Europese markt volledig geliberaliseerd zien. Zij waren aangepast aan een liberale handelspolitiek en gericht op competitieve export. Bovendien betekende liberalisering voor de Belgische en Nederlandse multinationals dat ze hun internationaal vertakte ondernemingen konden centraliseren. Over liberalisering werd anders gedacht door Franse bedrijven: vanwege een duurder nationaal sociaal stelsel gaven zij de voorkeur aan tijdelijke protectionistische overbruggingsmaatregelen. Opvallend is dat de onderzochte nationale secties veelal op één lijn stonden met de nationale regeringen die over de oprichting van een gemeenschappelijke markt onderhandelden. In de Bilderberg meetings verkondigden vertegenwoordigers van Europese multinationals eveneens hun instemming met de plannen voor liberalisering en integratie. Toen na de oprichting van de gemeenschappelijke markt duidelijk werd dat het Verenigd Koninkrijk samen met andere landen een eigen handelsblok zou opzetten, ontwikkelden de ELEC en de Bilderberg meetings zich uit vrees voor handelsverschuivingen als tegenstanders van afzonderlijke handelsblokken binnen Europa.

De Europese multinationals ontwikkelden niet alleen een visie op hoe Europese marktliberalisering moest worden vormgegeven, maar ook op de rol van instituties in die markt. Zowel in de Bilderberg meetings als de ELEC spraken bedrijven zich uit tegen de verdere introductie van interventionistische supranationale instituties, hetgeen sinds de oprichting van de Hoge Autoriteit van de Europese Gemeenschap van Kolen en Staal een reële mogelijkheid bleef voor andere sectoren. In plaats van een in het bedriffsleven ingrijpende instelling prefereerden de multinationals vrije competitie en een grote vrijheid van ondernemerschap. In hoofdlijnen ontwikkelde de gemeenschappelijke markt zich ook in de door deze bedrijven gewenste richting.

Gedurende de jaren 1960-1970 werd echter duidelijk dat de nieuwe Europese markt ongewenste consequenties met zich meebracht. In hoofdstuk 5 worden twee dominante debatten gevolgd rondom toenemende concurrentie voor Europese bedrijven op de Europese markt en welke gevolgen dit had voor hun visie op economische integratie. Hier gaat het om de reacties van Europese bedrijven op een 
golf aan investeringen door Amerikaanse bedrijven in Europa en daarnaast om hun reacties op de activiteiten van Oost Europese staatsbedrijven op de WestEuropese markt gedurende de jaren zestig.

De jaren zestig stonden voor Europese bedrijven in het teken van aanpassingen aan de nu grotere markt en pogingen om het speelveld waarop concurrerende krachten actief waren zoveel mogelijk gelijk te trekken. De investeringen van Amerikaanse bedrijven werden door veel Europese bedrijven ervaren als een bedreiging voor de eigen concurrentiepositie omdat ze veel kleiner waren door hun kleinere nationale markten. Bovendien waren Amerikaanse bedrijven in een positie om met enkele investeringen maximaal te profiteren van de nieuwe Europese marktschaal terwijl Europese multinationals en bedrijven vast zaten aan bestaande productiecentra die niet eenvoudig te verplaatsen waren. In de ELEC besloten Europese bedrijven dat onderlinge transnationale fusies nodig waren om in elk geval de schaalproblemen tegemoet te treden. De verschillende vormen van nationale bedrijfswetgeving binnen de EEG maakte deze fusies echter onaantrekkelijk. Over de oplossing van zulke problemen bestonden verschillende opvattingen, langs zowel sectorale als nationale lijnen. In de ELEC en de Bilderberg meetings stelden bedrijven uit de chemische sector voor dit probleem op te lossen via harmonisering van Europese bedrijfswetgeving. Nederlandse multinationals verzetten zich hiertegen omdat zij vreesden langs deze weg ongewenste medezeggenschapsregels uit Duitse wetgeving via de achterdeur binnen te halen. Tenslotte vond men elkaar in het voorstel tot afschaffing van onnodige dubbele belastingheffingen over transnationale kapitaalstromen tussen moeder en dochterbedrijven. Dan zouden Europese bedrijven meer animo tot fusies tonen, zo dachten zij. De lidstaten waren echter niet bereid een start te maken met het optuigen van een Europees industriebeleid. Zo werd in de ogen van Europese bedrijven het beperkt inrichten van de Gemeenschappelijke Markt een complicerende factor in het Europese industriele aanpassingsproces.

Als onderdeel van deze ontwikkelingen werden Europese bedrijven geconfronteerd met de stijgende kosten van kapitaal. Omdat Amerikaanse bedrijven sinds 1963 geen dollars meer mochten exporteren ten behoeve van buitenlandse investeringen haalden ze het benodigde kapitaal op in Europa, met hogere rentes tot gevolg. Europese bedrijven waren het niet meteen eens over de te volgen koers. Een groep sprak zich uit voor een Europees geregelde bevoorrechte toegang voor Europese bedrijven tot Europese kapitaalmarkten maar vertegenwoordigers van banken die zelf Amerikaanse bedrijven bedienden, blokkeerden zulke protectionistische voorstellen. Tenslotte vond men in de ELEC overeenstemming over het nastreven van een gedragscode voor Amerikaanse bedrijven op de Europese markt, teneinde hun als agressief ervaren concurrentiemethoden af te zwakken en zo het speelveld in Europa gelijk te trekken. Ook in de Bilderberg meetings werd dit punt in het bijzonder door Belgische bedrijven aangeroerd, omdat zij binnen hun nationale markt relatief veel Amerikaanse investeringen hadden meegemaakt. 
Tegelijkertijd dwong concurrentie van geavanceerde Amerikaanse producenten van fabrieken en machines de Europese kapitaalgoederenproducten mogelijkheden van afzet te onderzoeken in het Oostblok. Dit leidde tot complicaties in de verhoudingen tussen de Gemeenschappelijke Markt en de Oost-Europese staten. Vanuit West Europa werden fabrieken en machines geëxporteerd met behulp van door de West Europese overheden fors ondersteunde exportleningen met een lange looptijd. Het Oostblok ontwikkelde zo versneld een surplus aan goederen dat vervolgens werd gedumpt op onder andere de Gemeenschappelijke Markt. Dit werkte marktverstorend voor Europese goederenproducenten in de chemie en staal, waarop zij in de ELEC en de Bilderberg meetings krappere regels voor exportleningen bepleitten. Hierover kon op OESO niveau echter geen overeenstemming worden bereikt. Samen met de Europese Commissie zetten Europese bedrijven zich vervolgens via de ELEC in voor het organiseren van joint ventures tussen West Europese private bedrijven en de Oostblok-staatsbedrijven. Zo konden de verhoudingen tussen de markten nog enige vorm van ordening worden geboden waar staten dit moesten nalaten. Ten tijde van grote aanpassingen in internationale handelsstructuren verwachtten Europese multinationals een reeks aan ordeningshandelingen van de Europese Gemeenschap, welke deze niet wilden of konden bieden.

Hoofdstuk 6 onderzoekt hoe bedrijven in de ELEC, de Bilderberg meetings en de Trilateral Commission zich opstelden ten aanzien van energie-zekerheid gedurende de door crises geplaagde jaren zeventig en hoe deze veranderende omstandigheden hun visies op de Europese markt bepaalden. De ineenstorting van het monetaire systeem in 1971 en de olie crisis van 1973 leidden tot internationale spanningen en ondermijnden internationale samenwerking tussen Amerikaanse, Europese en Japanse overheden, nadrukkelijk op het gebied van de internationale energievoorziening. Naar aanleiding van deze ontwikkelingen verzochten Europese bedrijven de Europese Gemeenschap stappen te zetten naar een Europees industriebeleid. In de ELEC ontwikkelden Europese energiebedrijven voorstellen voor een Europees energie beleid waarin ondersteuning gevraagd werd voor de verdere ontwikkeling van de sectoren van olie, gas, kolen en nucleaire energie binnen de Gemeenschap. Tussen deze sectoren waren er grote verschillen in de gezochte ondersteuning. De gas-, kolen- en nucleaire sectoren streefden naar stimulering van hun activiteiten. De oliemultinationals British Petroleum en Shell wilden daarentegen vooral de Europese Gemeenschap bewegen tot actieve afstemming met de Verenigde Staten en Japan over de verdediging van Westerse energiebelangen. Daarnaast waren de olie bedrijven op zoek naar een externe representatie door de Europese Gemeenschap in hun contacten met de OPEC landen, problemen die ook werden aangekaart in de Bilderberg meetings. In de ELEC zochten ook de internationaal vertakte chemie- en auto-sectoren naar ondersteuning door de Europese Gemeenschap. Als antwoord op de Europese industriële herstructurering die zou volgen op de beschikbaarheid van goedkope energie in het Midden-Oosten en 
Amerika vroegen zij om Europese steun voor onderzoek en ontwikkeling. Die steun zou ook een antwoord vormen op de snel groeiende Japanse auto-exporten. Daarnaast zagen ze een rol voor de Europese Commissie als intermediair tussen industrie en bonden in het vlottrekken van een Europese industriële herstructurering. Ook in de Trilateral Commission bepleitte een reeks aan bedrijven een meer intensieve rol voor de Europese Gemeenschap. Deze toenemende roep om interventie op een Europees niveau laat goed zien hoe sterk de opstelling van Europese bedrijven was veranderend sinds de jaren vijftig. De posities van Europese energieproducenten en energie-intensieve sectoren in de Trilateral Commission maakten tevens duidelijk dat zij de Europese Gemeenschap graag ingebed wilden zien in een stabiele internationale orde waarin multilateraal werd onderhandeld over de ordening van de wereldwijde handelsverhoudingen.

\section{Conclusies}

De visies van Europese bedrijven op de Europese markt wijzigden zich over de periode 1950-1980. Gedurende de jaren vijftig waren de meeste onderzochte multinationals grote voorstanders van liberalisering in de West Europese markt vanwege het vooruitzicht van schaalvergroting. Tegelijkertijd verzette men zich tegen de invoering van interventionistische supranationale instituties die de markt van bovenaf zouden organiseren. De jaren zestig zagen echter de concurrentie door grote Amerikaanse bedrijven toenemen. Europese bedrijven zochten nu de medewerking van de Europese Gemeenschap in het faciliteren van hun aanpassing aan deze nieuwe omstandigheden. De Gemeenschap vond echter geen overeenstemming over het organiseren van gelijke internationale speelvelden en het aantrekkelijker maken van de volgens bedrijven gewenste transnationale fusies. De crises van de jaren zeventig maakte versnelde aanpassing aan de grotere markt alleen maar urgenter. Europese multinationals stelden nu een gemeenschappelijk industrieel beleid voor om onderzoek en ontwikkeling te ondersteunen en de Europese herstructurering te begeleiden. Waar in de jaren vijftig het van bovenaf organiseren van de markt door supranationale instituties nog werd afgewezen werd er in de jaren zeventig weer om gevraagd. Ook vroeg een deel van de bedrijven voor het eerst expliciet om wereldwijde belangenbehartiging door de Europese Commissie.

De Europese Commissie bleek een machteloze partner voor Europese bedrijven. Hoewel de Europese Commissie enkele genoemde voorstellen van de multinationals overnam, stuitten deze toch op een blokkade van de lidstaten. Zo raakten Europese bedrijven ingeklemd tussen internationale concurrentie, een supranationaal politiek ordeningssysteem dat niet aan hun behoeften beantwoordde, en een internationale crisis gedurende de jaren zeventig.

Deze dominante visies verbergen echter ook (subtiele) onenigheden onder bedrijven. Vooral in de jaren vijftig zorgden nationale contexten van Europese multinationals voor onderling afwijkende stellingnames; bedrijven in Frankrijk 
hadden bijvoorbeeld een ander opvatting over Europese vrijhandel dan Nederlandse multinationals. Maar ook verschillen tussen sectoren hadden invloed op het denken over hoe de Europese markt geordend moest worden. Chemiebedrijven bijvoorbeeld waren gebrand op Europese bedrijfswetgeving om de herstructurering van hun bedrijven te faciliteren, terwijl andere bedrijven daar niet op zaten te wachten. Tenslotte bepaalde de mate van internationalisering ook hoe er tegen de Europese marktordening werd aangekeken. Europese oliebedrijven met wereldwijde investeringen en leveringscontracten poogden bijvoorbeeld vooral de Europese Gemeenschap bij multilaterale, internationale ordeningsinitiatieven te betrekken. Het Europese bedrijfsleven was dus niet homogeen in hun opvattingen en mag in een transnationaal perspectief dus ook niet zo benaderd worden.

Europese bedrijven reageerden tevens verschillend op de herstructureringsuitdaging waar Amerikaanse bedrijven hen voor stelden. Bedrijven die al voor de jaren vijftig een omvangrijke multinationale organisatie hadden opgebouwd kampten niet met schaalproblemen maar moesten hun bestaande internationale organisaties herstructureren; hetgeen complex was in de Europese markt. Kleinere bedrijven moesten transnationale fusies aangaan maar werden daarin geremd door de gebrekkige harmonisering van de Europese regels. Ook dit zijn verschillen waar toekomstig onderzoek sterker rekening mee zou moeten houden.

Het perspectief van multinationals op de Europese markt maakte ook duidelijk dat allerlei Europese ordeningsvraagstukken zoals de harmonisering van handelsregels, gedragscodes en internationale economische beleidsvraagstukken onderdeel waren van processen die veel verder gingen dan integratie van Europese markten. Internationale concurrentie vroeg om strategische positionering in internationale speelvelden, zowel van bedrijven als van overheden die deze zaken via de OESO en zelfs de NAVO agendeerden. Deze verbanden tussen Europese integratie en wereldwijde afstemming rondom globaliseringskwesties zijn van belang in het bepalen van de Europese identiteit.

Tenslotte laat dit onderzoek zien dat de lobby van de European Round Table of Industrialists voor het vervolmaken van de gemeenschappelijke markt in de jaren tachtig voortkwam uit een breed gedeelde ervaring van Europese, multinationaal georiënteerde bedrijven sinds de jaren zestig. Door de aanhoudende nationale ordening van de Europese markt konden zij hun organisaties onvoldoende aanpassen aan de potentiële omvang van die markt. De gezochte schaalvoordelen bleven daardoor uit, terwijl de bedrijven die nodig hadden om de concurrentie uit de Verenigde Staten en Japan het hoofd te bieden.

Het thema van het herstructureringsproces kan een vruchtbare ingang zijn voor een onderzoeksagenda over het bedrijfsperspectief op de Europese Unie. Bedrijfsgeschiedenissen van multinationale ondernemingen kunnen hier een grote bijdrage aan leveren. Onderzoek naar de relaties tussen bedrijven en Europese instituties zou tevens inzicht geven in hoe bijvoorbeeld de Europese Commissie de diverse belangen van Europese, Amerikaanse en Japanse bedrijven afwoog terwijl 
ze dit herstructureringsproces begeleidde. Tegelijkertijd kan onderzoek naar hoe Europese bedrijven dit herstructureringsproces vorm gaven in wereldwijde lobby's voor het gelijktrekken van speelvelden, inzicht geven in de globale aspecten van Europese integratie. 


\section{Curriculum Vitae}

Ruud Geven was born in Boxmeer on the 8th of May 1980. He completed preuniversity education in the period 1992-1999. Between 2001 and 2006 he was trained in Culture and Science Studies at the Faculty of Arts and Social Sciences of Maastricht University. As part of his education he published an article on the role of several large Dutch breweries in the shake-out of the southern Dutch brewing industry between 1900-1940. In 2006 he received a Master's degree in Arts and Sciences after completing his master thesis on the emergence of an artistic genre of comics since the 1970 s. After his education he initially worked as a research assistant on a project of prof. dr. Johan Peter Murmann and prof. dr. Ernst Homburg on the social networks of chemists. From 2007 until 2009 Ruud Geven worked at the centre for debate Tumult in the city of Utrecht where he organized public debates on a variety of subjects such as science, media, art and politics. From 2009 until 2013 he investigated the herein presented subject at the Faculty of Arts and Social Sciences of Maastricht University. 